ISSN 2313-5891 (Online)

ISSN 2304-974X (Print)

\title{
Ukrainian
}

\section{Food Journal}

\section{Volume 10, Issue 4 \\ 2021}

Kyiv

Київ

2021 
Ukrainian Food Journal is an international scientific journal that publishes innovative papers of the experts in the fields of food science, engineering and technology, chemistry, economics and management.

Ukrainian Food Journal is abstracted and indexed by scientometric databases:
Ukrainian Food Journal - міжнародне наукове періодичне видання для публікації результатів досліджень фахівців у галузі харчової науки, техніки та технології, хімії, економіки і управління.

Ukrainian Food Journal індексується наукометричними базами:

$$
\begin{gathered}
\text { Index Copernicus (2012) } \\
\text { EBSCO (2013) } \\
\text { Google Scholar (2013) } \\
\text { UlrichsWeb (2013) } \\
\text { CABI full text (2014) }
\end{gathered}
$$

Online Library of University of Southern Denmark (2014)

Directory of Research Journals Indexing (DRJI) (2014)

Directory of Open Access scholarly Resources (ROAD) (2014)

European Reference Index for the Humanities and the Social Sciences (ERIH PLUS) (2014) Directory of Open Access Journals (DOAJ) (2015)

InfoBase Index (2015)

Chemical Abstracts Service Source Index (CASSI) (2016)

FSTA (Food Science and Technology Abstracts) (2018)

Emerging Sourses Citaton Index (2018)

Ukrainian Food Journal включено у перелік наукових фахових видань України з технічних наук, категорія А (Наказ Міністерства освіти і науки України № 358 від 15.03.2019)

Editorial office address:

National University

of Food Technologies

68 Volodymyrska str.

Kyiv 01601, Ukraine
Адреса редакції:

Національний університет харчових технологій вул. Володимирська, 68 Київ 01601

\section{e-mail: ufj_nuft@meta.ua}

Scientific Council of the National University of Food Technologies approved this issue for publication.

Protocol № 6, 24.12.2021
Рекомендовано вченою радою Національного університету харчових технологій.

Протокол № 6 від 24.12.2021 
Ukrainian Food Journal is open access journal published by the National University of Food Technologies (Kyiv, Ukraine). The Journal publishes original research articles, short communications, review papers, news and literature reviews dealing with all aspects of the food science, technology, engeneering, nutrition, food chemistry, economics and management.

Studies must be novel, have a clear connection to food science, and be of general interest to the international scientific community.

\section{Topic covered by the journal include:}

- Food engineering

- Food chemistry

- Food microbiology

- Food quality and safety

- Food processes

- Automation of food processes

- Food packaging

- Economics

- Food nanotechnologies

- Economics and management

Please note that the Journal does not consider:

1. The articles with medical statements (this topic is not covered by the journal); the subject of research on humans and animals.

2. The articles with statements, that do not contain scientific value (solving the typical practical and engineering tasks).

\section{Periodicity of the Journal}

4 issues per year (march, june, september, december).

\section{Reviewing a Manuscript for Publication}

The editor in chief reviews the correspondence of the content of a newly submitted article to the Journal Profile, approves the article design, style and illustrative material, can provide suggestions how to improve them, and makes the decision whether to send it for peer-review.

Articles submitted for publication in "Ukrainian Food Journal" are double-blind peerreviewed by at least two academics appointed by the Editors' Board: one from the Editorial Board and one, not affiliated to the Board and/or the Publisher.

For a Complete Guide for Authors please visit our website:

$$
\text { http://ufj.nuft.edu.ua }
$$




\section{International Editorial Board}

\section{Editor-in-Chief:}

Olena Stabnikova, PhD, Prof., National University of Food Technologies, Ukraine

Members of Editorial board:

Agota Giedrė Raišienė, $\mathrm{PhD}$, Lithuanian Institute of Agrarian Economics, Lithuania Cristina Popovici, PhD, Assoc. Prof., Technical University of Moldova

Egon Schnitzler, PhD, Prof., State University of Ponta Grossa, Ponta Grossa, Brazil Jasmina Lukinac, $\mathrm{PhD}$, Assoc. Prof., University of Osijek, Croatia

Lelieveld Huub, PhD, President of Global Harmonization Initiative Association, The Netherlands

Mark Shamtsyan, PhD, Assoc. Prof., Black Sea Association of Food Science and Technology, Romania

Octavio Paredes Lopez, $\mathrm{PhD}$, The Center for Research and Advanced Studies of the National Polytechnic Institute, Mexico.

Pascal Dupeux, PhD, University Claude Bernard Lion 1, France

Semih Otles, PhD, Prof., Ege University, Turkey

Sonia Amariei, PhD, Prof., University "Ştefan cel Mare" of Suceava, Romania

Stanka Damianova, PhD, Prof., Ruse University “Angel Kanchev”, branch Razgrad, Bulgaria

Stefan Stefanov, PhD, Prof., University of Food Technologies, Bulgaria

Tetiana Pyrog, PhD, Prof., National University of Food Technologies, Ukraine

Tomasz Bernat, PhD, Prof., Szczecin University, Poland

Valerii Myronchuk, PhD, Prof., National University for Food Technologies, Ukraine Viktor Stabnikov, PhD, Prof., National University for Food Technologies, Ukraine Vladimir Grudanov, PhD, Prof., Belarusian State Agrarian Technical University Yordanka Stefanova, PhD, Assist. Prof., University of Plovdiv "Paisii Hilendarski", Bulgaria

Yuliya Dzyazko, PhD, Prof., Institute of General and Inorganic Chemistry «Vernadskii» of National Academy of Sciences of Ukraine

Yurii Bilan, PhD, Prof., Rzeszow University of Technology, Poland

\section{Managing Editor:}

Oleksii Gubenia, PhD., Assoc. Prof., National University of Food Technologies, Ukraine 


\section{Contents}

Editorial.

Fang Wang, Valerii Sukmanov, Jie Zeng

Effect of the addition of soybean dregs treated by ultrafine grinding and microwave technology on the quality of crispy biscuits

Victoria Sapiga, Galina Polischuk, Magdalena Buniowska,

Iryna Shevchenko, Tetiana Osmak

Polyfunctional properties of oat $\beta$-glucan in the composition of milkvegetable ice cream.

Iryna Tsykhanovska, Olena Stabnikova, Oleksandr Alexandrov,

Roman Trishch, Olga Blagiy

Functional and technological properties of food nanoadditive based of double oxide of bi- and trivalent iron in lyophilic colloidal dispersed

systems

Pelin Günç Ergönül, Alev Yüksel Aydar, Tuba Göldeli,

Annalisa Mentana, Maurizio Quinto

Changes in volatile compounds of Ayvalık (Edremit) and Uslu olive oils

depending on conditions and time of storage.

Violeta Nour

Physico-chemical, antioxidant and sensorial properties of fruit leathers made from "Malga" and "Murano" strawberry cultivars

Trias Ayu Laksanawati, Muhammad Habbib Khirzin, Maghfirotul Amaniyah

Biodegradable film based on taro starch with variations of duck bone gelatin concentration: physical and barrier properties

Nataliia Sabadash, Olena Hrabovska, Igor Fesych, Alina Avramenko, Anastasiia Serhiienko

Effect of the combined use of $\beta$-amylase and pullulanase on the carbohydrate composition of maltose syrups

Zhivka Goranova, Iordanka Alexieva, Todorka Petrova

Effect of coconut products, mesquite flour and stevia on the thermal and quality properties of dark chocolate. 
Oksana Dorozhynska, Olena Kokhan, Yuliia Kambulova

Sorption characteristics of fondant candies based on tagatose

786

Tetiana Yaniuk, Tetiana Trakhalo, Halyna Liashko, Olena Galynska,

Nataliia Hriunvald

Substantiation of grain mass properties effect on the processes of

extraction and hydration.

797

Oleg Kuzmin, Nataliia Stukalska, Larysa Mykhonik, Olga Koval,

Volodymyr Polyovyk, Ganna Berezova

Antioxidant characteristics of tea-herbal compositions

Processes and Equipment

Iryna Dubovkina, Oleksandr Sigal, Veronica Rikhter, Nataliya Nizhnyk

Toxic substances formation in co-incineration process for food production..

828

Biotechnology, Microbiology

Tetiana Pirog, Daria Lutsai, Hanna Yarova

Regulation of biological activity of surfactants under cultivation of Acinetobacter calcoaceticus IMB B-7241 on glycerol.

Badra Boubakeur, Hafidha Khadem, Moustapha Sangalo Drabo,

Ahmad Ali, Aicha Tirtouil Meddah

Probiotic properties and exopolysaccharides production of Stretptococcus thermophilus CNRZ 447 and Enterococcus durans NCBI 53345...........

Abstracts.

Instructions for authors

Contents of Volume 10 (Year 2021).

896 


\section{Editorial}

\section{Dear colleagues, authors and readers!}

With this issue we are finishing 10 years of publication of the Ukrainian Food Journal. For 10 years, the Journal has accumulated an interesting, rich and fruitful experience. In 2012, the National University of Food Technologies founded the Ukrainian Food Journal to publish the research results of young scientists. Creative youth studied the global trends in the development of food science, the experience of leading scientists in this field and filled the journal with valuable research publications that interested the world scientific community.

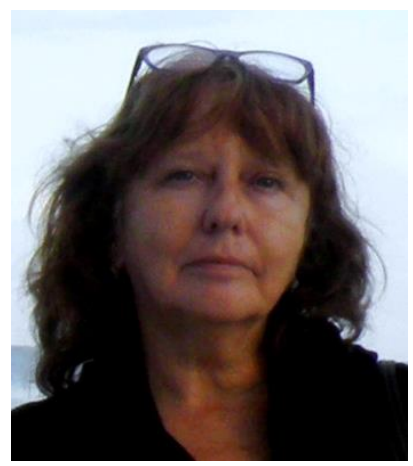

Leading scientists from Ukraine, Poland, Bulgaria and Belarus supported the journal by providing invaluable advice. The journal began to be indexed in international scientometric databases. The number of publications by authors from other countries gradually increased, and the overall citation of articles raised up. If 5 years ago authors from no more than ten countries took part in the publication of articles, now scientists from all continents are publishing in our journal. Modern science has internationalized character, and geographic boundaries do not have such a significant role as previously. Thanks to electronic networks and scientometric databases, research activity is not tied to a specific country, but develops in a single global direction.

Although the journal under the modern title has been published since 2012, the scientific tradition of the publisher, the National University of Food Technologies, comes from the middle of the 19th century, and the collection of scientific papers in the field of food science has been published since 1938 .

The successes achieved require the editorial board to be more responsible and adhere to the principles of academic integrity, high ethical and professional standards. We believe that the high potential and creativity of the authors of the articles and the professionalism of the editorial scientific team will help maintain the high level of the Ukrainian Food Journal and contribute to the authority of the Journal in professional circles.

We would like to acknowledge the contribution of the former editors-in-chief Sergii Ivanov, Valerii Mank, and Volodymyr Ivanov in the development of the Ukrainian Food Journal, and also the contribution of members of the editorial board professors Stanka Damyanova, Yurii Bilan, Semih Otles, Stefan Stefanov, Egon Schnitzler, Galyna Simakhina, Anatolii Sokolenko, Tetiana Pyrog, Oleksandr Shevchenko, Cristina Popovici, and Jasmina Lukinac.

We sincerely wish the authors, the editorial board and our readers good health, enrichment of scientific achievements and the fullest realization of scientific potential!

Editor-in-chief Olena Stabnikova

DOI: $10.24263 / 2304-974 X-2021-10-4-3$ 


\title{
Effect of the addition of soybean dregs treated by ultrafine grinding and microwave technology on the quality of crispy biscuits
}

Fang Wang ${ }^{1,2}$, Valerii Sukmanov ${ }^{1,3}$, Jie Zeng ${ }^{2}$

\author{
1 - Sumy National Agrarian University, Sumy, Ukraine \\ 2 - Henan Institute of Science and Technology, Xinxiang, People's Republic of China \\ 3 - Poltava State Agrarian University, Poltava, Ukraine
}

\section{Keywords: \\ Soybean \\ Dregs \\ Crispy biscuits \\ Ultrafine \\ Grinding \\ Microwave}

\section{Article history:}

Received

30.03.2021

Received in

revised form

28.08.2021

Accepted

30.12.2021

Corresponding author:

Fang Wang

E-mail:

Fangwang2019@

163.com

\section{DOI:}

$10.24263 / 2304-$ 974X-2021-10-4-

\section{Abstract}

Introduction. The aim of the research is to determine the effect of the addition of soybean dregs treated with ultrafine grinding and microwave irradiation on the quality of crispy pastry.

Materials and methods. The moist soybean dregs were dried at $50{ }^{\circ} \mathrm{C}$ for 48 hours and ground in an ultrafine grinding machine $\mathrm{KCW}$ $701 \mathrm{~S}$ at a frequency of $30 \mathrm{~Hz}$. Obtained soybean flour was processed in a microwave oven, the ratio of beans to water was set to $1: 7$, at a high level of heating for $6 \mathrm{~min}$, then dried in an oven at $50{ }^{\circ} \mathrm{C}$ for 48 $\mathrm{h}$ and sieved at 80 mesh. The color $\left(L^{*}, a^{*}, b^{*}\right)$ values of the crackers were determined by portable color difference meter (Cr-400 chromatic aberration meter Minolta, Japan).was determined using chromatic aberration meter Cr-400; texture was determined by the TA-XT Plus Texture Analyzer; sensory evaluation was conducted by 100-point hedonic scale for color, flavor, texture and overall acceptability.

Results and discussion. The increase of the amount of soybean dregs powder (SDP) decreased $L^{*}$ and increased $a^{*}$ values of crispy biscuits, meanwhile $b^{*}$ values were not changed significantly. The color of crispy biscuits became darker (lower $L^{*}$ ), more reddish (higher $a^{*}$ ), and less yellowish (lower $b^{*}$ ) when soybean dreg powder was added at amount of $15-25 \%$. The hardness of crispy biscuits increased gradually with the increase of bean dregs. The hardness reached the maximum of $2328.49 \mathrm{~N}$ at addition of SDP $15 \%$. With the addition of SDP at $20 \%$, the firmness of the biscuits decreased slightly. With increasing addition of SDP, the content of dietary fiber in the crispy biscuit increased, thereby reducing the gluten content in the dough and affecting the formation of the gluten network, which led to an increase in the hardness of the crispy biscuit. Increasing of the dietary fiber content ensures retaining of oil in the crispy biscuits, which results in a reduction of the product hardness. The addition of soybean dregs powder affected the sensorial properties of the product. However, there was no significant difference in the overall quality rating of the crispy biscuits containing 15 and 20\% SDP.

Conclusion. The addition of bean dreg powder had significant effects on the color, texture and sensorial properties of crispy biscuits compared with control. However, crispy biscuits with the addition of soybean dregs powder in the amount of $15-20 \%$ prepared by proposed technology had the crispy taste, golden color, and pleasant soybean flavor. 


\section{Introduction}

By-products of plant processing are widely used in food preparation (Stabnikova et al., 2021). The soybean dregs is residue from soy milk production containing insoluble components, which remain in the filtration bag (O'Toole \& Desmond, 1999). Dry soybean dregs has high content of proteins (24.5-37.5 g/100 g), lipids (9.3-22.3 g/100 g), dietary fiber $(14.5-55.4 \mathrm{~g} / 100 \mathrm{~g})$, and is a good source of isoflavones (Bourquin et el., 1996; Rinaldi et al., 2000; Tharanathan \& Mahadevamma, 2003; Surel \& Couplet, 2005; Pr'estamo et al., 2007; Redondo-Cuenca et al., 2008).

With the development of the soy milk production, the availability of soybean dregs has been gradually increased, and now they are commonly used in the manufacturing of baked goods such as cakes, bread, and biscuits (Yang et al., 2013). Addition the soybean dregs into flour not only improved the flavor of the traditional biscuits, but also provided a new type of healthy food for consumers (Chen, 2013; Yang et al., 2013). However, soybean dregs have poor taste, perishability, and low content of soluble dietary fiber (SDF). Therefore, most of them are used as feed for animals or discarded as waste disposal. In recent years, a large number of studies have been carried out to develop physical technologies to increase the content of water-soluble fibers in bean flour, for example, explosive extrusion has increased the content of SDF in bean flour from 1.34 to $36.28 \%$ at an explosive strength of $1.5 \mathrm{MPa}$ within $30 \mathrm{~s}$ (Chen et al., 2014). Twin-screw extrusion was applied for soluble dietary fiber extraction from soybean residue. The SDF content of soybean dregs reached $12.65 \%$, which was by $10.60 \%$ higher than that of unextruded and boiled soybean dregs (Yan \& Chi, 2013). Steam explosion is a kind of physical method recently used in food pretreatment. When the explosion strength was $1.5 \mathrm{MPa}$ for $30 \mathrm{~s}$, the content of soluble dietary fiber of soybean dregs increased from 1.34 to $36.28 \%$ ( $\mathrm{Li}$ et al., 2019). The solubility of bean dregs can be also increased using the high-pressure homogenization due to structural disruption of bean particles and release of fibre and proteins (Fayaz et al., 2019).

The dissolution rate of soluble polysaccharides in bean residue increased to $70 \%$ after microwave treatment at $200^{\circ} \mathrm{C}$ for $7 \mathrm{~min}$, while the appearance of new polyphenolic compounds with antioxidant activity was observed at temperatures above $180^{\circ} \mathrm{C}$ (Tsubaki et al., 2009). The content of soluble dietary fiber in soybean dregs increased 8 times during the treatment with high hydrostatic pressure of $400 \mathrm{MPa}$ at $60^{\circ} \mathrm{C}$. While there was also an improvement in swelling, water holding capacity and oil holding capacity of soybean dregs (Mateos-Aparicio et al., 2010). However, as far as we know, the treatment of bean dregs by physical techniques has not been used in preparation of baked products, and this topic requires further research.

In our previous research, the SDF contents in bean dregs treated with the above single and combination methods were determined according to the AOAC method (1995). The SDF contents in bean dregs after the ultrafine grinding (U), high pressure (HP), microwaves (M), high-temperature cooking (HTC) and combination technologies U-HP, U-M, U-HTC were $15.15 \pm 0.12 \%, 10.40 \pm 0.19 \%, 13.84 \pm 0.13 \%, 13.87 \pm 0.13 \%, 18.86 \pm 0.11 \%, 19.23 \pm 0.19 \%$, and $16.89 \pm 0.13 \%$, respectively. Meanwhile, the SDF content in the control sample was only $1.63 \pm 0.2 \%$ (Wang et al., 2021).

Therefore, the aim of the present research is to determine the effect of the addition of soybean dregs treated with ultrafine grinding and microwave irradiation on the quality of crispy biscuits. It can improve the dietary fiber intake and flavor as well as nutritional value of the crispy biscuits. 


\section{Materials and methods}

\section{Materials}

Wet soybean dregs were obtained at local markets (Fresh okra has high moisture content, bad taste and mouth feel, and is difficult to store).

Bean dregs powder, low-gluten flour, powdered sugar, butter, corn starch, egg yolks, salt, and baking powder were collected from local markets.

\section{Equipment}

Ultrafine grinder (KCW-701S, Beijing Yujie Yucheng Machinery Equipment Co., Ltd., Beijing, China); Microwave oven (P70D20N1P-G5, Guangdong Galanz Microwave Life Electric Appliance Manufacturing Co., Ltd., Zhongshan, China); Oven (YXD-60C, Guangzhou Saisida Machinery Equipment Co., Ltd., Baiyun Branch, Guangzhou, China.

\section{Methods}

\section{Combination technology}

Ultrafine grinding (U): the wet soybean dregs were dried in a constant temperature drying oven at $50{ }^{\circ} \mathrm{C}$ for $48 \mathrm{~h}$, and then ultrafine ground frequency of $30 \mathrm{~Hz}$ by an ultrafine grinder (KCW-701S).

Microwave (M): wet bean dregs were treated in a P70D20N1P-G5 microwave oven at a medium heat level for $4 \mathrm{~min}$, then dried in the oven at $50{ }^{\circ} \mathrm{C}$ for $48 \mathrm{~h}$ and sieved at 80 mesh.

Combination technology: the soybean dregs treated by ultrafine grinding were used as the raw material for combination with high pressure treatment, microwave treatment and high temperature cooking treatment. The ratio of soybean dregs to water was set as 1:3, 1:5, 1:7, $1: 9$ and 1:11. The other conditions were designed as follows: Ultrafine Grinding-Microwave (U-M): Low, M-Low (between low and medium heat), Med, M. High (between medium and high heat), High heat modes were selected for microwave conditions, and the treatment time ranged from $2 \mathrm{~min}$ to $10 \mathrm{~min}$.

The treatment of SDP was conducted according to the methods described in (Wang et al., 2021).

\section{Crispy dough preparation}

The crispy biscuits had the following formulation: low gluten flour and soybean dregs powder (100 g), butter (50 g), powdered sugar (20 g), corn starch $(5 \mathrm{~g})$, egg yolks $(20 \mathrm{~g})$, salt $(1 \mathrm{~g})$, and baking powder $(0.75 \mathrm{~g})$. Whisk butter until creamy and pale after the butter is softened, powdered sugar, salt and egg yolks were mixed for 1 min at speed 4 using a KitchenAid Professional mixer KPM5 (St. Joseph, Michigan, USA) to make it smooth, add the flour mixture (low gluten flour, bean dregs powder, corn starch and baking powder) in batches to make a soft dough. Seal with plastic wrap and leave at room temperature for 10 min. 


\section{Crispy biscuits preparation}

Preheat the oven to be preheated, the upper heat is $170{ }^{\circ} \mathrm{C}$, the lower heat is $160{ }^{\circ} \mathrm{C}$, weigh $8 \mathrm{~g}$ of the crispy dough, put it into a fixed mold, press it into a consistent biscuit shape and slowly the sample into the prepared baking pan. These samples were baked in an electric oven for 12 minutes. After baking, the crispy biscuits were removed from the oven, left to cool for 1 hour at room temperature, and packed into hermetically sealed plastic bags to prevent drying. All quality measurements were performed in 1 hour after baking.

\section{Crispy biscuits measurements}

\section{Color}

The color $\left(L^{*}, a^{*}, b^{*}\right)$ values of the crackers were determined by portable color difference meter (Cr-400 chromatic aberration meter Minolta, Japan). Color measurements were made of crust. All measurements were conducted at least three times. The $L^{*}$ value is a measure of lightness, ranging from black (0) to white (100), the $a^{*}$ value ranges from greenness $(-100)$ to redness $(+100)$, and the $b^{*}$ value ranges from blueness $(-100)$ to yellowness (100) (Yang et el., 2019).

\section{Texture analysis}

Crispy biscuits texture was determined by the TA-XT Plus Texture Analyzer (Stable Micro Systems, London, UK) according to the method described in (Tyagi et al., 2007). The complete biscuits were placed on the test bench of the texture tester, and the texture profile analysis test was carried out with the $\mathrm{P} / 5$ probe. Parameters were set as follows: pretest peed, $1.0 \mathrm{~mm} / \mathrm{s}$; test speed, $0.50 \mathrm{~mm} / \mathrm{s}$; posttest speed, $1.0 \mathrm{~mm} / \mathrm{s}$; strain, $30 \%$; interval time, $5 \mathrm{~s}$. Textural parameters, such as hardness, cohesiveness, gumminess and chewiness were determined. Measurements were performed on biscuits ( $5 \mathrm{~mm}$ thick), and the mean of the four measurements was recorded.

Samples were assessed for texture profile analysis with an aluminum cylindrical probe $\mathrm{P} / 5$ at ambient temperature $\left(20-25^{\circ} \mathrm{C}\right)$. The indicators of hardness, springiness, cohesiveness and chewiness were determined. Each measurement was replicated 5 times.

The data were generated by Exponent software (Exponent stable microsystem, version 5.1.2.0, Stable Microsystems Ltd., UK) provided with the instrument (Figure 1). Attributes of hardness, cohesiveness, gumminess and chewiness were determined. Each measurement was replicated 5 times.

Hardness. It is the biggest peak of compression for the first time (Bourne, 2002; Singh et al., 1993).

Cohesiveness. The relative resistance of the test sample to the second compression after the first compression deformation is shown in the curve as the ratio of positive work (Area $2 /$ Area 1) of the two compressions. This value represents the total work required to overcome the attraction between the two surfaces when the probe comes into contact with the sample [27].

Gumminess. It is expressed as the product of hardness and cohesiveness. The result is multiplied by 100 to eliminate decimals (Friedman et al., 1963).

Chewiness. It is only used to describe the test sample in solid state, indicating the energy required to chew the solid sample into a stable state when swallowing. The numerical value is expressed by the product of the stickiness and elasticity (hardness $\mathrm{x}$ cohesive elasticity) 
[27].

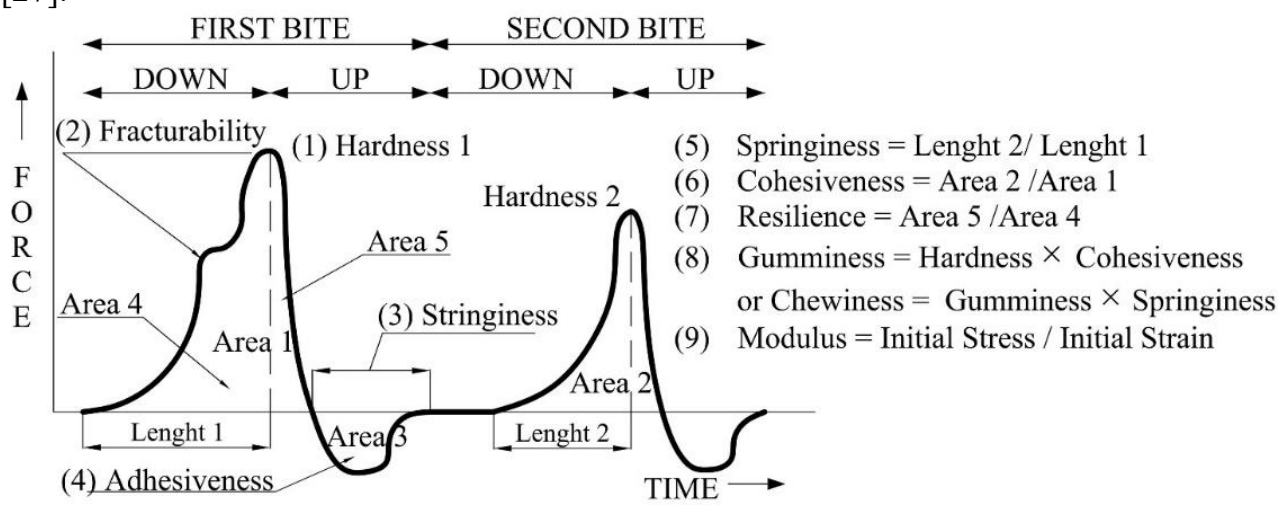

Figure 1. The parameter definition interpretation of qualitative curve analytical method (Szczesniak, 1963; Szczesniak et al., 1963)

\section{Sensory evaluation}

The sensory evaluation was done according to the method (Bose \& Shams-ud-Din, 2010). A sensory evaluation of biscuits was conducted initially for color, flavor and texture by a panel of 10 panelists (Qiu \& Qi, 2018). All the panelists were the postgraduate students of the Department of Food Science and Technology. A 100-point hedonic rating test was performed to assess the degree of acceptability of these biscuits. Three pieces from each biscuit lot were presented to 10 panelists as randomly coded samples. The test panelists were asked to rate the sample on a 100-point hedonic scale for color, flavor, texture and overall acceptability.

\section{Statistical analysis}

Experiments were conducted at least in triplicate, and the data were statistically analyzed and expressed as the means \pm standard deviation (SD). Data were subjected to analysis of variance (ANOVA) using the software package SPSS 12.0 for Windows (SPSS Inc., Chicago, USA) and $p<0.05$ was used as the standard for significance.

\section{Results and discussion}

\section{Analysis of color of crispy biscuits from bean dregs}

In Figure 2 shows examples of crispy biscuits produced with different amount of bean dregs and Table 2 presents the results of experiments evaluating the effect of using waste bean powder on crisp color. 


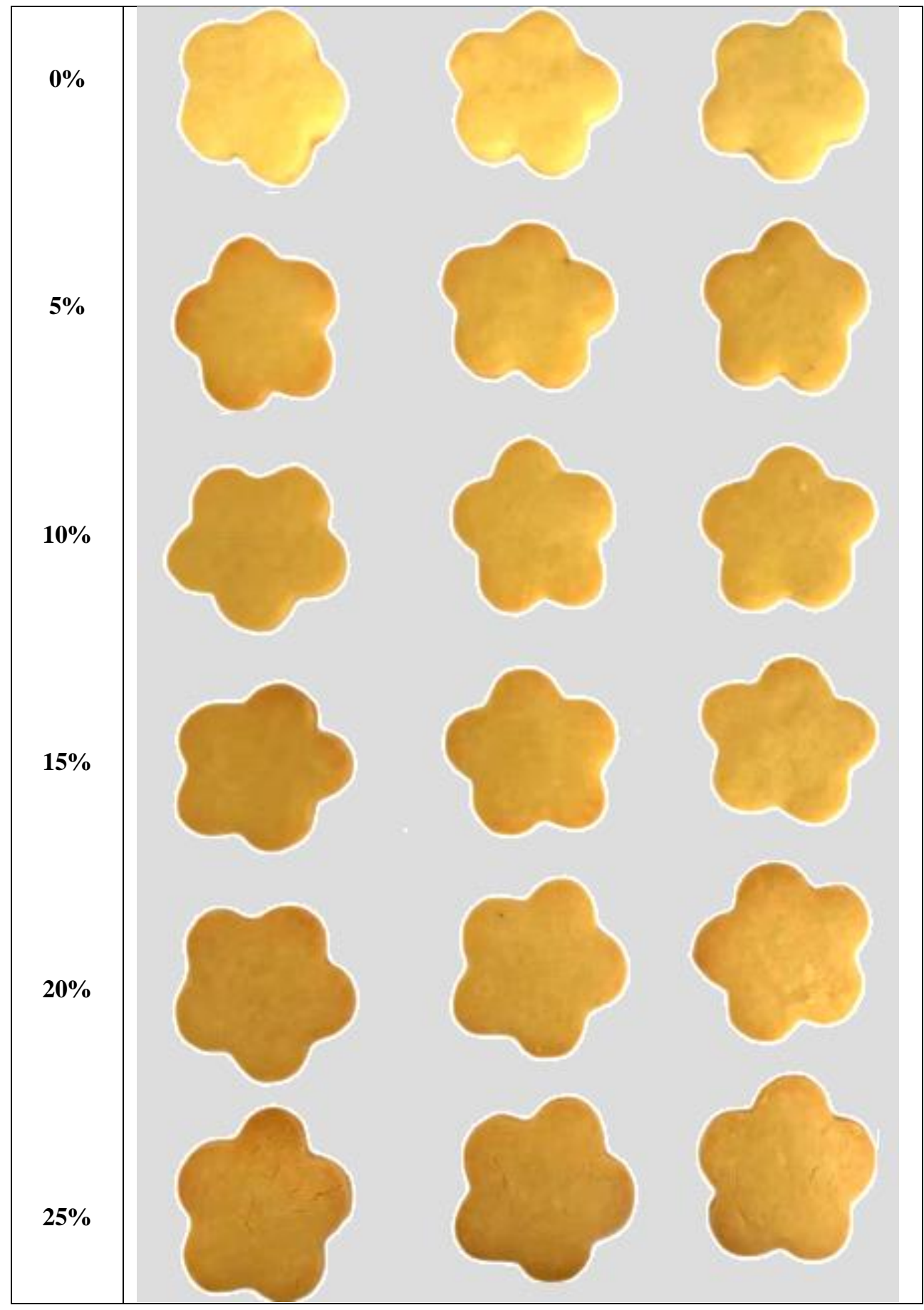

Figure 2. Morphology of crispy biscuits with different amount of soybean dregs powder 
Effect of soybean dregs powder on color of crispy biscuits

Table 1

\begin{tabular}{|c|c|c|c|}
\hline $\begin{array}{c}\text { Soybean dregs } \\
\text { powder, \% }\end{array}$ & $\boldsymbol{L}^{*}$ & $\boldsymbol{a}^{*}$ & $\boldsymbol{b}^{*}$ \\
\hline 0 & $75.59 \pm 0.74^{\mathrm{a}}$ & $-1.00 \pm 0.10^{\mathrm{f}}$ & $34.14 \pm 0.26^{\mathrm{c}}$ \\
\hline 5 & $74.31 \pm 0.26^{\mathrm{a}}$ & $1.01 \pm 0.07^{\mathrm{e}}$ & $36.17 \pm 0.13^{\mathrm{a}}$ \\
\hline 10 & $72.30 \pm 1.06^{\mathrm{b}}$ & $1.78 \pm 0.19^{\mathrm{d}}$ & $34.67 \pm 0.44 \mathrm{~b}^{\mathrm{c}}$ \\
\hline 15 & $70.59 \pm 1.11^{\mathrm{c}}$ & $2.93 \pm 0.38^{\mathrm{c}}$ & $34.86 \pm 0.34^{\mathrm{b}}$ \\
\hline 20 & $70.57 \pm 0.30^{\mathrm{c}}$ & $3.83 \pm 0.14^{\mathrm{b}}$ & $34.14 \pm 0.22^{\mathrm{c}}$ \\
\hline 25 & $69.70 \pm 0.69^{\mathrm{c}}$ & $4.17 \pm 0.06^{\mathrm{a}}$ & $34.28 \pm 0.33^{\mathrm{c}}$ \\
\hline
\end{tabular}

Data reported as mean \pm standard deviation, $n=3$. Values followed by different lower-case letters in the same column are significantly different from each other $(\mathrm{p} \leq 0.05)$.

The increase of the amount of SDP decreased $\mathrm{L}^{*}$ and increased $\mathrm{a}^{*}$ values for crispy biscuits, indicating more dark and yellowish color, meanwhile $b^{*}$ values were not changed significantly. The crisp biscuits color became darker (lower $\mathrm{L}^{*}$ ), more reddish (higher $\mathrm{a}^{*}$ values), and less yellowish (lower $b^{*}$ ) when soybean dregs powder was added at the amount of $15-25 \%$. The crust of the crispy biscuits was caramelized during baking and was responsible for the final color of the crust. The Mallard reaction involves a complex sequence of reactions, including condensation, cyclization, dehydration, rearrangement, isomerization, and polymerization. Thus, these changes in the color parameters may be related to the Mallard reaction, which is a temperature-dependent nonenzymatic reaction between reducing sugars and the amino groups of amino acids or proteins, resulting in the formation of brown pigments (melanoidins) (Muliterno et al., 2017).

\section{Analysis of texture of crisp biscuits from bean dregs}

The results of experimental studies of the effect of bean dregs powder on texture of crisp biscuits are shown in Figure 3. 



b 


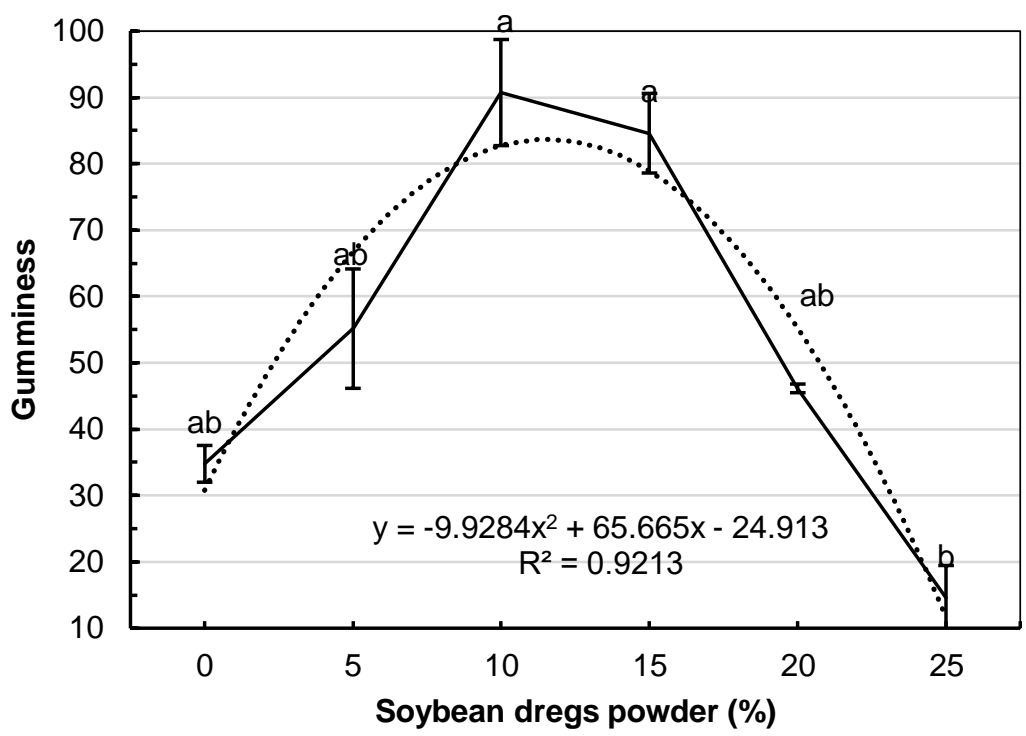

$c$

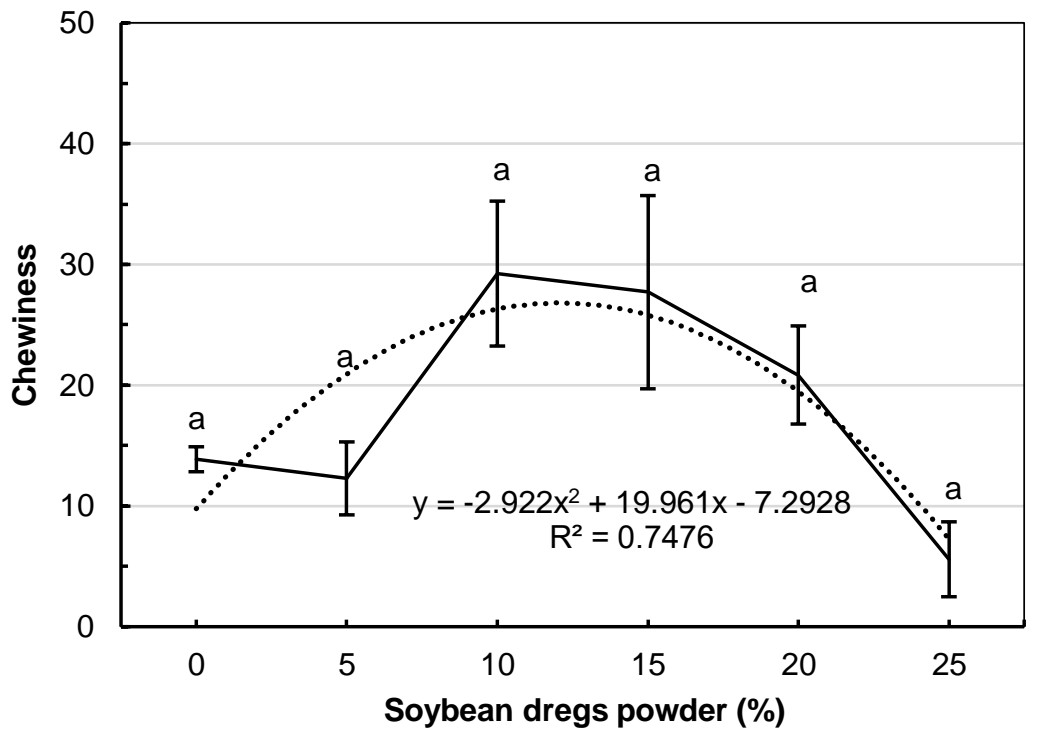

$d$

Figure 3. Effect of bean dregs powder on texture of crisp biscuits: a - hardness; $b$ - cohesiveness; $c$ - gumminess; $d$ - chewiness.

Data reported as mean \pm standard deviation, $n=3$. Values followed by different lower-case letters in the same column are significantly different from each other $(\mathrm{p} \leq 0.05)$. 
Biscuit texture is an important index to evaluate the biscuits quality, lower in hardness and chewiness of biscuit indicated less work to be consumed when chewing (Yang et al., 2019). However, biscuits with a certain hardness require more saliva when chewing, taste better and aging rate can be delayed. The effect of different contents of soybean dregs powder on biscuit texture are presented in Figure $3(\mathrm{a}-\mathrm{d})$. Hardness of the crispy biscuits with SDP was significantly higher than of control $(\mathrm{p}<0.05)$. When the soybean dregs powder was added at the amount of $15 \%$, the hardness reached the maximum of $2328.49 \mathrm{~N}$. This may be due to increase of the content of fiber that capable to absorb water or oil in dough, fills in the gluten network and leads to the increase of dough hardness (Yang et al., 2019). The hardness decreased and biscuits became very dark with bean flavor when the amount of soybean dregs powder was above $20 \%$. At the content of SDP $10-20 \%$, gumminess and chewiness of the biscuit increased and became higher than of control. Similar results were reported at the evaluation of addition of banana powder on biscuit texture ( $\mathrm{Li}$ et al., 2015). SDP content showed great correlation with the cohesiveness and gumminess properties of crispy biscuits. The value of $\mathrm{R}^{2}$ was close to 1 , indicating that the regression line fits the observed value well $(\mathrm{b}, \mathrm{c})$. In addition, the index between biscuit hardness and soybean dregs powder content was 0.770 (a), and the index between biscuit chewiness and the content of SDP was 0.748 (d), showing that soybean dregs powder had different effects on cohesiveness and chewiness of crispy biscuits.

\section{Subjective (sensory) evaluation of crispy biscuits}

A comprehensive assessment of crispy biscuits with SDP is shown in Figure 4.

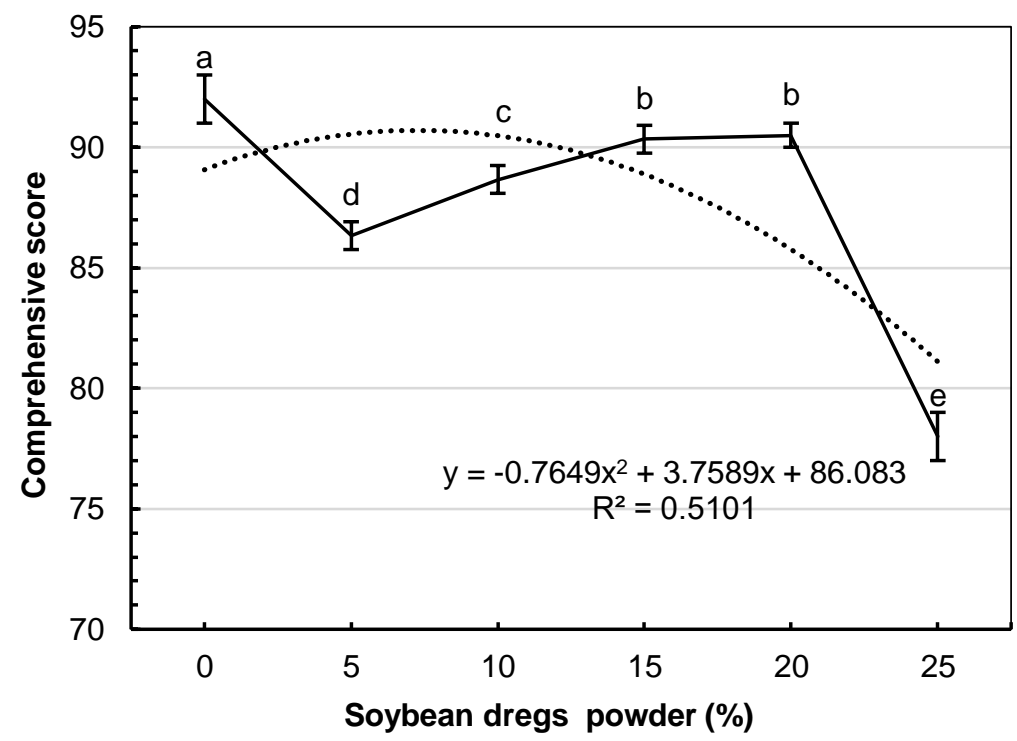

Figure 4. The comprehensive score of crispy biscuits with soybean dregs powder

In every group of data, values with the same following letter do not differ significantly from each other $(\mathrm{p} \leq 0.05)$. 
The mean scores for overall acceptability of biscuits were presented in Figure 4. A twoway analysis of variance indicated that these sensory attributes of the crispy biscuits were significantly affected $(\mathrm{p}<0.05)$ by addition of different amounts of SDP in biscuit formulations. As shown in Figure 4, overall acceptability of the control crispy biscuits was the highest and it was significantly better than of the biscuits added with SDP. Biscuits containing soybean dregs powder (even up to $20 \%$ level of substitution) had superior scores, overall acceptability of biscuits were judged to be very good. Biscuits with higher amount of soybean dregs powder (25\%) had the typical bean flavor, and the scores of biscuits were affected adversely. Similarly, the color of biscuits became darker gradually with increasing levels of soybean dregs powder. Therefore, among the processed crispy biscuits, $15 \%$ and $20 \%$ of soybean dregs powder containing biscuit was the most preferred one than the biscuit containing 5\%, 10\% and $25 \%$ SDP. The results of sensory evaluation indicated that it is possiblu to use wheat flour with up to $20 \%$ substitution level with SDP without adversely affecting the consumer acceptability of biscuits. Similar results were obtained when evaluating the effect of composite flours prepared from wheat, greengram, bengalgram and blackgram flours on the sensorial characteristics of cookies (Singh et al., 1993).

\section{Conclusions}

1. The present work investigated the effects of addition of soybean dregs powder on characteristics of crispy biscuits. Color, texture and sensorial characteristics were determined to evaluate the quality of crispy biscuits prepared with soybean dregs powder.

2. Addition of soybean dregs powder in quantity above $15 \%$ made biscuits yellower and darker, and lowered the $L^{*}$.

3. Hardness and chewiness of the biscuit prepared with the addition of $10-15 \%$ of soybean powder slightly increased, which was not beneficial for biscuit making.

4. Addition of soybean dregs powder to biscuits can enhance flavor. The maximum amount of soy flour at which the organoleptic evaluation remained acceptable was $20 \%$. Additionally, further research should be conducted to study the rheological and texture properties of crispsy biscuits dough. The present research might help to enlarge the application of soybean dregs in bakeries.

\section{References}

AOAC (1995), Method 991.42 \& 993.19 official methods of analysis (16th ed.), DC: Association of Official Analytical Chemists, Washington.

Bose D., Shams-ud-Din M. (2010), The effect of chickpea (Cicer arietinim) husk on the properties of cracker biscuits, Journal of the Bangladesh Agricultural University, 8(452-2016-35753).

Bourne M. (2002), Food texture and viscosity: concept and measurement, Elsevier.

Bourquin L.D., Titgemeyer E.C., Fahey G.C., Jr. (1996), Fermentation of various dietary fiber sources by human fecal bacteria, Nutrition Research, 16(7), pp. 1119-1131.

Chen Y.J. (2013), Study on the processing technology of the suga-free okara biscuit production using bean dregs, Journal of Anhui Agricultural Sciences, pp. 2013-36. 
Chen Y., Ye R., Yin L., Zhang N. (2014), Novel blasting extrusion processing improved the physicochemical properties of soluble dietary fiber from soybean residue and in vivo evaluation, Journal of Food Engineering, 120, pp. 1-8.

Fayaz G., Plazzotta S., Calligaris S., Manzocco L., Nicoli M. C. (2019), Impact of high pressure homogenization on physical properties, extraction yield and biopolymer structure of soybean okara, LWT-Food Science and Technology, 113, 108324.

Friedman H.H., Whitney J.E., Szczesniak A. S. (1963), The texturometer - a new instrument for objective texture measurement, Journal of Food Science, 28(4), pp. 390-396.

Li B., Yang W., Nie Y., Kang F., Goff H.D. \& Cui S.W. (2019), Effect of steam explosion on dietary fiber, polysaccharide, protein and physicochemical properties of okara, Food Hydrocolloids, 94, pp. 48-56.

Li M., Zhang Y., You X., Sun J., Li Z. C., Wei P., Li L. (2015), Sensory quality evaluation and digestion properties of biscuits containing green banana powder, Food Science, 36(21), 68173.

Mateos-Aparicio I., Mateos-Peinado C., Rup'erez P. (2010), High hydrostatic pressure improves the functionality of dietary fibre in okara by-product from soybean, Innovative Food Science \& Emerging Technologies, 11(3), pp. 445-450.

Muliterno M.M., Rodrigues D., Lima F., Ida E.I., Kurozawa L.E. (2017), Conversion/degradation of isoflavones and color alterations during the drying of okara, LWT - Food Science and Technology, 75, pp. 512-519.

O'Toole D. K., Desmond K. (1999), Characteristics and use of okara, the soybean residue from soy milk production - a review, Journal of Agricultural \& Food Chemistry, 47(2), pp. 363-371.

Pr'estamo G., Rup'erez P., Espinosa-Martos I., Villanueva M. J., Lasuncion M. A. (2007), The effects of okara on rat growth, cecal fermentation, and serum lipids, European Food Research and Technology, 225(5-6), pp. 925-928.

Qiu Y.Y., Qi Y. (2018), Production on crispy biscuit from bean dregs, Soybean Science \& Technology, pp. 39-43.

Redondo-Cuenca A., Ma V.S., Mateos-Aparicio I. (2008), Soybean seeds and its byproduct okara as sources of dietary fibre, Measurement by AOAC and Englyst methods. Food Chemistry, 108(3), pp. 1099-1105.

Rinaldi V.E.A., Ng P.K.W., Bennink M.R. (2000), Effects of extrusion on dietary fiber and isoflavone contents of wheat extrudates enriched with wet okara, Cereal Chemistry, 77(2), pp. 237-240.

Singh B., Bajaj M., Kaur A., Sharma S., Sidhu J. S. (1993), Studies on the development of high-protein biscuits from composite flours, Plant Foods for Human Nutrition, 43(2), pp. 181-189.

Stabnikova, O., Marinin, A., Stabnikov, V. (2021), Main trends in application of novel natural additives for food production, Ukrainian Food Journal, 10(3). 524-551.

Surel O., Couplet B. (2005). Influence of the dehydration process on active compounds of okara during its fractionation, Journal of the Science of Food and Agriculture, 85(8), pp. 1343-1349.

Szczesniak A.S. (1963), Classification of texture characteristics, Journal of Food Science.

Szczesniak A.S., Brandt M.A., Friedman H.H. (1963), Development of standard rating scales for mechanical parameters of texture and correlation between the objective and the sensory methods of texture evaluation, Journal of Food Science, 28(4), pp. 397-403.

Tharanathan R. N., Mahadevamma S. (2003), Grain legumes - A boon to human nutrition, Trends in Food Science \& Technology, 14(12), pp. 507-518. 
Tsubaki S., Nakauchi M., Ozaki Y., Azuma J. (2009), Microwave heating for solubilization of polysaccharide and polyphenol from soybean residue (Okara), Food Science and Technology Research, 15(3), pp. 307-314.

Tyagi S.K., Manikantan M.R., Oberoi H.S., Kaur G. (2007). Effect of mustard flour incorporation on nutritional, textural and organoleptic characteristics of biscuits. Journal of Food Engineering, 80(4), pp. 1043-1050.

Wang F., Zeng J., Gao H. Y., Sukmanov V. (2021), Effects of different physical technology on compositions and characteristics of bean dregs, Innovative Food Science and Emerging Technologies, 73, 02789.

Yan J., Chi Y. J. (2013), Effects of twin-screw extrusion on soluble dietary fibre and physicochemical properties of soybean residue, Food Chemistry, 138(2-3), pp. 884889.

Yang H., Li L., Yin Y., Li B., Zhang X., Jiao W., Liang Y. (2019), Effect of ground ginger on dough and biscuit characteristics and acrylamide content, Food Science and Biotechnology, 28(5), 1359-1366.

Yang J., Nie Y. H., Lin D. Q. (2013), Development of soybean dregs biscuit with high protein and dietary fiber, Modern Food Science \& Technology, 29(4), pp. 792-795. 


\title{
Polyfunctional properties of oat $\beta$-glucan in the composition of milk-vegetable ice cream
}

\section{Victoria Sapiga ${ }^{1}$, Galina Polischuk ${ }^{1}$, Magdalena Buniowska ${ }^{2}$, Iryna Shevchenko ${ }^{1}$, Tetiana Osmak ${ }^{1}$}

\author{
1 - National University of Food Technologies, Kyiv, Ukraine \\ 2 - University of Rzeszow, Rzeszow, Poland
}

Keywords:

Ice cream

$\beta$-glucan

Vegetable

Puree

Viscosity

thixotropic

Foam

Article history:

Received

25.03.2021

Received in

revised form

12.09.2021

Accepted

30.12.2021

Corresponding author:

Tetiana Osmak

E-mail:

osmaktg@ukr.net

\section{DOI:}

$10.24263 / 2304-$

974X-2021-10-4-

5

\section{Abstract}

Introduction. The aim of the work was to study the effect of oat $\beta$-glucan on the viscosity-speed indicators of mixtures and physicochemical characteristics of milk-vegetable ice cream.

Materials and methods. Milk-vegetable ice cream with a mass fraction of fat $3 \%$ and oat $\beta$-glucan in the amount of $0.5-$ $1.0 \%$ with a stabilization system and without, as well as control samples of classic milk ice cream, were prepared. Rotational viscometry and well-known methods for studying the resistance to melting, overrun and ice cream dispersion of the air phase were used.

Results and discussion. The structuring ability of $\beta$-glucan in ice cream with low fat and dry matter content was studied. The effective viscosity of ice cream mixtures with $\beta$-glucan in the amount of $0.5-1.0 \%$ is in the range of recommended values. Mixtures of milk ice cream with $\beta$-glucan are characterized by thixotropic ability, which is confirmed by the high degree of restoration of the destroyed structure. Combined use of $\beta$-glucan and fermented vegetable puree containing soluble pectin and softened vegetable fibers could significantly improve the viscosity-speed indicators of mixtures: the effective viscosity increases by $11.5-15.9 \%$, the degree of recovery in on average by $10 \%$. Low-fat milk-vegetable ice cream with a $\beta$-glucan content of $0-1.0 \%$ acquires a creamy consistency. The increase in overrun and resistance to melting of ice cream with $\beta$-glucan is due to the formation of a specific secondary foam microstructure that is characterized by the presence of an additional framework of microbubbles, which wraps larger air inclusions and gives them additional mechanical stability during heating. Thus, it was proved that $\beta$-glucan is a universal ingredient that can, in addition to enrichment, perform a structuring and stabilizing function in the composition of low-fat milk-vegetable ice cream.

Conclusions. Studies prove the feasibility of using oat $\beta$ glucan in the amount of $0.75-1.0 \%$ in the composition of low-fat milk-vegetable ice cream. 


\section{Introduction}

Ice cream is a structured multicomponent food product that is also an emulsion, foam and suspension (Landikhovskaya et al., 2021; Syed et al., 2018). High-calorie ice cream with a fat content of at least $10-12 \%$ is stably in high demand due to its rich creamy taste, creamy consistency, and high resistance to melting (Rolon et al., 2017). On the one hand, low-fat ice cream is of increasing interest to consumers as a new trend among low-calorie foods (El-Zeini et al., 2016). On the other hand, the low content of fat $(\leq 3 \%)$ and dry matter $(\leq 30 \%)$ in ice cream has a negative effect on its quality. Excess water causes thinning of the consistency of ice cream and is the cause of polydisperse distribution of the air phase, which worsens the sensory characteristics of ice cream (Landikhovskaya et al., 2020; Goff, 2019).

The effective viscosity of ice cream mixes is one of the most important characteristics, which determines the patterns of formation of the structure of ice cream throughout the technological process of its production. An equally important characteristic is the ability of ice cream after freezing to restore the structure in a static state after the formation of portions before hardening (Bass et al., 2017). To form the appropriate rheological characteristics of ice cream mixes, the components that capable to bind water and structure multi-component mixes were used. Such compounds include polysaccharides, in particular maltodextrin, inulin, polydextrose, gum, pectin and others (Alvarez et al., 2008; Armi Aghdaei et al., 2012; Chiampo et al., 1996; Javidi et al., 2016; Tvorogova et al., 2018; Zghurskyi et al., 2011).

Recently, scientists have shown special interest in $\beta$-glucans - polysaccharides formed from Dglucose monomers connected by beta-glycosidic bonds. This multifunctional ingredient is used in preparation of low-fat foods, as a source of soluble prebiotic fiber. Fermentation of fiber produces a substrate for the microbiota in the large intestine, which further affects digestive function and metabolism of cholesterol and glucose, as well as the immune system and other systemic functions (Bashir et al., 2017; Giavasis, 2014).

$\beta$-glucans from barley, oat, wheat, yeast are not only mimetics of fat, but also bind water, structure mixtures, increase overrun and resistance to melting of ice cream. Each type of $\beta$-glucan differs in molecular weight and structure, which determine its solubility, physiological and technological action (Abdel-Haleem et al., 2015). $\beta$-glucans as macromolecular compounds affect the viscosity characteristics and rheological behavior of aqueous solutions (Irakli et al., 2004). It was found that preparations of polysaccharides of Pleurotus ostreatus, containing $\beta$-glucans, in the amount of $0.1 \%$, improve the structural and mechanical properties of fermented milk drinks (Antontceva et al., 2019).

The feasibility of using beta-glucans of various origins in low-fat ice cream has been scientifically confirmed (Aljewicz et al., 2020). Highly purified oat $\beta$-glucans increased the overrun of ice cream. It was found that (1-3) $\beta$-glucan of linear structure obtained from Agrobacterium sp. bacteria is less effective compared to (1-3) (1-4) $\beta$-glucan from oat in the content range from 0.5 to $1.0 \%$. (Irakli et al., 2004). However, some important viscosity-speed characteristics of mixtures and physicochemical characteristics of ice cream have not been studied yet, including the combination with pectin-containing components. This is what outlines the topicality of a deeper study of this issue.

The purpose of the research is to study the functional and technological properties of oat $\beta$-glucan in the composition of low-fat milk-vegetable ice cream.

To achieve this purpose, it is necessary to solve the following tasks:

- To identify the features of structuring mixtures of low-fat ice cream with $\beta$-glucan;

- Check the structuring ability of $\beta$-glucan in the presence of pectin-containing vegetable raw materials;

- To study the effect of $\beta$-glucan from oats on resistance to melting and the content and dispersion of the air phase in low-fat milk ice cream. 


\section{Materials and methods}

\section{Materials and sample preparation}

The prescription composition of the studied ice cream samples is determined by the following requirements:

- The dry matter content should be from 27.5 to $30.0 \%$, which is typical for the chemical composition of low-fat ice cream;

- Mass fraction of fat should be $3.0 \%$, which corresponds to its content in low-fat ice cream;

- Mass fraction of dry skimmed milk residue should be $10.0 \%$, which ensures the completeness of the milk taste in ice cream with low fat content;

- Mass fraction of sugar should be $15.0 \%$, which provides the traditional degree of sweetness and maintains the dry matter content in ice cream not less than $27.5 \%$;

- Mass fraction of the stabilization system cremodan ${ }^{\circledR}$ si 320 (manufacturer - dupont danisco, denmark) should be $0.7 \%$, which corresponds to its recommended content for this type of ice cream according to the manufacturer's recommendations;

- Mass fraction of the composition of classic hydrocolloids (guar gum, locust bean gum, carrageenan) should be $0.6 \%$, according to the recommendations for low-fat ice cream;

- Mass fraction of $\beta$-glucan oat $70 \%$ (amulyn, china) should be from 0.5 to $1.0 \%$, which is consistent with existing recommendations for the use of such additives in ice cream (Aljewicz et al., 2020);

- Mass fraction of table beet puree with high content of soluble pectin was selected in the amount of $15.0 \%$, according to existing recommendations (Borisova et al., 2014), taking into account the sensory characteristics of table beets and not exceeding the maximum possible content of vegetable puree in ice cream $(\leq 35 \%)$ (Polishchuk et al., 2021). The puree was previously subjected to enzymolysis using the pectolytic enzyme pectolad (Enzim Biotech, Ukraine) (Sapiga et al., 2021).

Cow's milk (3.2\% fat, 9.0\% DSMR) and skimmed milk powder produced in Ukraine were used as a source of dry skimmed milk residue (10.0\%) and milk fat $(2.0 \%)$ in ice cream recipes.

It was studied 2 control mixtures with stabilizers:

- Control 1 was a mixture with a composition of classical hydrocolloids "guar gum + carob gum + carrageenan" $(0.6 \%)$;

- Control 2 was a mixture of Cremodan®SI $320(0.7 \%)$;

It was studied 6 samples without stabilizers with $\beta$-glucan:

- Samples 1-3 were mixtures with $\beta$-glucan in the amount of $0.5,0.75$ and $1.0 \%$, respectively;

- Samples 4-6 were mixtures with $\beta$-glucan $(0.5,0.75$ and $1.0 \%$, respectively) and vegetable puree $(15 \%)$.

Milk-vegetable mixtures were obtained by sequentially mixing the recipe ingredients at a temperature of $(35 \pm 5){ }^{\circ} \mathrm{C}$, followed by their pasteurization at a temperature of $(85 \pm 2){ }^{\circ} \mathrm{C}$ for $120 \mathrm{~s}$. Then the mixtures were homogenized under pressure $(12.0 \pm 1.0) \mathrm{mPa}$ using a laboratory homogenizer-dispersant model 15M-8TA "Lab Homogenizer \& Sub-Micron Disperser" (GAULIN CORPORATION, Massachusetts, USA), cooled to a temperature of $(4 \pm 2){ }^{\circ} \mathrm{C}$ and stored before freezing for 12 hours. 
Prototypes of ice cream were obtained using a freezer of periodic action brand FPM3.5 / 380-50 "Elbrus-400" (JSC "ROSS", Ukraine). The temperature of the mixtures before freezing was $(4 \pm 2){ }^{\circ} \mathrm{C}$. The temperature of the soft ice cream at the outlet of the freezer was minus $(4 \pm 0.5)^{\circ} \mathrm{C}$. Freezing was performed in two stages:

- In the first stage, the mixture was cooled in a cooling cylinder to a temperature of minus

$1{ }^{\circ} \mathrm{C}$ at a speed of the stirrer scraper type $4.5 \mathrm{~s}^{-1}$ for $120 \mathrm{~s}$;

- In the second stage, the mixture was freezed at a stirrer speed of $9 \mathrm{~s}^{-1}$ for $180 \mathrm{~s}$.

Ice cream samples were cooled and stored in a Caravell A / S freezer (Denmark) at minus $(22 \pm 1){ }^{\circ} \mathrm{C}$ during the study. Samples of the same chemical composition were made at least 2 times.

\section{Research methods}

During rheological measurements of milk mixtures and milk-vegetable mixtures, the effective viscosity of practically intact structure, the viscosity of extremely destroyed structure, as well as the ability of these systems to restore it spontaneously after ultimate destruction of the structure were determined, according to V.N. Matveenko and Ye.O. Kirsanova (Matveenko et al., 2011).

The viscosity characteristics of ice cream mixtures were determined on a rotary viscometer with a cylinder-cylinder measuring system by measuring the kinetics of deformation. Shear stress measurements $\tau(\mathrm{Pa})$ were performed at a temperature of $20^{\circ} \mathrm{C}$ at twelve values of the shear rate gradient $(\gamma)$ in the range from 3 to $1312 \mathrm{~s}^{-1}$ in forward and reverse (Bass et al., 2017). At some stages of the study, the maximum effective viscosity of the practically unstructured structure $\left(\gamma=3 \mathrm{~s}^{-1}\right)$, the minimum effective viscosity of the extremely destroyed structure $\left(\gamma=1312.2 \mathrm{~s}^{-1}\right)$ and the effective viscosity of the restored structure were recorded $\left(\gamma=3 \mathrm{~s}^{-1}\right)$.

Thixotropic ability, which is characterized by the degree of restoration of the structure, was determined as a percentage of the difference between the values of effective viscosity of virtually undamaged structure in the shear rate gradient $\left(\gamma=3 \mathrm{~s}^{-1}\right)$ and effective viscosity in reverse measurement with the same shear rate gradient (Polishchuk et al., 2014).

The overrun of soft ice cream was determined by the weight method by the difference between the mass of the samples of the same volume of the mixture and ice cream, expressed as a percentage, according to the formula:

$$
S=\frac{M_{1}-M_{2}}{M_{2}} \cdot 100,
$$

where $M_{1}$ is the mass of the beaker with the mixture, $g$;

$\mathrm{M}_{2}$ - weight of the beaker of ice cream, $\mathrm{g}$.

The resistance to melting of ice cream samples was analyzed by a modified method described by (Roland et al., 1999). Cylinders of $50 \mathrm{~mm}$ high and $35 \mathrm{~mm}$ wide were cut out of solid ice cream after pre-heating at a temperature of minus $12{ }^{\circ} \mathrm{C}$ using a special probe. At room temperature $(22 \pm 2){ }^{\circ} \mathrm{C}$, the formed samples were placed on a sieve, under which there were measuring cylinders with funnels. The melting characteristic of ice cream was taken as the time during which $10 \mathrm{~cm}^{3}$ of liquid mixture was separated.

For microstructural analysis of the air structure, the ice cream sample was taken from the center of the portion from at least three different places, at least $3 \mathrm{~cm}$ from the ice cream surface, placed at $(20 \pm 1){ }^{\circ} \mathrm{C}$ in Goryaev's chamber and covered with a cover glass. Microphotographs were obtained using an Olympus CX 41 light microscope and a camera (Tvorogova et al., 2018). 


\section{Results and discussion}

Study of viscosity-speed characteristics of ice cream mixes with vegetable purees

Table 1 shows viscosity-speed characteristics of the studied ice cream mixes.

Effective viscosity $(\mathrm{mPa} \cdot \mathrm{s})$ of ice cream mixtures with variable shear rate gradient

Table 1

$(\mathbf{P} \geq \mathbf{0 . 9 5} ; \mathbf{n}=\mathbf{3})$

\begin{tabular}{|c|c|c|c|c|c|}
\hline \multirow{2}{*}{$\begin{array}{c}\text { Sample } \\
\text { number }\end{array}$} & $\boldsymbol{\gamma} \mathbf{1}$ & $\boldsymbol{\gamma} \mathbf{2}$ & $\boldsymbol{\gamma 3}$ & $\begin{array}{c}\text { Time of ultimate } \\
\text { destruction of the } \\
\text { structure }(\boldsymbol{\gamma} \mathbf{2}) \mathbf{s}\end{array}$ & $\begin{array}{c}\text { Degree of } \\
\text { restoration of the } \\
\text { structure, \% }\end{array}$ \\
\hline Control 1 & $410.2 \pm 11.6$ & $25.1 \pm 1.1$ & $210.2 \pm 9.1$ & $300.0 \pm 8.2$ & 52.5 \\
\hline Control 2 & $652.2 \pm 15.6$ & $26.0 \pm 1.1$ & $413.2 \pm 11.8$ & $396.6 \pm 7.2$ & 63.4 \\
\hline 1 & $380 \pm 10,3$ & $34.5 \pm 1.0$ & $201.1 \pm 6.1$ & $360.0 \pm 8.1$ & 52.9 \\
\hline 2 & $440.2 \pm 15.6$ & $40.1 \pm 1.1$ & $239.5 \pm 11.8$ & $408.8 \pm 11.2$ & 55.7 \\
\hline 3 & $499.7 \pm 16.1$ & $46.2 \pm 1.7$ & $306.4 \pm 10.0$ & $420.0 \pm 10.2$ & 62.6 \\
\hline 4 & $425.5 \pm 12.8$ & $38.1 \pm 1.4$ & $295.4 \pm 10.2$ & $372.2 \pm 9.1$ & 69.4 \\
\hline 5 & $510.3 \pm 13.7$ & $47.4 \pm 1.3$ & $365.3 \pm 11.0$ & $414.4 \pm 9.2$ & 71.6 \\
\hline 6 & $557.3 \pm 17.5$ & $48.3 \pm 2.0$ & $402.0 \pm 9.3$ & $426.1 \pm 12.2$ & 72.1 \\
\hline
\end{tabular}

Symbols:

$\gamma 1$ - shear rate gradient in the direct course of measurement $\left(3 \mathrm{~s}^{-1}\right)$;

$\gamma 2$ is the maximum shear rate gradient $\left(1312.2 \mathrm{~s}^{-1}\right)$;

$\gamma 3$ is the gradient of the shear rate $\left(3 \mathrm{~s}^{-1}\right)$ at the reverse of the measurement.

According to the results of the study, the effective viscosity of all samples of mixtures at the beginning of the measurement was not lower than the recommended values for ice cream mixtures of different chemical composition (350-850 $\mathrm{mPa} \cdot \mathrm{s}$ ) (Kosoi et al., 2001; Nadtochii et al., 2016; Tvorogova et al., 2018). At the same time, it should be noted that $\beta$-glucan only at a content of $0.75 \%$ approached the values of effective viscosity characteristic of the control mixture 1 . With increasing $\beta$-glucan content, the structuring of mixtures increased due to the probable increase in low energy functional groups of polysaccharide macromolecules. However, it is interesting that the time of ultimate destruction of the structure before equilibrium and the viscosity of mixtures with $\beta$-glucan at the maximum shear rate gradient are greater in comparison with control samples. This effect can be explained by the greater number of sites of successive cellotriose units those "crosslink" $\beta$-glucan macromolecules into the gel matrix (Du et al., 2019).

Also of great interest is the effect of pectin-containing vegetable puree on the nature of the changes in effective viscosity throughout the rheometric measurement cycle. Fermented beet puree in the amount of $15 \%$, which contains about $1.0 \%$ of soluble pectin (Sapiga et al., 2021 ), ensures its presence in the composition of milk-vegetable mixtures in the amount of up to $0.15 \%$. The specific structuring ability of $\beta$-glucan $(0.5-1.0 \%)$ and pectin $(0.15 \%)$ in their joint action allows to increase the thixotropic capacity of ice cream mixtures from 52.9$62.6 \%$ to $69.4-72.1 \%$. This indicates a possible mutually selective synergism of polysaccharides, which is important for stabilizing the structure of ice cream after the formation of portions of ice cream before its low-temperature freezing and storage. Probably, not the last role in increase of thixotropic ability of mixes of milk-vegetable, numerous 
mechanical contacts between the shredded vegetable fibers are played. It should be noted that the detected effect requires further detailed study.

The most typical examples of the dynamics of changes in the effective viscosity of ice cream mixes during the measurement are shown in Figure 1.

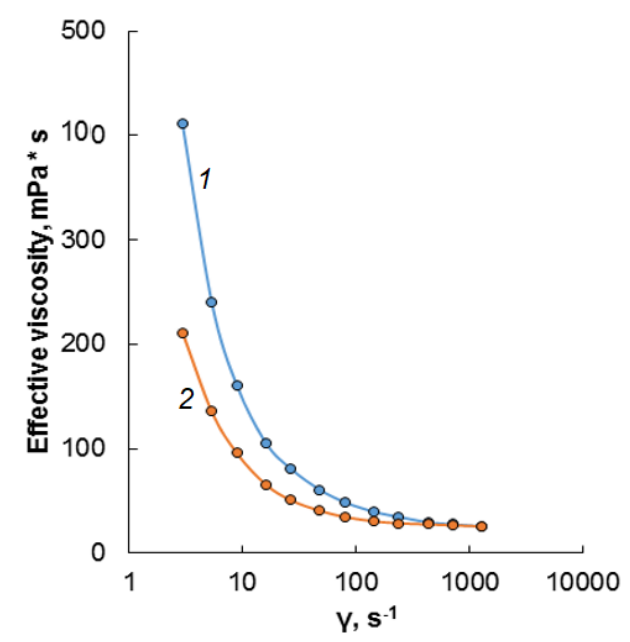

a

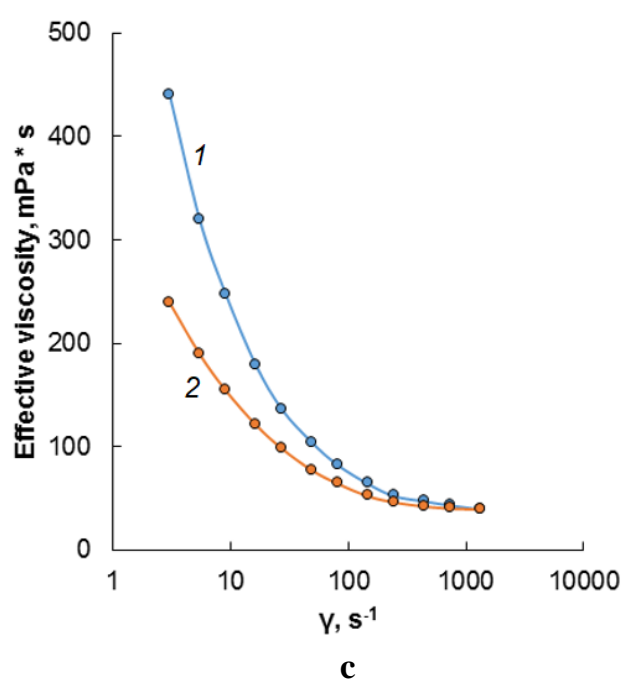

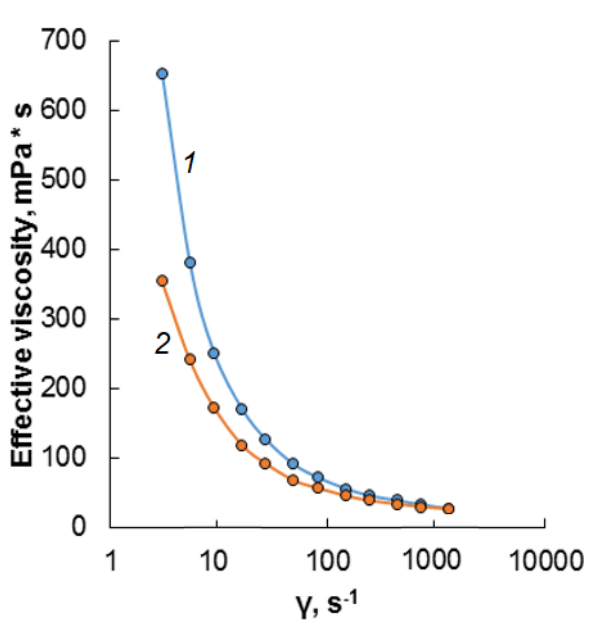

b

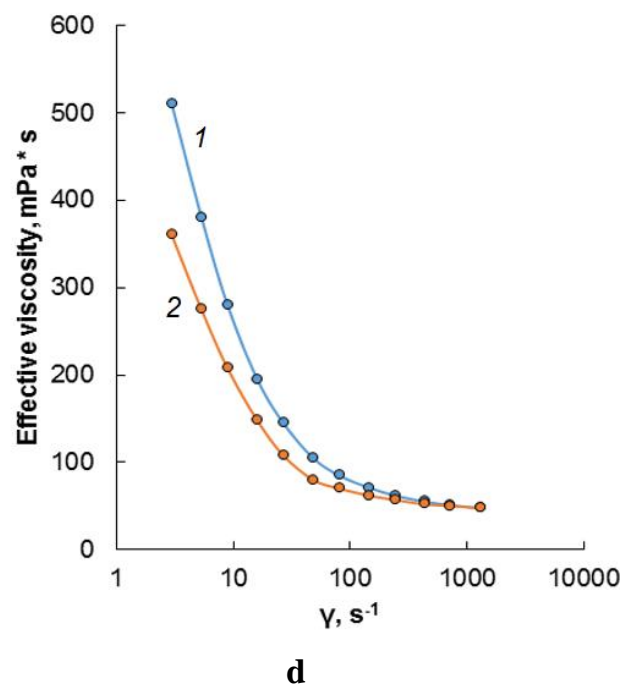

Figure 1. Viscosity-speed characteristics of ice cream mixes: a - control 1 ( $\mathrm{mix}$ with classic stabilizers);

b - control 2 (mixture with stabilization system Cremodan ${ }^{\circledR S I} 320$ ); $\mathbf{c}$ - a mixture with $\beta$-glucan $(0.75 \%) ; d-a$ mixture with $\beta$-glucan $(0.75 \%)$ and vegetable puree $(15 \%)$ 1 - forward course; 2 - reverse course. 
Comparative analysis of the flow rheograms of two control and two experimental samples suggests that the process of destruction of the structure of systems with $\beta$-glucan is slower. This process occurs until the values of effective viscosity $\left(\gamma 2=1312.2 \mathrm{~s}^{-1}\right)$ are almost twice as large - up to $40.1 \mathrm{mPa} \cdot \mathrm{s}$ for sample 2 and up to $47.4 \mathrm{mPa} \cdot \mathrm{s}$ for sample 5 , compared with control samples 1 and $2-25.1 \mathrm{mPa} \cdot \mathrm{s}$ and $26 \mathrm{mPa} \cdot \mathrm{s}$, respectively. Mixtures of milk and milk-vegetable ice cream can be attributed to systems with a pronounced coagulation structure with the detection of thixotropic properties. The latter characteristic is most pronounced for systems containing $\beta$-glucan.

The specific behavior of ice cream mixtures with $\beta$-glucan indicates the presence of low-energy coagulation-type bonds, including the content of vegetable raw materials. Due to the probability of the influence of the particle size of vegetable raw materials on the rheological characteristics of mixtures of dairy and vegetable with $\beta$-glucan, additionally studied sample 5 containing $0.75 \% \beta$-glucan and $15 \%$ vegetable puree:

- The mixture is not homogenized (sample 5a);

- The mixture is homogenized (sample 5b).

Figure 2 shows the effective viscosity of mixtures of both samples with the initial gradient of the shear rate at the forward stroke of the measurement $(\gamma 1)$ and the gradient of the shear rate at the reverse stroke at the end of the measurement $(\gamma 3)$.

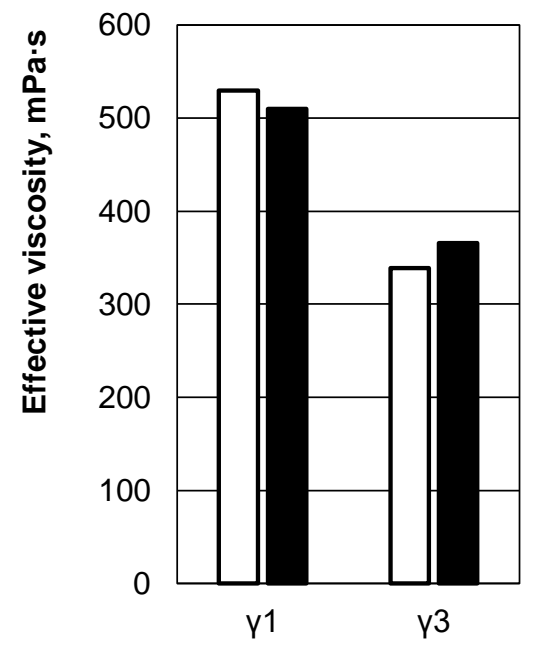

口Sample 5a - Sample 5b

Figure 2. Effective viscosity of a mixture

of non-homogenized milk and vegetable (sample 5a) and homogenized (sample 5b) at the beginning of the measurement (forward stroke, $\gamma 1=3 \mathrm{~s}^{-1}$ ) and at the end of the measurement (reverse stroke, $\gamma 3=3 \mathrm{~s}^{-1}$ )

A slight decrease in the effective viscosity of the homogenized mixture compared to the non-homogenized one was probably observed due to excessive grinding of the plant fibers, which partially lose the ability to form spatial frame grids. There is also a possibility of partial destruction of macromolecules of polysaccharides ( $\beta$-glucan, pectin) under the action of homogenization at a pressure of $(12.0 \pm 1.0) \mathrm{MPa}$. But it should be noted that the 
homogenized mixture to a greater extent showed the ability to restore the structure, which is a significant advantage for stabilizing the structure of ice cream before its formation and hardening. This characteristic is important for the choice of rational modes of operation of the equipment.

In view of this, there is a need for additional study of technological modes of the freezing process, in particular, the duration of freezing and whipping mixtures of ice cream with $\beta$-glucan. This will be taken into account in further research.

Study of oat $\beta$-glucan effect on resistance to melting, content and dispersion of the air phase in low-fat dairy ice cream

The rheological characteristics of ice cream mixes directly affect the physicochemical parameters of ice cream, in particular the overrun, resistance to melting and the state of the air phase in the product (Milliatti et al., 2018).

The different nature of the structuring of ice cream mixtures with $\beta$-glucan and without it may determine the specifics of the processes of formation and stabilization of dispersed systems of dairy ice cream. Therefore, the overrun, the degree of the air phase dispersion and the stability of the foam structure of ice cream with $\beta$-glucan and without it were studied. The overrun of control and experimental samples of soft ice cream at the outlet of the freezer, as well as the resistance to melting of hardened ice cream are shown in Figure 3.

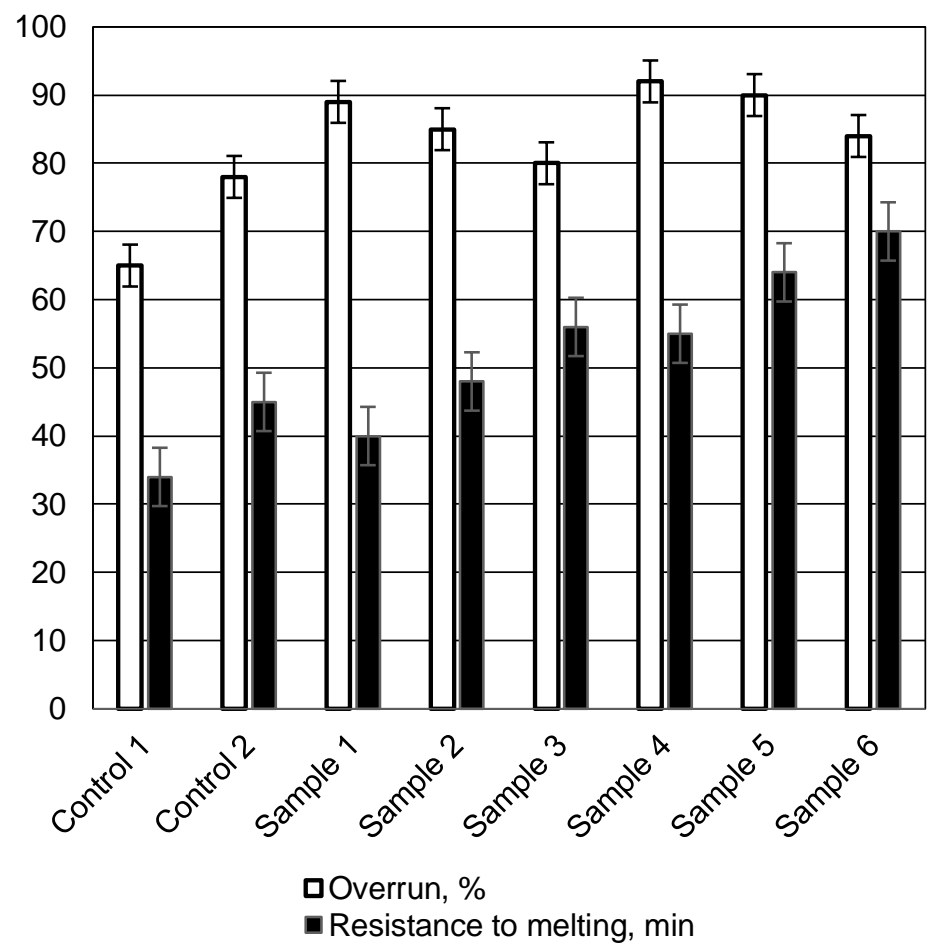

Figure 3. Overrun and resistance to melting of ice cream with and without $\beta$-glucan 
Figure 3 clearly illustrates the effect of structure stabilizers of different origins on the overrun of ice cream. It should be noted the higher foaming ability of the stabilization system Cremodan ${ }^{\circledR S I} 320$ (control 2), compared with the composition of classical stabilizers (control 1 ), due to the presence of emulsifiers-foaming agents. At the same time, the sample 1 with a content of $\beta$-glucan $0.5 \%$ shows the highest foaming ability, which is further enhanced in the presence of pectin in sample 4 . With a further increase in the content of $\beta$-glucan from $0.75 \%$ and above too strong specific mucus-like thickening of mixtures, the overrun of ice cream is somewhat reduced. Probably, long macromolecules of $\beta$-glucan to some extent mechanically limit the aeration of mixtures with its content exceeding $0.5 \%$. Thus, according to the ratio between overrun $(90 \%)$ and resistance to melting $(64 \mathrm{~min})$, the content of $\beta$-glucan at the level of $0.75 \%$ is rational in milk-vegetable ice cream.

As for resistance to melting, $\beta$-glucan undoubtedly has a significant effect on this indicator. There is a monotonous increase in the resistance to melting of ice cream with increasing content of $\beta$-glucan.

To explain the established effect on the peculiarities of the formation and stabilization of the foam structure of ice cream with different stabilizers, the authors further studied the microstructure of control and experimental samples of ice cream. Figure 4 shows the microstructure of ice cream on the example of a sample with classical stabilizers (control 1) and a test sample of ice cream with $\beta$-glucan (sample 5).

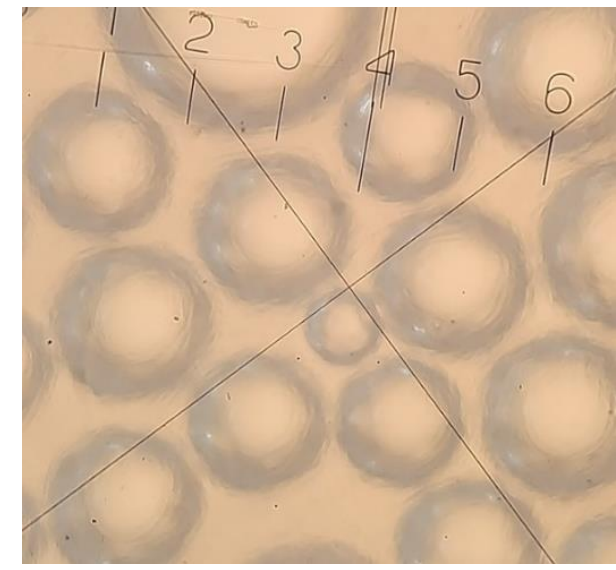

$a$

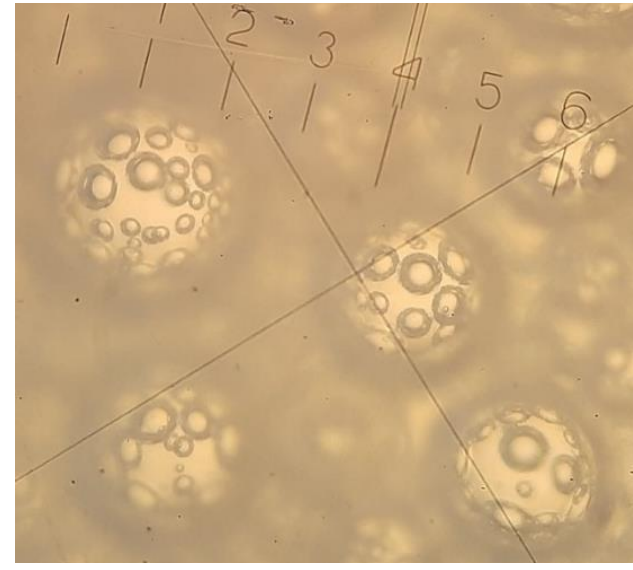

$b$

Figure 4. Microstructure of ice cream samples at a magnification of 10x15: a - control $1 ; \mathbf{b}$ - sample 5

Figure 4 demonstrates the ability of $\beta$-glucan to form a specific secondary foam structure in soft ice cream. This microstructure is characterized by the presence of an additional framework of microbubbles, which wraps larger air inclusions. Due to the complex foam structure of ice cream with $\beta$-glucan, air bubbles acquire additional mechanical strength in conditions of positive temperatures. The foaming ability of $\beta$-glucan has been studied by other scientists (Burkus, 2000), but the ability of this polysaccharide to form a complex foam structure in ice cream has not yet been described. 
The peculiarity of foaming in mixtures in the presence of $\beta$-glucan has been revealed and is a probable reason for the increase in whipping, creamy consistency and stability of ice cream samples during heating.

Thus, according to a set of indicators of technological activity, it can be argued that $\beta$ glucan is a universal multifunctional ingredient that can, in addition to enrichment, perform structuring, foaming and stabilizing functions in dairy ice cream.

\section{Conclusions}

1. The expediency of using oat $\beta$-glucan in low-fat ice cream has been proved, which provides structuring of mixtures within the recommended values of effective viscosity and increases their thixotropic ability.

2. The complex use of $\beta$-glucan with its content from 0.75 to $1.0 \%$ and fermented vegetable puree, which contains soluble pectin and softened plant fibers, can significantly improve the viscosity-speed characteristics of mixtures: the effective viscosity increases by $11-15.9 \%$, and the degree of recovery by an average of $10 \%$.

3 . The effect of $\beta$-glucan on the overrun and resistance to melting of ice cream has been proved. Increased overrun and resistance to melting of ice cream with $\beta$-glucan are due to the formation of a specific secondary foam microstructure, which is characterized by the presence of an additional framework of microbubbles, which wraps larger air inclusions.

4. Prospects for further research are to conduct a comparative analysis of the functional and technological properties of $\beta$-glucan of different origin and varying degrees of purification in ice cream mixes, as well as to clarify the technological modes of production of ice cream with $\beta$-glucan.

\section{References}

Abdel-Haleem A. M., Awad R. A. (2015), Some quality attributes of low fat ice cream substituted with hulless barley flour and barley B-glucan, Journal of Food Science and Technology, 52(10), pp. 6425-6434, DOI: 10.1007/s13197-015-1755-x

Aljewicz M., Florczuk A., Dabrowska A. (2020), Influence of $\beta$-glucan structures and contents on the functional properties of low-fat ice cream during storage, Polish Journal of Food and Nutrition Sciences, 70(3), pp. 233-240, DOI: 10.31883/pjfns/120915

Alvarez E., Cancela M. A., Delgado-Bastidas N., Maceiras R. (2008), Rheological characterization of commercial baby fruit purees, International Journal of Food Properties, 11(2), pp. 321-329, DOI: 10.1080/10942910701359424

Antontceva E., Sorokin S., Sedykh V., Krasnikova L., Shamtsyan M. (2019), Influence of fortification of dairy products by pleurotus ostreatus beta-glucans on product characteristics, Scientific Study \& Research. Chemistry \& Chemical Engineering, Biotechnology, Food Industry, 20(3), pp. 353-364.

Armi Aghdaei S.S., Aalami M., Rezaei R., Dadpour M., Khomeiri M. (2012), Effect of isfarzeh and basil seed mucilages on physicochemical, rheological and sensory properties of ice cream, Research and Innovation in Food Science and Technology, l(1), pp. 23-38, DOI: 10.22101/JRIFST.2012.05.21.113 
Bashir K.M.I., Choi J.S. (2017), Clinical and physiological perspectives of $\beta$-glucans: the past, present, and future, International Journal of Molecular Sciences, 18(9), p. 1906, DOI: 10.3390/ijms18091906

Bass O., Polischuk G., Goncharuk E. (2017), Investigation of viscous characteristics of ice cream mixtures with starch syrup. Ukrainian Food Journal, 6(2), pp. 269-277, https://doi.org/10.24263/2304- 974X-2017-6-2-8

Borisova A. V., Makarova N. V. (2014), Retceptury morozhenogo s antioksidantnymi svoistvami s ispolzovaniem plodoovoshchnogo piure, Pishchevaia Promyshlennost, (9), pp. 18-21.

Burkus Z., Temelli F. (2000), Stabilization of emulsions and foams using barley $\beta$ glucan, Food Research International,33(1), pp. 27-33, DOI: 10.1016/S09639969(00)00020-X

Chiampo F., Tasso M., Occelli A., Conti R. (1996), Rheological properties of fruit purees, Industria Conserve, 71(3), pp. 331-336.

Du B., Meenu M., Liu H., Xu B. (2019), A concise review on the molecular structure and function relationship of $\beta$-glucan, International Journal of Molecular Sciences, 20(16), p. 4032, DOI: 10.3390/ijms20164032

El-Zeini H. M., El-Abd M. M., Mostafa A. Z., El-Ghany F. H. Y. (2016), Effect of incorporating whey protein concentrate on chemical, rheological and textural properties of ice cream, Journal of Food Processing and Technology,7(2), p. 546, DOI: $10.4172 / 2157-7110.1000546$

Giavasis I. (2014), Bioactive fungal polysaccharides as potential functional ingredients in food and nutraceuticals, Current Opinion in Biotechnology, 26, pp. 162-173, DOI: 10.1016/j.copbio.2014.01.010

Goff H.D. (2019), The structure and properties of ice cream and frozen desserts, In: Melton L, Shahidi F, Varelis P, ed., Encyclopedia of food chemistry. Elsevier, pp. 47-54, DOI: 10.1016/b978-0-08-100596-5.21703-4

Irakli M., Biliaderis C. G., Izydorczyk M. S., Papadoyannis I. N. (2004), Isolation, structural features and rheological properties of water-extractable $\beta$-glucans from different Greek barley cultivars, Journal of the Science of Food and Agriculture, 84(10), pp. 11701178, DOI: $10.1002 /$ jsfa. 1787

Javidi F., Razavi S. M., Behrouzian F., Alghooneh A. (2016), The influence of basil seed gum, guar gum and their blend on the rheological, physical and sensory properties of low fat ice cream, Food Hydrocolloids, 52, pp. 625-633, DOI: 10.1016/j.foodhyd.2015.08.006

Kosoi V., Egorov A. (2001), Reologicheskie i reometricheskie isledovaniia po opredeleniiu konsistentcii smesi i zakalennogo morozhenogo na vsekh etapakh ego proizvodstva po fiziko-mekhanicheskim kharakteristikam, Teoreticheskie $i$ prakticheskie osnovy razvitiia protcessov i apparatov pishchevykh proizvodstv, Moscow, pp. 42-44.

Landikhovskaya A.V., Tvorogova A.A. (2021), Ice cream and frozen desserts nutrient compositions: current trends of researches, Food Systems, 4(2), pp. 74-81, DOI: 10.21323/2618-9771-2021-4-2-74-81

Landikhovskaya A. V., Tvorogova A. A., Kazakova N. V., Gursky I. A. (2020), The effect of trehalose on dispersion of ice crystals and consistency of low-fat ice cream, Food Processing: Techniques and Technology, 58(3), pp. 450-459, DOI: 10.21603/20749414-2020-3-450-459

Matveenko V.N., Kirsanov E.A. (2011), Viazkost i struktura dispersnykh sistem, Vestnik Moskovskogo Universiteta. Seriia 2. Khimiia, 52(4), pp. 243-275. 
Milliatti M. C., LANNES S.C.D.S. (2018), Impact of stabilizers on the rheological properties of ice creams, Food Science and Technology, 38, pp. 733-739, DOI: 10.1590/fst.31818

Nadtochii L. A., Arseneva T. P., Abdullaeva M. S., Lepeshkin A. I. (2016), Reologicheskie svoistva vysokobelkovykh smesei dlia izgotovleniia morozhenogo, Mezhdunarodnyi Nauchno-Issledovatelskii Zhurnal, 9(2), pp. 70-73, DOI: 10.18454/IRJ.2016.51.044

Polishchuk H. Ye., Martych V. V., Matsko L. M. (2014), Porivnialnyi analiz reolohichnykh pokaznykiv sumishei dlia vyrobnytstva morozyva na molochnii osnovi, Prodovolchi resursy. Seriia: Tekhnichni nauky, 3, pp. 73-78.

Polishchuk H., Sapiha V., Osmak T., Shevchenko I. (2021), Porivnialnyi analiz strukturuiuchoi zdatnosti ovochevykh piure u skladi sumishei morozyva, Naukovi Pratsi NUKhT, 27(4), pp. 154-164, DOI: 10.24263/2225-2924-2021-27-4-16

Roland A. M., Phillips L. G., Boor K. J. (1999), Effects of fat content on the sensory properties, melting, color, and hardness of ice cream, Journal of Dairy Science, 82(1), pp. 32-38, DOI: 10.3168/jds.S0022-0302(99)75205-7

Rolon M. L., Bakke A. J., Coupland J. N., Hayes J. E., Roberts R. F. (2017), Effect of fat content on the physical properties and consumer acceptability of vanilla ice cream, Journal of Dairy Science, 100(7), pp. 5217-5227, DOI: 10.3168/jds.2016-12379 


\title{
Functional and technological properties of food nanoadditive based of double oxide of bi- and trivalent iron in lyophilic colloidal dispersed systems
}

\author{
Iryna Tsykhanovska ${ }^{1}$, Olena Stabnikova ${ }^{2}$, \\ Oleksandr Alexandrov', Roman Trishch ${ }^{1}$, Olga Blagiy ${ }^{1}$ \\ 1 - Ukrainian Engineering-Pedagogics Academy, Kharkiv, Ukraine \\ 2 - National University of Food Technologies, Kyiv, Ukraine
}

Keywords:

Functional

Nanoadditive

Iron oxide

Colloids

\section{Article history: \\ Received \\ 16.04.2021 \\ Received in \\ revised form \\ 21.07.2021 \\ Accepted \\ 30.12.2021}

\section{Corresponding} author:

Olena

Stabnikova

E-mail:

stabstab6@

gmail.com

DOI:

10.24263/2304-

974X-2021-10-

4-6

\section{Abstract}

Introduction. Magnetofood is food nanoadditive based on double oxide of bi- and trivalent iron. Functional and technological properties of food nanoadditive Magnetofood incorporated in lyophilic colloidal dispersed systems were studied.

Materials and methods. Model systems included food nanoadditive Magnetofood $\left(\mathrm{Fe}_{3} \mathrm{O}_{4}\right)$, water, agar, pectin, and egg albumin. The effective viscosity and thixotropic properties were determined on a rotary viscometer; the strength of the whipped and gel masses was studied by the shear stress; the change in the foam stability was recorded by the settling of the foam column over time.

Results and discussion. Nanoparticles $\mathrm{Fe}_{3} \mathrm{O}_{4}$ of food additive Magnetofood capable to form clusters and exhibit properties of selforganizer caused the formation of electrostatic complexes with proteins and polysaccharides. The thickening, thixotropic, structure-forming, and stabilizing properties of Magnetofood added to lyophilic colloidal systems were studied. Addition of Magnetofood into lyophilic colloidal systems increases the viscosity of foam systems in 1.10-1.15 times, gel systems with agar in 1.22-1.27 times and gel systems with pectin in 1.24-1.29 times. This also slows down the destruction processes in gel structures in 1.15-1.22 times and accelerates the processes of their recovery after termination of mechanical action by $8.8-9.2 \%$, increasing their ability to thixotropy in 1.4-1.5 times. Determination of the ultimate shear stress of colloidal-dispersed systems showed that an addition of Magnetofood to lyophilic colloidal systems increases mechanical strength of foam systems with agar by $11.5-12.6 \%$ and with pectin by $8.2-9.1 \%$, of gel systems with agar in $1.32-1.8$ times and with pectin in 1.49-1.57 times. Addition of Magnetofood to lyophilic colloidal systems increases the speed of gel structuring in $1.73 \pm 0.01$ times for agar and in $1.67 \pm 0.01$ times for pectin compared with the control and a reduction of the amount of gelling agent by $10.0-12.0 \%$ for agar and by $7.0-9.0 \%$ for pectin. The foaming ability of egg albumin increases $1.14-1.40$ times at constant foam stability $99.0 \pm 1.0 \%$ due to the action of $\mathrm{Fe}_{3} \mathrm{O}_{4}$ nanoparticles.

Conclusions. For the first time, the thickening, thixotropic, structure-forming, stabilizing actions of $\mathrm{Fe}_{3} \mathrm{O}_{4}$ nanoparticles in "lyophilic colloids" were studied to determine the functional and technological properties of food additive Magnetofood. 


\section{Introduction}

Lyophilic colloidal disperse systems are microheterogeneous multi- or polyphasic food systems, often based on high molecular weight compounds such as proteins (egg albumin, gelatin), and polysaccharides (pectin, agar). Therefore, to find the methods to stabilize polyphasic "lyophilic colloids", in particular pastille-marmalade products, is relevant. In addition, in today's conditions of strong competition on the domestic market, producers of pastille and marmalade are looking for ways to increase competitive ability by improving the functional and technological characteristics of raw materials which will cause the increasing of consumer properties, reducing costs, and extending shelf life of the finished products. Novel natural additives such as materials of plant origins are widely used in recent years in preparation of different traditional food products (Stabnikova et al., 2021). Application of non-traditional raw plant materials with various properties are widely used to stabilize the polyphase structure of pastille and marmalade and maintain the quality and storage stability of finished products. These materials include industrial food processing wastes from canning, wine, and sugar beet production, and agricultural wastes from seed-growing farms, cotton growing, and melon cultivation. Alternative raw materials such as chitosan, vegetable and fruit products (Cappa et al., 2015; Shaaban et al., 2020) including puree of feijoa, kiwi, Jerusalem artichoke (Emelike and Akusu, 2019; Silva and Abud, 2017); extracts and powders of spicy aromatic herbs and vegetable, fruit and berry powders (help to improve the consistency and consumption characteristics of the finished product, however their disadvantage is insufficient stability of the gel-like structures) (Moghaddam et al., 2009; Sicari et al., 2017); sorbitol (Dai et al., 2020); hydrocolloids such as carrageenan and its sodium, potassium, ammonium salts, including furcellaran, guar gum, locust bean gum, and xanthan gum (help to increase the moisture holding capacity and improve the elastic properties of pastille-marmalade products for a long shelf life) (Gawkowska et al., 2018; Kambulova et al., 2017; Sanzharovskaya et al., 2017) are used in production of pastille and marmalade. Combined systems of structurants are also widely used, for example combinations of gelatin with high methoxyl pectin (Yang et al., 2013); hydrocolloids (Herbagel SW-010, ricogel 8100); sulphated polysaccharides, or k-carrageenan (Kambulova et al., 2017; Mudgil et al., 2011); agar with concentrate of animal proteins Scanpro (Pertsevoi et al., 2008), and various modifying systems such as sodium carboxymethylcellulose (NaCMC) with ferric chloride (Mudgil et al., 2011); sodium lactate or sodium citrate with glycerin (Sanzharovskaya et al., 2017), protein-polysaccharide composite materials (Bealer et al., 2020), and modification of metal nanoparticles and their oxides with polysaccharides, proteins of plant and animal origin such as egg albumin, gelatin, whey protein, gliadin, legume and soy proteins, elastin, zein, milk protein (Liang et al., 2007; Mousavi et al., 2019; Rana et al., 2019; Verma et al., 2018).

A food nanoadditive Magnetofood based on double oxide of bivalent and trivalent iron with a particle size of the nanometer range from 70 to $80 \mathrm{~nm}$ was proposed (Tsykhanovska et al., 2016). Magnetofood has a chemically active near-surface layer, and is characterized by amphiphilicity with $\zeta$-potential of $33-40 \mathrm{mV}$, which is the basis for its use in the production of food with lyophilic colloidal-dispersed structure, in particular pastillemarmalade products. Addition of Magnetofood corrects the surface activity of structurants and affects the effective viscosity of dispersed systems, which is one of the factors of gel and foam forming. Therefore, nanoadditive Magnetofood is able to correct the structural and mechanical properties of jelly masses and foam-like structures, and interact electrostatically with the structurants such as egg albumin, gelatin, pectin, and agar enhancing their actions. Magnetofood nanoparticles promote the formation of various supramolecular structures: 
monolayers, micelles, which capable to stabilize the polyphasic system of "lyophilic colloids", form certain of gel, and foam consistency (Tsykhanovska, 2019; Tsykhanovska et al., 2019a).

The aim of the present research was to study the influence of food additive Magnetofood on the processes of foaming and gelation in the production of pastille and marmalade.

\section{Materials and methods}

\section{Materials}

Food additive Magnetofood is a fine powder of brown or black colour with a particle size of 70-80 nm. By the chemical composition Magnetofood is double iron oxide, $\mathrm{Fe}_{3} \mathrm{O}_{4}$, which was obtained by the chemical coprecipitation from aqueous solutions of bivalent and trivalent iron salts at alkaline $\mathrm{pH}$ (Tsykhanovska et al., 2016).

Model systems, which used in the study, were: (a) gelling agent (pectin or agar) + Magnetofood; (b) foaming agent (egg albumin) + Magnetofood; (c) egg albumin + agar or highly esterified (HE) pectin + Magnetofood; suspensions of nanoparticles Magnetofood in $5 \%$ aqueous solution of highly esterified (HE) pectin, agar or $10 \%$ egg albumin.

A suspension of nanoparticles in egg albumin solution was obtained by addition of the calculated amount of Magnetofood into 10\% egg albumin solution at a temperature of 18$20^{\circ} \mathrm{C}$ under constant stirring 2.0-2.2 turns per second for $3-5 \mathrm{~min}$ followed by holding for 5-7 min.

A suspension of nanoparticles in solution of agar or HE pectin was obtained by addition of the calculated amount of Magnetofood into 5\% solution of polysaccharide at a temperature 55- $60^{\circ} \mathrm{C}$ under constant stirring $2.0-2.2$ turns per second for 5-7 min followed by cooling of the mixture to a temperature $18-20^{\circ} \mathrm{C}$ under continuous stirring.

A suspension egg albumin + agar or HE pectin + Magnetofood was obtained by addition of the calculated amount of food additive into $5 \%$ solution of polysaccharide at a temperature of 55-60 ${ }^{\circ} \mathrm{C}$ under constant stirring $2.0-2.2$ turns per second for 5-7 min followed by cooling the mixture to a temperature $18-20^{\circ} \mathrm{C}$ under continuous stirring, addition of egg albumin powder under continuous stirring for 3-5 min followed by holding for 5-7 min.

\section{Methods}

\section{Rheological properties}

Rheological properties of lyophilic colloidal dispersed systems were estimated by the measurement of the effective viscosity and calculation of the thixotropy coefficient.

The effective viscosity was determined on a rotary viscometer "Reotest-2" in 5\% or $10 \%$ aqueous suspensions of model systems of the structurants (agar, pectin, or egg albumin) at a temperature of $20 \pm 2^{\circ} \mathrm{C}$ according to formula (1):

$$
\eta=\mathrm{k} \cdot \mathrm{U} \cdot \mathrm{T} \cdot \mathrm{A}
$$

where $\eta$ is the effective viscosity, Pa's;

$\mathrm{k}$ is the constant of the measuring node, $\mathrm{Pa} / \mathrm{V}$;

$\mathrm{U}$ is voltage, $\mathrm{B}$;

$\mathrm{T}$ is period of rotation, $\mathrm{s}$; 
A is the shape factor of the measuring unit.

The shear rate was determined by formula (2):

$$
\gamma=1 / \mathrm{T} \cdot \mathrm{A}
$$

where $\gamma$ is the shear rate, $\mathrm{s}^{-1}$.

The thixotropy coefficient was calculated by formula (3):

$$
K_{\text {thix }}=\left(\eta_{\mathrm{rc}} / \eta_{\mathrm{dc}}\right) \cdot 100
$$

where $K_{\text {thix }}$ is thixotropy coefficient, \%;

$\eta_{\mathrm{dc}}$ is the effective viscosity (direct course), Pa's;

$\eta_{\mathrm{rc}}$ is the effective viscosity (reverse course), Pa's.

To determine the thixotropy coefficient the value of viscosity with a minimum and the same shear rate were inserted in formula (3).

Mechanical strength of foam systems and gel masses were expressed through the ultimate shear stress, $\tau, \mathrm{kPa}$, which was determined at a temperature of $20 \pm 2^{\circ} \mathrm{C}$ for foam systems and at $15-25^{\circ} \mathrm{C}$ for gel systems on agar and at $40-75^{\circ} \mathrm{C}$ for gel systems on pectin with an interval of $5^{\circ} \mathrm{C}$ on modified Kargin-Sogolova scales by studying the fracture force (under uniaxial compression).

The test sample was placed on a platform, the position of which was regulated bringing the sample and the punch into a tangential state, loaded scales and fixed the maximum value of load mass that leads to the crushing of the sample. The fracture force was determined by the formula (4):

$$
P_{f}=4 m \cdot g / \pi \cdot d^{2}
$$

where $\mathrm{P}_{\mathrm{f}}$ is the fracture force, $\mathrm{kPa}$;

$\mathrm{m}$ is weight of load, $\mathrm{kg}$;

$\mathrm{g}$ is free fall acceleration, $\mathrm{m} / \mathrm{s}^{2}$;

$\mathrm{d}$ is the diameter of the sample, $\mathrm{m}$;

$\pi$ is coefficient 3.14 .

The rate of structuring of gel masses was determined by formula (5):

where $\mathrm{V}_{\text {str }}$ is the rate of structuring, $\mathrm{kPa} / \mathrm{s}$;

$$
\mathrm{V}_{\mathrm{str}}=\left(\tau_{\max }-\tau_{0}\right) / \mathrm{t}_{\mathrm{str}}
$$

$\tau_{\max }$ is the maximum value of strength, $\mathrm{kPa}$;

$\tau_{0}$ is the initial value of strength, $\mathrm{kPa}$;

$t_{\text {str }}$ is the duration of structuring, min.

Foaming ability was determined by the Lurie method and calculated by formula (6):

$$
\mathrm{F}_{\mathrm{a}}=\left(\mathrm{V}_{\mathrm{f}} / \mathrm{V}_{\mathrm{s}}\right) \times 100
$$

where $\mathrm{F}_{\mathrm{a}}$ is the foaming ability, \%;

$V_{f}$ is the volume of foam, $\mathrm{m}^{3}$;

$\mathrm{V}_{\mathrm{s}}$ is the volume of the sample before beating, $\mathrm{m}^{3}$. 
Foam stability was determined as the ratio of the height of the foam column to the total height of the sample, expressed as a percentage after holding for $6 \mathrm{~min}$ for foamy systems, and $144 \mathrm{~min}$ for foam systems and calculated by formula (7):

$$
\mathrm{F}_{\mathrm{s}}=\left(\mathrm{H}_{\mathrm{f}} / \mathrm{H}_{0}\right) \times 100
$$

where $F_{s}$ is the foam stability, \%;

$\mathrm{H}_{\mathrm{f}}$ is the height of foam, $\mathrm{m}$;

$\mathrm{H}_{0}$ is the initial height of foam, $\mathrm{m}$.

\section{Statistical analysis}

All analyses were performed at least in triplicates, and data were expressed as mean \pm standard deviation. The differences were considered statistically significant with a reliability of $\alpha=0.95$.

\section{Results and discussion}

\section{Influence of Magnetofood addition on the effective viscosity of gel systems}

The dependence of the effective viscosity $(\eta)$ of aqueous solutions of gel systems "gelling agent + Magnetofood" from the content of Magnetofood, \% (w/w), is shown in Figure 1.

Addition of Magnetofood to all gel systems increased the viscosity in the entire range of shear stress: for change of $\gamma$ from 1.5 to $40 \mathrm{~s}^{-1}$ the effective viscosity increased by 1.22-1.27 times for systems with agar and by 1.24-1.29 times for systems with pectin in comparison with control (Figure 1). This is due to the chemical activity of the structure-forming cations $\mathrm{Fe}^{2+}$ and $\mathrm{Fe}^{3+}$ located on the surface of nanoparticles Magnetofood and their electrostatic interaction with macromolecules of polysaccharides, which resulted in the formation of a spatial grid. The expedient amount of Magnetofood to be added to gel systems is $0.15 \%$ $(w / w)$, because its further increase has almost no effect on the change in viscosity of gel solutions.

\section{Influence of Magnetofood addition on thixotropic reduction of gel systems}

Analysis of the change of thixotropic reduction coefficient of the primary structure of the aqueous solutions of gelling agents showed an increase in the coefficient of thixotropy, $\mathrm{K}_{\text {thix }}$, on average in 1.4-1.5 times when Magnetofood was added to the system in comparison with control) (Figure 2).

The thixotropic properties of gel-like systems with Magnetofood have been shown. The addition of Magnetofood to aqueous solutions of gelling agents slowed down the destruction processes in 1.15-1.22 times and accelerated the processes of restoration of the gel structure after the cessation of mechanical action by $8.8-9.2 \%$, increasing its ability to thixotropy in $1.4-1.5$ times. This is due to the surface-active properties of Magnetofood and their ability to form a certain consistency and stabilize the lyophilic colloidal dispersed system, which prevents its separation (Tsykhanovska, 2019; Tsykhanovska et al., 2019a). 

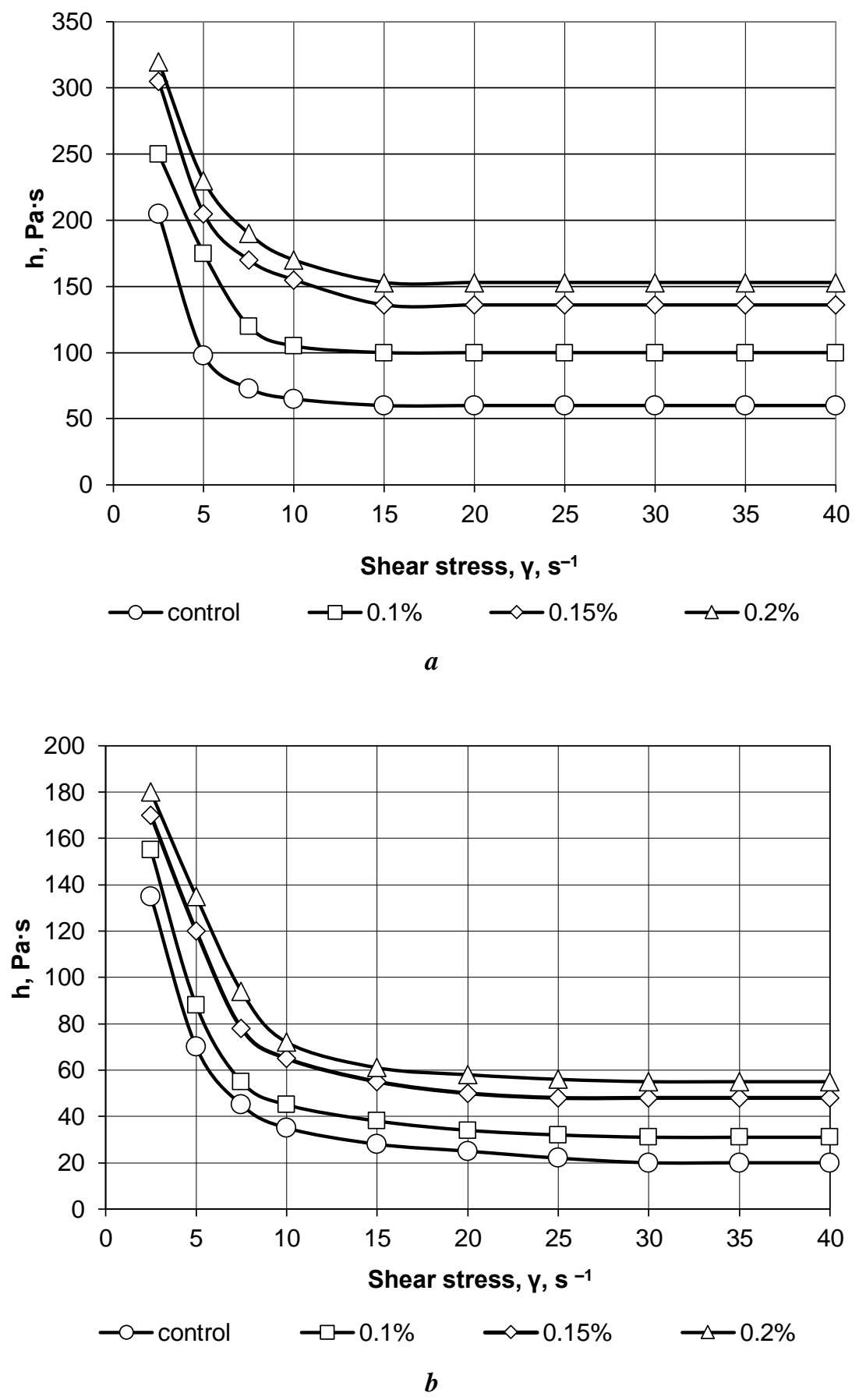

Figure 1. Influence of Magnetofood addition on the effective viscosity of gel systems containing agar $(a)$ and pectin $(b)$ 

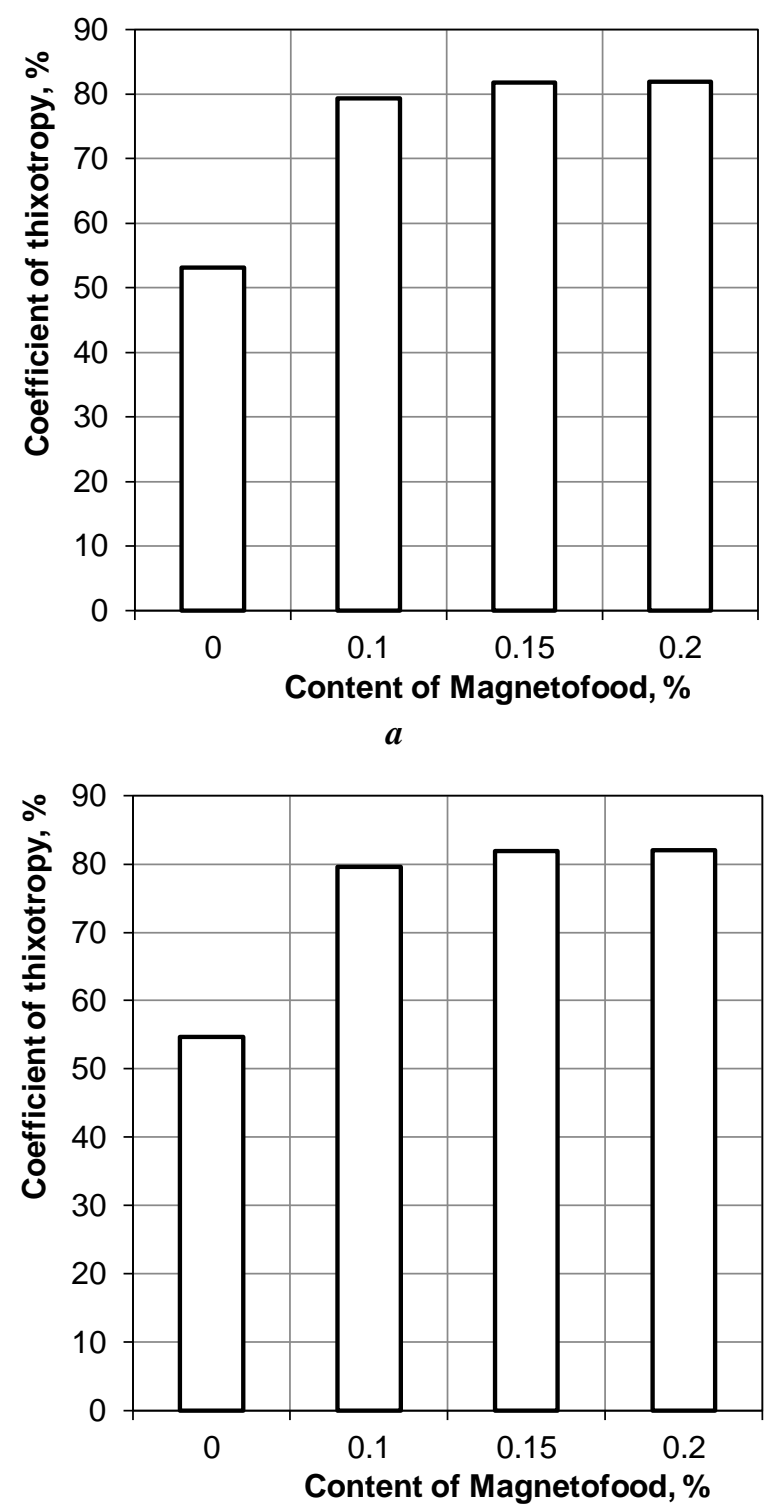

b

Figure 2. Influence of Magnetofood addition on thixotropic reduction of gel systems containing agar $(a)$ and pectin $(b)$ 
Influence of Magnetofood addition on foaming processes and rheological properties of lyophilic colloids

Surface activity and clusterophilicity of Magnetofood can be demonstrated by its influence on foaming processes and rheological properties of lyophilic colloids of egg albumin. Influence of Magnetofood addition in different amounts $0.05,0.10,0.15,0.20 \%$ (w/w of dry egg albumin) on foaming ability $\left(\mathrm{F}_{\mathrm{a}}\right)$ and effective viscosity $(\eta)$ of gel systems "egg albumin + Magnetofood" is shown in Figure 3.

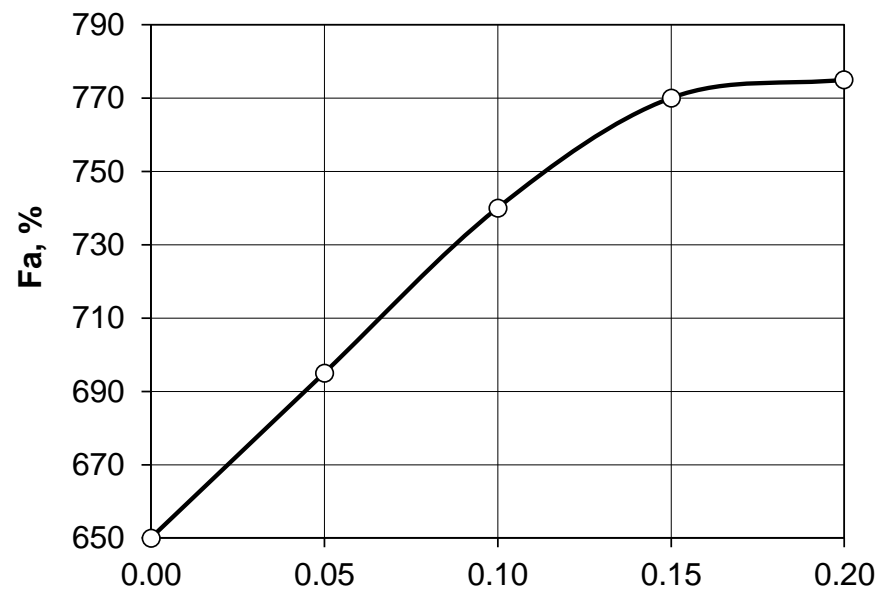

Content of Magnetofood, \%

$a$

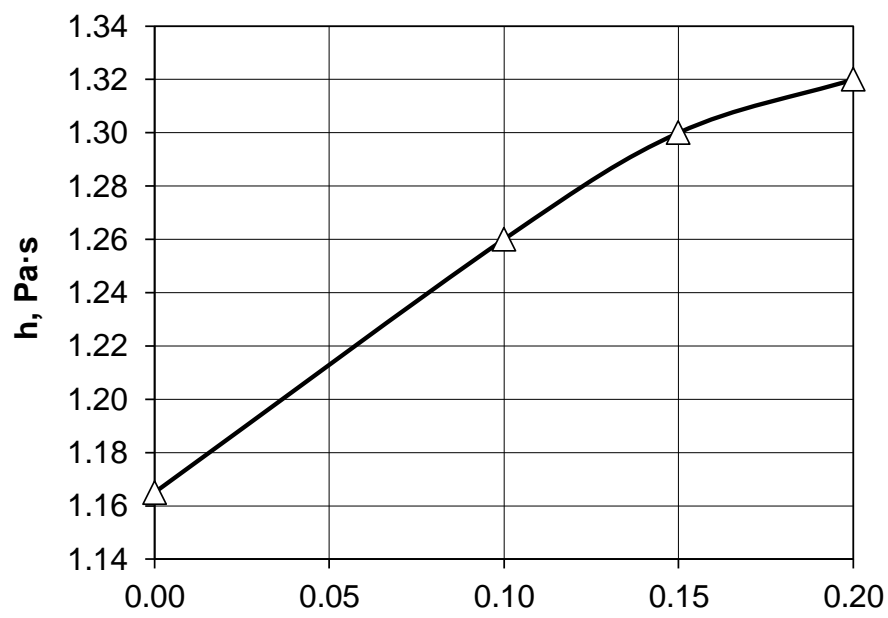

Content of Magnetofood, \%

$b$

Figure 3. Influence of Magnetofood addition on foam-producing property, $F_{a}, \%,(a)$ and effective viscosity, $\eta, \mathrm{Pa} \cdot \mathrm{s}(\mathrm{b})$ at shear stress $\gamma 4.4 \mathrm{~s}^{-1}$ of gel systems "Egg albumin + Magnetofood"“. 
The addition of Magnetofood into solution of egg albumin increased its foam-producing property in 1.14-1.19 times compared with control due to reduction of the surface tension of the protein and increased of the rate of coagulation of protein molecules under the action of Magnetofood. This led to an increase in the volume concentration of the air phase in the protein solution and to a decrease of the air bubbles sizes. The foam stability of all systems "egg albumin + Magnetofood" was $99 \pm 1 \%$ because of the stabilizing action of Magnetofood due to the presence of nanoparticles with chemically active surface on the interface of phases in the adsorption layer. This increased cohesion between protein molecules. As a result, the mobility of the liquid decreased, its flow in the film was slowed down, thus preventing the coalescence of foam bubbles. At the same time, the viscosity of the liquid in the foam films increased, which slowed down their destruction and stabilized the foam $\left(\mathrm{F}_{\mathrm{s}}\right)$ at the level of $99 \pm 1 \%$ (Tsykhanovska et al., 2019b). The addition of Magnetofood also increased in 1.101.15 times the effective viscosity of the system "egg albumin + Magnetofood" due to electrostatic and coordination interaction of nanoparticles with macromolecules of egg albumin and branching of the main chains of its macromolecules (Figure 3b). Thus, studies of the rheological properties of lyophilic colloidal-dispersed systems (aqueous solutions "gelling agent (agar, pectin) + Magnetofood" and "egg albumin + Magnetofood") confirmed the hypothesis of adjusting these properties of "lyophilic colloids" due to the influence of Magnetofood nanoparticles. The rational amount of Magnetofood addition was determined as $0.15 \%$ by weight of the structurant.

\section{Influence of Magnetofood addition on stability of foam systems}

Changes of the strength, $\tau, \mathrm{kPa}$, of foam systems "egg white + gelling agent + Magnetofood" during $90 \mathrm{~min}$ showed that the addition of Magnetofood accelerated the gelation process by $2.0-2.5 \mathrm{~min}$ on agar and by $2.0-2.2 \mathrm{~min}$ on pectin, and increased the maximum shear stress by $11.9-12.6 \%$ on agar and by $8.2-9.1 \%$ on pectin due the formation of supramolecular associates with nanoparticles (Figure 4).

The gel-forming effect of Magnetofood reveals in aggregation of polysaccharides and an increase in the roughness of their channels caused an increase of the stability of the foam films and an increase in the drag-forming ability of pectin and agar. This increases the viscosity in the Gibbs-Plateau channels that leads to stabilization of the gel framework of the foam structure and slows down the process of syneresis. As a result, the process of gel formation is accelerated and the strength of the whipped mass increases.

\section{Influence of Magnetofood addition on ultimate shear stress of gel systems}

Changes of the ultimate shear stress, $\tau, \mathrm{kPa}$, of gel systems" gelling agent + Magnetofood" with the amount of Magnetofood $0.15 \%$ in time is shown in Figure 5.

Addition of Magnetofood increased the strength of the gel system with agar in 1.32-1.8 times and with pectin in 1.49-1.57 times compared to control. 

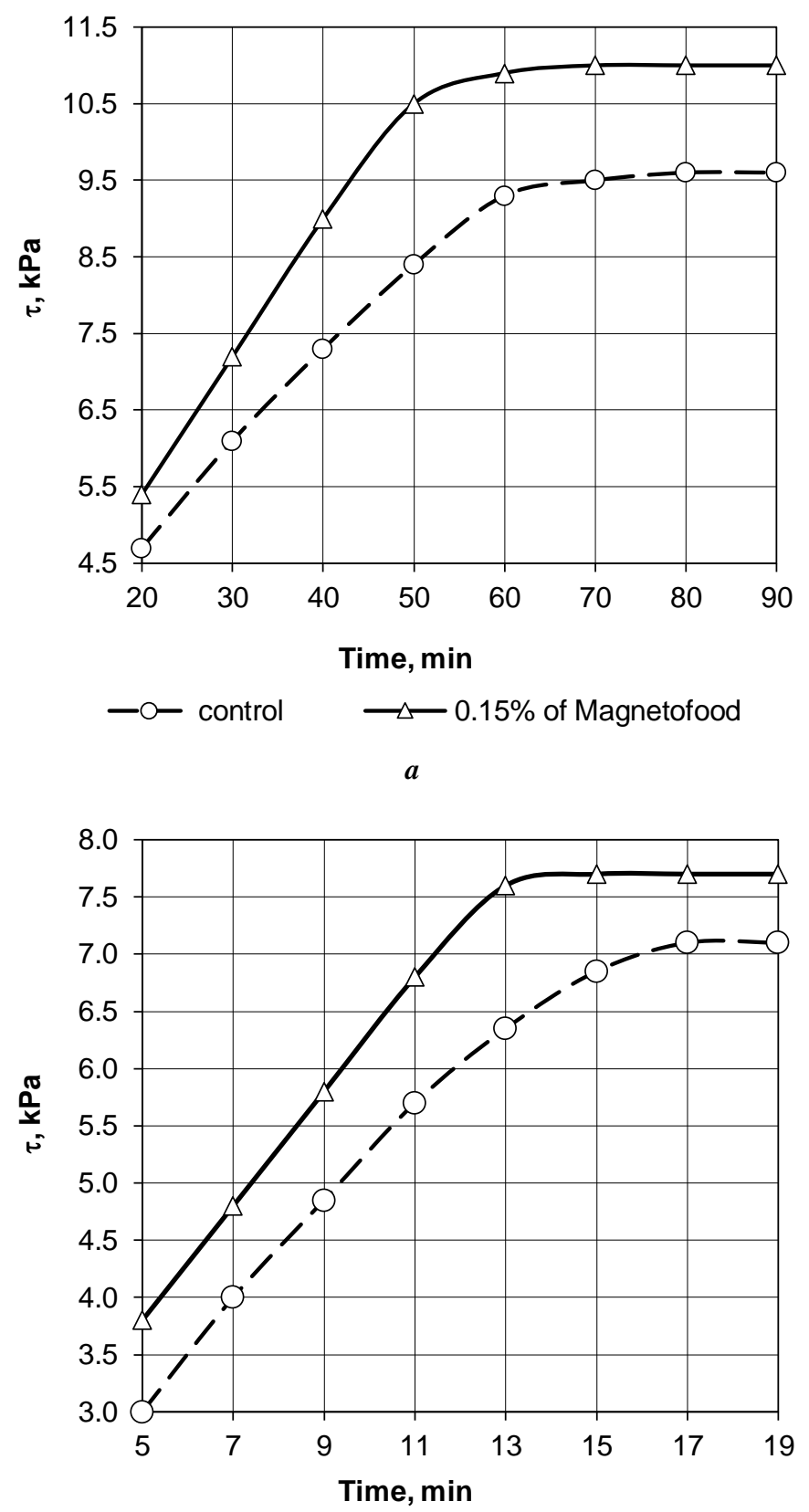

$-\infty$ control $\longrightarrow \longrightarrow 0.15 \%$ of Magnetofood

Figure 4. Changes of stability of foam systems "egg albumin + gelling agent + Magnetofood" in time with: $a$ - agar; $b$ - pectin. 


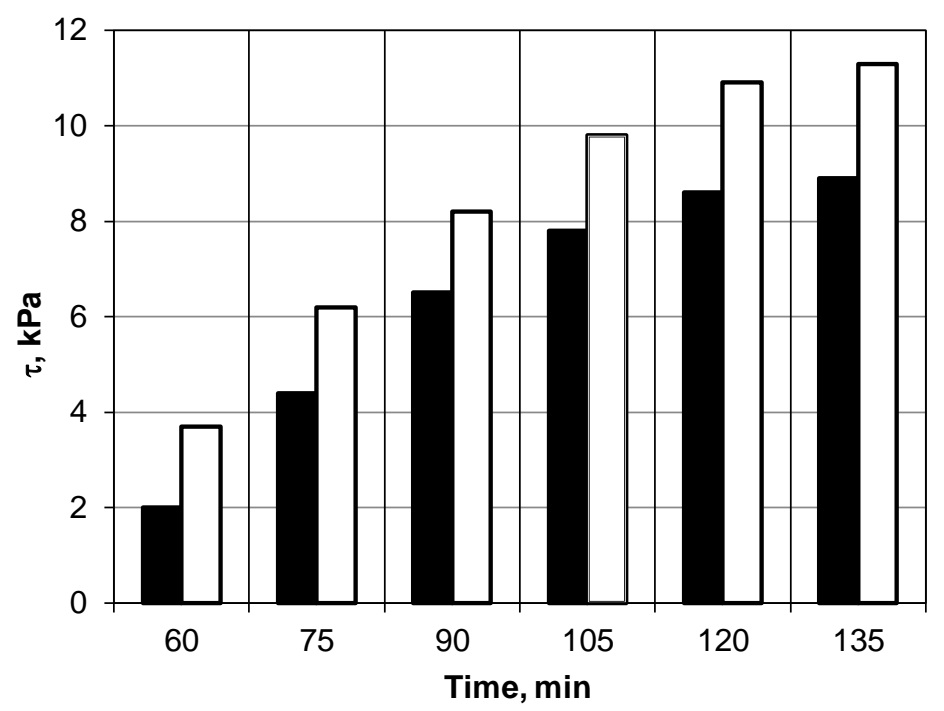

- control $\quad \mathbf{0} 0.15 \%$ of Magnetofood

$a$

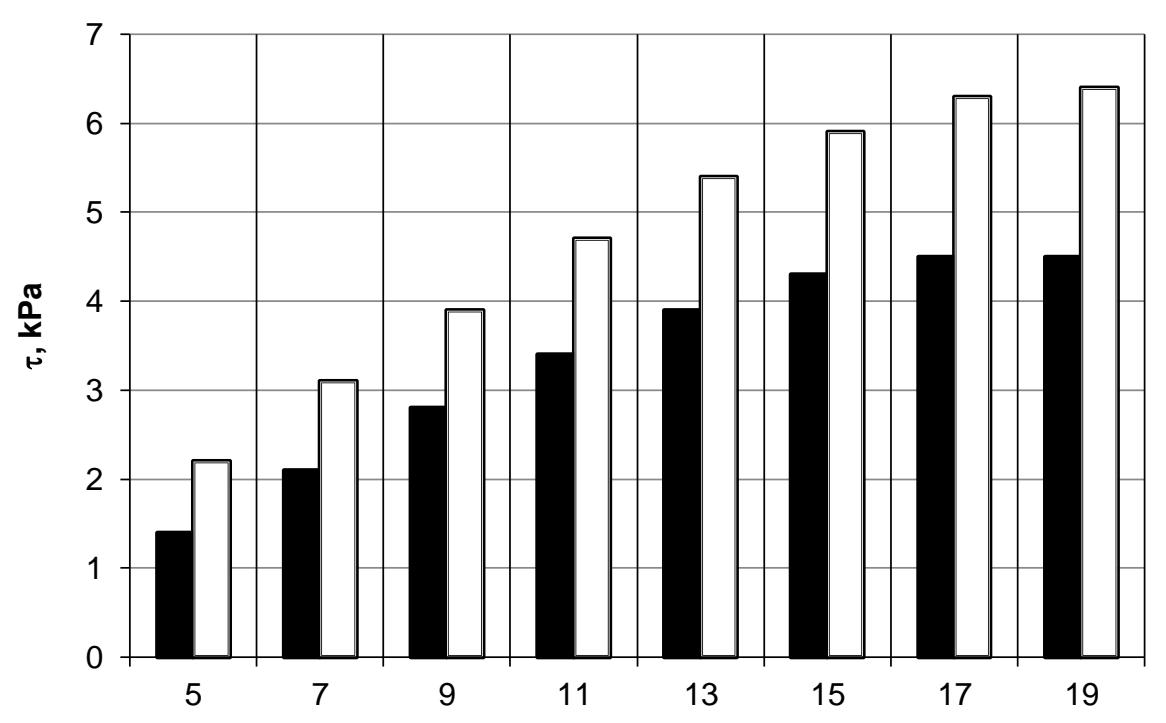

Time, $\min$

- control $\quad \square 0.15 \%$ of Magnetofood

$b$

Figure 5. Changes of the ultimate shear stress of gel systems

"gelling agent + Magnetofood" in time at different temperatures with: $a$-agar; $b$ - pectin. 


\section{Influence of Magnetofood addition on the rate of structuring of gel masses}

The rate of structuring of gel masses was determined using formula (5) (Figure 6).

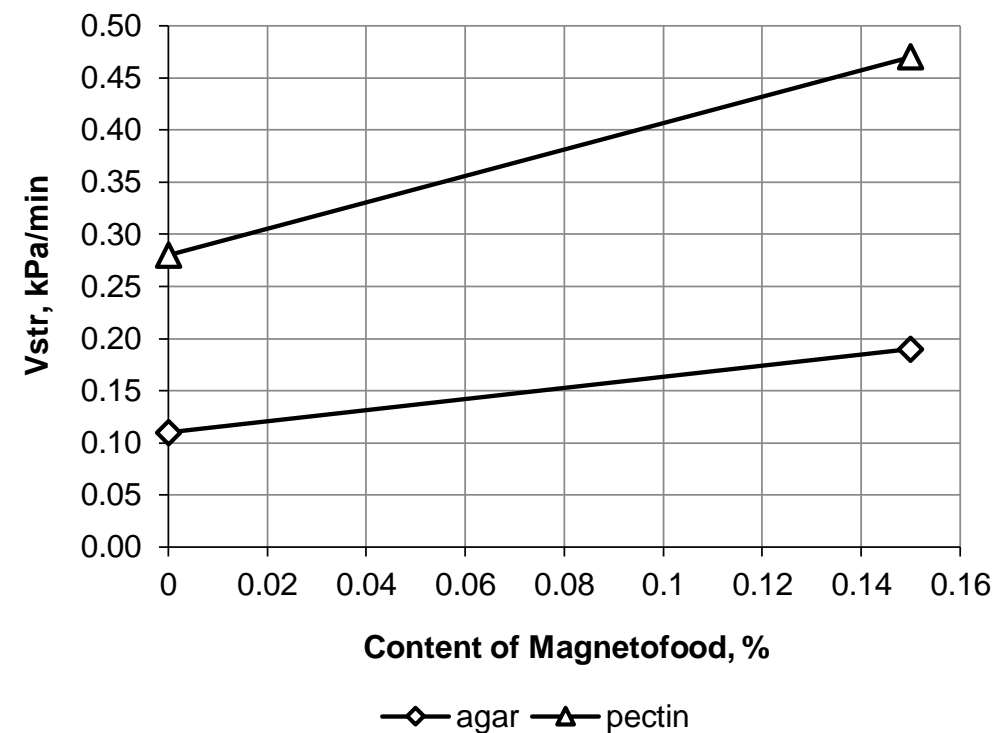

Figure 6. Rate of structuring of gel masses

Addition of Magnetofood leads to an increase of the rate of structuring of gel masses with agar in $1.73 \pm 0.01$ times and with pectin in $1.67 \pm 0.01$ times compared to control. This is due to the ability of Magnetofood to interact with polysaccharides and form an ordered spatial framework that strengthens the gel-like structures. As a result, the formation of a good texture of jelly products having high consumer properties is observed. Additionally, the release of moisture from the products during storage is significantly reduced, so they stay fresh for a longer time. Studies of the structural and mechanical parameters of lyophilic colloidaldispersed systems confirmed the stabilization effect of Magnetofood nanoparticles addition on the polyphasic structure of "lyophilic colloids". Introduction of Magnetofood, $0.15 \%$ by the weight of the structurants, in "lyophilic colloids" allows to reduce the amount of structurants, namely, agar by $9.0-11.0 \%$ and pectin by $7.0-9.0 \%$. It also increases the strength of (a) whipping masses with agar by $11.9-12.6 \%$ and with pectin by $8.2-9.1 \%$ in comparison with control; (b) gel jelly with agar in 1.32-1.80 times and with pectin in 1.491.57 times. Thus, application of food additive Magnetofood accelerates and enhances the processes of structure formation in lyophilic colloidal dispersed systems.

\section{Conclusions}

1. Nanoadditive Magnetofood based on double oxide of bivalent and trivalent iron possesses surface activity and clusterophilicity. 
2. Nanoadditive Magnetofood being added into lyophilic colloid-disperse system accelerates and enhances the processes of its structure formation due to electrostatic and coordination interactions of nanoparticles with macromolecules of egg albumin and polysaccharides.

3. Addition of Magnetofood into the polyphase dispersed system increases its effective viscosity, foaming ability; reduces the speed of structuring; increases the mechanical strength and improves the thixotropic properties of foam and gel systems, which ensured high quality of the final product and extend its shells life.

\section{Recommendations}

The conducted research demonstrated high functional-technological potential of food nanoadditive Magnetofood, which application in technologies of food products with polyphase structure can improve functional-technological properties of heterogeneous dispersed systems and extend shelf life of finished products.

\section{References}

Bealer E.J., Onissema-Karimu S., Rivera-Galletti A., Francis M., Wilkowski J., Cruz D.S., Hu X. (2020), Protein-polysaccharide composite materials: fabrication and applications, Polymers, 12(2), p. 464, DOI: 10.3390/polym12020464.

Cappa C., Lavelli V., Mariotti M. (2015), Fruit candies enriched with grape skin powders: Physicochemical properties. LWT Food Science and Technology, 62, pp. 569-575, DOI: 10.1016/j.lwt.2014.07.039.

Dai H., Li X., Du J., Ma L., Yu Y., Zhou H., Guo T., Zhang Y. Effect of interaction between sorbitol and gelatin on gelatin properties and its mechanism under different citric acid concentrations. Food Hydrocolloids, 2020, 101(4), pp. 105557-105564, DOI: 10.1016/j.foodhyd.2019.105557.

Emelike N.J.T., Akusu O.M. (2019), Quality attributes of jams and marmalades produced from some selected tropical fruits, Journal of Food Processing \& Technology, 10(5), DOI: 10.4172/2157-7110.1000790.

Gawkowska D., Cybulska J., Zdunek A. (2018), Structure-related gelling of pectins and linking with other natural compounds: a review, Polymers (Basel), 10(7), pp. 762-778, DOI: 10.3390/polym10070762.

Kambulova Y.I., Matyas D.I., Malinovsky V.I. (2017), Rheological indicators of marmalade masses on agar and carrageenan and varieties of sugars. Food Industry AIC, 4(46), pp. 1923.

Liang Y.Y., Zhang L.M., Li, W., Chen R.F. (2007), Polysaccharide-modified iron oxide nanoparticles as an effective magnetic affinity adsorbent for bovine serum albumin, Colloid and Polymer Science, 285, pp. 1193-1199, DOI: 10.1007/s00396-007-1672-2.

Mudgil D., Barak S., Khatkar B.S. (2011), Food additives in confectionery industry: An overview, Indian Food Packer, 65(3), pp. 80-83.

Moghaddam T.M., Razavi S.M.A., Malekzadegan F., Ardekani A.S. (2009), Chemical composition and rheological characterization of pistachio green hull's marmalade. Journal of Texture Studies, 40(4), pp. 390-405, DOI: 10.1111/j.1745-4603.2009.00188.x.

Mousavi S.M., Hashemi S.A., Ramakrishna S., Esmaeili H., Bahrani S., Koosha M., Babapoor A. (2019), Green synthesis of supermagnetic $\mathrm{Fe}_{3} \mathrm{O}_{4}-\mathrm{MgO}$ nanoparticles via Nutmeg essential 
oil toward superior anti-bacterial and anti-fungal performance, Journal of Drug Delivery Science and Technology, 54, 101352, DOI:10.1016/j.jddst.2019.101352.

Pertsevoi F.V., Teimurova A.T., Pohozhykh M.I., Pak A.O. (2008), Study of the mechanism of action of Scanpro additives on the structural and mechanical properties of gems, Modern directions of technology and mechanization of processes of processing and food production: A Collection of Scientific Works of Petro Vasylenko Kharkiv National University of Agriculture, 74, 146-153.

Rana P., Sharma S., Sharma R., Banerjee K. (2019), Apple pectin supported superparamagnetic $\left(\gamma-\mathrm{Fe}_{2} \mathrm{O}_{3}\right)$ maghemite nanoparticles with antimicrobial potency, Materials Science for Energy Technologies, 2(1), pp. 15-21, DOI: 10.1016/j.mset.2018.09.001.

Sanzharovskaya N.S., Khrapko O.P. (2017), Technology of jelly marmalade manufacture based on pectin extracts and herbal potions. International Research Journal, 10(64), pp. 95-98, DOI: 10.23670/IRJ.2017.64.055.

Sicari V. (2017), Use of orange by-products (dry peel) as an alternative gelling agent for marmalade: Evaluation of antioxidant activity and inhibition of HMF formation during production different storage temperature, Journal of Food Processing and Preservation, 42(2), e13429, DOI:10.1111/jfpp.13429.

Silva C.E.F., Abud A.K.S. (2017), Tropical fruit pulps: processing, product standardization ands ( $\mathrm{m}$ main control parameters for quality assurance. Brazilian Archives of Biology and Technology, 60, pp. 1-12. https://doi.org/10.1590/1678-4324-2017160209.

Shaaban H.A., El-Said A.N.M., Nagib A.I. (2020), Dates utilization to process some new dietary product (marshmallow and sheets) and their acceptability evaluation, Asian Journal of Biotechnology, 12(1), pp. 47-55, DOI: 10.3923/ajbkr.2020.47.55.

Stabnikova O., Marinin A., Stabnikov V. (2021), Main trends in application of novel natural additives for food production, Ukrainian Food Journal, 10(3), pp. 524-551.

Tsykhanovska I. (2019), Development of molded jelly marmelad technology with the introduction of food additive Magnetofood, Bulletin of the National Technical University "KhPI". Ser.: New Solutions in Modern Technologies, Kharkiv: NTU "KhPI", 10(1335), pp. 109-120, DOI: $10.20998 / 2413-4295.2019 .10 .14$.

Tsykhanovska I., Alexandrov O., Evlash V., Gontar T., Lazareva T. (2016), Food additive Magnetofood. Patent UA 126502.

Tsykhanovska I., Yevlash V., Khamitova B., Kaida N. (2019a), Influence of the Magnetofood food supplement on the structural and mechanical properties of molded fruit jelly with various structure-forming agents. Bulletin of the National Technical University "KhPI". Ser.: New Solutions in Modern Technologies, Kharkiv: NTU "KhPI", 5(1330), pp. 75-186, DOI:10.20998/2413-4295.2019.05.23.

Tsykhanovska I., Yevlash V., Alexandrov A., Khamitova B., Svidlo K., Nechuiviter O. (2019b), Forming the structure of whipped desserts when introducing the food additive «Magnetofood» to their formulation, Eastern-European Journal of Enterprise Technologies, 2, 11(98), pp. 45-55, DOI: 10.15587/1729-4061.2019.161855.

Verma D., Gulati N., Kaul S., Mukherjee S., Nagaich U. (2018), Protein based nanostructures for drug delivery, Journal of Pharmaceutics, Article ID 9285854, DOI: 10.1155/2018/9285854.

Yang Y., Zhang G., Hong Y., Gua Z., Fang F. (2013), Calcium cation triggers and accelerates the gelation of high methoxyl pectin, Food Hydrocolloids, 32(2), pp. 228-234, DOI: 10.1016/j.foodhyd.2013.01.003. 


\title{
Changes in volatile compounds of Ayvalık (Edremit) and Uslu olive oils depending on conditions and time of storage
}

\author{
Pelin Günç Ergönül ${ }^{1}$, Alev Yüksel Aydar ${ }^{1}$, \\ Tuba Göldeli ${ }^{1}$, Annalisa Mentana ${ }^{2}$, Maurizio Quinto
}

\author{
1 - Manisa Celal Bayar University, Manisa, Turkey \\ 2 - Foggia University, Foggia, Italy
}

\section{Keywords:}

GC-MS

Holding

Olive Oil

PCA

Volatile

Compounds

Article history:

Received

23.05.2021

Received in

revised form

21.12.2021

Accepted

30.12.2021

Corresponding

author:

Pelin Günç

Ergönül

E-mail:

pelin.ergonul@

cbu.edu.tr

\section{DOI:}

$10.24263 / 2304-$

974X-2021-10-4-

7

\section{Abstract}

Introduction. Volatile aromatic compounds present in olive oils extracted from Turkish olive cultivars including Edremit (Ayvalık) and Uslu were determined qualitatively.

Materials and methods. The olives were harvested from Akhisar/Manisa region, which is one of most important Turkish olive-growing locations, at almost the same maturity stage by hand. Harvested olives were put in case and nylon sacks and were stored under the same conditions until they analyzed. Determination of the volatile aroma compounds were done with the aim of Headspace Solid-Phase Microextraction (HS-SPME) and Gas Chromatography-Mass Spectrometry (GC-MS).

Results and discussion. 46 different volatile compounds were identified. The inappropriate storage conditions of olives had a negative impact on the aroma profiles of oils. The most abundant compounds were hexanal, $\alpha$-farnesene, dimethylpalmitamine, and $\alpha$-Farnesene, 2-hexanal, hexanal in olive oils extracted from Edremit (Ayvalık) and Uslu varieties, respectively.1-Hexanol was mostly increased compound in Edremit olive oils extracted from olives stored at nylon sacks during 14 days. The increase of concentration of 2-hexanal during holding periods could be explained by the activity of the fungal enzymes in Lipoxygenase pathway of olive fruits. While 5-Hepten-2-one 6-methyl and 1Butanol 3-methyl were not detected in Edremit and Uslu olive oils at initial day, they formed during both sack and box holding due to the microbial activity in olives. Three principal components (PCs) were extracted representing $81.27 \%$ of the total variance of olive oil samples extracted from Uslu cultivar and $80.14 \%$ of the total variance of olive oil samples extracted from Edremit cultivar. The first PCs, PC1, PC2 and PC3 represented 45.15 and $41.31 \%$, 21.90 and $21.39 \%, 14.21$ and $17.43 \%$, for Uslu and Edremit varieties, respectively.

Conclusions. It is recommended to store olives at $5{ }^{\circ} \mathrm{C}$ in air conditioning boxes for at least 30 days to reduce fungal development and to maintain the desired aroma. 


\section{Introduction}

Olive fruit (Olea europaea) is one of most important products in Mediterranean countries and olive cultivation and processing has been carried out since the beginning of human civilization (Ozdemir et al. 2018). Olive and olive oil have superior nutritional properties due to high content of volatile and phenolic compounds, so their regular consumprion could help in prevention of such diseases such as cardiovascular diseases, cancer and osteoporosis. Production of a high quality virgin olive oil requires the storing the olive fruit in proper holding conditions (Inarejos-García et al. 2009). In addition to the extraction process and storage, cultivar and cultivar applications, geographical origin, climatic conditions, degree of fruit ripening also affect the content and composition of volatiles compounds in olive oils (Issaoui et al. 2010; Kesen et al. 2013). Several researchers have determined that the olive storage types and times affect the virgin olive oil quality as much as technological operations (Bouaziz et al. 2008; Inarejos-García et al. 2009; Pereira et al. 2002; Rizzo et al. 2011).

The presence of volatile and phenolic compounds directly influence and determine the quality of virgin olive oil. Volatile aromatic compounds are one of the most important factors for olive oil's quality and affect sensorial perception (Bayrak \& Hu 2013). They are formed by the oxidation of oils with certain enzymes such as lipoxygenase (LOX pathway) (Cavalli et al. 2004). Olive oils possess more than 180 different aromas, and the majority of the volatile substances are presented by esters, aldehydes, hydrocarbons, ketones, and furans (Kesen et al. 2013). Servili et al (2003) studied the time of revealing of olive pastes to air during malaxation and found a positive correlation between air contact and the content of volatile compounds in olive oil including hexanal, 1-butanol, (Z)-3-hexen-1-ol, 1-penten-3ol, and 2-methyl-1-butanol. Inappropriate olive fruit storage generally induce the activity of microorganisms that are responsible for unpleasant odours and formation of volatile compounds (Koprivnjak \& Conte 2002).

Principal component analysis (PCA) is an statistical method that can be used to detemine the content of triglycerides, sterols, phenolic compounds and volatile compounds to distinguish oils from different cultivars (Boskou 2007; de Fernandez et al. 2014; Yang et al. 2017). The aim of this study was to examine the effects of different holding times and types on volatile aroma compounds of oil samples obtained from different olive cultivars named "Edremit and Uslu" collected from Aegean province, Akhisar Region of Turkey by Gas Chromatography- Mass Spectroscopy (GC-MS) headspace technique. There is no detailed information that compares the volatile profiles of oils extracted from olives holded in unsuitable conditions that is already applied by some olive producers. For this reason, this study carried out is of importance.

\section{Materials and methods}

\section{Materials}

Olive fruits (Olea europaea L.) from the Edremit and Uslu varieties grown in the Akhisar area were harvested in the 2012/2013 crop season. Maturity index of olives, which was calculated according to the method of the International Olive Oil Council (IOOC, 2011), was $3.75 \pm 0.35$ and $4.50 \pm 0.71$ for Edremit and Uslu cultivars, respectively. According to this method, 100 fruits were randomly taken to assess their level of maturity by a subjective evaluation of the color of the olive skin and flesh. The olives were distributed into eight 
groups according to the following characteristics: bright-green skin (group $\mathrm{N} 0$ ), greenishyellowish skin (group N 1), green skin with reddish spots (group N 2), reddish-brown skin (group N 3), black skin with white flesh (group N 4), black skin with $<50 \%$ purple flesh (group N 5), black skin with $>50 \%$ and $<100 \%$ purple flesh (group N 6), and black skin with $100 \%$ purple flesh (group N 7). Maturation indexes ranged from zero (intense green skin) to seven (black skin and $100 \%$ purple flesh). The maturity index was calculated by $\sum$ $\left(\mathrm{N}_{\mathrm{i}} \mathrm{n}_{\mathrm{i}}\right) / 100$, where $\mathrm{N}$ is the group number and $\mathrm{n}$ is the olive amount in that group (Aydar et al. 2017). Air temperature and weather conditions during olives holded periods were shown in Table 1 (Turkish State Meteorological Service, 2012-2013). Olives were put into nylon sacks $(60 \times 90 \mathrm{~cm})$ and plastic boxes $(53 \times 37 \times 31 \mathrm{~cm})$ and were hold inside them for $0,7,14$ and 21 days. Olive oil samples symbolized as E: Edremit variety, U: Uslu variety, K: Holded in plastic boxes, and C: Holded in nylon sacks.

Air temperature and weather conditions during olives holded periods

Table 1 (Turkish State Meteorological Service, 2012-2013)

\begin{tabular}{|l|l|l|}
\hline MANISA/AKHISAR & $\begin{array}{l}\text { Air } \\
\text { temperature }\left({ }^{\circ} \mathbf{C}\right)\end{array}$ & Weather \\
\hline $\begin{array}{l}\mathbf{2 1 . 1 2 . 2 0 1 2} \\
\text { (harvest-first extraction) }\end{array}$ & 7 & Snowy \\
\hline 1th day & 8 & Sunny \\
\hline 2th day & 8 & Sunny \\
\hline 3th day & 7 & Sunny \\
\hline 4th day & 12 & Sunny \\
\hline 5th day & 16 & Sunny \\
\hline 6th day & 15 & Partly cloudy \\
\hline $\begin{array}{l}\mathbf{2 8 . 1 2 . 2 0 1 2} \\
\text { (7th day-second extraction) }\end{array}$ & 14 & Stormy \\
\hline 8th day & 13 & Stormy \\
\hline 9th day & 12 & Stormy \\
\hline 10th day & 13 & Stormy \\
\hline 11th day & 13 & Some clouds \\
\hline 12th day & 13 & Some clouds \\
\hline 13th day & 13 & Some clouds \\
\hline $\begin{array}{l}\mathbf{0 4 . 0 1 . 2 0 1 3} \\
\text { (14th day-third extraction) }\end{array}$ & 10 & Foggy \\
\hline 15th day & 11 & Some clouds \\
\hline 16th day & 10 & Some clouds \\
\hline 17th day & 6 & Partly cloudy \\
\hline 18th day & 6 & Partly cloudy \\
\hline 19th day & 3 & Partly cloudy \\
\hline 20th day & 5 & Partly cloudy \\
\hline $\begin{array}{l}\text { 11.01.2013 } \\
\text { (21th day-fourth extraction) }\end{array}$ & 8 & Stormy \\
\hline & & \\
\hline
\end{tabular}




\section{Methods}

\section{Oil extraction}

A laboratory scale Abencor extraction system consisted of a small-quantity mill (MC2 Ingenieria Sistemas, Seville, Spain) equipped with a mixer (Kitchen Aid Mixer 4lt Model 5KSM45 220-240VN 50-60 HZ 250W, USA), a basket centrifuge (Marelli Motore Asinciono Trifase Tipo NR90S2) and a metal crusher was used to extract oil from olive fruits. The malaxation process was performed at $35 \pm 1{ }^{\circ} \mathrm{C}$ for $60 \mathrm{~min}$ for Edremit variety and at $35 \pm 1{ }^{\circ} \mathrm{C}$ for $90 \mathrm{~min}$ for Uslu variety, and the oil separation was carried out by decanter. Extracted olive oils were filtered and then kept at $4{ }^{\circ} \mathrm{C}$ in amber glass bottles until analysis.

\section{Volatile compound analysis}

Sample Preparation. An $8 \mathrm{~mL}$ of oil was put in a $20 \mathrm{~mL}$ glass headspace sample vial and to attain a final $3 \mathrm{ppm}$ concentration, $27 \mu \mathrm{L}$ and $24 \mu \mathrm{L}$ of internal standard solutions (butyl acetate and 1-nonanol, respectively) were added to each vial. The mixture was shaken carefully and allowed to equilibrate for 1 hour in the dark at ambient temperature before the analysis.

HS-SPME procedures. The SPME coated by polydimethylsiloxane (PDMS) fiber at $100 \mu \mathrm{m}$ thickness and 23 gauge was used in this study. It was purchased from Supelco and thermal conditions provided according to the manufacturer's recommendations before first use. The samples of oils were heated to $40{ }^{\circ} \mathrm{C}$ for $10 \mathrm{~min}$ before revealing the SPME fiber to the headspace of the sample. Headspace sampling/extraction took $30 \mathrm{~min}$ with continuous stirring $(250 \mathrm{rpm})$. The samples were analyzed in duplicate and as a blank sample (empty glass vial) was used before and after each analysis.

GC-MS analysis. The analytical system was constituted from A Gerstel MPS autosampler (Gerstel, Baltimore, MD, USA) installed to an Agilent $6890 \mathrm{~N}$ model Gas Chromatography (Little Falls, DE, USA) paired with an Agilent 5975 mass selective detector. The software was MSD ChemStation (Agilent). SPME injections were carried on a splitless mode using a SPME injection sleeve (0.75 mm I.D) at $250{ }^{\circ} \mathrm{C}$ for $350 \mathrm{sec}$ meanwhile thermal desorption of analyses was occurred in DB-Wax column $(60 \mathrm{~m} \times 0.25 \mathrm{mmI}$.D., $0.25 \mu \mathrm{m}$ film thickness) (J\&W Scientific, Folsom, CA, USA). Gas helium was used as a carrier with a total flow of $1.2 \mathrm{~mL} \cdot \mathrm{min}^{-1}$. The initial temperature $40{ }^{\circ} \mathrm{C}$ was kept for $1.0 \mathrm{~min}$, followed by an increased to $200{ }^{\circ} \mathrm{C}$ at a rate of $6{ }^{\circ} \mathrm{C} \mathrm{min}^{-1}$ and kept at this temperature for $5 \mathrm{~min}$, then raised to $250{ }^{\circ} \mathrm{C}$ at a rate of $8{ }^{\circ} \mathrm{C} \mathrm{min}{ }^{-1}$. Lastly, the the temperature was retained $250{ }^{\circ} \mathrm{C}$ for $10 \mathrm{~min}$. The total cycle time was $48.92 \mathrm{~min}$. The MS detector was handled in scan mode (mass range $30-500$ ) and the transfer line to the MS system was retained at $250{ }^{\circ} \mathrm{C}$. The identification of the compounds was carried out by comparing (i) the Kovats indices (KI) based on a homologous series of even numbered n-alkanes $\left(\mathrm{C}_{8}-\mathrm{C}_{20}\right)$, with those of standard compounds and by comparison with the data of literature, and (ii) by MS data received from NIST library (NIST/EPA/NIH Mass Spectral Library with Search Program, data version NIST 05, software version $2.0 \mathrm{~d}$ ). 


\section{Statistical analysis}

XLSTAT (Addinsoft SARL, NY, USA) for Microsoft Excel (Microsoft, Redwood, WA) was used to perform ANOVA. In order to identify the variations of headspace components and analyze the composition data in different samples of oil, principal component analysis (PCA) was performed by SCAN software (Minitab Inc., State College, PA, USA). The software autoscaled the content values before the statistical analysis, i.e. each variable was subtracted by the mean value and the result was divided by its standard deviation.

\section{Results and discussion}

Principal volatile compounds are commonly found in great sensory quality virgin olive oil that are synthetized by biogenic pathways of the olive fruit such as fatty acid or amino acid metabolism and LOX pathway (Morales 2005). In spite of that, especially storing types and conditions, climatic conditions are very effective on producing of disagreeable volatiles compounds (Gomes da Silva et al. 2012). In olive fruits stored in batches, under high humidity conditions, the most abundant deuteromycetes such as several species of genus Aspergillus, together with ascomycetes, Penicillium notatum are occurred. These microorganisms have the capacity to oxidise free fatty acids and produce volatile compounds such as methyl ketones (Morales 2005).

In this study, 46 different volatile compounds were identified during different holding times of olive oils extracted from Edremit and Uslu varieties (Table 2, 3 and 4).

Volatile compounds isolated from Edremit (Ayvalık) and and Uslu oils

Table 2*

\begin{tabular}{|l|l|c|c|c|l|}
\hline Codes & \multicolumn{1}{|c|}{ Compounds } & $\begin{array}{c}\text { tr } \\
(\mathbf{m i n})\end{array}$ & $\mathbf{K I}_{\mathbf{E}}$ & $\mathbf{K I}_{\mathbf{R}}$ & \multicolumn{1}{|c|}{ Odor } \\
\hline A1 & Hexanal (44) & 9.31 & 1103.5 & 1108 & Fatty; fruity; green \\
\hline A2 & 1-Propanol 2-methyl (43) & 9.31 & 1103.0 & 1103 & Sweet; musty odor \\
\hline A3 & Pyridine (79) & 11.62 & 1205.5 & 1193 & Sour; fishy \\
\hline A4 & 1-Butanol 2-methyl (57) & 11.99 & 1221.5 & 1220 & Natural \\
\hline A5 & 1-Butanol 3-methyl (70) & 12.00 & 1222.0 & 1224 & $\begin{array}{l}\text { Fusel; alcohol; } \\
\text { sweet; fruity }\end{array}$ \\
\hline A6 & Limonene (68) & 12.00 & 1222.0 & 1221.5 & Herbaceous; minty \\
\hline A7 & 2-Hexenal (E) (41) & 12.50 & 1243.6 & 1238 & Green type flavor \\
\hline A8 & Cyclodecane methyl (55) & 12.82 & 1257.4 & 1260 & \\
\hline A9 & 2-Butanone 3-hydroxy (45) & 14.10 & 1313.1 & 1314 & Butter; creamy \\
\hline A10 & Tridecane (57) & 14.15 & 1315.3 & 1300 & Floral \\
\hline A11 & $\begin{array}{l}\text { 5-Hepten-2-one 6-methyl } \\
\text { (43) }\end{array}$ & 15.20 & 1361.8 & 1361 & $\begin{array}{l}\text { Oily; herbaceous; } \\
\text { green }\end{array}$ \\
\hline A12 & 1-Hexanol (56) & 15.37 & 1369.3 & 1362 & Herbal \\
\hline
\end{tabular}




\begin{tabular}{|c|c|c|c|c|c|}
\hline & & & & & Table $2 *$ (continue) \\
\hline Codes & Compounds & $\begin{array}{c}\operatorname{tr} \\
(\min )\end{array}$ & $\mathbf{K I} \mathbf{E}$ & $\mathbf{K I}_{\mathbf{R}}$ & Odor \\
\hline A13 & 3-Hexen-1-ol (Z) (41) & 16.14 & 1403.5 & 1406 & Green \\
\hline A14 & Nonanal (57) & 16.50 & 1420.1 & 1422 & $\begin{array}{l}\text { Apple; coconut; } \\
\text { grape; grapefruit; } \\
\text { lemon }\end{array}$ \\
\hline A15 & 2-Hexen-1-ol (E) (57) & 16.60 & 1424.8 & 1420 & $\begin{array}{l}\text { Apple; banana; } \\
\text { orange; green; } \\
\text { wine-like; }\end{array}$ \\
\hline A16 & Acetic acid (45) & 17.74 & 1477.4 & 1477 & $\begin{array}{l}\text { Pungent; sour; } \\
\text { vinegar-like odor }\end{array}$ \\
\hline A17 & Cycloisosativene (147) & 18.43 & 1509.8 & 1522 & \\
\hline A18 & n.i. (119) & 19.61 & 1566.9 & n.d. & \\
\hline A19 & Dimethyl sulfoxide (63) & 20.38 & 1604.3 & 1603 & $\begin{array}{l}\text { Butter; alliaceous } \\
\text { (onion; garlic) }\end{array}$ \\
\hline A20 & Alpha-Bergamotene (119) & 20.67 & 1619.1 & 1609 & Woody \\
\hline A21 & $\begin{array}{l}\text { Decanoic acid methyl ester } \\
(74)\end{array}$ & 20.74 & 1622.7 & 1624 & $\begin{array}{l}\text { Oily; fruity; wine- } \\
\text { like }\end{array}$ \\
\hline A22 & $\begin{array}{l}\text { Cycloheptanone 2-methylene } \\
(43)\end{array}$ & 20.98 & 1634.9 & n.d. & \\
\hline A23 & $\beta$-Farnesene (69) & 21.85 & 1679.2 & 1674 & $\begin{array}{l}\text { Apple; lavender; } \\
\text { lime; green; } \\
\text { woody; }\end{array}$ \\
\hline A24 & 8-Heptadecene (69) & 23.00 & 1739.6 & 1718 & \\
\hline A25 & Eremophilene (161) & 23.31 & 1756.2 & 1744 & \\
\hline A26 & $\alpha$-Farnesene (93) & 23.75 & 1779.7 & 1778 & Woody \\
\hline A27 & $\beta$-Sesquiphellandrene (69) & 24.30 & 1809.6 & 1782 & Herbal \\
\hline A28 & $\begin{array}{l}\text { Dodecanoic acid methyl ester } \\
(74)\end{array}$ & 24.73 & 1833.7 & 1834 & $\begin{array}{l}\text { Coconut; creamy; } \\
\text { soapy; waxy }\end{array}$ \\
\hline A29 & Hexanoic acid (60) & 25.50 & 1876.9 & 1874 & Cheese; fatty; sour \\
\hline A30 & Phenylethyl alcohol (91) & 26.85 & 1955.1 & 1946 & Honey; floral; rose \\
\hline A31 & $\begin{array}{l}\text { 2.6-Bis(1.1-dimethylethyl)-4- } \\
\text { (1-oxopropyl)phenol (233) }\end{array}$ & 26.90 & 1958.0 & n.d. & \\
\hline A32 & $\begin{array}{l}\text { 4.6-Heptadienoic acid. 3.3.6- } \\
\text { trimethyl methyl ester (109) }\end{array}$ & 27.12 & 1971.0 & n.d. & \\
\hline A33 & n.i. (159) & 27.29 & 1981.0 & n.d. & \\
\hline A34 & 3-Buten-2-ol. 2-methyl (71) & 27.49 & 1992.7 & n.d. & Herbal \\
\hline A35 & 1-Dodecanol (55) & 27.53 & 1995.1 & 1984 & $\begin{array}{l}\text { Coconut; honey; } \\
\text { soapy; waxy; } \\
\text { earthy; fatty }\end{array}$ \\
\hline A36 & Dimethylpalmitamine (58) & 28.03 & 2017.4 & n.d. & \\
\hline A37 & Methyl tetradecanoate (74) & 28.37 & 2031.7 & 2032 & Honey; fatty \\
\hline
\end{tabular}




\begin{tabular}{|c|c|c|c|c|c|}
\hline & & & & & Table $2 *$ (continue) \\
\hline Codes & Compounds & $\begin{array}{c}\operatorname{tr} \\
(\mathrm{min})\end{array}$ & $\mathbf{K I} \mathbf{E}$ & $\mathbf{K} \mathbf{I}_{\mathbf{R}}$ & Odor \\
\hline A38 & Phenol (94) & 28.45 & 2035.0 & 2035 & Sweet; tarry odor \\
\hline A39 & Nerolidol 2 (69) & 28.86 & 2052.2 & 2052 & $\begin{array}{l}\text { Apple; green; } \\
\text { woody; citrus; rose }\end{array}$ \\
\hline A40 & $\begin{array}{l}\text { 2(3H)-Furanone dihydro-5- } \\
\text { propyl }(\gamma \text {-lactone }(85)\end{array}$ & 29.10 & 2062.3 & 2068 & $\begin{array}{l}\text { Waxy; creamy; } \\
\text { coconut character; }\end{array}$ \\
\hline A41 & $\begin{array}{l}\text { Benzoic acid 2-methoxy. } \\
\text { methyl ester (135) }\end{array}$ & 29.69 & 2087.0 & 2088 & \\
\hline A42 & $\begin{array}{l}\text { 2H-Pyran-2-one. 6- } \\
\text { hexyltetrahydro (99) }\end{array}$ & 32.70 & 2213.2 & 2215 & Fruity; sweet \\
\hline A43 & $\begin{array}{l}\text { Hexadecanoic acid methyl } \\
\text { ester (74) }\end{array}$ & 32.75 & 2215.3 & 2214 & Waxy \\
\hline A44 & n.i. (71) & 33.80 & 2259.3 & n.d. & \\
\hline A45 & $\begin{array}{l}\text { 9-Octadecenoic acid methyl } \\
\text { ester (oleic acid) (55) }\end{array}$ & 37.51 & 2414.8 & 2424 & Fatty \\
\hline A46 & p-Isopropenylphenol (134) & 37.76 & 2425.2 & n.d. & \\
\hline
\end{tabular}

* KIE. experiment value of Kovats index (KI);

$* \mathrm{KI}_{\mathrm{R}}$. reference value of $\mathrm{KI}$.

*The odor descriptors were obtained from SAFC "Flavors and Fragrances. European Ed. Catalogue 2009". 
Table 3*

Normalized peak area of volatile compounds isolated from Edremit (Ayvalık) oils in two different packaging at initial and after 7, 14 and 21 days of ripening

\begin{tabular}{|c|c|c|c|c|c|c|c|c|}
\hline \multirow{3}{*}{$\frac{\mathscr{e}}{\delta}$} & \multirow{3}{*}{$\begin{array}{l}\text { Compounds } \\
\qquad(\mathbf{m} / \mathbf{z})\end{array}$} & \multicolumn{7}{|c|}{ Normalised peak area $($ mean \pm SD. $n=2)$} \\
\hline & & \multirow[b]{2}{*}{$\mathbf{E}_{0}$} & \multicolumn{3}{|c|}{$\mathbf{E}_{\mathbf{C}}$} & \multicolumn{3}{|c|}{$\mathbf{E}_{\mathbf{K}}$} \\
\hline & & & $\mathbf{E}_{7 \mathrm{C}}$ & $\mathbf{E}_{14 C}$ & $\mathbf{E}_{21 \mathrm{C}}$ & $\mathbf{E}_{7 \mathrm{~K}}$ & $E_{14 K}$ & $\mathbf{E}_{21 \mathrm{~K}}$ \\
\hline $\mathbf{A 1}$ & Hexanal (44) & $(251 \pm 11)^{\mathrm{a}}$ & $\begin{array}{c}(29.74 \pm \\
0.14)^{\mathrm{b}} \\
\end{array}$ & n.d. ${ }^{\mathrm{c}}$ & n.d. ${ }^{\mathrm{c}}$ & $(9 \pm 2)^{\mathrm{c}}$ & n.d. ${ }^{\mathrm{c}}$ & n.d. ${ }^{c}$ \\
\hline $\mathbf{A 2}$ & $\begin{array}{l}\text { 1-Propanol 2-methyl } \\
\text { (43) }\end{array}$ & n.d. ${ }^{\mathrm{b}}$ & n.d. ${ }^{b}$ & $(9 \pm 2)^{\mathrm{a}}$ & \begin{tabular}{|c|}
$(10.6 \pm$ \\
$0.3)^{\mathrm{a}}$
\end{tabular} & n.d. ${ }^{b}$ & n.d. ${ }^{\mathrm{b}}$ & n.d. ${ }^{b}$ \\
\hline $\mathbf{A 3}$ & Pyridine (79) & n.d. ${ }^{b}$ & $\begin{array}{c}32.7 \pm \\
0.4)^{\mathrm{a}}\end{array}$ & n.d. ${ }^{\mathrm{b}}$ & n.d. ${ }^{b}$ & n.d. ${ }^{b}$ & n.d. ${ }^{\mathrm{b}}$ & n.d. ${ }^{b}$ \\
\hline A4 & $\begin{array}{l}\text { 1-Butanol 2-methyl } \\
\text { (57) }\end{array}$ & n.d. ${ }^{c}$ & $\begin{array}{l}(1.7 \pm \\
0.2)^{\mathrm{bc}}\end{array}$ & $\begin{array}{l}(4.0 \pm \\
1.0)^{\mathrm{a}}\end{array}$ & $\begin{array}{l}(5.0 \pm \\
0.7)^{\mathrm{a}}\end{array}$ & $\begin{array}{l}(1.32 \pm \\
0.10)^{\mathrm{bc}}\end{array}$ & $\begin{array}{l}(1.43 \pm \\
0.04)^{\mathrm{bc}}\end{array}$ & $\begin{array}{l}(1.9 \pm \\
0.2)^{\mathrm{b}}\end{array}$ \\
\hline A5 & $\begin{array}{l}\text { 1-Butanol 3-methyl } \\
\text { (70) }\end{array}$ & n.d. ${ }^{\mathrm{e}}$ & $\begin{array}{l}(1.8 \pm \\
0.3)^{\mathrm{cd}}\end{array}$ & $\begin{array}{l}(4.0 \pm \\
0.2)^{\mathrm{b}}\end{array}$ & \begin{tabular}{|c|}
$(5.59$ \\
$\pm 0.04)^{\mathrm{a}}$
\end{tabular} & $\begin{array}{c}(1.24 \\
\pm 0.08)^{\mathrm{d}}\end{array}$ & $\begin{array}{c}(1.73 \\
\pm 0.11)^{\mathrm{cd}}\end{array}$ & $\begin{array}{c}(2.06 \\
\pm 0.09)^{\mathrm{c}}\end{array}$ \\
\hline A6 & Limonene (68) & $\begin{array}{l}(2.70 \pm \\
0.06)^{\mathrm{bc}}\end{array}$ & $\begin{array}{c}(40.2 \pm \\
0.4)^{\mathrm{a}} \\
\end{array}$ & $\begin{array}{l}(1.95 \pm \\
0.12)^{\mathrm{cd}} \\
\end{array}$ & \begin{tabular}{|c|}
$(0.80 \pm$ \\
$0.07)^{\mathrm{e}}$ \\
\end{tabular} & $\begin{array}{l}(2.8 \pm \\
0.2)^{\mathrm{b}} \\
\end{array}$ & n.d. ${ }^{f}$ & \begin{tabular}{|l|}
$(1.9 \pm$ \\
$0.2)^{\mathrm{d}}$ \\
\end{tabular} \\
\hline $\mathbf{A} 7$ & 2-Hexenal (E) (41) & $\begin{array}{c}(14.0 \pm \\
1.3)^{\mathrm{a}}\end{array}$ & $\begin{array}{l}(0.43 \pm \\
0.09)^{\mathrm{b}}\end{array}$ & $\begin{array}{l}(0.82 \pm \\
0.03)^{\mathrm{b}}\end{array}$ & n.d. ${ }^{b}$ & n.d. ${ }^{b}$ & n.d. ${ }^{\mathrm{b}}$ & n.d. ${ }^{b}$ \\
\hline A8 & $\begin{array}{l}\text { Cyclodecane methyl } \\
(55)\end{array}$ & $\begin{array}{c}(12.25+ \\
0.12)^{\mathrm{d}} \\
\end{array}$ & $\begin{array}{c}(17.66 \pm \\
0.07)^{\mathrm{c}} \\
\end{array}$ & $\begin{array}{c}(22.8 \pm \\
0.6)^{\mathrm{a}}\end{array}$ & \begin{tabular}{|c|}
$(21.6 \pm$ \\
$1.3)^{\mathrm{ab}}$
\end{tabular} & $\begin{array}{l}(19.3 \pm \\
0.14)^{\mathrm{bc}}\end{array}$ & $\begin{array}{l}(9.6 \pm \\
0.5)^{\mathrm{e}}\end{array}$ & $\begin{array}{c}(17.4 \pm \\
0.8)^{\mathrm{d}} \\
\end{array}$ \\
\hline A9 & $\begin{array}{l}\text { 2-Butanone 3- } \\
\text { hydroxy (45) }\end{array}$ & n.d. ${ }^{b}$ & n.d. ${ }^{b}$ & $\begin{array}{l}(5.22 \pm \\
0.03)^{\mathrm{a}} \\
\end{array}$ & \begin{tabular}{|c|}
$(5.85 \pm$ \\
$0.13)^{\mathrm{a}}$ \\
\end{tabular} & n.d. ${ }^{b}$ & $\begin{array}{l}(1.7 \pm \\
0.5)^{\mathrm{b}}\end{array}$ & $\begin{array}{l}(1.8 \pm \\
1.1)^{\mathrm{b}} \\
\end{array}$ \\
\hline A10 & Tridecane (57) & $\begin{array}{l}(2.20 \pm \\
0.04)^{\mathrm{a}}\end{array}$ & $\begin{array}{l}(2.0 \pm \\
0.2)^{\mathrm{a}}\end{array}$ & $\begin{array}{l}(1.9 \pm \\
0.4)^{\mathrm{a}}\end{array}$ & $\begin{array}{l}(2.9 \pm \\
0.6)^{\mathrm{a}}\end{array}$ & $\begin{array}{l}(2.51 \pm \\
0.11)^{\mathrm{a}}\end{array}$ & $\begin{array}{l}(1.9 \pm \\
1.0)^{\mathrm{a}}\end{array}$ & $\begin{array}{l}(1.7 \pm \\
0.5)^{\mathrm{a}}\end{array}$ \\
\hline A11 & $\begin{array}{l}\text { 5-Hepten-2-one. 6- } \\
\text { methyl (43) }\end{array}$ & n.d. ${ }^{b}$ & $\begin{array}{l}(2.0 \pm \\
0.3)^{\mathrm{ab}}\end{array}$ & $\begin{array}{l}(1.2 \pm \\
0.3)^{\mathrm{ab}}\end{array}$ & $\begin{array}{l}(2.6 \pm \\
0.4)^{\mathrm{a}}\end{array}$ & $\begin{array}{l}(0.42 \pm \\
0.11)^{\mathrm{b}}\end{array}$ & $\begin{array}{c}(0.48 \\
\pm 0.02)^{\mathrm{b}}\end{array}$ & $\begin{array}{l}(1.19 \pm \\
0.02)^{\mathrm{ab}}\end{array}$ \\
\hline A12 & 1-Hexanol (56) & $(33 \pm 2)^{\mathrm{f}}$ & $(236 \pm 9)^{d}$ & $\begin{array}{c}(503 \pm \\
11)^{\mathrm{a}}\end{array}$ & $\begin{array}{c}(268 \pm \\
3)^{\mathrm{c}}\end{array}$ & $\begin{array}{c}(356 \pm \\
4)^{\mathrm{b}}\end{array}$ & $(119 \pm 13)^{\mathrm{e}}$ & $\begin{array}{c}(144.3 \pm \\
0.2)^{\mathrm{e}}\end{array}$ \\
\hline A13 & $\begin{array}{l}\text { 3-Hexen-1-ol (Z) } \\
\text { (41) }\end{array}$ & $\begin{array}{c}(13.87 \pm \\
0.11)^{\mathrm{e}} \\
\end{array}$ & $(52 \pm 2)^{\mathrm{b}}$ & $\begin{array}{c}(60.5 \pm \\
1.4)^{\mathrm{a}} \\
\end{array}$ & \begin{tabular}{|c|}
$(51.9 \pm$ \\
$0.8)^{\mathrm{b}}$ \\
\end{tabular} & $\begin{array}{c}(49.4 \pm \\
0.9)^{\mathrm{bc}} \\
\end{array}$ & $(30 \pm 3)^{\mathrm{d}}$ & \begin{tabular}{|c|}
$(44.1 \pm$ \\
$0.4)^{\mathrm{c}}$ \\
\end{tabular} \\
\hline A14 & Nonanal (57) & $\begin{array}{c}(8.7 \pm \\
1.5)^{\mathrm{b}} \\
\end{array}$ & $\begin{array}{l}(3.0 \pm \\
0.4)^{\mathrm{bc}}\end{array}$ & $\begin{array}{c}(54.9 \pm \\
1.4)^{\mathrm{a}}\end{array}$ & $\begin{array}{l}(3.9 \pm \\
0.4)^{\mathrm{bc}}\end{array}$ & $\begin{array}{l}(4.32 \pm \\
2.03)^{\mathrm{bc}}\end{array}$ & $\begin{array}{l}(1.6 \pm \\
0.8)^{\mathrm{c}}\end{array}$ & n.d. ${ }^{c}$ \\
\hline A15 & $\begin{array}{l}\text { 2-Hexen-1-ol (E) } \\
\text { (57) }\end{array}$ & n.d. ${ }^{\text {d }}$ & $\begin{array}{c}(19.3 \pm \\
0.5)^{\mathrm{c}} \\
\end{array}$ & $\begin{array}{c}(53.6 \pm \\
0.5)^{\mathrm{a}} \\
\end{array}$ & n.d. ${ }^{\mathrm{d}}$ & $(35 \pm 3)^{\mathrm{b}}$ & n.d. ${ }^{\mathrm{d}}$ & \begin{tabular}{|c|}
$(18.2 \pm$ \\
$0.7)^{\mathrm{c}}$ \\
\end{tabular} \\
\hline A16 & Acetic acid (45) & $\begin{array}{c}(14.1 \pm \\
0.2)^{\mathrm{a}}\end{array}$ & $\begin{array}{c}(10.5 \pm \\
1.1)^{\mathrm{a}}\end{array}$ & $(11 \pm 2)^{\mathrm{a}}$ & $(12 \pm 2)^{\mathrm{a}}$ & $(8 \pm 2)^{\mathrm{a}}$ & $(7 \pm 6)^{\mathrm{a}}$ & $\begin{array}{l}(7.5 \pm \\
0.7)^{\mathrm{a}}\end{array}$ \\
\hline A17 & $\begin{array}{l}\text { Cycloisosativene } \\
\text { (147) }\end{array}$ & n.d. ${ }^{a}$ & n.d. ${ }^{\mathrm{a}}$ & n.d. ${ }^{\mathrm{a}}$ & n.d. ${ }^{\mathrm{a}}$ & n.d. ${ }^{\mathrm{a}}$ & n.d. ${ }^{\mathrm{a}}$ & n.d. ${ }^{a}$ \\
\hline A18 & h.i. (119) & $\begin{array}{l}(3.0 \pm \\
0.3)^{\mathrm{a}} \\
\end{array}$ & $\begin{array}{l}(2.0 \pm \\
0.7)^{\mathrm{a}} \\
\end{array}$ & \begin{tabular}{|c|}
$(4.41 \pm$ \\
$0.12)^{\mathrm{a}}$ \\
\end{tabular} & $\begin{array}{l}(4.5 \pm \\
0.2)^{\mathrm{a}} \\
\end{array}$ & $\begin{array}{l}(6.2 \pm \\
1.5)^{\mathrm{a}} \\
\end{array}$ & $\begin{array}{c}(4.2 \pm \\
0.2)^{\mathrm{a}} \\
\end{array}$ & $\begin{array}{l}(5.8 \pm \\
0.2)^{\mathrm{a}} \\
\end{array}$ \\
\hline A19 & $\begin{array}{l}\text { Dimethyl sulfoxide } \\
\text { (63) }\end{array}$ & $\begin{array}{l}(3.0 \pm \\
0.2)^{\mathrm{a}}\end{array}$ & $\begin{array}{l}(0.8 \pm \\
0.3)^{\mathrm{b}}\end{array}$ & $\begin{array}{l}(1.18 \pm \\
0.01)^{\mathrm{b}} \\
\end{array}$ & $\begin{array}{l}3.7 \pm \\
0.7)^{\mathrm{a}} \\
\end{array}$ & $\begin{array}{l}(0.5 \pm \\
0.2)^{\mathrm{b}}\end{array}$ & $\begin{array}{l}(0.75 \pm \\
0.14)^{\mathrm{b}}\end{array}$ & $\begin{array}{l}(0.74 \pm \\
0.04)^{\mathrm{b}} \\
\end{array}$ \\
\hline A20 & a-Bergamotene (119) & $\begin{array}{l}(1.99 \pm \\
0.01)^{\mathrm{b}}\end{array}$ & $\begin{array}{l}(2.3 \pm \\
0.3)^{\mathrm{b}}\end{array}$ & $\begin{array}{l}(2.32 \pm \\
0.01)^{\mathrm{b}} \\
\end{array}$ & \begin{tabular}{|l|}
$(2.25 \pm$ \\
$0.12)^{\mathrm{b}}$ \\
\end{tabular} & $\begin{array}{l}(4.2 \pm \\
0.9)^{\mathrm{a}}\end{array}$ & $\begin{array}{c}(1.63 \\
\pm 0.05)^{\mathrm{b}}\end{array}$ & \begin{tabular}{|l|}
$(3.0 \pm$ \\
$0.2)^{\mathrm{ab}}$ \\
\end{tabular} \\
\hline A21 & $\begin{array}{l}\text { Decanoic acid methyl } \\
\text { ester (74) }\end{array}$ & n.d. ${ }^{b}$ & n.d. ${ }^{b}$ & n.d. ${ }^{b}$ & $\begin{array}{c}(31.5 \pm \\
0.9)^{\mathrm{a}}\end{array}$ & n.d. ${ }^{\mathrm{b}}$ & n.d. ${ }^{\mathrm{b}}$ & n.d. ${ }^{b}$ \\
\hline A22 & $\begin{array}{l}\text { Cycloheptanone 2- } \\
\text { methylene (43) }\end{array}$ & n.d. ${ }^{c}$ & n.d. ${ }^{\mathrm{c}}$ & $\begin{array}{l}(3.1 \pm \\
0.4)^{\mathrm{b}} \\
\end{array}$ & $\begin{array}{l}(5.1 \pm \\
0.2)^{\mathrm{a}} \\
\end{array}$ & n.d. ${ }^{c}$ & n.d. ${ }^{c}$ & n.d. ${ }^{c}$ \\
\hline
\end{tabular}




\begin{tabular}{|c|c|c|c|c|c|c|c|c|}
\hline & & & & & & & Table3* & (continue) \\
\hline & & & Norma & lised pe & ak area & $($ mean \pm & SD. $n=2)$ & \\
\hline تِ & Compounds (m/z) & & & $\mathbf{E}_{\mathbf{C}}$ & & & $\mathbf{E}_{\mathbf{K}}$ & \\
\hline ن & & $\mathbf{E}_{0}$ & $\mathbf{E}_{7 \mathrm{C}}$ & $\mathbf{E}_{14 \mathrm{C}}$ & $\mathbf{E}_{21 \mathrm{C}}$ & $\mathbf{E}_{7 \mathrm{~K}}$ & $\mathbf{E}_{14 \mathrm{~K}}$ & $\mathbf{E}_{21 K}$ \\
\hline A23 & (E)- $\beta$-Fanesene (69) & $\begin{array}{l}(9.1 \pm \\
0.3)^{\mathrm{b}}\end{array}$ & $\begin{array}{c}(10.2 \pm \\
0.5)^{\mathrm{b}}\end{array}$ & $\begin{array}{c}(11.2 \pm \\
0.3)^{\mathrm{b}}\end{array}$ & \begin{tabular}{|l|}
$(12.1 \pm$ \\
$1.0)^{\mathrm{ab}}$
\end{tabular} & $(19 \pm 5)^{\mathrm{a}}$ & $\begin{array}{l}(7.4 \pm \\
0.2)^{\mathrm{b}}\end{array}$ & $\begin{array}{l}(14.0 \pm \\
0.4)^{\mathrm{ab}}\end{array}$ \\
\hline A24 & 8-Heptadecene (69) & n.d. ${ }^{\mathrm{a}}$ & n.d. $^{\mathrm{a}}$ & n.d. $^{\mathrm{a}}$ & n.d. $^{\mathrm{a}}$ & n.d. ${ }^{a}$ & n.d. $^{\mathrm{a}}$ & n.d. $^{\mathrm{a}}$ \\
\hline A25 & Eremophilene (161) & $\begin{array}{l}(0.79 \pm \\
0.03)^{\mathrm{d}} \\
\end{array}$ & $\begin{array}{l}(2.62 \pm \\
0.03)^{\mathrm{bc}}\end{array}$ & $\begin{array}{l}5.3 \pm \\
0.4)^{\mathrm{a}} \\
\end{array}$ & $\begin{array}{l}(5.0 \pm \\
0.2)^{\mathrm{a}} \\
\end{array}$ & $\begin{array}{l}(3.7 \pm \\
1.0)^{\mathrm{abc}}\end{array}$ & $\begin{array}{l}(2.02 \pm \\
0.07)^{\mathrm{cd}}\end{array}$ & $\begin{array}{l}(3.8 \pm \\
0.2)^{\mathrm{ab}}\end{array}$ \\
\hline A26 & $\alpha$-Farnesene (93) & $\begin{array}{c}(150 \pm \\
20)^{\mathrm{a}}\end{array}$ & $\begin{array}{l}(88 \pm \\
2)^{\text {bcd }}\end{array}$ & $\begin{array}{c}(136 \pm \\
8)^{\mathrm{ab}}\end{array}$ & $\begin{array}{c}(120 \pm \\
4)^{\mathrm{abc}}\end{array}$ & $\begin{array}{l}(110 \pm \\
40)^{\mathrm{abc}}\end{array}$ & $\begin{array}{c}(41 \pm \\
2)^{\mathrm{d}}\end{array}$ & $\begin{array}{l}(62.8 \pm \\
0.2)^{\mathrm{cd}}\end{array}$ \\
\hline A27 & $\begin{array}{c}\beta \text {-Sesquiphellandrene } \\
\text { (69) }\end{array}$ & $\begin{array}{l}(8.7 \pm \\
1.0)^{\mathrm{ab}}\end{array}$ & $\begin{array}{l}(8.3 \pm \\
0.6)^{\mathrm{ab}}\end{array}$ & $\begin{array}{l}(7.3 \pm \\
0.6)^{\mathrm{ab}}\end{array}$ & $\begin{array}{l}(8.20 \pm \\
0.14)^{\mathrm{ab}}\end{array}$ & $\begin{array}{c}(14 \pm \\
5)^{\mathrm{a}}\end{array}$ & $\begin{array}{l}(4.5 \pm \\
0.2)^{b}\end{array}$ & $\begin{array}{l}(8.3 \pm \\
0.4)^{\mathrm{ab}}\end{array}$ \\
\hline A28 & $\begin{array}{l}\text { Dodecanoic acid } \\
\text { methyl ester (74) }\end{array}$ & $\begin{array}{c}\text { n.d. } \\
\text { b }\end{array}$ & $\begin{array}{c}\text { n.d. } \\
\text { b }\end{array}$ & $\underset{\mathrm{b}}{\mathrm{n} . \mathrm{d} .}$ & $\begin{array}{c}(27.0 \pm \\
0.3)^{\mathrm{a}}\end{array}$ & $\begin{array}{c}\text { n.d. } \\
\mathrm{b}\end{array}$ & $\begin{array}{l}(0.8 \pm \\
0.3)^{\mathrm{b}}\end{array}$ & $\begin{array}{c}(0.43 \\
\pm 0.2)^{0 \mathrm{~b}}\end{array}$ \\
\hline A29 & Hexanoic acid (60) & $\begin{array}{c}(17 \pm \\
6)^{\mathrm{a}}\end{array}$ & $\begin{array}{l}(10 \pm \\
2)^{\mathrm{ab}}\end{array}$ & \begin{tabular}{|c|}
$(16.9 \pm$ \\
$1.3)^{\mathrm{a}}$ \\
\end{tabular} & $\begin{array}{c}(20.9 \pm \\
0.2)^{\mathrm{a}} \\
\end{array}$ & $\begin{array}{l}(4 \pm \\
2)^{\mathrm{b}} \\
\end{array}$ & $\begin{array}{l}(1.7 \pm \\
1.0)^{\mathrm{a}} \\
\end{array}$ & $\begin{array}{l}(3 \pm \\
2)^{b} \\
\end{array}$ \\
\hline A30 & $\begin{array}{l}\text { Phenylethyl alcohol } \\
\text { (91) }\end{array}$ & $(5 \pm 3)^{\mathrm{c}}$ & $(12 \pm 5)^{\mathrm{abc}}$ & $(18 \pm 5)^{\mathrm{ab}}$ & $\begin{array}{c}(19.6 \pm \\
0.7)^{\mathrm{a}} \\
\end{array}$ & \begin{tabular}{|l}
$(9.4 \pm$ \\
$0.3)^{\mathrm{abc}}$ \\
\end{tabular} & $\begin{array}{l}(4.9 \pm \\
0.8)^{\mathrm{c}} \\
\end{array}$ & $\begin{array}{l}(7.1 \pm \\
0.4)^{\mathrm{bc}}\end{array}$ \\
\hline A31 & $\begin{array}{c}\text { 2.6-Bis(1.1- } \\
\text { dimethylethyl)-4-(1- } \\
\text { oxopropyl) phenol } \\
(233)\end{array}$ & $(15 \pm 7)^{\mathrm{a}}$ & $\begin{array}{l}(9.32 \pm \\
0.08)^{\mathrm{ab}}\end{array}$ & $\begin{array}{c}(10.4 \pm \\
0.5)^{\mathrm{ab}}\end{array}$ & $\begin{array}{l}(10.7 \pm \\
0.8)^{\mathrm{ab}}\end{array}$ & $\left|\begin{array}{l}(9.74 \pm \\
0.05)^{\mathrm{ab}}\end{array}\right|$ & $\begin{array}{l}(0.9 \pm \\
0.2)^{b}\end{array}$ & $\begin{array}{l}(10.1 \pm \\
0.5)^{\mathrm{ab}}\end{array}$ \\
\hline A32 & $\begin{array}{c}\text { 4.6-Heptadienoic acid } \\
\text { 3.3.6-trimethyl. methyl } \\
\text { ester (109) }\end{array}$ & n.d. ${ }^{a}$ & $\begin{array}{l}(2.1 \pm \\
1.1)^{\mathrm{a}}\end{array}$ & $\begin{array}{l}(20 \pm \\
15)^{\mathrm{a}}\end{array}$ & $\begin{array}{l}(1.4 \pm \\
0.6)^{\mathrm{a}}\end{array}$ & $(7 \pm 5)^{\mathrm{a}}$ & n.d. ${ }^{a}$ & $(1.6 \pm 0.9)^{\mathrm{a}}$ \\
\hline A33 & + & n.d. ${ }^{\mathrm{c}}$ & $\begin{array}{l}(0.96 \pm \\
0.05)^{\mathrm{bc}}\end{array}$ & $\begin{array}{l}(1.2 \pm \\
0.4)^{\mathrm{ab}}\end{array}$ & $\begin{array}{l}(1.65 \pm \\
0.14)^{\mathrm{a}}\end{array}$ & n.d. ${ }^{c}$ & n.d. ${ }^{\mathrm{c}}$ & n.d. ${ }^{\mathrm{c}}$ \\
\hline A34 & $\begin{array}{c}\text { 3-Buten-2-ol 2-methyl } \\
\text { (71) }\end{array}$ & n.d. ${ }^{b}$ & $(6 \pm 5)^{\mathrm{ab}}$ & $\begin{array}{l}(11 \pm \\
7)^{\mathrm{ab}}\end{array}$ & $\begin{array}{l}(3.1 \pm \\
0.5)^{\mathrm{ab}}\end{array}$ & $\begin{array}{c}(13.1 \pm \\
0.9)^{\mathrm{a}}\end{array}$ & $\begin{array}{c}(1.43 \\
0.07)^{\mathrm{ab}}\end{array}$ & $\begin{array}{l}(2.8 \pm \\
0.3)^{\mathrm{ab}}\end{array}$ \\
\hline A35 & 1-Dodecanol (55) & $(8 \pm 5)^{\mathrm{a}}$ & n.d. ${ }^{a}$ & $\begin{array}{l}(1.5 \pm \\
0.3)^{\mathrm{a}}\end{array}$ & n.d. ${ }^{\mathrm{a}}$ & $\begin{array}{c}(10 \pm \\
4)^{\mathrm{a}}\end{array}$ & n.d. ${ }^{\mathrm{a}}$ & $\begin{array}{c}(0.8 \pm \\
0.5)^{\mathrm{a}}\end{array}$ \\
\hline A36 & $\begin{array}{c}\text { Dimethylpalmitamine } \\
(58)\end{array}$ & $(80 \pm 70)^{\mathrm{a}}$ & n.d. ${ }^{a}$ & n.d. ${ }^{a}$ & n.d. ${ }^{a}$ & $(5 \pm 4)^{\mathrm{a}}$ & n.d. ${ }^{a}$ & n.d. ${ }^{a}$ \\
\hline A37 & $\begin{array}{c}\text { Methyl tetradecanoate } \\
\text { (74) }\end{array}$ & n.d. ${ }^{b}$ & n.d. ${ }^{b}$ & n.d. ${ }^{b}$ & $(27 \pm 2)^{\mathrm{a}}$ & n.d. ${ }^{b}$ & n.d. ${ }^{\mathrm{b}}$ & n.d. ${ }^{\mathrm{b}}$ \\
\hline A38 & Phenol (94) & $\begin{array}{l}(2.8 \pm \\
0.9)^{\mathrm{a}}\end{array}$ & $\begin{array}{l}(2.3 \pm \\
0.2)^{\mathrm{a}}\end{array}$ & $\begin{array}{l}(2.66 \pm \\
0.10)^{\mathrm{a}}\end{array}$ & $\begin{array}{l}(3.44 \pm \\
0.09)^{\mathrm{a}}\end{array}$ & $\begin{array}{l}(2.4 \pm \\
0.2)^{\mathrm{a}}\end{array}$ & $(3.5 \pm 0.4)^{\mathrm{a}}$ & $\begin{array}{l}(2.21 \pm \\
0.02)^{\mathrm{a}}\end{array}$ \\
\hline A39 & Nerolidol 2 (69) & n.d. ${ }^{a}$ & n.d. ${ }^{\mathrm{a}}$ & n.d. ${ }^{\mathrm{a}}$ & n.d. ${ }^{a}$ & n.d. $^{a}$ & n.d. ${ }^{a}$ & n.d. $^{a}$ \\
\hline A40 & $\begin{array}{c}\text { 2(3H)-Furanone. } \\
\text { dihydro-5-propyl (85) }\end{array}$ & $\begin{array}{l}(3.1 \pm \\
0.8)^{\mathrm{b}}\end{array}$ & $\begin{array}{l}(4.0 \pm \\
1.2)^{\mathrm{b}}\end{array}$ & $\begin{array}{l}(7.0 \pm \\
0.5)^{\mathrm{a}} \\
\end{array}$ & $\begin{array}{l}(8.65 \pm \\
0.05)^{\mathrm{a}}\end{array}$ & $\begin{array}{l}(4.14 \pm \\
0.13)^{\mathrm{b}}\end{array}$ & $(2.8 \pm 0.3)^{\mathrm{b}}$ & $(3.2 \pm 0.3)^{\mathrm{b}}$ \\
\hline A41 & $\begin{array}{c}\text { Benzoic acid. 2- } \\
\text { methoxy. methyl ester } \\
\text { (135) }\end{array}$ & $(5 \pm 2)^{\mathrm{a}}$ & $\begin{array}{l}(1.9 \pm \\
0.6)^{\mathrm{ab}}\end{array}$ & $\begin{array}{l}(2.10 \pm \\
0.09)^{\mathrm{ab}}\end{array}$ & $\begin{array}{l}(1.3 \pm \\
0.4)^{\mathrm{ab}}\end{array}$ & $\begin{array}{l}(2.5 \pm \\
0.3)^{\mathrm{ab}}\end{array}$ & n.d. ${ }^{\mathrm{b}}$ & $\begin{array}{l}(0.96 \pm \\
0.05)^{\mathrm{ab}}\end{array}$ \\
\hline
\end{tabular}




\begin{tabular}{|c|c|c|c|c|c|c|c|c|}
\hline & & & & & & & able 3* & (continue) \\
\hline & & & Jormal & ised peal & $\mathrm{k}$ area (I & $\operatorname{mean} \pm$ & D. $n=2$ & \\
\hline$\frac{0}{8}$ & Compounds $(\mathbf{m} / \mathbf{z})$ & & & $\mathbf{E}_{\mathbf{C}}$ & & & $\mathbf{E}$ & \\
\hline ن & & $\mathbf{E}_{\mathbf{0}}$ & $\mathbf{E}_{7 \mathrm{C}}$ & $\mathbf{E}_{14 \mathrm{C}}$ & $\mathbf{E}_{21 \mathrm{C}}$ & $\mathbf{E}_{7 \mathrm{~K}}$ & $\mathbf{E}_{14 \mathrm{~K}}$ & $\mathbf{E}_{21 K}$ \\
\hline A42 & $\begin{array}{l}\text { 2H-Pyran-2-one. 6- } \\
\text { hexyltetrahydro (99) }\end{array}$ & $(4 \pm 2)^{\mathrm{a}}$ & $(5 \pm 3)^{\mathrm{a}}$ & $(3 \pm 2)^{\mathrm{a}}$ & $\begin{array}{l}(2.0 \pm \\
0.2)^{\mathrm{a}}\end{array}$ & $\begin{array}{l}(2.0 \pm \\
0.7)^{\mathrm{a}}\end{array}$ & n.d. ${ }^{\mathrm{a}}$ & n.d. ${ }^{a}$ \\
\hline A43 & $\begin{array}{c}\text { Hexadecanoic acid methyl } \\
\text { ester (74) }\end{array}$ & $(9 \pm 4)^{b}$ & $(5 \pm 4)^{\mathrm{b}}$ & $(12 \pm 2)^{b}$ & $(33 \pm 5)^{\mathrm{a}}$ & $(5 \pm 4)^{\mathrm{b}}$ & $\begin{array}{l}(5.0 \pm \\
0.3)^{\mathrm{b}}\end{array}$ & $(6 \pm 2)^{b}$ \\
\hline A44 & n.i. (71) & $(1.3 \pm 0.4)^{\mathrm{a}}$ & $\begin{array}{l}(12 \pm \\
10)^{\mathrm{a}}\end{array}$ & $\begin{array}{l}(30 \pm \\
20)^{\mathrm{a}}\end{array}$ & $\begin{array}{l}(14.9 \\
\pm 1.3)^{\mathrm{a}}\end{array}$ & $(5 \pm 3)^{a}$ & n.d. ${ }^{\mathrm{a}}$ & $(2.2 \pm 0.2)^{\mathrm{a}}$ \\
\hline A45 & $\begin{array}{c}\text { 9-Octadecenoic acid methyl } \\
\text { ester (55) }\end{array}$ & $\begin{array}{l}(5.77 \pm \\
0.08)^{\mathrm{b}}\end{array}$ & $(4 \pm 3)^{b}$ & $\begin{array}{c}(18.0 \pm \\
0.3)^{\mathrm{a}} \\
\end{array}$ & $\begin{array}{c}(15 \pm \\
5)^{\mathrm{ab}}\end{array}$ & $(6 \pm 7)^{\mathrm{b}}$ & $\begin{array}{l}(4.5 \pm \\
0.7)^{\mathrm{b}} \\
\end{array}$ & $(8 \pm 2)^{\mathrm{b}}$ \\
\hline A46 & p-Isopropenylphenol (134) & $\begin{array}{l}(1.7 \pm \\
0.4)^{\mathrm{b}}\end{array}$ & $\begin{array}{l}(1.6 \pm \\
0.8)^{\mathrm{b}}\end{array}$ & $\begin{array}{l}(2.2 \pm \\
0.8)^{\mathrm{b}}\end{array}$ & $\begin{array}{l}(1.8 \pm \\
0.3)^{\mathrm{b}}\end{array}$ & $\begin{array}{l}(2.4 \pm \\
0.3)^{\mathrm{b}}\end{array}$ & \begin{tabular}{|c|}
$(11 \pm$ \\
$3)^{\mathrm{a}}$ \\
\end{tabular} & $\begin{array}{l}(2.40 \pm \\
0.09)^{\mathrm{b}}\end{array}$ \\
\hline
\end{tabular}

${ }^{*}$ Peak areas are normalised respect to internal standard ${ }^{1}$ n.d. not detected.

${ }^{\text {a-f }}$ Values in the same row with different superscript letters differ significantly $(p<0.05)$.

Data showed mean of two independent tests (mean \pm sd). 
Table 4*

Volatile compounds ( $\left.\mathrm{AU} \times 10^{4}\right)$ isolated from Uslu oils in two different packaging at initial and after 7, 14 and 21 days of stages of ripening

\begin{tabular}{|c|c|c|c|c|c|c|c|c|}
\hline \multirow{3}{*}{$\frac{n}{8}$} & \multirow{3}{*}{$\begin{array}{c}\text { Compounds } \\
(\mathbf{m} / \mathbf{z})\end{array}$} & \multicolumn{7}{|c|}{ Normalised peak area $($ mean \pm SD. $n=2)$} \\
\hline & & & \multicolumn{3}{|c|}{$\mathbf{U}_{\mathbf{C}}$} & \multicolumn{3}{|c|}{$\mathbf{U}_{\mathbf{K}}$} \\
\hline & & $\mathbf{U}_{\mathbf{0}}$ & $\mathbf{U}_{7 \mathbf{C}}$ & $\mathbf{U}_{14 \mathrm{C}}$ & $\mathbf{U}_{21 \mathrm{C}}$ & $\mathbf{U}_{7 \mathbf{K}}$ & $\mathbf{U}_{14 \mathrm{~K}}$ & $\mathbf{U}_{21 \mathrm{~K}}$ \\
\hline A1 & Hexanal (44) & $\begin{array}{c}(140.5 \pm \\
4.6)^{\mathrm{a}}\end{array}$ & $\begin{array}{c}(51.4 \pm \\
0.2)^{\mathrm{b}}\end{array}$ & n.d. ${ }^{\mathrm{c}}$ & n.d. ${ }^{c}$ & $\begin{array}{c}(52.5 \pm \\
0.8)^{\mathrm{b}}\end{array}$ & n.d. ${ }^{\mathrm{c}}$ & n.d. ${ }^{c}$ \\
\hline A2 & $\begin{array}{c}\text { 1-Propanol 2- } \\
\text { methyl (43) }\end{array}$ & $\begin{array}{c}\text { n.d. } \\
\mathrm{c}\end{array}$ & $\begin{array}{c}\text { n.d. } \\
\text { c }\end{array}$ & $\begin{array}{c}(17.54 \pm \\
0.02)^{\mathrm{a}} \\
\end{array}$ & $\begin{array}{c}(18.1 \pm \\
0.2)^{\mathrm{a}} \\
\end{array}$ & n.d. ${ }^{\mathrm{c}}$ & $\begin{array}{l}(12.2 \pm \\
1.4)^{\mathrm{b}} \\
\end{array}$ & $\begin{array}{l}(13.8 \pm \\
0.08)^{\mathrm{b}}\end{array}$ \\
\hline A3 & Pyridine (79) & n.d. ${ }^{\mathbf{b}}$ & n.d. ${ }^{\mathrm{b}}$ & n.d. ${ }^{b}$ & n.d. & n.d. ${ }^{b}$ & n.d d $^{\text {b. }}$ & $\begin{array}{l}(7.1 \pm \\
0.3)^{\mathrm{a}}\end{array}$ \\
\hline A4 & $\begin{array}{l}\text { 1-Butanol 2- } \\
\text { methyl (57) }\end{array}$ & $\begin{array}{l}(1.9 \pm \\
0.05)^{\mathrm{c}}\end{array}$ & $\begin{array}{l}(2.9 \pm \\
1.2)^{\mathrm{bc}}\end{array}$ & $\begin{array}{c}(11.69 \pm \\
0.14)^{\mathrm{a}}\end{array}$ & $(5.0 \pm 0.7)^{\mathrm{b}}$ & $\begin{array}{l}(3.1 \pm \\
0.2)^{\mathrm{bc}}\end{array}$ & $\begin{array}{l}(1.23 \pm \\
0.08)^{\mathrm{c}}\end{array}$ & $\begin{array}{l}(2.12 \pm \\
0.07)^{\mathrm{bc}}\end{array}$ \\
\hline A5 & $\begin{array}{l}\text { 1-Butanol 3- } \\
\text { methyl (70) }\end{array}$ & $\begin{array}{l}(2.09 \pm \\
0.04)^{\mathrm{d}}\end{array}$ & $\begin{array}{l}(3.5 \pm \\
0.4)^{\mathrm{d}}\end{array}$ & $\begin{array}{c}(12.8 \pm \\
0.6)^{\mathrm{a}}\end{array}$ & $\begin{array}{l}(5.5 \pm \\
0.3)^{\mathrm{c}}\end{array}$ & $\begin{array}{l}(3.2 \pm \\
0.2)^{\mathrm{d}}\end{array}$ & $\begin{array}{l}(9.3 \pm \\
0.6)^{\mathrm{b}}\end{array}$ & $\begin{array}{l}(2.21 \pm \\
0.02)^{\mathrm{d}}\end{array}$ \\
\hline A6 & Limonene (68) & $\begin{array}{l}(0.82 \pm \\
0.01)^{\mathrm{b}}\end{array}$ & $\begin{array}{l}(2.42 \pm \\
0.06)^{\mathrm{a}} \\
\end{array}$ & $\begin{array}{l}(1.02 \pm \\
0.02)^{\mathrm{b}}\end{array}$ & $\begin{array}{l}(1.14 \pm \\
0.04)^{\mathrm{b}}\end{array}$ & $\begin{array}{l}(3.00 \pm \\
0.02)^{\mathrm{a}} \\
\end{array}$ & $\begin{array}{l}(1.10 \pm \\
0.14)^{\mathrm{b}}\end{array}$ & $\begin{array}{l}(1.83 \pm \\
0.02)^{\mathrm{ab}}\end{array}$ \\
\hline A7 & $\begin{array}{c}\text { 2-Hexenal (E) } \\
(41)\end{array}$ & $(146 \pm 3)^{\mathrm{a}}$ & $\begin{array}{c}(28.3 \pm \\
0.9)^{\mathrm{b}}\end{array}$ & $\begin{array}{c}(2.0 \\
\pm 1.1)^{\mathrm{c}}\end{array}$ & $\begin{array}{c}(1.00 \\
\pm 0.00)^{\mathrm{c}}\end{array}$ & $(37 \pm 6)^{b}$ & n.d. ${ }^{\mathrm{c}}$ & n.d. ${ }^{c}$ \\
\hline A8 & $\begin{array}{l}\text { Cyclodecane } \\
\text { methyl (55) }\end{array}$ & $\begin{array}{c}(16.3 \pm \\
0.3)^{\mathrm{a}}\end{array}$ & $\begin{array}{c}(15.1 \pm \\
0.4)^{\mathrm{a}}\end{array}$ & $\begin{array}{c}(10.34 \pm \\
0.14)^{c}\end{array}$ & $\begin{array}{c}(10.9 \pm \\
1.1)^{\mathrm{c}}\end{array}$ & $\begin{array}{l}(11.2 \pm \\
0.2)^{\mathrm{bc}}\end{array}$ & $\begin{array}{c}(13.1 \pm \\
0.3)^{\mathrm{b}}\end{array}$ & $\begin{array}{l}(11.3 \pm \\
0.2)^{\mathrm{bc}}\end{array}$ \\
\hline A9 & $\begin{array}{l}\text { 2-Butanone 3- } \\
\text { hydroxy (45) }\end{array}$ & $\begin{array}{l}(4.02 \pm \\
0.11)^{\mathrm{d}}\end{array}$ & $\begin{array}{l}(9.6 \pm \\
0.5)^{\mathrm{cd}}\end{array}$ & $\begin{array}{l}(12.1 \pm \\
0.2)^{\mathrm{bcc}}\end{array}$ & $\begin{array}{c}(17.37 \\
\pm 0.08)^{\mathrm{b}}\end{array}$ & $\begin{array}{l}(9.0 \pm \\
0.7)^{\mathrm{cd}}\end{array}$ & $(39 \pm 4)^{\mathrm{a}}$ & $\begin{array}{l}(8.6 \pm \\
0.4)^{\mathrm{cd}}\end{array}$ \\
\hline A10 & Tridecane (57) & $\begin{array}{c}(3.53 \\
\pm 0.01)^{\mathrm{a}}\end{array}$ & $(4 \pm 2)^{\mathrm{a}}$ & $\begin{array}{l}(2.44 \pm \\
0.08)^{\mathrm{a}}\end{array}$ & $\begin{array}{l}(2.3 \pm \\
0.3)^{\mathrm{a}}\end{array}$ & $\begin{array}{l}(2.02 \pm \\
0.08)^{\mathrm{a}}\end{array}$ & $\begin{array}{l}(3.5 \pm \\
0.8)^{\mathrm{a}}\end{array}$ & $\begin{array}{l}(2.32 \pm \\
0.04)^{\mathrm{a}}\end{array}$ \\
\hline A11 & $\begin{array}{l}\text { 5-Hepten-2-one. } \\
\text { 6-methyl (43) }\end{array}$ & $\begin{array}{l}(1.64 \pm \\
0.04)^{\mathrm{de}}\end{array}$ & $\begin{array}{l}(1.4 \pm \\
0.5)^{\mathrm{e}}\end{array}$ & $\begin{array}{l}(3.0 \pm \\
0.3)^{c}\end{array}$ & $\begin{array}{l}(3.32 \pm \\
0.09)^{\mathrm{bc}}\end{array}$ & $\begin{array}{l}(2.6 \pm \\
0.2)^{\mathrm{cd}}\end{array}$ & $\begin{array}{l}(4.52 \pm \\
0.12)^{\mathrm{a}}\end{array}$ & $\begin{array}{l}(4.02 \pm \\
0.06)^{\mathrm{ab}}\end{array}$ \\
\hline A12 & 1-Hexanol (56) & $\begin{array}{c}(46.8 \pm \\
0.9)^{\mathrm{d}} \\
\end{array}$ & $\begin{array}{c}(186 \pm \\
2)^{\mathrm{a}} \\
\end{array}$ & $\begin{array}{l}(91.9 \pm \\
1.2)^{\mathrm{c}} \\
\end{array}$ & $\begin{array}{c}(51.3 \pm \\
0.2)^{\mathrm{d}} \\
\end{array}$ & $\begin{array}{c}(114 \pm \\
2)^{\mathrm{b}} \\
\end{array}$ & $\begin{array}{c}(18.7 \pm \\
0.2)^{\mathrm{f}} \\
\end{array}$ & $\begin{array}{c}(34.3 \pm \\
0.3)^{\mathrm{e}}\end{array}$ \\
\hline A13 & $\begin{array}{c}\text { 3-Hexen-1-ol (Z) } \\
\text { (41) }\end{array}$ & $\begin{array}{l}(5.00 \pm \\
0.09)^{\mathrm{a}}\end{array}$ & $\begin{array}{l}(4.3 \pm \\
0.3)^{\mathrm{ab}} \\
\end{array}$ & $\begin{array}{c}(2.5 \pm \\
0.8)^{\mathrm{bcd}}\end{array}$ & $\begin{array}{l}(2.0 \pm \\
0.4)^{\mathrm{cd}}\end{array}$ & $\begin{array}{c}(3.8 \pm \\
0.2)^{\mathrm{abc}}\end{array}$ & n.d. ${ }^{\mathrm{e}}$ & $\begin{array}{l}(1.2 \pm \\
0.2)^{\mathrm{de}}\end{array}$ \\
\hline A14 & Nonanal (57) & $(6.2 \pm 0.2)^{\mathrm{a}}$ & $(3 \pm 2)^{\mathrm{b}}$ & $\begin{array}{l}(2.8 \pm \\
0.6)^{\mathrm{b}}\end{array}$ & $\begin{array}{l}(1.3 \pm \\
0.5)^{\mathrm{b}}\end{array}$ & $\begin{array}{l}(1.65 \pm \\
0.12)^{\mathrm{b}}\end{array}$ & $\begin{array}{l}(1.9 \pm \\
0.5)^{\mathrm{b}}\end{array}$ & $\begin{array}{l}(1.75 \pm \\
0.09)^{\mathrm{b}}\end{array}$ \\
\hline A15 & $\begin{array}{c}\text { 2-Hexen-1-ol (E) } \\
(57)\end{array}$ & $\begin{array}{c}(30.8 \pm \\
0.2)^{\mathrm{a}}\end{array}$ & $\begin{array}{c}(128 \pm \\
2)^{\mathrm{a}}\end{array}$ & $\begin{array}{c}(45.1 \pm \\
0.8)^{\mathrm{b}}\end{array}$ & $\begin{array}{c}(23.95 \pm \\
0.11)^{\mathrm{c}}\end{array}$ & $(71 \pm 3)^{\mathrm{a}}$ & $\begin{array}{l}(1.1 \pm \\
0.3)^{\mathrm{a}}\end{array}$ & $\begin{array}{c}(22.6 \pm \\
0.8)^{\mathrm{a}}\end{array}$ \\
\hline A16 & Acetic acid (45) & $\begin{array}{c}(21.8 \pm \\
0.5)^{\mathrm{a}}\end{array}$ & $\begin{array}{c}(19 \pm \\
2)^{\mathrm{a}}\end{array}$ & $\begin{array}{c}(11.6 \pm \\
0.8)^{\mathrm{a}}\end{array}$ & $\begin{array}{c}(16.4 \pm \\
0.4)^{\mathrm{a}}\end{array}$ & $\begin{array}{c}(13.3 \pm \\
0.9)^{\mathrm{a}}\end{array}$ & $\begin{array}{c}(15.01 \pm \\
0.08)^{\mathrm{a}}\end{array}$ & $\begin{array}{c}(13 \pm \\
8)^{\mathrm{a}}\end{array}$ \\
\hline A17 & $\begin{array}{c}\text { Cycloisosativene } \\
(147)\end{array}$ & $\begin{array}{l}(1.27 \pm \\
0.04)^{\mathrm{a}} \\
\end{array}$ & \begin{tabular}{|l|}
$(1.81 \pm$ \\
$0.04)^{\mathrm{a}}$ \\
\end{tabular} & $\begin{array}{l}(2.66 \pm \\
0.05)^{\mathrm{a}} \\
\end{array}$ & $\begin{array}{l}(2.82 \pm \\
0.05)^{\mathrm{a}} \\
\end{array}$ & $\begin{array}{l}(1.66 \pm \\
0.14)^{\mathrm{a}} \\
\end{array}$ & $\begin{array}{c}(3.0 \pm \\
0.3)^{\mathrm{a}} \\
\end{array}$ & $\begin{array}{l}(2.8 \pm \\
0.2)^{\mathrm{a}} \\
\end{array}$ \\
\hline A18 & n.i. (119) & $\begin{array}{l}(2.32 \pm \\
0.07)^{\mathrm{a}} \\
\end{array}$ & $\begin{array}{l}(2.4 \pm \\
0.2)^{\mathrm{a}}\end{array}$ & $\begin{array}{l}(1.49 \pm \\
0.08)^{\mathrm{b}}\end{array}$ & $\begin{array}{l}(1.69 \pm \\
0.05)^{\mathrm{b}}\end{array}$ & $\begin{array}{l}(1.66 \pm \\
0.01)^{\mathrm{b}} \\
\end{array}$ & $\begin{array}{l}(1.9 \pm \\
0.2)^{\mathrm{b}}\end{array}$ & $\begin{array}{l}(1.7 \pm \\
0.1)^{\mathrm{b}}\end{array}$ \\
\hline A19 & $\begin{array}{c}\text { Dimethyl } \\
\text { sulfoxide (63) }\end{array}$ & $\begin{array}{c}(13.3 \pm \\
0.3)^{\mathrm{b}}\end{array}$ & $\begin{array}{l}(2.0 \pm \\
0.3)^{\mathrm{d}}\end{array}$ & $\begin{array}{c}(14.7 \pm \\
0.2)^{\mathrm{a}}\end{array}$ & $\begin{array}{l}(14.0 \pm \\
0.4)^{\mathrm{ab}}\end{array}$ & $\begin{array}{l}(2.1 \pm \\
0.3)^{d}\end{array}$ & $\begin{array}{l}(2.2 \pm \\
0.5)^{\mathrm{d}}\end{array}$ & $\begin{array}{l}(4.75 \pm \\
0.13)^{\mathrm{c}}\end{array}$ \\
\hline A20 & $\begin{array}{c}\alpha \text {-Bergamotene } \\
\text { (119) }\end{array}$ & $\begin{array}{l}(2.32 \pm \\
0.01)^{\mathrm{a}}\end{array}$ & $\begin{array}{l}(2.35 \pm \\
0.03)^{\mathrm{a}}\end{array}$ & $\begin{array}{l}(1.62 \pm \\
0.07)^{\mathrm{bc}}\end{array}$ & $\begin{array}{l}(1.7 \pm \\
0.2)^{\mathrm{bc}}\end{array}$ & $\begin{array}{l}(1.42 \pm \\
0.13)^{\mathrm{c}}\end{array}$ & $\begin{array}{l}(1.96 \pm \\
0.01)^{\mathrm{ab}}\end{array}$ & $\begin{array}{l}(1.7 \pm \\
0.2)^{\mathrm{bc}}\end{array}$ \\
\hline
\end{tabular}




\begin{tabular}{|c|c|c|c|c|c|c|c|c|}
\hline \multicolumn{9}{|c|}{ Table $4 *$ (continue) } \\
\hline \multirow{3}{*}{$\frac{\tilde{e}}{8}$} & \multirow{3}{*}{$\begin{array}{c}\text { Compounds } \\
(\mathbf{m} / \mathbf{z})\end{array}$} & \multicolumn{7}{|c|}{ Normalised peak area $($ mean \pm SD. $n=2)$} \\
\hline & & & \multicolumn{3}{|c|}{$\mathbf{U}_{\mathbf{C}}$} & \multicolumn{3}{|c|}{$\mathbf{U}_{\mathbf{K}}$} \\
\hline & & $\mathbf{U}_{0}$ & $\mathbf{U}_{7 \mathrm{C}}$ & $\mathbf{U}_{14 \mathrm{C}}$ & $\mathbf{U}_{21 \mathrm{C}}$ & $\mathbf{U}_{7 \mathbf{K}}$ & $\mathbf{U}_{14 \mathrm{~K}}$ & $\mathbf{U}_{21 \mathrm{~K}}$ \\
\hline A21 & $\begin{array}{c}\text { Decanoic acid } \\
\text { methyl ester (74) }\end{array}$ & n.d. ${ }^{\mathrm{a}}$ & n.d. ${ }^{a}$ & n.d. ${ }^{a}$ & n.d. ${ }^{a}$ & n.d. ${ }^{\mathrm{a}}$ & n.d. ${ }^{a}$ & n.d. ${ }^{\mathrm{a}}$ \\
\hline A22 & $\begin{array}{l}\text { Cycloheptanone } \\
\text { 2-methylene (43) }\end{array}$ & n.d. ${ }^{\mathrm{a}}$ & n.d. ${ }^{a}$ & n.d. ${ }^{\mathrm{a}}$ & n.d. ${ }^{\mathrm{a}}$ & n.d. ${ }^{a}$ & n.d. ${ }^{\mathrm{a}}$ & n.d. ${ }^{\mathrm{a}}$ \\
\hline A23 & $\begin{array}{c}(E) \text { - } \beta \text {-Farnesene } \\
\text { (69) }\end{array}$ & $\begin{array}{l}(6.70 \pm \\
0.18)^{\mathrm{ab}}\end{array}$ & $\begin{array}{l}(7.1 \pm \\
0.7)^{\mathrm{a}}\end{array}$ & $\begin{array}{l}(3.8 \pm \\
0.3)^{\mathrm{cd}}\end{array}$ & $\begin{array}{l}(4.8 \pm \\
0.5)^{\mathrm{bcd}}\end{array}$ & $\begin{array}{l}(3.27 \pm \\
0.14)^{\mathrm{d}}\end{array}$ & $\begin{array}{l}(5.5 \pm \\
0.2)^{\mathrm{abc}}\end{array}$ & $\begin{array}{l}(4.7 \pm \\
0.9)^{\mathrm{cd}}\end{array}$ \\
\hline A24 & $\begin{array}{c}\text { 8-Heptadecene } \\
(69)\end{array}$ & $\begin{array}{l}(7.64 \pm \\
0.10)^{\mathrm{a}} \\
\end{array}$ & $(7 \pm 2)^{\mathrm{a}}$ & $\begin{array}{l}(2.7 \pm \\
0.4)^{\mathrm{b}}\end{array}$ & $\begin{array}{l}(3.1 \pm \\
0.5)^{\mathrm{b}}\end{array}$ & $\begin{array}{l}(2.7 \pm \\
0.3)^{\mathrm{b}} \\
\end{array}$ & $\begin{array}{l}(3.6 \pm \\
0.3)^{\mathrm{b}}\end{array}$ & \begin{tabular}{|l|}
$(3.7 \pm$ \\
$0.6)^{\mathrm{b}}$ \\
\end{tabular} \\
\hline A25 & $\begin{array}{c}\text { Eremophilene } \\
(161)\end{array}$ & $\begin{array}{c}(10.7 \pm \\
0.4)^{\mathrm{a}} \\
\end{array}$ & \begin{tabular}{|c|}
$(13.8 \pm$ \\
$1.2)^{\mathrm{b}}$ \\
\end{tabular} & $\begin{array}{c}(12.3 \pm \\
0.4)^{\mathrm{bc}} \\
\end{array}$ & $\begin{array}{l}(11.9 \pm \\
1.0)^{\mathrm{bc}} \\
\end{array}$ & $\begin{array}{l}(9.6 \pm \\
1.0)^{\mathrm{c}} \\
\end{array}$ & $\begin{array}{c}(17.7 \pm \\
0.3)^{\mathrm{a}} \\
\end{array}$ & \begin{tabular}{|l|}
$(11.0 \pm$ \\
$1.3)^{\mathrm{bc}}$ \\
\end{tabular} \\
\hline A26 & $\alpha$-Farnesene (93) & $(614 \pm 2)^{\mathrm{a}}$ & $\begin{array}{c}(570 \pm \\
90)^{\mathrm{a}} \\
\end{array}$ & $\begin{array}{c}(219.70 \pm \\
0.05)^{\mathrm{b}}\end{array}$ & $\begin{array}{c}(230 \pm \\
30)^{\mathrm{b}}\end{array}$ & $\begin{array}{c}(200 \pm \\
20)^{b}\end{array}$ & $\begin{array}{c}(259 \pm \\
6)^{\mathrm{b}}\end{array}$ & $\begin{array}{c}(210 \pm \\
20)^{b} \\
\end{array}$ \\
\hline A27 & $\begin{array}{c}\beta- \\
\text { Sesquiphellandre } \\
\text { ne (69) }\end{array}$ & n.d. ${ }^{a}$ & n.d. ${ }^{a}$ & n.d. ${ }^{a}$ & n.d. ${ }^{a}$ & n.d. ${ }^{a}$ & n.d. ${ }^{a}$ & n.d. ${ }^{\mathrm{a}}$ \\
\hline A28 & $\begin{array}{l}\text { Dodecanoic acid. } \\
\text { methyl ester (74) }\end{array}$ & $\begin{array}{l}(1.5 \pm \\
0.01)^{\mathrm{a}} \\
\end{array}$ & $\begin{array}{l}(0.7 \pm \\
0.2)^{\mathrm{ab}}\end{array}$ & n.d. ${ }^{b}$ & n.d. ${ }^{b}$ & $\begin{array}{l}(0.91 \pm \\
0.13)^{\mathrm{ab}}\end{array}$ & $\begin{array}{l}(1.11 \pm \\
0.13)^{\mathrm{a}} \\
\end{array}$ & n.d. ${ }^{b}$ \\
\hline A29 & $\begin{array}{c}\text { Hexanoic acid } \\
(60)\end{array}$ & $\begin{array}{c}(20.4 \pm \\
0.4)^{\mathrm{a}}\end{array}$ & \begin{tabular}{|c|}
$(15.4 \pm$ \\
$1.3)^{\mathrm{b}}$ \\
\end{tabular} & $(8 \pm 2)^{\mathrm{cd}}$ & $\begin{array}{l}(3.4 \pm \\
0.7)^{\mathrm{ef}}\end{array}$ & $\begin{array}{l}(9.9 \pm \\
0.5)^{\mathrm{c}} \\
\end{array}$ & $\begin{array}{l}(4.1 \pm \\
0.2)^{\mathrm{de}}\end{array}$ & n.d. ${ }^{\mathrm{f}}$ \\
\hline A30 & $\begin{array}{l}\text { Phenylethyl } \\
\text { alcohol (91) }\end{array}$ & $\begin{array}{l}(6.20 \pm \\
0.12)^{\mathrm{b}}\end{array}$ & $\begin{array}{l}(6.7 \pm \\
0.3)^{b}\end{array}$ & $\begin{array}{l}(80 \pm \\
30)^{\mathrm{a}}\end{array}$ & $\begin{array}{l}(28.6 \pm \\
0.6)^{b}\end{array}$ & $\begin{array}{l}(6.9 \pm \\
0.2)^{\mathrm{b}}\end{array}$ & $\begin{array}{c}(23.4 \pm \\
0.8)^{\mathrm{b}}\end{array}$ & $\begin{array}{c}(18.2 \pm \\
0.8)^{\mathrm{b}}\end{array}$ \\
\hline A31 & $\begin{array}{c}\text { 2.6-Bis(1.1- } \\
\text { dimethylethyl)-4- } \\
\text { (1-oxopropyl) } \\
\text { phenol (233) }\end{array}$ & $\begin{array}{l}(9.70 \pm \\
0.13)^{\mathrm{ab}}\end{array}$ & $\begin{array}{c}(10.6 \pm \\
0.7)^{\mathrm{a}}\end{array}$ & $\begin{array}{c}(10.06 \pm \\
0.04)^{\mathrm{ab}}\end{array}$ & $\begin{array}{l}(9.10 \pm \\
0.11)^{\mathrm{b}}\end{array}$ & $\begin{array}{l}(9.4 \pm \\
0.4)^{\mathrm{ab}}\end{array}$ & $\begin{array}{l}(10.3 \pm \\
0.5)^{\mathrm{ab}}\end{array}$ & $\begin{array}{l}(8.95 \pm \\
0.070^{\mathrm{b}}\end{array}$ \\
\hline A32 & $\begin{array}{l}\text { 4.6-Heptadienoic } \\
\text { acid 3.3.6- } \\
\text { trimethyl. methyl } \\
\text { ester (109) }\end{array}$ & n.d. ${ }^{\mathrm{b}}$ & $(5 \pm 3)^{\mathrm{ab}}$ & $\begin{array}{l}(7.8 \pm \\
1.4)^{\mathrm{a}}\end{array}$ & $\begin{array}{l}(1.4 \pm \\
0.6)^{\mathrm{b}}\end{array}$ & n.d. ${ }^{b}$ & $\begin{array}{l}(0.94 \pm \\
0.08)^{\mathrm{b}}\end{array}$ & $\begin{array}{l}(1.4 \pm \\
0.5)^{\mathrm{b}}\end{array}$ \\
\hline A33 & n.i. (159) & $\begin{array}{l}(7.72 \pm \\
0.13)^{\mathrm{a}} \\
\end{array}$ & $(3 \pm 2)^{\mathrm{b}}$ & $\begin{array}{l}(4.54 \pm \\
0.10)^{\mathrm{ab}}\end{array}$ & $\begin{array}{l}(2.4 \pm \\
0.5)^{\mathrm{ab}} \\
\end{array}$ & $\begin{array}{c}(1.4 \pm \\
0.6)^{\mathrm{b}}\end{array}$ & $(2 \pm 2)^{\mathrm{b}}$ & \begin{tabular}{|l|}
$(2.3 \pm$ \\
$0.2)^{\mathrm{ab}}$ \\
\end{tabular} \\
\hline A34 & $\begin{array}{c}\text { 3-Buten-2-ol. 2- } \\
\text { methyl (71) }\end{array}$ & $\begin{array}{l}(3.31 \pm \\
0.10)^{\mathrm{a}} \\
\end{array}$ & n.d. ${ }^{\text {b }}$ & n.d. ${ }^{\mathrm{b}}$ & n.d ${ }^{b}$ & n.d. ${ }^{b}$ & n.d. ${ }^{b}$ & n.d. ${ }^{b}$ \\
\hline A35 & 1-Dodecanol (55) & $\begin{array}{c}\text { n.d. } \\
\text { a }\end{array}$ & $\begin{array}{c}\text { n.d. } \\
\text { a }\end{array}$ & $\begin{array}{c}\text { n.d. } \\
\text { a }\end{array}$ & $\begin{array}{c}\text { n.d. } \\
\text { a }\end{array}$ & $\begin{array}{c}\text { n.d. } \\
\text { a }\end{array}$ & $\begin{array}{c}\text { n.d. } \\
\text { a }\end{array}$ & $\begin{array}{c}\text { n.d. } \\
\text { a }\end{array}$ \\
\hline A36 & $\begin{array}{l}\text { Dimethylpalmita } \\
\text { mine (58) }\end{array}$ & $\begin{array}{l}(8.2 \pm \\
0.2)^{\mathrm{a}} \\
\end{array}$ & $\begin{array}{l}(8.1 \pm \\
0.6)^{\mathrm{a}} \\
\end{array}$ & $(16 \pm 5)^{\mathrm{a}}$ & $(12 \pm 6)^{a}$ & $\begin{array}{r}(4.0 \pm \\
0.4)^{\mathrm{a}} \\
\end{array}$ & $\begin{array}{r}(6.8 \pm \\
0.9)^{\mathrm{a}} \\
\end{array}$ & $\begin{array}{l}(7.3 \pm \\
0.7)^{\mathrm{a}} \\
\end{array}$ \\
\hline A37 & $\begin{array}{c}\text { Methyl } \\
\text { tetradecanoate } \\
(74) \\
\end{array}$ & n.d. ${ }^{a}$ & n.d. ${ }^{\mathrm{a}}$ & n.d. ${ }^{\mathrm{a}}$ & n.d. ${ }^{\mathrm{a}}$ & n.d. ${ }^{\mathrm{a}}$ & n.d. ${ }^{\mathrm{a}}$ & n.d. ${ }^{\mathrm{a}}$ \\
\hline A38 & Phenol (94) & $\begin{array}{l}(3.43 \pm \\
0.07)^{\mathrm{b}}\end{array}$ & $\begin{array}{l}(2.2 \pm \\
0.4)^{\mathrm{c}}\end{array}$ & $(9 \pm 2)^{\mathrm{a}}$ & $\begin{array}{l}(6.18 \pm \\
0.09)^{\mathrm{b}}\end{array}$ & $\begin{array}{l}(2.0 \pm \\
0.5)^{\mathrm{c}}\end{array}$ & $\begin{array}{l}(3.43 \pm \\
0.08)^{\mathrm{bc}}\end{array}$ & $\begin{array}{l}(3.08 \pm \\
0.09)^{\mathrm{bc}}\end{array}$ \\
\hline A39 & Nerolidol 2 (69) & $(54 \pm 2)^{\mathrm{a}}$ & $(21 \pm 10)^{b}$ & $(15 \pm 2)^{\mathrm{bc}}$ & $(3.3 \pm 0.8)^{\mathrm{c}}$ & $\begin{array}{l}(3.0 \pm \\
1.4)^{\mathrm{c}} \\
\end{array}$ & $\begin{array}{l}(7.0 \pm \\
0.2)^{\mathrm{bc}}\end{array}$ & \begin{tabular}{|l|}
$(2.59 \pm$ \\
$0.04)^{\mathrm{c}}$ \\
\end{tabular} \\
\hline A40 & $\begin{array}{c}\text { 2(3H)-Furanone } \\
\text { dihydro-5-propyl } \\
(85)\end{array}$ & $\begin{array}{l}(8.07 \pm \\
0.12)^{\mathrm{b}}\end{array}$ & $(9 \pm 2)^{b}$ & $(25 \pm 9)^{\mathrm{a}}$ & $\begin{array}{l}(5.9 \pm \\
0.7)^{\mathrm{b}}\end{array}$ & $\begin{array}{c}(4.6 \pm \\
0.3)^{\mathrm{b}}\end{array}$ & $\begin{array}{c}(12.44 \pm \\
0.04)^{\mathrm{ab}}\end{array}$ & $\begin{array}{l}(4.21 \pm \\
0.04)^{\mathrm{b}}\end{array}$ \\
\hline
\end{tabular}




\begin{tabular}{|c|c|c|c|c|c|c|c|c|}
\hline \multicolumn{9}{|c|}{ Table $4 *$ (continue) } \\
\hline \multirow{3}{*}{$\frac{e}{8}$} & \multirow{3}{*}{$\begin{array}{c}\text { Compounds } \\
(\mathbf{m} / \mathbf{z})\end{array}$} & \multicolumn{7}{|c|}{ Normalised peak area $($ mean \pm SD. $n=2)$} \\
\hline & & & \multicolumn{3}{|c|}{$\mathbf{U}_{\mathbf{C}}$} & \multicolumn{3}{|c|}{$\mathbf{U}_{\mathbf{K}}$} \\
\hline & & $\mathbf{U}_{\mathbf{0}}$ & $\mathbf{U}_{7 \mathrm{C}}$ & $\mathbf{U}_{14 C}$ & $\mathbf{U}_{21 \mathrm{C}}$ & $\mathbf{U}_{7 \mathbf{K}}$ & $\mathbf{U}_{14 \mathrm{~K}}$ & $\mathbf{U}_{21 \mathrm{~K}}$ \\
\hline A41 & $\begin{array}{l}\text { Benzoic acid. 2- } \\
\text { methoxy. methyl } \\
\text { ester (135) }\end{array}$ & $\begin{array}{l}(18.0 \\
\pm 0.5)^{\mathrm{a}}\end{array}$ & $\begin{array}{l}(7.4 \pm \\
0.5)^{\mathrm{b}}\end{array}$ & $\begin{array}{l}(3.7 \pm \\
1.3)^{\mathrm{c}}\end{array}$ & $(1.2 \pm 0.2)^{\mathrm{d}}$ & $\begin{array}{l}(2.79 \pm \\
0.04)^{\mathrm{cd}}\end{array}$ & $\begin{array}{l}(2.73 \pm \\
0.02)^{\text {cd }}\end{array}$ & $\begin{array}{l}(1.7 \pm \\
0.2)^{\mathrm{cd}}\end{array}$ \\
\hline A42 & $\begin{array}{c}\text { 2H-Pyran-2-one. } \\
6 \text { - } \\
\text { hexyltetrahydro } \\
\text { (99) }\end{array}$ & $\begin{array}{l}(14.83 \\
\pm 0.50)^{\mathrm{a}}\end{array}$ & $\begin{array}{c}(11 \\
\pm 5)^{\mathrm{ab}}\end{array}$ & $\begin{array}{c}(10.8 \\
\pm 0.8)^{\mathrm{ab}}\end{array}$ & $\begin{array}{c}(1.8 \\
\pm 0.2)^{\mathrm{c}}\end{array}$ & $\begin{array}{c}(2.1 \\
\pm 0.6)^{\mathrm{c}}\end{array}$ & $\begin{array}{c}(5.5 \\
\pm 0.3)^{\mathrm{bc}}\end{array}$ & $\begin{array}{c}(1.3 \\
\pm 0.2)^{\mathrm{c}}\end{array}$ \\
\hline A43 & $\begin{array}{c}\text { Hexadecanoic } \\
\text { acid methyl ester } \\
(74)\end{array}$ & $\begin{array}{c}(5.30 \\
\pm 0.08)^{\mathrm{a}}\end{array}$ & $\begin{array}{c}(4.6 \\
\pm 0.8)^{\mathrm{a}}\end{array}$ & $\begin{array}{c}(60 \\
\pm 60)^{\mathrm{a}}\end{array}$ & $\begin{array}{c}(2.8 \\
\pm 0.4)^{\mathrm{a}}\end{array}$ & $\begin{array}{c}(2.7 \\
\pm 0.3)^{\mathrm{a}}\end{array}$ & $\begin{array}{c}(3.23 \\
\pm 0.10)^{\mathrm{a}}\end{array}$ & $\begin{array}{c}(4.1 \\
\pm 1.4)^{\mathrm{a}}\end{array}$ \\
\hline A44 & n.i. (71) & n.d. ${ }^{b}$ & \begin{tabular}{|c}
$(1.4$ \\
$\pm 0.5)^{\mathrm{ab}}$
\end{tabular} & $\begin{array}{c}(5.7 \\
\pm 0.4)^{\mathrm{a}}\end{array}$ & n.d. ${ }^{b}$ & n.d. ${ }^{b}$ & $\begin{array}{c}(7.6 \\
\pm 1.2)^{\mathrm{a}}\end{array}$ & n.d. ${ }^{b}$ \\
\hline A45 & $\begin{array}{l}\text { 9-Octadecenoic } \\
\text { acid methyl ester } \\
(55)\end{array}$ & $\begin{array}{r}(4.63 \pm \\
0.14)^{\mathrm{a}}\end{array}$ & $(7 \pm 4)^{\mathrm{a}}$ & $\begin{array}{c}(15 \pm \\
6)^{\mathrm{a}}\end{array}$ & $\begin{array}{l}(3.03 \pm \\
1.85)^{\mathrm{a}}\end{array}$ & $\begin{array}{l}(3.8 \pm \\
1.0)^{\mathrm{a}}\end{array}$ & $(3.3 \pm 1.0)^{\mathrm{a}}$ & $(6 \pm 2)^{\mathrm{a}}$ \\
\hline A46 & $\begin{array}{c}p- \\
\text { Isopropenylphen } \\
\text { ol (134) }\end{array}$ & $\begin{array}{r}(2.16 \pm \\
0.07)^{\mathrm{a}}\end{array}$ & $\begin{array}{l}(2.5 \pm \\
0.8)^{\mathrm{a}}\end{array}$ & $\begin{array}{l}(2.1 \pm \\
0.3)^{\mathrm{a}}\end{array}$ & $\begin{array}{l}(1.90 \pm \\
0.05)^{\mathrm{a}}\end{array}$ & $\begin{array}{l}(1.6 \pm \\
0.3)^{\mathrm{a}}\end{array}$ & $\begin{array}{l}(2.14 \pm \\
0.10)^{\mathrm{a}}\end{array}$ & $\begin{array}{l}(1.90 \pm \\
0.05)^{\mathrm{a}}\end{array}$ \\
\hline
\end{tabular}

${ }^{1}$ n.d. not detected.

Data showed mean of two independent tests (mean \pm sd).

${ }^{a-c}$ Values in the same row with different superscript letters differ significantly $(p<0.05)$.

The storage of olives in inappropriate conditions had a negative impact on the aroma profiles of oils. Uslu olive oil was characterized with high concentrations of terpene volatile compound such as $\alpha$-Farnesene (614 \pm 2$)$ and aldehydes as 2-hexenal (146 \pm 3$)$ and hexanal (140.5 \pm 4.6$)$. In contrast, Edremit olive oil had lower concentrations of $\alpha$-Farnesene and 2exenal, which were determined as $150 \pm 20$ and $14 \pm 1.3$, respectively. The increase of concentration of 2-hexanal (E) during holding periods could be explained by the activity of the fungal enzymes in LOX pathway of olive fruits (Schnurer et al. 1999). However, the concentration of hexanal $(251 \pm 11)$ in Edremit olive oil was immediately increased after extraction. In this study, from alcohol compounds 1-Hexanol and 3-Hexen-1-ol were found as the most potent volatiles of the Edremit oils, which concentration increased over holding time in both holding types. In Uslu olive oils, the concentration of 1-hexanol also increased significantly $(\mathrm{p}<0.05)$ during the holding time as observed for Edremit oil. The concentration of 3-Hexen-1-ol in Uslu oil during holding time did not increase in contrast to Edremit oil. Lower values of hexanal, hexanol, cis-3-hexenol and higher values of methanol, ethanol and 2-methyl butanol (fusty) in samples from plastic bags were also observed by other researchers (Koprivnjak \& Conte 2002). The presence of hexanol was in virgin olive oils also reported (Haddada et al. 2007; Krichene et al. 2010; Manai et al. 2008). However, Kaftan (2007) did not identify hexanol in Memecik olive oils of 2005 and 2006 harvesting seasons. These differences between the findings can be related to the activity of alcohol dehydrogenase enzyme. As seen from Table 3 and Table 4, phenylethyl alcohol was also detected and its content increased during holding periods in both type of olive oils. Its occurrence was due to the degradation of phenylalanine (Issaoui et al. 2009). 
Previous studies focused on relationship between irradiation or weather conditions and content of volatile compounds in olive oil before harvesting. However, no studies determined the effect of weather conditions on the content of volatile compounds in olive oil after harvesting. Servili et al. (2007) found that the presence of several volatile compounds, such as hexanal, (E)-2-hexenal, and other lipoxygenase derivative products positively correlated with the irrigation rate. In our study hexanal was not detected between 7-14 days when weather was stormy and heavy rain in both two variety of olive oils, while dimethylpalmitamine was not detected in stormy weather only in Edremit variety olive oils. The content of 2-hexen-1-ol significantly increased in Edremit olive oils holded in nylon sacks between 7-14 days. However, it was not detected in oils holded in plastic boxes. Similarly, the content of cycloheptanone 2-methylene significantly increased in Edremit olive oils holded in nylon sacks between 14-21 days (cloudy weather), however it was not detected in Uslu and Edremit oils holded in plastic boxes. While decrease in $\alpha$-Farnesene in Edremit olive oils holded in nylon sacks between 0-7 days (sunny weather) was significant, this decrease was not so great in Uslu olive oils holded in nylon sacks during the days of 0 7.

Hexanal, which is responsible for fatty, fruity, green odor perceptions and contributed to pleasant sensory perceptions, was formed due to activity of aldehyde-lyase enzyme (Table 2). Therefore, the content of hexanal has been correlated with the highest overall grading of virgin olive oil (Morales \& Aparicio 1999). In this study, the concentration of hexanal decreased more in oils obtained from Edremit variety holded at cases compared to oils extracted from Edremit variety holded at nylon sacks during 7 days. It decreased to $29.74 \pm 0.14$ and to $9 \pm 2$ in nylon sacks and case, respectively. While the ratio of hexanal to nonanal was lower than 2, the oil was evaluated as rancid which detectes the beginning of oxidation (Kesen et al. 2013). Therefore, according to the results of $14^{\text {th }}$ and $21^{\text {th }}$ days, it has seen that hexanal did not occur in the oil because of it is under the detectable limits. This indicated that hexanal/nonanal ratio was below 2 . However, the decrease in hexanal content was not significantly different in oils obtained from Uslu variety olives which were holded for 7 days in sacks and cases ( $p>0.05$ ). Acetic acid which is responsible for pungent, sour, vinegar-like odor can be formed by microorganisms growing on or in the olives during storage and are undesirable for olive oils (Davis 2007). Because of the production of acetic acid, Acetobacter could develop and cause vinegary defect. Acetic acid concentration in this sudy was not effected significantly by holding time and holding type in both olive oils during 21 days of storage ( $p>0.05)$. While 5-Hepten-2-one 6-methyl and 1-Butanol 3-methyl volatiles compounds were not detected in Edremit and Uslu olive oils at initial day, they formed during both sack and box holding due to the activity of the microorganisms in olives (Table 3 and Table 4). The occurence of 5-Hepten-2-one 6-methyl can be explained by the presence of bacteria from the genus Pseudomonas which are capable to degradate terpenic alcohols (Morales 2005).

PCA was used to highlight the data and to determine the relationships between the content of volatile compounds and olive oil variety during different holding times and types (Figure 1-3). 


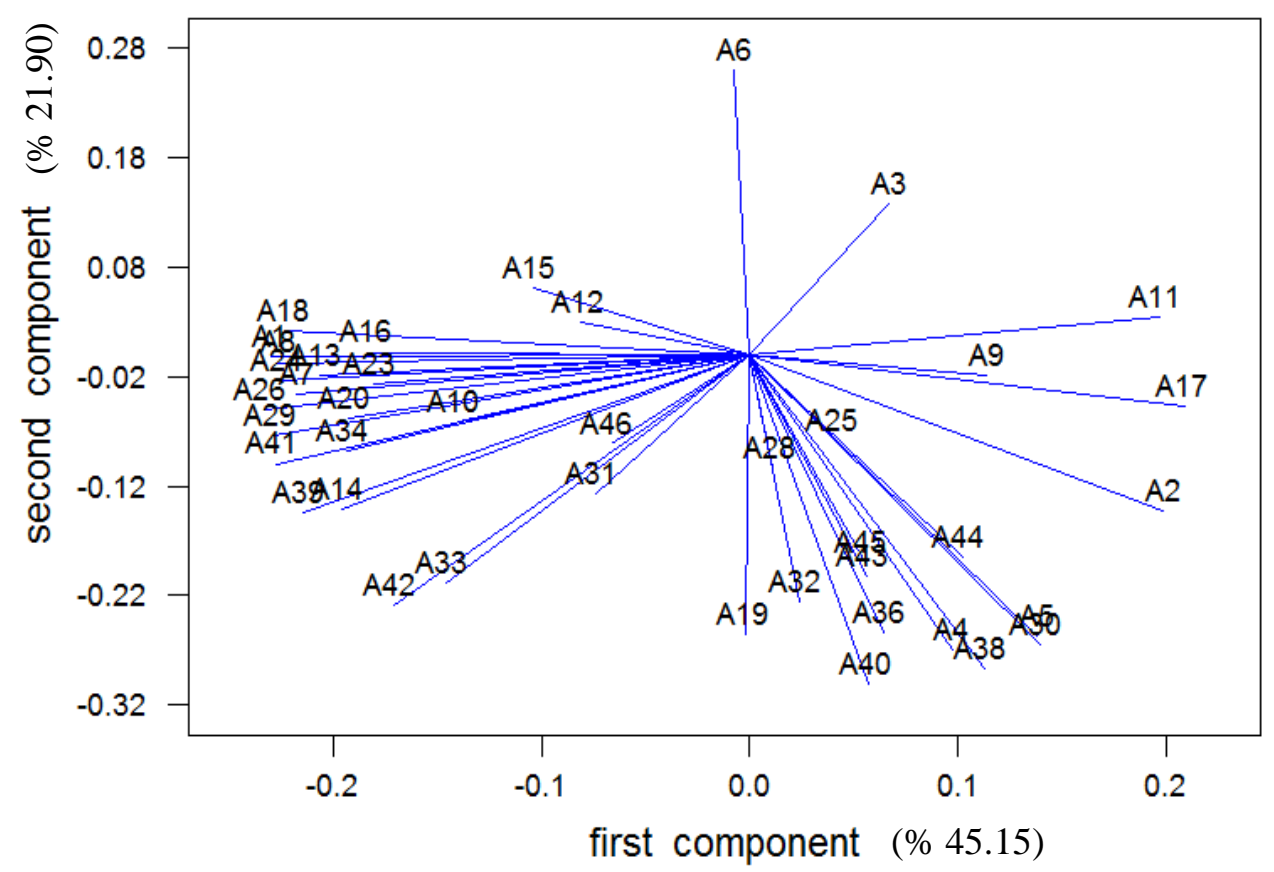

Figure 1. PCA plots of volatile compounds of Uslu variety olive oils.

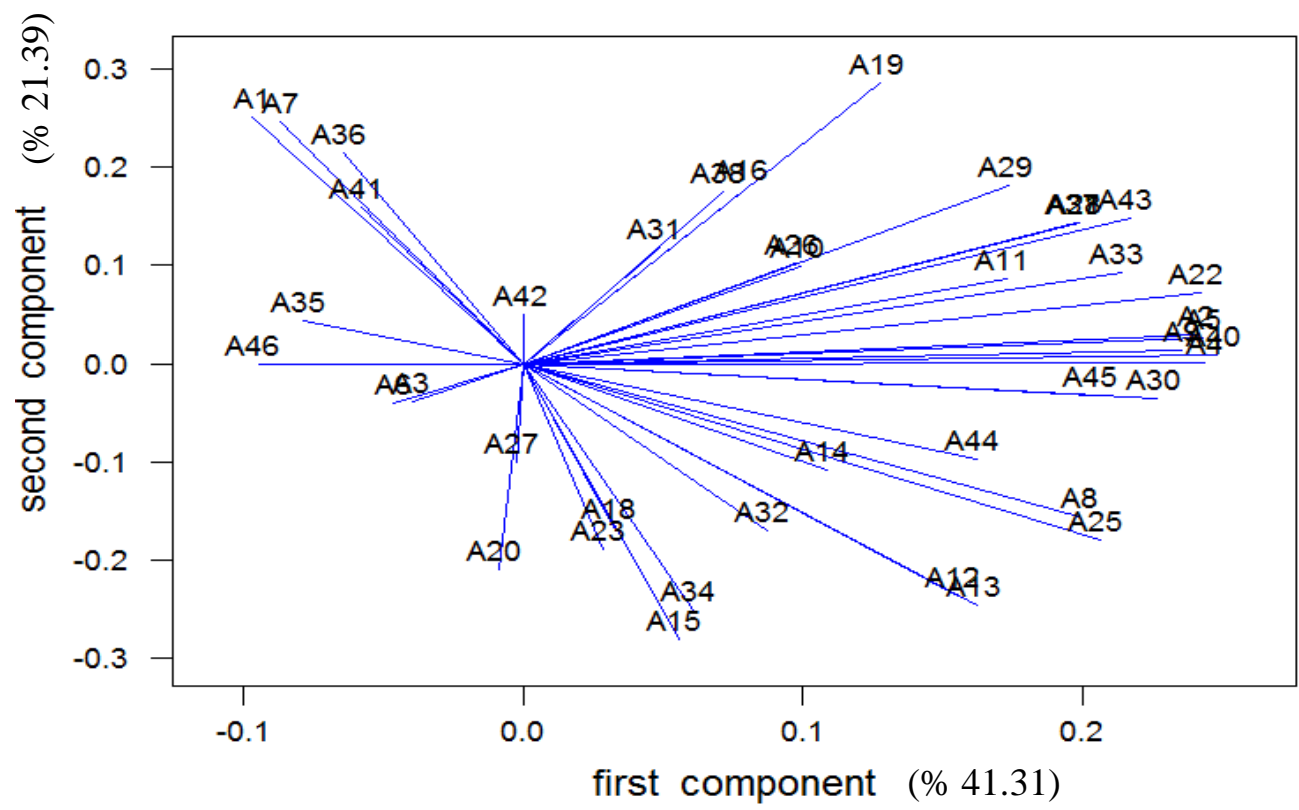

Figure 2. PCA plots of volatile compounds of Edremit variety olive oils 


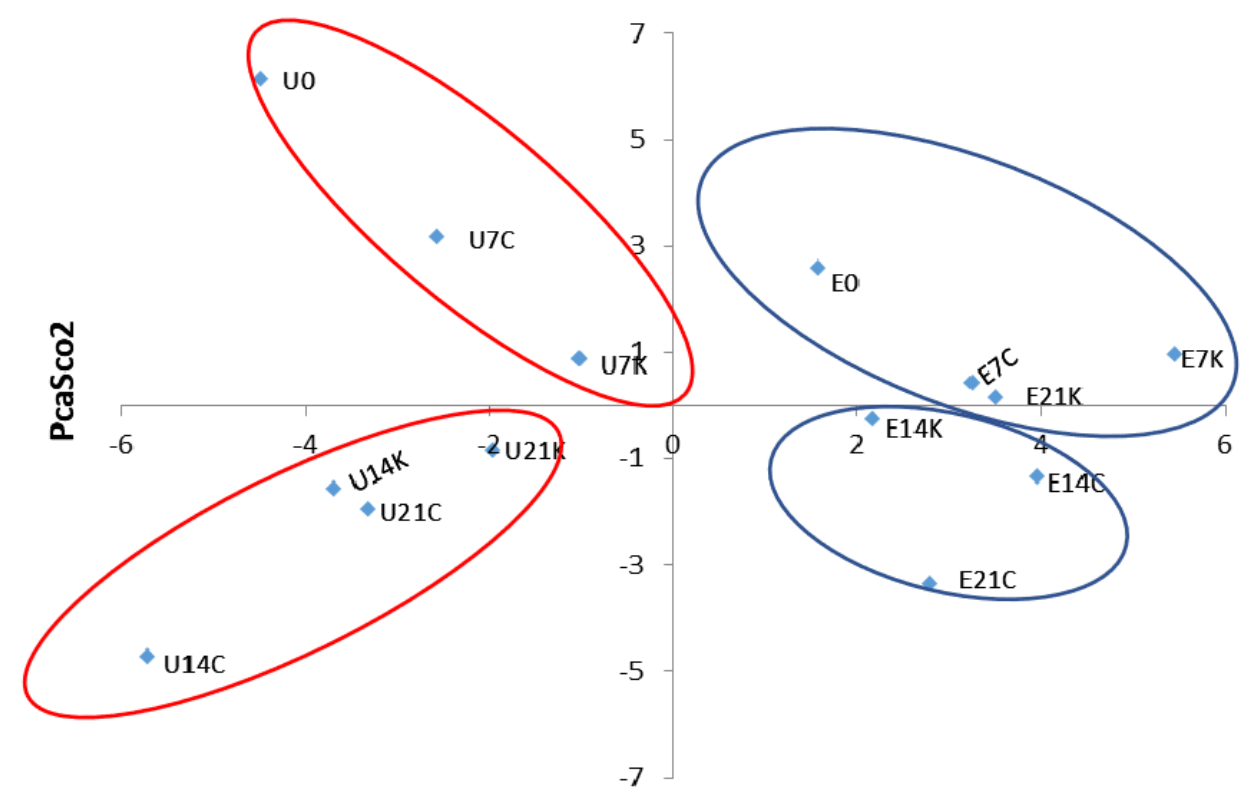

\section{PcaSco1}

Figure 3. Score plots of two first components applied to volatile compounds of olive oils extracted from Uslu and Edremit cultivars stored at case and nylon sacks until 21 days

PCA permitted a reduction of volatile compounds found in olive oil to three principal components (with eigenvalues $>1$ ). PCA results showed that 5 components were found (eigenvalues $>1$ ) for both olive varieties (Figure 4), but eigenvalues of two components were lower than the calculated percentile $95 \%$ they were dropped and only the first 3 components which eigenvalues were greater than percentile 95\% were retained. Yang et al. (2017) used PCA and AHC chemometric analysis to determine the sensitive oxidation marker compounds, including (E, E)-2,4-heptadienal marker, by lipid oxidation in the n-3 PUFA rich oils. They found that oxidized volatiles did not rise linearly during oxidation and volatile compounds of lipid oxidation were not clearly identicable with PCA analysis (Yang et al. 2017).

Three PCs were extracted represent $81.27 \%$ of the total variance of olive oil samples extracted from Uslu cultivar and $80.14 \%$ of the total variance of olive oil samples extracted from Edremit cultivar. The first principal components PC1, PC2 and PC3 represented $45.15 \%$ and $41.31 \%, 21.90 \%$ and $21.39 \%, 14.21 \%$ and $17.43 \%$, respectively for Uslu and Edremit varieties. First component was mainly defined by A11, A17 and A2 with positive correlation and second component mainly by A42 and A33 (with a high negative correlation) in olive oils obtained from Uslu varieties (Figure 1). On the other hand, first component was mainly defined by A22, A40 and A43 and second component mainly by A19, A1 and A7 with a high positive correlation in olive oils extracted from Edremit varieties (Figure 2). 


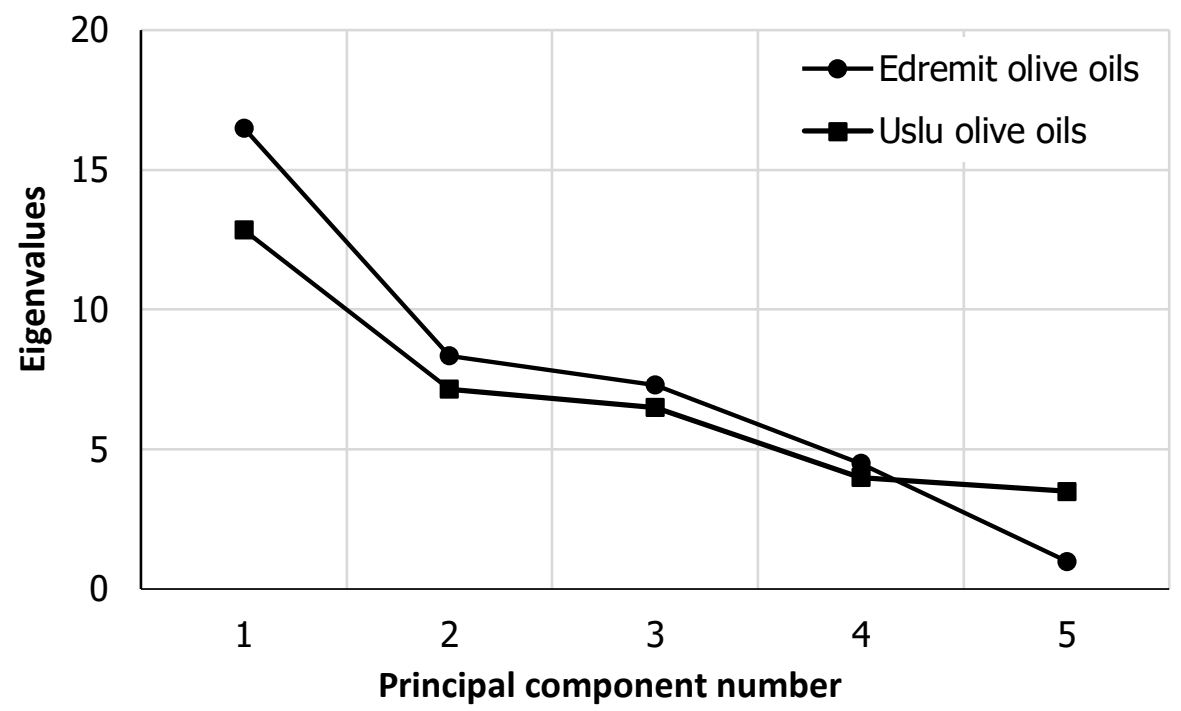

Figure 4. Eigenvalues of volatile compounds of Uslu and Edremit olive oils obtained by PCA

\section{Conclusions}

Principal component analysis (PCA) was used to evaluate the effect of different types of olive packaging (plastic box and nylon socks) and different period of olive storage in these packaging on oil aroma profiles and to find the relationships between volatile compounds and olive oil varieties. Content of hexanal decreased significantly in oils obtained from Edremit variety during 7 days of holding in case. However, the holding type had no effect on the hexanal content in Uslu olive oils. PC1, PC2 and PC3 identified the $81.27 \%$ of the total variance of olive oil samples extracted from Uslu cultivar and $80.14 \%$ of the total variance of olive oil samples extracted from Edremit cultivar. The content of acetic acid, which is an undesirable compound in virgin olive oils, was not changed significantly in both two oils depending on holding type or time.

To provide high quality of olive oils conditions for its storage should be controlled.The recommended storage conditions for olives is about $5{ }^{\circ} \mathrm{C}$ in air conditioning boxes for at least 30 days to reduce development of fungi and protect aroma profiles of obtained oils from changes.

It's needed more studies on the investigation of olive oils aroma profile for reveal the effects of harvesting time and method, olive varieties, climatic factors, storage conditions, and extraction techniques.

\section{References}

Aydar A., Öncü Öner, T., Ücok E.F. (2017), Effects of Hydroxytyrosol on Human Health. 11, pp.147-157.

Bayrak A., Hu H. (2013), Determination of Aroma Profiles of Olive Oils from Turkish Olive Cultivars, Journal of the American Oil Chemists Society, pp. 1281-1300. 
Boskou D., (2007), Olive oil, Chemistry and Technology, Second Ed., AOCS, ThessalonikiGreece.

Bouaziz M., Fki I., Jemai H., Ayadi M., Sayadi S. (2008), Effect of storage on refined and husk olive oils composition: Stabilization by addition of natural antioxidants from Chemlali olive leaves, Food Chemistry, 108(1), pp.253-262.

Cavalli J.F., Fernandez X., Cuvelier L.L., Loiseau A.M. (2004), Characterization of volatile compounds of French and Spanish virgin olive oils by HS - SPME of quality freshness markers Food Chemistry Characterization of volatile compounds of French and Spanish virgin olive oils by HS-SPME : Identification of quality-f, Food Chemistry, 88(1), pp. $151-157$.

Davis B.M. (2007), Volatile Organic Compounds and Antioxidants in Olive Oil : Their Analysis by Selected Ion Flow Tube Mass Spectrometry, University of Canterbury.

Fernandez M.D.L.A., SotoVargas V.C., Silva M.F. (2014), Phenolic Compounds and Antioxidant Capacity of Monovarietal Olive Oils Produced in Argentina, Journal of American Oil Chemists Society, 91, pp. 2021-2033.

Gomes da Silva M.D.R. et al. (2012), Olive Oil Composition : Volatile Compounds. in Dimitrios Boskou, (Ed.) Olive Oil - Constituents, Quality, Health Properties and Bioconversions, Intech Open Science, Shanghai, pp. 17-41.

Haddada F.M., Manai H., Daoud D., Fernandez X., Cuvelier L.L., Zarrouk M. (2007), Food Chemistry Profiles of volatile compounds from some monovarietal Tunisian virgin olive oils: Comparison with French PDO. Food Chemistry, 103(2), pp. 467-476.

Inarejos-García A.M., Gomez-Rico A., Salvador M.D., Fregapane G. (2009), Influence of malaxation conditions on virgin olive oil yield, overall quality and composition, European Food Research and Technology, 228, pp. 671-677.

Issaoui M., Hassine K.B., Flamini G., Brahmi F., Chehab H., Aouni Y., Mechri B., Zarrouk M., Hammami M. (2009), Discrimation of Some Tunisian Olive Oil Varieties Compounds and Chemometric Analysis. Journal of Food Lipids, 16, pp. 64-186.

Issaoui M., Flamini G., Brahmi F., Dabbou S., Ben Hassine K., Taamali A., Chehab H., Ellouz M., Zarrouk M., Hammami M. (2010), Effect of the growing area conditions on differentiation between Chemlali and Chétoui olive oils. Food Chemistry, 119 (1), pp. $220-225$.

Kaftan A. (2007), Farklı Yöre Zeytinlerinden Elde Edilen Naturel Zeytinyağının Duyusal Kalitesini Oluşturan Lezzet Maddelerinin SPME/GC/MS ve Lezzet Profili Analizi Teknikleri Kullanılarak Belirlenmesi. Ege University PhD thesis

Kesen S., Kelebek H., Sen K., Ulaş M., Selli S. (2013), GC - MS - olfactometric characterization of the key aroma compounds in Turkish olive oils by application of the aroma extract dilution analysis, Food Research International, 54(2), pp. 1987-1994.

Koprivnjak O., Conte L. (2002), Influence of Olive Fruit Storage in Bags on Oil Quality and Composition of Influence of Olive Fruit Storage in Bags on Oil Quality and Composition of Volatile Compounds, Food Technology and Biotechnology, 40(2), pp. 129-134.

Krichene D., Haddada F.M., Fernandez X., Cuvelier L.L., Zarrouk M. (2010), Original article Volatile compounds characterising Tunisian virgin olive oils : the influence of cultivar, International Journal of Food Science and Technology, 45, pp. 944-950.

Manai H., Haddada F.M., Oueslati I., Daoud D., Zarrouk M. (2008), Characterization of monovarietal virgin olive oils from six crossing varieties, Scientia Horticulturae, 115(3), pp. 252-260.

Morales M.T., Luna G., Aparicio R. (2005), Comparative study of virgin olive oil sensory defects, Food Chemistry, 91(2), pp. 293-301. 
Morales M.T., Aparicio R. (1999), Effect of extraction conditions on sensory quality of virgin olive oil, Journal of the American Oil Chemists' Society, 76, pp. 295-300.

Ozdemir Y., Tangu N.A., Ozturk A., Akçay M.E., Ercişli S. (2018), Fruit characteristics of six candidate olive cultivars, Folia Horticulturae, 30(1), pp. 169-177.

Pereira J.A., Casal S., Bento A., Oliveira M.B.P.P. (2002), Influence of Olive Storage Period on Oil Quality of Three Portuguese Cultivars of Olea europea, Cobrancosa, Madural, and Verdeal Transmontana, Journal of Agricultural and Food Chemistry, 50(22), pp. 6335-6340.

Rizzo V., Torri L., Muratore G. (2011), The Influence of Lighting Shelf Life of Extra Virgin Olive Oil Packaged in Coloured Pet Bottles, Italian Journal of Food Science, 33, pp. 30-34.

Servili M., Esposto S., Lodolini E., Selvaggini R., Taticchi A., Urbani S., Montedoro G., Serravalle M., Gucci R. (2007), Irrigation Effects on Quality, Phenolic Composition, and Selected Volatiles of Virgin Olive Oils Cv. Leccino, Journal of Agriculture and Food Chemistry, 55(16), pp. 6609-6618.

Servili M., Selvaggini R., Taticchi A., Esposto S., Montedoro G. (2003), Volatile Compounds and Phenolic Composition of Virgin Olive Oil: Optimization of Temperature and Time of Exposure of Olive Pastes to Air Contact during the Mechanical Extraction Process, Journal of Agriculture and Food Chemistry, 51(27), pp. $7980-7988$.

Veillet S., Tomao V., Chemat F. (2010), Ultrasound assisted maceration: An original procedure for direct aromatisation of olive oil with basil, Food Chemistry, 123 (3), pp. 905-911.

Yang K.M., Cheng, M.C., Chen W.C., Tseng C.Y., Lin L.Y., Chiang P.Y. (2017), Characterization of Volatile Compounds with HS-SPME from Oxidized n-3 PUFA Rich Oils via Rancimat Tests, Journal of Oleo Science, 66(2), pp. 113-122. 


\section{Physico-chemical, antioxidant and sensorial properties of fruit leathers made from "Malga" and "Murano" strawberry cultivars}

\section{Violeta Nour}

\section{University of Craiova, Craiova, Romania}

Keywords:

Strawberry

Fruit leathers

Dehydration

Anthocyanins

Phenolics

Antioxidant

\section{Article history:}

Received

11.04.2021

Received in revised form 20.08.2021

Accepted

30.12.2021

\section{Corresponding author:}

Violeta Nour

E-mail:

vionor@yahoo.com

DOI:

$10.24263 / 2304-$

974X-2021-10-4-8

\section{Abstract}

Introduction. Strawberries are recognized as an antioxidant source due to their high content of anthocyanins, other phenolic compounds and ascorbic acid. The objective of this study was to formulate and to characterize fruit leather made from two strawberry cultivars using honey and lemon juice as ingredients.

Materials and methods. The fresh fruits were pureed, mixed with honey and lemon juice and then dried in a dehydrator at $57^{\circ} \mathrm{C}$ for 6 hours. Both fruit homogenates and leathers were characterized in terms of moisture content, total soluble solids content, titratable acidity, color by CIE $L^{*} a^{*} b^{*}$ system, total phenolic content by FolinCiocalteu method, total flavonoid content by the aluminium nitrate method, total anthocyanin content by the $\mathrm{pH}$ differential spectrophotometric method and antioxidant activity by the DPPH (2diphenyl-1-picrylhydrazyl) procedure. A 9-point hedonic scale was used to evaluate strawberry leathers for color, sweetness, sourness, flavor, texture, and general acceptability.

Results and discussion. There was a substantial increase in soluble solids content and titratable acidity of both strawberry leathers as a result of honey and lemon juice addition and drying. Fresh strawberry homogenates were lighter (higher $\mathrm{L}^{*}$ values) as compared to fruit leathers. In addition, the color parameter $\mathrm{a}^{*}$ showed a significant decrease in both cultivars after drying, that may be attributed to the oxidation of anthocyanins as well as thermal degradation. The total phenolic, flavonoid and anthocyanin content were higher both in the fresh homogenate and in the leather of "Malga" cultivar than in "Murano". However, DPPH antioxidant activity was slightly higher in "Murano" (35.21 mmol Trolox/100 g) than in "Malga" homogenates (34.45 mmol Trolox/100 g) but differences were not significant. After dehydration, the anthocyanin content in the strawberry leather decreased by $67.38 \%$ ("Murano") and $64.07 \%$ ("Malga"), while the total phenolic content decreased by 43.81\% ("Murano") and 32.33\% ("Malga"). In addition, after drying, reductions in the DPPH antioxidant activity of $40.5 \%$ ("Murano") and $38.5 \%$ ("Malga") were observed. In terms of sensory evaluation, "Murano" leather stand out as compared with "Malga", due to its more reddish color, stronger sweetness, lower sourness and more pleasant texture.

Conclusions. Apart from their attractive appearance, taste and flavor, strawberry leathers are a good source of natural antioxidants including anthocyanins and other phenolic compounds. 


\section{Introduction}

Based on its unique taste and flavor as well as low caloric value, strawberry (Fragaria $x$ ananassa, Duch.) is among the most desirable fruit worldwide. Strawberries are a rich source of several nutritional and bioactive compounds such as easily digestible sugars, organic acids, minerals, vitamins and phenolic compounds (Forbes-Hernandez et al., 2016; Kowalska et al., 2018), which take part in various health-promoting and disease preventive effects (Afrin et al., 2016). The main phenolic compounds in strawberry are anthocyanins, flavonols, and hydroxycinnamic and ellagic acid derivatives, which exert antioxidant, antiinflammatory, anticarcinogenic, antimutagenic, antibacterial or antiviral activity (Aaby et al., 2007; Ariza et al., 2018).

Due to moisture loss, mechanical injury, and physical and microbial decay (Velde et al., 2013) fresh strawberries have a short postharvest life (5 to 7 days) when stored at $0-4^{\circ} \mathrm{C}$ while fruit losses can range up to $40 \%$ during storage (Guo et al. 2018). As a consequence, there is a current interest in the enhancement of strawberry fruit shelf life by using various preservation techniques including ultraviolet light, controlled atmosphere storage, modified atmosphere packaging, high oxygen treatment, UV-C or gamma irradiation, edible coatings, and chemical treatments (Parvez and Wani, 2018; Nour et al., 2021).

In order to reduce the postharvest losses and to respond to consumer demand for new value-added products, strawberries are subjected to processed, mainly into jams or beverages (Kowalska et al., 2018). Recently, strawberry leathers have been considered as an alternative dessert or replacement for confectionery due to their high nutritional values and sensorial properties (Phuong et al., 2016).

An alternative for preserving and adding value to various fruits using dehydration is the development of fruit leathers (Diamante et al., 2014). They are dried sheets or flexible strips of fruit pulp that taste sweet and have a soft, rubbery texture (Addai et al., 2016). Fruits leathers are made typically by hot air drying of fruit puree or fruit juice concentrate, with or without the addition of sweeteners (glucose syrup, honey or sugar such as sucrose, glucose, and fructose), thickeners (starch, pectin, gelatin, alginate, gums, and cellulose derivatives) or preservatives (sulfur dioxide and sorbic acid) (Da Silva Simão et al., 2020). Artificial and natural colors, flavors, and citric acid can also be added (Al-Hinai et al., 2013). Fruit leathers could serve as a nutritious breakfast, snack or dessert as they are rich in dietary fiber, carbohydrate, vitamins, minerals and antioxidants (Momchilova et al., 2016; Setiaboma et al., 2019).

Thus, the production of fruit leather mainly involves the steps of processing the fruit into the puree or concentrate juice, the addition of ingredients, and drying. Fruit leathers are dried at 30 to $80{ }^{\circ} \mathrm{C}$ until the final moisture content of $12-20 \%$ has been reached (Diamante et al., 2014; Phuong et al., 2016). However, many changes in the color, texture, flavor, odor and physio-chemical properties of the product as well as loss of desirable nutrients take place during drying (Bandaru and Bakshi, 2020; Suna, 2019). The leathers tend to darker and turn to brown due to the sensitivity of the pigments to the drying temperature, and to the enzymatic oxidation of polyphenols (Momchilova et al., 2016).

"Malga" and "Murano" are two new strawberry cultivars with high sensorial and nutritional properties. "Malga" is a cultivar of Russian origin, bred in Italy, having large fruits with an attractive orange tint. The pulp is moderately dense and juicy, with pronounced sweetness, delicate sourness and persistent aroma (https://gardenluxen.designluxpro.com/sad-i-ogorod/yagody/opisanie-i-harakteristiki-remontantnoy-klubnikimalga-malga.html). "Murano" is an Italian cultivar with excellent product characteristics. The berries are red-orange in color, very sweet, aromatic, having an excellent balance of 
sugar and acid (https://naturelux.woman365pro.com/en/klubnika-zemlyanika/sort-klubnikimurano.html).

The aim of this study was to investigate the effects of the cultivar and of the drying process on antioxidant content, physico-chemical and sensorial properties of strawberry fruit leathers made with honey and lemon juice as natural ingredients.

\section{Materials and methods}

\section{Samples collection and preparation}

Strawberries (Fragaria x ananassa cvs. "Malga" and "Murano") used in the present study were hand-harvested at the commercially mature stage of ripening from a farm in Marsani, Dolj county $\left(44^{\circ} 00^{\prime} \mathrm{N} 23^{\circ} 59^{\prime} \mathrm{E}\right)$. The fruits were sorted to eliminate damaged, poor quality, and unripe fruits, and selected for uniform size, color and maturity. After removing the calyx and peduncle, fruits were washed in tap water, drained at ambient temperature, and then stored at $4{ }^{\circ} \mathrm{C}$ until fruit leather processing and analysis.

\section{Chemicals}

Folin-Ciocalteu reagent, gallic acid, 2,2-diphenyl-1-picrylhydrazyl (DPPH), 6hydroxy-2,5,7,8-tetramethylchroman-2-carboxylic acid (Trolox) and sodium acetate were purchased from Sigma-Aldrich (Germany). Sodium carbonate and aluminium nitrate were purchased from Merck (Darmstadt, Germany). All other chemicals used were of analytical grade.

\section{Preparation of fruit leather}

Five hundred grams of strawberries were ground using a home type blender (Bosch MS61B6170, $1000 \mathrm{~W}$, Germany) until obtaining a purée (2 minutes). Honey (4\%, w/w) and lemon juice $(2 \%, \mathrm{w} / \mathrm{w})$ were weighed and mixed with strawberry purees. The blending process was carried out at high speed for 2 min to get a smooth mixture. The mixture was then spread evenly as a thin layer over carbon steel trays covered with parchment paper smeared with oil to prevent the strawberry leather from sticking to paper after drying. The trays were placed in a cabinet type laboratory dryer (Deca +SS Design, Profimatic, Romania) set at $57{ }^{\circ} \mathrm{C}$. The fruit puree mixtures were dried from one side (top surface) with air flowing parallel to the leathers. Moisture loss of the samples was determined periodically during drying by removing the sample from the oven and weighing the tray using a $0.01 \mathrm{~g}$ sensitive digital scale (Radvag WLC/6/A2, Poland). Drying was terminated when the calculated moisture content of the dried sample reached $10-12 \%$. After drying, fruit leather samples were pulled from the surface, packaged with a low density polyethylene film and stored at room temperature until analyzed. The drying experiments were carried out in triplicate.

\section{Physicochemical properties of strawberry fruits and leathers}

The moisture content of the initial fruit homogenates was determined by drying the samples in a forced air oven (Memmert, Germany) at $105{ }^{\circ} \mathrm{C}$ until constant weight was obtained. Triplicate samples were used for the determination of moisture content and the average values were reported. 
Homogenous fruit samples were prepared by blending twenty fruits from replicate sample in an electrical blender. The total soluble solids content was measured with a digital refractometer (Hanna Instruments, Woonsocket, USA), and the results were expressed as percentage of soluble solids. Titratable acidity was determined titrimetrically in $10 \mathrm{~g}$ of homogenate or fruit leather, made up to $100 \mathrm{~g}$ with deionized water and titrated to $\mathrm{pH} 8.2$ with $0.1 \mathrm{~N} \mathrm{NaOH}$ solution. The results were expressed as grams of citric acid per $100 \mathrm{~g}$ fresh weight. Two independent extracts were prepared for each sample and each one was titrated in duplicate.

\section{Color measurement}

The color values (CIE $L^{*}, a^{*}$ and $b^{*}$ ) of the fruit purées and leathers were measured with a PCE-CSM1 reflectance colorimeter (PCE Instruments, UK) calibrated against a white standard, where $L^{*}$ is a measure for lightness, $a^{*}$ for redness and $b^{*}$ for yellowness. Chroma (C) was calculated as $\left(a^{* 2}+b^{* 2}\right)^{1 / 2}$ while hue angle (h) was calculated as $\arctan \left(-b^{*} / a^{*}\right)$. The analysis was performed on three samples from each cultivar with five readings for each sample.

Color degradation after drying was evaluated by determining the browning degree and expressed as the color difference $(\Delta \mathrm{E})$, as follows:

$$
\Delta \mathrm{E}=\sqrt{(\mathrm{L} 1-\mathrm{L} 0)^{2}+(\mathrm{a} 1-\mathrm{a} 0)^{2}+(\mathrm{b} 1-\mathrm{b} 0)^{2}},
$$

where L1, a1, b1 represent color values of leather after the drying process, while L0, $\mathrm{a} 0, \mathrm{~b} 0$ are color values of fresh homogenate.

\section{Extraction of phenolic compounds}

Fruit and leather samples $(1.5 \mathrm{~g})$ were extracted with $10 \mathrm{~mL}$ methanol in a Bandelin Sonorex Digital 10P ultrasonic bath (Bandelin Electronic GmbH, Germany) for $60 \mathrm{~min}$ at ambient temperature. After extraction, the samples were centrifuged for $5 \mathrm{~min}$ at $4200 \mathrm{rpm}$. Supernatants were collected, filtered through $0.45 \mu \mathrm{m}$ polyamide membranes and used for the assays.

\section{Total phenolic content}

Total phenolic content was assessed by using the Folin-Ciocalteu spectrophotometric method as described by Singleton and Rossi (1965) with slight modifications. Briefly, aliquots of extracts $(0.1 \mathrm{~mL})$ were mixed with $5 \mathrm{~mL}$ of distilled water and $0.5 \mathrm{~mL}$ of FolinCiocalteu reagent in a test tube. After $2 \mathrm{~min}, 4 \mathrm{~mL}$ of $7.5 \%$ sodium carbonate aqueous solution were added and the mixture was allowed to stand for $30 \mathrm{~min}$ at $40{ }^{\circ} \mathrm{C}$ in a dark. The absorbance of each sample was read at $765 \mathrm{~nm}$ using a Varian Cary $50 \mathrm{UV}$ spectrophotometer (Varian Co., USA). Results were expressed as mg gallic acid equivalent per 100 fresh weight (fw).

\section{Total flavonoid content}

The total flavonoid content was determined according to the aluminium nitrate spectrophotometric method described by Mohammadzadeh et al. (2007). $0.5 \mathrm{~mL}$ fruit or leather extract prepared as described above was mixed with $0.1 \mathrm{~mL}$ aluminum nitrate $(10 \%)$, 
$0.1 \mathrm{~mL}$ sodium acetate $(1 \mathrm{M})$ and $4.3 \mathrm{~mL}$ methanol. After incubation for $40 \mathrm{~min}$ at room temperature, the absorbance of the mixture was read at $415 \mathrm{~nm}$ on a Varian Cary $50 \mathrm{UV}$-VIS spectrophotometer (Varian Co., USA). A calibration curve was prepared using a standard solution of quercetin. Results were expressed as mg of quercetin equivalents (QE) per 100 fresh weight (fw).

\section{Total anthocyanin content}

Anthocyanins were extracted from fruit homogenate or fruit leather with methanol acidified with $0.1 \% \mathrm{HCl}(\mathrm{v} / \mathrm{v})$. The quantification of total anthocyanins was performed using the $\mathrm{pH}$ differential spectrophotometric method described by Giusti and Wrolstad (2001).

Each extract $(2 \mathrm{~mL})$ was separately diluted to $25 \mathrm{~mL}$ with $0.025 \mathrm{M}$ potassium chloride buffer ( $\mathrm{pH} 1.0)$ and $0.4 \mathrm{M}$ sodium acetate buffer $(\mathrm{pH} 4.5)$. The diluted solutions were then left at room temperature for $15 \mathrm{~min}$ and the absorbance of each dilution was read at 510 and 700 $\mathrm{nm}$. The total anthocyanin content was calculated using the following equation:

Total anthocyanins $(\mathrm{mg} \mathrm{CGE} / \mathrm{L})=(\mathrm{A} \times \mathrm{MW} \times \mathrm{DF} \times 1,000) / \varepsilon$

where $\mathrm{A}=(\mathrm{A} 510 \mathrm{~nm}-\mathrm{A} 700 \mathrm{~nm}) \mathrm{pH} 1.0-(\mathrm{A} 510 \mathrm{~nm}-\mathrm{A} 700 \mathrm{~nm}) \mathrm{pH} 4.5$; MW (molecular weight $)=449.2 \mathrm{~g} / \mathrm{mol}$ for cyanidin-3-O-glucoside; $\mathrm{DF}=$ dilution factor of the samples; $\varepsilon$ (molar absorbtivity of cyanidin-3-glucoside) $=29,600 \mathrm{~L} /(\mathrm{mol} \cdot \mathrm{cm})$. Results were expressed as milligrams of cyanidin 3-O-glucoside equivalents (CGE) per $100 \mathrm{~g}$ of fresh weight (fw).

\section{DPPH radical scavenging activity}

Antioxidant activity of the fruit and leather samples was measured using a DPPH (2diphenyl-1-picrylhydrazyl) procedure described by Hatano et al. (1988). Briefly, aliquots of extracts $(50 \mu \mathrm{L})$ were mixed with $3 \mathrm{~mL}$ of a $0.004 \%$ (v/v) DPPH methanolic solution. After $30 \mathrm{~min}$, the absorbance was read at $517 \mathrm{~nm}$ using a Varian Cary $50 \mathrm{UV}$ spectrophotometer (Varian Co., USA). The inhibition of the DPPH radical by the samples was calculated according to the following formula: DPPH scavenging activity $(\%)=[1-$ Abs.sample/Abs.blank] $\times 100$. The DPPH scavenging activity was subsequently calculated with respect to the 6-hydroxy-2,5,7,8-tetramethylchroman-2-carboxylic acid (Trolox), which was used as a standard reference. Results were expressed as milimoles Trolox equivalents per $100 \mathrm{~g}$ of fresh weight.

\section{Sensorial analysis}

A 9-point hedonic scale varying from like extremely (9) to dislike extremely (1) was used to evaluate strawberry leather samples for color, sweetness, sourness, flavor, texture, and general acceptability. The sensory panel included ten panelists consisting of graduate students and staff members from the Department of Food Science, University of Craiova.

\section{Statistical analysis}

All experiments were done in three replicates and results reported by mean \pm standard deviation. The means were compared by using the Least Significant Difference (LSD) test and statistical significance was considered at $\mathrm{p}<0.05$. Statgraphics Centurion XVI software (StatPoint Technologies, VA, USA) was employed in this study. 


\section{Results}

The moisture content, titratable acidity and soluble solids content of fresh fruits and leathers for the two strawberry cultivars are shown in Table 1. The cultivars exhibited considerable differences in terms of titratable acidity and soluble solids content $(\mathrm{p}<0.05)$. The "Malga" cultivar had a higher level of titratable acidity while "Murano" cultivar had a higher soluble solids content. The results indicated that the titratable acidity of fresh strawberries was between $0.51 \%$ ("Murano") and $0.83 \%$ ("Malga") of citric acid equivalent. After processing, the highest acidity was found in the "Malga" leather (3.48\%) as compared with "Murano" leather (2.02\%) (Table 1).

Table 1

Effect of processing on moisture content, titratable acidity and soluble solids of two strawberry cultivars

\begin{tabular}{|l|c|c|c|c|c|c|}
\hline Cultivars & \multicolumn{2}{|c|}{$\begin{array}{c}\text { Moisture content } \\
(\%)\end{array}$} & \multicolumn{2}{c|}{$\begin{array}{c}\text { Titratable acidity } \\
\text { (g citric acid/100 g) }\end{array}$} & \multicolumn{2}{c|}{$\begin{array}{c}\text { Soluble solids } \\
(\%)\end{array}$} \\
\cline { 2 - 7 } & Fresh & Leather & Fresh & Leather & Fresh & Leather \\
\hline "Murano" & $88.22 \pm 0.53$ & $12.61 \pm 0.47^{\mathrm{a}}$ & $0.51 \pm 0.03^{\mathrm{b}}$ & $2.02 \pm 0.09^{\mathrm{b}}$ & $10.43 \pm 0.68^{\mathrm{a}}$ & $43.26 \pm 0.88^{\mathrm{a}}$ \\
\hline "Malga" & $89.12 \pm 1.08$ & $9.85 \pm 0.15^{\mathrm{b}}$ & $0.83 \pm 0.04^{\mathrm{a}}$ & $3.48 \pm 0.12^{\mathrm{a}}$ & $9.65 \pm 0.46^{\mathrm{b}}$ & $39.50 \pm 0.69^{\mathrm{b}}$ \\
\hline
\end{tabular}

* Results show means \pm standard deviation. Different superscript letters indicate a significant difference at $\mathrm{p}<0.05$ level between cultivars

The fruits of the two strawberry cultivars also differed greatly with regard to soluble solids content $(\mathrm{p}<0.05)$. "Murano" fruits displayed the highest levels of soluble solids content $(10.43 \%)$ as compared to "Malga" $(9.65 \%)$. There was a substantial increase in the soluble solids content of both fruit leathers because of honey addition and drying, with levels of 43.26\% and 39.5\% respectively for "Murano" and "Malga" leathers. Previous studies reported higher levels of soluble solids content in fruit leathers (Addai et al., 2016; Kumar et al., 2010; Phimpharian et al., 2011).

Vaidya et al. (2007) reported a soluble solids content of $68^{\circ}$ Brix in kiwifruit leather made with $15 \%$ sugar addition and dried for 15 hours at $45^{\circ} \pm 2^{\circ} \mathrm{C}$. The low level of honey addition in this experiment (4\%) may be one of the reasons for the lower soluble solids content in our strawberry leathers.

Table 2

Effect of processing on color values of two strawberry cultivars

\begin{tabular}{|l|c|c|c|c|}
\hline \multirow{2}{*}{ Cultivars } & \multicolumn{2}{|c|}{ Fresh } & \multicolumn{2}{c|}{ Leather } \\
\cline { 2 - 5 } & "Murano" & "Malga" & "Murano" & "Malga" \\
\hline$L^{*}$ & $34.04 \pm 2.95$ & $32.75 \pm 3.44$ & $31.43 \pm 1.12$ & $30.20 \pm 1.50$ \\
\hline$a^{*}$ & $33.35 \pm 3.72$ & $27.95 \pm 7.76$ & $29.03 \pm 5.18$ & $24.22 \pm 1.49$ \\
\hline$b^{*}$ & $21.16 \pm 2.68^{\mathrm{b}}$ & $29.98 \pm 6.21^{\mathrm{a}}$ & $34.17 \pm 2.75$ & $33.16 \pm 7.89$ \\
\hline$C$ & $39.56 \pm 3.88$ & $41.44 \pm 12.29$ & $45.07 \pm 3.04$ & $41.19 \pm 7.13$ \\
\hline$h$ & $32.44 \pm 3.63$ & $45.81 \pm 10.64$ & $49.83 \pm 6.37$ & $53.18 \pm 4.98$ \\
\hline$\Delta \mathrm{E}$ & & & 7.74 & 5.53 \\
\hline
\end{tabular}

* Results show means \pm standard deviation. Different superscript letters indicate a significant difference at $\mathrm{p}<0.05$ level between cultivars 
The moisture content of the two strawberry leathers were $12.61 \%$ ("Murano") and 9.85\% ("Malga"). No significant differences were found between moisture content of fruit leathers from the two strawberry cultivars $(\mathrm{p}<0.05)$. Previously, Addai et al. (2016) reported $14.31 \%$ and $15.42 \%$ moisture content in leathers of two papaya cultivars while Huang and Hseih (2005) found relative low moisture contents in pear fruit leathers, ranging from $6.42 \%$ to $13.47 \%$. Lower levels of moisture content suppress bacterial development and extend shelf life of fruit leathers, but may have an adverse effect on texture quality (Irwandi et al., 1998).

In terms of instrumental color, the strawberry leather from "Malga" cultivar was lighter than the leather from "Murano" cultivar ( $L^{*}$ mean value of 31.43 and 30.20 , respectively); however, the differences were not significant. Lightness significantly decreased in fruit leathers as compared to the strawberry homogenates (Table 2). The $a^{*}$ values were significantly higher in "Murano" fresh homogenate as compared to "Malga", thus confirming the more reddish tint of the pulp of this variety.

For $a^{*}$ values a significant decrease was found in both strawberry cultivars after drying while $b^{*}$ values were higher in leathers than in fresh fruit homogenates. Chroma value, which is used to perceive the color intensity, was highest in "Murano" leather.

A comparison between fresh fruits and fruit leathers in terms of total phenolic content (TPC), total flavonoid content (TFC), total anthocyanins content (TAC) and DPPH antioxidant activity (AA) is presented in Table 3.

Table 3

Effect of processing on the total phenolics content, total flavonoids content, total anthocyanins content and DPPH antioxidant activity of two strawberry cultivars

\begin{tabular}{|l|c|c|c|c|}
\hline \multirow{2}{*}{ Cultivars } & \multicolumn{2}{|c|}{ Fresh } & \multicolumn{2}{c|}{ Leather } \\
\cline { 2 - 5 } & "Murano" & "Malga" & "Murano" & "Malga" \\
\hline $\begin{array}{l}\text { Total phenolics } \\
\text { content } \\
\text { (mg GAE/100 g) }\end{array}$ & $1308.59 \pm 42.94^{\mathrm{b}}$ & $1423.47 \pm 54.38^{\mathrm{a}}$ & $735.30 \pm 26.67^{\mathrm{b}}$ & $963.18 \pm 34.20^{\mathrm{a}}$ \\
\hline $\begin{array}{l}\text { Total flavonoids } \\
\text { content } \\
\text { (mg QE/100 g) }\end{array}$ & $538.58 \pm 23.22^{\mathrm{b}}$ & $694.17 \pm 25.04^{\mathrm{a}}$ & $217.29 \pm 9.77^{\mathrm{b}}$ & $259.99 \pm 11.56^{\mathrm{a}}$ \\
\hline $\begin{array}{l}\text { Total anthocyanins } \\
\text { content } \\
\text { (mg CG/100 g) }\end{array}$ & $134.68 \pm 4.84^{\mathrm{b}}$ & $181.43 \pm 6.39^{\mathrm{a}}$ & $43.93 \pm 1.65^{\mathrm{b}}$ & $65.18 \pm 2.33^{\mathrm{a}}$ \\
\hline $\begin{array}{l}\text { DPPH antioxidant } \\
\text { activity } \\
\text { (mmol rolox/100 g) }\end{array}$ & $35.21 \pm 1.68$ & $34.45 \pm 1.98$ & $20.95 \pm 0.78$ & $21.19 \pm 1.05$ \\
\hline
\end{tabular}

* Results show means \pm standard deviation. Different superscript letters indicate a significant difference at $\mathrm{p}<0.05$ level between cultivars

The TPC, TFC and TAC were higher both in the fresh fruit and in the leather of "Malga" cultivar than in "Murano". No significant differences were found between cultivars regarding the DPPH antioxidant activity. However, the DPPH antioxidant activity was higher in "Murano" (35.21 mmol Trolox/100 g) than in "Malga" homogenates $(34.45 \mathrm{mmol}$ Trolox/100 g).

As shown in Table 3, there were significant decreases $(\mathrm{p}<0.05)$ in term of TPC, TFC and TAC of strawberry leather after drying. 
TPC of the leathers obtained from the two strawberry cultivars were lower as compared to TPC of the fresh fruits. TPC found in the strawberry leathers (735.3 mg GAE/100 g DW and $963.18 \mathrm{mg} \mathrm{GAE} / 100 \mathrm{~g}$ for "Murano" and "Malga", respectively) were lower than that found in mulberry leathers dried at $60{ }^{\circ} \mathrm{C}(1179 \mathrm{mg} \mathrm{GAE} / 100 \mathrm{~g} \mathrm{DW})$ by Phuong et al. (2016) but higher than TPC reported by Minakschhi (2011) in blueberry leathers (446 mg GAE/100 g DW) or by Senem et al. (2013) in apricot leather (60.34 mg GAE/100 g DW).

The anthocyanin contents of strawberry leather decreased by $67.38 \%$ ("Murano") and $64.07 \%$ ("Malga") of the initial value found in fruit homogenate while total phenolic contents were reduced by $43.81 \%$ ("Murano") and 32.33\% ("Malga"). In addition, reductions of $40.5 \%$ ("Murano") and 38.5\% ("Malga") in the DPPH antioxidant activity of strawberry leathers were observed after drying.

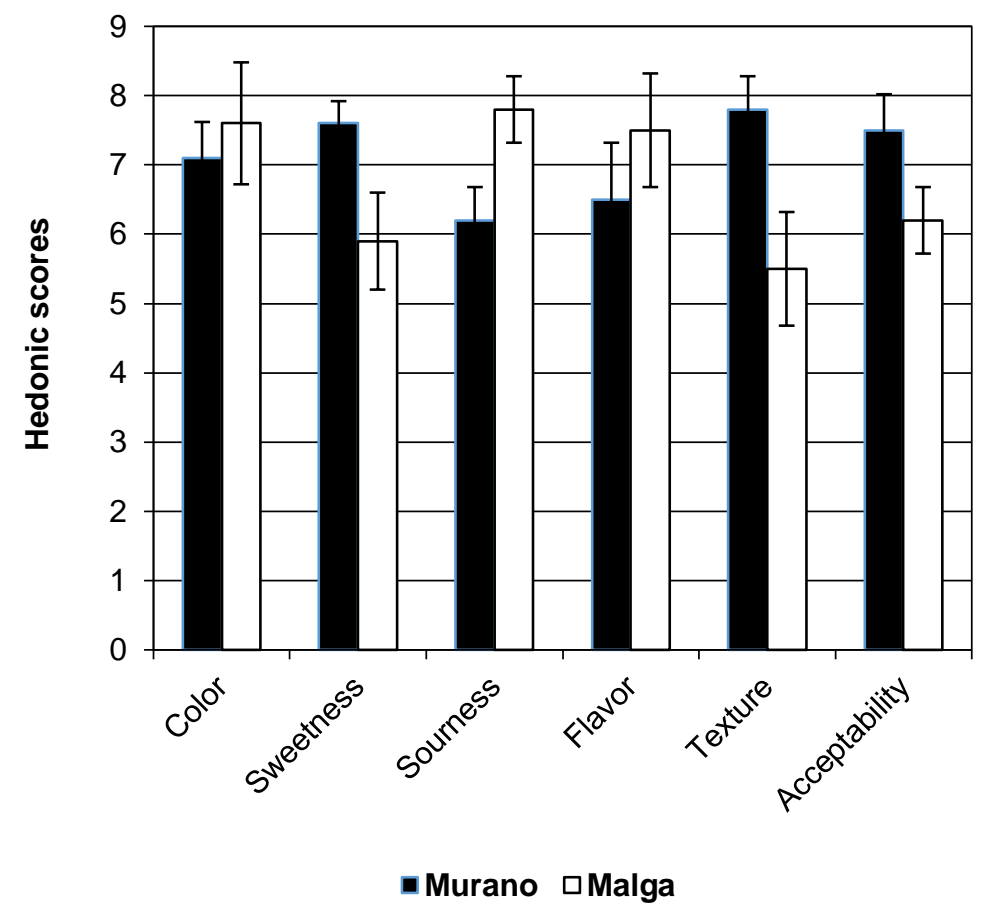

Figure 1. Sensory evaluation of leathers made from two strawberry cultivars

The average scores for six properties of the fruit leathers are presented in Figure 1. Leathers from the two cultivars differed significantly $(p<0.05)$ in terms of sweetness, sourness, texture, and general acceptability.

Of the two cultivars, "Murano" leather achieved the lowest scores for color, however, the differences in color scores were not significant at $\mathrm{p}<0.05$. There was a significant difference $(p<0.05)$ concerning sweetness scores, the leather made from "Murano" strawberries obtained an average sweetness score of 7.60 as compared with "Malga" (5.90). "Murano" leather was sweeter, in good agreement with its higher total soluble solids content, as compared with "Malga" leather. 
In terms of sourness and flavor, "Malga" stands out significantly with scores of 7.80 and 7.50 as compared to 6.20 and 6.50 for the "Murano" leather, respectively. Regarding the texture, "Murano" leather was much better appreciated (score 7.80) compared to "Malga" (score 5.50) because it was more elastic, softer and rehydrated faster during chewing.

\section{Discussion}

The addition of lemon juice to the fruit leather puree increased the titratable acidity of the leather from both strawberry cultivars. In addition, drying contributes to concentration in the fruit's natural acidity, leading to a substantial increase in the acidity of the fruit leather. Similar increases in titratable acidity after drying have been reported in previous studies (Phuong et al., 2016).

The higher levels of titratable acidity have a positive effect on leather shelf life as they inhibit bacterial growth and protect the color and flavor of the fruit product (Addai et al., 2016). Vega-Gálvez et al. (2009) reported an acidity of $2.2 \%$ (as citric acid) in dried blueberries while Vaidya et al. (2007) reported 3.8\% acidity in the fruit leather made from kiwifruit.

Fresh strawberry homogenates had a lighter color compared to the fruit leathers. The decrease of lightness after drying may be attributed to the loss of anthocyanins because of thermal degradation and to the formation of brown pigments as a result of the non-enzymatic oxidation of anthocyanins and subsequent condensation reactions (Singleton, 1987). In addition, citric acid is a strong acid that may affect the stability of anthocyanins, causing their degradation (Addai et al., 2016).

The decrease of $a^{*}$ values in both strawberry cultivars after drying may be due to anthocyanin oxidation as well as thermal degradation. Similar decreases of $a^{*}$ values were reported in papaya fruit leather after drying (Addai et al., 2016).

The reduction in total phenolic content after drying (by $43.81 \%$ and $32.33 \%$ in "Murano" and "Malga" leather, respectively) may be attributed to the heat sensitivity of phenolic compounds (Masibo and He, 2008), to the binding of phenolics to other compounds such as proteins or to the changes in their chemical structure (Di Scala et al., 2011). Suna (2019) reported a decrease of total phenolic content of $50.59 \%$ in medlar fruit leather after hot air drying at $60{ }^{\circ} \mathrm{C}$. Similar decreases of TPC were reported in promeganate (Fatih et al., 2015), mulberry (Phuong et al., 2016), blueberry and rose hip leathers (Chen and Martynenko, 2018; Ruiz et al., 2014) and they were ascribed to the degradation and oxidation during heat treatment.

The loss of anthocyanins was found higher in both strawberry cultivars as compared with the loss of total phenolic content. This could be due to the higher sensitivity of anthocyanin compounds to thermal damage and process exposure time than colorless phenolic compounds (Karaaslan et al., 2014). Previous studies reported that total anthocyanin content reduced up to $80 \%$ in pomegranate fruit leather compared to initial mixture when increasing drying temperature from 50 to $70{ }^{\circ} \mathrm{C}$ (Fatih et al., 2015) while in mulberry leather the anthocyanin contents reduced from 22 to $72 \%$ of the initial value (Phuong et al., 2016).

Strawberries are known as an antioxidant source due to their high content of anthocyanin, phenolic and ascorbic acid. The decrease of the antioxidant activity after the processing of fruits in leathers may be attributed to the losses of antioxidant compounds as a result of their vulnerability to heat treatment (Brewer, 2011). Phuong et al. (2016) revealed that the free radical scavenging capacities positively correlated with TPC and TAC in mulberry leathers. 
Despite the higher $a^{*}$ values, the lowest color score was granted to "Murano" leather because of its paler appearance, in good agreement with its higher $L^{*}$ values. In addition, the color difference $(\Delta \mathrm{E})$ was significantly $(\mathrm{p}<0.05)$ higher in "Murano" processing, demonstrating the higher color degradation during drying in the fruit homogenates of this cultivar.

The taste of strawberry fruit leather was enhanced by adding honey and lemon juice. The sweetness of the fruit leather was influenced by the amount of sugar in the fresh pulp as was previously reported by Okilya et al. (2010). As found in previous studies, the panelists liked the product sweetness while the sourness of the fruit leathers was 'moderately liked' by the panelists (Addai et al., 2016). The strong aroma of the strawberries constituted a major asset to the strawberry leathers. The more persistent aroma of "Malga" strawberries resulted in a better grading of the flavor in "Malga" leather. However, in terms of general acceptability, there was a greater preference for the strawberry leather cultivar "Murano" (7.50) as compared with "Malga" (6.20) due to its reddish color, stronger sweetness, lower sourness and more pleasant texture.

\section{Conclusions}

1. The suitability of "Malga" and "Murano" strawberry cultivars as raw material for industrial processing in leathers was evaluated.

2. Apart from their attractive appearance, taste and flavor, strawberry leathers are a good source of natural antioxidants including anthocyanins and other phenolic compounds.

3. Significant decreases of phenolic content and antioxidant capacity was noted during the drying processing.

4. Further studies should focus on pre-treatment methods and ingredients for making strawberry leather in order to shorten drying time and maintain the antioxidant properties of the product.

\section{References}

Aaby K., Wrolstad R.E., Ekeberg D., Skrede G. (2007), Polyphenol composition and antioxidant activity in strawberry purees; impact of achene level and storage, Journal of Agricultural and Food Chemistry, 55(13), pp. 5156-5166.

Addai Z.R., Abdullah A., Mutalib S.A., Musa K.H. (2016), Evaluation of fruit leather made from two cultivars of papaya, Italian Journal of Food Science, 28, pp. 73-82.

Afrin S., Gasparrini M., Forbes-Hernandez T.Y., Reboredo-Rodriguez P., Mezzetti B., Varela-Lopez A., Giampieri F., Battino M. (2016), Promising health benefits of the strawberry: a focus on clinical studies, Journal of Agricultural and Food Chemistry, 64, pp. 4435-4449.

Al-Hinai K.Z., Guizani N., Singh V., Rahman M. S. and Al-Subhi L. (2013), Instrumental texture profile analysis of date-tamarind fruit leather with different types of hydrocolloids, Food Science and Technology Research, 19(4), pp. 531.

Ariza M.T., Reboredo-Rodríguez P., Mazzoni L., Forbes-Hernández T.Y., Giampieri F., Afrin S., Gasparrini M., Soria C., Martínez-Ferri E., Battino M., Mezzetti B. (2016), Strawberry achenes are an important source of bioactive compounds for human health, International Journal of Molecular Sciences, 17(7), pp. 1103. 
Bandaru H., Bakshi M. (2020), Fruit Leather: Preparation, packaging and its effect on sensorial and physico-chemical properties: A review, Journal of Pharmacognosy and Phytochemistry, 9(6), pp. 1699-1709.

Brewer M.S. (2011), Natural antioxidants: sources, compounds, mechanisms of action, and potential applications, Comprehensive Reviews of Food Science and Food Safety, 10, pp. 221-247.

Chen Y., Martynenko A. (2018), Combination of hydro-thermodynamic (HTD) processing and different drying methods for natural blueberry leather, LWT Food Science and Technology, 87, pp. 470-477.

Diamante L.M., Bai X., Busch J. (2014), Fruit leathers: Methods of preparation and effect of different conditions on qualities, International Journal of Food Science, 3, ID 139890, pp. 1-12.

Di Scala K., Vega-Gálvez A., Uribe E., Oyanadel R., Miranda M., Vergara J., Quispe I., Lemus-Mondaca R. (2011), Changes of quality characteristics of pepino fruit (Solanum muricatum Ait) during convective drying, International Journal of Food Science and Technology, 46(4), pp. 746-753.

Fatih M.Y., Sultan Y., Hasan V., Mehmet K. (2015), The effects of drying conditions on moisture transfer and quality of pomegranate fruit leather (pestil), Journal of the Saudi Society of Agricultural Sciences, 16(1), pp. 33-40.

Forbes-Hernandez T.Y., Gasparrini M., Afrin S., Bompadre S., Mezzetti B., Quiles J.L., Giampieri F., Battino M. (2016), The healthy effects of strawberry polyphenols: Which strategy behind antioxidant capacity? Critical Review in Food Science and Nutrition, 56 , pp. S46-59.

Giusti M.M., Wrolstad R.E. (2001), Unit F1.2: Anthocyanins. Characterization and measurement of anthocyanins with UV visible spectroscopy. In: Wrolstad R.E. (ed) Current protocols in food analytical chemistry, New York: John Wiley \& Sons, pp. 113.

Guo M., Jin T.Z., Gurtler J.B., Fan X., Yadav M.P. (2018), Inactivation of Escherichia coli O157:H7 and Salmonella and native microbiota on fresh strawberries by antimicrobial washing and coating, Journal of Food Protection, 81, pp. 1227-1235.

Hatano T., Kagawa H., Yasuhara T., Okuda T. (1988), Two new flavonoids and other constituents in licorice root: their relative astringency and radical scavenging effects, Chemical and Pharmaceutical Bulletin, 36, pp. 2090-2097.

Huang X., Hsieh F.H. (2005), Physical properties, sensory attributes and consumer preference of pear fruit leather, Journal of Food Engineering, 100(2), pp. 254-260.

Irwandi J., Man Y., Yusof S., Jinap S. and Sugisawa H. (1998), Effects of type of packaging materials on physicochemical, microbiological and sensory characteristics of durian fruit leather during storage, Journal of the Science of Food and Agriculture, 76(3), pp. 427-434.

Karaaslan M., Yilmaz F.M., Cesur O., Vardin H., Ikinci A., Dalgic A.C. (2014), Drying kinetics and thermal degradation of phenolic compounds and anthocyanins in pomegranate arils dried under vacuum conditions, International Journal of Food Science and Technology, 49(2), pp. 595-605.

Kowalska J., Kowalska H., Marzec A., Brzezin T., Samborska K., Lenart A. (2018), Dried strawberries as a high nutritional value fruit snack, Food Science and Biotechnology, 27, pp. 799-807.

Kumar R., Patil R., Mondal G. (2010), Development and evaluation of blended papaya leather, Acta Horticulturae, 851, pp. 565-570. 
Masibo M., He Q. (2008), Major mango polyphenols and their potential significance to human health, Comprehensive Reviews in Food Science and Food Safety, 7, pp. 309319.

Minakschhi K. (2011), Evaluation of fruit leathers made from New Zealand grown blueberries. A thesis submitted in partial fulfillment of the requirements for the Degree of Master of Science at Lincoln University.

Mohammadzadeh S., Sharriatpanahi M., Hamedi M., Amanzadeh Y., Sadat Ebrahimi S.E., Ostad S.N. (2007), Antioxidant power of Iranian propolis extract, Food Chemistry, 103, pp. 729-733.

Momchilova M., Zsivanovits G., Milkova-tomova I., Buhalova D., Dojkova P. (2016), Sensory and texture characterisation of plum (Prunus domestica) fruit leather, Bulgarian Chemical Communications, 48, pp. 428-434.

Nour V., Plesoianu A.M., Ionica M.E. (2021), Effect of dip wash treatments with organic acids and acidic electrolyzed water combined with ultraviolet irradiation on quality of strawberry fruit during storage, Bragantia, 80, e1921.

Okilya S., Mukisa I., Kaaya A. (2010), Effect of solar drying on the quality and acceptability of jackfruit leather, Electronic Journal of Environmental, Agricultural and Food Chemistry, 9(1), pp. 101-111.

Omolola A.O., Jideani A.I.O., Kapila P.F. (2017), Quality properties of fruits as affected by drying operation, Critical Reviews in Food Science and Nutrition, 57(1), pp. 95-108.

Parvez S., Wani, I.A. (2018). Postharvest biology and technology of strawberry, In S. Mir, M. Shah and M. Mir (Eds.), Postharvest Biology and Technology of Temperate Fruits, Cham: Springer, p. 331-348.

Phuong H.M.K., Hoa N.D.H., Ha N.V.H. (2016), Effects of added pectin amounts and drying temperatures on antioxidants properties of mulberry fruit leather, Journal of Biotechnology, 14(1A), pp. 487-495.

Phimpharian C., Jangchud A., Jangchud K., Therdthai N., Prinyawiwatkul W., No H.K. (2011), Physicochemical characteristics and sensory optimisation of pineapple leather snack as affected by glucose syrup and pectin concentrations, International Journal of Food Science and Technology, 46(5), pp. 972-981.

Ruiz N.A.Q., Demarchi S.M., Giner S.A. (2014), Effect of hot air, vacuum and infrared drying methods on quality of rose hip (Rosa rubiginosa) leathers, International Journal of Food Science and Technology, 49, pp. 1799-1804.

Senem S., Canan E., Bige İ.Ö.S.G., Ömer U. (2014), Impact of drying methods on physicochemical and sensory properties of apricot pestil, Indian Journal of Traditional Knowledge, 13(1), pp. 47-55.

Setiaboma W., Fitriani V., Mareta D.T. (2019), Characterization of fruit leather with carrageenan addition with various bananas, IOP Conf. Series: Earth and Environmental Science, 258, 012004.

da Silva Simão, R., de Moraes, J.O., Carciofi, B A.M., Laurindo, J.B. (2020), Recent advances in the production of fruit leathers, Food Engineering Reviews, 12(1), pp. 6882.

Singleton V.L., Rossi J.A. (1965), Colorimetry of total phenolics with phosphomolybdic phosphotungstic acid reagent, American Journal of Enology and Viticulture, 16, pp. 144-158.

Singleton V.L. (1987), Oxygen with phenols and related reactions in musts, wines, and model systems: observations and practical implications, American Journal of Enology and Viticulture, 38(1), pp. 69-77. 
Suna S. (2019), Effects of hot air, microwave and vacuum drying on drying characteristics and in vitro bioaccessibility of medlar fruit leather (pestil), Food Science and Biotechnology, 28, pp. 1465-1474.

Van de Velde F., Tarola A., Güemes D., Pirovani M. (2013), Bioactive compounds and antioxidant capacity of camarosa and selva strawberries (Fragaria $x$ ananassa Duch.), Foods, 2, pp. 120-131.

Vaidya D., Vaidya M. and Sharma P. (2007), Development of value-added products from kiwifruit in India, Acta Horticulturae, 753(2), pp. 809.

Vega-Gálvez A., López J., Miranda M., Di Scala K., Yagnam F., Uribe E. (2009), Mathematical modelling of moisture sorption isotherms and determination of isosteric heat of blueberry variety $\mathrm{O}^{\prime}$ Neil, International Journal of Food Science \& Technology, 44(10), pp. 2033-2041. 


\title{
Biodegradable film based on taro starch with variations of duck bone gelatin concentration: physical and barrier properties
}

\section{Trias Ayu Laksanawati, Muhammad Habbib Khirzin, Maghfirotul Amaniyah}

\author{
State Polytechnic of Banyuwangi, Banyuwangi, Indonesia
}

\section{Keywords:}

Bifilm

Starch

Gelatin

Physical

Barrier

\section{Article history:}

Received

18.09.2021

Received in

revised form

01.12.2021

Accepted

30.12.2021

Corresponding

author:

Trias Ayu

Laksanawati

E-mail:

trias@

poliwangi.ac.id

DOI:

10.24263/2304-

974X-2021-10-

4-9

\section{Abstract}

Introduction. This study aims to improve the physical properties of biodegradable films based on taro starch added with duck bone gelatin and glycerol as a plasticizer by using the solution casting method.

Materials and methods. A non-factorial completely randomized design (CRD) with ANOVA was used, followed by the DUNCAN test to determine the effect of different treatments. Various concentrations of duck bone gelatin were used, including $0,5,15,25$ and $35 \%$ of the total weight of solids (taro starch and duck bone gelatin). The functional groups of biodegradable films were analyzed using Fourier Transport Infrared (FTIR). The morphological structure of the product was studied using Scanning Electron Microscope (SEM).

Results and discussion. The parameters observed included the water vapor transmission rate test, which resulted in a value of $0.465-$ $0.529 \mathrm{~g} / \mathrm{m}^{2}$.hour. The highest water vapor transmission rate was at a concentration of $35 \%$ duck bone gelatin of $0.529 \mathrm{~g} / \mathrm{m}^{2}$ hour. The factor that affects the value of the water vapor transmission rate is the chemical nature of the material polymer. Water absorption was 85.17$40.47 \%$, and the highest water absorption was at a concentration of $0 \%$ duck bone gelatin. The percentage of water absorption is used to assess the value of the water resistance of the resulting film. Water solubility was $31.08-64.60 \%$. The highest water solubility value was at a concentration of $35 \%$ duck bone gelatin of $64.60 \%$ because the addition of duck bone gelatin can reduce the intermolecular forces of the film and increase water activity so that free water molecules can occupy the matrix in the film.

The FTIR spectrum for biodegradable film products showed a peak wavenumber at $3600-3000 \mathrm{~cm}^{-1}$, indicating the presence of N-H and O$\mathrm{H}$ groups. The presence of $\mathrm{N}-\mathrm{H}$ and $\mathrm{O}-\mathrm{H}$ groups in biodegradable films can help the degradation process because they have hydrophilic properties that enable water molecules to access and enter the film matrix.

The results of SEM analysis showed that the taro starch film with the addition of duck bone gelatin produced a homogeneous and flexible biodegradable film with compact structure.

Conclusions. The addition of duck bone gelatin had an insignificant effect on the water vapor transmission rate but a very significant effect on water solubility and a significant effect on water absorption. 


\section{Introduction}

Plastic is a common packaging material but is not decomposable (Muin et al., 2017). It has advantages, including practical, transparent, flexible, economical, strong, and multifunctional. This is what causes plastic packaging to be widely used by the community, resulting in increasing waste. This can cause environmental damage. Therefore, an alternative for making biodegradable plastics, called biodegradable films, is needed. Biodegradable film is a biodegradable and environmentally friendly plastic (Aripin et al., 2017). The main ingredients for making biodegradable films come from cellulose, chitosan, starch, protein, or a combination of components (Asngad et al., 2018). Among these natural polymers, starch is a polysaccharide that is widely used as a material for making biodegradable films. It is one type of carbohydrate that is found in nature, one of which is from plant body parts such as seeds, roots, stems, and cereals (Aryanti et al., 2017). Starch contains compact-structure amylose and amylopectin (Udjiana et al., 2019). Different levels of amylose and amylopectin can affect film formation (Rosseto et al., 2019). Starch from taro tubers was used because it has a starch content of $80 \%$, which is greater than corn starch content of $71.3 \%$ and cassava starch content of $72.17 \%$ (Rahmawati et al., 2012); besides, taro starch is a natural renewable material. The use of starch in biodegradable films has the advantages of being easy to decompose (biodegradation), easy to form films (plastic), easy to obtain (Winarti et al., 2012), and not easily penetrated by water vapor (Aripin et al., 2017) However, starch also has drawbacks, including low mechanical properties and being easy to dissolve in water (Bani, 2019). Other additives are needed to improve these, one of which is duck bone gelatin to reduce the stiffness of the polymer and its hydrophilic properties to water (Resalina et al., 2013). Taro starch and duck bone gelatin is renewable in making biodegradable films. Gelatin added to the biodegradable film will provide flexural and elastic properties (Illing et al., 2017). Gelatin can also increase its solubility in water to facilitate the degradation process (Kumar et al., 2019).

Biodegradable film based on gelatin is usually very good as a barrier to oxygen, carbon dioxide, and some aromatic compounds, and has excellent mechanical properties (mechanical strength of the film) and barrier properties (the ability to inhibit the entry and exit of certain substances through the film) (Jagadeesh et al., 2016). In addition, gelatin also basically has good barrier properties against UV rays due to the presence of aromatic amino acids (the structure resembles a ring) which is able to absorb UV light, so that it can prevent oxidation in food products wrapped in plastic from the protein. Mixing two different polymers, such as gelatin and polysaccharides, proteins and lipids, polysaccharides and lipids or synthetic polymers and natural polymers aims to improve the biodegradable film properties.

Gelatin is an animal protein product from the hydrolysis of collagen (Chaves da Silva et al., 2018). It is widely used by the food and non-food industries. The food industry uses gelatin as an emulsifier, binder, stabilizer, and thickener (Miskah et al., 2010). The non-food industry uses gelatin as an additive for making films or plastics (Puspawati et al., 2017). The raw materials of gelatin come from cow bones, cow skins, pig skins (Santosa et al., 2018), and poultry including ducks, chickens, and birds (Puspawati et al., 2017). Duck bone waste was used as a source for making gelatin. Generally, duck bone waste has not been utilized optimally. Therefore, it is necessary to conduct research on making biodegradable films based on taro starch and duck bone gelatin to produce better physical properties, namely water vapor transmission rate, water solubility, and water absorption.

The aim of research is to improve the physical and barrier properties of biodegradable films based on taro starch added with duck bone gelatin. 


\section{Materials and methods}

\section{Materials}

The main ingredients used were taro tubers and duck bone gelatin obtained from markets and restaurants in Banyuwangi Regency, Indonesia. Sodium hydroxide $(\mathrm{NaOH}$, analytical grade, Merck KGaA, Darmstadt, Germany); hydrochoric acid ( $\mathrm{HCl}$, analytical grade, PT. Smart Lab Indonesia); aquadest (CV. Makmur Sejati, Malang, Indonesia); glycerol (CV. Sahabat Lab, Indonesia). Thermometer, hot plate, magnetic stirrer, food dehydrator, dry box, beaker glass, spatula, desiccator, petri dish, measuring cup, dropper, pot, stove, knife, oven, scale analytics, Fourier Transform Infrared Stresscopy (FTIR), and Scanning Electron Microscope (SEM) were used in research.

\section{Synthesis of Biodegradable Film}

In this study, the biodegradable films of taro starch and duck bone gelatin were made using the solution casting method. Five treatments were used with different concentrations of duck bone gelatin, namely $0,5,15,25$ and $35 \%$ of the total solids weight (taro starch and duck bone gelatin). Taro starch and duck bone gelatin were weighed according to the treatment. Starch was dissolved in $10 \mathrm{ml}$ of distilled water using a hot plate and stirred with a magnetic stirrer at $70{ }^{\circ} \mathrm{C}$ with a speed of $375 \mathrm{rpm}$. Gelatin was also dissolved in the same way as taro starch. The solutions of taro starch and duck bone gelatin were then mixed, heated, stirred, and added with $0.5 \mathrm{ml}$ of glycerol and $5 \mathrm{ml}$ of distilled water. The solution was heated, stirred, and kept a constant temperature of $70{ }^{\circ} \mathrm{C}$. Then, the gelatinization occurred for 40 minutes. The biodegradable film solution was left for 3 minutes. It was poured into a petri dish mold and put in the oven for 24 hours at $60{ }^{\circ} \mathrm{C}$. The sample was left at room temperature after being removed from the mold. The biodegradable film was stored in a zip bag log and given silica gel so that it was not easily damaged and was ready for Fourier Transform Infrared (FTIR), SEM, water vapor transmission rate, water solubility, and water absorption tests.

\section{Fourier Transform Infrared (FTIR)}

Infrared spectra of biodegradable film samples were measured using $\mathrm{KBr}$ pellets with the FTIR Prestige-21 Shimadzu spectrophotometer at wavenumbers between $4000 \mathrm{~cm}^{-1}$ to $400 \mathrm{~cm}^{-1}$. The sample was placed into the set holder and searched with the appropriate spectrum. The result was obtained in the form of spectra of the relationship between wavenumber and intensity. The FTIR spectrum was recorded using a spectrometer at room temperature (Darni et al., 2010).

\section{Water Vapor Transmission Rate Test}

Measurement of the water vapor transmission rate was carried out using a porcelain cup and a glass jar. The porcelain cup was filled with $15 \mathrm{ml}$ of water and covered with a biodegradable film. Then, the porcelain cup was placed in a glass jar containing $30 \mathrm{~g}$ of silica gel with known initial weight and left in a closed glass jar for hours (Sunardi et al., 2019). The water vapor transmission rate test was calculated using the following formula: 


$$
W V T W=\frac{\Delta W}{A \times T}
$$

Remark:

WVTR - water vapor transmission rate; $\Delta \mathrm{W}$ - change in weight of silica gel (gram); A - film area $\left(\mathrm{m}^{2}\right) ; \mathrm{T}-$ storage time interval (hours).

\section{Water Solubility Test}

The cup was cleaned and dried at $100^{\circ} \mathrm{C}$ for 30 minutes. A sample of 1 gram was poured in a cup and placed in an oven at $100{ }^{\circ} \mathrm{C}$ for 30 minutes. The dried sample was weighed as the initial dry weight $\left(\mathrm{W}_{0}\right)$ before being immersed for 24 hours. The sample that was not dissolved in water was removed and dried in an oven for 2 hours at $100^{\circ} \mathrm{C}$; then, it was stored in a desiccator for 20 minutes. The dried sample was weighed as the sample weight after immersion $\left(\mathrm{W}_{1}\right)$ (Gontard et al., 1993). The percentage of water solubility of the sample was calculated by the following formula:

$$
\mathrm{S}=\mathrm{W}_{0} / \mathrm{W}_{1} \times 100 \%
$$

Remark:

$\mathrm{S}$ - Water solubility (\%); $\mathrm{W}_{0}$ - Initial dry weight (gram); $\mathrm{W}_{1}$ - Weight after immersion (gram).

\section{Water Absorbtion Test (Swelling)}

The biodegradable film was cut and weighed the initial weight (W0), then put into a glass beaker containing $15 \mathrm{ml}$ of distilled water for 2 minutes. The sample was removed and there was water on the surface of the plastic then drained using a tissue for 5 minutes, after which it was weighed. Weighing and immersion of the biodegradable film was repeated until the sample had a constant final weight. The water absorption test (swelling) can be calculated using the following formula:

$$
\text { Swelling }=\Delta \mathrm{W} / \mathrm{W}_{0} \times 100 \%
$$

Remark:

$\Delta \mathrm{W}$ - Weight change of biodegradable film (grams);

$\mathrm{W}_{0}$ - Initial weight of biodegradable film (grams).

\section{Morphological Structure Analysis (SEM)}

Observation of the cross sectional morphological structure of biodegradable film products was carried out using Scanning Electron Microscope (SEM) analysis (ZEOL, Germany). Before testing, the samples were placed in a desiccator with $54 \%$ humidity at room temperature. The biodegradable film was prepared by breaking it down in liquid nitrogen and then observing it according to standard procedures. 


\section{Results and discussion}

\section{Fourier Transform Infrared (FTIR) Analysis}

Figure 1 shows the FTIR spectrum of taro starch, duck bone gelatin, glycerol, and biodegradable film.

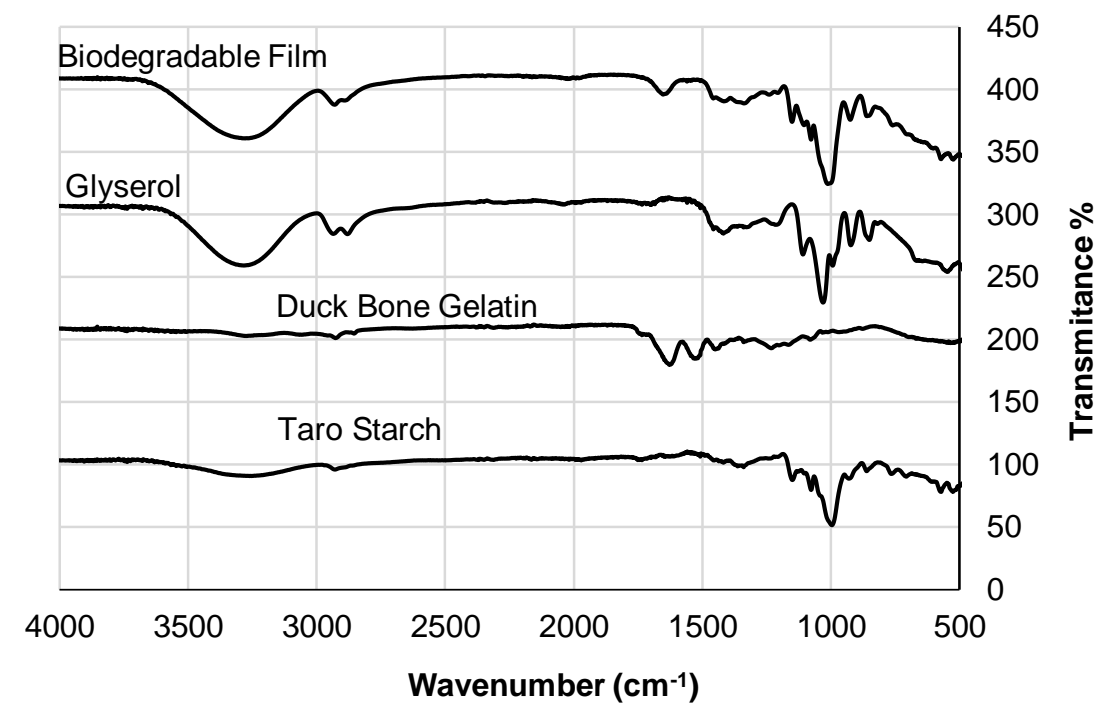

Figure 1. Spectrum FTIR of taro starch, glycerol, duck bone gelatin, and biodegradable film

The biodegradable film was made of three ingredients, namely taro starch, duck bone gelatin, and glycerol; therefore, the functional groups contained in these three ingredients must be present in the biodegradable film. The FTIR spectrum for biodegradable film products showed the peak wavenumber at $3600-3000 \mathrm{~cm}^{-1}$, indicating the presence of $\mathrm{N}-\mathrm{H}$ and $\mathrm{O}-\mathrm{H}$ groups. This causes water to be easily absorbed due to the presence of inter- and intra-molecular hydrogen bonds. Therefore, there is an interaction and molecular solubility between taro starch, duck bone gelatin, and glycerol in biodegradable films (Tongdeesoontorn et al., 2012). The peak wavenumber at $1,589 \mathrm{~cm}^{-1}$ indicated the $\mathrm{C}=\mathrm{C}$ group contained in gelatin (Radiyatullah et al., 2015). The peak wavenumber at $1,468 \mathrm{~cm}^{-1}$ represented the $\mathrm{C}-\mathrm{H}$ group found in starch and glycerol (Iling et al., 2017). The peak wavenumber at $1,350 \mathrm{~cm}^{-1}$ indicated the $\mathrm{C}-\mathrm{N}$ group in gelatin (Kong et al., 2007). The mixture of materials in the biodegradable film showed the functional groups contained in the three constituent materials and can be found in the biodegradable film product. This shows the presence of hydrogen bonds between polymers so that the biodegradable film is still hydrophilic (Aritonang et al., 2020). This FTIR analysis is in line with research (Iling et al., 2017) using sago waste and gelatin materials, showing the presence of functional groups in the form of $\mathrm{C}-\mathrm{H}, \mathrm{O}-\mathrm{H}, \mathrm{C}-\mathrm{O}, \mathrm{C}=\mathrm{O}$, and $\mathrm{N}-\mathrm{H}$. Tongdeesoontorn et al. (2012) stated that the functional groups contained in cassava starch and gelatin in the film had such functional groups as $\mathrm{O}-\mathrm{H}, \mathrm{C}-\mathrm{H}, \mathrm{C}=\mathrm{O}, \mathrm{C}-\mathrm{N}$, and $\mathrm{N}-\mathrm{H}$. The presence of $\mathrm{N}-\mathrm{H}$ and $\mathrm{O}-\mathrm{H}$ groups in biodegradable films can help the degradation process because they have hydrophilic 
properties that enable water molecules to access and enter the film matrix (Aritonang et al., 2020).

\section{Biodegradable Film Water Vapor Transmission Rate Test}

Figure 2 shows that the different concentration of duck bone gelatin has no significant effect $(\mathrm{P}>0.05)$ on the water transmission rate of the biodegradable film.

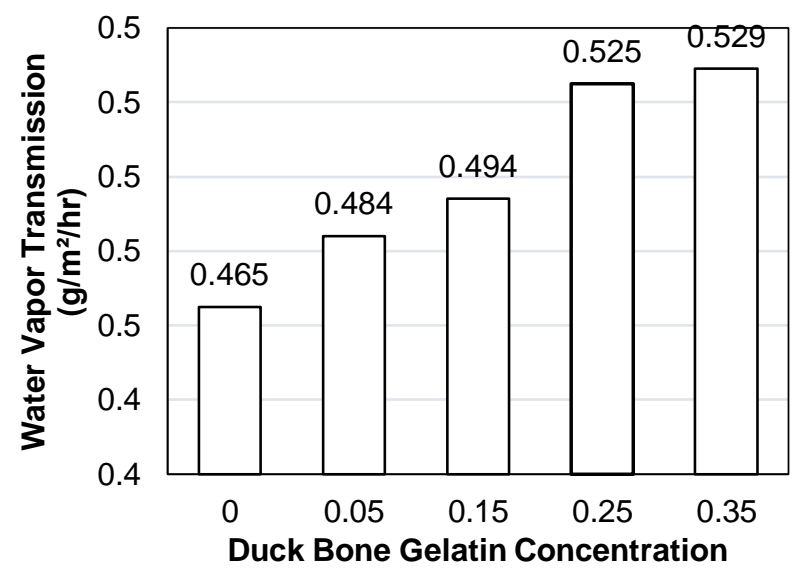

Figure 2. Water vapor transmission rate of biodegradable film

Higher concentration of duck bone gelatin increases the value of the water vapor transmission rate. The highest water vapor transmission rate was $0.529 \mathrm{~g} / \mathrm{m}^{2}$ hour at a concentration of $35 \%$ duck bone gelatin. The factor that affects the value of the water vapor transmission rate is the chemical nature of the material polymer (Budianto et al., 2019). The main ingredients for making biodegradable films in the form of polysaccharides (taro starch) and protein (duck bone gelatin) are polar polymer components that are hydrophilic because they have long hydrogen bonds and can increase the matrix or empty space, thereby accelerating the water vapor transmission rate (Deden et al., 2020). Thicker films will result in less water evaporation (Wijayani et al., 2021). The film structure with many air bubbles can cause water molecules to easily diffuse through the film surface (Widyaningsih et al., 2012). The value of the water vapor transmission rate was low from $0.465 \mathrm{~g} / \mathrm{m}^{2}$ hour to 0.5296 $\mathrm{g} / \mathrm{m}^{2}$ hour and did not exceed the steam transmission rate standard set by the Japanese Industrial Standard (JIS) (1975) for biodegradable film of $7 \mathrm{~g} / \mathrm{m}^{2}$ hour. The result of this study is lower than that of the previous research (Santoso et al., 2020) with low water vapor transmission values ranging from $1.07 \mathrm{~g} / \mathrm{m}^{2}$ hour to $1.60 \mathrm{~g} / \mathrm{m}^{2}$ hour with catfish bone gelatin and breadfruit starch as the main ingredients. The low value of water evaporation makes it difficult for water to penetrate the film so that the product is safer and not easy to damage (Salimah et al., 2016). The higher value of the water vapor transmission rate influenced by duck bone gelatin will result the faster film decomposition because gelatin can be hydrolyzed by adsorbtion of water in the soil and the polymer chains of the film will be broken and easily decomposed (Silviana et al., 2018). 


\section{Biodegradable Film Solubility Test}

Figure 3 shows that the different concentration of duck bone gelatin has a very significant effect $(\mathrm{P}>0.01)$ on the water solubility of the biodegradable film.

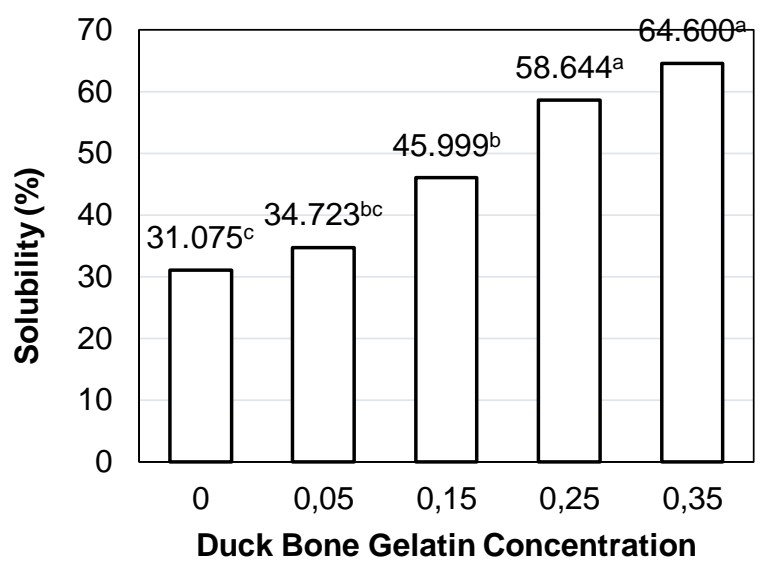

Figure 3. Solubility of biodegradable film

The more concentration of duck bone gelatin increases the value of water solubility. The highest water solubility value was at a concentration of 35\% duck bone gelatin of $64.60 \%$ because the addition of duck bone gelatin can reduce the intermolecular forces of the film and increase water activity so that free water molecules can occupy the matrix in the film (Sutra et al., 2020). Protein-based films (gelatin) have hydrophilic properties due to the presence of polar groups such as hydroxyl, carbonyl, and amino acids that can form hydrogen bonds that can bind to water molecules (Putri, 2018). In addition, gelatin has almost all amino acids except tryptophan (Otoni et al., 2017). The large number of hydrophilic amino acids can increase the affinity of gelatin to water, causing the film to easily bind water molecules (Dhirisma et al., 2014). Therefore, the amount of water that diffuses into the film can cause the breakdown of the film cavity, increasing its water solubility (Wang et al., 2017). This is following Darni et al. (2008) stating that the biodegradable film structure using gelatin has many cavities so that the ability to absorb water is higher.

The solubility value in this study is quite high, from $31.08 \%$ to $64.60 \%$. The solubility value is in line with the finding of Kumar et al. (2020) using corn starch and gelatin, resulting in a solubility value ranging from $20 \%$ to $60 \%$ with increasing concentration of added gelatin. Zulferiyani (2014) reported that the high solubility value could facilitate the biodegradation of the film due to the hydrophilic component because it can absorb water in the soil so that the film is easily broken into polymer units. 


\section{Biodegradable Film Water Absorption Test (Swelling)}

Figure 4 shows that the different concentration of duck bone gelatin has a very significant effect $(\mathrm{P}>0.05)$ on the water absorption of the biodegradable film.

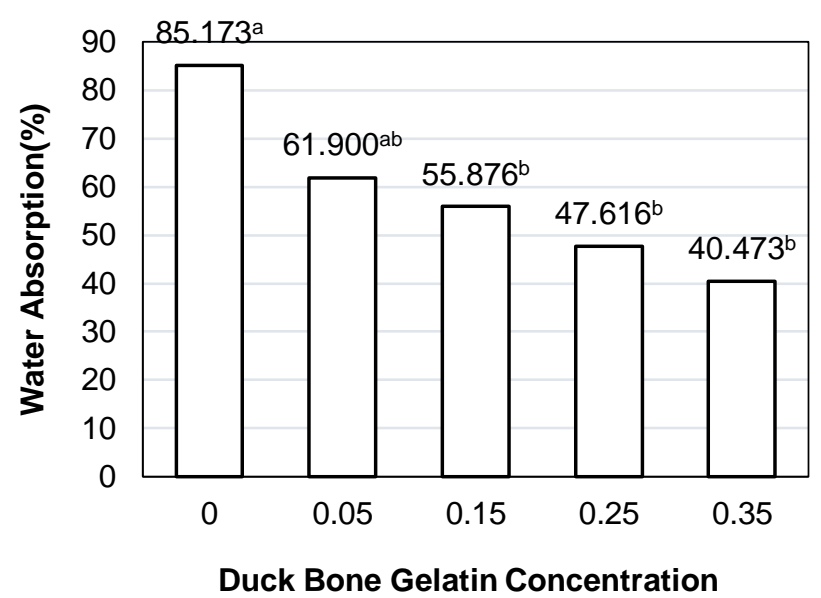

Figure 4. Water absorption (swelling) of biodegradable film

The higher the concentration of duck bone gelatin is, the lower the value of water absorption (swelling) will be. This is because proteins in the form of gelatin have hydrophilic properties due to the presence of polar groups in the form of hydroxyl, carbonyl, and amino acids that can form hydrogen bonds that can bind to water molecules (Putri, 2018). Hydrophilic starch and gelatin can bind to water molecules more quickly so that water easily diffuses, and the film is easy to swell (Kumar et al., 2020). The percentage of water absorption is used to assess the value of the water resistance of the resulting film. This is stated by Iling et al. (2017) that the lower the water absorption value is, the higher the water resistance of the biodegradable film will be. However, this theory is different from the research results. This study found that lower water absorption did not result in higher but lower water resistance values. This is presumably because the increasing concentration of added gelatin can affect the affinity of gelatin. According to Kumar et al. (2019), gelatin can increase the hydrophilicity of water molecules so that it is easier to absorb into the surface of the film. Water resistance will decrease, and solubility will increase. This is also supported by the results of the water solubility test and water content which increase with the higher concentration of duck bone gelatin. The higher solubility causes the film to hold less water so that the water absorption is low and affects the value of water resistance. Phenomenon found in the present study made this study inverse to other studies such as research of Kumar et al. (2020) and Iling et al. (2017). The lower water absorption is caused by the amount of dissolved film. The easier it is for the film to dissolve into water, the faster the process of decomposition (degradation) of the film will be (Asngad, 2018). 


\section{Analysis of Biodegradable Film Cross-Section Morphological Structure (SEM)}

The cross-sectional view of the biodegradable film is shown in Figure 5.

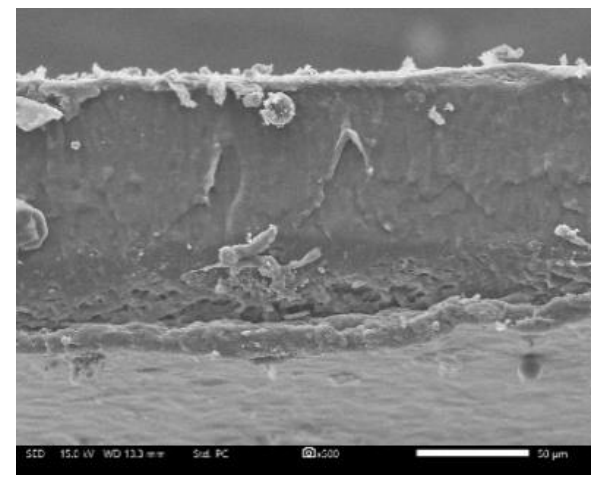

$\mathbf{a}$

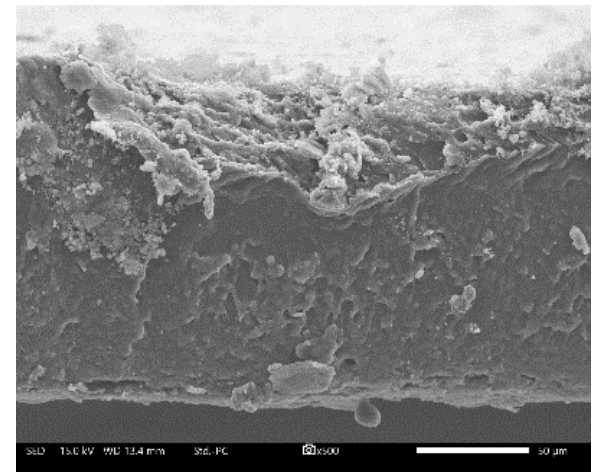

b

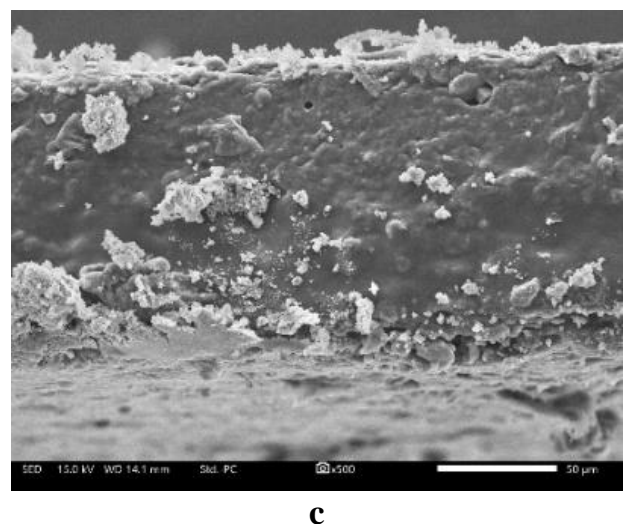

Figure 5. Cross section of biodegradable film with different content of duck bone gelatin: (a) 0\%, (b) $5 \%$, (c) $35 \%$

To obtain the observed cross-sections, the biodegradable films were cryogenically cut in liquid nitrogen. The micrographs of biodegradable taro starch films with the addition of content of $0 \%, 5 \%$, and 35\% duck bone gelatin are shown in Figures 5a, 5b, and 5c, respectively. SEM of biodegradable taro starch film (Fig. 5a) shows a relatively rough, dense, and continuous cross-section without pores and cracks, which confirm the solid and homogeneous structure. The micrograph of the biodegradable film with $5 \%$ duck bone gelatin can be seen in the cross-section showing dense and rough results with multiple folds. However, neither duck bone gelatin nor taro starch was seen, meaning that the addition of $5 \%$ duck bone gelatin resulted in a homogeneous and flexible biodegradable film with a compact structure. The micrograph of the biodegradable film with $35 \%$ duck bone gelatin had an uneven, rough, and multiple-fold cross-section (Fig. 5c), which may be due to the flexibility of the gelatin film (Wang et al., 2017). Figure 5c shows a cross-section that is very rough and duck bone gelatin, which is not bound to taro starch, meaning that many hydroxyl groups in duck bone gelatin are bound to free water. This is in accordance with the results of 
the analysis of solubility, water absorption, and water vapor transmission rate. Mixing taro starch with duck bone gelatin aims to improve the internal structure of the taro starch film, where the biodegradable taro starch film with $0 \%$ gelatin shows less roughness and is denser and more compact, which may be caused by its less flexibility (Tongdeesoontorn et al., 2012). Biodegradable films with the addition of duck bone gelatin are a more flexible and will be easily decomposable and environmentally friendly.

\section{Conclusion}

1. Based on the findings, in making biodegradable films based on taro (Xanthosoma saggitifolium) starch and duck bone gelatin, there are some functional groups including $\mathrm{NH}$ at a wavenumber of $3.250 \mathrm{~cm}^{-1}, \mathrm{OH}$ at $2.892 \mathrm{~cm}^{-1}, \mathrm{C}=\mathrm{C}$ at $1.539 \mathrm{~cm}^{-1}, \mathrm{CH}$ at 1.438 $\mathrm{cm}^{-1}$, and $\mathrm{CN}$ at $1.350 \mathrm{~cm}^{-1}$. The biodegradable film functional groups have similarities in the manufacturing materials, namely starch, glycerol, duck bone gelatin, and hydrophilic hydrogen bonds that can facilitate the film degradation.

2. In addition, at a concentration of $35 \%$, duck bone gelatin affects the physical characteristics of the biodegradable film in the form of a water vapor transmission rate of $0.53 \mathrm{~g} / \mathrm{m}^{2}$.hour and a water solubility value of $64.60 \%$. It also affects the value of water absorption (swelling) of $40.47 \%$. The value of water absorption is depend on the number of films that dissolved in water and cause the solubility value to increase.

3. The results of the micrograph of the biodegradable film in the cross-section with SEM analysis show that dense and rough results with many folds, which means that the biodegradable film added with duck bone gelatin gives more flexibility and accelerates degradation.

Acknowledgements. This research was funded by State Polytechnic of Banyuwangi through Research Induk Penelitian (RIP) grant with contract number 2674.37/PL36/PG/2021. The authors also thank to Siti Alfiyah and Rohmatul Iftitah who have helped in completing this research.

\section{References}

[JIS] Japanse Industrial Standar 21770 (1975), General Rules of Plastic Film fod FoodPackaging, Japanesse Standars Association, JSA, Tokyo.

Aripin S., Saing B., Kustiyah E. (2017), Intercalation, Studi Pembuatan Bahan Alternatif Plastik Biodegrdable Dari Pati Ubi jalar Dengan Plasticizer Gliserol dengan metode Melt, Jurnal Teknik Mesin, 6(1), pp. 79-84.

Aritonang D H., Hartiati A., Harsojuwono B A. (2020), Karakteristik Komposit Bioplastik pada Variasi Pati Ubi Talas Belitung (Xanthosoma sagittifolum) dan Karagenan, Jurnal Rekayasa dan Manajamen Agroindustri, 8(3).pp. 348-359.

Aryanti N., Kusumastuti Y., Rahmawati W. (2017), Pati Talas (Colocasia Esculenta (L.) Schott) Sebagai Alternatif Sumber Pati Industri, Jurnal Momentum, 13(1), pp. 46-52, DOI: 0.36499/jim.v13i1.1759

Asngad A., Amella R., Aeni, N. (2018), Pemanfaatan Kombinasi Kulit Kacang Dengan Bonggol Pisang Dan Biji Nangka Untuk Pembuatan Plastik Biodegradable Dengan Penambahan Gliserol, Bioeksperimen: Jurnal Penelitian Biologi, 4(1), pp. 11-19, DOI: 10.23917/bioeksperimen.v4i1.5924

Bani M. D. S. (2019), Variasi Volume Gliserol terhadap Sifat Fisis Plastik Biodegradable Berbahan Dasar Pati Ubi Kayu (Manihot Esculenta Cranz), Jurnal Pendidikan Matematik 
Dan Ilmu Pengetahuan Alam, 7(1), pp. 61-78.

Budianto A., Ayu Dewi F., Johan Vonny S. (2019), Pemanfaataan Pati Kulit Ubi Kayu dan Selulosa Kulit Kacang Tanah Pada Pembuatan Plastik Biodegradable, Sagu, 18(2), pp. 1118.

Chaves Da Silva N. M., Fakhouri F M., Fialho R. L. L., Cabral Albuquerque E. C. D. M. (2018), Starch-Recycled Gelatin Composite Films Produced By Extrusion: Physical And Mechanical Properties, Journal Of Applied Polymer Science, 135(19), pp. 1-9, DOI: 10.1002/App.46254

Darni Y., Chici A., Ismiyati S. (2008), Sintesa Bioplastik dari Pati Pisang dan Gelatin dengan Plasticizer Gliserol, Prosiding Seminar Nasional Sains dan Teknologi-II, UNIL, Lampung, pp. 182-189.

Darni Y., Utami H. (2010), Studi Pembuatan dan Karakteristik Sifat Mekanik dan Hidrofobisitas Bioplastik dari Pati Sorgum, Jurnal Rekayasa Kimia \& Lingkungan, 7(2), pp. 88-93.

Dhirisma F., Sari D. P. (2014), Formulaion of a Membrane-Based Porous Gidrogel Combination of HMPC (Hydroxy Propyl Metyl Celuluse), and Gelatin by using Foamin Gas Method and Determination of Physical-Mechanical Cahartestis, Naskah Publikasi Karya Tulis Ilmiah, 1(1), pp. 1-10.

Gontard N., Guilbert S., Cuq J.L. (1993), Water And Glycerol As Plasticizers Affect Mechanical And Water Vapor Barrier Properties Of An Edible Wheat Gluten Film, Journal of Food Science, 58(1), 206-211, DOI: 10.1111/J.1365-2621.1993.Tb03246.X

Illing I., MB S. (2017), Uji Ketahanan Air Bioplastik Dari Limbah Ampas Sagu Dengan Penambahan Variasi Konsentrasi Gelatin, Prosiding Seminar Nasional, 3(1), pp. 182-189.

Jagadeesh D., Prashantha K., Mithil Kumar Nayunigari N., Maity A. (2016), Effect of Gelatin Content on Potato Starch Green Composite Films, Indian Journal of Advances in Chemical Science, 4(4), pp. 355-361.

Kong J., S Yu. (2007), Fourier Transform Inrared Spectroscopic Analysis of protein Secondary Structures, Acta Bioch Sin, 39(8), pp. 529-559

Kumar R., Ghoshal G., Goyal M. (2019), Synthesis and functional properties of gelatin/CA-starch composite film: excellent food packaging material, Journal of Food Science and Technology, 56(4),pp. 1-12, DOI: 10.1007/s13197-019-03662-4

Kumar R., Ghoshal G., Goyal M. (2020), Biodegradable composite films / coatings of modified corn starch / gelatin for shelf life improvement of cucumber, Journal of Food Science and Technology, 1(1), pp. 1-11, DOI: 10.1007/s13197-020-04685-y

Miskah S., Ramadianti I. M., Hanif A. F. (2010), Pelarut Dan Waktu Perendaman Pada Pembuatan Gelatin Berbahan Baku Tulang / Kulit Kaki Ayam, Jurnal Teknik Kimia, 1(17), pp. 1-6.

Muin R., Anggraini, D., Malau F. (2017), Karakteristik Fisik dan Antimikroba Edible Film Dari Tepung Tapioka Dengan Penambahan Gliserol Dan Kunyit Putih, Jurnal Teknik Kimia, 23(3), pp. 191-198.

Otoni C. G., Avena-Bustillos RJ, Azeredo HMC, Lorevice MV, Moura MR, Mattoso LHC, Tara H, McHugh TH. (2017), Recent advances on edible films based on fruits and vegetables - a review, Compr Rev Food Sci, 16, pp. 1151-1169, DOI: 10.1111/1541-4337.12281

Puspawati N. M., Widihati I. A. G., Widana I. N. (2017), Komposisi Asam Amino dan Pola Pita Protein Gelatin Halal dari Kulit Ayam Boiler, Jurnal Kimia, 11(1), pp. 36-42.

Putri S Y. (2018), Pengaruh Konsentrasi Plasticizer Sorbitol Terhadap Sifat Fisik dan Mekanik Edible Film Berbasis Protein Sorgum Manis, Fakultas Matematika dan Ilmu Pengetahuan Alam, Departemen Fisika, Institut Pertanian Bogir, Bogor.

Radhiyatullah A., Indriani N., Ginting M. H. S. (2015), Pengaruh Berat Pati Dan Volume Plasticizer Gliserol Terhadap Karakteristik Film Bioplastik Pati Kentang, Jurnal Teknik Kimia USU, 4(3), pp. 35-39, DOI: 10.32734/jtk.v4i3.1479

Rahmawati W., Kusumastuti Y. A., Aryanti N. (2012), Karakterisasi Pati Talas (Colocasia Esculenta (L.) Schott) Sebagai Alternatif Sumber Pati Industri Di Indonesia, Jurnal 
Teknologi Kimia Dan Industri, 1(1), pp. 347-351, Available at: http://ejournals1.undip.ac.id/index.php/jtki

Resalina, Basa, Sri, Mulyadi, D., Yetri, Y. (2013), Pengaruh Penambahan Serbuk Gelatin Terhadap Sifat Mekanik dan Biodegradabilitas Plastik Campuran Polietilen Tereftalat Bekas dan Pati Sagu, Jurnal Fisika Unad, 2(1), pp. 26-32.

Rosseto M., Krein D D., Balbé Naina P., Dettmer A. (2019), Starch - gelatin film as an alternative to the use of plastics in agriculture : a review, Journal of The Science of Food and Agricultur, 99(15), pp. 671-679, DOI: 10.1002/jsfa.9944

Salimah T., Ma'ruf, W F., Romadhon. (2016). Pengaruh Transglutaminase Terhadap Mutu Edible Film Gelatin Kulit Ikan Kakap Putih (Lates calcalifer), Jurnal pengetahuan \& Bioteknologi Hasil Perikanan. 5(1), pp. 49-55.

Santosa H., H Noer, A., Guyana Nurmy L., Handono Sigit Firman D. (2018), Hidrolisa kolagen dalam ceker ayam hasil perendaman dengan asam asetat pada proses pembuatan gelatin, Jurnal Gema Teknologi, 20(1), pp. 32-36.

Satriawan MB., Iling I. (2017), Uji FTIR Bioplastik dari Limbah Ampas Sagu dengan Penambahan Variasi Konsentrasi Gelatin, Jurnal Dinamika, 8(2), pp. 1-13.

Silviana., Brandon P B., Silawanda B A., (2018), Preparation of Cassava Bagasse Starch-Based Biodegradable Film Reinforced with Chicken Feet Gelatin, Citric Acid as Crosslinker, and Glycerol as Plasticizer, Journal Chemistry Indonesia, 4(1), pp. 688-695

Sunardi Susanti Y., Mustikasari, K. (2019), Sintesis Dan Karakterisasi Bioplastik Dari Pati Ubi Nagara Dengan Kaolin Sebagai Penguat, Jurnal Riset Industri Hasil Hutan, 11(2), pp. 6576, DOI: $10.24111 /$ jrihh.v11i2.5084

Sutra L U., Hermalena, L., Salihat, R, A. (2020), Karakteristik Edible Film Dari Pati Jahe Gajah (Zingiber officinale) dengan Perbandingan Gelatin Ikan Tuna, Journal of Scientech Research and Development, 2(2), pp. 34-44.

Tongdeesoontorn W., Mauer L. J., Wongruong S., Sriburi P., Rachtanapun P. (2012), Mechanical and physical properties of cassava starch-gelatin composite films, International Journal of Polymeric Materials and Polymeric Biomaterials, 61(10), pp. 778-792, DOI: 10.1080/00914037.2011.610049

Udjiana S. S., Hadiantoro S., Syarwani, M., Suharti, P. H. (2019), Pembuatan dan Karakterisasi Plastik Biodegradable dari Umbi Talas (Xanthosoma sagittifolium) dengan Penambahan Filler Kitosan dan Kalsium Silikat, Jurnal Teknik Kimia Dan Lingkungan, 3(1), pp.10-19, DOI: $10.33795 /$ jtkl.v3i1.80

Wang W., Wang K., Xiao J., Liu Y., Zhao Y., Liu A. (2017), Performance of high amylose starchcomposited gelatin films influenced by gelatinization and concentration, International Journal of Biological Macromolecules, 94(1), pp. 258-265, DOI: 10.1016/j.ijbiomac.2016.10.014

Widiyaningsih S., Kartik D., Nurhayati Y T. (2012), Pengaruh Penambahan Sorbitol dan Kalsium karbonat Terhadap Karakteristik dan Sifat Biodegradadable Film Dari Kulit Pisang, Molekul., 7(1), pp. 69-81.

Wijayani Kartika D., Darmanto Y S., Susanto E. (2021), Karakteristik Edible Film Dari Gelatin Kulit Ikan Yang Berbeda, Jurnal Ilmu Dan Teknologi Perikanan, 3(1), pp. 59-64.

Winarti C., Miskiyah, \& Widaningrum. (2012), Teknologi produksi dan aplikasi pengemas Edible Antimikroba berbasis Pati, Jurnal Litbang Pertanian, 31(3), 85093.

Zulferiyani, Marniza, Sari erli N. (2014), Pengaruh Konsentrasi gliserol dan tapioka terhadap karakteristik biodegradable film berbasi rumput laut (Euscheuma cottoni), Jurnal Teknologi Dan Industri Hasil Pertanian, 19(3), pp. 257-270. 


\title{
Effect of the combined use of $\beta$-amylase and pullulanase on the carbohydrate composition of maltose syrups
}

\author{
Nataliia Sabadash ${ }^{1}$, Olena Hrabovska ${ }^{2}$, Igor Fesych ${ }^{1}$, \\ Alina Avramenko ${ }^{1}$, Anastasiia Serhiienko ${ }^{1}$
}

\author{
1 - National University of Food Technologies, Kyiv, Ukraine \\ 2 - Kyiv National University of Trade and Economics, Kyiv, Ukraine
}

\begin{tabular}{|c|c|}
\hline & Abstract \\
\hline Keywords: & $\begin{array}{l}\text { Introduction. The aim of this study was to investigate the effect } \\
\text { of a complex of saccharifving amylolvtic enzyme preparations of } \beta \text { - }\end{array}$ \\
\hline \multirow{7}{*}{$\begin{array}{l}\text { Maltose } \\
\text { Syrups } \\
\text { Saccharification } \\
\text { Enzyme } \\
\alpha \text {-amylase } \\
\beta \text {-amylase } \\
\text { Pullulanase }\end{array}$} & amylase and pullulanase on the carbohydrate composition of maltose \\
\hline & syrups. \\
\hline & Materials and methods. Bacterial $\alpha$-amylase, $\beta$-amylase and \\
\hline & pullulanase, corn starch, starch hydrolysates and maltose syrups were \\
\hline & used in the present research. The process of hydrolysis of starch has \\
\hline & ried out in two successive stages: liquefaction and \\
\hline & $\begin{array}{l}\text { saccharification. Physicochemical methods of analysis have been } \\
\text { used. The carbohydrate composition of the hydrolysates has been } \\
\text { determined by chromatographic method. }\end{array}$ \\
\hline & Results and discussion. The highest value of dextrose \\
\hline Article history: & $\begin{array}{l}\text { equivalent (DE) at the stage of saccharification to maltose is achieved } \\
\text { at the optimal degree of dilution of the starch suspension, which }\end{array}$ \\
\hline & corresponds to the value of dextrose equivalent of $10-15 \%$. \\
\hline Received & Hydrolysates with higher DE values have more short starch \\
\hline 21.02 .2021 & molecules, which are very slowly saccharified by $\beta$-amylase; \\
\hline $\begin{array}{l}\text { Received in } \\
\text { revised form }\end{array}$ & tetrasaccharides are even more resistant to its action, and \\
\hline 16.06 .2021 & trisaccharides are not broken down at all, because this maltogenic \\
\hline Accepted & enzyme has a high affinity for macromolecular substrates. \\
\hline 30.12 .2021 & $\begin{array}{l}\text { Hydrolysates with lower DE values have a hign viscosity, adnere to } \\
\text { the walls of the equipment and undergo retrogradation, which leads }\end{array}$ \\
\hline $\begin{array}{l}\text { Corresponding } \\
\text { author: }\end{array}$ & $\begin{array}{l}\text { The most effective way to obtain maltose syrups is to use a } \\
\text { complex of enzyme preparations (EP) of } \beta \text {-amylase and pullulanase } \\
\text { at the rate of } 0.03 \text { units of } \beta \text {-amylase activity/g of starch and } 0.0006\end{array}$ \\
\hline Nataliia Sabadash & units of pullulanase activity/g of starch, respectively. It has been \\
\hline E-mi & determined that with a duration of saccharification of 24 hours, the \\
\hline & $\begin{array}{l}\text { content of maltose in the hydrolysates reaches } 60-62 \% \text { by weight of } \\
\text { reducing substances (RS) with a low glucose content (about } 2.7 \% \text { by }\end{array}$ \\
\hline DOI: & $\begin{array}{l}\text { Conclusions. Kinetic regularities have been established to } \\
\text { determine the optimal conditions for the process of liquefaction and }\end{array}$ \\
\hline $10.24263 / 2304-$ & saccharification using a complex of saccharifying enzyme \\
\hline $\begin{array}{l}974 X-2021-10-4- \\
10\end{array}$ & $\begin{array}{l}\text { preparations of } \beta \text {-amylase and pullulanase for the production of } \\
\text { syrups with high concentration of maltose. }\end{array}$ \\
\hline
\end{tabular}




\section{Introduction}

The trend in the application of enzymes in the food industry is a relevant modern area of research. Microbial enzymes have long been used in food production, but every year they find new areas of application (Ivanov et al., 2021). Enzymatic conversion of starch to obtain syrups with a high content of maltose (more than $50 \%$ by weight of reducing sugars) are widely used for the production of ice cream, marmalade, jams, juices, beverages, beer, as well as to replace sugar in the production of lollipop caramel. High resistance to spontaneous crystallization, lower viscosity and hygroscopicity compared to glucose syrups (dextrose equivalent $38-42 \%$ ) characterizes these syrups. In addition, they contain a large amount of fermentable saccharides (Baks et al., 2008; Souza et al., 2019).

In the production of maltose syrups, it is important to transfer starch grains in suspension to a soluble state by temperature gelatinization in the presence of a catalyst. Gelatinized starch responds to the action of amylolytic enzymes much faster than the native one (Porras et al., 2018; Souza et al., 2019). To achieve minimum starch losses and obtain a syrup with good filtration properties, it is necessary to fully gelatinize all starch grains, including small ones. The gelatinization temperature of small starch grains is $120-140{ }^{\circ} \mathrm{C}$ (Souza et al., 2019). The process of enzymatic conversion of starch is carried out in two stages: liquefaction and saccharification. In the process of gelatinization, the viscosity increases significantly, which makes it difficult to carry out the liquefaction process. It is also necessary to prepare the substrate for saccharification. The maltogenic enzyme $\beta$-amylase, like other saccharifying enzymes, cannot effectively catalyze the hydrolysis of gelatinized starch due to its high viscosity. $\beta$-amylase is capable of cleaving the maltose molecule only from the non-reducing edge formed at the site of the $\alpha$-1,4-glucoside bond rupture (Porras et al., 2018; Souza et al., 2019). Therefore, in order to reduce the viscosity and avoid the phenomenon of retrogradation, it is necessary that the gelatinization of starch will be accompanied by its liquefaction. In the obtained low viscosity hydrolyzate it is easier to further break the starch molecule for final products of saccharification.

The degree of liquefaction of starch has a significant effect on the quality of maltose hydrolysates after saccharification. It is known (Lin et al., 2013; Radovanovic et al., 2018; Saini et al., 2017) that short starch molecules are attacked by the enzyme $\beta$-amylase very slowly, tetrasaccharides are even more resistant to its action, and trisaccharides are not broken down at all because this maltogenic enzyme shows a high affinity for high molecular weight substrates. Therefore, for maltose syrups to be obtained, in the saccharification stage it is desirable to use hydrolyzed starch with the lowest dextrose equivalent after liquefaction and a minimum amount of glucose. However, such a hydrolysate has a high viscosity (more than $2 \mathrm{~Pa} \cdot \mathrm{s}$ ) and adheres to the walls of equipment and pipelines (Gebremariam et al., 2013). Therefore, it is necessary to establish the optimal value of DE hydrolysates after enzymatic liquefaction for effective saccharification of starch hydrolysates to maltose.

It has been shown (Porras et al., 2018) that optimal parameters for the liquefaction process are: the concentration of the corn starch suspension - 30\%; using of thermostable bacterial enzyme preparation of $\alpha$-amylase Alphasin T7L -4 units of amylolytic activity per gram of dry matter of starch. The degree of liquefaction of the starch suspension should correspond to the DE value of 18-20\%. However, these studies focused on the effect of the degree of starch liquefaction on the subsequent saccharification of hydrolysates to glucose, where glucoamylase was used as a saccharifying enzyme (Trisnaputri et al., 2018; Yadav et al., 2017). To obtain syrups with a high maltose content at the saccharification stage, we used maltogenic enzyme preparations. In order to clarify the results of previous studies, it was necessary to establish the effect of the degree of starch liquefaction on the kinetics of further 
saccharification of hydrolysates to maltose. As it is known (Baks et al., 2008), for the production of maltose syrups with an amount of maltose of about $50 \%$, a preparation of the maltogenic enzyme $\beta$-amylase is used as a biocatalyst for the hydrolysis reaction. The subsequent accumulation of maltose is prevented by $\beta$-limit dextrins, which are formed in an amount of about $23 \%$ under the action of $\beta$-amylase on rarefied starch (Baks et al., 2008; Lin et al., 2013). To make the substrate more accessible for the action of $\beta$-amylase, it is necessary to use an enzyme that breaks the branches in the amylopectin chains that are not affected by the enzyme preparation of $\beta$-amylase (EP 0294093 A2).

A promising direction for expanding the range of maltose syrups is the search for new enzyme preparations and their combinations to increase the accumulation of maltose in hydrolysates. One of these enzyme is a pullulanase preparation (amylo-1,6-glucosidase), which hydrolyzes $\alpha-1,6$-glucosidic bonds at the branch points of the starch molecule. The ability to break $\alpha-1,6$-bonds is significantly increased if they are surrounded on all sides by $\alpha$-1,4-bonds. As a result of its action, linear dextrins are formed with non-reducing residues of molecules that can be hydrolyzed by the enzyme preparation of $\beta$-amylase. The use of pullulanase in the composition with $\beta$-amylase will change the carbohydrate composition of the hydrolysates in the direction of the accumulation of maltose (Gangadharan et al., 2009; Rittenauer et al., 2021; Souza et al., 2019).

The aim of the work was to determine the effect of a complex of saccharifying amylolytic enzyme preparations of $\beta$-amylase and pullulanase on the carbohydrate composition of maltose syrups.

\section{Materials and methods}

\section{Materials}

For the purposes of our research, corn starch and maltose hydrolysates of various degrees of saccharification were used.

\section{Chemical reagents and enzymes}

Hydrochloric acid (1 N concentration).

Amylolytic enzyme preparations: (1) Thermostable bacterial $\alpha$-amylase Alphasin T7L from Genencor International B.V. (A Danisco Division), activity - 1240 units of $\alpha$-amylase activity/g of enzyme preparation (units $\mathrm{AA} / \mathrm{g}$ of $\mathrm{EP}$ ), $\mathrm{pH} 5.5-7.0$, optimal $\mathrm{pH}$ 5.8, temperature $60-110^{\circ} \mathrm{C}$, optimal temperature $108{ }^{\circ} \mathrm{C}$ (retains activity for 1 hour at a temperature of $105-108^{\circ} \mathrm{C}$ ); (2) $\beta$-amylase Optimalt BBA from Genencor International B.V. (A Danisco Division), activity - 69 units of $\beta$-amylase (saccharifying) activity/g of enzyme preparation (units $\mathrm{SA} / \mathrm{g}$ of $\mathrm{EP}$ ), $\mathrm{pH} 4.8-6.0$, optimum $\mathrm{pH} 5.2-5.5$, temperature $55-60^{\circ} \mathrm{C}$, optimum temperature $57{ }^{\circ} \mathrm{C}$ (retains activity for 6 hours at a temperature of $60-63{ }^{\circ} \mathrm{C}$; inactivated in 15 minutes at a temperature of $75^{\circ} \mathrm{C}$ ); (3) Pullulanase Gamylozym KPU-L Gammazym (Germany), activity - 0.8 units of pullulanase activity/g of enzyme preparation (units PA/g of EP), $\mathrm{pH} 4.3-7.5$, optimal $\mathrm{pH} 5.0-6.3$, temperature $45-68{ }^{\circ} \mathrm{C}$, optimum temperature $55^{\circ} \mathrm{C}$ (inactivated in 10 minutes at a temperature of $95^{\circ} \mathrm{C}$ ). 


\section{Research methods}

The dry substances (DS) content, \% by weight, in the hydrolysates and the finished product was determined refractometrically, while in the raw material it was determined by drying to constant weight (Nielsen, 2010).

The $\mathrm{pH}$ was determined potentiometrically (Manso et al., 2017).

Liquefaction of the starch suspension was performed under the influence of an ultrahigh frequency electromagnetic field or in a special thermostat under a slight excess pressure at a temperature of $110^{\circ} \mathrm{C}$ (Nawaz et al., 2020) [JPH06102032B2].

The total content of reducing substances (\% by weight of DS) - dextrose equivalent (DE) - was determined by the iodometric method of Wilshtetter and Schudl (Nielsen, 2010).

\section{Activity of enzyme preparations}

Amylolytic activity of bacterial $\boldsymbol{\alpha}$-amylase. Determination of amylolytic activity of bacterial $\alpha$-amylase was performed by colorimetric method. The method is based on the hydrolysis of starch by enzymes of the amylolytic complex to dextrins of different molecular weight (Iskakova et al., 2017).

Amylolytic activity of $\alpha$-amylase (AA) characterizes the ability of amylolytic enzymes to catalyze the hydrolysis of starch to dextrins of different molecular weight and is expressed by the number of unit's activity of these enzymes in $1 \mathrm{~g}$ of the enzyme preparation.

One unit of amylolytic activity is the ability of the enzyme at certain values of temperature, $\mathrm{pH}$ and time of action to catalyze the hydrolysis of $1 \mathrm{~g}$ of starch to dextrins of different molecular weight.

Amylolytic activity of thermostable EP was determined at a temperature of $50{ }^{\circ} \mathrm{C}$. Hydrolysis of starch under these conditions occurred at $25-30 \%$.

Saccharification activity of $\boldsymbol{\beta}$-amylase. Determination of the saccharification activity of $\beta$-amylase (SA) was performed by the polarimetric method. The polarimetric method is based on determining the rate of the enzymatic reaction of starch hydrolysis, which is set by decreasing the angle of rotation of the polarization plane. This reduction is due to the formation of low molecular weight carbohydrates due to the action of enzymes on starch (Manisha et al., 2016).

One unit of saccharification activity is defined as the amount of enzyme which in strictly defined conditions ( $\mathrm{pH} 4.7-4.9$, temperature $50{ }^{\circ} \mathrm{C}$, reaction time $30 \mathrm{~min}$ ) catalyzes the hydrolysis of $1 \mathrm{~g}$ of starch (which is $25-30 \%$ ) to low molecular weight carbohydrates.

To determine the saccharification activity, $1 \%$ of the starch solution is hydrolyzed and the polarization of the reaction mixture before and after the action of the enzyme is determined, thus establishing a decrease in the angle of rotation of the substrate polarization plane $(\Delta \mathrm{P})$ under the action of enzymes.

Pullulanase activity. Pullulanase activity (PA) is determined by the amount of reducing carbohydrates formed from the substrate (phosphodestrin) during the enzymatic reaction. The amount of reducing substances is determined by iodometric method (Meile et al., 2018). The number of units of activity of the enzyme taken for analysis is calculated according to the number of reducing carbohydrates that have been formed.

One unit of pullulanase activity is the amount of enzyme which in defined conditions (temperature $30{ }^{\circ} \mathrm{C}, \mathrm{pH} 4.7-4.9$, reaction time $60 \mathrm{~min}$ ) catalyzes $30 \%$ hydrolysis of $\alpha-1,6-$ glucoside bonds in $1 \mathrm{~g}$ of phosphodiesters to reducing carbohydrates. 
Carbohydrate composition of hydrolysates. The carbohydrate composition of the hydrolysates was determined by chromatographic analysis on a liquid chromatograph «Agilent 1100» (manufacturer - Agilent, USA). Concentration of working solutions was 3$5 \%$ DS; water served as eluent; eluent flow rate was $0.5 \mathrm{ml} / \mathrm{min}$. Analytical columns were SupelCogel Ca (manufacturer - SupelCo, USA) and HPH 87C (manufacturer - Bio-Rad) size $300 \times 7.8 \mathrm{~mm}$ for the separation of carbohydrates and alcohols. Adsorbent analytical column (filler, gel filtration resin) was styrene-divinylbenzene polymer in grafted calcium form with a particle diameter of $5 \mu \mathrm{m}$.

Sample injection was performed using a syringe and injector with a dosing loop of 10 $\mu 1$. The column was thermostated in a thermostat maintaining a column temperature of $80{ }^{\circ} \mathrm{C}$ $\left( \pm 0.1^{\circ} \mathrm{C}\right)$. To protect the column, a safety cartridge was used, which, in addition to cleaning the sample from impurities, also provides its demineralization from salts (primarily from sodium chloride).

\section{Experiment 1. Determination of the optimal degree of starch suspension liquefaction with bacterial $\alpha$-amylase for further saccharification of hydrolysates to maltose}

To carry out the liquefaction in one-step, we used a thermostable enzyme preparation of bacterial $\alpha$-amylase as a biocatalyst, which does not lose activity at high temperatures required for gelatinization of small starch grains (Gebremariam et al., 2013; Lin et al., 2013). This will significantly increase the rate of starch liquefaction. From a wide range of enzyme preparations of $\alpha$-amylase of bacterial origin, Alphasin T7L was selected, which is a thermostable enzyme preparation with the highest optimal temperature $108^{\circ} \mathrm{C}$, and the $\mathrm{pH}$ of 5.5-7.0.

The method of single-stage hydrolysis, which allows obtaining a hydrolyzate with residues of starch molecules of average size and has a number of advantages, was used. The use of thermostable enzyme preparation allows one not to lower the temperature below 95 ${ }^{\circ} \mathrm{C}$, which prevents retrogradation. This method of liquefaction also enables one to reduce the dosage of the enzyme preparation.

During the study, a suspension of corn starch with a mass fraction of 30\% DS was prepared. For enzymatic liquefaction, the enzyme preparation of thermostable bacterial $\alpha$ amylase Alphasin T7L was used, which was added in the recommended amount of 4 units AA/g DS of corn starch (Lin et al., 2013). To detect the maximum activity of the enzyme preparation, the optimal $\mathrm{pH}$ value is 5.8 , which was achieved by adding $1 \mathrm{~N} \mathrm{HCl}$ solution to the substrate. Thinning of the suspension was carried out in one stage under a slight excess pressure in a special thermostat at a temperature of $110^{\circ} \mathrm{C}$ to different values of DE 10,15 , $20,25 \%$.

For saccharification, the mixture of $\beta$-amylase and pullulanase enzyme preparations was added to the obtained liquefied suspension in the amount of 0.12 units of saccharifying activity per gram of dry matter of starch (units SA/g) and 0.003 units of pullulanase activity per gram of dry matter of starch (units PA/g). Saccharifying lasted for 48 hours, during which samples were taken and the dextrose equivalent (DE) was determined.

\section{Experiment 2. Study of saccharification kinetics depending on the dosage of saccharifying enzyme preparations of $\beta$-amylase and pullulanase}

During the study, a suspension of corn starch with a dry substance content of $30 \%$ was prepared. The enzymatic liquefaction was performed as described in experiment 1 . 
The liquefaction time was 13 minutes before reaching the value of DE hydrolyzate in the range of $10-15 \%$, which, according to experiment 1 , was determined as optimal for further saccharification.

After liquefaction, the hydrolyzate was cooled to a temperature of $57{ }^{\circ} \mathrm{C}$ and the $\mathrm{pH}$ was adjusted to $5.2-5.5$ by adding a solution of $1 \mathrm{~N} \mathrm{HCl}$. These parameters are optimal for the action of the enzyme preparation $\beta$-amylase Optimalt BBA and are within the optimum for pullulanase Gamylozym KPU-L (optimum effect at $\mathrm{pH}$ is 5.0-7.5 and temperature 45-68 ${ }^{\circ} \mathrm{C}$ ), which also does not contradict the optimal parameters of $\beta$-amylase. Therefore, this enzyme preparation of pullulanase was chosen.

The saccharification process was performed by simultaneously adding to the substrate enzyme preparations of $\beta$-amylase and pullulanase in different amounts. Dosing of $\beta$-amylase was performed in all samples at the rate of 0.03 units of saccharifying activity per $g$ of dry substances (units SA/g DS) of starch (Sabadash et al., 2015). Pullulanase was dosed in amounts of $0.00005 ; 0.0002 ; 0.0004 ; 0.0006 ; 0.0008 ; 0.005 ; 0.01 ; 0.02 ; 0.03$ units of pullulanase activity per g of dry substances (units PA/g DS) of starch (Figs. 3, 4). Pullulanase was not added to the control sample. Enzymatic saccharification of hydrolysates was performed for $48 \mathrm{~h}$ in an EL-20R thermostat at a temperature of $57{ }^{\circ} \mathrm{C}$ with constant stirring. Samples of hydrolysates taken in the saccharification process at 1, 4, 8, 12, 16, 20, 24 and 48 hours were kept in a boiling water bath for 15 minutes to inactivate the enzyme. In chilled samples, the DE index was determined by the iodometric method of Wilshtetter and Schudl.

\section{Results and discussion}

Experiment 1. Influence of the degree of liquefaction of starch on the kinetics of subsequent saccharification of hydrolysates by enzymatic preparations of $\beta$-amylase and pullulanase

The kinetics of starch saccharification to maltose by a complex of $\beta$-amylase and pullulanase enzyme preparations was studied. The effect of DE after liquefaction on the saccharification of hydrolysates to maltose was determined. The duration of the experiment was 48 hours before reaching the maximum content of maltose in the hydrolyzate. The graphs of the kinetics of the saccharification process for the first twelve hours of the experiment for different values of DE, which were achieved during liquefaction, are presented in Figure 1. Figure 2 shows the effect of the degree of liquefaction on the glucose equivalent after 24 and 48 hours of saccharification. 


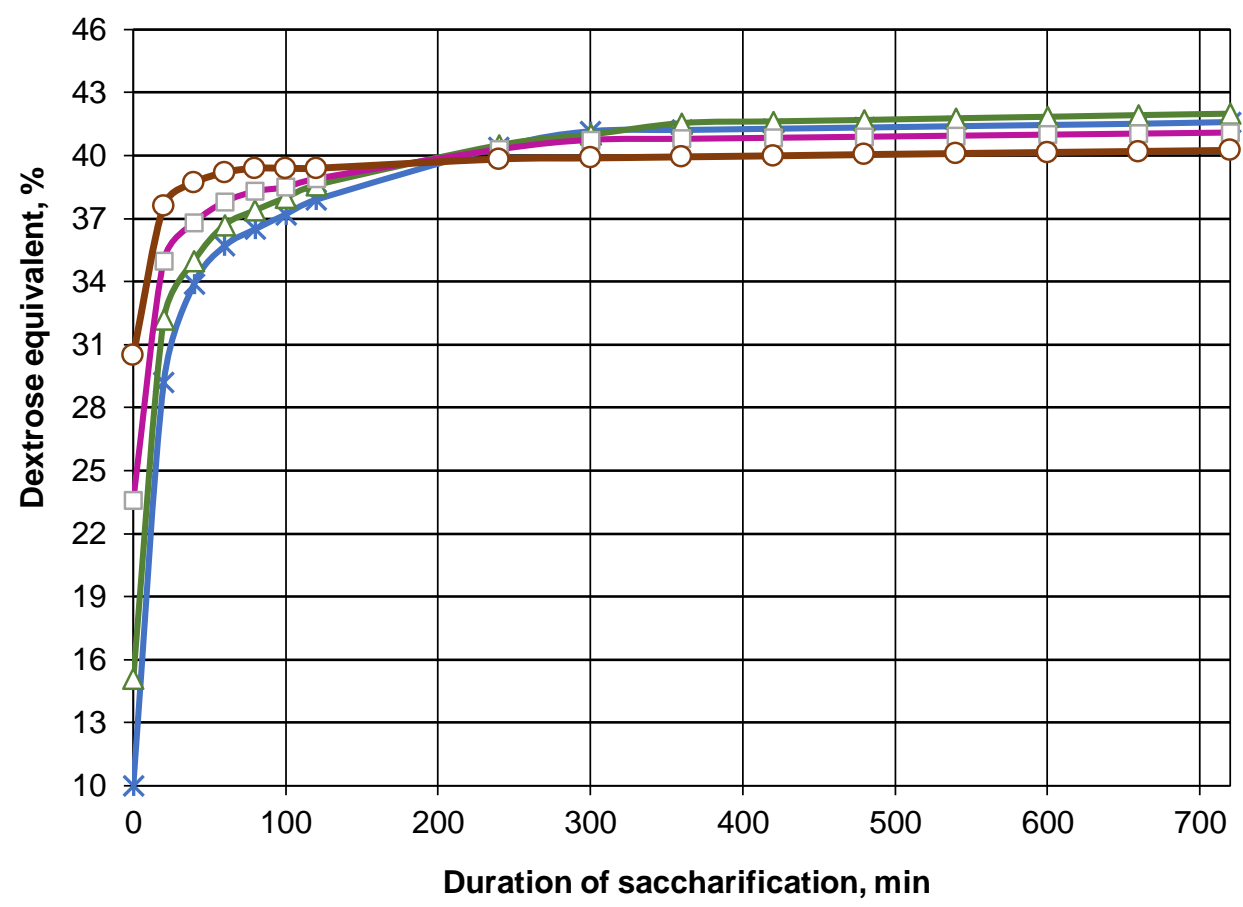

$\because$ DE $10 \% \rightarrow$ DE $15 \% \quad \square-D E 20 \% \quad \longrightarrow$ DE $25 \%$

Figure 1. Kinetics of the process of enzymatic saccharification of liquefied starch hydrolysates at different DE values after liquefaction: $10 ; 15 ; 20 ; 25 \%$

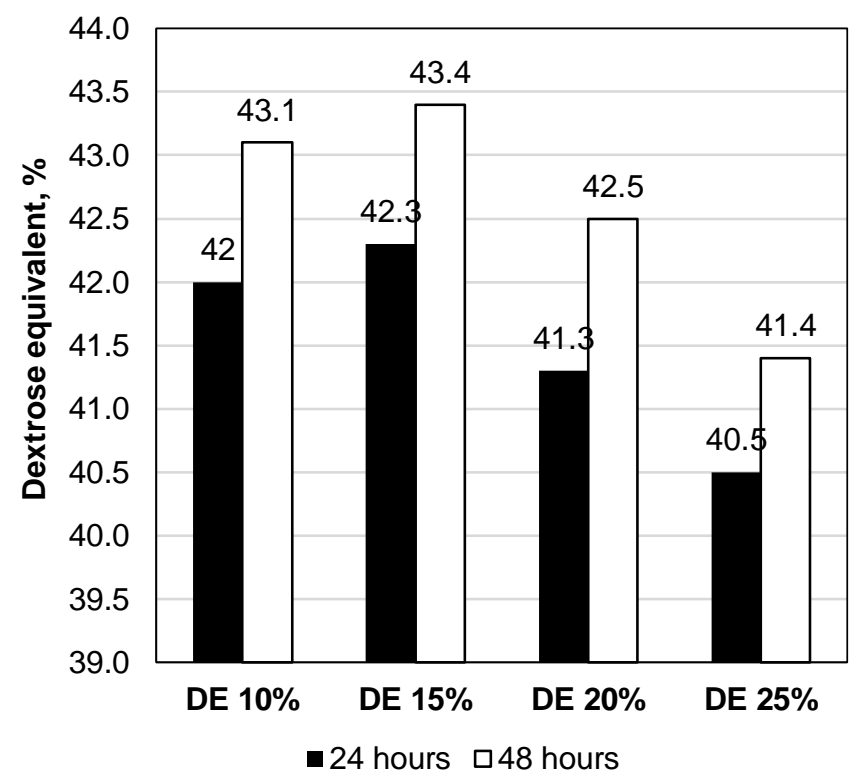

Figure 2. Effect of the degree of liquefaction on glucose equivalent after saccharification after 24 and 48 hours 
At the beginning of the saccharification process, the increase in DE for all four samples occurs at different speeds, but after 3-4 hours from the beginning of the process the values of DE almost coincide (Figure 1). Continuation of the saccharification process leads to a gradual increase in the DE in the hydrolysates that had lower DE values after liquefaction (DE $10 ; 15 \%)$. That is, with a decrease in the degree of polymerization of hydrolyzate molecules after liquefaction (DE 20;25\%) there is a decrease in the rate of their cleavage during saccharification to maltose, because $\beta$-amylase has an affinity for high molecular weight substrate. In addition, the ability of pullulanase to cleave $\alpha-1,6$-bonds is significantly increased if they are surrounded on all sides by $\alpha-1,4$-bonds, which is possible with a low degree of liquefaction (DE 10; 15\%). Low DE after liquefaction (DE 10;15\%) enables the formation of linear dextrins that are hydrolyzed by the maltogenic enzyme preparation of $\beta$ amylase (Souza et al., 2019; Gangadharan et al., 2009; Rittenauer et al., 2021), which allows to obtain hydrolysates with higher DE after saccharification (Figure 2).

However, samples with low DE values after liquefaction (10\%) have a high viscosity of the suspension (Baks et al., 2008), which impairs its contact with the enzyme (Rittenauer et al., 2021) and complicates the saccharification process (Rittenauer et al., 2021). Also, the saccharification of high-molecular substrate (GE 10\%) is complicated by its tendency to retrogradation (Souza et al., 2019).

For saccharification in the production of maltose syrups, it is desirable to use a liquefied hydrolyzate containing cleavage products of medium size. The degree of pre-dilution of starch has a significant effect on the liquefaction of hydrolysates to maltose, even minor changes in carbohydrate composition after liquefaction could slow down the saccharification process. Due to the presence of unwanted by-substances in the hydrolyzate, the quality of final maltose syrups deteriorates, their yield and maltose content decrease, as it is impossible to achieve sufficient complete saccharification of starch (Baks et al., 2008; Rittenauer et al., 2021). Therefore, the enzymatic liquefaction of the suspension should be carried out to the value of GE hydrolyzate $15 \%$ (Figure 2), which is optimal for further saccharification to maltose. The viscosity of such hydrolysates is significantly reduced (Souza et al., 2019), and the degree of polymerization of polysaccharide molecules remains high (Rittenauer et al., 2021).

\section{Experiment 2. Study of the saccharification process depending on the dosage of enzyme preparations of $\beta$-amylase and pullulanase}

According to experimental data, kinetic curves of the process of saccharification of liquefied starch with a complex of enzyme preparations of $\beta$-amylase and pullulanase depending on their dosage were constructed (Figure 3). Pullulanase was not added to the control sample. The research results are presented in Figures 3 and 4. The carbohydrate composition, in particular the maltose content in the obtained hydrolysates, was determined by the method of chromatographic analysis on a liquid chromatograph «Agilent 1100» (Figure 5). 


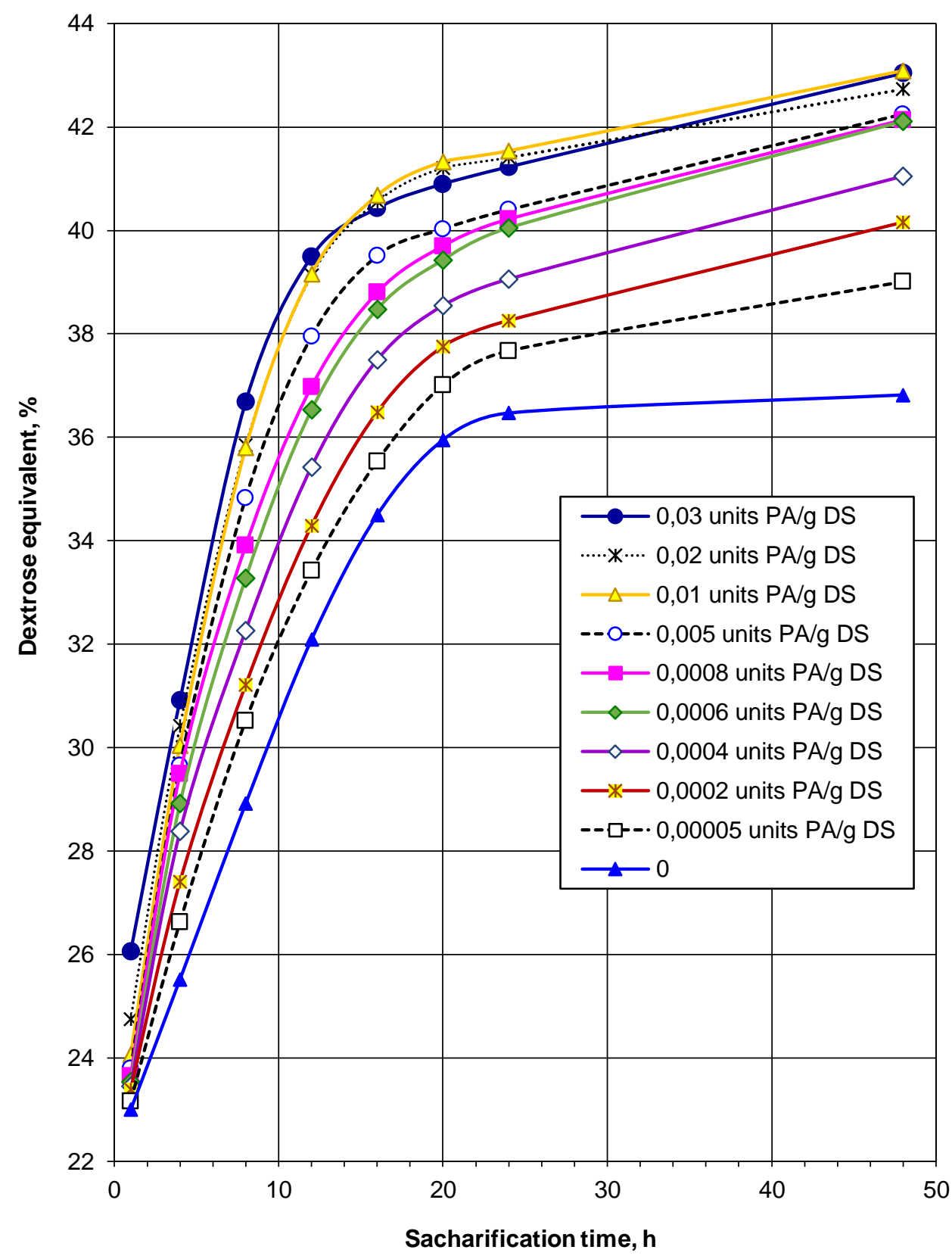

Figure 3. Kinetics of enzymatic saccharification of liquefied starch under the conditions of using a complex of enzymatic preparations of $\beta$-amylase (in the amount of 0.03 units SA/g DS of starch) and different amounts of pullulanase 


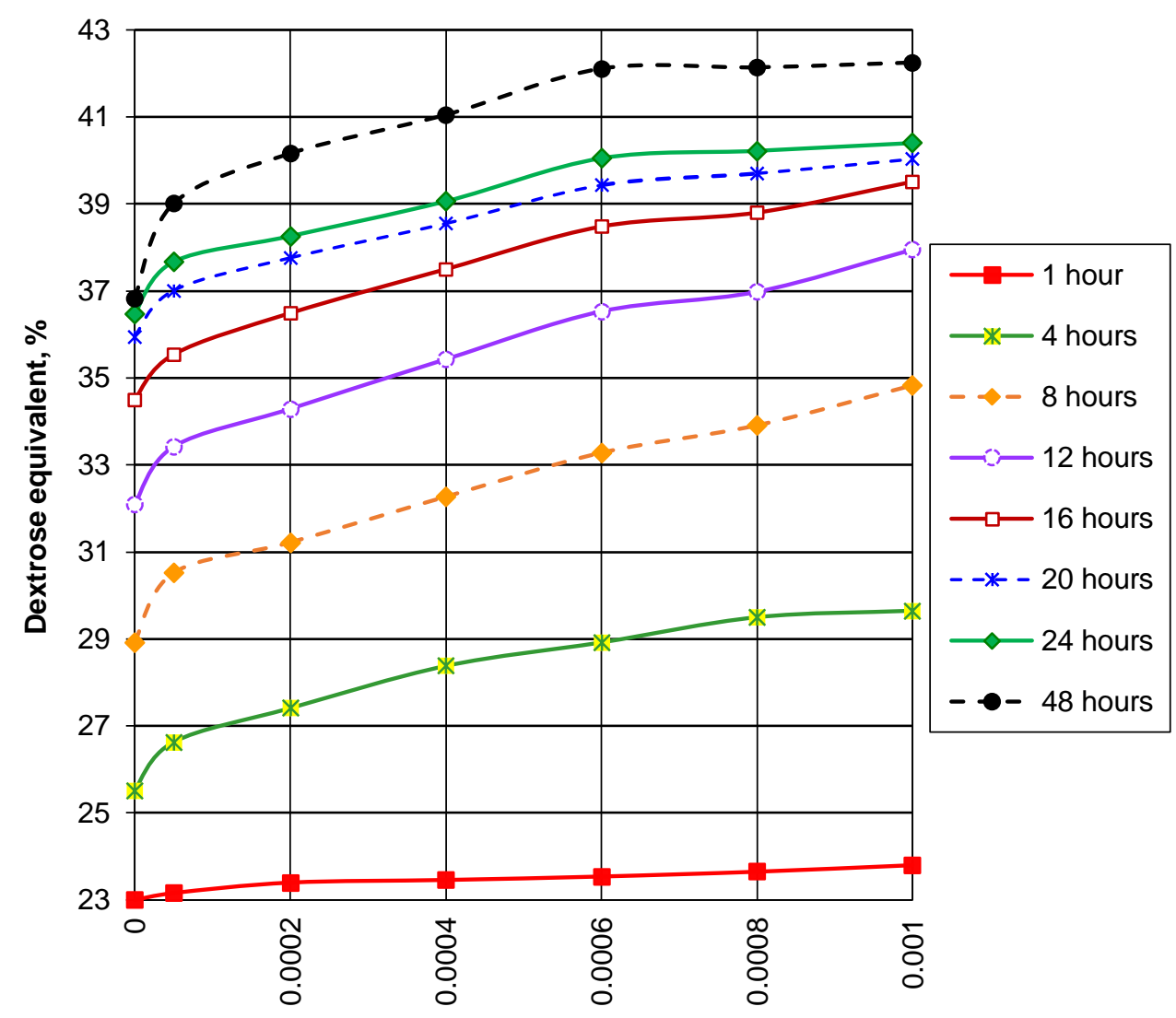

Amount of pullulanase, units PA/g DS of starch

Figure 4. Dependence of the glucose equivalent of maltose syrup on the amount of enzyme preparation of pullulanase, the amount of added $\beta$-amylase 0.03 units SA/g DS of starch

The data obtained (Figures 3,4) show that the use of a complex of enzyme preparations of $\beta$-amylase and pullulanase improves the saccharification process, compared with the use of $\beta$-amylase only (control sample), and leads to increased maltose content in hydrolysates. This is due to the hydrolysis of dextrins to maltose (Table 1) (Lin et al., 2013). Depending on the consumption of pullulanase, DE increases by $1-5 \%$ in 24 hours of saccharification (Figure 4). During the second day, there is an increase in DE by another 1.3-2\%, which does not happen in the control sample (Figure 4). It is most effective to use a complex of enzyme preparations of $\beta$-amylase and pullulanase at the rate of $0.03 \mathrm{SA} / \mathrm{g}$ and $0.0006 \mathrm{PA} / \mathrm{g} \mathrm{DS}$ of starch, respectively. At the same time, after 24 hours of saccharification a DE value of $40 \%$ can be achieved. It is optimal to carry out the saccharification process for 24 hours.

Table 1 shows the results of chromatographic studies of starch hydrolyzate obtained at the optimal dosage of $\beta$-amylase (control sample) and at the optimal dosage of the complex of enzyme preparations of $\beta$-amylase and pullulanase after 24 hours of saccharification. 
Table 1

Results of chromatographic studies of starch hydrolysate obtained after 24 hours of saccharification

\begin{tabular}{|l|c|c|}
\hline $\begin{array}{l}\text { Carbohydrate } \\
\text { composition of } \\
\text { hydrolysates }\end{array}$ & $\begin{array}{c}\text { Saccharification with } \\
\boldsymbol{\beta} \text {-amylase (at the } \\
\text { rate of 0.03 units } \\
\text { SA/g DS of starch) } \\
\text { (control sample), } \\
\text { \% by weight of RS }\end{array}$ & $\begin{array}{c}\text { Saccharification with a complex of } \\
\text { enzymatic preparations of } \boldsymbol{\beta} \text {-amylase } \\
\text { (at the rate of } \mathbf{0 . 0 3} \text { units SA/g DS of } \\
\text { starch) and pullulanase (at the rate of } \\
\mathbf{0 . 0 0 0 6} \text { units PA/g DS of starch) } \\
\mathbf{\%} \text { by weight of RS }\end{array}$ \\
\hline Glucose & 2.5 & 2.7 \\
\hline Maltose & 50.8 & 58.6 \\
\hline Trisaccharides & 23.5 & 29.4 \\
\hline Tetrasaccharides & 1.8 & 1.5 \\
\hline DP5 and more & 21.4 & 7.8 \\
\hline
\end{tabular}

According to the results of chromatographic analysis, the carbohydrate composition of maltose syrups was calculated, which is presented in the diagram (Figure 5).

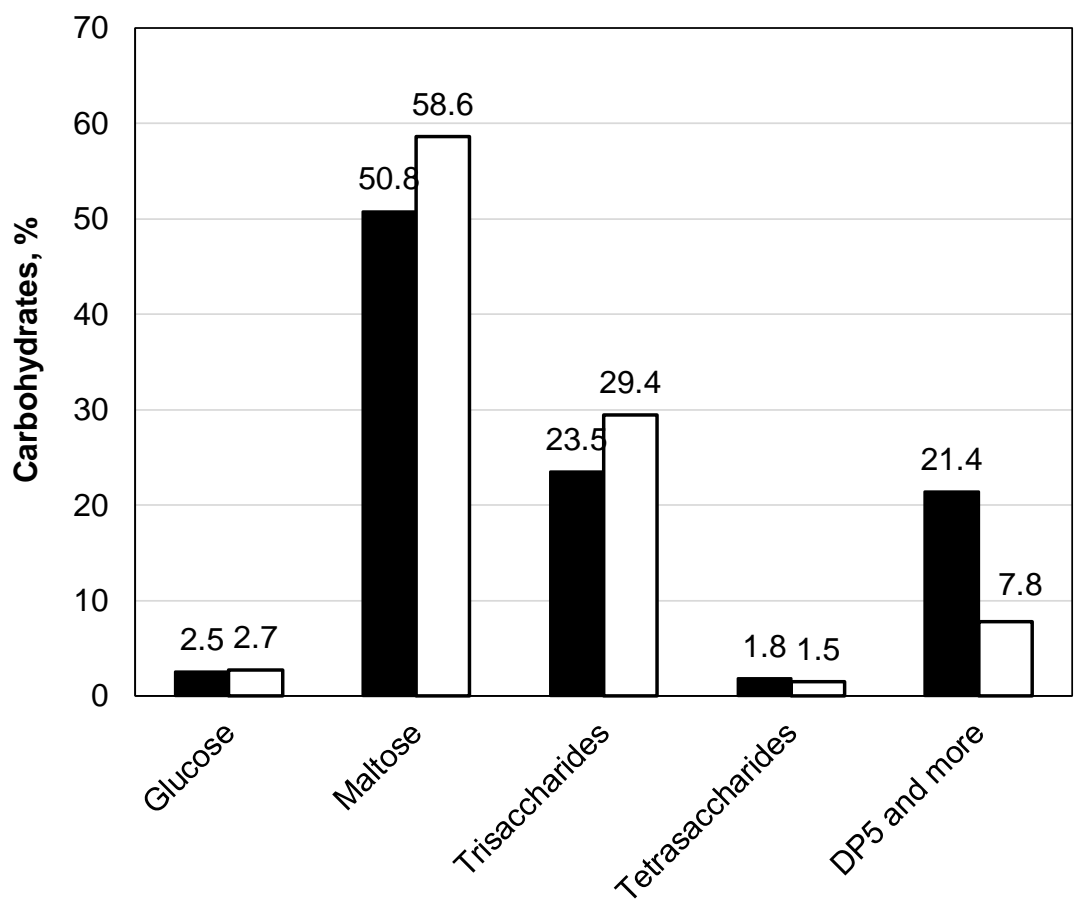

- $\beta$-amylase $\quad \square \beta$-amylase + pullulanase

Figure 5. Carbohydrate composition of maltose syrups obtained under optimal conditions and amounts of added saccharifying enzyme preparations:

$\beta$-amylase (control sample) and a complex of $\beta$-amylase and pullulanase

- Ukrainian Food Journal. 2021. Volume 10. Issue 4- 
These data make it possible to compare the carbohydrate composition of maltose syrups obtained using different saccharifying enzyme preparations: $\beta$-amylase (control sample) and mixture of $\beta$-amylase and pullulanase.

The results of chromatographic analysis allow to compare the carbohydrate composition of maltose hydrolysates obtained at the optimal dosage of the complex of enzyme preparations of $\beta$-amylase and pullulanase, with the control sample, in which saccharification occurred only with maltogenic enzyme preparation of $\beta$-amylase (Table 1). Figure 5 shows that the composition of starch hydrolysates after saccharification differs significantly depending on the combinations of saccharifying enzyme preparations. The introduction of pullulanase makes it possible to obtain syrups with a higher content of maltose $(58.6 \%$, compared with $50.8 \%$ in the absence of pullulanase). The accumulation of maltose occurs due to the rupture of $\alpha-1,6$ glucoside bonds in amylopectin chains, which are not affected by the enzyme preparation of $\beta$-amylase (EP 0294093 A2). The hydrolysates obtained using pullulanase have a lower content of $\beta$-limiting dextrins (7.8\%, compared with $21.4 \%$ in the absence of pullulanase). These dextrins are a source of additional maltose accumulation, as the substrate becomes available for $\beta$-amylase action in the absence of branching (Baks et al., 2008; Lin et al., 2013).

Based on the research results, the optimal parameters of the saccharification process of liquefied starch with a complex of enzyme preparations of $\beta$-amylase and pullulanase were determined. Using a complex of enzyme preparations it is possible to obtain maltose syrups with a maltose content of 60-62\% and a DE value of 40-42\% (Figure 3 and Table 1).

\section{Conclusion}

The kinetics of the process of enzymatic saccharification of starch hydrolysates depending on the obtained values of dextrose equivalent after liquefaction has been studied. It has been established that the highest value of dextrose equivalent in the process of saccharification to maltose is achieved at the optimal degree of liquefaction of the starch suspension, which corresponds to the value of glucose equivalent of $10-15 \%$.

The kinetics of the process of enzymatic saccharification of liquefied starch by a complex of enzymatic preparations of $\beta$-amylase and pullulanase has been examined. It has been found out that these enzyme preparations are best used in quantities of 0.03 units $\mathrm{SA} / \mathrm{g}$ DS and 0.0006 units PA/g DS of starch, respectively. It has been determined that with the 24 hours' duration of saccharification the content of maltose in the hydrolysates reaches 60 $62 \%$ by weight of RS, with the content of glucose being insignificant (about $2.7 \%$ by weight of RS). Low glucose is a key indicator of the quality of syrups in the production of caramel and many other foods.

\section{References}

Ahmad R.A., Rizwana N., Manas N.H.A., Azelee N.I.W. (2019), Bioconversion of starch to maltooligosaccharides (MOS) by the reaction of maltogenic amylase, Jurnal Teknologi, 82(1), pp. 99-101.

Baks T., Kappen F.H.J., Janssena A.E.M., Booma R.M. (2008), Towards an optimal process for gelatinisation and hydrolysis of highly concentrated starch-water mixtures with alpha-amylase from B. licheniformis, Journal of Cereal Science, 47(2), pp. 214-225. 
Gangadharan D., Nampoothiri K.M., Sivaramakrishnan S., Pandey A. (2009), Immobilized bacterial $\alpha$-amylase for effective hydrolysis of raw and soluble starch, Food Research International, 42(4), pp. 436-442, DOI: 10.1016/j. foodres.2009.02.008.

Gebremariam, M.M., Zarnkow, M., Becker, T. (2013), Effect of drying temperature and time on alpha-amylase, beta-amylase, limit dextrinase activities and dimethyl sulphide level of teff (Eragrostis tef) malt, Food Bioprocess Technology, 6, pp. 3462-3472.

Iskakova J., Smanalieva J., Kulmyrzaev A., Fischer P., Methner F.J. (2017), Comparison of rheological and colorimetric measurements to determine $\alpha$-amylase activity for malt used for the beverage Bozo, International Journal of Food Properties, 20(9), pp. 2060 2070.

Ivanov A V., Shevchenko O., Marynin A., Stabnikov V., Gubenia O., Stabnikova O., Shevchenko., Gavva O., Saliuk A. Trends and expected benefits of the breaking edge food technologies in 2021-2030. Ukrainian Food Journal, 2021, 10(1), 7-36.

Lin Q., Xiao H., Liu G.Q., Liu Z., Li L., Yu F. (2013), Production of maltose syrup by enzymatic conversion of rice starch, Food and Bioprocess Technology, 6, pp. 242-248.

Manisha N.C., Dipali K.S., Rohini B.K., Tajeswini S.M., Pooja P.S., Kirti B.J., Rajeshwari V.R. (2016), Extraction and partial purification and kinetic study of beta amylase from sweet potato, Journal of Global Biosciences, 5(4), pp. 3892-3901.

Manso S., Aguado A. (2017), A review of sample preparation and its influence on $\mathrm{pH}$ determination in concrete samples, Materiales de Construcción, 67(325), pp. 1-9.

Meile K., Zhurinsh A., Briede L., Viksna A. (2018), Investigation of the sugar content in wood hydrolysates with iodometric titration and UPLC-ELSD, Agronomy Research, 16(1), pp. 167-175.

Nawaz H., Waheed R., Nawaz M., Shahwar D. (2020), Physical and chemical modifications in starch structure and reactivity, DOI:10.5772/intechopen.88870.

Nielsen S.S. (2010), Food Analysis, Food Science Texts Series, DOI 10.1007/978-1-44191478-1-6.

Porras M.A., Ramos F.D., Diaz M.S., Cubitto M.A., Villar M.A. (2018), Modeling the bioconversion of starch to $\mathrm{P}(\mathrm{HB}-\mathrm{co}-\mathrm{HV})$ optimized by experimental design using Bacillus megaterium BBST4 strain, Environmental Technology, 40(9), pp. 1185-1202, DOI: 10.1080/09593330.2017.1418436.

Radovanovic N., Davidivic S., Miljkovic M., Pavlovic M., Buntic P., Lazic V., Mihajlovski K. (2018), $\beta$-amylase production by a novel strain Paenibacillus chitinolyticus CKS1 using commercial and waste substrates, Journal on Processing and Energy in Agriculture, 22(1), pp. 18-22.

Rittenauer M., Gladis S., Gastl M., Becker T. (2021), Gelatinization or pasting? The impact of different temperature, Foods, 10, pp. 1-15.

Sabadash N.I., Hrabovska O.V. (2015), Doslidzhennia protsesu ztsukriuvannia rozridzhenoho krokhmaliu fermentnym preparatom $\beta$-amilazy, Naukovi pratsi NUKHT, 21(2), pp. 223-230.

Saini R., Saini H.S., Dahiya A. (2017), Amylases: characteristics and industrial applications, Journal of Pharmacognosy and Phytochemistry, 6(4), pp. 1865-1871.

Souza I.A., Orsi D.S., Gomes A.J., Lunardi C.N. (2019), Enzymatic hydrolysis of starch into sugars is influenced by microgel assembly, Biotechnology Reports, 22, pp. 1-10.

Trisnaputri A.C., Usman N.R., Muhammad A., Mustawa M.A., Jaya M.A. (2018), Production Banana Glucose Syrup with the $\alpha$-Amylase Supplementation, International Journal of Applied Biology, 2(1), pp. 61-65.

Yadav P., Majumder C.B (2017), Production of glucose syrup by the hydrolysis of starch made from rotten potato, Journal of Integrated Science \& Technology, 5(1), pp. 19-22. 


\title{
Effect of coconut products, mesquite flour and stevia on the thermal and quality properties of dark chocolate
}

\author{
Zhivka Goranova ${ }^{1}$, Iordanka Alexieva ${ }^{2}$, Todorka Petrova ${ }^{1}$
}

1 - Institute of Food Preservation and Quality, Plovdiv, Agricultural Academy, Bulgaria

2 - University of Food Technologies, Plovdiv, Bulgaria

Keywords:

Chocolate

Coconut

Mesquite

Stevia

Sweetener

Melting

\section{Article history:}

Received 12.03.2021

Received in revised

form 28.10.2021

Accepted 30.12.2021

\section{Corresponding}

author:

Zhivka Goranova

E-mail:

jivka_goranova@ abv.bg

DOI: $10.24263 / 2304-$ 974X-2021-10-4-11

\section{Abstract}

Introduction. The present study aimed to investigate the effect of coconut products and mesquite flour on the thermal properties of dark chocolate with stevia.

Materials and methods. Cocoa butter, cocoa mass, stevia, coconut flour, mesquite powder, and coconut butter are used for the preparation of dark chocolate. Chocolate samples were prepared according to a classic technology. The determination of the energy value of the dark chocolate samples was performed through AOAC procedures. A differential scanning calorimeter was used for the determination of the melting points of the chocolate samples.

Results and discussion. An increase in the mass concentration of functional ingredients leads to an increase in the proteins, fats and a decrease in the carbohydrate content and lipid content. Lower concentrations of carbohydrates were identified in chocolate $1(38.11 \%)$ and chocolate $2(45.50 \%)$. From a statistical point of view $(\mathrm{p}<0.05)$ it can be stated that there are notable differences between the concentration of carbohydrates in chocolate with stevia $0.01 \%$ and that of chocolate with stevia $0.03 \%$. These differences can be explained by the higher carbohydrate content of coconut flour.

Sweetener type and functional ingredients did not change the melting properties of the dark chocolate samples significantly ( $p>0.05$ ). However, low melting temperatures around $27-35{ }^{\circ} \mathrm{C}$ implied that thus low-melting polymorphic forms occurred during the production of the samples. For stevia including dark chocolates, onset temperature $\left(\mathrm{T}_{\text {onset }}\right)$, peak temperature $\left(\mathrm{T}_{\text {peak }}\right)$ and end temperature ( $\mathrm{T}_{\text {end }}$ ) values were found between 25.01-28.57 ${ }^{\circ} \mathrm{C}, 33.95-34.64{ }^{\circ} \mathrm{C}$, and $38.69-38.01{ }^{\circ} \mathrm{C}$. Concerning the $\Delta \mathrm{H}$ parameter, it varied from 32.60 to $33.06 \mathrm{~J} / \mathrm{g}$.

Samples with functional ingredients have significantly higher values for the antioxidant capacity indicator $97.21 \mu \mathrm{mol} \mathrm{TE} / \mathrm{g}$ d.m. $-112.62 \mu \mathrm{mol} \mathrm{TE} / \mathrm{g}$ d.m.

Conclusion. Results of melting profile, and nutritional and antioxidant properties showed that the quality attributes of the chocolates with stevia were substantially affected by the ratio of the functional ingredients (mesquite flour and coconut products). 


\section{Introduction}

Chocolate and cocoa are produced from cacao beans, the seed of Theobroma cacao, and contain fats (the dry weight of whole cacao beans is composed of 50-57\% lipid, often called cocoa butter) (Hannum et al., 2000). This cocoa butter, predominantly found in dark chocolate, is composed on average of $33 \%$ of oleic acid, $25 \%$ of palmitic acid, and $33 \%$ of stearic acid (Latif, 2013), the latter two are saturated fatty acid. Cocoa products are also very rich in plant phytochemicals, especially flavonoids, which are now objects of increased scientific attention due to their potential health benefits (Almoosawi et at., 2010; WangPolagruto et at., 2006).

Cocoa butter crystallizes in different forms as a function of processing condition, time and temperature of storage (Afoakwa et al., 2009). Phase transitions in cocoa butter polymorphs from less to more stable are irreversible and dependent on temperature and time. Polymorphism about solid continuous phases of cocoa butter has a large impact on chocolate quality, dictating their structural properties (Schenk et al., 2004). Structural factors such as microstructural elements and microstructure characteristics can provide quantitative information about the mechanical properties of the network, and therefore information about the sensory hardness of the network (Narine et al., 1999). Polymorphic changes can be observed as an overall contraction of chocolate, appearance, or undesirable fat bloom formation dependent on relative stabilities of crystal forms and temperature. Due to its thermal stability, it can be used in the production of chocolate (Mitchell et al., 2006).

Mesquite (Prosopis spp) pods having a high protein content in addition to the sucrose content offers a wide potential for the development of new functional products (Sandoval et al., 2018). The nutritional content of the powders reveals important properties for the mesquite flours. Flours have a high content of sugars and fiber, and an important content in protein (Sandoval et al., 2018). Flours are highly hygroscopic, and this fact can be explained by the content of sugar (Sandoval et al., 2018).

Chocolate is primarily composed of its natural fat, i.e., cocoa butter, with a total solid content of $65-75 \%$. In chocolate, the continuous phase provides a network structure that maintains the spatial position of the dispersed phase, determining its microstructure, texture, crystallization, and rheological properties, and conferring chocolate its characteristic flavor (Ramlah, 2016). There is no information relating antioxidant, sensory, and melting properties in chocolate products with stevia and functional ingredients. A priority area of expansion of the chocolate assortment is the development of enriched products with targeted functional properties while preserving traditional consumer characteristics. This can be achieved by reducing or replacing the amount of sugar and enrichment with functional ingredients. This is achieved through plant sources rich in fiber (mesquite flour and coconut flour), proteins (mesquite), and natural sugar substitutes (stevia and mesquite flour). In the literature, there is no data on the use of mesquite flour and coconut flour as functional components in the development of chocolate.

According to (Pantzaris et al., 2002), coconut oil is a desirable oil for confectionery formulations and has been applied in confectionery products like non-dairy/imitation dairy products, coffee whiteners, and biscuit-filler creams. In the production of chocolate, coconut oil was applied as a cocoa butter substitute to replace cocoa butter at a certain amount. Indarti et al. (2013) had observed that chocolate containing cocoa butter substitute from virgin coconut oil had a glossy appearance compared to chocolate without cocoa butter substitute. There were several research focused on using cocoa butter substitutes in chocolate from palm kernel oil (Sonwai et al., 2006; Wang et al., 2010). However, to the best of our knowledge, there is no attempt to use coconut oil as a cocoa butter substitute in chocolate. The use of 
coconut oil may affect the physicochemical properties of chocolate, improve the appearance and increase the stability against melting.

This research aims to find out the effect of functional ingredients namely mesquite flour and coconut products (flour and oil) on the sensory, physicochemical, thermal properties and the antioxidant content of chocolate using stevia as sweetener stevia.

\section{Materials and methods}

\section{Raw materials}

The raw materials were bought from the local market and the online market depends upon the availability. The required raw materials were as follows: cocoa mass, mesquite flour, cocoa butter, stevia, coconut flour, and coconut oil.

The study was conducted to develop and assess the nutritional value and melting properties of chocolates with functional ingredients. Two types of chocolates were prepared depending on the varying amount of stevia, coconut flour, and oil.

\section{Preparation of chocolate samples}

\section{Samples}

- Chocolate 1: cocoa mass $-60 \%$; cocoa butter $-20 \%$; stevia $-0.01 \%$; coconut flour $3 \%$; mesquite flour $-10 \%$; coconut oil $-6.99 \%$.

- Chocolate 2: cocoa mass $-60 \%$; cocoa butter - $15 \%$; stevia $-0.03 \%$; coconut flour $5 \%$; mesquite flour $-10 \%$; coconut oil $-9.97 \%$.

- Chocolate 3: cocoa mass $-60 \%$; cocoa butter $-13 \%$; stevia $-0.04 \%$; coconut flour $5 \%$; mesquite flour - 10\%; coconut oil $-11.96 \%$.

- Chocolate 4: cocoa mass $-60 \%$; cocoa butter $-10 \%$; stevia $-0.05 \%$; coconut flour $5 \%$; mesquite flour $-10 \%$; coconut oil $-14.95 \%$.

Chocolate was prepared using cocoa butter, coconut oil which were heated at a temperature of $40{ }^{\circ} \mathrm{C}$ in a double boiling setup. After the heating up of butter, the sieved powder of mesquite flour, coconut flour, and stevia were added and that was continuously stirred and mixed till the added ingredients were blended to form a brown smooth paste. The chocolate is cooled down to room temperature and further molded into the chocolate tray for stability, and the chocolate is cooled in the refrigerator.

\section{Sensory evaluation}

For the sensory evaluation, 4 chocolate samples were selected of possible sensory differences among the samples (Table 1).

For this reason, the chocolate samples were randomly selected and differed in ingredients. Samples were stored at a constant temperature of $20{ }^{\circ} \mathrm{C}$. Chocolate samples were presented in odorless transparent cups, containing a small amount of chocolate (around $10 \mathrm{~g}$ ), foreseen with a random 3-digit code. Descriptive sensory profiling, according to the generic descriptive analysis (Lawless et al., 2010), was used to evaluate the selected chocolate samples. This panel consisted of 10 assessors (aged between 23 and 55 years old). 
The descriptive analysis was carried out at the sensory facilities of IFPQ-Plovdiv. Panelists were seated in individual booths and evaluated each sample. The assessors scored the samples using a 9 -point scale $(1=$ low intensity $-9=$ high intensity $)$.

Table 1

\section{Sensory indicators of chocolates}

\begin{tabular}{|c|c|c|c|c|c|}
\hline \multirow{2}{*}{ 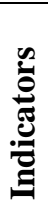 } & \multicolumn{5}{|c|}{ Characteristics } \\
\hline & 9 & $7-8$ & $5-6$ & $3-4$ & $1-2$ \\
\hline 苛 & $\begin{array}{l}\text { The surface is } \\
\text { shiny and } \\
\text { smooth }\end{array}$ & $\begin{array}{l}\text { The surface is } \\
\text { shiny, with a } \\
\text { little scratch }\end{array}$ & $\begin{array}{l}\text { The surface is } \\
\text { shiny, with a } \\
\text { small number } \\
\text { of bubbles }\end{array}$ & $\begin{array}{l}\text { The surface is } \\
\text { matte, the } \\
\text { presence of } \\
\text { pieces, crumbs, } \\
\text { bubbles }\end{array}$ & $\begin{array}{l}\text { The surface is } \\
\text { matte, the } \\
\text { presence of } \\
\text { bruises, } \\
\text { scratches, } \\
\text { crumbs }\end{array}$ \\
\hline 总 & $\begin{array}{l}\text { Hardness, } \\
\text { melting in the } \\
\text { mouth }\end{array}$ & $\begin{array}{l}\text { Hardness, } \\
\text { melting in } \\
\text { fingers }\end{array}$ & Stickiness & Breaking, snap & Creaminess \\
\hline 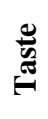 & $\begin{array}{c}\text { Sweet, with a } \\
\text { pleasant } \\
\text { bitterness }\end{array}$ & $\begin{array}{l}\text { Sweet, with } \\
\text { bitterness }\end{array}$ & Sweet & $\begin{array}{l}\text { Uncharacteristi } \\
\text { c, earthy }\end{array}$ & Aftertaste bitter \\
\hline 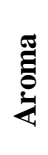 & $\begin{array}{l}\text { The expressive } \\
\text { aroma of fruits, } \\
\text { cocoa, coconut, } \\
\text { nuts, caramel }\end{array}$ & $\begin{array}{l}\text { Pleasant aroma } \\
\text { of fruits, cocoa, } \\
\text { coconut, nuts, } \\
\text { caramel }\end{array}$ & Light aroma & Lack of aroma & $\begin{array}{c}\text { Specific aroma, } \\
\text { uncharacteristic } \\
\text { of chocolate }\end{array}$ \\
\hline
\end{tabular}

\section{Determination of moisture content}

The moisture was determined by the method described by AOAC. Determination of moisture content was done by the hot air oven method.

\section{Nutritional Value}

The proximate composition (moisture, proteins, fat, carbohydrates, and fiber) of chocolates was determined using AOAC procedures (AOAC, 1990). The protein content (N $\times 6.25$ ) of the samples was estimated by the macro-Kjeldahl method; the fat content was determined by extraction using a Soxhlet apparatus. Total carbohydrates were calculated by difference. The energy was calculated according to the following equation: Energy $(\mathrm{kcal})=$ $4 \times(\mathrm{g}$ protein $+\mathrm{g}$ carbohydrate $)+9 \times(\mathrm{g}$ fat $)$. 


\section{Antioxidant activity assays (ABTS)}

The antioxidants of chocolates were determined by the spectrophotometric ABTS method according to procedures described in our previous article with some minor modifications (Szydłowska-Czerniak et al., 2014). The resulting absorbance of each obtained solution was measured in five repetitions using a spectrophotometer in a $1-\mathrm{cm}$ glass cell. The results were expressed as $\mu$ mol Trolox equivalents (TE) per $1 \mathrm{~g}$ of sample.

\section{Melting properties of the samples}

The melting properties of chocolate samples were determined using a differential scanning calorimeter (Perkin Elmer FC100 ped2 27603). $5 \mathrm{mg}$ of each sample was placed into a pan, which was sealed with lids using a sample press. The corresponding parameters representing melting profile of the samples, onset temperature ( $\mathrm{T}_{\text {onset }}$ where melting of the samples started), peak temperature ( $\mathrm{T}_{\text {peak }}$ where the highest rate of the melting was observed), end temperature ( $T_{\text {end }}$ where the samples melted completely), and $\Delta \mathrm{H}$ (energy required for complete melting of the samples) were calculated from the thermograms obtained after heating the pans from 0 to $60{ }^{\circ} \mathrm{C}$ at $10{ }^{\circ} \mathrm{C} / \mathrm{min}$ heating rate performed by $\mathrm{N}_{2}$ stream (Gloria et al., 2001).

\section{Data analysis}

All the data were statistically analyzed for variance (ANOVA) using Excel 10. The comparisons for means were done using Duncan's Multiple Range Tests. Duncan's new multiple range tests, provide significance levels for the difference between any pair of means, regardless of whether a significant $\mathrm{F}$ resulted from an initial analysis of variance. Principal component analysis using the correlation matrix was conducted using ANOVA to visualize the relationships between the chocolate samples and the sensory attributes for the different types of chocolate (Naes et al., 2010).

\section{Results and discussion}

A major difficulty in the production of chocolate with stevia, which completely replaces sugar, is the appearance of a specific bitterness, the elimination of which is a major task in the development of chocolate with natural sugar substitutes. To eliminate bitterness, functional components such as mesquite flour, coconut flour, and coconut oil are added. An optimal quantitative ratio of all ingredients contained in chocolate is selected. The compositions of chocolate were selected after preliminary sensory evaluations. The differences in the composition of the chocolate samples were in the amount of stevia and coconut oil. The selected two variants of chocolates were the best sensory characteristics and were included in subsequent analyzes regarding their quality.

\section{Sensory evaluation}

The trained panel indicated that no significant difference was present in the appearance of the four dark chocolate. The cocoa aroma was dominating the aroma of the dark chocolate although hints of coffee, tobacco, and fruit were perceived. Further, the evaluations of the trained panel indicated that significant differences were found in the texture of the four chocolates, chocolate samples 3 and 4 are melting behavior. 


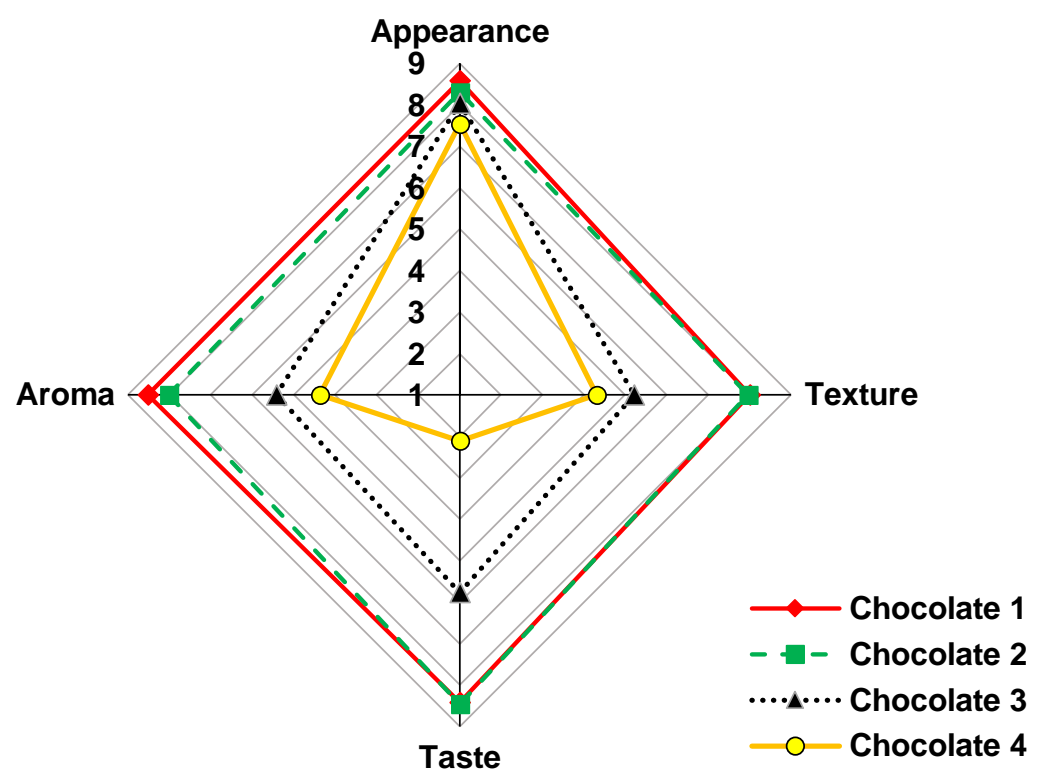

Figure 1. Sensory evaluation

The differences between the samples were found in the taste of the chocolate. The bitter taste was found to be most present in dark chocolate 3 and 4 . Chocolate 4 was evaluated as the most bitter chocolate. No significant difference was found between chocolate 1 and 2 regarding the bitter taste. Other significant differences were found for fruit and cocoa flavor. The fruity flavor of chocolate 2 was higher than that of other chocolates. Finally, the aftertaste after swallowing the samples was higher for chocolate 4.

Standardized plots using the correlation matrix are commonly used in sensory analysis to display differences between attributes as well as between samples. Figure 2 display the positioning and association between the chocolate attributes. The chocolate 1 larger differences are present for texture than for aroma and flavor.

Figure 2 shows that the three chocolate are closely related in terms of aroma. This suggests that the difference between the four types of chocolate is larger when looking at the aroma of the chocolate. This is also because not all ingredients were used in the equal qua of the different chocolate. The chocolate samples 1 and 4 are further from each other which indicates that these are more different from each other in aroma than the other two types of chocolate. The bitter taste and to a lesser extent sour taste are related to dark chocolates 3 and 4. Coffee, tobacco, earth and fruity flavor are also related to dark chocolate.

These plots can also demonstrate whether correlations exist between an aroma and flavor attribute that has been analyzed by the nose and by mouth (Naes et al., 2010). Most of these attributes such as caramel, nuts, cocoa, tobacco, fruity, honey, each were closely associated with one another, indicating that these notes were perceived similarly on the nose as well as the palate with the same intensity. Future research could combine this analysis from a trained panel with instrumental aroma or flavor analysis. This was not included in this research due to limited time. 


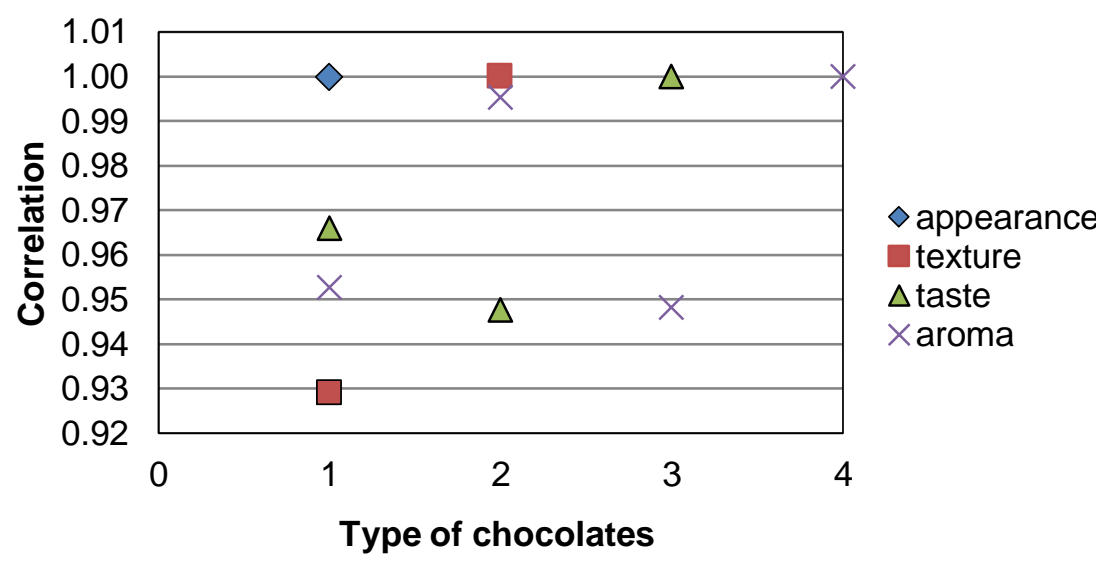

Figure 2. Correlation analysis of the significant attributes for the four types of chocolate

\section{Nutritional characteristics}

The nutritional composition of chocolate is mainly determined by the nature and nutritional value of the ingredients from which it is obtained and has different values, depending on the type of chocolate, how to obtain it (Barišic et al., 2019). Table 2 presents the fat, protein, carbohydrate, moisture content of sucrose-free chocolate.

Nutritional properties of dark chocolate g/100g

Table 2

\begin{tabular}{|l|c|c|c|c|c|}
\hline $\begin{array}{l}\text { Types of } \\
\text { chocolate }\end{array}$ & $\begin{array}{c}\text { Fat } \\
(\boldsymbol{\%})\end{array}$ & $\begin{array}{c}\text { Protein } \\
(\boldsymbol{\%})\end{array}$ & $\begin{array}{c}\text { Carbohydrate } \\
(\boldsymbol{\%})\end{array}$ & $\begin{array}{c}\text { Fiber } \\
(\boldsymbol{\%})\end{array}$ & $\begin{array}{c}\text { Moisture } \\
(\boldsymbol{\%})\end{array}$ \\
\hline Chocolate 1 & 23.25 & 7.20 & 38.11 & 7.34 & 7.34 \\
\hline Chocolate 2 & 21.03 & 8.90 & 45.50 & 8.61 & 8.12 \\
\hline
\end{tabular}

It can be seen from Table 2 that the fat content in dark chocolate 1 has a higher value than chocolate 2. This difference is because dark chocolate uses a higher proportion of cocoa butter. In addition, the effect of functional ingredients can determine the fat content in chocolate. The results show that the protein content in chocolate 2 is higher than in dark chocolate 1 . This variance is probably due to stevia, which does not affect the protein content in chocolate. Lin et al. (2010) used erythritol as a substitute for sucrose in making Danish cookies which is not much different from using sucrose. Analyzing the proximate composition of two types of chocolate, Latif et al. (2013) obtained the following values: per $100 \mathrm{~g}$ of the dark chocolate: $6.6 \mathrm{~g}$ of protein, $33.6 \mathrm{~g}$ of lipids, $49.7 \mathrm{~g}$ of carbohydrates, 50.5 of sugar; the energy value was $515 \mathrm{kcal}$ and per $100 \mathrm{~g}$ of the milk chocolate: $7.3 \mathrm{~g}$ of protein, $36.3 \mathrm{~g}$ of lipids, $50.7 \mathrm{~g}$ of of carbohyFdrates, $49.7 \mathrm{~g}$ of sugar, the energy value was $545 \mathrm{kcal}$.

Albak and Tekin (2014) made some assortments of functional chocolate with spices (cinnamon, aniseed, and ginger) and lemon peel powder. Proximate composition of of these chocolates is the following: 0.52 (dark chocolate) $-0.96 \%$ (aniseed chocolate) for moisture; 30.70 (in cinnamon chocolate) $-34.71 \%$ (in ginger chocolate) for fats; 8.42 (in dark 
chocolate) $-9.47 \%$ (in aniseed chocolate), for protein; 1.73 (in dark chocolate) $-2.15 \%$ (in cinnamon chocolate), for ash; 52.49 (in dark chocolate) - 57.80 (in cinnamon chocolate), for carbohydrate.

Stevia is also good for preventing moisture adsorption on chocolate. If the stevia concentration increases, the moisture absorption will be less, so the water content will decrease. According to research by Shourideh et al. (2012), in milk chocolate with an inulin concentration below $50 \%$, the water content of the product did not increase. In contrast, if the concentration increased, the water content would increase.

The higher water content is caused by stevia, which is hygroscopic and can bind free water in the material. The higher the addition of sweetener in a food, the more free water is bound (Afoakwa et al., 2007). When there is heating in the manufacture of sucrose-free dark chocolate, the water is evaporated slightly. This is because when measuring the moisture content in chocolate, it will produce more water when compared to sucrose.

Statistically significant differences $(\mathrm{p}<0.05)$ were determined in the two chocolates with added new ingredients. Comparing the average value of the protein content determined in chocolate $1(7.20 \%)$ with that determined in chocolate $2(8.90 \%)$, it is observed that there are statistically significant differences $(\mathrm{p}<0.05)$. These differences can be explained by the amount of protein contained in the mesquite addition. As can be seen from the data presented in Table 2, the highest carbohydrate content was identified in chocolate 2 (45.50\%). Lower content of carbohydrates was identified in chocolate $1(38.11 \%)$. From a statistical point of view $(\mathrm{p}<0.05)$ it can be stated that there are notable differences between the concentration of carbohydrates in chocolate 1 and that of chocolate 2 . These differences can be explained by the higher carbohydrate content of coconut flour.

\section{Melting properties}

DSC evaluates the structure density, homogeneity, crystal network, and tempering of dark chocolate. The melting characteristic investigated by DSC is an important quality parameter relating to flavor release and oral epithelial sensations. Melting properties $\left(\mathrm{T}_{\text {onset }}\right.$, $\mathrm{T}_{\text {peak }}, \mathrm{T}_{\text {end }}$ and $\left.\Delta \mathrm{H}\right)$ of the sugar-free chocolates with functional ingredients are presented in Table 3.

Table 3

Melting profile of dark chocolates

\begin{tabular}{|l|c|c|c|c|}
\hline \multirow{2}{*}{$\begin{array}{c}\text { Type of } \\
\text { chocolate }\end{array}$} & \multicolumn{4}{|c|}{ Melting Profile } \\
\cline { 2 - 5 } & $\mathbf{T}_{\text {onset }}\left({ }^{\circ} \mathbf{C}\right)$ & $\mathbf{T}_{\text {peak }}\left({ }^{\circ} \mathbf{C}\right)$ & $\mathbf{T}_{\text {endset }}\left({ }^{\circ} \mathbf{C}\right)$ & $\Delta \mathbf{H ~ ( J / g )}$ \\
\hline Chocolate 1 & $25.01 \pm 0.03^{\mathrm{a}}$ & $33.95 \pm 0.05^{\mathrm{a}}$ & $38.69 \pm 0.07^{\mathrm{a}}$ & $32.60 \pm 0.05^{\mathrm{a}}$ \\
\hline Chocolate 2 & $28.57 \pm 0.01^{\mathrm{b}}$ & $34.64 \pm 0.05^{\mathrm{b}}$ & $38.01 \pm 0.04^{\mathrm{a}}$ & $33.06 \pm 0.09^{\mathrm{b}}$ \\
\hline
\end{tabular}

All values are shown as mean \pm standard deviations $(\mathrm{n}=3)$.

Different letters $a, b$, indicate significant differences $(\mathrm{p}<0.05)$ in the melting profile of different types of dark chocolate.

For stevia including dark chocolates, Tonset, Tpeak and Tend values were found between 25.01-28.57 ${ }^{\circ} \mathrm{C}, 33.95-34.64{ }^{\circ} \mathrm{C}$, and 38.69-38.01 ${ }^{\circ} \mathrm{C}$. Concerning the $\Delta \mathrm{H}$ parameter, it varied from 32.60 to $33.06 \mathrm{~J} / \mathrm{g}$. Neither sweetener type nor seeding did not change the melting properties of the dark chocolate samples significantly $(\mathrm{p}>0.05)$. However, low melting temperatures around $27-35{ }^{\circ} \mathrm{C}$ implied that thus low-melting polymorphic forms occurred during the production of the samples (Afoakwa et al., 2007). The thermal behavior of chocolate, with additives in question, was studied in DSC to see 
their effect on the melting point characteristics. It is seen that the fat melting profile corresponding to each additive is different. It is known that the peak temperature for melting is the average melting point of chocolate and the onset of melt indicates the time when the fat just starts to melt. The melting properties of chocolate are important because of its contribution to the taste and sensation in the mouth. Marangoni and McGauley (2003) stated that the structure of fat in a food product is an important property that strongly influences its perceived mechanical and melting properties. These results show that functional ingredients affected the melting point of the dark chocolate within the proportion they added. Especially coconut flour and oil were observed to be more effective in increasing the melting point in comparison with cocoa butter probably due to its higher fiber content.

Thermal behaviors and the ratio of sugar/fat-melting enthalpies in chocolates differing in temper regime were studied using DSC to provide information on differences in structure.

The DSC data showed differences in fat melting profile, resulting from the widened peak width in the under-tempered (bloomed) sample; but no differences were noted in the sugar melting profiles, suggesting that blooming of under-tempered dark chocolate is associated with structural transformations in the fat component alone while the crystalline network of the sugar remains unchanged.

Chocolate refers to products with high antioxidant activity. The antioxidant capacity of the newly developed chocolate samples has been determined and compared to that of the control (Table 4).

\section{Total content of antioxidants in the chocolates}

Table 4

\begin{tabular}{|c|c|}
\hline Type of chocolate & TE $_{\text {ABTs, } \boldsymbol{\mu m o l ~ T E} / \mathbf{g} \text { d.m. }}$ \\
\hline Sample 1 & $97.21 \pm 0.03$ \\
\hline Sample 2 & $112.62 \pm 0.06$ \\
\hline
\end{tabular}

It is known that antioxidants interrupt radical-chain oxidation processes in the human body caused by free radicals as a result of exposure to factors of exogenous origin (chemical environmental pollutants, ionizing radiation of radionuclides) and as a result of biochemical metabolic reactions in the cells of the body (Kozlova et al., 2014). From the data obtained in Table 4, samples with functional ingredients can be seen to have significantly higher values for the antioxidant capacity indicator $-97.21 \mu \mathrm{mol} \mathrm{TE} / \mathrm{g} \mathrm{d} . \mathrm{m}$. and $112.62 \mu \mathrm{mol} \mathrm{TE} / \mathrm{g} \mathrm{d}$.m. The effect of rosemary and grape seed particles on crystallization, rheological, shelf life, and antioxidant activities of chocolate was studied (Ozgen et al., 2010). They found that there was no effect of these additives on the crystallization and rheological properties of chocolate while they increased its shelf life and antioxidant capacity. In a Ph.D. thesis by Çağındı (Cağındı et al., 2009) some physical, chemical, and sensory properties of white and dark chocolates with enriched milk, sunflower seed, flaxseed, oat, and dried damson plum particle was investigated. It was concluded that these ingredients increased the nutritional value of chocolate and changed some physical, chemical, and sensory properties during the storage period.

In a study on the identification of antioxidants compounds from dark chocolate with the addition of some spices and herbs, Mira Suprayatmi et al. (2017a) found that the addition of ground ginger, cinnamon powder, red chili powder, powdered mint leaf, powdered green tea leaf, and powdered linden leaf, increases the antioxidant content of chocolate. Moreover, in another study, Mira Suprayatmi et al. obtained three types of dark chocolate with the addition 
of powdered mint leaves, powdered green tea leaves, and powdered lime leaves, each at $4 \%$ (w/w) (Suprayatmi et al., 2017b).

The study authors found that the chocolate products with the addition of powdered mint leaves, powdered green tea leaves and powdered lime leaf were experiencing an increase in the number of types of antioxidants.

\section{Conclusion}

1. The combination of stevia and mesquite flour and coconut products as a bulking agent on dark chocolate can improve the protein and fat content. Addition of stevia decreases the content of carbohydrates.

2. An increase in the mass concentration of functional ingredients, leads to an increase in the contents of proteins, fats and a decrease in the carbohydrate content.

3. Results of the melting profile showed that the quality attributes of the chocolates were not substantially affected by functional ingredients level, which is important for the consumer acceptability of the product. Considering the purpose of improving the nutritional and technological quality of dark chocolate, the use of stevia and functional ingredients is highly recommended.

\section{Reference}

Afoakwa E. O., Paterson A., Fowler M. (2007), Factors Influencing Rheological and Textural Qualities in Chocolate - A Review, Trends in Food Science and Technology, 18, pp. 290 298.

Afoakwa E., Paterson A., Fowler M., Vieira, J. (2009), Influence of tempering and fat crystallization behaviours on microstructural and melting properties in dark chocolate systems, Food Research International, 42(1), pp. 200-209.

Albak F., Tekin A.R. (2014), Development of functional Chocolate with spices and lemon peel powder by using response surface method, Akademik Gida, 12(2), pp. 19-25.

Almoosawi S., Fyfe L., Ho C., Al-Dujaili E. (2010), The effect of polyphenol-rich dark chocolate on fasting capillary blood glucose, total cholesterol, blood pressure and glucocorticoids in healthy overweight and obese subjects, British Journal of Nutrition, 103, pp. 842-850.

AOAC (1990), Official Methods of Analysis vol 2. 15 th edition Aspects of Official Analysis Chemistry, Inc. Arlington.

Barišic V., Kopjar M., Jozinovic A., Flanjak I., Ackar D., Milicevic B., Šubaric D., Jokic S., Babic J. (2019), The Chemistry behind Chocolate Production, Molecules, 24, pp. 3163-3176

Cağındı Ö. (2009), Investigation of some physical, chemical and sensory properties of sunflower seed, flax seed, oat and dried damson plum enriched milk, dark and white chocolates during shelf life. PhD Thesis, Ege University, İzmir, Turkey.

Gloria H., Sievert D. (2001), Changes in the physical state of sucrose during dark chocolate, processing, Journal of Agricultural Food Chemistry, 49, pp. 2433-2436.

Hannum S. M., Erdman Jr. J. W. (2000), Emerging health benefits from cocoa and chocolate, Journal of Medicinal Food, 3, pp. 73-75.

Indarti E., Arpi N., Widayat H. P., Anhar A. (2013), Appearance, texture and flavour improvement of chocolate bar by Virgin Cococnut Oil (VCO) as Cocoa Butter Substitute (CBS), In: Proceedings of the Annual International Conference, Syiah Kuala University-Life Sciences \& Engineering, Chapter 3(1). 
Kozlova T.S., Syngeeva E.V., Balchugova N.N. (2014), Study of the effect of germination duration and processing methods on the antioxidant properties of grain, Polzunov Altai State Technical University, Barnaul, pp. 442-444.

Lawless H.T., Heymann, H. (2010), Sensory Evaluation of Food: Principles and Practices (second edtion ed.), Springer, New York.

Latif R. (2013), Chocolate/cocoa and human health: a review, The Netherlands Journal of Medicine, 71, pp. 63-68.

Lin S. D., Lee C. C., Mau J. L., Lin L. Y., Chiou S. Y. (2010), Effect of erythritol on quality characteristics of reduced-calorie danish cookies, Journal of Food Quality, 33, pp. 14-26

Naes T., Brockhoff P. B., Tomic O. (2010), Statistics for Sensory and Consumer Science, John Wiley \& Sons, Ltd, Chichester, pp. 209-224.

Nur M., Suryatiani D. R., Dewi R. L., Sari A. B. T. (2021), The effect of bulking agent and type of chocolate on the physicochemical characteristics of sucrose-free chocolate using stevia as a sweetener, IOP Conference Series: Earth Environmental Science, 733, 012102.

Marangoni A. G., McGauley, S. E. (2003), Relationship between crystallizationbehavior and structure in cocoa butter, Crystal Growth \& Design, 3(1), pp. 95-108

Mitchell H., (2006), Sweetners and sugar alternatives in food technology, Blackwell publishing Ltd, Oxford.

Narine S.S., Marangoni, A.G. (1999), Relating structure of fat crystal networks to mechanical properties: A review, Food Research International, 32, pp. 227-248.

Ozgen O. (2010), The effects of rosemary (Rosmarinus officinalis) and grape seed (Vitis vinifera) on crystallization, rheological properties, shelf life and antioxidant activities of chocolate. PhD Thesis, İstanbul Technical University, İstanbul.

Pantzaris T.P., Basiron Y. (2002), The lauric (coconut and palm kernel) oils F.D. Gunstone (Ed.), Vegetable Oils in Food Technology: Composition, Properties and Uses, Blackwell Publishing, USA and Canada, pp. 157-202.

Ramlah S. (2016), Quality characteristics and taste of chocolate rich in polyphenols, Journal of Plantation Products Industry, 11, pp. 23-32.

Sandoval Torres S., Reyes López L., Méndez Lagunas L., Rodríguez Ramírez J., Barriada Bernal G. (2018), Physicochemical characterization of mesquite flours, 21st International Drying Symposium, Editorial Universitat Politècnica De València, pp. 989-996, DOI: 10.4995/ids2018.2018.7707

Schenk H., Pescha R. (2004), Understanding the structure of chocolate, Radiation Physics and Chemistry, 71, pp. 829-835.

Shourideh M., Taslimi A., Azizi M., Mohammadifar M. (2012), Effects of D-tagatose and inulin on some physicochemical, rheological and sensory properties of dark chocolate, International Journal of Bioscience, Biochemistry and Bioinformatics, 2, pp. 314.

Sonwai S., Rousseau, D. (2006), Structure evolution and bloom formation in tempered cocoa butter during long-term storage, Eur. J. Lipid Sci. Tech., 108(9), pp. 735-745

Suprayatmi M., Hutami R., Tiastadia I.P. (2017a), Identification of antioxidants on dark chocolate compound with addition of some spices and herbs, Short communication, DOI: 10.13140/RG.2.2.29430.40004

Suprayatmi M., Hutami R., Tiastadia I.P., Purnamasari D. (2017b), Profile of antioxidant in dark chocolate product that enriched with herbs, Proceedings of the International Food Research Conference, Selangor, Malaysia, 2017, Available at: https://www.researchgate.net/publication/350781474

Szydłowska-Czerniak A., Tułodziecka A. (2014), Antioxidant capacity of rapeseed extracts obtained by conventional and ultrasoundassisted extraction, Journal of the American Oil Chemists' Society, 91, pp. 2011-2019.

Tokede O., Gaziano J., Djoussé L. (2011), Effects of cocoa products/dark chocolate on serum lipids: a meta-analysis, European Journal of Clinical Nutrition, 65, pp. 879-886. 
Wang F., Liu, Y., Shan, L., Jin, Q., Meng, Z., Wang X. (2010), Effect of fat composition on texture and bloom of lauric compound chocolate, European Journal of Lipid Science and Technology, 112(11), pp. 1270-1276.

Wang-Polagruto J.F., Villablanca A.C., Polagruto J.A., Lee L., Holt R R., Schrader H.R. (2006), Chronic consumption of flavanol-rich cocoa improves endothelial function and decreases vascular cell adhesion molecule in hypercholesterolemic postmenopausal women, Journal of Cardiovascular Pharmacology, 47(Suppl 2), pp. S177-S186. 
Sorption characteristics of fondant candies based on tagatose

\title{
Oksana Dorozhynska, Olena Kokhan, Yuliia Kambulova
}

\author{
National University of Food Technologies, Kyiv, Ukraine
}

Keywords:
Fondant candy
Tagatose
Sorption
Storage

Article history:

Received

20.03.2021

Received in

revised form

25.06.2021

Accepted

30.12.2021

Corresponding author:

Olena Kokhan

E-mail:

eagavva@

gmail.com

DOI:

$10.24263 / 2304-$

974X-2021-10-412

\section{Abstract}

Introduction. Studies which established the sorption characteristics of sucrose-based fondant candies and fondant candies based on the combination of tagatose with fructose were conducted.

Materials and methods. Fondant candies made on the basis of sucrose and tagatose with the addition of fructose in the ratio of 9:1 were investigated on a weight vacuum adsorption device with spring quartz scales using gravimetric method.

Results and discussion. The sorption curves of both samples of the studied candies were identical in nature and belonged to isotherms of type III, which is characteristic of microporous adsorbents with low energy of adsorbent-adsorbate interaction. The sorption curves were sigmoid, with a well-developed hysteresis, which indicates a completely irreversible process of dehydration. After the desorption process, a small part of the adsorbed moisture remains in the samples on sucrose and tagatose with fructose $(0.55$ and $0.37 \%$, respectively).

The coefficients of determination of both BET and Friendlich models used for the analysis were in the range of 0.85-0.97, which indicates their suitability for describing the isotherms of the studied products. Analysis of the constant characterizing the adsorption energy showed that in the sample based on tagatose and fructose adsorption was $18 \%$ higher than in the control sample.

The amount of adsorbed moisture in the studied samples of candies at low values of $a_{w}$ had a slight difference, while in the area of capillary moisture $\left(\mathrm{a}_{\mathrm{w}}=1.0\right)$ this value differed significantly: the amount of adsorbed moisture in the control sample of fondant candies on sucrose was $0.6498 \mathrm{~cm}^{3} / \mathrm{g}$, while in the sample based on tagatose and fructose it was $1.5499 \mathrm{~cm}^{3} / \mathrm{g}$. The amount of strongly bound moisture in the sample based on tagatose and fructose was greater than in the control sample and was $8.33 \%$, while in the control sample only $5.24 \%$.

Conclusions. The sorption isotherms allow to predict the behavior of candy samples during their storage at different values of relative humidity. The obtained data can be used for rational selection of packaging material and packaging method to extend the shelf life of developed fondant candies based on tagatose. 


\section{Introduction}

Fondant candies are a complex heterogeneous system, which tries to balance and minimize energy, the reduction of which is possible during the transition of the system to a state of crystallization that may occur due to intensive desorption of products causing an increase in part of solids and size of crystals, and this is reflected in deterioration quality of finished products in general (Bund et al., 2010; Hartel et al, 2011; Ivanov et al, 2021).

The previous research aimed to develop fondant candies that would focus on the requirements of modern consumers, namely, having high sensorial characteristics, and low calories and glycemic value.

To achieve this goal, it was proposed to use the innovative sugar tagatose. However, due to the low hygroscopicity of this sugar, it is advisable to make confectionery in combination with a hygroscopic component. Thus, the possibility of making marmalade from orange with complete replacement of sucrose by a combination of tagatose with oligofructose was proposed (Rubio-Arraez et al.,2015). With an increase of tagatose in the recipe of the product, samples of marmalade were characterized by the phenomenon of intense moisture loss during storage. With increasing dosage of hygroscopic oligofructose in the recipe of marmalade with tagatose, the intensity of moisture removal was significantly slowed down. Therefore, it can be assumed that in the development of products which are prone to hardening during storage, based on tagatose, it is desirable to add additional hygroscopic component to the recipe, including hygroscopic monosaccharide fructose.

To expand the range of fondant candies, a product recipe was developed in which sucrose was completely replaced with a combination of low-glycemic and low-calorie tagatose in combination with hygroscopic low-glycemic monosaccharide fructose in a ratio of 9:1.

When developing new types of confectionery, especially those where the main component of the recipe is replaced, in particular the replacement of white crystal sugar with other sugars, in addition to texture and sensory properties, the stability of the product during storage and selection of a rational packaging method must be taken into account. The relationship between moisture content and water activity or relative humidity can be described using the moisture sorption isotherm (Andrade et al., 2011). Information on the behavior of moisture in products is a necessary condition for the choice of packaging material and packaging method, as well as to establish the warranty period for the preservation of their quality characteristics (Chetana et al., 2004; Kuzmyk et al., 2021; Sokolenko et al., 2019). For classic fondant candies based on white crystal sugar it was established that desorption processes and their negative impact on product quality are the dominant factor during their storage (Ozcan et al., 2019), and for developed fondant candies based on tagatose with the addition of fructose study of sorptiondesorption properties to predict the behavior during storage is quite an urgent task.

The aim of the study was to determine the relationship between the equilibrium moisture content in fondant candies, which were made according to the classic recipe based on sucrose and using a combination of tagatose sugar and fructose in a ratio of 9:1. Analysis of changes in the hygroscopicity of the studied product provided a basis for the study of phase transitions in the product depending on its carbohydrate composition and moisture content.

In all cases, the suitability of several mathematical models for describing the sorption isotherms of a multicomponent food product with a high content of mono- and disaccharides was evaluated and those offering the most accurate description were identified.

Identification of the sorption model, which describes the change in water content in the product as dependent on water activity in the widest possible range, can be useful for predicting changes in product quality during storage and to extend its shelf life, and therefore to optimize production and improve product quality. 


\section{Materials and methods}

\section{Materials}

Fondant candies made by boiling sucrose-based fondant syrup (control sample) and completely replacing sucrose with a combination of tagatose and fructose sugars in a ratio of 9:1, followed by cooling and whipping to obtain a fine crystalline fondant mass, which was cast in polymeric forms in the laboratory.

\section{Sorption properties of candies}

Determination of the sorption properties of the studied samples was carried out by gravimetric method using a sorption vacuum device with spring quartz scales. (Sylchuk et al., 2021).

\section{Data analysis}

To select the model that best describes the sorption isotherms of sucrose fondant candy (control sample) and a sample based on tagatose with fructose, two popular models (BET and Freindlich) are considered. It should be noted that they have a theoretical basis (based on the theory of adsorption), and their parameters have a physical meaning.

Equations to describe sorption isotherms

Table 1

\begin{tabular}{|l|c|l|}
\hline $\begin{array}{c}\text { Title of the } \\
\text { equation }\end{array}$ & \multicolumn{1}{|c|}{ Equation } & \multicolumn{1}{c|}{ Nomenclature } \\
\hline & $a=\frac{a_{m} \cdot K \cdot P / P_{s}}{\left(1-\frac{P}{P_{s}}\right)\left\{1+(K-1) \cdot \frac{P}{P_{s}}\right\}}$ & $\begin{array}{l}\text { a }- \text { the amount of adsorbed moisture } \\
a_{m}-\text { monolayer capacity } \\
\mathrm{K}-\text { equilibrium constant of } \\
\text { polyslayer adsorption } \\
P / P_{s}-\text { relative equilibrium water } \\
\text { vapor pressure }\end{array}$ \\
\hline Freundlich & $G=K \cdot P^{\frac{1}{n}}$ & $\begin{array}{l}\mathrm{G}-\text { the amount of adsorbed moisture } \\
\mathrm{P}-\text { equilibrium water vapor } \\
\text { pressure } \\
\mathrm{K} \mathrm{i} \text { - empirical constants }\end{array}$ \\
\hline
\end{tabular}

\section{Results and discussion}

\section{Sorption properties of fondant candies}

Isotherms of adsorption-desorption of water by samples of fondant candies based on sucrose (control sample) and a combination of tagatose and fructose in the ratio 9:1 are shown in Figure 1 in such coordinates: the amount of adsorbed water - its activity, which is directly related to the relative equilibrium vapor pressure $\mathrm{a}_{\mathrm{w}}=\mathrm{P} / \mathrm{Ps}$. 


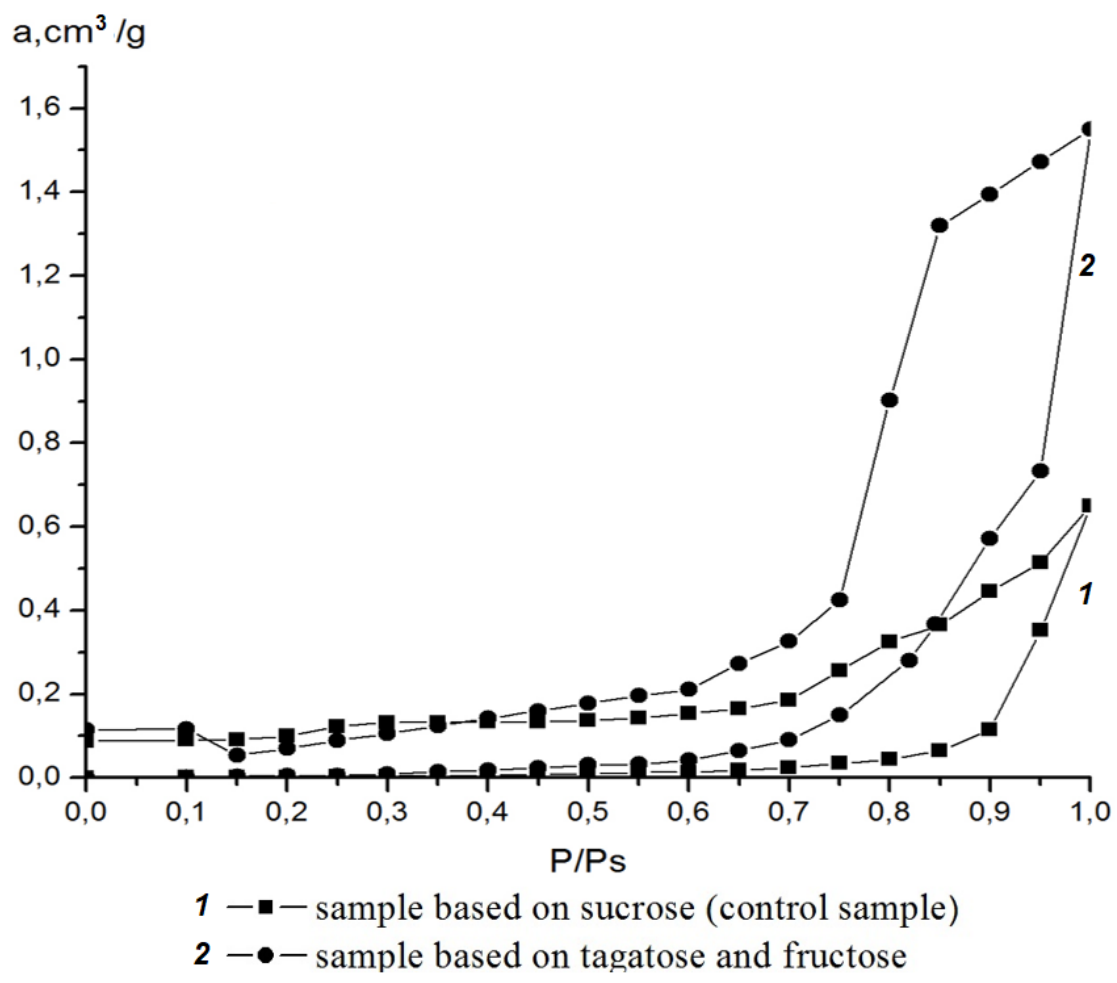

Figure 1. Isotherms of adsorption-desorption of water by samples of fondant candies

Products with high content of sugar such as caramel (Hadjikinova et al., 2003, Netramai et al., 2011) and fruit powders (Rodríguez-Bernal et al., 2015), usually have a J-shaped isotherm or isotherm of type III (Bell et al., 2000). The sorption isotherms of the tested samples also correspond to the characteristic form of food products with high sugar content, which adsorbs a small amount of water at low values of water activity. At the bottom value of $a_{w}$ the slope of the curve is smaller, while with increasing $a_{w}$ the slope increases rapidly, which can be explained by the increase in hygroscopicity of the studied sugars (Dorokhovich, 2013).

Sorption isotherms for both samples of fondant candies were identical. In the interval of $\mathrm{a}_{\mathrm{w}}=0-0.7$ the sorption and desorption curves were located close to each other, and in the interval of $\mathrm{a}_{\mathrm{w}}=0.75-1.0$ there was a hysteresis loop.

The hysteresis loop indicates that during the sorption in this period there was a pseudophase transition associated with changes in the crystal structure of fondant candies. There is also a noticeable difference in the height of the isotherms, which depends on the amount of adsorbed moisture. Thus, the isotherm of the control sample was much lower compared to the isotherm of fondant candies based on tagatose and fructose. The increase in the water absorption capacity of the candy sample based on the combination of tagatose and fructose can be explained by the presence of different sugars with different sorption properties in the recipes of candies. The sorption properties of the used sugars were studied and it was inserted that the rate of sorption of water vapor increases significantly for sucrose and tagatose by 
P/Ps 0.8; and for fructose at lower pressure values 0.62, which indicates higher hygroscopicity of this sugar (Dorokhovich, 2013; Han, 2021). Due to the different rate of sorption, sugars are able to attach different amounts of moisture at the maximum possible adsorbent pressure $(\mathrm{P} / \mathrm{Ps}=1.0)$. Among the used sugars, sucrose has the lowest content, while fructose has the highest content of moisture, and tagatose has an intermediate value, which is consistent with obtained data for candies using these sugars.

The influence of prescription components on the formation of sorption properties of the finished product is also evidenced by the results of previous studies. The sorption properties of caramel made from polyols (isomaltitol and sorbitol) were considered. The sample based on isomaltitol had a lower water absorption capacity than the sample on sorbitol due to the greater hydrophobicity of this sugar substitute (Hadjikinova et al., 2011).

\section{Analysis of sorption models}

The rate of chemical reactions in food is highly dependent on the water content. It is assumed that the maximum amount of moisture at which most reactions have a low rate, corresponds to the water content in the monolayer. The monolayer can be determined using theoretical models, where it is one of the constants of the equation describing the physical properties of the material. Two-parameter BET and Freundlich models were considered in the search for the best fit of the sorption isotherm model to the experimental data. The BET model (Figure 2) was used for $\mathrm{a}_{\mathrm{w}}$ range from 0.02 to 0.25 .

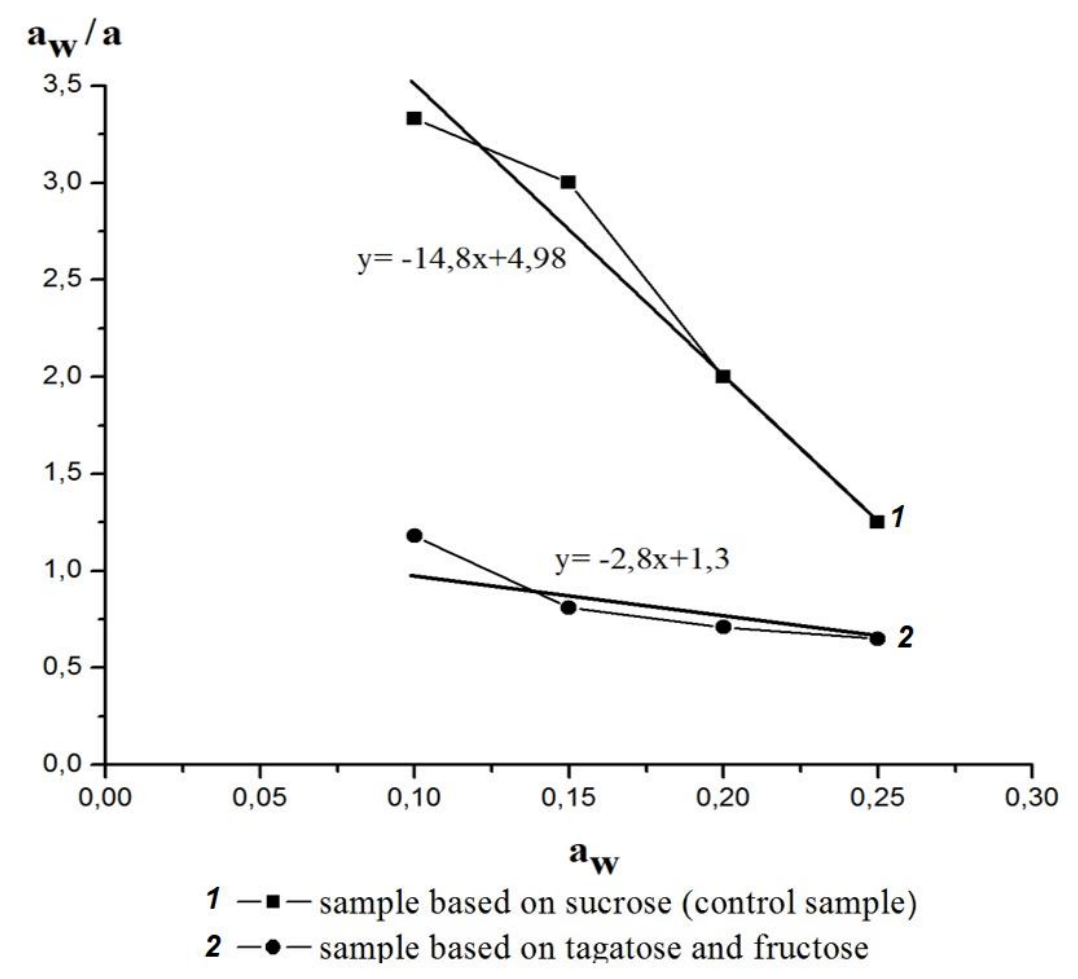

Figure 2. Graphic representation of the BET equation for samples of fondant candies 
At higher values of $a_{w}$, the research results did not form a straight line, which made it impossible to calculate the parameters of the equation, because in parallel with the adsorption in this zone there is dissolution of the crystal structure. Similar results were demonstrated in the selection of the BET model for powdered sugar. According to the presented graph, it was noted that this equation was valid in the range $\mathrm{a}_{\mathrm{w}}$ from 0.0 to 0.3 (Clément et al., 2018). In practice, to describe the phenomena of adsorption in such complex systems, it is more appropriate to use the empirical Freindlich equation, which is well valid for medium humidity. The division of adsorption curves into 3 zones is more clearly observed, and in each zone the experimental results are quite accurately described by straight lines (Figure 3 ).

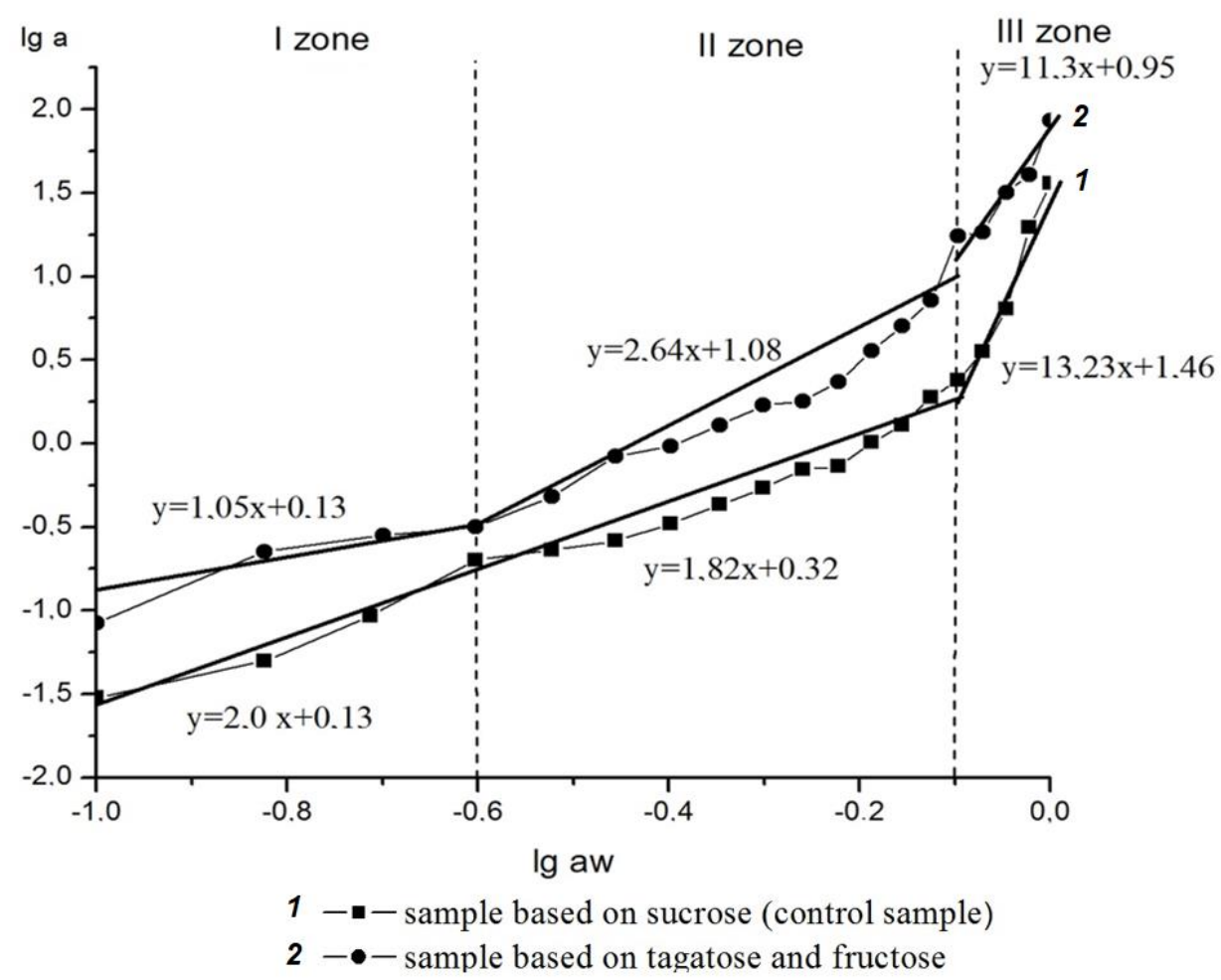

Figure 3. Graphic representation of the Friendlich equation

Table 2 shows the calculated model parameters and the coefficient of determination $\mathrm{R}^{2}$. The values of the capacity of monolayer of the adsorbed moisture obtained using the BET model were significantly lower for sucrose-based fondant candies compared to the sample on tagatose and fructose, which can be explained by the presence of hygroscopic fructose, which begins to absorb moisture at lower values than sucrose. It was explored that the water content in the monolayer tended to increase with decreasing sucrose content in the studied samples of candied orange (Witczak, T. et al., 2016). Regarding the analysis of the constant $\mathrm{K}$, which characterizes the energy of adsorption, in the sample based on tagatose and fructose it was $18 \%$ higher than in the control sample. 
Parameters of BET and Friendlich models for samples of fondant candies

\begin{tabular}{|c|c|c|c|}
\hline \multirow[b]{2}{*}{ Model } & \multirow[b]{2}{*}{ Parameter } & \multicolumn{2}{|r|}{ Sample } \\
\hline & & $\begin{array}{l}\text { Candies based } \\
\text { on sucrose }\end{array}$ & $\begin{array}{c}\text { Candies based on a combination of } \\
\text { tagatose and fructose }\end{array}$ \\
\hline \multirow{3}{*}{ BET } & $\mathrm{a}_{\mathrm{m}}$ & 0.0682 & 0.2500 \\
\hline & $\mathrm{K}$ & 0.2660 & 0.3250 \\
\hline & $\mathrm{R}^{2}$ & 0.969 & 0.841 \\
\hline \multirow{3}{*}{ Friendlich } & $\mathrm{n}$ & 0.4230 & 0.5211 \\
\hline & $\mathrm{K}$ & 2.9806 & 9.6095 \\
\hline & $\mathrm{R}^{2}$ & 0.939 & 0.925 \\
\hline
\end{tabular}

The studied sorption curves were sigmoid, with a well-developed hysteresis and can be divided into three zones: the first zone, corresponding to $a_{w}<0.25$, which refers to the adsorption of monomolecular film of water; the second zone corresponding to the adsorption of additional layers over this monolayer at $\mathrm{a}_{\mathrm{w}}=0.26-0.75$ and the third zone for $\mathrm{a}_{\mathrm{w}}>0.76$ corresponds to the condensation of water in the pores of the sample with subsequent dissolution of the soluble material (Mathlouthi, 2001).

Since there were conditionally identified three zones on the sorption isotherm, the moisture content of the adsorption zones was determined to characterize the amount of water adsorbed by the samples. The results are shown in Table 3.

Table 3

Amount of adsorbed moisture by the investigated samples of fondant candies

\begin{tabular}{|c|c|c|c|c|c|c|}
\hline \multirow{3}{*}{$\begin{array}{c}\text { Sample } \\
\text { of } \\
\text { candies }\end{array}$} & \multicolumn{6}{|c|}{ Amount of adsorbed moisture, $\mathrm{cm}^{3} / \mathrm{g}$} \\
\hline & \multicolumn{2}{|c|}{$\begin{array}{c}\text { First zone } \\
a_{w}=0.02-0.25\end{array}$} & \multicolumn{2}{|c|}{$\begin{array}{c}\text { Second zone } \\
\mathbf{a}_{\mathbf{w}}=\mathbf{0 . 2 6}-0.75\end{array}$} & \multicolumn{2}{|c|}{$\begin{array}{c}\text { Third zone } \\
\mathbf{a}_{\mathrm{w}}=0.76-1.0\end{array}$} \\
\hline & Sorption & Desorption & Sorption & Desorption & Sorption & Desorption \\
\hline $\begin{array}{l}\text { Control } \\
\text { sample }\end{array}$ & $\begin{array}{c}0.0005- \\
0.0036\end{array}$ & $\begin{array}{c}0.1226- \\
0.0874\end{array}$ & $\begin{array}{c}0.0040- \\
0.0340\end{array}$ & $\begin{array}{c}0.2549 \\
0.1229\end{array}$ & $\begin{array}{c}0.0341- \\
0.6498\end{array}$ & $\begin{array}{c}0.6498- \\
0.2552\end{array}$ \\
\hline $\begin{array}{l}\text { Sample } \\
\text { based on } \\
\text { tagatose } \\
\text { and } \\
\text { fructose }\end{array}$ & $\begin{array}{c}0.0005- \\
0.0057\end{array}$ & $\begin{array}{c}0.1207- \\
0.1138\end{array}$ & $\begin{array}{c}0.0086- \\
0.1291\end{array}$ & $\begin{array}{c}0.4091- \\
0.1219\end{array}$ & $\begin{array}{c}0.1308- \\
1.5499\end{array}$ & $\begin{array}{c}1.5498 \\
0.4138\end{array}$ \\
\hline
\end{tabular}

The first zone corresponds to the hydration of the most active adsorption centers, which include hydrophilic - $\mathrm{OH}$ groups of sugars. It is represented by the adsorption of the monomolecular layer. Since adsorption occurs on the surface of the adsorbent, the larger the surface, the higher its adsorption capacity. But adsorption can occur only in certain areas of the adsorbent - active centers: corners, ribs of crystals which have a greater excess surface energy compared to the total surface area (Clément et al., 2018). Despite the fact that fondant candies have a fine crystalline structure, which is filled with active centers, in this area of pressure sorption is almost non-existent. This can be explained by the fact that in samples with a crystalline structure, moisture can interact only through hydrogen bonding on the 
crystal surface, because the location of a dense crystal lattice excludes foreign molecules such as water (Bell et al., 2000). Thus, the moisture content remains low and almost constant until the $a_{w}$ value becomes high enough to cause the crystal surface dissolution at the point of contact. Above this relative humidity, water is able to dissolve the crystals, and the content of adsorbed moisture increases rapidly (Ergun et al., 2010; Sokolenko et al., 2020).

The amount of adsorbed moisture in the studied samples of candies at low values of $\mathrm{a}_{\mathrm{w}}$ had a slight difference. This can be explained by the fact that sucrose and tagatose form a dense surface which minimizes the permeability of water to the central layers of candies.

The next stage of hydration of candies (zone II) is manifested in the appearance of a small rise of the adsorption curve in the range of activities $a_{w}=0.25-0.75$. This is due to the gradual dissolution of the outer crystals of fondant with the gradual penetration of water molecules into the central layers of candy. The increase in the sorption properties of confectionery in this zone is due to the fact that the dissolution of sugars begins, similar patterns were observed in determining the sorption properties of rahat-lukum (Gostus et al., 1998). It is known that for pure crystalline sucrose the increase in moisture is very small, as long as the value of $\mathrm{a}_{\mathrm{w}}$ does not exceed 0.8 , and below this value water is connected by hydrogen bonds with groups $-\mathrm{OH}$, which are on the crystal surface (Labuza et al., 2008). No similar results were found for tagatose.

It can be assumed that the faster the process of dissolving sugar crystals, the faster the moisture will be able to penetrate into the central layers of fondant samples. In this zone, the lowest amount of adsorbed moisture was in the control sample of fondant candies on sucrose $-0.0340 \mathrm{~cm}^{3} / \mathrm{g}$, compared to the sample based on tagatose and fructose $-0.1291 \mathrm{~cm}^{3} / \mathrm{g}$. This is due to the higher solubility of fructose compared to other studied sugars and its ability to absorb moisture at $\mathrm{a}_{\mathrm{w}}=0.45-0.50$.

In zone III there is a process of active absorption of moisture by samples of candies. The amount of water adsorbed in the third zone was $91.67-94.76 \%$ of the total amount of moisture (at $\mathrm{a}_{\mathrm{w}}=1.00$ ). The difference between the indicators of adsorbed moisture in the samples at $\mathrm{a}_{\mathrm{w}}=0.76 \ldots 1.0 \mathrm{had}$ a pronounced value, which can be explained by the different chemical composition of the studied samples of candies. Thus, in the developed sample the sorption capacity was higher than in the control sample due to the higher hygroscopicity of not only fructose but also tagatose in this moisture range. Thus, in the zone of capillary moisture $\left(\mathrm{a}_{\mathrm{w}}=1.0\right)$ the lowest amount of adsorbed moisture was in the control sample of fondant candies on sucrose $-0.6498 \mathrm{~cm}^{3} / \mathrm{g}$, compared to the sample based on tagatose and fructose $-1.5499 \mathrm{~cm}^{3} / \mathrm{g}$.

Table 4 shows the ratio of less bound and strongly bound water in the studied samples of candies. Free water has an enthalpy of vaporization almost the same as pure water, it freezes and is a solvent.

Table 4

Amount and ratio of bound and free moisture in the samples of fondant candies

\begin{tabular}{|l|c|c|c|}
\hline \multirow{2}{*}{ Sample } & \multicolumn{3}{|c|}{$\begin{array}{c}\text { Amount of strongly bound and less bound moisture, } \\
\mathbf{c m}^{\mathbf{3}} / \mathbf{h} / \text { ratio, \% }\end{array}$} \\
\cline { 2 - 4 } & $\begin{array}{c}\text { Zone I and zone II, } \\
\text { strongly bound } \\
\text { moisture }\end{array}$ & $\begin{array}{c}\text { Zone III, } \\
\text { less bound } \\
\text { moisture }\end{array}$ & $\begin{array}{c}\text { Total amount of } \\
\text { sorbed moisture }\end{array}$ \\
\hline Control sample & $0.0340 / 5.24$ & $0.6158 / 94.76$ & $0.6498 / 100$ \\
\hline $\begin{array}{l}\text { Sample based on } \\
\text { tagatose and fructose }\end{array}$ & $0.1291 / 8.33$ & $1.4207 / 91.67$ & $1.5499 / 100.0$ \\
\hline
\end{tabular}


Comparative analysis of the obtained isotherms (Figure 1) shows that the isotherms of desorption (drying) in all samples were situated above the isotherms of sorption (humidification). The hysteresis loop covers the entire range of equilibrium vapor pressures. This indicates that the dehydration process is completely irreversible. After the desorption process, a small part of the adsorbed moisture remains in the samples $(0.55$ and $0.37 \%)$. Obtained data may suggest that some part of the adsorbed moisture binds to the sample with very strong bonds, most likely chemical. This moisture is not removed under these desorption conditions.

With the help of sorption analysis it is also possible to establish the equilibrium humidity of the studied samples of unglazed fondant candies with different carbohydrate composition. It is known that during storage of fondant candies on sucrose, they will give off moisture to the environment until the establishment of equilibrium humidity (Opris et al., 2020). Table 5 shows the values of equilibrium humidity of samples of fondant candies at values of relative humidity, which are in the range of $65-80 \%$. This range of values of relative humidity is due to the fact that there are recommendations for storage of most finished confectionery products with a relative humidity of 70-75\% (Sweets. General technical conditions, 2015). However, storage conditions may be such that the relative humidity may be lower or higher than the standard, so the range of relative humidity values was expanded from 65 to $80 \%$.

Table 5

Value of equilibrium humidity of samples of fondant candies depending on the relative humidity

\begin{tabular}{|c|c|c|c|c|}
\hline \multirow{3}{*}{ Sample } & \multirow{3}{*}{ Moisture, \% } & \multirow{2}{*}{\multicolumn{3}{|c|}{$\begin{array}{c}\text { Value of the equilibrium humidity of samples of } \\
\text { candies, } \%\end{array}$}} \\
\hline & & & & \\
\hline & & 70 & 75 & 80 \\
\hline $\begin{array}{l}\text { Fondant candies } \\
\text { based on sucrose }\end{array}$ & 10.0 & 0.23 & 3.40 & 4.32 \\
\hline $\begin{array}{l}\text { Fondant candies } \\
\text { based on tagatose } \\
\text { and fructose }\end{array}$ & 10.5 & 9.10 & 12.90 & 34.10 \\
\hline
\end{tabular}

Analyzing the data in table 5, it should be noted that the sample of fondant candies on sucrose had an equilibrium moisture content below the mass fraction of moisture when stored within a relative humidity of $70-80 \%$, so the phenomenon of desorption will be active in it. But in the sample of candies based on tagatose with fructose, the phenomenon of desorption will be observed at a relative humidity of $70 \%$ and below, and at a relative humidity above $75 \%$ there will be a phenomenon of sorption of moisture from the environment. It can be assumed that this is due to the hygroscopic properties of the sugars, as it is known that sucrose and tagatose at $\mathrm{a}_{\mathrm{w}}=0.75$ do not absorb moisture. Fructose begins to absorb moisture at $\mathrm{a}_{\mathrm{w}}=$ $0.45-0.55$ and at $\mathrm{a}_{\mathrm{w}}=0.75$ absorbs it up to $36.3 \%$ by weight of sugar (Polumbrik, 2011).

To ensure the stability of fondant candies based on tagatose during storage, one of the effective ways can be a rational selection of packaging and packaging material, the use of which will avoid contact with unstable environmental characteristics and prevent undesirable sorption and desorption of unglazed fondant candies. 


\section{- Food Technology -}

\section{Conclusion}

1. Sorption properties of fondant candies based on sucrose and on low-glycemic sugars of tagatose and fructose were studied by analyzing their sorption-desorption isotherms.

2. The parameters of BET and Friendlich models were determined and it was found that the coefficients of determination of both models were in the range of $0.8-1.0$, which indicates their suitability for describing the isotherms of the studied products. The value of the coefficient of determination $\mathrm{R}^{2}$ indicates that the obtained experimental values of samples based on sucrose are described with greater accuracy by the considered equations compared to samples based on tagatose and fructose.

3. The adsorbed moisture was distributed by zones and the ratio of less bound and more bound moisture in the studied candies was established, which shows an increase in the amount of more bound moisture in candies based on tagatose and fructose.

4. The equilibrium humidity of candies at different values of relative humidity of ambient air was determined. It was found that the control sample on sucrose is characterized by the phenomenon of desorption, even when stored at relative humidity of $80 \%$, while for the sample of candies based on tagatose and fructose desorption is observed to relative humidity of $70-72 \% \%$, and with increasing of this indicator the phenomenon of sorption will occur.

\section{References}

Andrade R., Lemus R., Perez C. (2011), Models of sorption isotherms for food: Uses and limitations, Vitae, 18(3), pp. 325-334.

Bell L., Labuza T.P. (2000), Moisture Sorption: Practical Aspects of Isotherm Measurement and Use, American Association of Cereal Chemists, Biosystems Engineering, XC(1), pp. 47-61

Bund R., Hartel R. (2010), Crystallization in foods and food quality deterioration. In L. H. Skibsted, J. Risbo, M. L. Andersen (Eds.), Chemical deterioration and physical instability of food and beverages (pp. 186-213), Woodhead Publishing Limited, Cambridge.

Chetana R., Srinivasa P., Yella Reddy S. (2004), Moisture sorption characteristics of milk burfi, an traditional Indian sweet, using sugar substitutes, European Food Research and Technology, 220(2), pp. 136-141, DOI:10.1007/s00217-004-1007-1.

Clément Y., Clément A., Djakalia B. Kablan T. (2018), The prediction of moisture adsorption isotherm for sucrose powder in Côte d'Ivoire. International Journal of Scientific Research and Management, 6(4), pp. 1-9, DOI: 10.18535/ijsrm/v6i4.ft01

Dorokhovych A., Dorokhovych V., Badruk V., Murzin A., Abramova A. (2013), Physicochemical, technological, physiological properties of polyolies and sugars, Food Science and Technology, 1(22), pp. 76-76.

Ergun R., Lietha R., Hartel R. (2010), Moisture and shelf life in sugar confections. Critical Reviews in Food Science and Nutrition, 50(2), pp. 162-192, DOI: 10.1080/10408390802248833

Gögtüş F., Maskan M., Kaya A. (1998), Sorption isotherms of turkish delight. Journal of Food Processing and Preservation, 22(5), pp. 345-357, DOI: 10.1111/j.17454549.1998.tb00355.x

Hadjikinova M., Menkov N., Hadjikinov D. (2011), Sorption characteristics of dietary hard candy, Czech Journal of Food Sciences, 21(3), pp. 97-99, DOI: 10.17221/3483-cjfs 
Han D., Lee B., Yoo S. (2021), Physicochemical properties of turanose and its potential applications as a sucrose substitute, Food Science and Biotechnology, 30(3), pp. 433441, DOI: 10.1007/s10068-021-00876-1.

Hartel R., Ergun R., Vogel S. (2011), Phase/state transitions of confectionery sweeteners: Thermodynamic and kinetic aspects, Comprehensive Reviews in Food Science and Food Safety, 10(1), pp.17-32.

Hadjikinova M., Menkov N., Hadjikinov D. (2003), Sorption characteristics of dietary hard candy, Czech Journal of Food Sciences, 21(3), 97-99.

Ivanov V., Shevchenko O., Marynin A., Stabnikov V., Gubenia O., Stabnikova O., Shevchenko A., Gavva O., Saliuk A. (2021), Trends and expected benefits of breaking edge food technologies in 2021-2030, Ukrainian Food Journal, 10(1), pp. 7-36, DOI: 10.24263 / 2304-974X-2021-10-1-3

Kuzmyk U., Marynin A., Svyatnenko R., Zheludenko Y., Kurmach M. (2021), Determining the effect of apple and banana powders dried by sublimation on the quality indicators of a sour milk dessert during storage, Eastern-European Journal of Enterprise Technologies, 3(11(111), pp. 28-35, DOI: 10.15587/1729-4061.2021.228083

Labuza T., Altunakar L. (n.d.),(2008), Water Activity Prediction and Moisture Sorption Isotherms, Water Activity in Foods, pp. 109-154, DOI:10.1002/9780470376454.ch5

Mathlouthi M. (2001), Water content, water activity, water structure and the stability of foodstuffs. Food Control, 12(7), pp. 409-417, DOI:10.1016/s0956-7135(01)00032-9

Netramai S., Kijchavengkul T., Sompoo P., Kungnimit W. (2018), The effect of intrinsic and extrinsic factors on moisture sorption characteristics of hard candy, Journal of Food Processing and Preservation, 42(5), DOI:10.1111/jfpp.13599

Opris O., Lung I., Soran M.,Sturza R., Chendov-Mosanu A. (2020), Fondant candies enriched with antioxidants from aronia berries and grape marc, Revista de Chimie, 71(2), pp. 74 79, DOI: 10.37358/RC.20.2.7895

Ozcan O., Yildirim R. M., Toker O. S., Akbas N., Ozulku G., Yaman M. (2019), The effect of invertase concentration on quality parameters of fondant, Journal of Food Science and Technology, DOI: 10.1007/s13197-019-03894-4.

Rodríguez-Bernal, J., Flores-Andrade E., Lizarazo-Morales C., Bonilla E., Pascual-Pineda L., Gutierrez-Lopez G., Quintanilla-Carvajal M. (2015), Moisture adsorption isotherms of the borojo fruit (Borojoa patinoi. Cuatrecasas) and gum Arabic powders, Food and Bioproducts Processing, 94, pp. 187-198.

Rubio-Arraez S., Sahuquillo S., Capella J., Ortolá M., Castelló M. (2015), Influence of healthy sweeteners (tagatose and oligofructose) on the physicochemical characteristics of orange marmalade, Journal of Texture Studies, 46(4), pp. 272280, DOI: $10.1111 /$ jtxs. 12127

Sokolenko A., Shevchenko O., Vasylkivskyi K., Boiko O., Shevchenko A. (2019), Modeling and synthesis of intensive mass exchange systems, Ukrainian Food Journal, 8(4), pp. 861-872, DOI:10.24263/2304-974X-2019-8-4-16

Sokolenko A., Shevchenko O., Koval O., Vasylkivskyi K., Maksymenko I., Shevchenko A. (2020), Phase transitions in food production technologies, Ukrainian Food Journal, 9(4), pp. 889-900, DOI: 10.24263 / 2304-974X-2020-9-4-13

Sylchuk T., Tsyrulnikova V., Zuiko V., Riznyk A. (2021), Sorption properties of bread based on oatmeal. Ukrainian Food Journal, 10(3), pp. 361-374

Witczak T., Witczak M., Socha R., StĘPień A., Grzesik M. (2016), Candied orange peel produced in solutions with various sugar compositions: sugar composition and sorption properties of the product. Journal of Food Process Engineering, 40(2), DOI:10.1111/jfpe. 12367 


\title{
Effect of grain mass properties on the processes of extraction and hydration
}

\author{
Tetiana Yaniuk, Tetiana Trakhalo, Halyna Liashko, \\ Olena Galynska, Nataliia Hriunvald
}

National University of Food Technologies, Kyiv, Ukraine

Keywords:

Grain

Hydration

Extraction

Hydromodul

Grinding

\section{Article history:}

Received

01.05.2021

Received in

revised form

12.09.2021

Accepted

30.12.2021

\section{Corresponding} author:

Tetiana Yaniuk

E-mail:

ytata13@ukr.net

DOI:

$10.24263 / 2304-$

974X-2021-10-

4-13

\section{Abstract}

Introduction. The aim of the present research was to determine the quantity of non-freezing water in the mixtures of flax seeds where carbohydrates are mainly heteropolysaccharides and in amaranth, oats and rice mixtures where carbohydrates are mainly monopolysaccharides.

Materials and methods. Water and whey were chosen as solvents. Extracts were prepared by solvent addition to hydrated raw materials with a moisture content, \%: flax seeds, 6.3; amaranth seeds, 9.4; oats. 10.5, and rice, 11.8. The state of water in the mixtures at different stages of hydration was studied by the method of low-temperature canning calorimetry.

Results and discussion. In samples with water as a solvent the total moisture content is $92.4 \%$, bound moisture is $3.77 \%$, and in samples with whey as a solvent it is $83.49 \%$ and $13.44 \%$, respectively. Whereas after the first stage of processing (percolation) these indicators were as follows: total moisture was $99.91 \%$ and bound moisture was $0.09 \%$. Thus, the mechanical treatment that was used to intensify the extraction and hydration processes has provided redistribution of the fractional composition of moisture increasing the amount of the bound water. When using whey as a solvent, this redistribution is even more defined. This process is influenced by the $\mathrm{pH}$ of the environment changed by the whey, but the main factor is carbohydrates, the amount of which in the whey is up to $6.0 \%$.

The weight of freezing water in the treated sample of amaranth suspensions increased to $2.56 \mathrm{mg}$ from the weight of $2.16 \mathrm{mg}$ in the untreated sample. And the mass of bound water in the treated sample was $0.52 \mathrm{mg}$, while in the untreated sample was $0.14 \mathrm{mg}$. In the oat suspensions samples both the initial and treated peaks were almost the same; the shift towards low temperatures was not observed. In the treated sample of rice suspensions, a second small peak occurred and the total area towards the untreated sample increased. It means that the mass of freezing water in rice increased to $2.59 \mathrm{mg}$ from $2.28 \mathrm{mg}$ after treatment in the untreated sample, at the same time, the mass of bound water increased to $0.28 \mathrm{mg}$ from 0.06 $\mathrm{mg}$ in the untreated sample. Percentage of the total moisture in the suspension of amaranth seeds, the amount of freezing water after treatment decreased by $10.84 \%$, in oat suspension by $4.69 \%$, in rice suspension by $7.4 \%$. At the same time, the amount of bound water increased by $10.94 \%$ for the suspension of amaranth seeds, for the suspension of oats by $4.67 \%$, and for the suspension of rice by $7.4 \%$.

The presence of salt or acid also effects on the completeness and speed of the swelling and wet absorption processes, as well as on redistribution of water in the grinded grain.

Conclusions. The mechanical treatment used to intensify the processes of extraction and hydration ensured the redistribution of the fractional composition of moisture in the crushed grain raw materials, increasing the percentage of bound water. 


\section{Introduction}

The role of grain products is often analyzed in the scientific literature regarding the level of consumption and nutritional value (Papanikolaou and Fulgoni, 2017; 2018). Grain products contain dietary fiber (Papanikolaou and Fulgoni, 2017), B vitamins (including thiamine, niacin, riboflavin), vitamin $\mathrm{E}$ and minerals (calcium, magnesium, potassium, phosphorus, iron, sodium, manganese and zinc) (O’Neil et al., 2010).

An important task of the food preparation is the use of gentle modes of processing of raw materials for the purpose of the maximum preservation of valuable nutrients as well as the use of advanced methods of its preparation for increasing the content of biologically active components (Bazhai-Zhezherun et al., 2017).

Cereal-based beverages have a huge potential as functional food. They can serve as carriers for a range of functional compounds, for example antioxidants, dietary fiber, minerals, probiotics, and vitamins. However, more research is needed to fully understand the impact of some of the functional components (e.g. antioxidants) present in cereal-based beverages (Kreisz et al., 2008).

In the current era, the customers are very demanding for an innovative nutritious food with enhanced functionality. Diet containing healthy foods and beverages plays a major role in avoiding and healing of chronic dreadful diseases eventually improving human health. Nutraceuticals are part of food ingredient or source from food products/by-products leading to offer additional strength and beneficial effects. The research on functional constituent has shown promising results for the utilization of such components in food commodities eventually results value addition for manufacturer and healthy for consumers.

Nowadays nutraceuticals are the major components that are being incorporated in novel drug formulations, healthy foods, and food added mixtures. There is slight vagueness among the terms functional foods and nutraceuticals. When plant extract /bioactives/ phytochemicals are used as food additives it is generally termed as functional food, but when the same is consumed in the form of pill/capsule the term nutraceutical is used. Functional beverage, the fastest growing area, is the subsection of functional foods along with nonalcoholic beverages. Therefore, the manufacturing and utilization of functional beverages has achieved much impact. These include processed beverages with health-promoting additives such as dietary fibers, minerals, vitamin-rich beverages, probiotic-rich fermented beverages, vitamin D supplemented milk, vitamins A-, C-, E-enriched nonalcoholic beverages, etc. In the current era beverages are an ideal delivery vehicle for protein, antioxidants, minerals, vitamins, fibers, $\omega-3$ fatty acids, natural plant extracts, prebiotics, probiotics, and other functional ingredients due to the convenience and prospect to fulfill the customers demand. Low-temperature preservation facilitates sustaining these nutrients in active condition. Nonetheless, special apprehension has been boosted up over their security in most cases. The objective of this review includes promising trends of usage of functional beverages with special attention on commercial beverages and their health benefits vs. their health implications (Ghoshal and Kansal, 2019).

Processing is a prerequisite for the use of cereal grains in food. Processing involves the use of one or more-unit operations, involving application of mechanical or thermal energy, hydration and often activation of the endogenous biological enzymatic system of the grains. These operations induce various macroscopic to molecular level changes in the grain components, hence affecting the nutritional, technological and sensory properties of the products (Poutanen et al., 2014; Rosa-Sibakov et al., 2015).

While cereal processing (milling, extrusion, and baking) is designed to create intentional changes in dietary fiber, unintentional changes due to oxidation and enzymatic hydrolysis by endogenous or microbial enzymes can also occur. Both intentional and unintentional changes in solubility, extractability and physicochemical properties of dietary fiber and restructuring of the 


\section{— Food Technology —}

grain matrix can either unlock or hamper the physiological and technological value of dietary fiber (Smith et al., 2020; Seal et al., 2021).

One such way of processing vegetable raw materials is extraction. This process makes it possible to extract biologically active substances from raw materials. The advantages of this method are as follows: short duration of the extraction process, usability, and mild conditions preventing the destruction of raw material, high efficiency and ability to be combined with other methods (Gulevich et al., 2009).

There are two stages in the extraction process: swelling of the raw material with a solution of the constituent components of the grinded grain particles and the extraction process, when the particles are transported from cell membranes and capillaries into the mass of the solvent. As a rule, the swelling of raw materials takes about 5-6 hours and even more.

The use some methods of preparation and processing of raw materials, such as infrared and ultraviolet radiation, ultrasonic action, the use of rotary pulse devices and dispersants can accelerate the extraction process by 5-6 times and significantly increase the yield of extractives to $20-40 \%$.

The extract is a concentrated substrate removed from the grain. There are liquid extracts, viscous masses with a moisture content not more than $25 \%$, dry extracts with a moisture content not more than 5\%.

The purpose of this research is to obtain experimental results determining the amount of antifreeze water in mixtures of flax seeds where carbohydrates are mainly heteropolysaccharides, in amaranth, oats, rice mixtures where carbohydrates are represented mainly by monopolysaccharides.

\section{Materials and methods}

\section{Materials}

\section{Sample preparation: grain and seed extracts}

The following samples were selected as materials for the research:

a. Flax seed extracts with water and whey:

1 - sample after mechanical treatment, whey as an extractant (upper layer),

2 - sample after mechanical treatment, whey as an extractant (suspension),

3 - sample after mechanical treatment, water (upper layer);

b. Extracts of amaranth seeds with water:

4 - suspension of amaranth in water (initial sample),

5 - suspension of amaranth in water (mechanical treatment);

c. Oat grain extracts with water:

6 - oat suspension in water (initial sample),

7 - oat suspension in water (mechanical treatment);

d. Rice grain extracts with water

8 - suspension of rice in water (initial sample),

9 - suspension of rice in water (mechanical treatment).

Extracts were prepared by addition of water or whey to the raw material in a ratio of 5: 1 at a temperature of $25^{\circ} \mathrm{C}$. 


\section{Methods}

\section{Mass fraction of moisture}

The mass fraction of moisture in the experimental samples was determined by the method of drying to constant weight. Preparation of samples. To determine the mass fraction of moisture from the average grain sample allocate about $30 \mathrm{~g}$, grind to standard size, so that when sifting through a wire sieve with a hole size of $0.8 \mathrm{~mm}$ passed oats - not less than $30 \%$, rice and amaranth $-50 \%$ of total grinding. The ground grain is collected in a glass jar with a ground lid and mix well. From different places jars spoon take portions of ground grain weighing $5 \mathrm{~g}$, weighed on analytical balances and placed in a pre-dried box and dried in an oven at $\mathrm{t}=100-105^{\circ} \mathrm{C}$ until a constant weight of the residue. Constant weight is considered to be achieved if the difference between the two weighings does not exceed $0.001 \mathrm{~g}$. The first weighing is carried out in 4-6 hours from the beginning of drying, and each subsequent - in 2 hours. Differences between re-determinations by this method are within $1 \%$ (relative).

In order to determine the moisture content of flax seeds, it does not need to be crushed. The mass fraction of moisture is determined by the same parameters as for other grain samples (Koryakov et al., 2012).

\section{Determination of water status in the obtained extracts}

Water state in the obtained mixtures at different stages of hydration was investigated by the method of low-temperatures canning calorimetry.

To determine the state of water in the obtained extracts from flax seeds and starchy grain raw materials, thermodynamic method was used. The essence of this method is to determine the fractional composition of water, i.e. water in the bound state has other physical and chemical properties, and it has no phase of the first order transition below $273 \mathrm{~K}$.

If the system, which contains both free and bound water, is subjected to cooling and subsequent heating in the calorimeter, one can see the peaks of crystallization and melting of only free water on the corresponding thermograms.

The exothermic peak of crystallization, which corresponds to a non-equilibrium process, has the form of a ballistic curve. Therefore, the quantification of heat dissipation cannot be performed. The melting process on the thermogram is recorded in the form of a time-stretched endothermic peak or several peaks.

Since the melting process is an equilibrium process, the peak area bounded by the DSC curve and the baseline of the calorimeter is proportional to the heat of the phase transition, and accordingly to the amount of free water (Sniezhkin et al., 2011).

\section{Determination of absolute values of heat absorption}

Absolute values of heat absorption were calculated using the data obtained during calibration, where double-distilled water was used as a standard substance.

The mass of non-freezing water defined as the bound one, is the difference between the total mass of water in the samples and the mass of the freezing part:

$$
m_{n f}=m_{w}-\frac{A_{f} \cdot m_{s t} \cdot \Delta H_{s t}}{A_{s t} \cdot \Delta H_{f}}
$$


where:

$A$ is the area under the melting curve; $m_{2}$

$\mathrm{m}$ is mass; $\mathrm{kg}$

$\mathrm{H}$ is enthalpy of melting; $\mathrm{J} / \mathrm{kg}$

$r$ is the correlation coefficient;

$\mathrm{f}$ is freezing water;

$\mathrm{nf}$ is non-freezing water;

st is a standard substance;

$\mathrm{w}$ is a total moisture.

In this case it is assumed that the enthalpy of water melting in a jelly-like mixture and water are equal (Dmytrenko et al. 2011).

\section{Result and discussion}

\section{Mass fraction of moisture}

The mass fraction of moisture in studied materials has the following meanings (Table 1):

Mass fraction of moisture in studied materials

Table 1

\begin{tabular}{|c|c|}
\hline Seed & Mass fraction of moisture, \% \\
\hline Flax seeds & $6,3 \pm 0,1$ \\
\hline Amaranth seeds & $9,4 \pm 0,2$ \\
\hline Oats & $10,5 \pm 0,4$ \\
\hline Rice & $11,8 \pm 0,3$ \\
\hline
\end{tabular}

The study of the mass fraction of moisture in cereals showed that $1 / 3$ of the moisture is in the form of a solvent in the intercellular space, $2 / 3$ is bound to the polymers and are included into plant fibers and polysaccharides.

\section{Water status in the obtained flax seed extracts}

If the system, which includes both free and bound water, is subjected to cooling and subsequent heating in the calorimeter, the peaks of crystallization and melting of only free water on the corresponding thermograms can be observed (Pooria et al., 2010) (Figure 1).

Figure 1 shows specific DSC curves of heating samples of flax seed extracts. As can be seen from thethermogram, qualitative changes in the investigated samples do not occur, and they start at $-58^{\circ} \mathrm{C}$ temperature in the form of an almost straight line:

1. DSC curve (liquid part, where whey was used as a solvent), the state of almost straight line (slight voltage fluctuations) ends at $-16{ }^{\circ} \mathrm{C}$;

2. DSC curve (machined sample, homogeneous by means of mixing, with whey as a solvent), the state of the straight line ends at $-12{ }^{\circ} \mathrm{C}$, this is the largest angle of inclination and we recorded the voltage change from 2 to $2.5 \mathrm{mV}$; 
3. DSC curve (machined sample, homogeneous, water as a solvent), the state of the straight line ends at $-16^{\circ} \mathrm{C}$.

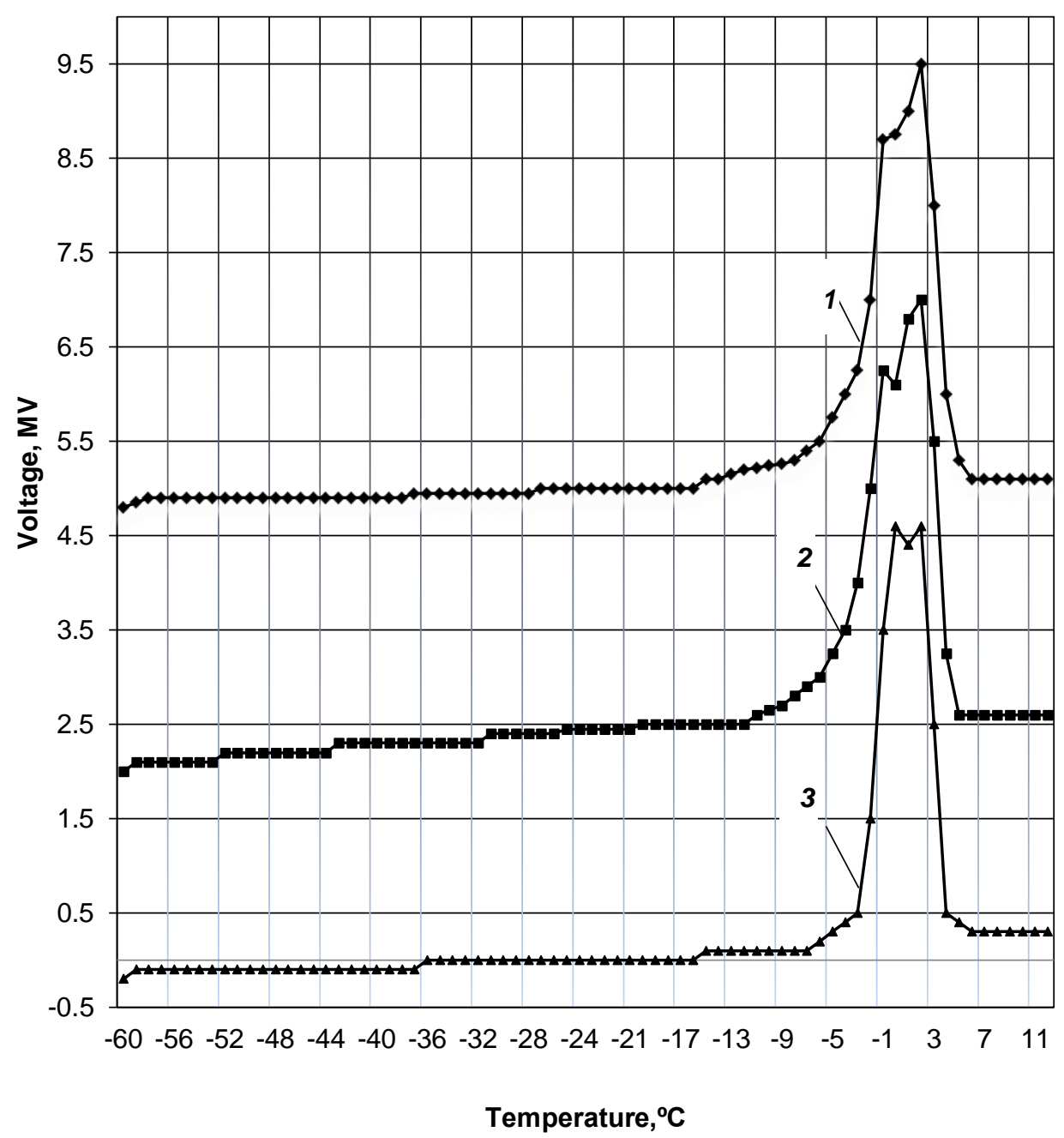

Figure 1. DSC curves of flax seed suspension samples:

1 - sample of flax seed extract with whey after mechanical treatment (upper layer);

2 - sample of flax seed extracts with whey (suspension);

3 - sample of flax seed extract with water after mechanical treatment (upper layer).

If the suspension's cooling takes place faster than water diffusion can occur (subsequently this does not allow water to crystallize intensively), the concentrated amorphous solution has a low concentration (Pooria et al., 2010). As a result, the vitreous transition takes place at low temperature, as in the flax seeds sample $\left(-12--16^{\circ} \mathrm{C}\right)$. If the 


\section{Food Technology —}

cooling is slow, the glassy transition takes place at higher temperatures $(-2--4){ }^{\circ} \mathrm{C}$ and constant concentration (the same concentration as in grain raw materials consisting mainly of starch). Thus, it can be argued that the concentration of the amorphous solution has a constant concentration of $0.1-0.25 \mathrm{~g} / \mathrm{g}$ and below. In this case, the vitreous transition has insignificant values even in case of DSC measurements at high temperatures $\left(70{ }^{\circ} \mathrm{C}\right)$, as it is known from the scientific resource (Dmytrenko et al., 2011).

A rapid decrease in temperature during cooling of the samples leads to a sharp increase in the viscosity of cellular moisture. Thus, this leads to a decrease of moisture diffusion rate to the surface of the growing ice crystals (Pooria et al., 2010). As a result, the part of freezing water in the solution and in the capillaries of the dietary fibers is in the state of glass transition. It crystallizes only during the next slow heating. As we can see on 1 and 2 curves (whey as a solvent), the path of the curves of glassy transition is much less than on the curve 3 . It can be explained by the fact that the whey due to the presence of lactic acid accelerates the movement of moisture and therefore is subjected to the process of glassy transition. The process of moisture crystallization takes place faster on the 3 DSC curve than on the 1 and 2 DSC curves, as they used whey as a solvent.

Analysis of experimental data for flax seeds shows that in samples with water as a solvent the total moisture is $92.4 \%$, bound moisture is $3.77 \%$, and in samples with whey as a solvent it is $83.49 \%$ and $13.44 \%$ respectively. Whereas after the first stage of processing (percolation) these indicators were as follows: total moisture was $99.91 \%$ and bound moisture $-0.09 \%$. Thus, the mechanical treatment that was used to intensify the extraction and hydration processes has provided redistribution of the fractional composition of moisture in the bound water's favor. When using serum as a solvent, this redistribution is even more defined. Of course, this is influenced by the $\mathrm{pH}$ of the environment changed by the whey, but the main factor is carbohydrates, the amount of which in the whey is up to 6.0\% (Dmytrenko et. al., 2011).

The obtained experimental results provide a basis for a new description of the moisture transition from the free state to the bound one by hydration during the extraction process.

\section{Water status in the obtained extracts of amaranth, oats, and rice}

According to the same scheme, the redistribution of water during hydration of grinded grain raw materials was investigated. The raw materials contained starch (amaranth seeds, oats, rice which belong to monopolysaccharides) and starch grains consist of amylose (70$80 \%$ ) and amylopectin (30-20\%). These polysaccharides contribute to the maximum swelling figures and water retention at a temperature of $60-80^{\circ} \mathrm{C}$. But in order to with stand the same experimental conditions, the determination of the water state and its redistribution after treatment in the secereals was also carried out at a temperature of $25^{\circ} \mathrm{C}$, along with flax seeds, in which carbohydrates are represented by heteropolysaccharides (Mihaylik et al., 2007).

The obtained DSC curves of water melting in suspensions of all types of grain raw materials, which consist mainly of monopolysaccharides without mechanical treatment (Figure 2) have a specific shape that differs from DSC curves of melting water with mechanical treatment and differs significantly from DSC curves of heteropolysaccharides (flaxseeds) (Figure 1). 


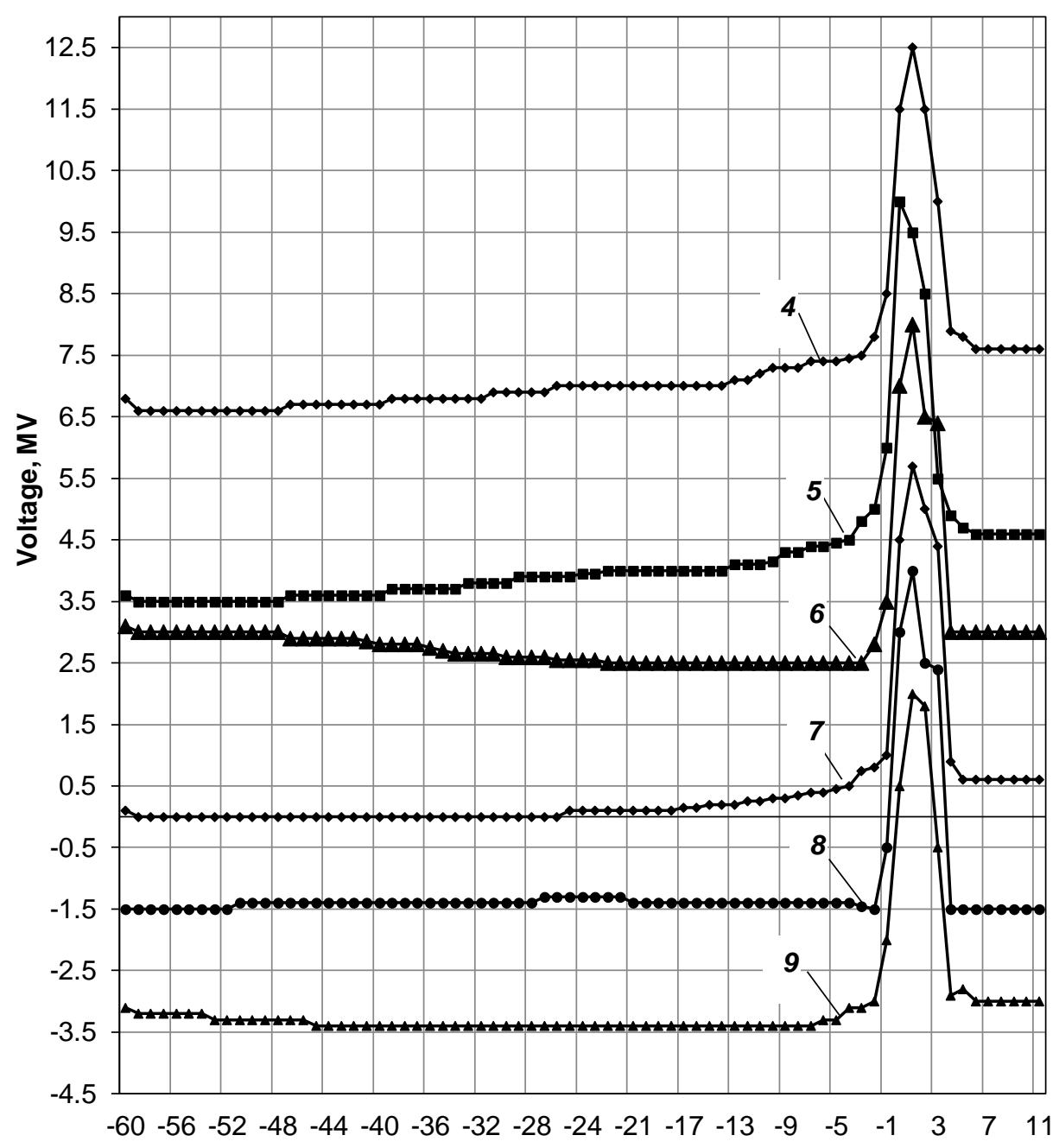

Temperature, ${ }^{\circ} \mathrm{C}$

Figure 2. DSC curves of suspensions samples of amaranth, oats, and rice seeds.

4 - suspension of amaranth in water (initial sample);

5 - suspension of amaranth in water (mechanical treatment );

6 - suspension of oats in water (initial sample);

7 - suspension of oats in water (mechanical treatment );

8 - suspension of rice in water (initial sample);

9 - suspension of rice in water (mechanical treatment ). 


\section{Food Technology —}

The weight of freezing water in the treated sample of amaranth suspensions increased to $2.561 \mathrm{mg}$ from the weight of $2.164 \mathrm{mg}$ in the untreated sample. And the mass of bound water in the treated sample was $0.519 \mathrm{mg}$, while in the untreated sample $-0.136 \mathrm{mg}$. In the oat suspensions samples both the initial and treated peaks were almost the same; the shift towards low temperatures was not observed. In the treated sample of rice suspensions, a second small peak occurred and the total area towards the untreated sample increased. It means that the mass of freezing water in rice increased to $2.590 \mathrm{mg}$ from $2.275 \mathrm{mg}$ after treatment in the untreated sample, at the same time, the mass of bound water increased to $0.280 \mathrm{mg}$ from $0.055 \mathrm{mg}$ in the untreated sample. Analysis of the obtained experimental data showed that percentage of the total moisture in the suspension of amaranth seeds, the amount of freezing water after treatment decreased by $10.84 \%$, in oat suspension by $4.69 \%$, in rice suspension by $7.4 \%$. At the same time, the amount of bound water increased by $10.94 \%$ for the suspension of amaranth seeds, for the suspension of oats by $4.67 \%$, and for rice by $7.4 \%$ (Dmytrenko et. al., 2011).

Based on the above, it can be concluded that the mechanical treatment used to intensify the extraction and hydration processes has provided a redistribution of the fractional composition of moisture increasing content of bound moisture. However, the processes of moisture binding by monopolysaccharides, which include amaranth, oats, rice, are significantly different from the moisture binding by heteropolysaccharides (flaxseeds). Further experiments to determine the state of water and its redistribution during hydration at different environment temperatures will be planned in the future researches.

\section{Conclusions}

1. Experimentally, using the DSC method the results of determining the amount of antifreeze water in suspensions were obtained and the dynamics of its change during hydration was determined. The amount of bound water after pre-treatment with water as a solvent (infusion) was $0.09 \%$ and after mechanical treatment it was $3.77 \%$; after mechanical treatment with whey as a solvent (upper part) the amount was $11.04 \%$ and mixed homogeneous sample $13.44 \%$.

2. It was revealed that the total content of dissolved substances and moisture content can be judged by the amount of displacement of the melting peak's maximum. Thus, in the initial mixture of flax and water it is $93.5 \mathrm{~g} / \mathrm{g}_{\mathrm{d} . \mathrm{m} .}$. , in machined $12.16 \mathrm{~g} / \mathrm{g}_{\mathrm{d} . \mathrm{m}}$; in suspensions with whey, respectively $7.53 \mathrm{~g} / \mathrm{g}_{\mathrm{d} . \mathrm{m} .}$ and $5.06 \mathrm{~g} / \mathrm{g}_{\mathrm{d} . \mathrm{m}}$.

3. Based on the results it was proved that the applied mechanical treatment, type of the solvent and ambient temperature provide intensification of extraction and hydration processes, as well as redistribution of the fractional composition of bound water's favor.

4. The method of low-temperature DSC was used to study the content of bound water in the system of grain raw materials (amaranth seeds, oats, rice), which consists mainly of starch (water depending on the processing parameters (infusion) and mechanical treatment at a constant temperature $-25^{\circ} \mathrm{C}$ and type of solvent (water).

5. It was investigated that the content of bound water during mechanical treatment in comparison with infusion increased by 4 times for amaranth seeds, 3 times for rice, and 1.4 times for oats. 


\section{References}

Bazhai-Zhezherun S., Bereza-Kindzerska L., Tohachynska L. (2017), Vplyv roslynnykh ekstraktiv na syntez vitaminiv pid chas proroshchuvannia zerna, Proceedings of the XIV International Conference "Strategy of Quality in Industry and Education" is issued in two volumes (articles, theses), 2017, Varna, Bulgaria, 2, pp. 118-121.

Dmytrenko N. V., Dubovikova N. S., Snjezhkin Ju. F., Mykhajlyk V. A., Dekusha L. V., Vorobjov L. J. (2011), Vyvchennja vplyvu stanu vody v kharchovykh roslynnykh materialakh na teplotuvy parovuvannja, Naukovi praci Odesjkoji nacionaljnoji akademiji kharchovykh tekhnologhij, 40(2), pp. 71-75.

Ghoshal G., Kansal S.K. (2019), The emerging trends in functional and medicinal beverage research and its health implication, Functional and Medicinal Beverages, Volume 11: The Science of Beverages, pp. 41-71.

Gulevich A.L., Leshchev S.M., Rakhman'ko E.M. (2009), Ekstraktsionnye metody razdeleniya i kontsentrirovaniya veshchestv, BGhU, Minsk.

Koryakov V.I., Medvedevskikh M.Y., Medvedevskikh S.V., Parfenova E.G., Sobina E.P. (2012), Development of standard samples of mass fractions of moisture and protein in grain and grain products, Measurement Techniques, 54(10), pp. 1198-1210.

Kreisz S., Arendt E. K., Hübner F., Zarnkov M. (2008), Cereal-based gluten-free functional drinks, Food Science and Technology, pp. 373-392.

Mihaylik V.A., Dmitrenko N.V., Mihaylik T.A. (2007), Vliyanie termicheskogo vozdeystviya na sostoyanie vodyi v rastitelnyih tkanyah, Promyishlennaya Teplotehnika, 29(7), pp. 212-217.

O’Neil C.E., Nicklas T.A., Zanovec M., Cho S. (2010), Whole-Grain Consumption Is Associated with Diet Quality and Nutrient Intake in Adults: The National Health and Nutrition Examination Survey, 1999-2004, Available at: https://www.jandonline.org/article/S00028223\%2810\%2901191-0/fulltext

Papanikolaou Y., Fulgoni V. (2017), Certaingrain foods can be meaningful contributors to nutrient density in the diets of U.S. children and adolescents: Data from the national health and nutrition examination survey, 2009-2012, Available at: https://grainfacts.com/grains-contributeshortfall-nutrients

Papanikolaou Y., Fulgoni V. (2018), Grains Contribute Shortfall Nutrients and Nutrient Density to Older US Adults: Data from the National Health and Nutrition Examination Survey, 2011-2014, Available at: https://www.ncbi.nlm.nih.gov/pmc/articles/PMC5986414/

Poutanen K., Sozer N., Della Valle G. (2014), How can technology help to deliver more of grain in cereal foods for a healthy diet?, Journal of Cereal Science, 54, pp. 327-336.

Gill P., Moghadam T.T., Ranjbar B. (2010) Differential scanning calorimetry techniques: Applications in biology and nanoscience, Journal of Biomolecular Techniques, 21(4): 167-193.

Rosa-Sibakov N., Poutanen K., Micard V. (2015), How does wheat grain, bran and aleurone structure impact their nutritional and technological properties?, Trends Food Science Technology, 41, pp. 118-134.

Seal C.J., Courtin C.M., Venema K., de Vries J. (2021), Health benefits of whole grain: effects on dietary carbohydrate quality, the gut microbiome, and consequences of processing, Comprehensive Reviews in Food Science and Food Safety, 20, pp. 2742-2768.

Smith C., Van Haute M.J., Rose, D.J. (2020), Processing has differential effects on microbiota-accessible carbohydrates in whole grains during in vitro fermentation, Applied and Environmental Microbiology Journal, 86, pp. 105-120.

Sniezhkin Yu., Mykhailyk V., Dmytrenko N. (2011), Dynamika zminy stanu vody v parenkhimnykh tkanynakh roslyn pry sushinni, Promyslova Teplotekhnika, 33(2), pp. 35-40. 


\title{
Antioxidant characteristics of tea-herbal compositions
}

\section{Oleg Kuzmin, Nataliia Stukalska, Larysa Mykhonik, Olga Koval, Volodymyr Polyovyk, Ganna Berezova}

\author{
National University of Food Technologies, Kyiv, Ukraine
}

Keywords:

Herbal tea

Infusion

Antioxidant

Redox potential

Quality

\section{Article history:}

Received 21.03.2021

Received in revised

form 30.07.2021

Accepted

30.12.2021

\section{Corresponding author:}

Oleg Kuzmin

E-mail:

kuzmin_ovl@ukr.net

DOI:

$10.24263 / 2304-$ 974X-2021-10-4-14

\section{Abstract}

Introduction. The aim of the study was to determine the antioxidant capacity of herbal infusions and evaluate the possibility of using them to create herbal tea compositions.

Materials and methods. Antioxidant capacity of tea-herbal compositions was determined by redoxmetry and $\mathrm{pH}$-metry; sensory indicators were evaluated by expert method; results of mathematical and statistical processing were assessed by the method of linear Pearson correlation.

Results and discussion. The $\mathrm{pH}$ for water infusions from raw materials has a value of 2.35 for Hibiscus sabdariffa and 6.55 for Calamintha nepeta. The minimum theoretical value of RP $\left(E h_{\min }\right)$ for plant water infusions was obtained, which has a value from 267.0 $\mathrm{mV}$ for Calamintha nepeta to $519.0 \mathrm{mV}$ for Hibiscus sabdariffa. The actual measured RP of infusions $\left(E h_{a c t}\right)$ was established as 37.0 $\mathrm{mV}$ for Daucus carota and $203.0 \mathrm{mV}$ for Hibiscus sabdariffa. Water infusions from vegetable raw materials have the value of regenerative capacity (recovery energy, $R E_{i n f}$ ) in the range from $R E_{\text {inf }} 150.8 \mathrm{mV}$ for Vitis vinifera) to $R E_{\text {inf }} 316.0 \mathrm{mV}$ for Hibiscus sabdariffa. For the restaurant business in the manufacture of beverages are promising water infusions of Hibiscus sabdariffa and Citrus limonum, which received increased antioxidant characteristics $R E_{\text {inf }} 316.0 \mathrm{mV}$ and $298.0 \mathrm{mV}$, respectively, and positive sensory evaluation. It is proved that the energy of reduction/oxidation of vegetable raw materials $\left(R E_{\text {plant }}\right)$ relative to the solvent - prepared water is in the range of values from $45.8 \mathrm{mV}$ for Vitis vinifera to $211.0 \mathrm{mV}$ for Hibiscus sabdariffa. Based on mathematical and statistical analysis, it was found that physicochemical parameters in the range of values with very high correlation ( $r$ 0.9-1.0) includes the following indicators: $\mathrm{pH}, E h_{\text {min }}$, $R E_{i n f}, R E_{\text {plant }}$. Rational composition of tea-herbal composition was found: Hibiscus sabdariffa, $30 \%$; Matricaria chamomilla, $20 \%$; Ilex paraguariensis, $10 \%$; Rosae fructus, $10 \%$; Mentha piperita, $10 \%$; Citrus sinensis, $8 \%$; Citrus limonum, $7 \%$; Calendulae flores, $5 \%$.

Conclusion. For the technology of the restaurant industry, the use of tea-herbal compositions from plant materials Hibiscus sabdariffa, Matricaria chamomilla, Ilex paraguariensis, Rosae fructus, Mentha piperita, Citrus sinensis, Citrus limonum, Calendulae flores, which have increased antioxidant characteristics, is proposed. 


\section{Introduction}

\section{Characteristics of tea}

The interest of consumers in tea (Camellia sinensis) (Spizzirri et al., 2019) is explained by the fact that tea has pleasant characteristics of taste, aroma, color (Banerjee (Roy) et al. 2016; Xu et al., 2018; Zeng et al., 2017). The aroma molecules are formed mainly from precursor groups: carotenoids, fatty acids, glycosides, amino acids/sugars, volatiles ketones and alkenes (Chen et al., 2019; Feng et al., 2019; Guo et al., 2019; Li et al., 2019; Qi et al., 2018; Zhu et al., 2016). Tea aroma concentration determined by the following sequence: black $>$ white $>$ oolong $>$ dark $>$ yellow $>$ green. Black tea has the highest volatile concentration of $710 \mu \mathrm{g} / \mathrm{g}$, while green tea has the lowest concentration of $20 \mu \mathrm{g} / \mathrm{g}$ (Feng et al., 2019). Tea has a tonic effect (Długaszek et al., 2020) - to maintain the health (Hayat et al., 2015; Spizzirri et al., 2019; Vuong, 2014), normalizes metabolism, increases efficiency, eliminates fatigue (Długaszek, Kaszczuk, 2020), increases resistance to stress (Xia et al., 2020). If soft drinks lower the temperature only in the oral cavity, then tea has the ability to lower the temperature of the whole body by $1-2{ }^{\circ} \mathrm{C}$.

Tea possesses significant antioxidative, anti-inflammatory, antimicrobial, anticarcinogenic, antihypertensive, anti-cancer, neuroprotective, cholesterol-lowering, and thermogenic properties (Bekhit et al., 2011; Hayat et al., 2015; Pérez-Burillo et al., 2018; Somasundaram et al., 2019; Spizzirri et al., 2019; Vuong, 2014; Xu et al., 2018).

In teas it has been found, according to some authors 143 (Guo et al., 2019), 168 (Feng et al., 2019) and 172 (Chen et al., 2019) bioactive compounds. These ones include catechins (Pérez-Burillo et al., 2018; Somasundaram et al., 2019), polyphenols with the properties of vitamin P (Hayat et al., 2015; Pérez-Burillo et al., 2018; Spizzirri et al., 2019; Vuong, 2014), and accumulates such vitamins as ascorbic acid, thiamine, riboflavin, nicotinic, pantothenic and folic acids, carotenoids (Aboagye et al., 2021).

The tea contains antioxidants, in particular catechin, which protects the body from peroxidation - the process of self-oxidation of intracellular and tissue fat, the products of which not only reduce the function of the cell, but can also lead to its death. Tea catechins almost completely eliminate the harmful effects on the body during radioactive fallout. They have the ability to adsorb an isotope and remove it from the body before it can reach the bone marrow. Catechins also «monitor» the level of polyunsaturated fatty acids in the body, normalize cholesterol metabolism (Chen et al., 2020).

The tea leaves contain alkaloids - caffeine (Pérez-Burillo et al., 2018), theophylline, theobromine. The peculiarity of tea alkaloids is that they show their biological effect in combination with catechins and other constituents of tea. As a result, the tonic effect of tea does not cause such a sharp stimulating effect as coffee, in which the alkaloid caffeine is present in its pure form (Chen et al., 2020).

Tea is a rich source of minerals. About 20 amino acids are found in tea, and in their composition - all irreplaceable, it also contains carbohydrates, pectin substances, organic acids, resins, and essential oils (Theuma and Attard, 2020).

\section{Characteristics of herbal tea}

Herbal tea determined by the herbal components that make up the complex tea mixture. Herbal tea a mixture of black or green tea with medicinal or aromatic herbs (Coppock and Dziwenka, 2021). Tea drinks are used as substitutes for black tea in the case when there is an intolerance to the components of the tea leaf extract tannins and alkaloids such as caffeine, and theobromine because herbal tea unlike the tea, do not contain caffeine. In China, 759 species of plants are used as herbal tea (Fu et al., 2018). 
Herbal tea is a versatile drink that has a healing effect and can also be used as a preventive or therapeutic agent (Ağagündüz, 2020; Chen et al., 2019; Halim et al., 2020). Herbal tea contains a much larger amount of irreplaceable biologically active substances; constantly maintain the chemical balance of the body (Liu et al., 2020). Herbal teas increase antioxidant status (Bekhit et al., 2011; Debnath-Canning et al., 2020; Ertas, Yener, 2020; Spizzirri et al., 2019), oxidative status (Ağagündüz, 2020; Abdullah and Mazlan, 2020), anticancer activity (Morré and Morré, 2006), and has radio-protective effect (Ansari et al., 2021). Although many people drink herbal teas for pleasure, elderly people that live in rural areas often use herbal teas as affordable, accessible, and effective alternatives to medicine (Joubert et al., 2008).

Depending on the composition of raw materials and physiological effects, tea drinks are divided into groups: (a) multivitamin; regulating metabolism in the body; (b) tonic; soothing; anti-inflammatory; universal, and children's (Sviridonov et al., 2003). Most often, complex herbal compositions are used and one or more of the following components are added to the main infusion based on black (less often green) tea:

- Leaves: black currant (Liu et al., 2014), blueberry (Debnath-Canning et al., 2020), lemongrass (Aboagye et al., 2021), mint (Chan et al., 2010; Cohen et al., 2020; Somasundaram et al., 2019), nettle (Shonte et al., 2020), oregano (Chan et al., 2010), raspberry (Han et al., 2012), sea buckthorn (Ma et al., 2019), St. John's wort (Dell'Aica et al., 2007), rooibos, honeybush (Małyjurek et al., 2021), and mate (Mesquita et al., 2021);

- Flowers: hibiscus (Bekhit et al., 2011; Frész et al., 2014), cloves (Somasundaram et al., 2019), linden (Pavlović et al., 2020), calendula (Nicolaus et al., 2017), rose hip (Frész et al., 2014), and chamomile (Chaves et al., 2020);

- Fruits: apple (Bobrowska-Grzesik and Jakóbik-Kolon, 2008), apricot (Saeed et al., 2021), berberis (Atefi et al., 2021; Salehi et al, 2019), bilberry (Bobrowska-Grzesik and JakóbikKolon, 2008; Šavikin et al., 2014), black currant (Šavikin et al., 2014), chokeberry (Šavikin et al., 2014), grapes (Ansari et al., 2021; Bekhit et al., 2011; Morré, Morré, 2006), hawthorn (Dragan et al., 2012), lemon (He et al., 2018; Spizzirri et al., 2019), peach (Spizzirri et al., 2019), raspberries (Falcó et al., 2019), strawberries (Falcó et al., 2019), viburnum (Podsędek et al., 2020), and rose hip (Piljac-Žegarac et al., 2010);

- Stalks: cloudberries (Puupponen-Pimiä et al., 2016), cherries (Zhang et al., 2016), and sweet cherries (Faienza et al., 2020);

- seeds: dill (Cohen et al., 2020), caraway (Cohen et al., 2020), and coriander (Beyzi et al., 2017);

- Roots: ginger (Somasundaram et al., 2019), burdock (Maghsoumi-Norouzabad et al., 2019), and licorice (Jeon et al., 2007).

\section{Perspective directions of tea-herbal compositions}

To improve tea drinks assortment, the following ideas and suggestions are proposed:

- Use of new breeding varieties of tea plants and areas of its growth (Xu et al., 2021);

- Development of new technological solutions for tea plant processing (Dubey et al., 2020; Zohurul et al., 2020);

- Addition of leaves of various medicinal plants to tea (Baek et al., 2018; Vidović et al., 2013);

- Addition of various flavors to tea. 


\section{Relevance of the research direction}

The relevance of this topic is that the tea market is over flowing with a variety of tea drinks. Therefore, there is a need to create a qualitatively new tea-herbal composition for functional purposes.

The aim of the research is to determine the antioxidant capacity of plant raw materials infusions and evaluate their prospects for the creation of tea-herbal compositions.

To achieve the desired results, it was necessary:

(a) Confirm the feasibility of using plant materials in the creation of tea and herbal compositions.

(b) Determine the antioxidant capacity of plant materials used for the preparation of infusions.

(c) Perform mathematical and statistical analysis of antioxidant capacity of pant raw materials used in the tea-herbal compositions and to establish the internal correlation.

(d) Identify the richest sources of natural antioxidants from plant raw materials in the technology of tea-herbal compositions.

(e) Study the changes in vegetable materials in the process of blending tea and herbal compositions.

The introduction of various medicinal plants into tea makes it possible to increase the physiological activity of the original drink (Bag et al., 2022; Peng et al., 2021; Shabab et al., 2021). Since medicinal plants contain various vitamins and vitamin-like substances (Khan et al., 2021; Pohl et al., 2016), phenolic compounds (Albergaria et al., 2020), ash elements, organic acids, their introduction into tea could significantly increase the physiological value of this drink.

\section{Materials and methods}

\section{Materials}

23 samples of vegetable raw materials were used in the present study : Vitis vinifera; Calamintha nepeta; Monarda didyma; Satureja hortensis; Agastache foeniculum; Rosae fructus; Ruta graveolens; Elsholtzia stauntonii Benth; Perilla frutescens; Artemisia abrotanum; Melissae herba; Aspalathus linearis; Tiliae flos; Mentha piperita; Matricaria chamomilla; Herba Hyperici; Inonotus obliquus; Daucus carota; Ilex paraguariensis; Calendulae flores; Citrus sinensis; Citrus limonum; Hibiscus sabdariffa. Prepared water was used as a control sample and extractant.

\section{Methods of obtaining water infusion}

Drying of vegetable raw materials was carried out to constant humidity of 6-8\%. Collected and inspected raw materials were laid out on clean white paper, each type separately. Vegetable raw materials were ground with scissors to a size of $3 \times 3 \mathrm{~mm}$, samples weighing $4 \mathrm{~g}$ were placed in $100 \mathrm{ml}$ of prepared hot water. The infusions were filtered and studies were performed to determine the indicators of active acidity, which was measured on a $\mathrm{pH}$ meter in the mode of $\mathrm{pH}$ measurement with a combined glass electrode. The RP was measured in the potential measurement mode with a combined redoxmetric platinum electrode (Kuzmin et al., 2020). 


\section{Methods for determining active acidity and $R P$}

The active acidity index was measured on a $\mathrm{pH}-$ meter $« \mathrm{pH}-150 \mathrm{M} »$ with a combined glass electrode «ESC 10601/4». RP was measured on the $\mathrm{pH}-$ meter «pH-150M», in the mode of measuring the potential, with a redoxmetric platinum electrode «ERP-105».

To assess the antioxidant properties of aqueous infusions of plant raw materials a method based on the difference of RP in inactivated inorganic solutions and complex biochemical media was used (Priluckij, 1997). The main criteria of this method were its clarity, simplicity, specificity, reproducibility of results and efficiency. A number of researchers also emphasize that method allows to determine the total antioxidant activity of liquid products, including in total in a complex mixture, and multifunctional antioxidants (Kuzmin et al., 2020).

Formula (1) holds for inactivated inorganic solutions in equilibrium. This formula links the active acidity of the $\mathrm{pH}$ and the RP (Priluckij, 1997):

$$
E h_{\text {min }}=660-60 \cdot \mathrm{pH}, \mathrm{mV}
$$

where $E h_{\min }$ is the minimum theoretically expected value of the $R P$;

$\mathrm{pH}$ is active acidity of the test solution.

Acquired meanings of $E h_{\min }$ were compared with the actual measurements of $E h_{a c t}$ of infusions. The shift of the $R P$ to the side of the recovered meanings - recovery energy $\left(R E_{i n f}\right)$ was determined by the formula (Priluckij, 1997):

$$
R E_{\text {inf }}=E h_{\text {min }}-E h_{\text {act }}, \mathrm{mV}
$$

where $R E_{\text {inf }}$ is the shift of the RP to the side of recovered meanings;

$E h_{a c t}$ is actual measured of the $R P$.

The energy of reduction/oxidation of vegetable raw materials $\left(R E_{\text {plant }}\right)$ is determined by the difference between the $R P$ of infusions of vegetable raw materials $\left(R E_{\text {inf }}\right)$ and solvent $\left(R E_{s o l}\right)$ (control is prepared water) (Kuzmin et al., 2020):

$$
R E_{\text {plant }}=R E_{\text {inf }}-R E_{\text {sol }}, \mathrm{mV}
$$

Based on the research results, an improved method for assessing the antioxidant capacity of herbal infusions for creating tea-herbal compositions has been developed.

\section{Expert method of sensory evaluation}

The expert method of values quality indexes determination is based on committing the thought of the highly skilled and experienced specialists-experts (Kuzmin et al., 2020).

\section{Mathematical and statistical methods}

Pearson correlation coefficient measures the strength of the linear association between variables. Each variable should be continuous, random sample and approximately normally distributed. There are many rules of thumb on how to interpret a correlation coefficient, but all of them are domain specific. For example, here is correlation coefficient (Table 1) interpretation for behavioral sciences offered by Hinkle et al., 2003. 
Correlation coefficient interpretation

\begin{tabular}{|c|c|}
\hline Absolute value of coefficient $(\boldsymbol{r})$ & Strength of correlation \\
\hline $0.90-1.00$ & Very high \\
\hline $0.70-0.90$ & High \\
\hline $0.50-0.70$ & Moderate \\
\hline $0.30-0.50$ & Low \\
\hline $0.00-0.30$ & Little, if any \\
\hline
\end{tabular}

The correlation coefficient can take a range of values from +1 to -1 . Positive correlation coefficient means that if one variable gets bigger, the other variable also gets bigger, so they tend to move in the same direction. Negative correlation coefficient means that the variables tend to move in the opposite directions: If one variable increases, the other variable decreases, and vice-versa. When correlation coefficient is close to zero two variables have no linear relationship (Hinkle et al., 2003; Shendrik et al., 2019).

\section{Results and discussions}

\section{Results of antioxidant capacity}

Physicochemical studies, namely determination of the $p H$ level and RP (Nicoli et al., 2004; Prévost, Brillet-Viel, 2014), were performed according to the method (Priluckij, 1997) and calculations given above (Kuzmin et al., 2020). As a result of extraction received infusions (Andreou et al., 2018), physicochemical indicators (Breiter et al., 2011) of which are presented in the Table 2. As a solvent used a prepared water: $p H 8.00$ units $\mathrm{pH} ; E h_{\text {min }}$ $180.0 \mathrm{mV} ; E h_{\text {act }} 75.0 \mathrm{mV}$; $R E_{\text {inf }} 105.0 \mathrm{mV}$.

Figures 1-5 show graphically the change in the physicochemical indicators of the quality of extracts of raw materials on the extractant.

The $p H$ for water infusions from raw materials (Figure 1) has a value of 2.35 units $p H$ (Hibiscus sabdariffa) to 6.55 units $\mathrm{pH}$ (Calamintha nepeta).

The minimum theoretical value of $R P\left(E h_{\min }\right)$ for plant water infusions (Priluckij, 1997) was obtained, which has a value from $267.0 \mathrm{mV}$ (Calamintha nepeta) to $519.0 \mathrm{mV}$ (Hibiscus sabdariffa) (Figure 2).

The actual measured $R P$ of infusions $\left(E h_{a c t}\right)$ was established - from $37.0 \mathrm{mV}$ (Daucus carota) to $203.0 \mathrm{mV}$ (Hibiscus sabdariffa) (Figure 3). 
Table 2

Quality indicators of extracts on extractant

\begin{tabular}{|c|c|c|c|c|c|}
\hline Plant raw materials & $\begin{array}{c}p H, \text { units } \\
\text { pH }\end{array}$ & $\begin{array}{c}E h_{\min }, \\
\mathbf{m V}\end{array}$ & $\begin{array}{c}\text { Eh } \\
\text { mV }\end{array}$ & $\begin{array}{c}R E_{\text {inf }}, \\
\mathrm{mV}\end{array}$ & $\begin{array}{c}R E_{\text {plant }}, \\
\mathrm{mV}\end{array}$ \\
\hline 1. Extractant-prepared water & 8.00 & 180.0 & 75.0 & 105.0 & 0.0 \\
\hline 2. Vitis vinifera & 6.47 & 271.8 & 121.0 & 150.8 & 45.8 \\
\hline 3. Calamintha nepeta & 6.55 & 267.0 & 94.0 & 173.0 & 68.0 \\
\hline 4. Monarda didyma & 6.39 & 276.6 & 102.0 & 174.6 & 69.6 \\
\hline 5. Satureja hortensis & 6.48 & 271.2 & 96.0 & 175.2 & 70.2 \\
\hline 6. Agastache foeniculum & 6.32 & 280.8 & 95.0 & 185.8 & 80.8 \\
\hline 7. Rosae fructus & 6.11 & 293.4 & 107.0 & 186.4 & 81.4 \\
\hline 8. Ruta graveolens & 6.07 & 295.8 & 108.0 & 187.8 & 82.8 \\
\hline 9. Elsholtzia stauntonii Benth & 6.48 & 271.2 & 80.0 & 191.2 & 86.2 \\
\hline 10. Perilla frutescens & 6.24 & 285.6 & 93.0 & 192.6 & 87.6 \\
\hline 11. Artemisia abrotanum & 6.23 & 286.2 & 89.0 & 197.2 & 92.2 \\
\hline 12. Melissae herba & 6.18 & 289.2 & 90.0 & 199.2 & 94.2 \\
\hline 13. Aspalathus linearis & 6.00 & 300.0 & 95.0 & 205.0 & 100.0 \\
\hline 14. Tiliae flos & 6.31 & 281.4 & 76.0 & 205.4 & 100.4 \\
\hline 15. Mentha piperita & 6.01 & 300.0 & 86.0 & 214.0 & 109.0 \\
\hline 16. Matricaria chamomilla & 5.58 & 325.2 & 105.0 & 220.2 & 115.2 \\
\hline 17. Herba Hyperici & 5.00 & 360.0 & 132.0 & 228.0 & 123.0 \\
\hline 18. Inonotus obliquus & 5.40 & 336.0 & 97.0 & 239.0 & 134.0 \\
\hline 19. Daucus carota & 6.39 & 276.6 & 37.0 & 239.6 & 134.6 \\
\hline 20. Ilex paraguariensis & 5.87 & 307.8 & 57.0 & 250.8 & 145.8 \\
\hline 21. Calendulae flores & 5.55 & 327.0 & 63.0 & 264.0 & 159.0 \\
\hline 22. Citrus sinensis & 5.18 & 349.2 & 54.0 & 295.2 & 190.2 \\
\hline 23. Citrus limonum & 4.85 & 369.0 & 71.0 & 298.0 & 193.0 \\
\hline 24. Hibiscus sabdariffa & 2.35 & 519.0 & 203.0 & 316.0 & 211.0 \\
\hline $\min$ & 2.35 & 267.0 & 37.0 & 150.8 & 45.8 \\
\hline $\max$ & 6.55 & 519.0 & 203.0 & 316.0 & 211.0 \\
\hline
\end{tabular}

where: $p H$ - active acidity of the test solution; $E h_{\min }$ - the minimum theoretically expected value of the $R P ; E h_{a c t}$-actual measured of the $R P ; R E_{\text {inf }}$ - the shift of the $R P$ to the side of recovered meanings; $R E_{\text {plant }}$ - the energy of reduction/oxidation of vegetable raw materials

Water infusions from vegetable raw materials have the value of regenerative capacity (recovery energy $-R E_{i n f}$ ) in the range from $R E_{\text {inf }}-150.8 \mathrm{mV}$ (Vitis vinifera) to $R E_{\text {inf }}-316.0$ $\mathrm{mV}$ (Hibiscus sabdariffa).

For the restaurant business in the manufacture of beverages are promising water infusions of Hibiscus sabdariffa and Citrus limonum, which received increased antioxidant characteristics $R E_{\text {inf }}-316.0 \mathrm{mV}$ and $R E_{\text {inf }}-298.0 \mathrm{mV}$, respectively (Figure 4), and positive sensory evaluation. 


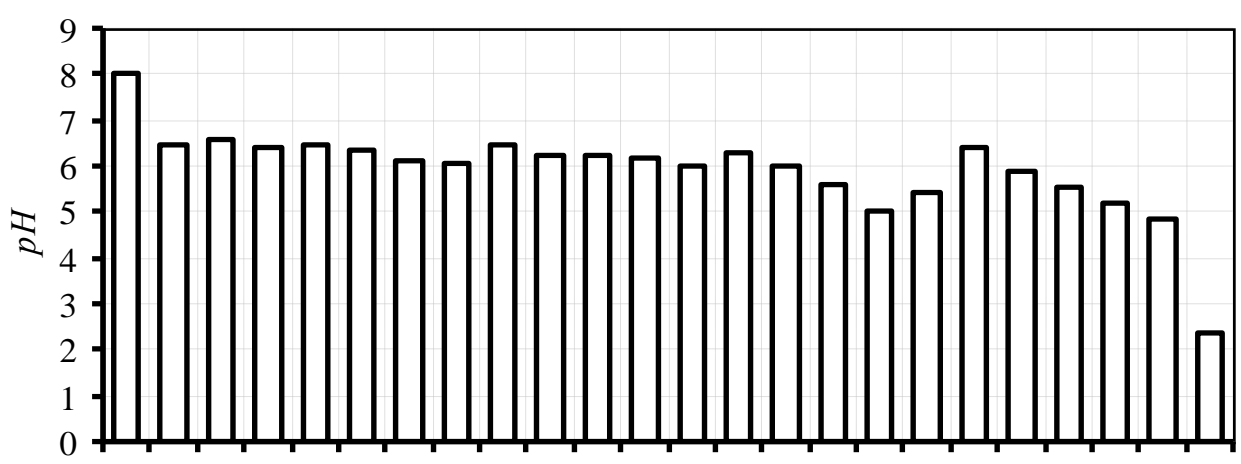

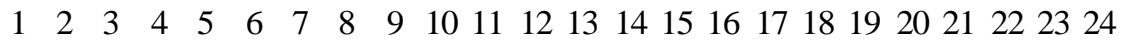

Figure 1. Hydrogen index $(\mathrm{pH})$ of infusions of the investigated raw material:

1 - Extractant; 2 - Vitis vinifera; 3 - Calamintha nepeta; 4 -Monarda didyma;

5 -Satureja hortensis; 6-Agastache foeniculum; 7 -Rosae fructus; 8 -Ruta graveolens;

9 - Elsholtzia stauntonii Benth; 10 - Perilla frutescens; 11 - Artemisia abrotanum;

12 -Melissae herba; 13 - Aspalathus linearis; 14 -Tiliae flos; 15 -Mentha piperita;

16 - Matricaria chamomilla; 17 - Herba Hyperici; 18 - Inonotus obliquus; 19 -Daucus carota;

20 -Ilex paraguariensis; 21 -Calendulae flores; 22 -Citrus sinensis; 23 -Citrus limonum; 24 - Hibiscus sabdariffa

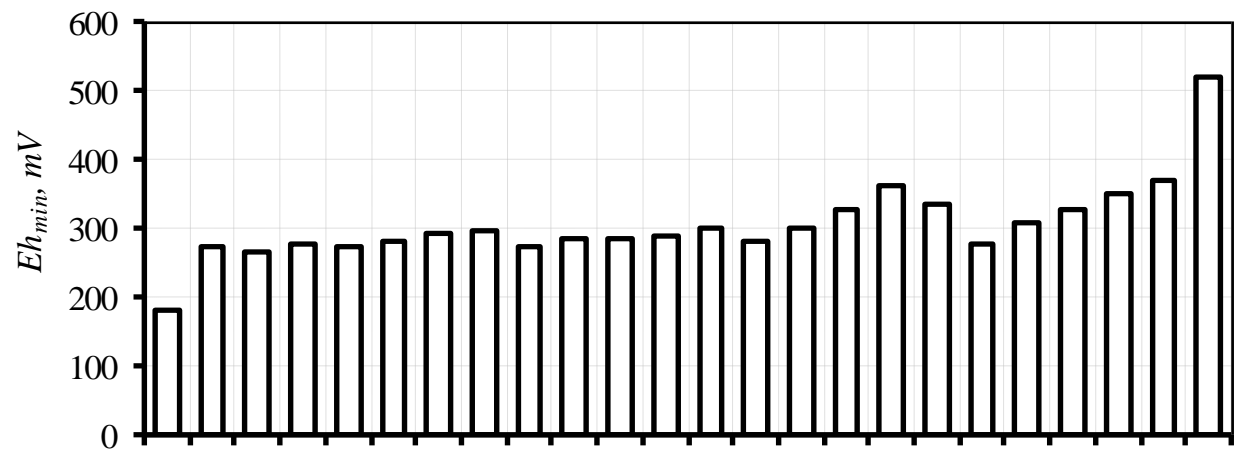

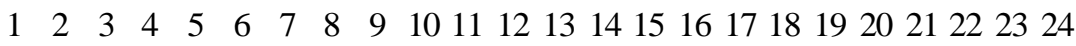

Figure 2. Minimum theoretical value of $R P\left(E h_{\min }\right)$ of infusions of the investigated raw material: 1 - Extractant; 2 - Vitis vinifera; 3 - Calamintha nepeta; 4 -Monarda didyma;

5 -Satureja hortensis; 6-Agastache foeniculum; 7 -Rosae fructus; 8 -Ruta graveolens;

9 - Elsholtzia stauntonii Benth; 10 - Perilla frutescens; 11 - Artemisia abrotanum;

12 -Melissae herba; 13 - Aspalathus linearis; 14 -Tiliae flos; 15 -Mentha piperita;

16 -Matricaria chamomilla; 17 - Herba Hyperici; 18 -Inonotus obliquus; 19 -Daucus carota;

20 - Ilex paraguariensis; 21 -Calendulae flores; 22 -Citrus sinensis; 23 -Citrus limonum; 24 - Hibiscus sabdariffa 


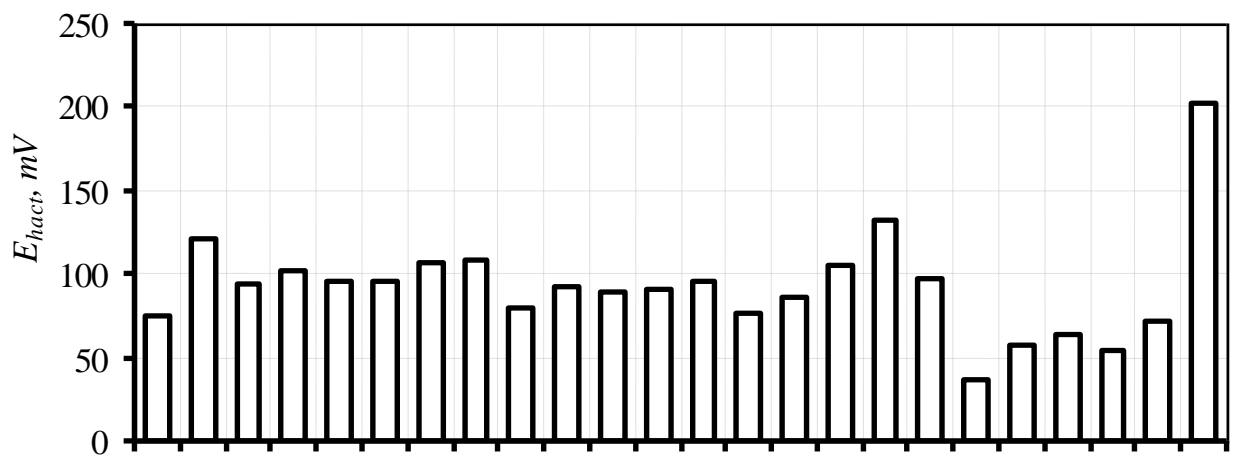

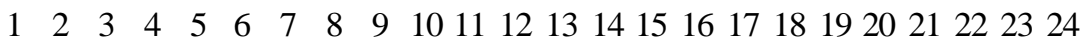

Figure 3. Actual measured $R P$ of infusions $\left(E h_{a c t}\right)$ of the investigated raw material: 1 - Extractant; 2 - Vitis vinifera; 3 - Calamintha nepeta; 4 -Monarda didyma;

5 -Satureja hortensis; 6-Agastache foeniculum; 7 -Rosae fructus; 8 -Ruta graveolens;

9 - Elsholtzia stauntonii Benth; 10 - Perilla frutescens; 11 -Artemisia abrotanum;

12 -Melissae herba; 13 - Aspalathus linearis; 14 -Tiliae flos; 15 -Mentha piperita; 16 - Matricaria chamomilla; 17 - Herba Hyperici; 18 -Inonotus obliquus; 19 -Daucus carota; 20 - Ilex paraguariensis; 21 - Calendulae flores; 22 -Citrus sinensis; 23 -Citrus limonum; 24 - Hibiscus sabdariffa

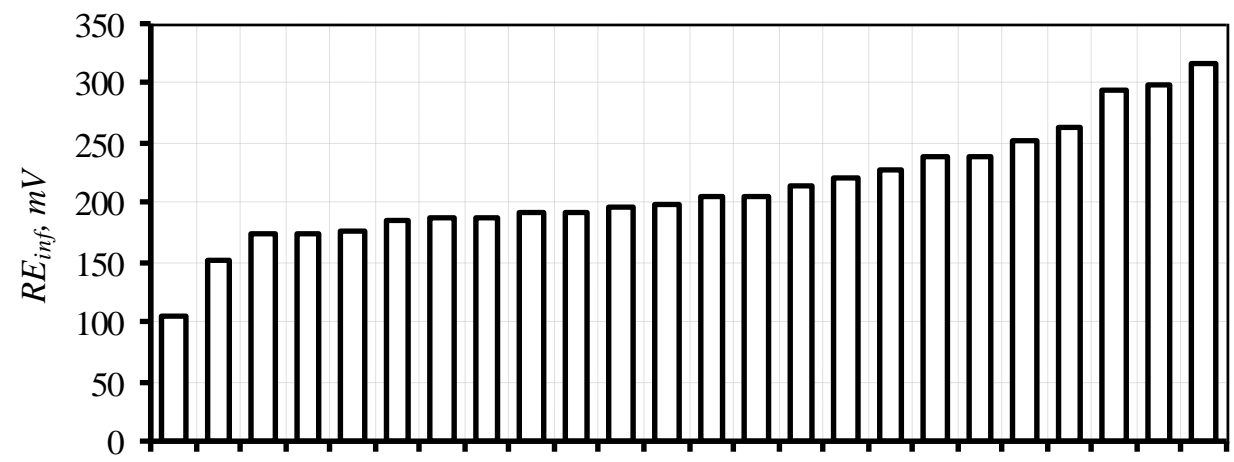



Figure 4. Recovery energy $\left(R E_{\text {inf }}\right)$ of infusions of the investigated raw material:

1 -Extractant; 2 - Vitis vinifera; 3 - Calamintha nepeta; 4 -Monarda didyma;

5 -Satureja hortensis; 6 -Agastache foeniculum; 7 -Rosae fructus; 8 -Ruta graveolens;

9 - Elsholtzia stauntonii Benth; 10 - Perilla frutescens; 11 - Artemisia abrotanum;

12 -Melissae herba; 13 -Aspalathus linearis; 14 -Tiliae flos; 15-Mentha piperita;

16 - Matricaria chamomilla; 17 - Herba Hyperici; 18 -Inonotus obliquus; 19 -Daucus carota;

20 - Ilex paraguariensis; 21 - Calendulae flores; 22 - Citrus sinensis; 23 - Citrus limonum; 24 - Hibiscus sabdariffa

It is proved that the energy of reduction/oxidation of vegetable raw materials $\left(R E_{\text {plant }}\right)$ 
relative to the solvent - prepared water is in the range of values from $45.8 \mathrm{mV}$ (Vitis vinifera) to $211.0 \mathrm{mV}$ (Hibiscus sabdariffa) (Figure 5). It was found that water infusions, depending on the activity of plant raw materials have a reducing capacity (over $0 \mathrm{mV}$ ) $-100 \%$ of samples.

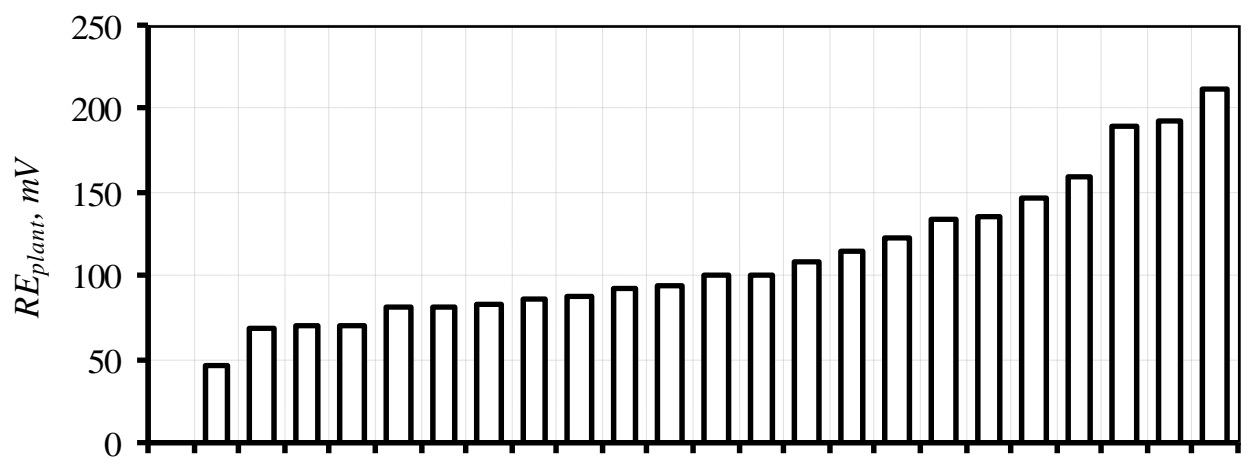

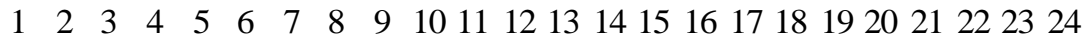

Figure 5. Energy of reduction/oxidation of vegetable raw materials $\left(\boldsymbol{R E}_{\text {plant }}\right)$ :

1 - Extractant; 2 - Vitis vinifera; 3 - Calamintha nepeta; 4 - Monarda didyma;

5 - Satureja hortensis; 6 -Agastache foeniculum; 7 -Rosae fructus; 8 -Ruta graveolens;

9 - Elsholtzia stauntonii Benth; 10 - Perilla frutescens; 11 -Artemisia abrotanum;

12 -Melissae herba; 13 - Aspalathus linearis; 14 -Tiliae flos; 15 -Mentha piperita;

16 - Matricaria chamomilla; 17 - Herba Hyperici; 18 -Inonotus obliquus; 19 - Daucus carota;

20 -Ilex paraguariensis; 21 -Calendulae flores; 22 -Citrus sinensis; 23 -Citrus limonum; 24 - Hibiscus sabdariffa

\section{Determination of Pearson's linear correlation}

According to the physicochemical and sensory evaluation, mathematical and statistical analysis (Hinkle et al., 2003; Shendrik et al., 2019) was performed in the Pearson correlation matrix (Table 3).

Table 3

Marked correlations $(r)$ are significant at $p<0,05 ; N=24$

\begin{tabular}{|l|c|c|c|c|c|}
\hline & $\boldsymbol{p H}$ & $\boldsymbol{E h}_{\min }$ & $\boldsymbol{E h}_{\text {act }}$ & $\boldsymbol{R E}_{\text {inf }}$ & $\boldsymbol{R E}_{\text {plant }}$ \\
\hline$p H$ & & $\mathbf{- 1 . 0 0}$ & -0.58 & -0.85 & -0.85 \\
\hline$E h_{\text {min }}$ & $\mathbf{- 1 . 0 0}$ & & 0.58 & 0.85 & 0.85 \\
\hline$E h_{\text {act }}$ & -0.58 & 0.58 & & 0.06 & 0.06 \\
\hline$R E_{\text {inf }}$ & -0.85 & 0.85 & 0.06 & & $\mathbf{1 . 0 0}$ \\
\hline$R E_{\text {plant }}$ & -0.85 & 0.85 & 0.06 & $\mathbf{1 . 0 0}$ & \\
\hline
\end{tabular}

where: $p H$ - active acidity of the test solution; $E h_{\min }$ - the minimum theoretically expected value of the $R P ; E h_{a c t}$ - actual measured of the $R P ; R E_{i n f}$ - the shift of the $R P$ to the side of recovered meanings; $R E_{\text {plant }}$ - the energy of reduction/oxidation of vegetable raw materials

According to the obtained matrix $5 * 5$, it was found that of the 5 indicators $\left(p H, E h_{\min }\right.$, $\left.E h_{a c t}, R E_{\text {inf }}, R E_{\text {plant }}\right)$ in the range of values with very high correlation (r 0.9-1.0) includes the following indicators: $p H, E h_{\min }, R E_{\text {inf }}, R E_{\text {plant }}$. 
Figure 6 shows the graphical dependence of $p H$ on $E h_{\min }$. It was found that the $p H$ is in the range of 2.35-8.00, and $E h_{\min }-519.0-180.0 \mathrm{mV}$. According to the obtained equation, at a $p H$ value of $6.00 E h_{\min }$ is $300 \mathrm{mV}$. When the $p H$ value changes by 1 ( $\left.p H 5.00\right)$, the $E h_{\text {min }}$ increases by $60 \mathrm{mV}\left(E h_{\min } 360 \mathrm{mV}\right)$. That is, the relationship between $E h_{\min }$ and $p H$ is very high, because $r=-1$, because it is inversely correlated, which leads to an increase in $p H$ to a decrease in the level of $E h_{\text {min }}$.

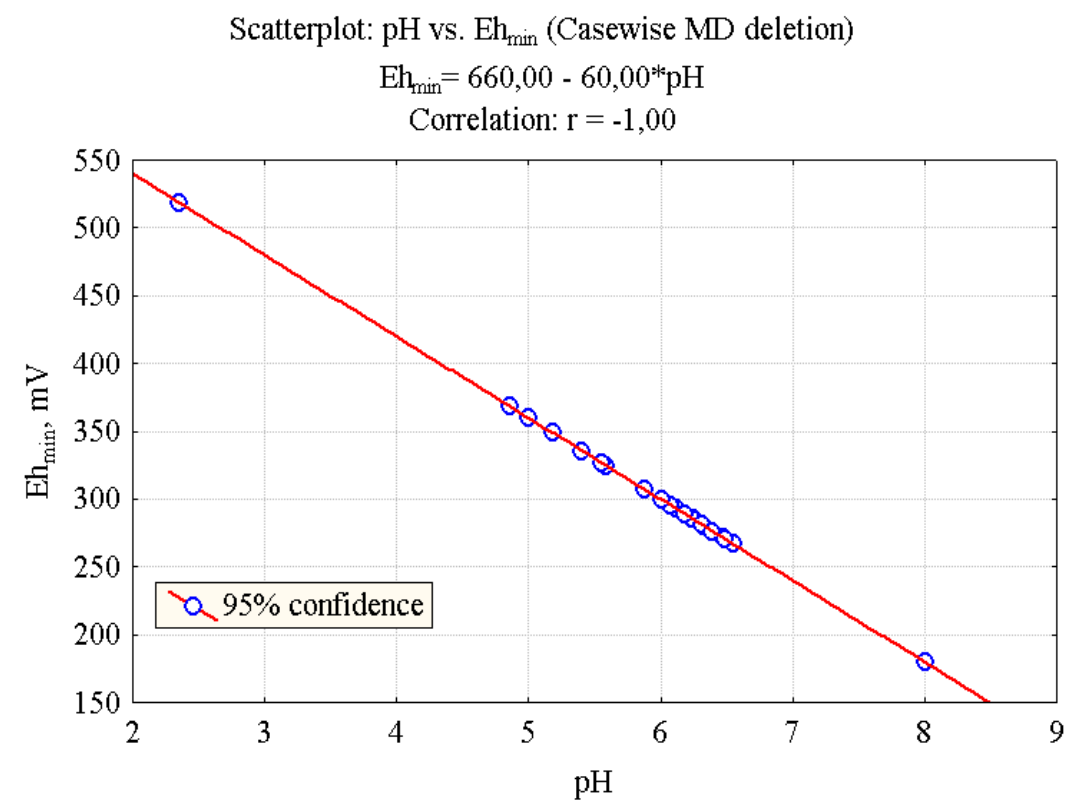

Figure 6. Dependence of $\mathrm{pH}$ level on $E h_{\min }$

Figures 7-11 show the graphical dependence of the $p H$ level, $E h_{\min }, R E_{\text {inf }}, R E_{\text {plant }}$.

It was found that $R E_{i n f}$, is in the range from 105 to $316 \mathrm{mV}$, and the $p H$ is $8.00-2.35$. At the value of $R E_{\text {inf }} 205 \mathrm{mV}$, the $p H$ level is 6.0. If you reduce the $p H$ to by one to 5.0 then the value of $R E_{\text {inf }}$ will be $228 \mathrm{mV}$, i.e. $R E_{\text {inf }}$ will increase by $23 \mathrm{mV}$. This is due to the fact that there is a high interdependence between the variables $R E_{\text {inf }}$ and $p H(r=-0.85)$. As the $p H$ value increases, the $R E_{\text {inf }}$ index decreases (Figure 7).

It was found that $R E_{\text {plant }}$ is in the range from 0.0 to $211.0 \mathrm{mV}$, and the $p H$ is $8.00-2.35$. When the value of $R E_{\text {plant }} 100.0 \mathrm{mV}$, the $p H$ level is 6.0. If you reduce the $p H$ by one to 5.0, the value of $R E_{\text {plant }}$ will be $123.0 \mathrm{mV}$. Decreasing the $\mathrm{pH}$ per unit from 6.0 to 5.0 leads to a decrease in $R E_{\text {plant }}$ by $23 \mathrm{mV}$. This is due to the fact that there is a high interdependence between the variables $R E_{\text {plant }}$ and $p H(r=-0.85)$. As the $p H$ value increases, the $R E$ decreases (Figure 8).

Figure 11 shows the graphical dependence of $R E_{\text {plant }}$ on $R E_{\text {inf. }}$ It was found that the $R E_{\text {plant }}$ is in the range of 0.0 to $211.0 \mathrm{mV}$, and $R E_{\text {inf }}-105$ to $316 \mathrm{mV}$. According to the obtained equation, at a $R E_{\text {plant }}$ value of $100 \mathrm{mV} R E_{\text {inf }}$ is $205 \mathrm{mV}$. When the $R E_{\text {plant }}$ value changes by 1 $\left(R E_{\text {plant }} 101 \mathrm{mV}\right)$, the $R E_{\text {inf }}$ decreases by $105 \mathrm{mV}\left(R E_{\text {inf }} 206 \mathrm{mV}\right)$. That is, the relationship between $R E_{\text {plant }}$ and $R E_{\text {inf }}$ is very high, because $r=1$, because it is directly correlated, which leads to an increase in $R E_{\text {plant }}$ to a increase in the level of $R E_{\text {inf }}$. 
Scatterplot: $\mathrm{pH}$ vs. $\mathrm{RE}_{\text {inf }}$ (Casewise $\mathrm{MD}$ deletion)

$$
\mathrm{RE}_{\text {inf }}=456,57-41,29 * \mathrm{pH}
$$

Correlation: $r=-0,85$

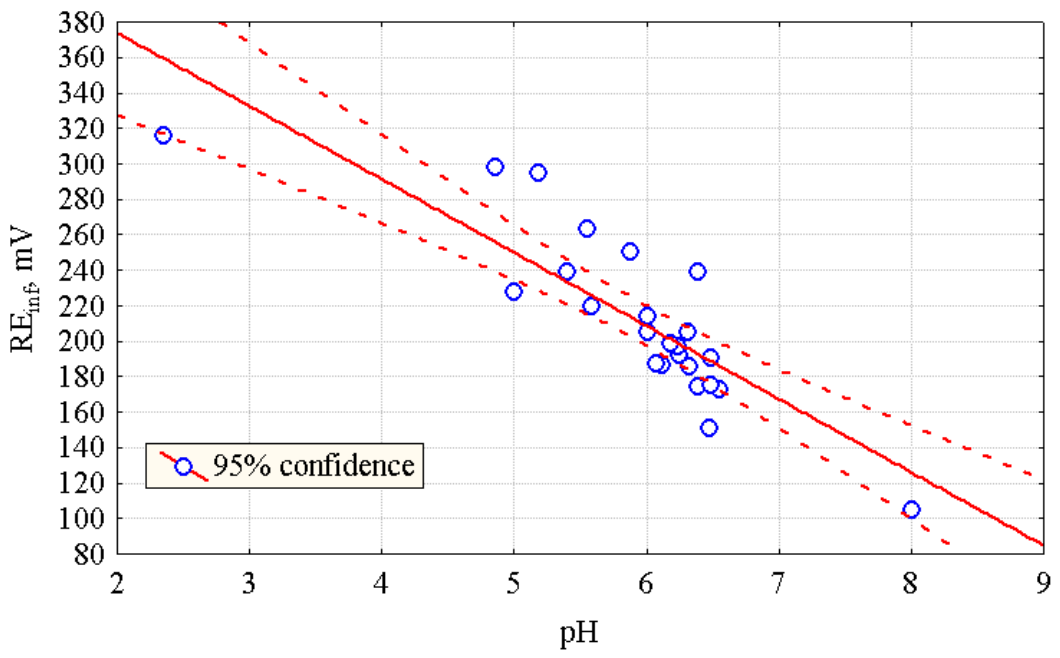

Figure 7. Dependence of $p H$ level on $R E_{i n f}$

Scatterplot: $\mathrm{pH}$ vs. $\mathrm{RE}_{\text {plant }}$ (Casewise MD deletion)

$$
\mathrm{RE}_{\mathrm{plant}}=351,57-41,29 * \mathrm{pH}
$$

Correlation: $r=-0,85$

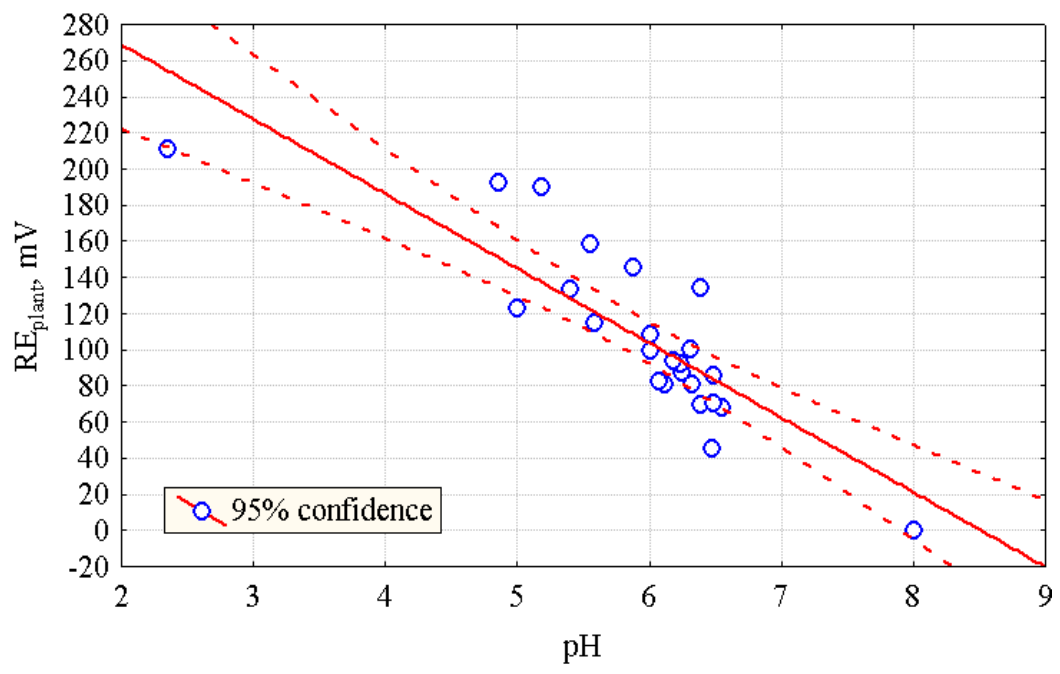

Figure 8. Dependence of $p H$ level on $R E_{p l a n t}$ 
Scatterplot: $\mathrm{Eh}_{\min }$ vs. $\mathrm{RE}_{\text {inf }}$ (Casewise $\mathrm{MD}$ deletion)

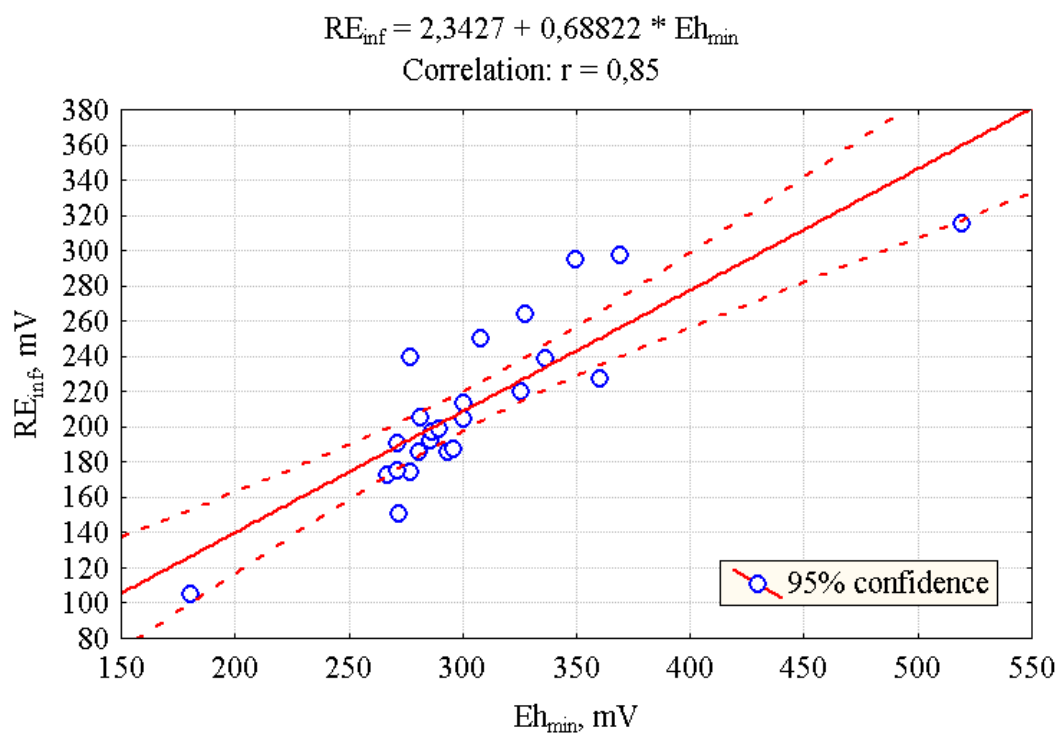

Figure 9. Dependence of $E h_{\min }$ on $R E_{i n f}$

Scatterplot: $\mathrm{Eh}_{\min }$ vs. $\mathrm{RE}_{\text {plant }}$ (Casewise $\mathrm{MD}$ deletion)

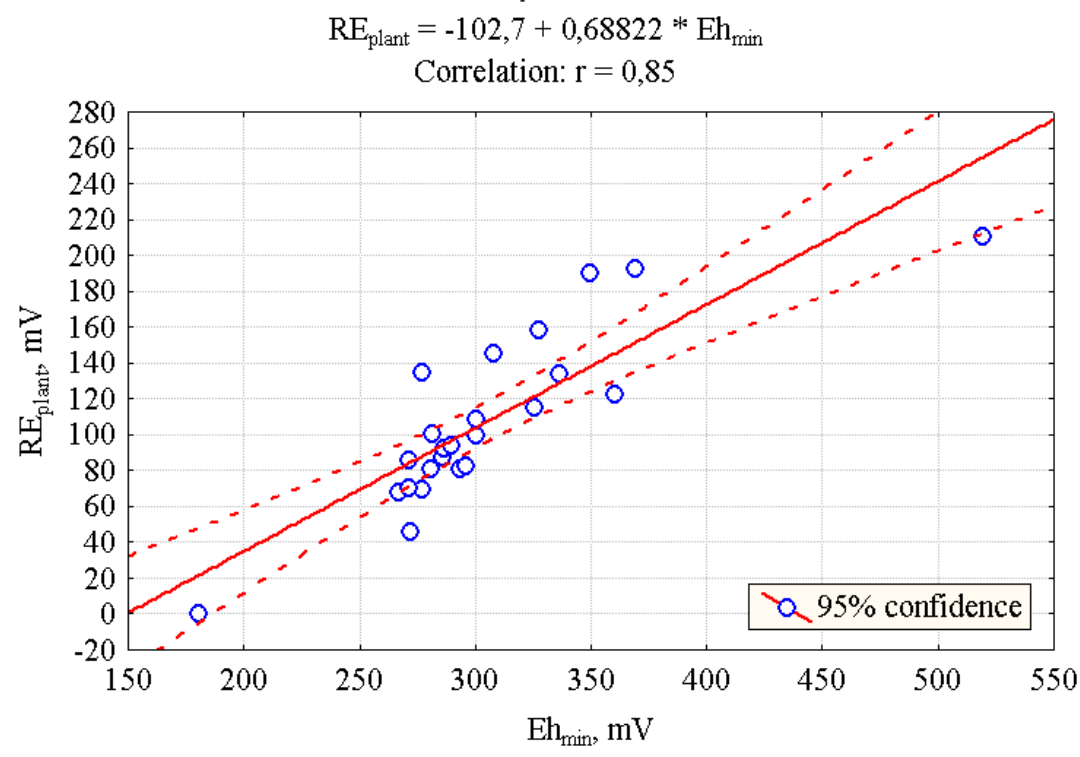

Figure 10. Dependence of $E h_{\min }$ on $R E_{p l a n t}$ 
Scatterplot: $\mathrm{RE}_{\text {plant }}$ vs. $\mathrm{RE}_{\text {inf }}$ (Casewise $\mathrm{MD}$ deletion)

$$
\mathrm{RE}_{\text {inf }}=105,00+1,0000 * \mathrm{RE}_{\text {plant }}
$$

Correlation: $r=1,00$

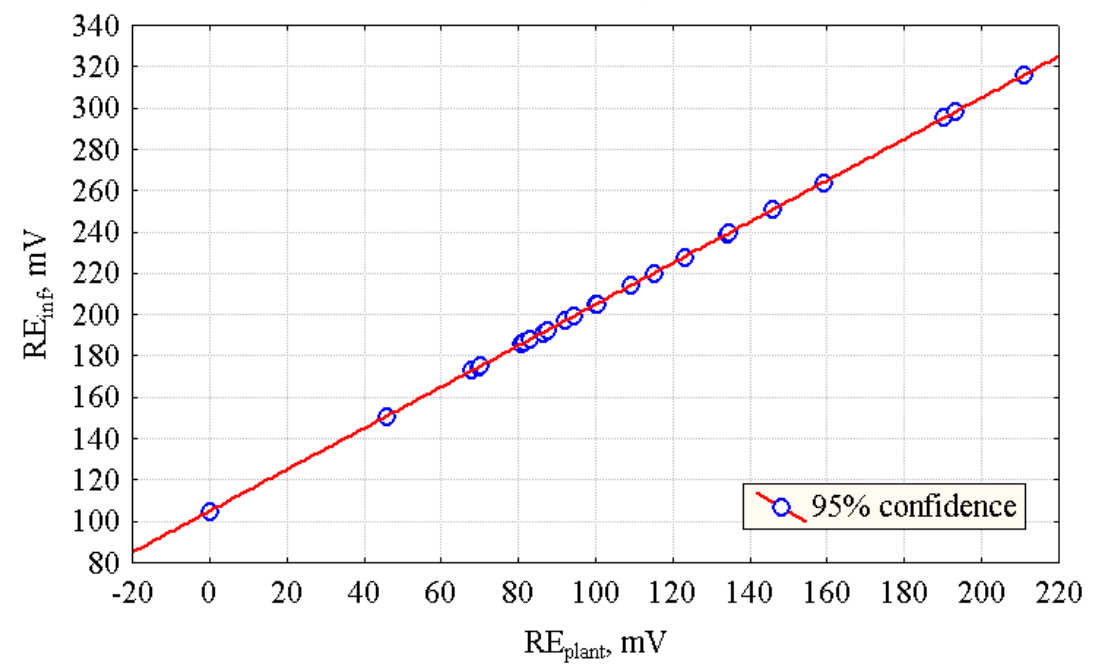

Figure 11. Dependence of $R E_{\text {plant }}$ on $R E_{\text {inf }}$

The general graph of the three most correlation-significant physicochemical parameters is shown in Figure 12. In volumetric form, it is seen that some points $\left(E h_{\text {min }}, R E_{\text {plant }}, R E_{\text {inf }}\right)$ are as close as possible to the surface, i.e. there is a very strong correlation between them. The farther the points are from the surface, the weaker the relationship.

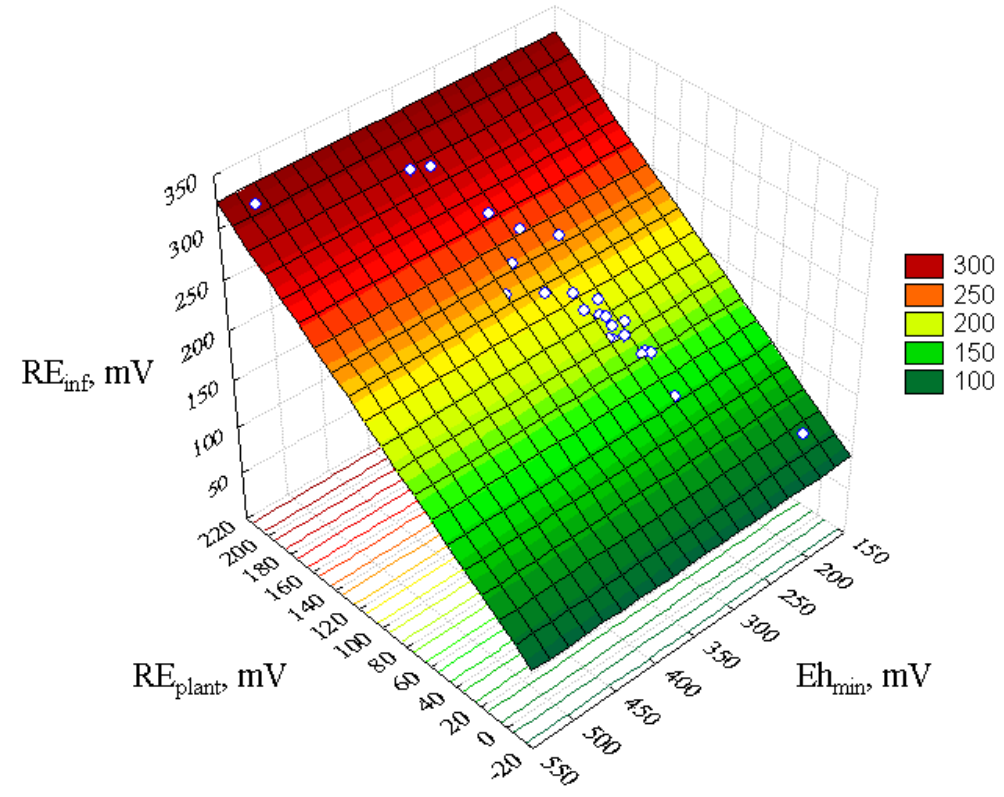

Figure 12. Response surface of $E h_{\text {min }}$ from $R E_{\text {plant }}$ and $R E_{\text {inf }}$ 
Based on mathematical and statistical analysis, it was found that physicochemical parameters in the range of values with very high correlation $(r 0.9-1.0)$ includes the following indicators: $p H, E h_{m i n}, R E_{i n f}, R E_{p l a n t}$.

\section{Creation of tea-herbal compositions}

The prospects of creating tea-herbal compositions based on ready-made dried mixtures have been confirmed by many authors (Alaşalvar, Çam, 2019; Tülek et al., 2020).

The composition of the tea-herbal mixture was obtained by mixing in the claimed ratio of dried and ground ingredients. Dried and crushed components were mixed in the following ratios: Hibiscus sabdariffa - 30\%; Matricaria chamomilla - $20 \%$; Ilex paraguariensis - 10 $\%$; Rosae fructus - $10 \%$; Mentha piperita - $10 \%$; Citrus sinensis - $8 \%$; Citrus limonum $7 \%$; Calendulae flores $-5 \%$. The resulting mixture was brewed in boiling water, kept for several minutes and consumed.

The rational concentration of the components of the mixture was chosen based on the sensory properties of the finished product. The results of sensory evaluation of tea-herbal compositions are shown in Figure 13. The highest score was obtained by tea-herbal composition - S.e. 9,1 points.



Figure 13. Sensory evaluation of tea-herbal compositions:

1 - color - 9.2 point ( 2 - homogeneous; 3 -red; 4 -pleasant; 5 - pronounced); 6 -infusion - 9.1

point (7-bright; 8 -transparent; 9 -intensive $) ; 10$-taste - 9.0 point $(11$ - pleasant; 12 harmonious; 13 - palpable freshness; 14 -mild; 15 -tart 16 - bitter; 17 -rich; 18 -smell/aroma9.1 point (19-fragrant; 20 -floral; 21 -fresh; 22 - herbal; 23 - pronounced; 24 - pleasant; 24 pleasant; 25 - balanced)

The data obtained are correlated with the basic scientific concepts which are displayed in the works (Abdullah, Mazlan, 2020; Aboagye et al., 2021; Ağagündüz D., 2020; Bekhit et al., 2011; Chan et al., 2010; Gerolis et al., 2017; Gulua et al., 2018; Pérez-Burillo et al., 2018; Silka et al., 2016), regarding the processes of extracting of plant materials.

The developed composition of the tea and herbal mixture ensures the achievement of a synergistic effect, expressed in obtaining a new product with pleasant, harmonious sensory 
properties (Chen et al., 2019; Feng et al., 2019; Guo et al., 2019; Li et al., 2019; Qi et al., 2018; Theuma, Attard, 2020; Xia et al., 2020; Xu et al., 2018; Zeng et al., 2017), high uniformity of distribution of flavoring and biologically active substances (Breiter et al., 2011; Bekhit et al., 2011; Hayat et al., 2015; Spizzirri et al., 2019; Xu et al., 2018).

A functional tea-herbal composition is perfect for everyday consumption, rich in vitamins and microelements, does not contain caffeine and allows you to get a high content of microelements necessary for a person (Aboagye et al., 2021; Guo et al., 2019; Feng et al., 2019; Chen et al., 2019; Hayat et al., 2015).

\section{Conclusions}

Based on the performed theoretical and experimental studies, the following conclusions can be drawn:

1. In the technology of beverages is promising to create tea-herbal compositions, the chemical composition of which includes plants that have bioactive compounds, in particular: catechins, polyphenols, vitamins, carotenoids.

2. Experimental studies show that all aqueous infusions of plant raw materials contain antioxidant systems. It was found that the recovery value of all the tested infusions is positive and ranges from $\left(R E_{\text {inf }}\right)$ in the range from $R E_{\text {inf }}-150.8 \mathrm{mV}$ (Vitis vinifera) to $R E_{\text {inf }}-316.0 \mathrm{mV}$ (Hibiscus sabdariffa).

3. Based on mathematical and statistical analysis, it was found that physicochemical parameters in the range of values with very high correlation $(r$ 0.9-1.0) includes the following indicators: $p H, E h_{\text {min }}, R E_{\text {inf }}, R E_{\text {plant }}$.

4. For the restaurant business in the manufacture of beverages are promising water infusions of Hibiscus sabdariffa and Citrus limonum, which received increased antioxidant characteristics $R E_{\text {inf }}-316.0 \mathrm{mV}$ and $R E_{\text {inf }}-298.0 \mathrm{mV}$, respectively.

5. Rational composition of tea-herbal composition was found: Hibiscus sabdariffa -30 $\%$; Matricaria chamomilla - $20 \%$; Ilex paraguariensis - $10 \%$; Rosae fructus -10 $\%$; Mentha piperita - $10 \%$; Citrus sinensis - 8\%; Citrus limonum-7\%; Calendulae flores $-5 \%$.

\section{References}

Abdullah S.S.S., Mazlan A.N. (2020), Quantification of polyphenols and antioxidant activity in several herbal and green tea products in Malaysia, Materials Today: Proceedings, 31(1), pp. A106-A113.

Aboagye G., Tuah B., Bansah E., Tettey C., Hunkpe G. (2021), Comparative evaluation of antioxidant properties of lemongrass and other tea brands, Scientific African, 11, e00718.

Ağagündüz D. (2020), Determination of the total antioxidant and oxidant status of some galactagogue and herbal teas, Food Science and Human Wellness, 9(4), pp. 377-382.

Alaşalvar H., Çam M. (2019), Process for production of ready to drink iced teas from sage (Salvia officinalis L.) and linden (Tilia cordata): pressurized hot water extraction and spray drying, Food Science and Biotechnology, 28(3), pp. 779-785.

Albergaria E.T., Oliveira A.F.M., Albuquerque U.P. (2020), The effect of water deficit stress on the composition of phenolic compounds in medicinal plants, South African Journal of Botany, 131, pp. 12-17.

Andreou V., Strati I.F., Fotakis C., Liouni M., Sinanoglou V.J. (2018), Herbal distillates: A new 
era of grape marc distillates with enriched antioxidant profile, Food Chemistry, 253, pp. $171-178$.

Ansari L., Banaei A., Dastranj L., Majdaeen M., Vafapour H., Zamani H., Ataei G., AbediFirouzjah R. (2021), Evaluating the radioprotective effect of single dose and daily oral consumption of green tea, grape seed, and coffee bean extracts against gamma irradiation, Applied Radiation and Isotopes, 174, 109781.

Atefi M., Ghavami A., Hadi A., Askari G. (2021), The effect of barberry (Berberis vulgaris L.) supplementation on blood pressure: A systematic review and meta-analysis of the randomized controlled trials, Complementary Therapies in Medicine, 56, 102608.

Baek Y., Kim H., Mun S., Lee S. (2018), Three-component herbal tea alleviates prolonged fatigue and improves sleep quality: a randomized controlled pilot study, Explore, 14(6), pp. 420-423.

Bag S., Mondal A., Majumder A., Banik A. (2022), Tea and its phytochemicals: Hidden health benefits \& modulation of signaling cascade by phytochemicals, Food Chemistry, 371, 131098.

Banerjee (Roy) R., Bandyopadhyay R., Tudu B., Bhattacharyya N. (2016), Chapter 13 - Tea and the Use of the Electronic Nose, Editor(s): María Luz Rodríguez Méndez, Electronic Noses and Tongues in Food Science, Academic Press, pp. 125-135.

Bekhit A.E.A., Cheng V.J., McConnell M., Zhao J.H., Sedcole R., Harrison R., (2011), Antioxidant activities, sensory and anti-influenza activity of grape skin tea infusion, Food Chemistry, 129(3), pp. 837-845.

Beyzi E., Karaman K., Gunes A., Beyzi S.B. (2017), Change in some biochemical and bioactive properties and essential oil composition of coriander seed (Coriandrum sativum L.) varieties from Turkey, Industrial Crops and Products, 109, pp. 74-78.

Bobrowska-Grzesik E., Jakóbik-Kolon A. (2008), Leaching of cadmium and lead from dried fruits and fruit teas to infusions and decoctions, Journal of Food Composition and Analysis, 21(4), pp. 326-331.

Breiter T., Laue C. Kressel G., Gröll S., Hahn A. (2011), Bioavailability and antioxidant potential of rooibos flavonoids in humans following the consumption of different rooibos formulations, Food Chemistry, 128(215), pp. 338-347.

Chaves P.F.P., Hocayen P.A.S., Dallazen J.L.,. Werner M.F.P, Iacomini M., Andreatini R., Cordeiro L.M.C. (2020), Chamomile tea: Source of a glucuronoxylan with antinociceptive, sedative and anxiolytic-like effects, International Journal of Biological Macromolecules, 164, pp. 1675-1682.

Chan E.W.C., Lim Y.Y., Chong K.L., Tan J.B.L., Wong S.K. (2010), Antioxidant properties of tropical and temperate herbal teas, Journal of Food Composition and Analysis, 23(2), pp. 185-189.

Chen D., Chen G, Sun Y, Zeng X., Ye H. (2020), Physiological genetics, chemical composition, health benefits and toxicology of tea (Camellia sinensis L.) flower: A review. Food Research International, 137, 109584.

Chen Q., Zhu Y., Dai W., Lv H., Mu B., Li P., Tan J., Ni D., Lin Z. (2019), Aroma formation and dynamic changes during white tea processing, Food Chemistry, 274, pp. 915-924.

Chen L., Mulder P.P.J., Peijnenburg A., Rietjens I.M.C.M. (2019), Risk assessment of intake of pyrrolizidine alkaloids from herbal teas and medicines following realistic exposure scenarios, Food and Chemical Toxicology, 130, pp. 142-153.

Cohen S.M., Eisenbrand G., Fukushima S., Gooderham N.J., Guengerich F.P., Hecht S.S., Rietjens I.M.C.M., Bastaki M., Davidsen J.M., Harman C.L., McGowen M.M., Taylor S.V. (2020), FEMA GRAS assessment of natural flavor complexes: Mint, buchu, dill and caraway derived flavoring ingredients, Food and Chemical Toxicology, 135, 110870.

Coppock R.W., Dziwenka M. (2021), Chapter 41 - Green tea, Editor(s): Gupta R.C., Lall R., Srivastava A. Nutraceuticals. Efficacy, Safety and Toxicity (Second Edition), Academic Press, pp. 697-723. 
Debnath-Canning M., Unruh S., Vyas P., Daneshtalab N., Igamberdiev A.U., Weber J.T. (2020), Fruits and leaves from wild blueberry plants contain diverse polyphenols and decrease neuroinflammatory responses in microglia, Journal of Functional Foods, 68, 103906.

Dell'Aica I., Caniato R., Biggin S., Garbisa S. (2007), Matrix proteases, green tea, and St. John's wort: Biomedical research catches up with folk medicine, Clinica Chimica Acta, 381(1), pp. 69-77.

Długaszek M., Kaszczuk M. (2020), Assessment of the nutritional value of various teas infusions in terms of the macro- and trace elements content, Journal of Trace Elements in Medicine and Biology, 59, 2020, 126428.

Dragan S., Gustavsson L., Streian C., Jupaneant O., Socaciu C., (2012), Comparison of the effects of green tea and hawthorn extracts on endothelial function in isolated human mammary arteries, European Journal of Integrative Medicine, 4(1), p. 170.

Dubey K.K., Janve M., Ray A., Singhal R.S. (2020), Chapter 4 - Ready-to-Drink Tea, Editor(s): Charis M. Galanakis, Trends in Non-alcoholic Beverages, Academic Press, pp. 101-140.

Ertas A., Yener I. (2020), A comprehensive study on chemical and biological profiles of three herbal teas in Anatolia; rosmarinic and chlorogenic acids, South African Journal of Botany, 130, pp. 274-281.

Faienza M.F., Corbo F., Carocci A., Catalano A., Clodoveo M.L., Grano M., Wang D.Q.H., D'Amato G., Muraglia M., Franchini C., Brunetti G., Portincasa P. (2020), Novel insights in health-promoting properties of sweet cherries, Journal of Functional Foods, 69, 103945.

Falcó I., Flores-Meraz P.L., Randazzo W., Sánchez G., López-Rubio A., Fabra M.J. (2019), Antiviral activity of alginate-oleic acid based coatings incorporating green tea extract on strawberries and raspberries, Food Hydrocolloids, 87, pp. 611-618.

Feng Z., Li Y., Li M., Wang Y., Zhang L., Wan X., Yang X. (2019), Tea aroma formation from six model manufacturing processes, Food Chemistry, 285, pp. 347-354.

Frész T., Nagy E., Hilbert Á., Tomcsányi J. (2014), The role of flavonoids in false positive digoxin assays caused by the consumption of hibiscus flower and rose hip tea, International Journal of Cardiology, 171(2), pp. 273-274.

Fu Y., Yang J., Cunningham A.B., Towns A.M., Zhang Y., Yang H., Li J., Yang X., (2018), A billion cups: The diversity, traditional uses, safety issues and potential of Chinese herbal teas, Journal of Ethnopharmacology, 222, pp. 217-228.

Gerolis L.G.L., Lameiras F.S., Krambrock K., Neves M.J. (2017), Effect of gamma radiation on antioxidant capacity of green tea, yerba mate, and chamomile tea as evaluated by different methods, Radiation Physics and Chemistry, 130, pp. 177-185.

Gulua L., Nikolaishvili L., Jgenti M., Turmanidze T., Dzneladze G. (2018), Polyphenol content, anti-lipase and antioxidant activity of teas made in Georgia, Annals of Agrarian Science, 16 (3), pp. 357-361.

Guo X., Ho C.T., Schwab W., Song C., Wan X. (2019), Aroma compositions of large-leaf yellow tea and potential effect of theanine on volatile formation in tea, Food Chemistry, 280, pp. 73-82.

Halim A.M., Sirajuddin S., Bahar B., Jafar N., Syam A., Masni (2020), The effect of African leaf herbal tea on fast blood glucose on centration of prediabetes teachers in Makassar city, Enfermería Clínica, 30(4), pp. 261-264.

Han N., Gu Y., Ye C., Cao Y., Liu Z., Yin J.(2012), Antithrombotic activity of fractions and components obtained from raspberry leaves (Rubus chingii), Food Chemistry, 132(1), pp. 181-185.

Hayat K., Iqbal H., Malik U., Bilal U., Mushtaq S. (2015), Tea and its consumption: benefits and risks, Critical reviews in food science and nutrition, 55(7), pp. 939-954.

He F., Qian Y.L., Qian M.C. (2018), Flavor and chiral stability of lemon-flavored hard tea during storage, Food Chemistry, 239, pp. 622-630.

Hinkle D.E., Wiersma W., Jurs S.G. (2003), Applied statistics for the behavioral sciences, 


\section{- Food Technology -}

Boston, Mass: Houghton Mifflin.

Jeon J.H., Park D., Shin S., Kang D.H., Moon S.H., Kim Y.B. (2007), Effect of green tea and licorice extracts on cyclophosphamide teratogenicity, Reproductive Toxicology, 24(1), p. 75.

Joubert E., Gelderblom W.C.A., Louw A., de Beer D. (2008), South African herbal teas: Aspalathus linearis, Cyclopia spp. and Athrixia phylicoides - A review, Journal of Ethnopharmacology, 119(3), pp. 376-412.

Khan A., Ali S., Murad W., Hayat K., Siraj S., Jawad M., Khan R.A., Uddin J., Al-Harrasi A., Khan A. (2021), Phytochemical and pharmacological uses of medicinal plants to treat cancer: A case study from Khyber Pakhtunkhwa, North Pakistan, Journal of Ethnopharmacology, 281, 114437.

Kuzmin O., Kucherenko V., Sylka I., Isaienko V., Furmanova Y., Pavliuchenko E., Hubenia V. (2020), Antioxidant capacity of alcoholic beverages based on infusions from non-traditional spicy-aromatic vegetable raw materials, Ukrainian Food Journal, 9 (2), pp. 404-424.

Kuzmin O., Kucherenko V., Stukalska N., Kuts A., Oliynyk S., Rakhmetov D. (2020), Antioxidant ability of alcoholic infusions from vegetable raw materials, Ukrainian Food Journal, 9 (4), 795-808.

Li J., Yuan H., Yao Y., Hua J., Yang Y., Dong C., Deng Y., Wang J., Li H., Jiang Y., Zhou Q. (2019), Rapid volatiles fingerprinting by dopant-assisted positive photoionization ion mobility spectrometry for discrimination and characterization of Green Tea aromas, Talanta, 191, pp. 39-45.

Liu Y., Hu R., Shen S., Zhang Z., Zhang J., Song X., Qiang S. (2020), Plant diversity in herbal tea and its traditional knowledge in Qingtian County, Zhejiang Province, China, Plant Diversity, 42(6), pp. 464-472.

Liu P., Kallio H., Yang B., (2014), Flavonol glycosides and other phenolic compounds in buds and leaves of different varieties of black currant (Ribes nigrum L.) and changes during growing season, Food Chemistry, 160, pp. 180-189.

Ma X., Moilanen J., Laaksonen O., Yang W., Tenhu E., Yang B. (2019), Phenolic compounds and antioxidant activities of tea-type infusions processed from sea buckthorn (Hippophaë rhamnoides) leaves, Food Chemistry, 272, pp. 1-11.

Maghsoumi-Norouzabad L., Shishehbor F., Abed R., Javid A.Z., Eftekhar-Sadat B., Alipour B. (2019), Effect of Arctium lappa linne (Burdock) root tea consumption on lipid profile and blood pressure in patients with knee osteoarthritis, Journal of Herbal Medicine, 17-18, 100266.

Małyjurek Z., Zawisza B., de Beer D., Joubert E., Walczak B. (2021), Authentication of honeybush and rooibos herbal teas based on their elemental composition, Food Control, 123, 107757.

Mesquita M., Santos E., Kassuya C.A., Salvador M.J. (2021), Chimarrão, terere and mate-tea in legitimate technology modes of preparation and consume: A comparative study of chemical composition, antioxidant, anti-inflammatory and anti-anxiety properties of the mostly consumed beverages of Ilex paraguariensis St. Hil., Journal of Ethnopharmacology, 279, 114401.

Morré D.M., Morré D.J. (2006), Anticancer activity of grape and grape skin extracts alone and combined with green tea infusions, Cancer Letters, 238(2), pp. 202-209.

Nicolaus C., Junghanns S., Hartmann A., Murillo R., Ganzera M., Merfort I. (2017), In vitro studies to evaluate the wound healing properties of Calendula officinalis extracts, Journal of Ethnopharmacology, 196, pp. 94-103.

Nicoli M.C., Toniolo R., Anese M. (2004), Relationship between redox potential and chainbreaking activity of model systems and foods, Food Chemistry, 88(1), pp. 79-83.

Pavlović T., Dimkić I., Andrić S., Milojković-Opsenica D., Stanković S., Janaćković P., Gavrilović M., Ristivojević P. (2020), Linden tea from Serbia - an insight into the phenolic profile, radical scavenging and antimicrobial activities, Industrial Crops and Products, 154, 
112639.

Peng Y., Tao H., Wang S., Xiao J., Wang Y., Su H. (2021), Dietary intervention with edible medicinal plants and derived products for prevention of Alzheimer's disease: A compendium of time-tested strategy, Journal of Functional Foods, 81, 104463.

Pérez-Burillo S., Giménez R., Rufián-Henares J.A., Pastoriza S. (2018), Effect of brewing time and temperature on antioxidant capacity and phenols of white tea: Relationship with sensory properties, Food Chemistry, 248, pp. 111-118.

Piljac-Žegarac J., Valek L., Stipčević T., Martinez S. (2010), Electrochemical determination of antioxidant capacity of fruit tea infusions, Food Chemistry, 121(3), pp. 820-825.

Podsędek A., Zakłos-Szyda M., Polka D., Sosnowska D. (2020), Effects of Viburnum opulus fruit extracts on adipogenesis of 3T3-L1 cells and lipase activity, Journal of Functional Foods, 73, 104111.

Pohl P., Dzimitrowicz A., Jedryczko D., Szymczycha-Madeja A., Welna M., Jamroz P. (2016), The determination of elements in herbal teas and medicinal plant formulations and their tisanes, Journal of Pharmaceutical and Biomedical Analysis, 130, pp. 326-335.

Prévost H., Brillet-Viel A. (2014), Ecology of bacteria and fungi in foods, Influence of Redox Potential, Encyclopedia of Food Microbiology (Second Edition), pp. 595-601.

Priluckij V.I. (1997), Okislitel'no-vosstanovitel'nyj potencial dlja harakteristiki protivokislitel'noj aktivnosti razlichny napitkov $i$ vitaminnyh komponentov, Jelektrohim. aktivacija v medicine, sel. hozjajstve, prom-sti: I Mezhdunar. Simpozium.

Puupponen-Pimiä R., Nohynek L., Juvonen R., Kössö T., Truchado P., Westerlund-Wikström B., Leppänen T., Moilanen E., Oksman-Caldentey K.M. (2016), Fermentation and dry fractionation increase bioactivity of cloudberry (Rubus chamaemorus), Food Chemistry, 197(A), pp. 950-958.

Qi D., Miao A., Cao J., Wang W., Chen W., Pang S., He X., Ma C. (2018), Study on the effects of rapid aging technology on the aroma quality of white tea using GC-MS combined with chemometrics: In comparison with natural aged and fresh white tea, Food Chemistry, 265, pp. 189-199.

Saeed I., Guo X., Azeem M., Elshikh M.S., Zainab B., Ayaz Z., You L., Alwahibi M.S., Abbasi A.M. (2021), Comparative assessment of polyphenolics' content, free radicals' scavenging and cellular antioxidant potential in apricot fruit, Journal of King Saud University - Science, 33(5), 101459.

Salehi B., Selamoglu Z., Şener B., Kılıç M., Jugran A.K., Tommasi N.D., Sinisgalli C., Milella L., Rajkovic J., Morais-Braga M.F., Bezerra C.F., Rocha J.E., Coutinho H.D., Ademiluyi A.O., Shinwari Z.K., Jan S.A., Erol E., Ali Z., Ostrander E.A., Sharifi-Rad J., Cádiz-Gurrea M.D., Taheri Y., Martorell M., Segura-Carretero A., Cho W.C. (2019), Berberis Plants Drifting from Farm to Food Applications, Phytotherapy, and Phytopharmacology, Foods, 8(10), p. 522.

Šavikin K., Zdunić G., Janković T., Gođevac D., Stanojković T., Pljevljakušić D., (2014), Berry fruit teas: Phenolic composition and cytotoxic activity, Food Research International, 62, pp. 677-683.

Shabab S., Gholamnezhad Z., Mahmoudabady M. (2021), Protective effects of medicinal plant against diabetes induced cardiac disorder: A review, Journal of Ethnopharmacology, 265, 113328.

Shendrik T., Levandovskyi L., Kuts A., Prybylskyi V., Karputina M. (2019), Correlation between the quality indicators of activated coal in vodka technology, Ukrainian Journal of Food Science, 7(1), pp. 33-48.

Shonte T.T., Duodu K.G., de Kock H.L. (2020), Effect of drying methods on chemical composition and antioxidant activity of underutilized stinging nettle leaves, Heliyon, 6(5), $\mathrm{e} 03938$.

Silka I., Frolova N., Huts V. (2016), Kinetic model of the quality change of modern foodstuffs, 


\section{- Food Technology -}

Food Science and Technology, 10(1), pp. 11-15.

Somasundaram R., Choraria A., George S.M., Narayanaswamy K., Vasudevan K., Antonysamy M., Zhang X., (2019), A preliminary pilot scale analysis of anti-cariogenic activity of green tea powder extract flavoured with Ginger, Cloves and Mint against clinical oral pathogens, Clinical Nutrition Experimental, 24, pp. 66-71.

Spizzirri U.G., Carullo G., De Cicco L., Crispini A., Scarpelli F., Restuccia D., Aiello F. (2019), Synthesis and characterization of a (+)-catechin and L-(+)-ascorbic acid cocrystal as a new functional ingredient for tea drinks, Heliyon, 5(8), e02291.

Sviridonov G.M., Sviridonova L.G., Sviridonov M.G. (2003), Ekologicheskij krizis: kak spastis' i byt' zdorovym, Bijsk, Kedr, $47 \mathrm{~s}$.

Theuma M., Attard E. (2020), From herbal substance to infusion: The fate of polyphenols and trace elements, Journal of Herbal Medicine, 21, 100347.

Tülek Z., Alaşalvar H., Başyiğit B., Berktas S., Salum P., Erbay Z., Telci I., Çam M. (2020), Extraction optimization and microencapsulation of phenolic antioxidant compounds from lemon balm (Melissa officinalis L.): Instant soluble tea production, Journal of Food Processing and Preservation, Available at: https://ifst.onlinelibrary.wiley.com/doi/10.1111/jfpp.14995.

Vidović S., Cvetkovic D., Ramić M., Dunjić M., Malbaša R., Tepić A., Šumić Z., Velićanski A., Jokić S. (2013), Screening of changes in content of health benefit compounds, antioxidant activity and microbiological status of medicinal plants during the production of herbal filter tea, Industrial Crops and Products, 50, pp. 338-345.

Vuong Q.V. (2014), Epidemiological evidence linking tea consumption to human health: a review, Critical reviews in food science and nutrition, 54(4), pp. 523-536.

Xia E., Tong W., Hou Y., An Y., Chen L., Wu Q., Liu Y., Yu J., Li F., Li R., Li P., Zhao H., Ge R., Huang J., Mallano A.I., Zhang Y., Liu S., Deng W., Song C., Zhang Z., Zhao J., Wei S., Zhang Z., Xia T., Wei C., Wan X., (2020), The Reference Genome of Tea Plant and Resequencing of 81 Diverse Accessions Provide Insights into Its Genome Evolution and Adaptation, Molecular Plant, 13(7), pp. 1013-1026.

Xu J., Wang M., Zhao J., Wang Y.H., Tang Q., Khan I.A. (2018), Yellow tea (Camellia sinensis L.), a promising Chinese tea: Processing, chemical constituents and health benefits, Food Research International, 107, pp. 567-577.

Xu C., Liang L., Li Y., YangT., Fan Y., Mao X., Wang Y. (2021), Studies of quality development and major chemical composition of green tea processed from tea with different shoot maturity, $L W T, 142,111055$.

Zhang Y., Wong A.I.C., Wu J., Karim N.B.A., Huang D. (2016), Lepisanthes alata (Malay cherry) leaves are potent inhibitors of starch hydrolases due to proanthocyanidins with high degree of polymerization, Journal of Functional Foods, 25, pp. 568-578.

Zeng L., Zhou Y., Fu X., Mei X., Cheng S., Gui J., Dong F., Tang J., Ma S., Yang Z. (2017), Does oolong tea (Camellia sinensis) made from a combination of leaf and stem smell more aromatic than leaf-only tea? Contribution of the stem to oolong tea aroma, Food Chemistry, 237, pp. 488-498.

Zhu Y., Lv H.P., Dai W.D., Guo L., Tan J.F., Zhang Y., Yu F.L., Shao C.Y., Peng Q.H., Lin Z. (2016), Separation of aroma components in Xihu Longjing tea using simultaneous distillation extraction with comprehensive two-dimensional gas chromatography-time-offlight mass spectrometry, Separation and Purification Technology, 164, pp. 146-154.

Zohurul I.M., Kitamura Y., Kokawa M., Fujii S. (2020), Processing of green tea pastes by micro wet milling system: Influences on physicochemical and functional properties, Innovative Food Science \& Emerging Technologies, 64, 102408. 


\section{Toxic substances formation in co-incineration process for food production}

\section{Iryna Dubovkina ${ }^{1}$, Oleksandr Sigal ${ }^{1}$, \\ Veronica Rikhter ${ }^{2}$, Nataliya Nizhnyk ${ }^{1}$}

\section{1 - Institute of Engineering Thermophysics of National Academy of Sciences of Ukraine, Kyiv, Ukraine \\ 2 - Technikal University of Wien, Austria}

\section{Keywords:}

Hydrogen

Heating

Nitrogen oxides

Hydrogen

peroxide

Flame

Toxic

\section{Article history:}

Received

28.02.2021

Received in revised

form 11.06.2021

Accepted

30.12.2021

Corresponding

author:

Iryna Dubovkina

E-mail:

dubovkinai@ukr.net

DOI:

$10.24263 / 2304-$

974X-2021-10-4-15

\section{Abstract}

Introduction. The research aim is to define the influence of the using hydrogen combustion technologies on existing or upgraded boiler equipment in food technologies and the choice of rational ways to use the modernized fuel and energy complex equipment for operating on new fuel, in compliance with the industrial and environmental safety requirements.

Materials and methods. General scientific methods and special methods were used. The laboratory unit for experimental process at the semi-lamina front follow-up is created for research the role hydrogen in co-firing with natural gas, depends on concentrations of oxide and nitrogen dioxide in combustion products.

Results and discussion. Separate $\mathrm{NO}$ and $\mathrm{NO}_{2}$ measurements showed that the dependence of the $\mathrm{NO}_{2}$ fraction on the $\mathrm{H}_{2}$ content in the solution, supplied to the laminar methane flare, is ambiguous and significantly depends on the sampling location at the flame front cut section of the.

An intensive increasing the nitrogen oxides concentration is observed in the initial cut flame front sections from the moment where the mixture start the heating to the maximum temperature.

Moreover, the higher the $\mathrm{H}_{2} \mathrm{O}_{2}$ solution concentration is injected into the flame front (similarly, the smaller the hydrogen proportion in the solution), the more intense the increase in the nitrogen oxides content.

When a $30 \% \mathrm{H}_{2} \mathrm{O}_{2}$ solution injected into the flame front, the NO concentration practically reaches the initial one, which obtained without the drip moisture injection $\left(90-95 \mathrm{mg} / \mathrm{m}^{3}\right)$. At the same time, the $\mathrm{H}_{2} \mathrm{O}$ injection into the flame front leads to a decrease in NO concentration by $35-40 \%$, up to $65 \mathrm{mg} / \mathrm{m}^{3}$. This can be explained by the fact that hydrogen peroxide forms the $\mathrm{OH}$ radical, which is actively involved in the hydrocarbons and $\mathrm{CO}$ oxidation, more intense than water.

The $\mathrm{OH}$ radical forms hydroperoxide-radical $\mathrm{HO}_{2}$ from $\mathrm{H}_{2} \mathrm{O}_{2}$, which dissociates with the superoxide ion $\mathrm{O}_{2}$-formation and gives the $\mathrm{H}$-radical from $\mathrm{H}_{2} \mathrm{O}_{2}$.

Conclusions. With increasing hydrogen content in the solution the NOx formation decreases, which can be explained by the oxygen consumption in fast reactions that require less energy. 


\section{Introduction}

There are a variety of ways for the food processing industry to reduce their manufacturing costs with energy saving methods and technologies.

While many lab-scale investigations have been carried out on the thermochemical conversion, commercial production and utilization of biofuels and or chemicals are still at an early stage (Chengfang Song et. al., 2020; Myronchuk V. et. al., 2019). Several projects have been launched to demonstrate the potential of hydrogen at an industrial scale (Yue M. et. al., 2021). Although the role of hydrogen in the industry has been widely assessed over the last two decades, and considering that the heat sector is highly energy consuming, significant adaptations in production processes are necessary, requiring a longer study period. (Guilbert Damien et. al., 2021)

In the work (Jaruwan Wongthanate et. al., 2020) it was describe of producing hydrogen from food and beverage processing wastewater by anaerobic microflora enriched of starch versus in a batch reactor. Besides authors (Sang Eun Oh et. al., 2005 ) showed that hydrogen production from a food processing wastewater high in sugar can be linked to electricity generation using a microbial fuel cell to achieve more effective wastewater treatment.

Some food processing companies are using organic waste from their facility and convert them into fuel for the phosphoric acid fuel cell at their facilities. Many of these companies use proven technology such as anaerobic digestion to convert organic waste and manure into hydrogen to power the fuel cells (S. Curtin et. al., 2017) Therefore, converting food waste into biofuels, bio-based fertilizers, bio-based enzymes, chemicals, proteins and other biobased molecules and materials will accelerate the sustainable development goals. (Tsegaye B. et. al., 2021)

Fuel cell technology is a maturing technology that has been implemented in the food industry for several years (Ping Wu et. al., 2018).

It well known that hydrogen is combined with compounds such as oxygen, natural gas, coal, and oxygen-carbon from plant biomass (Guilbert Damien et. al., 2021). Consequently, as part of strategy to use hydrogen, need to gradually change the composition of existing gas infrastructure by blending hydrogen and natural gas. For instance, is targeting 20 to $30 \%$ blends of hydrogen and natural gas in the short term. (Abbas A.J. et. al., 2021). Therefore, in addition to the determination of the amount of hydrogen gas that would deliver equivalent energy contents as natural gas, accurate investigation of the effect of fluid and flow properties such as the compressibility factor, and velocity on the safe and efficient transportation of hydrogen and hydrogen blends is important as they influence gas flow in the pipelines (Andre J. et. al., 2014).

While current appliances may be compatible with natural gas that is enriched with up to 20 per cent hydrogen, higher percentage blends of hydrogen will require new appliances or significant upgrades to existing appliances specifically in relation to burner designs (Orana Sandri et. al., 2021).

The research aims to define the influence of the using hydrogen combustion technologies on existing or upgraded boiler equipment and the choice of rational ways to use the modernized fuel and energy complex equipment for operating on new fuel, in compliance with the industrial and environmental safety requirements.

To achieve this aims it is necessary to solve the following tasks:

1. Develop a concept and laboratory unit for the experimental investigation the hydrogen and natural gas mixtures combustion.

2. Conduct the experimental research with the aim of determining the effect of changes in hydrogen content by adding hydrogen peroxide drops with different concentrations to 


\section{- Processes and Equipment -}

laminar flame front of natural gas and compare with the same volume, number and technology for using distilled water.

3. Determine the dependences that characterize the hydrogen combustion in a mixture with natural process gas and propose the recommendations for the technology of possible hydrogen mixtures in boilers combustion adaptation.

\section{Materials and methods}

The object of study was the process of combustion of the hydrogen and natural gas mixtures. The subject of the research was determination of the nitrogen oxides formation by the hydrogen effect on the combustion process.

\section{Chemicals}

The hydrogen peroxide solution by the various concentrations from $0 \%$ up to $30 \%$ was used for experimental investigations.

Gas and gaseous fuel was used for experimental investigations.

Water and steam was used for experimental investigations.

\section{Experimental installation}

An experimental installation is designed and manufactured for studying the moisture effect on the toxic substances formation during fuel combustion and described in detail in (Sigal A. et. al.,2021) and several experiments series conducted with it. The unit described (Sigal A. et. al.,2021) was taken as a base, and a device for hydrogen peroxide solutions preparation and a perilstatic pump for supplying moisture to the flame front was installed.

The experimental installation (Figure 1) consists of a gas duct, mounted on the frame, equipped with air supply systems, gaseous fuel and steam supply systems, heating system that can maintain the required temperature, gas burner device, drip moisture to the flame front supply system, gas sampling probe precision movement system, thermocouple and capillary for drip moisture supply and combustion process control system. The frame provides the experimental unit rigidity and stability in general.

The flue is made from a heat-insulated cylindrical pipe that made heat-refractory material with $16.0 \mathrm{~mm}$ diameter and $4.0 \mathrm{~mm}$ wall thickness, and has an attached fan to supply air for combustion. A diaphragm with a micro-manometer for measuring airflow is installed in the horizontal section. A nozzle for gaseous fuel and steam supply and an electric heater to heat the mixture to the desired temperature are mounted in the vertical section. A gas burner device is mounted at the end of the vertical flue section. The gas supply was carried out through a $10.0 \mathrm{~mm}$ diameter copper tube in which a measuring diaphragm with a micromanometer (type INN-1) is mounted for measuring gas flow. Precision needle valves are installed in the appropriate communications to regulate air and gas flow. Steam generator connected to a flue by $10 \mathrm{~mm}$ diameter copper heat-insulated tube is used for steam production. The gas distribution device, with holes $0.8-1.0 \mathrm{~mm}$ diameter, provided gas and air complete mixing. 


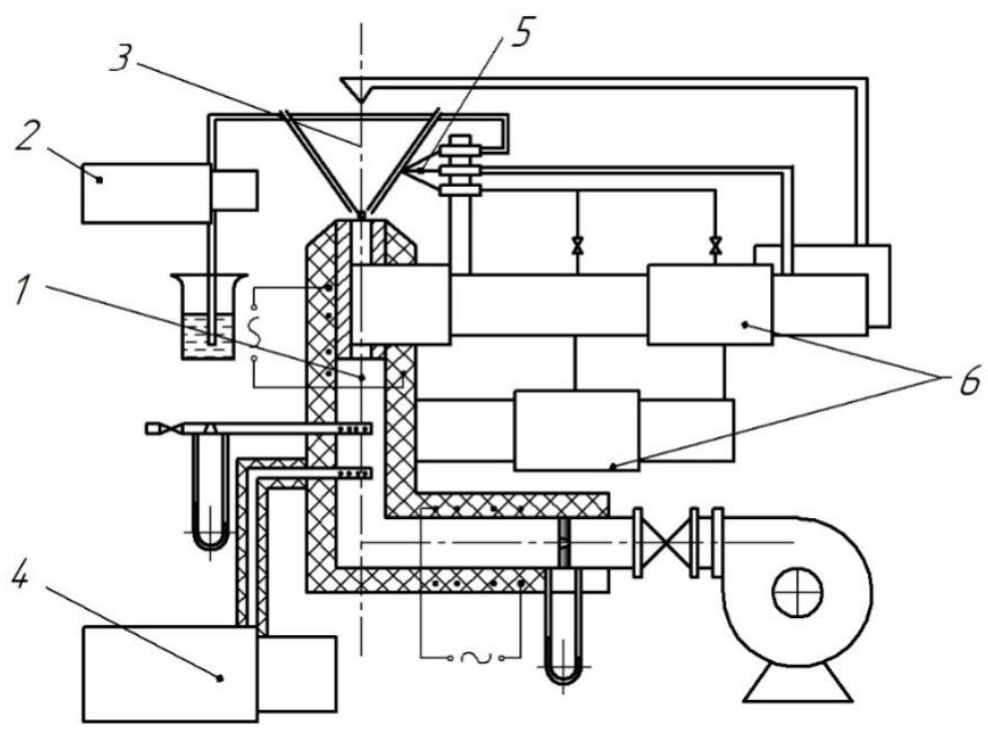

Figure 1. Experimental installation:

1 - gas duct; 2 - peristaltic pump; 3 - flame; 4 - flowmeter;

5 -drip moisture to the flame front supply system: 6 - combustion process control system

\section{Research method of nitrogen oxides formation}

The hydrogen effect on the nitrogen oxides formation researched directly in the flame front at the laboratory on a stand with precision measuring instruments. The measurements scheme is shown in Figure 2.

In experimental studies, the main attention was paid to the maximum local temperature and nitrogen oxides concentrations that was measurement in the "trace" of the drop, which contained hydrogen peroxide different concentrations from 0 to $30 \%$. The experimental research of the normal combustion front was carried out in a stationary "reverse" flame, which is formed by continuous mixture supply to the burner after a steel cylindrical stabilizer $(\mathrm{d}=3.0 \mathrm{~mm})$. Previous research, carried out by authors, showed that within the stabilizer diameters from 1 to $5 \mathrm{~mm}$, the flame front elementary structure did not depend on the one's diameter. When changed up $\alpha$ to 1.8 , the flame front width did not exceed $2.5 \mathrm{~mm}$, the mixture flow parameters corresponded to $u=1500 \mathrm{~mm} / \mathrm{s}, \operatorname{Re}=250$.

Control of the main parameters in the process experimental research included: measuring the position of the microprobe, thermocouple and capillary for the droplets injection, the all components of the mixture for combustion flows, and the combustion products gas analysis. 


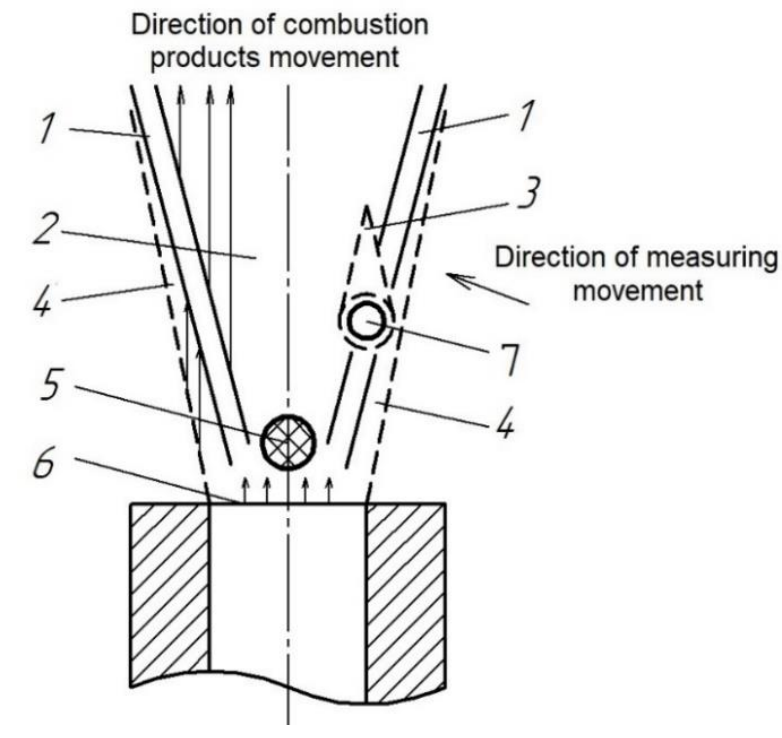

Figure 2. Measurements scheme:

1 - Flame front; 2 - Combustion products; 3 - Drop "frace";

4 - Cold mixture; 5 - Stabilizer; 6 - Burner cut; 7 - Drop.

\section{Research methods of the measuring the position of the microprobe thermocouple and capillary for the droplets injection}

Micromanipulators arrow indicators of stereotactic unit with value of division $0.1 \mathrm{~mm}$ controlled the microprobe, micro-thermocouple and capillary for moisture supply geometric location. The manipulators device allowed moving the probe and the micro-thermocouple fixed in them, in three planes and provided angular movements in two planes. The remote control minimized the vibration possibility in the micro-sensors movement controlling process.

Therefore, stereotactic unit allowed selecting a step equal to $0.05 \mathrm{~mm}$ in the direction, perpendicular to the flame front, for probing the flame front. The coordinate's equality in this direction for the micro-thermocouple junction and the probe enclosure of the (subject to a correction of $0.1 \mathrm{~mm}$ through the perturbation zone) was not violated. The flame front was flat, which precluded measurement errors due to mismatch between the probe and thermocouple coordinates in a parallel to the front plane direction.

\section{Research method of the all components of the mixture for combustion flows}

Perilstatic pumps, which were connected to the moisture source and capillary by silicone rubber hoses, were used to supply drip moisture to the flame front. Moisturecapillary capillaries were made of steel X10CrNiTi18-10 and had $0.8 \mathrm{~mm}$ outer diameter. Perilstatic pumps were equipped with a flow regulator, which stabilized the moisture flow at a given value. The flow was chosen to compensate the moisture evaporation in the flare, and to keep surface volume and evaporation of the drop injected into the laminar flame front. 


\section{Statistical data processing}

Data were expressed as means \pm standard deviations for triplicate determination. The measurement error value due to inaccurate probe and thermocouple relative to this point of flame fixation did not exceed $5 \%$ of the flame front width. The flams' opening angle was taken into account during the experimental data processing. Thus, data on the temperature and concentration fields' distribution over the flame front width were obtained. All statistical procedures were computed using the Microsoft Excel 2007 software. Differences were considered to be significant at a validity of $\alpha=0.95$.

\section{Results and discussion}

\section{Investigation of the hydrogen peroxide injection}

The various concentrations (up to 30\%) hydrogen peroxide solution was fed in the drop of liquid form into the flame laminar methane flame front. The obtained results testified to the equidistant character of the concentrations distribution dependences during the distilled water injection.

The moisture influence in the fuel combustion process was previously studied at the experimental stand developed by the authors (Klimenko V.M. et. al., 2008). In those studies, the various volumes of distilled water drops injected into the methane combustion zone (laminar flame). According to the conclusions, the moisture added to the combustion process with the initial products can be divided into moisture, which is involved in the chemical fuel oxidation process and which is not involved.

Fig. 3 shows the following dependence between the nitrogen oxides concentration and the hydrogen content in an aqueous hydrogen peroxide solution: with decreasing hydrogen content in the solution, and, accordantly, increasing the oxygen content, nitrogen oxides concentration increase. Authors (Soroka B.S. et. al., 2020) attempted to describe household burners on the possibility of their operation with a methane-hydrogen mixture in the range of $\mathrm{H}_{2}$ from 0 to $50 \%$.

The obtained results and conclusions show the possibility of applying the studied methane-hydrogen ratios on domestic gas stoves. However, these results could hardly be scaled either for industrial burners or for burners installed in existing boiler units in general, due to differences in technical characteristics.

\section{Investigation of the nitrogen oxides formation}

The increasing the nitrogen oxides formation in atmosphere during the combustion hydrogen and hydrogen mixtures is well known problem (Castilla-Martinez C.A. et. al., 2021).

This can be explained by the assumption that the growth of the thermodynamic component for these ratios dominates over the kinetic. In Figure 3 dashed line (beginning at point $\mathrm{A}^{\prime}$ ) shows the probable expected nitrogen oxides concentration value flame front cut for the $\delta=0.511 \mathrm{~mm}$.

However, a series of experiments performed in this section showed a point A that is deviates. At the same time, it lowers the temperature in the combustion zone, which leads to a decrease the nitrogen oxides concentration. In addition, the water molecule disintegrates into hydrogen $\left(\mathrm{H}_{2}\right)$ and oxygen $\left(\mathrm{O}_{2}\right)$, if the energy of flame is sufficient. The released hydrogen is involved in combustion reactions, that is, in fact the process we are studying (Klimenko V.M. et. al., 2008). 


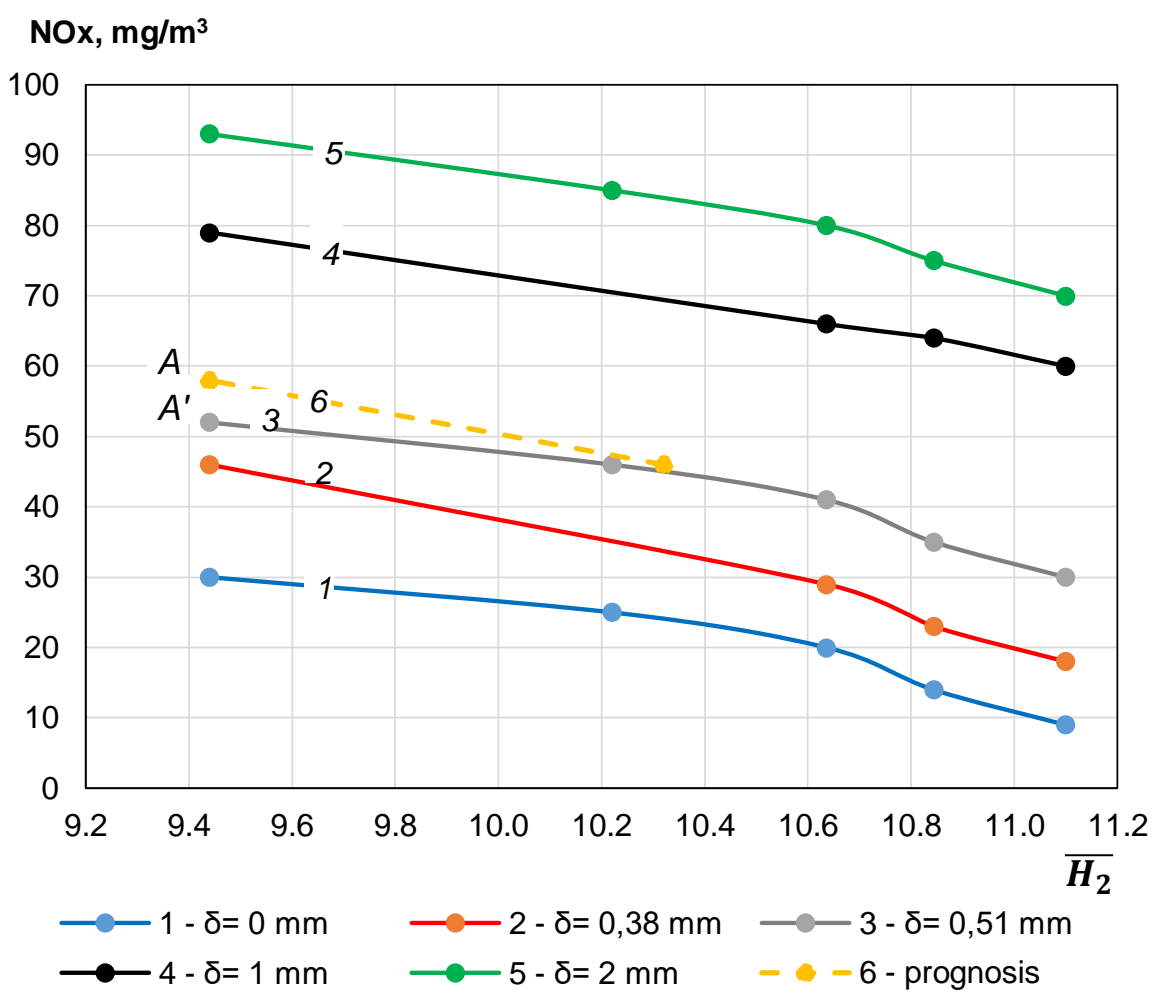

Figure 3. The $\mathrm{NO}_{\mathrm{x}}$ content in the combustion products depending on the hydrogen content in the solution

The authors suggest that this area, approximately the middle of the flame front, is a relevant area for further study with the aim of more accurately explains the deviations. The difference between the obtained and expected nitrogen oxides values is $10.5 \%$ and is equal to $6-8 \mathrm{mg} / \mathrm{m}^{3}$.

In the results of (Sigal O.I. et. al., 2020), the authors found that at temperatures, less than $1000 \mathrm{~K}$ the nitrogen oxides concentration is close to $1011 \mathrm{~cm} / \mathrm{mol} \cdot \mathrm{s}$, but at temperatures more than $1000^{\circ} \mathrm{K}$ increases sharply, the $\mathrm{CO}$ combustion intensifies and the reaction thermal effect increases. That is, increasing the $\mathrm{H}_{2} \mathrm{O}_{2}$ solution concentration to $30 \%$ and, accordingly, reducing the hydrogen content in the solution to $9.44 \%$ led to increase in the nitric oxide total yield by $35-45 \%$ for these experimental conditions This may be due to more intensive $\mathrm{OH}$ and $\mathrm{OH}_{2}$ radicals' formation and an increasing the temperature in the $\mathrm{CO}$ afterburning.

For chain radical reactions in a hydrogen-oxygen mixture at $\mathrm{T}>1000 \mathrm{~K}$, the branching mechanisms are relatively independent of the nature of the fuel. However, at temperatures below $1000 \mathrm{~K}$, that is traditional for most boilers, they become much more complicate and depend on the fuel nature (Warnatz, J. et. al., 2006).

Experimental studies expectedly showed that with increasing hydrogen content, higher temperatures are reached. However, it is impossible to estimate the effectiveness of the additional substance (ballasts) to the combustion process by calculating their thermodynamic characteristics only. It is also necessary to take into account the process kinetics. For example, in (Klimenko V.M. et. al.,2008) the ballasts, which are often added during staged 
combustion, such as excess air and steam are compared. The authors showed that with increasing maximum local temperatures of the process, the efficiency of the addition thermodynamically different ballasts converges. This can be explained by the assumption the dominance of kinetic aspects over thermodynamic ones.

Separate $\mathrm{NO}$ and $\mathrm{NO}_{2}$ measurements showed that the dependence of the $\mathrm{NO}_{2}$ fraction on the $\mathrm{H}_{2}$ content in the solution, supplied to the laminar methane flare, is ambiguous and significantly depends on the sampling location at the flame front cut section of the.

In the anterior front border (Figure 4, graph 1) the $\mathrm{NO}_{2}$ share reaches $78 \%$ of the maximum at a $9.85 \%$ hydrogen content in solution (corresponding to concentration of $\mathrm{H}_{2} \mathrm{O}_{2}$ solution $22 \%$ ), reaches the limit values and remains unchanged with further hydrogen in solution reduction that is equal to increasing in the hydrogen peroxide solution concentration. In the average front cut section (fig. 4), graph 2 has its extremum, which corresponds to a hydrogen content of 0.63 in the ordinate. That is, a decreasing the hydrogen concentration in the solution (increasing the $\mathrm{H}_{2} \mathrm{O}_{2}$ concentration to $15 \%$ ) for this cut flame front section is also leads to a significant increase in the $\mathrm{NO}_{2}$ proportion. However, a further increasing the hydrogen peroxide percentage leads to a decreasing the ratio to 0.3 , which roughly corresponds to the hydrogen content effect of $9.44 \%$ in the solution $\left(3 \% \mathrm{H}_{2} \mathrm{O}_{2}\right.$ solution). Graph 3, corresponding to the point with coordinate 2.0 , equidistantly repeats graph 2 , but with less pronounced maximum at the point with the coordinate where the hydrogen content in the solution is about $9.4 \%$.

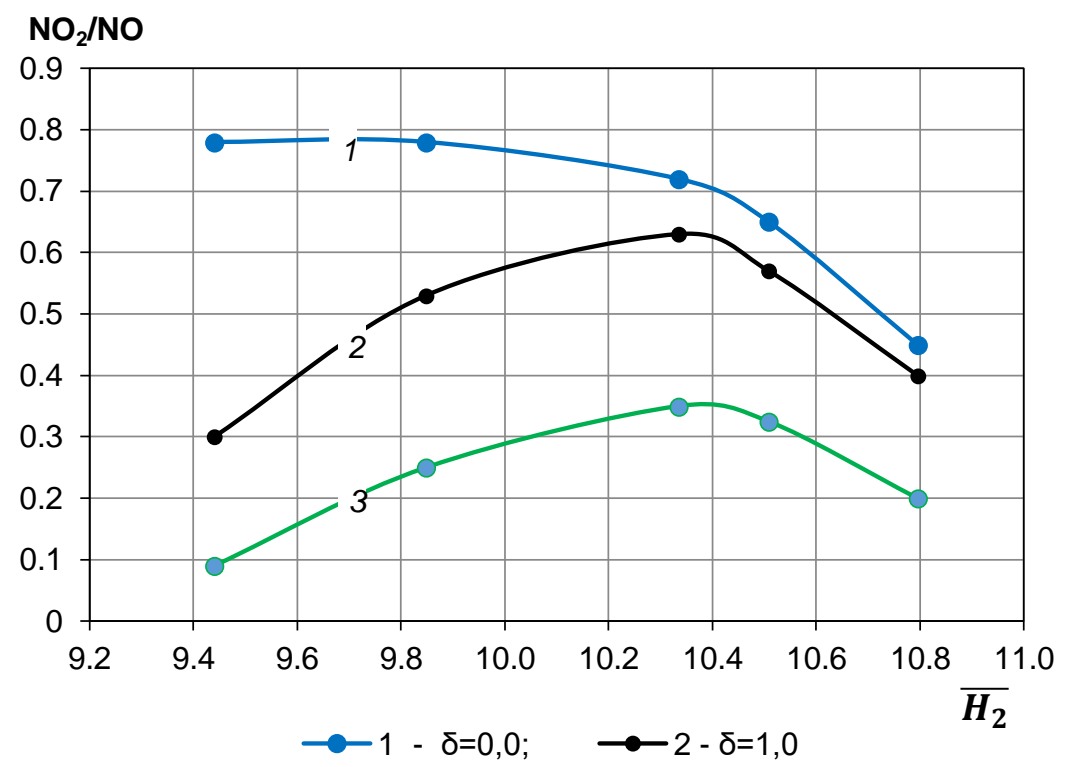

Figure 4. The hydrogen content in the solution effect on the $\mathrm{NO}_{2}$ formation in the laminar methane flare flame front, where:

1 - anterior front border, coordinate $\delta=0,0 \mathrm{~mm}$;

2 - average front cut section, the coordinate $\delta=1.0 \mathrm{~mm}$;

3 - rear front boundary, coordinate $\delta=2,0 \mathrm{~mm}$. 
Thus, temperatures above $800 \mathrm{~K}$ significantly affect the reaction rate and change the kinetics of processes. This occurs with the participation of hydrogen in a hydrogen peroxide solution. Moreover, in different front cuts, these changes are different by nature, which can be explained decreasing in the $\mathrm{H}_{2} \mathrm{O}_{2}$ existence time in the flame to $20 \mathrm{~ms}$ or less.

It is also important that the influence degree of hydrogen, which is present in the hydrogen peroxide solution, on the $\mathrm{NO}$ to $\mathrm{NO}_{2}$ oxidation process for different temperatures have its extremum in the added substance concentration. Figure 4 shows that for this maximum $\mathrm{NO}_{2}$, the $\mathrm{H}_{2}$ content in solution is about $9.4 \%$.

Calculation and experimental research allow determining the influence degree of the moisture content in the initial components on the hydrocarbon fuels combustion. The initial moisture in the fuel-air mixture should be about $8-9 \%$ by combustion products weight. This fact underlies the idea that the moisture content in the initial products influence on the combustion process insignificantly.

Experimental data in this work were obtained for the air excess coefficient of $\alpha=1.1$. These data illustrate that the nitrogen monoxide content increase at the beginning of the flame front and decreases behind the flame front when the combustion products temperature reducing because of the dilution and recombination reactions.

The nitrogen monoxide concentration decreases depending on the temperature and approximately repeats the changes of last one with some delay. These results have a good agreement with the results in (Sigal I.Ya. et. al.,2020) by the form of temperatures and concentrations absolute values curves and also confirm the assumption, made as a result in analytical studies (Sigal A. et. al.,2021), about the mismatch between the maximum temperatures and the maximum concentrations zones.

Mostly just such a dual role moisture explains the diversity and discrepancy in data on its effect on combustion process, resulted in various research (Klimenko V.M. et. al.,2008; Sigal A. et. al.,2021). There are even opposing views to this problem, from the combustion process intensification to an increase in the inefficient ballast volume. It can also be assumed that such common methods as combustion products recirculation to the flame root and flame turbulence in diffusion burners, which has the same function, provide flame root fertilization with the first type of moisture. The kinetic studies lead to a simplified kinetic scheme for NOx formation and reduction under conditions of sludge combustion. (C. Philippek et. al., 1997)

In (Sigal I.Ya. et. al.,2020) for burning gas-oil emulsions at the gas-turbine units, the steam injection used as an additive. Calculations performed for the following values of relative between the fuel consumption and injected steam: $\mathrm{G}_{\mathrm{s}} / \mathrm{G}_{\mathrm{f}}=0 ; 0.02 ; 0.053 ; 0.11 ; 0.33$ and 1.0, where $\mathrm{G}_{\mathrm{s}}, \mathrm{G}_{\mathrm{f}}$ - weight consumption of steam and fuel respectively. With increasing the steam injection, the combustion zone is stretching in some measure and the maximum local flame temperature decrease by $80-100 \mathrm{~K}$. After adding a small amount of $\mathrm{H}_{2} \mathrm{O}$, the $\mathrm{CO}$ content may decrease, and with a large amount, it may increase. The fuel $\mathrm{NO}$ concentration decreased by approximately $7 \%$, which shows a weak effect of moisture additives on the fuel nitrogen oxides formation. An intensive increasing the nitrogen oxides concentration is observed in the initial cut flame front sections from the moment where the mixture start the heating to the maximum temperature. Incomplete combustion processes lead to the formation of many gaseous byproducts that can be challenging to monitor in flue gas released via chimneys. (Magnus Galfalk et. al., 2018),

Moreover, the higher the $\mathrm{H}_{2} \mathrm{O}_{2}$ solution concentration is injected into the flame front (similarly, the smaller the hydrogen proportion in the solution), the more intense the increase in the nitrogen oxides content. 
When a $30 \% \mathrm{H}_{2} \mathrm{O}_{2}$ solution injected into the flame front, the NO concentration practically reaches the initial one, which obtained without the drip moisture injection (90-95 $\mathrm{mg} / \mathrm{m}^{3}$ ). At the same time, the $\mathrm{H}_{2} \mathrm{O}$ injection into the flame front leads to a decrease in $\mathrm{NO}$ concentration by $35-40 \%$, up to $65 \mathrm{mg} / \mathrm{m}^{3}$. This can be explained by the fact that hydrogen peroxide forms the $\mathrm{OH}$ radical, which is actively involved in the hydrocarbons and $\mathrm{CO}$ oxidation, more intense than water. The spatial distribution of the flame generated radicals ( $\mathrm{OH}$ and $\mathrm{CH}$ ) (Mörtberg M. et. al., 2006).

The $\mathrm{OH}$ radical forms hydroperoxide-radical $\mathrm{HO}_{2}$ from $\mathrm{H}_{2} \mathrm{O}_{2}$, which dissociates with the superoxide ion $\mathrm{O}_{2}$-formation and gives the $\mathrm{H}$-radical from $\mathrm{H}_{2} \mathrm{O}_{2}$. The reaction rate is determined by the reaction:

$$
\begin{gathered}
\mathrm{CO}+\mathrm{OH} \rightarrow \mathrm{CO}_{2}+\mathrm{H}, \\
\mathrm{W}^{1}=4,4 \cdot 10^{6} \mathrm{~T}^{1 / 5} \exp (3,1 /(\mathrm{RT}))
\end{gathered}
$$

It can be concluded that the most appropriate conditions for the $\mathrm{NO}$ in $\mathrm{NO}_{2}$ oxidation is the hydrogen injecting with a hydrogen peroxide concentration in a solution $10.3 \%$ and the temperature range $800-1000 \mathrm{~K}$. The flammable area, but not the flame front is the most suitable for these conditions. However, these assumptions need further study. Therefore when hydrogen is burned in the boiler furnace, the NO concentration increases accordingly, and the $\mathrm{NO}_{2}$ share decrease accordingly.

Decreasing temperature with a change in the excess air coefficient leads to a decrease $\mathrm{NO}$ concentration in the flame front both without moisture addition and with it. $\mathrm{H}_{2} \mathrm{O}$ drops addition reduces the maximum local temperature by at least 200 degrees for any excess air coefficient and the nitrogen monoxide content in this case is significantly decreases too. The combination helps in emission reductions, saving of fuel consumption and increased efficiency (Nugroho Agung Pambudia et. al., 2017). Number of moisture that can be used in the combustion process chemically, obviously, must be different for different fuels and depend on the excess air coefficient. Any information about the experiments of other researchers with the moisture addition to the combustion process with a variable proportion of hydrogen is unknown to the authors.

Experiments showed that droplet moisture addition to the flame front provided a reduction in the maximum local temperature in the drop trace by $200 \pm 10$ degrees that led to decreasing the nitrogen monoxide content in the combustion products by $30-50 \%$. After coprocessing, the concentrations of $\mathrm{NOx}, \mathrm{SO}_{2}, \mathrm{CO}$, and all heavy metals in the flue gas emitted from the coal-fired drop-tube furnace did not change a lot. (Chen T. et. al., 2020).

Thus the most effective reduction of NO formation due to the drip moisture addition into the flame front was achieved at lower $\alpha$, or at higher flame temperatures. Local mean concentrations of $\mathrm{O}_{2}, \mathrm{CO}, \mathrm{SO}_{2}$ and $\mathrm{NO}$ gas species and gas temperatures were determined in the region above the grate (Li Z. et. al., 2009).

This effect can be used for reducing nitric oxide emissions by purifying the flue gases in the contact apparatus, for example the $\mathrm{NO}$ and $\mathrm{NO}_{2}$ absorption by water. It is known that $\mathrm{NO}_{2}$ is completely soluble in water, and the $\mathrm{NO}$ dissolution proportion does not exceed $7 \%$ and depends on the temperature and the catalysts presence. The hydrogen solutions injection into the combustion zone can be carried out by different ways and, in particular, in the liquid droplets form, as it is shown in this work. 


\section{Conclusions}

1. The analysis of obtained results showed that with increasing hydrogen content in the solution the NOx formation decreases, which can be explained by the oxygen consumption in fast reactions that require less energy. It is shown that with increasing hydrogen content in the solution, the $\mathrm{NO}_{2}$ formation increases to maximum values at $\overline{\mathrm{H}_{2}}=10,32 \%$, and then decreases again by $70 \%$ of the maximum concentration.

2. Research and analysis of the $\mathrm{NO}_{2}$ concentration in the relevant investigated flame front areas with the hydrogen peroxide solution injection depends on: the $\mathrm{H}_{2}$ concentration in the solution, maximum local temperature in the flame front, points of additional ingredients injection. The formation of up to $80 \% \mathrm{NO}_{2}$ in the composition of $\mathrm{NOx}$ is observed near the anterior flame front border and in the first part of the flame front that is, $\mathrm{NO}$ is only $20 \%$ of the NOx composition, if the hydrogen peroxide concentration is $15 \%$.

3. The study of obtained results shown, the most appropriate conditions for the $\mathrm{NO}$ to $\mathrm{NO}_{2}$ oxidation is the injection into the flame a solution, when the hydrogen content is $10.32 \%$ and the temperature range $800-1000^{\circ} \mathrm{K}$. The flammable area rather than the flame front suitable for these conditions. Therefore, when burning hydrogen in the boiler furnace increase the $\mathrm{NO}$ concentration and the $\mathrm{NO}_{2}$ share decrease.

4. It was established that with decreasing of the $\mathrm{H}_{2}$ concentration in the hydrogen peroxide solution of (respectively, an increase hydrogen peroxide to $30 \%$ the concentration) $\mathrm{H}_{2} \mathrm{O}$ ballast cooling effect in the solution decreases to zero by increasing the thermal $\mathrm{CO}$ oxidation effect by $\mathrm{OH}$ radicals, $\mathrm{H}_{2} \mathrm{O}$ disintegration and increase the flame temperature by approximately $150^{\circ}$.

\section{References}

Abbas A.J., Hassani H., Burby, M., John I.J. (2021), An Investigation into the Volumetric Flow Rate Requirement of Hydrogen Transportation in Existing Natural Gas Pipelines and Its Safety, Implications. Gases, 1, pp. 156-179.

Andre J., Auray S., De Wolf D., Memmah M.M., Simonnet A. (2014), Time development of new hydrogen transmission pipeline networks for France, Int. J. Hydrogen Energy, 39, pp. 10323-10337.

Castilla-Martinez C.A., Moury R., Ould-Amara S. Demirci U.B. (2021), Destabilization of Boron-Based Compounds for Hydrogen Storage in the Solid-State: Recent, Advances. Energies, 14, 7003.

Chen T., Sun C., Zhan M.X., Hu P.L., Lu S.Y., Qiang-Yu (2020), Co-processing of the MSWI flue gas in a lab-scale coal-fired drop-tube furnace, Environmental science and pollution research international, 27 , pp. 34172-34181.

Chengfang Song, Cheng Zhang, Shicheng Zhang, Hui Lin, Yrjala Kima, Muthusamy Ramakrishnan,Yanqiang Du, Yan Zhang, Huabao Zheng, Damia Barcelo (2020) ,Thermochemical liquefaction of agricultural and forestry wastes into biofuels and chemicals from circular economy perspectives, Science of the Total Environment, 749, 141972.

Curtin S., Gangi J. (2017), Food Science and Technology, Institute of Food Science \& Technology, 30 May 2017, Available: http://fstjournal.org/features/31-2/fuel-cells.

Damien G., Gianpaolo V. (2021), Hydrogen as a Clean and Sustainable Energy Vector for Global Transition from Fossil-Based to Zero-Carbon, Clean Technol., 3, pp. 881-909. 


\section{- Processes and Equipment -}

Klimenko V.M., Mazur A.I., Sabashuk P.P. (2008), Cogeneration systems with thermal motors. - Part 1. Headquarters of cogeneration technologies, IPC ALKON NAS of Ukraine, Kyiv.

Li Z., Zhao W., Li R., Wang Z., Li Y., Zhao G. (2009), Combustion characteristics and NO formation for biomass blends in a 35-ton-per-hour travelling grate utility boiler, Bioresource technology, 100(7), pp. 2278-2283.

Magnus Gålfalk, David Bastviken (2018), Remote sensing of methane and nitrous oxide fluxes from waste incineration, Waste Management, 75, pp. 319-326.

Mörtberg M., Blasiak W., Gupta A. K. (2006), Combustion of normal and low calorific fuels in high temperature and oxygen deficient environment, Combustion Science and Technology, pp. 1345-1372.

Myronchuk V., Obodovych O., Sydorenko V. (2019), The influence of discrete-pulsed energy input on the distribution of plant biomass, Ukrainian Food Journal, 8(3), pp. 634-645

Nugroho Agung Pambudia, Kenshi Itaokaa, Atsushi Kurosawab, Natsuki Yamakawa (2017), Impact of hydrogen fuel for $\mathrm{CO}_{2}$ emission reduction in power generation sector in Japan, Energy Procedia, 105, pp. 3075 -3082.

Orana Sandri, Sarah Holdsworth, Jan Hayes, Nicola Willand, Trivess Moore (2021), Hydrogen for all? Household energy vulnerability and the transition to hydrogen in Australia, Energy Research \& Social Science, 79, 102179.

Philippek C., Knoebig T., Schoenfelder H., Werther J. (1997), NOx formation and reduction during combustion of wet sewage sludge in the circulating fluidized bed-Measurements and simulation, American Society of Mechanical Engineers, New York.

Sang Eun Oh, Bruce E. Logan (2005), Hydrogen and electricity production from a food processing wastewater using fermentation and microbial fuel cell technologies, Water Research, 39(19), pp. 4673-4682.

Sigal A., Paderno D. (2021), Effect of moisture on nitrogen dioxide formation in laminar flame of natural gas, Journal of Environmental Engineering and Landscape Management, DOI: 10.3846/jeelm.2021.15492.

Sigal I.Ya.,. Smikhula A.V, Sigal O.I., Marasin O.V. (2020), Combustion Research Of Impinging Gas Jets At Stabilization Of The Flame Front On A Vertical Surface, Energy Technologies \& Resource Saving, 4, pp. 29-38.

Sigal O.I., Nizhnik N.A. (2020), Prospects of hydrogen use in industrial combustion processes, Thermophysics and Thermal Power Engineering, 3, pp. 68-75.

Soroka B.S., Pyanykh K.E., Zgursky V.O., Gorupa V.V., Kudryavtsev V.S. (2020), Energy and environmental characteristics of household gas appliances using methane-hydrogen mixture as a fuel gas, Oil and Gas Industry of Ukraine, 6, pp. 3-13

Tsegaye B., Jaiswal S., Jaiswal A.K. (2021), Food Waste Biorefinery: Pathway towards Circular Bioeconomy, Foods, 10, 1174.

Warnatz J., Maas Ulrich, Dibble Robert W. (2006), Combustion. Physical and chemical fundamentals, modeling and simulations, experiments, pollutant formation, SpringerVerlag, Berlin-Heidelberg.

Wongthanate J., Khumpong M. (2015), Biohydrogen Production from Food and Beverage Processing Wastewater by Enriching Sludge Compost, Research Journal of Microbiology, 10, pp. 433-439.

Wu P., Clemmer R. (2018), Fuel Cell Technology: Applications in the Food Industry, CSBE/SCGAB Annual Conference University of Guelph, Guelph, ON, 22-25 July 2018, Paper No. CSBE18-245.

Yue M., Lambert H., Pahon E., Roche R., Jemei, S., Hissel D. (2021), Hydrogen energy systems: A critical review of technologies, applications, trends and challenges, Renew. Sustain. Energy Rev., 146, 111180. 


\title{
Regulation of biological activity of surfactants under cultivation of Acinetobacter calcoaceticus IMB B-7241 on glycerol
}

\section{Tetiana Pirog ${ }^{1,2}$, Daria Lutsai ${ }^{1}$, Hanna Yarova ${ }^{1}$}

\author{
1 - National University of Food Technologies, Kyiv, Ukraine \\ 2 - Institute of Microbiology and Virology of the NAS, Kyiv, Ukraine
}

\section{Keywords: \\ Acinetobacter \\ calcoaceticus \\ IMV B-7241 \\ Surfactants \\ Glycerol \\ Regulation \\ Properties}

\section{Article history:}

Received

07.05.2021

Received in

revised form

21.11.2021

Accepted

30.12.2021

Corresponding

author:

Tetiana Pirog

E-mail:

tapirog@

nuft.edu.ua

\section{DOI:}

10.24263/2304974X-2021-10-416

\section{Abstract}

Introduction. The aim of this research was to study the biological activity of surfactants synthesized by Acinetobacter calcoaceticus IMV B-7241 in the medium with glycerol of various degrees of purification and high content of calcium cations (activators of $\mathrm{NADH}^{+}$-dependent glutamate dehydrogenase, which is a key enzyme of biosynthesis of surface-active aminolipids responsible for antimicrobial activity of surfactant complex).

Materials and methods. Cultivation of A. calcoaceticus was carried out in liquid mineral medium using as substrates refined glycerol and the waste from biodiesel production. The base medium did not contain calcium chloride, the content of $\mathrm{CaCl}_{2}$ in the modified medium was 0.1 and $0.2 \mathrm{~g} / \mathrm{l}$. Surfactants were extracted from the supernatant of the culture luquid with a modified mixture of Folch. The number of adhered cells and the degree of biofilm destruction in the presence of surfactants was determined by spectrophotometric method, antimicrobial activity of surfactants - by the minimum inhibitory concentration (MIC).

Results and discussion. It was found that the additional introduction of $0.1-0.2 \mathrm{~g} / 1$ of $\mathrm{CaCl}_{2}$ into cultivation medium with refined glycerol was accompanied by the synthesis of surfactants, the MIC of which against bacteria (Bacillus subtilis BT-2, Enterobacter cloacae C-8, Staphylococcus aureus BMS-1) and yeast (Candida albicans D-6) were $1.01-21.3 \mu \mathrm{g} / \mathrm{ml}$ and were 1.4-29 times lower compared to the MIC of surfactants obtained in base medium $(1.83-58.8 \mu \mathrm{g} / \mathrm{ml})$. The adhesion of test cultures on abiotic materials treated with such surfactants was $8-13 \%$ lower, and the degree of biofilms destruction was 5-19\% higher compared to the values, established for surfactants obtained on base medium. The increasing antimicrobial and anti-adhesive activity of surfactants synthesized on waste of biodiesel production was observed only when $\mathrm{CaCl}_{2}$ was introduced into the medium at a concentration of $0.2 \mathrm{~g} / \mathrm{l}$. Surfactants synthesized in the presence of calcium cations in the medium with the waste of biodiesel production proved to be more effective destructors of bacterial biofilms in comparison with those obtained in the base medium only at low concentrations $(0.7-5.5 \mu \mathrm{g} / \mathrm{ml})$.

Conclusion. The results demonstrate the possibility of regulating the biological activity of A. calcoaceticus IMV B-7241 surfactants by changing in the composition of medium content of calcium cations activators of $\mathrm{NADH}^{+}$-dependent glutamate dehydrogenase (key enzyme of surface-active aminolipids biosynthesis). Surfactants synthesized under different cultivation conditions of A. calcoaceticus IMB B-7241 on glycerol are more effective biofilm destructors and antimicrobial and anti-adhesive agents compared to the known lipopeptides and rhamnolipids formed on glycerol. 


\section{Introduction}

The disadvantages of technologies for obtaining microbial surfactants, which due to a combination of unique physicochemical and biological properties are metabolites of a wide range of applications, are changes in these properties in different cultivation conditions, as well as the high cost of such microbial synthesis products (Sharma and Sharma, 2021; Shu et al., 2021).

One of the ways to increase the efficiency of microbial surfactant technologies is using cheap industrial waste as a substrate, waste of biodiesel production, in particular (Crosse et al., 2019). Interest in waste of biodiesel production is due to the fact that the problem today is the need to dispose of large amounts of toxic industrial waste. The most effective way to dispose of such waste is to use them as substrates in biotechnological processes to obtain practically valuable products (Diamantopoulou et al., 2020).

There is no data in the literature about ways to regulate the biological activity of surfactants under the cultivation of the producer and notes that the main approaches to regulating the biological properties of microbial surfactants are their post-fermentation chemical modification and improvement of producer strains by metabolic and genetic engineering (Pirog et al., 2019).

It was previously established that Acinetobacter calcoaceticus IMV B-7241 synthesizes a complex of surfactant amino- and glycolipids on a wide range of carbon substrates, including glycerol of various degrees of purification. A study of the biological activity of surfactants synthesized on the waste of biodiesel production showed that such surfactants proved to be less effective antimicrobial agents compared to those formed on refined glycerol (Pirog et al., 2018).

Our previous studies have shown that one of the approaches to increase the antimicrobial and anti-adhesive activity of microbial surfactants is to increment the content of activators of key enzymes of aminolipid biosynthesis - the most effective antimicrobial agents (Pirog et al., 2018; 2019; 2021).

Activators of $\mathrm{NADH}^{+}$-dependent glutamate dehydrogenase in strain A. calcoaceticus IMV B-7241 grown on refined glycerol are calcium cations. However, no activating effect of $\mathrm{Ca}^{2+}$ on the activity of this enzyme was detected during the cultivation of $A$. calcoaceticus IMV B-7241 on the waste of biodiesel production (Pirog et al., 2021)

In connection with the above, this work aimed to study the biological activity of surfactants synthesized by A. calcoaceticus IMV B-7241 in a medium with glycerol of different degrees of purification and higher content of calcium cations (activators of $\mathrm{NADH}^{+}-$ dependent glutamate dehydrogenase - key enzyme of biosynthesis of surfactant aminolipids).

\section{Materials and methods}

\section{Object of research}

The main object of research was a strain of oil-oxidizing bacteria, identified as Acinetobacter calcoaceticus K-4 and isolated from an oil-contaminated soil sample. Strain A. calcoaceticus K-4 is registered in the Depository of Microorganisms of the D.K. Zabolotny Institute of Microbiology and Virology of the National Academy of Sciences of Ukraine under the number IMV B-7241.

Bacterial strains (Bacillus subtilis BT-2, Enterobacter cloacae C-8, Staphylococcus aureus BMS-1) and yeast (Candida albicans D-6) from the collection of live cultures of the 


\section{—Biotechnology. Microbiology —}

Department of Biotechnology and Microbiology of the National University of Food Technology were used as test cultures in determining the antimicrobial and anti-adhesive activity of surfactants, as well as their role in the destruction of biofilms.

\section{Medium composition and conditions of cultivation}

Strain A. calcoaceticus IMV B-7241 was grown in the medium $(\mathrm{g} / \mathrm{l}):\left(\mathrm{NH}_{2}\right)_{2} \mathrm{CO}-0.35$; $\mathrm{MgSO}_{4} \cdot 7 \mathrm{H}_{2} \mathrm{O}-0.1 ; \mathrm{NaCl}-1.0 ; \mathrm{Na}_{2} \mathrm{HPO}_{4}-0.6 ; \mathrm{KH}_{2} \mathrm{PO}_{4}-0.14 ; \mathrm{pH}$ 6.8-7.0. Yeast autolysate $-0.5 \%(\mathrm{v} / \mathrm{v})$ and microelement solution $-0.1 \%(\mathrm{v} / \mathrm{v})$ were additionally added into the medium. The micronutrient solution contained (g/100 ml): $\mathrm{ZnSO}_{4} \cdot 7 \mathrm{H}_{2} \mathrm{O}-1,1 ; \mathrm{MnSO}_{4}$ - $\mathrm{H}_{2} \mathrm{O}-0.6 ; \mathrm{FeSO}_{4} \cdot 7 \mathrm{H}_{2} \mathrm{O}-0.1 ; \mathrm{CuSO}_{4} \cdot 5 \mathrm{H}_{2} \mathrm{O}-0.004 ; \mathrm{CoSO}_{4} \cdot 7 \mathrm{H}_{2} \mathrm{O}-0.03 ; \mathrm{H}_{3} \mathrm{BO}_{3}-$ 0.006 ; KI - 0.0001; EDTA (Trilon B) -0.5 .

\section{Modifications of the base medium:}

1. Adding of $\mathrm{CaCl}_{2}(0.1 \mathrm{~g} \mathrm{l})$,

2. Adding of $\mathrm{CaCl}_{2}(0.2 \mathrm{~g} / \mathrm{l})$.

As carbon sources used $(\%, \mathrm{v} / \mathrm{v})$ : refined glycerol -3 , waste of biodiesel production 5. Concentrations of glycerol of different quality are equimolar on carbon.

As the inoculum was used culture in the exponential phase, grown in a medium of the above composition with $0.5 \%$ of the corresponding substrate. The inoculum with the number of bacteria $10^{4}-10^{5}$ cells $/ \mathrm{ml}$ was applied in an amount of $10 \%$ of the medium volume.

Cultivation of A. calcoaceticus IMV B-7241 was carried out in $750 \mathrm{ml}$ flasks with 100 $\mathrm{ml}$ of medium on a shaker $(320 \mathrm{rpm})$ at $30^{\circ} \mathrm{C}$ for 7 days.

\section{Determination of extracellular surfactant concentration}

The amount of extracellular surfactants was determined using our modified method of Bly and Dyer (Bligh and Dyer, 1959) after extraction with a mixture of chloroform and methanol (2:1) from the supernatant of the culture liquid. To obtain the supernatant, the culture liquid was centrifuged at $5000 \mathrm{~g}$ for 20 minutes.

We modified the classical solvent system (Folch mixture - the known Bly and Dyer method used to isolate surfactants allows to isolate mainly nonpolar lipids) by adding $1 \mathrm{n}$ $\mathrm{HCl}$ (chloroform-methanol $-1 \mathrm{n} \mathrm{HCl}=4: 3:$ 2) because A. calcoaceticus IMV B-7241 synthesizes a complex of polar and non-polar lipids. This system allows to completely isolate both polar and non-polar lipids.

$25 \mathrm{ml}$ of supernatant was placed in a $100 \mathrm{ml}$ cylindrical separation glass-stoppered funnel, added $1 \mathrm{n} \mathrm{HCl}$ solution to achieve a pH of 4.0-4.5 (about $5 \mathrm{ml}$ ). The funnel was shaken for $3 \mathrm{~min}$, then added $15 \mathrm{ml}$ of chloroform and methanol (2:1) and shaken again (lipid extraction) for 5 minutes. The mixture obtained after extraction was left in a separation funnel for phase separation, after which the lower fraction was drained (organic extract 1), and the aqueous phase was subjected to re-extraction. Upon re-extraction, $1 \mathrm{n} \mathrm{HCl}$ solution was added to the aqueous phase to achieve a $\mathrm{pH}$ of 4.0-4.5 (about $5 \mathrm{ml}$ ), $15 \mathrm{ml}$ of a mixture of chloroform and methanol (2:1) and the lipids were extracted for 5 minutes. After phase separation, the lower fraction was drained to obtain organic extract 2 . In the third step, $25 \mathrm{ml}$ of a mixture of chloroform and methanol (2:1) was added to the aqueous phase, and extraction was carried out as described above for obtaining organic extract 3. Extracts 1-3 were combined and evaporated on a rotary evaporator IP-1M2 at $50^{\circ} \mathrm{C}$ and an absolute pressure of 0.4 ATM to constant weight. 


\section{Obtaining surfactant preparations}

Solutions of A. calcoaceticus IMV B-7241 surfactants with various concentrations were used as preparations in the researches. For this, the dry surfactant residue was dissolved in sterile phosphate buffer $(0.1 \mathrm{M}, \mathrm{pH} 7.0)$ to the original volume $(25 \mathrm{ml})$ and then diluted with this buffer to the required concentration. Surfactant solutions were sterilized in an autoclave at $112^{\circ} \mathrm{C}$ for 30 minutes.

\section{Analysis of antimicrobial activity of surfactants}

The antimicrobial activity of surfactants was analyzed by the minimum inhibitory concentration (MIC) (Chebbi et al., 2017). Determination of MIC was carried out by the method of double serial dilutions in meat-peptone broth (MPB) for bacteria and liquid wort for yeast. $1 \mathrm{ml}$ of medium was added to 10 tubes, $1 \mathrm{ml}$ of a surfactant solution of a certain concentration was added to the first tube, then mixed, after that $1 \mathrm{ml}$ was taken and transferred to the next tube under sterile conditions. A similar dilution was performed for the next nine tubes. $1 \mathrm{ml}$ was taken from the last tube. Thus, the final volume in each tube was 1 $\mathrm{ml}$ (MPB or wort and surfactant solution), and the surfactant concentration in each next tube was reduced by 2 times. As a control, $1 \mathrm{ml}$ of MPB (for bacteria) or wort (for yeast) was used without the adding of surfactant solution. Next, $0.1 \mathrm{ml}$ of test culture suspension $\left(10^{5}-10^{6}\right.$ $\mathrm{CFU} / \mathrm{ml}$ ) was added to each tube and mixed. The tubes were incubated for $24 \mathrm{~h}$ at $28-30^{\circ} \mathrm{C}$ for bacteria and $24-26^{\circ} \mathrm{C}$ for yeast. The results were evaluated visually by the medium turbidity: $(+)$ - tubes, medium turbidity was observed (growth of the test culture), (-) - there was no turbidity (no growth). The minimum inhibitory concentration of surfactant solution was defined as the surfactant concentration in the last tube where growth was absent.

\section{Determination of anti-adhesive activity of surfactants}

The anti-adhesive activity of surfactants was determined as described in (Rufino et al., 2011). Identical plates $\left(1 \mathrm{~cm}^{2}\right)$ of test materials (tile, steel, glass) were pre-cleaned with detergent, rinsed with distilled water, air-dried and sterilized at $112^{\circ} \mathrm{C}$ for 30 minutes. After sterilization, the plates were treated with a surfactant solution (in the control version - sterile phosphate buffer) and kept at $30^{\circ} \mathrm{C}$ for $18-24$ hours. Next, control and pre-treated surfactant materials were rinsed with sterile phosphate buffer or distilled water to remove residual preparations.

Test cultures of microorganisms were suspended in $100 \mathrm{ml}$ of sterile tap water, pretreated and untreated (control) materials were placed in the suspension and were kept for $2 \mathrm{~h}$ at $30^{\circ} \mathrm{C}$. Control and pre-treated materials were rinsed with phosphate buffer to wash away non-adherent cells. Materials with adherent cells were left to air dry, after which the adherent cells were fixed by placing the material first in methanol (99\%) for $15 \mathrm{~min}$ and stained in $1 \%$ gentian violet solution for $5 \mathrm{~min}$. The plates of the material were rinsed with tap water and left at room temperature to dry. Next, the coloured adherent cells were washed from the surface of the materials with $1 \mathrm{ml}$ of glacial acetic acid, made $9 \mathrm{ml}$ of distilled water and measured the optical density of the resulting suspension spectrophotometrically using a wavelength of $540 \mathrm{~nm}$.

The number of adherent cells was defined as the ratio of the optical density of the suspension obtained after treatment of materials with surfactants to the optical density of the suspension obtained after treatment of materials with phosphate buffer (control) and expressed as a percentage. 


\section{Study of the degree of the biofilm destruction under the action of surfactants}

Determination of the effect of surfactants on the destruction of the biofilm was carried out as described in (Gomes et al., 2012). To obtain the biofilm, $180 \mu \mathrm{l}$ of MPB or liquid wort and $20 \mu \mathrm{l}$ of one-day test culture suspension were added to the polystyrene microplates, previously incubated for $24 \mathrm{~h}$ at the optimal temperature. Then the culture liquid was poured off and added another $180 \mu \mathrm{l}$ of fresh MPB or wort and $20 \mu \mathrm{l}$ of test culture suspension. Test culture suspensions were incubated for the next 24 hours. After $48 \mathrm{~h}$, the culture liquid was poured off, and $200 \mu \mathrm{l}$ solution with the different concentrations of surfactants was added to the microplate wells (with the biofilm of the test culture previously formed on them). In the control variants (wells) sterile tap water $(200 \mu \mathrm{l})$ was added instead of surfactants. After exposure, the wells were washed three times with $200 \mu \mathrm{l}$ of distilled water and the number of adherent cells was determined spectrophotometrically. The degree of biofilm destruction (\%) was determined as the difference between cells adhesion in untreated and surfactant wells of the polystyrene plate.

\section{Statistical analysis}

All experiments were performed in 3 replicates, the number of parallel determinations in the experiments was 3-5. Statistical processing of experimental data was carried out as described in previous papers (Pirog et al., 2018). The differences in averages were considered reliable at the level of significance $\mathrm{p}<0.05$.

\section{Results and discussion}

\section{Effect of the concentration of activators of $\mathrm{NADH}^{+}$-dependent glutamate dehydrogenase in the culture medium on antimicrobial synthesized surfactants}

The table 1 shows the minimum inhibitory concentrations of the strain IMV B-7241 surfactants, synthesized in a medium with different concentrations of calcium chloride. The results of the studies showed that the cultivation of $A$. calcoaceticus IMV B-7241 in medium with refined glycerol and different concentrations of $\mathrm{CaCl}_{2}$ was accompanied by the synthesis of surfactants with increased antimicrobial activity. Thus, the minimum inhibitory concentrations of such surfactants (1.01-21.3 $\mu \mathrm{g} / \mathrm{ml})$ were 1.4-29 times lower than the MIC surfactants obtained in the base medium $(1.83-58.8 \mu \mathrm{g} / \mathrm{ml})$.

However, the data in table 1 , show that the antimicrobial activity of surfactants synthesized in the presence of $0.1 \mathrm{~g} / 1 \mathrm{CaCI}_{2}$ in the medium with the waste of biodiesel production was lower than the surfactants obtained on the base medium (MIC relative to the test cultures was $44.4-355$ and $29.7-59.5 \mu \mathrm{g} / \mathrm{ml}$, respectively). In our opinion, one of the reasons for the lower antimicrobial activity of surfactants synthesized on waste of biodiesel production is the presence of potassium and sodium cations in these wastes, which may be potential inhibitors of $\mathrm{NADH}^{+}$-dependent glutamate dehydrogenase A. calcoaceticus IMV B7241.

At the same time, the adding of $0.2 \mathrm{~g} / \mathrm{l}$ of calcium chloride into the medium with the waste of biodiesel production was accompanied by the synthesis of surfactants with higher antimicrobial activity compared with thoses synthesized on the medium with $0.1 \mathrm{~g} / \mathrm{l} \mathrm{CaCl}$ (14.7-29.4 and 44.4-355 $\mu \mathrm{g} / \mathrm{ml}$, respectively, see Table 1). Moreover, the minimum inhibitory concentrations for B. subtilis BT-2 and E. cloacae C-8 surfactants synthesized in 
the presence of $0.2 \mathrm{~g} / \mathrm{l}$ of calcium chloride did not differ from those established for surfactants obtained on the base medium with the waste of biodiesel production $(29.4-29.7 \mu \mathrm{g} / \mathrm{ml})$, and the MIC for S. aureus BMS-1 and C. albicans D-6 such surfactants were even 4 times lower than the MIC of preparations synthesized in the base medium $(14.7$ and $59.5 \mu \mathrm{g} / \mathrm{ml}$, respectively) (Table 1).

Table 1

Antimicrobial activity of $A$. calcoaceticus IMV B-7241 surfactants, synthesized in a medium with different concentrations of calcium cations

\begin{tabular}{|c|c|c|c|c|c|}
\hline \multirow{3}{*}{$\begin{array}{c}\text { Carbon } \\
\text { source }\end{array}$} & \multirow{2}{*}{$\begin{array}{c}\text { Concentration of } \\
\mathbf{C a C l}_{2} \text { in the } \\
\text { medium, } \mathbf{g} / \mathbf{l}\end{array}$} & $\begin{array}{c}\text { Minimum inhibitory concentrations }(\boldsymbol{\mu g} / \mathbf{m l}) \\
\text { relative }\end{array}$ \\
\cline { 3 - 6 } & $\begin{array}{c}\text { Bacillus } \\
\text { subtilis } \\
\text { BT-2 } \\
\text { (spores) }\end{array}$ & $\begin{array}{c}\text { Entero- } \\
\text { bacter } \\
\text { cloacae } \\
\text { C-8 }\end{array}$ & $\begin{array}{c}\text { Staphylo- } \\
\text { coccus } \\
\text { aureus } \\
\text { BMS-1 }\end{array}$ & $\begin{array}{c}\text { Candida } \\
\text { albicans } \\
\text { D-6 }\end{array}$ \\
\hline $\begin{array}{c}\text { Waste of } \\
\text { biodiesel } \\
\text { production }\end{array}$ & 0 & 29.7 & 29.7 & 59.5 & 59.5 \\
\cline { 2 - 6 } & 0.1 & 88.7 & 44.4 & 88.7 & 355 \\
\hline \multirow{2}{*}{$\begin{array}{c}\text { Purified } \\
\text { glycerol }\end{array}$} & 0.2 & 29.4 & 29.4 & 14.7 & 14.7 \\
\cline { 2 - 6 } & 0 & 3.67 & 1.83 & 58.8 & 29.4 \\
\cline { 2 - 6 } & 0.1 & 2.65 & 1.33 & 21.3 & 21.3 \\
\hline
\end{tabular}

Note. When determining the minimum inhibitory concentration, the error did not exceed $5 \%$.

The detected dependence of the antimicrobial activity of surfactants synthesized on the waste of biodiesel production on the concentration of calcium cations in the medium can be explained for the following reasons. First, given the presence of monovalent cations potential inhibitors of $\mathrm{NADH}^{+}$-dependent glutamate dehydrogenase in biodiesel waste, may be required a higher concentration of calcium cations to activate this enzyme. Secondly, apparently, the strain IMV B-7241 has several glutamate dehydrogenases that are activated by different concentrations of calcium cations.

Our previous studies (Pirog et al., 2019) of the effect of different concentrations of calcium cations on the antimicrobial activity of surfactants synthesized during the cultivation of A. calcoaceticus IMV B-7241 on ethanol showed that the minimum inhibitory concentration against bacteria (Escherichia coli IEM-1, B. subtilis BT-2, E. cloaceae C-8, Proteus vulgaris PA-12) surfactants formed on a medium with $0.1 \mathrm{~g} / \mathrm{l} \mathrm{CaCl}$, was $1.3-3.5$ times lower, than MIC surfactants synthesized in the base medium (4-32 and 14-56 $\mu \mathrm{g} / \mathrm{ml}$, respectively).

Note that in the literature information on the antimicrobial activity of surfactants synthesized on refined glycerol are few and relate to lipopeptides synthesized by bacteria of the genus Bacillus (Das et al., 2009; Singh et al., 2014), and rhamnolipids synthesized by representatives of the genus Pseudomonas and Halomonas (Alvionita and Hertadi, 2019; Buonocore et al., 2020). However, minimal inhibitory concentrations of surfactants Bacillus circulans (Das et al., 2009), Bacillus amylofaciens AR2 (Singh et al., 2014) and Bacillus thuringiensis pak2310 (Deepak and Jayapradha, 2015) against bacteria (E. coli NCIM 2931, Micrococcus flavus 2376, P. vulgaris NCIM 2857 and S. aureus MRS) and fungi (Aspergillus niger, C. albicans, Fusarium solani ATCC 36031, Fusarium oxysporum MTCC 7229, 
Alternaria alternata MTCC 2724, Alternaria citri MTCC 4875, Cladosporium cladispororecopular ATCC 160 ATCC 58636, Microsporum gypseum MTCC 4522, Trichophyton rubrum MTCC 296) were in the range of 50-750 $\mu \mathrm{g} / \mathrm{ml}$, which is significantly higher than the values, established for our studied surfactants A. calcoaceticus IMV B-7241 (see Table 1). The MIC of rhamnolipids relative to bacterial (S. aureus 6538P, Bacillus cereus, Listeria monocytogenes, Staphylococcus epidermidis, Stenotrophomonas maltophilia 13637) and fungal (T. rubrum, Trichophyton mentagrophytes) test cultures were 3.13-433 $\mu \mathrm{g} / \mathrm{ml}$ (Buonocore et al., 2020; Sen et al., 2020) and were higher than the minimum inhibitory indexes of surfactant A. calcoaceticus IMV B-7241 (see Table 1).

To date, we have found only one work in the available literature that investigated the antimicrobial activity of surfactants synthesized on biodiesel waste (Bharali et al., 2014). However, the authors of this work determined the antimicrobial activity of rhamnolipids synthesized by Pseudomonas aeruginosa JBK1 by the method of diffusion into agar, so compare their data with those given in table 1 does not seem possible.

Therefore, our results point out the possibility of regulating the antimicrobial activity of A. calcoaceticus surfactants IMV B-7241 synthesized in the medium with glycerol different degrees of purification by adding calcium cations and are consistent with the preliminary results of cultivation strain IMV B-7241 on medium with ethanol and different concentrations of $\mathrm{Ca}^{2+}$ (Pirog et al., 2019).

\section{Influence of calcium cations on anti-adhesive activity of surfactants}

The data shown in table 2 indicate that the additional introduction of calcium cations into the medium with refined glycerol was accompanied by the synthesis of surfactants with increased anti-adhesive activity.

Thus, under the action of surfactants synthesized in such medium, the adhesion $S$. aureus BMS-1 to abiotic materials was $3-28 \%$ and was lower than in the presence of surfactants formed in a medium without calcium cations $-11-33 \%$. In the case of adding of $0.2 \mathrm{~g} / \mathrm{l} \mathrm{CaCl} \mathrm{C}_{2}$ into the medium with the waste of biodiesel production, the synthesis of surfactants was observed, in the presence of which the adhesion of S. aureus BMS-1 on tiles, steel and glass was only $7-25 \%$, while the anti-adhesive activity of surfactants, synthesized in a medium without calcium cations, was lower: the degree of adhesion was $10-64 \%$ (Table 2).

Similar patterns were observed during the study of the anti-adhesive activity of surfactants against $B$. subtilis BT-2. The adhesion of this test culture cells on abiotic surfaces treated with surfactant solutions synthesized in a medium with calcium chloride was 26$45 \%$, that is lower than after the treatment of surfactants obtained on a base medium (31$48 \%)$. At the same time, the number of $E$. cloacae C-8 cells attached to the surfaces decreased (compared to the control) by several percent only in the case of their treatment with surfactants synthesized in the presence of $0.2 \mathrm{~g} / \mathrm{l}$ in the medium. Note that only at the lowest concentration of surfactants $(0.55 \mu \mathrm{g} / \mathrm{ml})$ synthesized in the presence of $0.2 \mathrm{~g} / \mathrm{l}$ of calcium chloride, a decrease of $12-13 \%$ in the adhesion of C. albicans D-6 on tiles and steel in compared with the indicators established for surfactants obtained on the base medium. Note that such patterns were observed for surfactants synthesized on both refined glycerol and waste of biodiesel production.

The obtained data points out that the anti-adhesive activity of surfactants depends on many factors: the concentration of surfactants, the type of abiotic surface and the type of test cultures. In addition, no direct correlation was found between the antimicrobial and antiadhesive activity of surfactants synthesized under different culture conditions of $A$. 


\section{— Biotechnology. Microbiology}

calcoaceticus IMV B-7241. It is obvious that the anti-adhesive action of microbial surfactants is based not only on antimicrobial activity but also on other mechanisms (for example, changes in the surface charge of cells or the surface).

Table 2

Effect of A. calcoaceticus IMV B-7241 surfactant, synthesized in a medium with different content of calcium cations, on the adhesion of Staphylococcus aureus BMS-1 to different surfaces

\begin{tabular}{|c|c|c|c|c|c|}
\hline \multirow{2}{*}{ Carbon source } & \multirow{2}{*}{$\begin{array}{l}\text { Contents } \\
\text { CaCI}_{2}, \text { g/l }\end{array}$} & \multirow{2}{*}{$\begin{array}{c}\text { Surfactant } \\
\text { concentration, } \mu \mathrm{g} / \mathrm{ml}\end{array}$} & \multicolumn{3}{|c|}{ Adhesion, \% } \\
\hline & & & Tile & Steel & Glass \\
\hline \multirow{15}{*}{$\begin{array}{l}\text { Waste of biodiesel } \\
\text { production }\end{array}$} & \multirow{5}{*}{0} & 8.87 & 23 & 11 & 10 \\
\hline & & 4.43 & 51 & 17 & 17 \\
\hline & & 2.2 & 55 & 19 & 21 \\
\hline & & 1.1 & 58 & 28 & 21 \\
\hline & & 0.55 & 64 & 33 & 24 \\
\hline & \multirow{5}{*}{0,1} & 8.87 & 62 & 6 & 10 \\
\hline & & 4.43 & 68 & 14 & 24 \\
\hline & & 2.20 & 70 & 14 & 24 \\
\hline & & 1.10 & 77 & 22 & 38 \\
\hline & & 0.55 & 83 & 25 & 52 \\
\hline & \multirow{5}{*}{0,2} & 8.87 & 17 & 25 & 10 \\
\hline & & 4.43 & 11 & 22 & 7 \\
\hline & & 2.20 & 8 & 14 & 10 \\
\hline & & 1.10 & 9 & 14 & 7 \\
\hline & & 0.55 & 9 & 8 & 7 \\
\hline \multirow{15}{*}{ Refined glycerol } & \multirow{5}{*}{0} & 8.87 & 19 & 13 & 11 \\
\hline & & 4.43 & 25 & 17 & 17 \\
\hline & & 2.20 & 25 & 23 & 25 \\
\hline & & 1.10 & 30 & 23 & 25 \\
\hline & & 0.55 & 33 & 27 & 30 \\
\hline & \multirow{5}{*}{0,1} & 8.87 & 15 & 11 & 10 \\
\hline & & 4.43 & 15 & 15 & 11 \\
\hline & & 2.20 & 20 & 19 & 19 \\
\hline & & 1.10 & 23 & 19 & 25 \\
\hline & & 0.55 & 28 & 26 & 32 \\
\hline & \multirow{5}{*}{0,2} & 8.87 & 13 & 8 & 3 \\
\hline & & 4.43 & 19 & 11 & 14 \\
\hline & & 2.20 & 23 & 14 & 17 \\
\hline & & 1.10 & 28 & 19 & 21 \\
\hline & & 0.55 & 28 & 25 & 28 \\
\hline
\end{tabular}

Note. When determining adhesion, the error did not exceed 5\%.

Despite the information on the antimicrobial activity of surfactants synthesized on glycerol, in the available literature there is much less information about their anti-adhesive action. 
In (Chebbi et al., 2017) it was found that the degree of adhesion of Bacillus licheniformis CAN55 and Staphylococcus capitis SH6 was 15 and $35 \%$, respectively, on polystyrene after treatment with solutions of rhamnolipids $P$. aeruginosa W10 synthesized on refined glycerol at a concentration of $3125 \mu \mathrm{g} / \mathrm{ml}$.

The amount of adherent $S$. aureus ATCC 29523, B. cereus MTCC 7190, Salmonella typhimurium ATCC 19430 cells to a polystyrene surface treated with solutions of B. subtilis VSG4 lipopeptides obtained on refined glycerol $(3000 \mu \mathrm{g} / \mathrm{ml})$ was in the range of $33-40 \%$ (Giri et al., 2019).

Therefore, synthesized in both base and modified medium with refined glycerol and waste of biodiesel production surfactants $A$. calcoaceticus IMV B-724 are significantly more effective anti-adhesive agents than those described in (Chebbi et al., 2017; Giri et al., 2019) because they show anti-adhesive activity in orders of magnitude lower concentrations $(0.55-8.87 \mu \mathrm{g} / \mathrm{ml})$.

\section{Destruction of biofilms under the action of surfactants synthesized in an medium with different concentrations of calcium cations}

Surfactants of microbial origin also have the ability to destroy biofilms in addition to antimicrobial and anti-adhesive activity. Therefore, the destruction of bacterial and yeast biofilms under the action of A. calcoaceticus IMV B-7241 surfactants, synthesized in medium of different compositions were studied in the next step.

The results showed that surfactants synthesized in a medium with refined glycerol and $\mathrm{CaCl}_{2}$ were more effective in destroying bacterial and yeast biofilms than surfactants obtained on a similar base medium without calcium cations (Tables 3-6).

Table 3

Destruction of Enterobacter cloacae C-8 biofilm by the action of surfactants synthesized on glycerol

\begin{tabular}{|c|c|c|c|c|}
\hline \multirow[t]{2}{*}{ Carbon source } & \multirow[t]{2}{*}{$\begin{array}{c}\text { Concentration } \\
\mathrm{CaCI}_{2}(\mathrm{~g} / \mathrm{l})\end{array}$} & \multicolumn{3}{|c|}{$\begin{array}{l}\text { Destruction of biofilm }(\%) \text { under the } \\
\text { action of surfactants at a concentration } \\
\qquad(\mu \mathrm{g} / \mathrm{ml})\end{array}$} \\
\hline & & 5.5 & 1.4 & 0.7 \\
\hline \multirow{3}{*}{$\begin{array}{l}\text { Waste of biodiesel } \\
\text { production }\end{array}$} & 0 & 38.6 & 32.9 & 21.6 \\
\hline & 0.1 & 48.8 & 41.0 & 33.8 \\
\hline & 0.2 & 54.5 & 46.3 & 41.0 \\
\hline \multirow{3}{*}{ Refined glycerol } & 0 & 68.7 & 71.5 & 75.6 \\
\hline & 0.1 & 56.0 & 83.4 & 86.5 \\
\hline & 0.2 & 92.0 & 93.2 & 93.9 \\
\hline
\end{tabular}

Note. Table. 3-6: when determining the destruction of the biofilm, the error did not exceed 5\%. 
Table 4

Effect of calcium cations content in the culture medium of $A$. calcoaceticus IMV B-7241 on the ability of synthesized surfactants to destroy the biofilm of Bacillus subtilis BT-2

\begin{tabular}{|c|c|c|c|c|c|c|c|}
\hline \multirow{2}{*}{$\begin{array}{c}\text { Carbon } \\
\text { source }\end{array}$} & $\begin{array}{c}\text { Concentration } \\
\text { CaCI2 (g/l) }\end{array}$ & \multicolumn{4}{|c|}{$\begin{array}{c}\text { Destruction of biofilm } \\
\text { surfactants at a concentration }(\boldsymbol{\mu g} / \mathbf{m l})\end{array}$} \\
\cline { 3 - 9 } & & $\mathbf{4 4 . 3}$ & $\mathbf{2 2 . 2}$ & $\mathbf{5 . 5}$ & $\mathbf{2 . 7}$ & $\mathbf{1 . 4}$ & $\mathbf{0 . 7}$ \\
\hline \multirow{2}{*}{$\begin{array}{c}\text { Waste of } \\
\text { biodiesel } \\
\text { production }\end{array}$} & 0 & 52.6 & 45.3 & 37.1 & 33.7 & 33.7 & 30.0 \\
\cline { 2 - 9 } & 0.1 & 33.7 & 36.8 & 38.2 & 40.3 & 41.4 & N.d. \\
\cline { 2 - 9 } & 0.2 & 38.9 & 41.3 & 42.3 & 45.6 & 48.7 & 49.4 \\
\hline \multirow{2}{*}{$\begin{array}{c}\text { Refined } \\
\text { glycerol }\end{array}$} & 0 & 44.2 & 51.6 & 59.7 & 72.3 & 78.5 & N.d. \\
\cline { 2 - 9 } & 0.1 & 45.1 & 56.7 & 64.7 & 79.2 & 85.2 & N.d. \\
\cline { 2 - 9 } & 0.2 & 57.4 & 63.1 & 72.4 & 85.2 & 87.3 & N.d. \\
\hline
\end{tabular}

Note. N.d. - not determined.

Table 5

Destruction of Staphylococcus aureus BMS-1 biofilm under the influence of $A$. calcoaceticus IMV B-7241 surfactants, synthesized in a medium with different content of calcium cations

\begin{tabular}{|c|c|c|c|c|}
\hline \multirow{2}{*}{ Carbon source } & \multicolumn{3}{|c|}{$\begin{array}{c}\text { Concentration } \\
\text { CaCI } \mathbf{2}(\mathbf{g} / \mathbf{l})\end{array}$} & \multicolumn{3}{|c|}{$\begin{array}{c}\text { Destruction of biofilm (\%) under the } \\
\text { action of surfactants at a concentration } \\
(\boldsymbol{\mu} \mathbf{m})\end{array}$} \\
\cline { 2 - 5 } & 0 & $\mathbf{4 4 . 3}$ & $\mathbf{2 . 7}$ & $\mathbf{1 , 4}$ \\
\hline \multirow{2}{*}{$\begin{array}{c}\text { Waste of } \\
\text { biodiesel } \\
\text { production }\end{array}$} & 0.1 & 28.8 & 28.8 & 31.7 \\
\cline { 2 - 5 } & 0.2 & 29.5 & 30.5 & 33.7 \\
\hline \multirow{3}{*}{ Refined glycerol } & 0 & 38.1 & 40.4 & 43.7 \\
\cline { 2 - 5 } & 0.1 & 74.5 & 54.7 & 45.6 \\
\cline { 2 - 5 } & 0.2 & 98.3 & 64.3 & 56.1 \\
\hline
\end{tabular}

Antibiofilm activity against Candida albicans D-6 surfactants synthesized

Table 6 by $A$. calcoaceticus IMV B-7241

\begin{tabular}{|c|c|c|c|c|c|}
\hline \multirow[t]{2}{*}{ Carbon source } & \multirow[t]{2}{*}{$\begin{array}{c}\text { Concentration } \\
\mathrm{CaCI}_{2}(\mathrm{~g} / \mathrm{l})\end{array}$} & \multicolumn{4}{|c|}{$\begin{array}{l}\text { Destruction of biofilm }(\%) \text { under the } \\
\text { action of surfactants at a concentration } \\
\qquad(\mu \mathrm{g} / \mathrm{ml})\end{array}$} \\
\hline & & 22.2 & 5.5 & 1.4 & 0.7 \\
\hline \multirow{3}{*}{$\begin{array}{l}\text { Waste of } \\
\text { biodiesel } \\
\text { production }\end{array}$} & 0 & 71.4 & 60.2 & 53.0 & 52.1 \\
\hline & 0.1 & 25.5 & 33.7 & 37.7 & 40.8 \\
\hline & 0.2 & 33.7 & 43.9 & 45.1 & 48.2 \\
\hline \multirow{3}{*}{ Refined glycerol } & 0 & 79.1 & 78.1 & 76.5 & 72.3 \\
\hline & 0.1 & 88.6 & 86.5 & 84.4 & 78.2 \\
\hline & 0.2 & 95.8 & 94.0 & 91.8 & 84.7 \\
\hline
\end{tabular}


Thus, under the action of surfactants synthesized in a medium with 0.1 and $0.2 \mathrm{~g} / \mathrm{l}$ of calcium chloride, the destruction of biofilms was on average 5-10 and $12-19 \%$, respectively, higher than in the presence of surfactants obtained on a medium without $\mathrm{CaCI}_{2}$.

Note that the destruction of biofilms of all studied test cultures was $6-12 \%$ higher under the influence of surfactants synthesized in a medium with refined glycerol containing $0.2 \mathrm{~g} / \mathrm{l}$ of calcium chloride than under the action of surfactants obtained on a similar medium with $0.1 \mathrm{~g} / \mathrm{l} \mathrm{CaCl}_{2}$. In addition, a high degree of biofilms destruction (on average 70-90\%) was achieved at low $(0.7-5.5 \mu \mathrm{g} / \mathrm{ml})$ concentrations of surfactants synthesized on refined glycerol.

Slightly different patterns were observed during the study of the biofilms destruction by surfactants obtained on the waste of biodiesel production with different calcium chloride content (see Tables 3-6). First, surfactants synthesized in the medium with calcium cations proved to be more effective destructors of bacterial biofilms compared to those obtained in the base medium only at low concentrations $(0.7-5.5 \mu \mathrm{g} / \mathrm{ml})$. Second, the additional introduction of calcium chloride into the medium with the waste of biodiesel production was accompanied by the formation of surfactants, which were characterized by a lower ability to destroy yeast biofilm than synthesized in the base medium: the degree of destruction $C$. albicans D-6 biofilm was $25-48$ and $52-71 \%$ respectively (see table. 6). In addition, surfactants obtained under different conditions of A. calcoaceticus IMV B-7241 cultivation on the waste of biodiesel production have a lower ability to destroy bacterial and yeast biofilms than those synthesized on refined glycerol (destruction 21-71 and 56-96 accordingly, see Tables 3-6).

There is limited data in the literature on the ability of surfactants synthesized in a glycerol-containing medium to destroy microbial biofilms. Giri et al. (2019) found that the destruction of biofilms of $S$. aureus ATCC 29523, E. coli MTCC 65, S. typhimurium ATCC 19430 was in the range of $58-78 \%$ in the presence of lipopeptides B. subtilis VSG4 in a sufficiently high concentration $(3000-5000 \mu \mathrm{g} / \mathrm{ml})$. The destruction of the biofilm of $F$. oxysporum (strain not specified) was observed by $58 \%$ in the presence of $500 \mu \mathrm{g} / \mathrm{ml}$ lipopeptides of B. thuringiensis pak2310 (Deepak and Jayapradha, 2015). The work of Sen et al. (2020) show that the destruction of biofilms of fungi T. rubrum MTCC 8477 and $T$. mentagrophytes NCCPF 800049 reached $80-85 \%$ under the influence of rhamnolipids at a concentration of 2000 and $250 \mu \mathrm{g} / \mathrm{ml}$, respectively. De Rienzo and Martin (2016) found that rhamnolipids of Burkholderia thailandensis E264 at a concentration of $400 \mu \mathrm{g} / \mathrm{ml}$ are able to destroy the biofilm of B. subtilis BBK066. In this work, the destruction of the biofilm was examined visually using confocal microscopy, and the degree of its destruction by the authors is not given.

Thus, described in the literature the rhamnolipids and lipopeptides synthesized on purified glycerol, destroy $58-85 \%$ of bacterial and fungal biofilms at sufficiently high concentrations (400-5000 $\mu \mathrm{g} / \mathrm{ml}$ ). Our results (see Table 3-6) show that the same degree of destruction of bacterial and yeast biofilms is achieved by the action of A. calcoaceticus IMV B-7241 surfactants in much lower (several orders of magnitude) concentrations (0.7-44, 3 $\mu \mathrm{g} / \mathrm{ml})$.

\section{Conclusion}

1. The results demonstrate the possibility tof regulate the biological activity of surfactants produced by A. calcoaceticus IMB B-7241 by changing in the composition of medium with refined glycerol and waste of biodiesel production content of calcium cations, which are activators of $\mathrm{NADH}^{+}$-dependent glutamate dehydrogenase (key enzyme of surface-active aminolipids biosynthesis). 
2. Surfactants synthesized under different cultivation conditions by A. calcoaceticus IMB B-7241 on refined glycerol and waste of biodiesel production are more effective biofilm destructors and antimicrobial and anti-dhesive agents compared to the known lipopeptides and rhamnolipids formed on glycerol.

\section{References}

Alvionita M., Hertadi R. (2019), Bioconversion of glycerol to biosurfactant by halophilic bacteria Halomonas elongata BK-AG18, Indonesian Journal of Chemistry, 19, pp. 4857.

Bharali P., Singh S.P., Dutta N., Gogoi S., Bora L.C., Debnath P., Konwar B.K. (2014), Biodiesel derived waste glycerol as an economic substrate for biosurfactant production using indigenous Pseudomonas aeruginosa, RSC Advances, 4(73), pp. 38698-38706, DOI: $10.1039 / \mathrm{c} 4 \mathrm{ra} 05594 \mathrm{~b}$.

Bligh E.G., Dyer W.J. (1959), A rapid method for total lipid extraction and purification, Canadian Journal of Biochemistry and Physiology, 37(8), pp. 911-917.

Buonocore C., Tedesco P., Vitale G.A., Esposito F.P., Giugliano R., Monti M.C., D’Auria M.V., de Pascale D. (2020), Characterization of a new mixture of mono-rhamnolipids produced by Pseudomonas gessardii isolated from Edmonson Point (Antarctica), Marine Drugs, 18, DOI: 10.3390/md18050269.

Chebbi A., Elshikh M., Haque F., Ahmed S., Dobbin S., Marchant R., Sayadi S., Chamkha M., Banat I.M. (2017), Rhamnolipids from Pseudomonas aeruginosa strain W10; as antibiofilm/antibiofouling products for metal protection, Journal of Basic Microbiology, 57(5), pp. 364-375, DOI: 10.1002/jobm.201600658.

Crosse A.J., Brady D., Zhou N., Rumbold K. (2019), Biodiesel's trash is a biorefineries' treasure: the use of "dirty» glycerol as an industrial fermentation substrate, World Journal of Microbiology \& Biotechnology, 36(1), DOI: 10.1007/s11274-019-2776-9.

Das P., Mukherjee S., Sen R. (2009), Substrate dependent production of extracellular biosurfactant by a marine bacterium, Bioresource Technology, 100(2), pp. 1015-1019, DOI: 10.1016/j.biortech.2008.07.015.

Deepak R., Jayapradha R. (2015), Lipopeptide biosurfactant from Bacillus thuringiensis pak2310: a potential antagonist against Fusarium oxysporum, Journal de Mycologie Médicale, 25(1), pp.15-24, DOI: 10.1016/j.mycmed.2014.10.011.

De Rienzo M.A.D., Martin P.J. (2016), Effect of mono- and di-rhamnolipids on biofilms preformed by Bacillus subtilis BBK006, Current Microbiology, 73(2), pp. 183-189, DOI: 10.1007/s00284-016-1046-4.

Diamantopoulou P., Filippousi R., Antoniou D., Varfi E., Xenopoulos E., Sarris D., Papanikolaou S. (2020), Production of added-value microbial metabolites during growth of yeast strains on media composed of biodiesel-derived crude glycerol and glycerol/xylose blends, FEMS Microbiology Letters, 367(10), DOI: 10.1093/femsle/fnaa063.

Giri S.S., Ryu E., Sukumaran V., Chang Park S. (2019), Antioxidant, antibacterial, and antiadhesive activities of biosurfactants isolated from Bacillus strains, Microbial Pathogenesis, 132, pp. 66-72, DOI: 10.1016/j.micpath.2019.04.035.

Gomes M.Z.V., Nitschke M. (2012), Evaluation of rhamnolipids surfactants as agents to reduce the adhesion of Staphylococcus aureus to polystyrene surfaces, Letters in 
Applied Microbiology, 49(1), pp. 960-965.

Pirog T.P., Lutsai D.A., Shevchuk T.A., Iutynska G.O., Elperin I.V. (2018), Antimicrobial and anti-adhesive activity of surfactants synthesized by Acinetobacter calcoaceticus IMV B-7241 on technical glycerol, Mikrobiologichny Zhurnal, 80(2), pp. 14-27, DOI: 10.15407/microbiolj80.02.014.

Pirog T.P., Shevchuk T.A., Nikituk L.V., Lutsai D.A., Paliichuk O.I. (2018), Influence of cultivation conditions on antimicrobial and anti-adhesive activity of surfactants of bacteria of Acinetobacter, Rhodococcus and Nocardia genera. Proceedings of the National Academy of Sciences of Belarus. Biological series, 63(3), pp. 307-315. 10.29235/1029-8940-2018-63-3-307-315.

Pirog T.P., Kliuchka L.V., Shevchuk T.A., Muchnyk F.V. (2019), Interrelation of chemical composition and biological properties of microbial surfactants, Mikrobiologichny Zhurnal, 81(3), pp. 84-104, DOI: 10.15407/microbiolj81.03.084.

Pirog T., Kluchka L., Lytsai D., Stabnikov V. (2021a), Factors affecting antibiofilm properties of microbial surfactants, Scientific Study \& Research: Chemistry \& Chemical Engineering, Biotechnology, Food Industry, 21(1), pp. 27-37.

Rufino R.D., Luna J.M., Sarubbo L.A., Rodrigues L.R., Teixeira J.A., Campos-Takaki G.M. (2011), Antimicrobial and anti-adhesive potential of a biosurfactant Rufisan produced by Candida lipolytica UCP 0988, Colloids and Surfaces B: Biointerfaces, 84(1), pp.1-5, DOI: 10.1016/j.colsurfb.2010.10.045.

Sen S., Borah S.N., Bora A., Deka S. (2020), Rhamnolipid exhibits anti-biofilm activity against the dermatophytic fungi Trichophyton rubrum and Trichophyton mentagrophytes, Biotechnology Reports, 27, DOI: 10.1016/j.btre.2020.e00516.

Sharma P., Sharma N. (2021), Microbial biosurfactants - an ecofriendly boon to industries for green revolution, Recent Patents on Biotechnology, 14(3), pp.169-183, DOI: $10.2174 / 1872208313666191212094628$.

Shu Q., Lou H., Wei T., Liu X., Chen Q. (2021), Contributions of glycolipid biosurfactants and glycolipid-modified materials to antimicrobial strategy: a review, Pharmaceutics, 13(2), DOI: 10.3390/pharmaceutics13020227.

Singh A., Rautela R., Cameotra S. (2014), Substrate dependent in vitro antifungal activity of Bacillus sp strain AR2, Microbial Cell Factories, 13(1), DOI: 10.1186/1475-2859-1367. 


\title{
Probiotic properties and exopolysaccharides production of Stretptococcus thermophilus CNRZ 447 and Enterococcus durans NCBI 53345
}

\section{Badra Boubakeur ${ }^{1}$, Hafidha Khadem ${ }^{1}$, Moustapha Sangalo Drabo ${ }^{2}$, Ahmad $\mathrm{Ali}^{3}$, Aicha Tirtouil Meddah ${ }^{4}$}

\author{
1 - Ibn Khaldoun University, Tiaret, Algeria \\ 2 - Ouagadougou University, Ouagadougou, Burkina Faso \\ 3 - Mumbai Vidyanagari University, Mumbai, India \\ 4 - Mustapha Stambouli University, Mascara, Algeria
}
Keywords:
Probiotic
Resistance
Exopolysaccharide
S. thermophilus
E. durans

Article history:

Received

29.05.2021

Received in revised form 16.09.2021

Accepted

30.12.2021

\section{Corresponding author:}

Badra Boubakeur

E-mail:

badra.boubakeur@

univ-tiaret.dz

\section{DOI:}

$10.24263 / 2304-$

974X-2021-10-4-17

\section{Abstract}

Introduction. The aim of the present study was investigation of probiotic and technological properties of Streptococcus thermophilus CNRZ 447 and Enterococcus durans NCBI 53345.

Materials and methods. The characterization tests were carried out in batches with different conditions of $\mathrm{pH}$ ( 2 and 3$)$, temperature (15, $37,45,50,60$ and $\left.65{ }^{\circ} \mathrm{C}\right)$, bile salts $(0.3,0.5$ and $1 \%$ ), and antibiotics $\left(\mathrm{C}_{10}, \mathrm{GM}, \mathrm{AN}_{30}\right.$ and $\left.\mathrm{TE}_{30}\right)$. The antagonistic effect was realized against E. coli and $S$. aureus. The bacterial adhesion and exopolysaccharide production were performed under optimized cultivation conditions. The exopolysaccharide were then profiled by HPLC using the Agilent LC 1260 system coupled with refractive index detector.

Results and discussion. The strains have proven a considerable ability to persist in vitro under conditions simulating the human gastrointestinal tract. They survied at $\mathrm{pH} 2$ and 3 for $3 \mathrm{~h}$ of incubation. Only a minimal reduction of $1 \%$ and $0.99 \log$ cfu was reported for both bacterial strains $S$. thermophilus and $E$. durans at $\mathrm{pH} 2$. A small reduction in the strains growth was noted in presence of bile salts at different concentrations (the discount rates recorded were between 1 and $3 \%$ ), revealing their ability to survive through the gastrointestinal tract. A significant tolerance of temperature variation was also noted. The ideal temperatures for the $E$. durans and $S$. thermophilus growth were respectively $37^{\circ} \mathrm{C}$ and $45^{\circ} \mathrm{C}$. The auto-aggregation rates registered after $4 \mathrm{~h}$ of decantation are 76 and $51 \%$ for S. thermophilus and E durans, respectively. Surface hydrophobicity of $81 \%$ and $61 \%$ for $S$. thermophilus and E. durans, antagonistic capacity against $E$. coli and $S$. aureus, and antibiotic resistance has been recorded. S. thermophilus was resistant to 3 of 4 antibiotics tested. Meanwhile E. durans was resistant to tetracycline and nalidixic acid. An appreciable production of exopolysaccharides was noticeable. E. durans was more prolific in exopolysaccharides (ESP) production than S. thermophilus (1661 \pm 27 $\mathrm{mg} / \mathrm{L}$ vs $176 \pm 4 \mathrm{mg} / \mathrm{L}$ ). The EPS produced by S. thermophilus CNRZ 447 was primarily composed of two triholosides that consisted predominantly of glucose. Analysis of $E$. durans EPS yielded peaks at 7 and 9 min representing oligosaccharides, and a single peak eluting at $20.4 \mathrm{~min}$, which is presumably sorbitol.

Conclusion. The tested strains have demonstrated promising probiotic potential and high exopolysaccharide production. 


\section{Introduction}

The food preservation time can be prolonged due to the antagonistic and/or antimicrobial activity of microorganisms performing the fermentation. Lactic acid bacteria are the most commonly encountered bacterial group in traditional fermented foods (Bogsan et al., 2015). The protective role of lactic acid bacteria against pathogens, their GRAS (Generally Recognized as Safe) character, and the diversity of their pharmaceutical and technological metabolites have received great attention (Kos et al., 2003). They have traditionally been associated with food and feed fermentations, and are generally classified in the technological flora and considered as beneficial microorganisms. Their exploitation in the fermentation industry is widely developed, aiming essentially the establishment of more efficient starter cultures. However, some genera (Streptococcus, Lactococcus, Enterococcus, and Carnobacterium) may also include species or strains that are recognized human or animal pathogens (FAO, 2001; Kos et al., 2003). A thorough understanding of the taxonomy, metabolism, and molecular biology of lactic acid bacteria is therefore necessary to fully utilize the technological, nutritional, and health aspects of these bacteria while avoiding potential risks.

The development of the food industry and in particular the use of new raw materials, as well as the need to create new high-quality products without the addition of plant or animal texturizing and stabilizing compounds, explain the increased interest in this diverse group of bacteria and their metabolites responsible for the nutritional properties acquisition or the foods sensorial and sanitary quality. The use of probiotic lactic acid bacteria is not only limited to improving the sensory properties of foods, but they are also involved in various applications, such as preparation of functional foods, vaccines, and pharmaceuticals, which requires the selection of robust lactic acid bacteria. The main selection criteria are resistance during food processing and production (e.g., cold and heat resistance). Probiotic lactic acid bacteria are also expected to be resistant enough to survive in the digestion process and reach the consumer's colon alive, where they may have various health effects. Adhesion and autoaggregation capacity of probiotic strains also appear to be necessary criteria for attachment to intestinal epithelial cells, and the ability to co-aggregate may provide a barrier that prevents colonization by pathogenic microorganisms (Boubakeur et al., 2018; O'Grady and Gibson, 2005; Gregirchak et al., 2019). Regarding the technological aspect, the adhesion properties and the propensity to form biofilm represent important attributes enabling a more effective production of technological interest metabolites, as in case of exopolysaccharides (EPS) (Kos et al., 2003).

In this context, the main objective of the present study was to investigate the technological and probiotic attributes of two lactic bacteria, Streptococcus thermophilus CNRZ 447 and Enterococcus durans NCBI 53345.

\section{Materials and methods}

\section{Lactic acid strains}

The lactic acid bacteria used in the present study were chosen for their potential technological interest, especially in the food industry. S. thermophilus CNRZ 447 was obtained from the collection of microorganisms of the National Center of Zootechnical Research INRA "Rennes-France". E. durans was subsequently isolated among several lactic strains from a locally consumed fermented product known as "Hamoum" (Drabo et al., 2019). 
It was phenotypically identified following the procedures described by Cowan (2004). Isolation on the selective media (MRS, M17) generated two bacterial species with overlapping biochemical and microscopic characteristics. Hence, the latter were identified based on their proteomic spectra by Mass Spectrometry-Matrix-Assisted Laser Desorption Ionization-Time Of Flight (MS-MALDI-TOF) (Pavlovic et al., 2013). Isolate aliquots were performed on MRS and M17 selective agar and were delivered in a coolbox to the Center for Scientific and Technical Research in Physical and Chemical Analysis (CRAPC-Algeria). The identification was carried out using the MALDI Biotyper software.

\section{Inocula preparation}

To confirm the strain's purity, culture was grown on M17 agar, in aerobic conditions at $42{ }^{\circ} \mathrm{C}$. Before each test, an overnight culture was prepared. Colonies were recovered with a Pasteur pipette and suspended in sterile physiological solution. Suspensions were adjusted to an optical density (OD) of 0.11 (corresponds to $10^{8} \mathrm{CFU} / \mathrm{mL}$ ) at a wavelength of $578 \mathrm{~nm}$ (BIOCHROM Libra S6) (Andrew et al., 2008).

\section{Assessment of strains probiotic and technological potential}

Typical methods for in vitro determination of probiotic potential include low $\mathrm{pH}$ tolerance, bile salts tolerance, antibiotic susceptibility, antimicrobial activity, and adhesion capacity (Mulaw et al., 2019).

Survival in gastric juice similar solution. The test was performed according to the method described by Charteris et al. (1998) with some modifications. A solution similar to gastric juice was freshly prepared by suspending $0.3 \%$ pepsin in $0.5 \%$ sterile saline, the $\mathrm{pH}$ of the solution was then adjusted to $\mathrm{pH} 2$ and $\mathrm{pH} 3$. An $18 \mathrm{~h}$ culture was centrifuged at $6000 \mathrm{~g}$, $20 \mathrm{~min},+5^{\circ} \mathrm{C}$, then washed 3 times in $\mathrm{PBS}(0.1 \mathrm{M}, \mathrm{pH} 7)$. The recovered pellet was dissolved in $3 \mathrm{~mL}$ of PBS, and then $1 \mathrm{~mL}$ of this suspension was collected by centrifugation $(12000 \mathrm{~g}$, for $5 \mathrm{~min}$, at $+5 \mathrm{C}^{\circ}$ ) and added to the gastric juice-like solution at $\mathrm{pH} 2$ and $\mathrm{pH} 3$. The ODs were determined at $575 \mathrm{~nm}$ before and after incubation for $3 \mathrm{~h}$ at $+37^{\circ} \mathrm{C}$.

Tolerance to bile salt. The tolerance of both strains to bile salts was assessed by adopting the modified protocol of Anukam and Koyama (2007). $1 \mathrm{~mL}$ of $10^{7} \mathrm{CFU} / \mathrm{mL}$ inocula were added into $0.3,0.5$ and $1 \%$ bile M17 medium. ODs were measured at $575 \mathrm{~nm}$ after $24 \mathrm{~h}$ of incubation at $+37{ }^{\circ} \mathrm{C}$. The growth inhibition percentage (GI \%) in bile salts presence was calculated according to the following formula:

GI $\%=\left[\left(\log N_{0}-\log N_{t}\right) / \log N_{0}\right] x 100$. Where $N_{0}$ is a viable cell number in M17 broth without bile salts after $3 \mathrm{~h}$ of incubation and $\mathrm{N}_{\mathrm{t}}$ is a viable cell number in M17 broth containing bile salts after $3 \mathrm{~h}$ of incubation.

Acid pH tolerance. Tolerance to low $\mathrm{pH}$ was tested as described by Anukam and Koyama (2007), with some modifications; M17 broth was adjusted to $\mathrm{pH} 2$, $\mathrm{pH} 3$, by addition of $\mathrm{HCl}(1 \mathrm{~N})$, and then inoculated with $1 \mathrm{~mL}$ of an $18 \mathrm{~h}$ culture $\left(10^{8} \mathrm{CFU} / \mathrm{mL}\right)$. ODs were determined at $578 \mathrm{~nm}$ and were compared to the control at $\mathrm{pH} 7$ after $3 \mathrm{~h}$ of incubation.

Optimal temperature, thermotolerance, and lethal temperature. The growth optimal temperatures of the two bacterial strains, their thermotolerance, and low-temperature resistance were determined according to the method described by Haddaji et al. (2015) with some modifications. A suspension $\left(10^{8} \mathrm{CFU} / \mathrm{mL}\right)$ from an $18 \mathrm{~h}$ fresh culture was added into a series of tubes containing M17 broth. The tubes series were then incubated at different temperatures: $+15^{\circ} \mathrm{C},+37^{\circ} \mathrm{C},+45^{\circ} \mathrm{C},+50^{\circ} \mathrm{C}$ for $24 \mathrm{~h}$. The tubes serving for the thermoresistance test were incubated at $+60^{\circ} \mathrm{C}$ and $+65^{\circ} \mathrm{C}$ for 120 and 90 min respectively. ODs were read at $578 \mathrm{~nm}$. 
Adhesion capacity "hydrophobicity and auto-aggregation". The aggregation capacity was performed according to the method of Kos et al. (2003). Bacterial biomass from $18 \mathrm{~h}$ fresh cultures were recovered by centrifugation at $5000 \mathrm{~g}$ for $15 \mathrm{~min}$ and washed three times in PBS. Then the cells suspension were adjusted to a final charge of $10^{8} \mathrm{CFU} / \mathrm{mL}$ and distributed in two tubes series at $4 \mathrm{ml}$. The tubes were decanted for $5 \mathrm{~h}$, and every hour 0.1 $\mathrm{mL}$ of the culture taken from the surface of each tube and was transferred to another tube containing $3.9 \mathrm{~mL}$ of PBS. ODs were measured at $578 \mathrm{~nm}$, and the results were expressed as a percentage according to the following formula: \% Autoaggregation= $1-\left(A_{t} / A_{0}\right) .100$; where $A_{t}$ : the suspension OD after $1 \mathrm{~h}, 2 \mathrm{~h}, 3 \mathrm{~h}, 4 \mathrm{~h}, 5 \mathrm{~h}$ decantation, $\mathrm{A}_{0}$ : the suspension $\mathrm{OD}$ at t0. For the hydrophobicity test, bacterial biomasses of both strains were harvested from the $24 \mathrm{~h}$ cultures, washed once with PBS and adjusted to $10^{8} \mathrm{CFU} / \mathrm{mL}$ in $\mathrm{KNO}_{3}\left(0.1 \mathrm{~mol} . \mathrm{l}^{-1}\right) .3$ $\mathrm{mL}$ of each bacterial suspension was added to $1 \mathrm{~mL}$ of each solvent (xylene, ethyl acetate, and chloroform). The mixtures were incubated for $10 \mathrm{~min}$ at room temperature and then shaken rigorously for $2 \mathrm{~min}$. The ODs of the aqueous phase were measured after a $20 \mathrm{~min}$ decantation. The solvent adhesion percentage was calculated according to the following formula:

$$
\% \text { Solvent adhesion }=\left(1-\frac{A_{t}}{A_{0}}\right) \times 100
$$

where $A_{t}$ - the aqueous phase OD after 20 min decantation, $A_{0}$ - the suspension OD at $t_{0}$.

Antibiotic resistance. Antibiotic resistance was investigated by adopting the disc diffusion method described by Bauer (1966). total of four antibiotics were tested: nalidixic acid $(30 \mu \mathrm{g})$, chloramphenicol $(30 \mu \mathrm{g})$, gentamicin $(10 \mu \mathrm{g})$, tetracycline $(30 \mu \mathrm{g})$. The diameters of the inhibition zones $(\mathrm{mm})$ were measured after incubation for $24 \mathrm{~h}$ at $+37^{\circ} \mathrm{C}$.

Antagonistic effect. The antagonistic effect of lactic strains was tested against two pathogenic strains, Escherichia coli (ATCC 25922) and Staphylococcus aureus (ATCC 25923), by adopting the cross streak technique described by Balouirin et al. (2016); the lactic acid bacterial strain was streaked in the center of the agar plate. After incubation, the agar was streaked with the pathogenic strains in single streaks perpendicular to the central streak. After a second incubation, the antimicrobial interactions were analyzed by determining the inhibition zones and the inhibition percentage according to the following formula:

$$
\% \text { inhibition percentage }=\left(\frac{\text { Inhibitory diameter }(\mathrm{mm})}{\text { Petri dish diameter }}\right) \times 100
$$

Production and recovery of exopolysaccharides. Bacterial cultures were grown under the optimal conditions determined earlier. The extraction of EPSs and their purification was performed by adopting the protocol described by Oleksy-Sobczak and Klewicka( 2019) with some modifications. After incubation, the series of tubes containing the bacterial cultures were placed in a water bath at $+80^{\circ} \mathrm{C}$ for $15 \mathrm{~min}$, with shaking every $5 \mathrm{~min}$, to release the wall-attached EPSs. Then, the cultures were passed through a millipore filter $(0.45 \mu \mathrm{m})$, to remove the bacterial cells and to recover a filtrate. Three volumes of ethanol at $-80^{\circ} \mathrm{C}$ were added to this filtrate, and the tubes were stored at $-18{ }^{\circ} \mathrm{C}$ overnight. The EPSs were precipitated and recovered by cryocentrifugation $\left(12000 \mathrm{~g}\right.$ for $20 \mathrm{~min}$ at $\left.+4^{\circ} \mathrm{C}\right)$ three times and solubilized in sterile distilled water.

Exopolysaccharides quantification. The quantification of EPSs was performed according to the total sugars technique of Dubois (1956).

HPLC characterization of the produced EPSs. The EPS produced by each of the two strains was identified by HPLC (Agilent LC 1260). Briefly, 100 $\mu$ of solubilized biopolymer was added to $200 \mu \mathrm{l}$ of HCL (2M) and sonicated in a thermostatically controlled bath at 45 
min, then subjected to continuous shaking. A volume of acid-hydrolyzed EPSs was made up to $1 \mathrm{~mL}$ with an eluent of $80 \%$ acetonitrile and $20 \%$ water. A $300 \mu \mathrm{L}$ volume of crude extract was also mixed with the eluent. The extracts were filtered $(0.22 \mu \mathrm{m})$, and a volume of $10 \mu \mathrm{L}$ was injected. The crude and hydrolyzed extracts were analyzed on an Agilent Zorbax Carbohydrate analysis column $(4.6 \times 150 \mathrm{~mm}, 5 \mu \mathrm{m})$. The column flow rate was $1.3 \mathrm{~mL} / \mathrm{min}$, and the operating temperature was $+30^{\circ} \mathrm{C}$.

\section{Data processing}

All tests were performed in duplicate, and the data were analyzed by one-way analysis of variance (ANOVA) and means were compared using the Turkey HSD (Honest Significance Difference) post hoc test $(\mathrm{P} \leq 0.05)$. All statistical tests were performed using the $\mathrm{R}$ program (version 3.6.1).

\section{Results and discussion}

\section{Enterococcus durans: isolation and identification}

Several lactic and non-lactic bacteria were isolated from the fermented food "Hamoum" (Drabo et al., 2019). Strains which colonies had mucous appearance indicating that these strains produce exopolysaggharides were chosed for further study. A purification step on M17 agar, after a succession of subcultures, resulted in colonies with the same appearance, whose phenotypic identification (cultural, microscopic, and biochemical characters), was done following the assortment table described by Cowan (2004). The results of the phenotypic identification are presented in Table 1.

Phenotypic identification of $E$. durans

Table 1

\begin{tabular}{|l|c|}
\hline Profil & Result \\
\hline Cultures Conditions & $\mathrm{M} 17\left(\mathrm{O}_{2}, 37^{\circ} \mathrm{C}, 24 \mathrm{~h}\right)$ \\
\hline Colony appearance & Translucent \\
\hline Gram & +/ Single cocci, pairs, tetrads, and chains \\
\hline Catalase & - \\
\hline Oxydase & + \\
\hline Mannitol / Mobility & $-/-$ \\
\hline ONPG & + \\
\hline Simmons' Citrate & - \\
\hline Proteolysis & +++ \\
\hline ADH/LDH/ODC & $+/-/-$ \\
\hline Identification & E. durans/ Pediococcus spp. \\
\hline
\end{tabular}

After biochemical identification, the isolate was characterized by MS-MALDI-TOF (Figure 1), the strain isolated was presumed to be Enterococcus durans. 


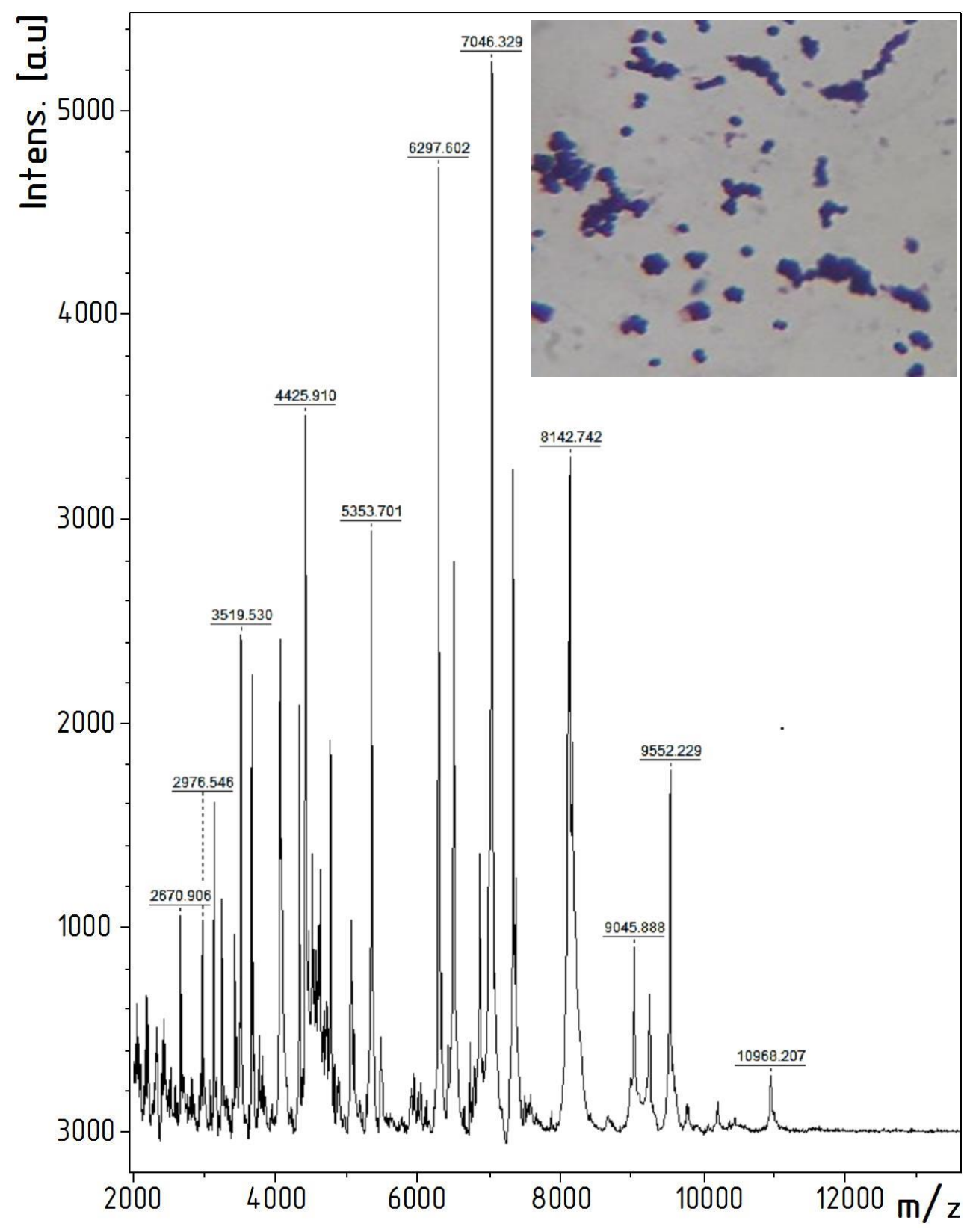

Figure 1. MALDI-TOF spectra of Enterococcus durans 


\section{Evaluation of the probiotic potential of $S$. thermophilus and $E$. durans}

Growth, resistance to environmental variations, adhesion and biofilm formation are phenomena that enable microorganisms to colonize a habitat and to maintain themselves there, provide species with an ecological, technological, and sanitary advantage microbial cells are directly in contact with their substrate which avoids the diffusion of enzymes in the external environment (Akers et al., 2015)

Growth at different temperatures/thermoresistance. Stress due to temperature variation, is probably, the most common that bacteria and other organisms face in the natural world (Varmanen and Savijoki, 2011). Figure 2, shows the effect of temperature, on the growth and viability of both lactic strains. It was well shown that the temperature values of $37{ }^{\circ} \mathrm{C}$ and $45^{\circ} \mathrm{C}$ are the most ideal for the growth of E. durans and S. themophilus and correspond to the cell concentrations of $9.08 \log \mathrm{CFU} / \mathrm{mL}$ and $9.05 \log \mathrm{CFU} / \mathrm{mL}$, respectively. The growth of $E$. durans at a low temperature of $+15{ }^{\circ} \mathrm{C}$ was reduced, however, the reduction was not significant $(\mathrm{P}>0.05)$ for $S$. thermophilus, and a reduction of $0.3 \log 10$ was noted at $+15^{\circ} \mathrm{C}$. The optimal temperatures recorded for both strains were $+37^{\circ} \mathrm{C}(37 \mathrm{vs}$ $45: \mathrm{P}=0.411, \mathrm{P}>0.05 ; 37$ vs $15: \mathrm{P}=0.00001, \mathrm{P}<0.001 ; 37$ vs $50:: \mathrm{P}=0.000003, \mathrm{P}<0$. 001) for E. durans and $+45^{\circ} \mathrm{C}(45$ vs $15: \mathrm{P}=0.23, \mathrm{P}>0.05 ; 45$ vs $37: \mathrm{P}=0.193, \mathrm{P}>0.05$; 45 vs $50: \mathrm{P}=0.01, \mathrm{P}<0.05 ; 45$ vs $60: \mathrm{P}=0.000006, \mathrm{P}<0.001)$ for $S$. thermophilus. A minimal growth rate at $+50{ }^{\circ} \mathrm{C}$ was noted for both strains. A small but very highly significant $(\mathrm{P}<0.001)$ reduction in growth rates at $+60{ }^{\circ} \mathrm{C}$ and $+65{ }^{\circ} \mathrm{C}$ during $2 \mathrm{~h}$ of incubation was recorded, 1.69 and $1.68 \log \mathrm{cfu} / \mathrm{mL}$ for $E$. durans and 1.48 and $1.44 \log \mathrm{cfu} / \mathrm{mL}$ for $S$. thermophilus. Auffray et al (1995) reported that $S$. thermophilus grew at temperatures ranging from 20 to $52{ }^{\circ} \mathrm{C}$ and was able to acquire thermotolerance when subjected to heat shock. They recorded survival rates of $1 \%$ and $0.1 \%$ at $58{ }^{\circ} \mathrm{C}$ for 15 and $30 \mathrm{~min}$ respectively. The low growth when the temperature was switched from +42 to $+52{ }^{\circ} \mathrm{C}$ was attributed to the protein synthesis profile of $S$. thermophilus, which showed a decrease in the synthesis of many polypeptides, thus indicating inhibition of protein synthesis due to the temperature change. Fang et al (2002), on the other hand, reported that exposure to a low temperature of $+5{ }^{\circ} \mathrm{C}$ for 15 days did not affect the survival of $S$. thermophilus. They noted high survival rates at $10^{\circ} \mathrm{C}$ for $2 \mathrm{~h}$ and $4 \mathrm{~h}$ and at $+15^{\circ} \mathrm{C}$ for $2 \mathrm{~h}$. Růžičková et al. (2020) reported that due to their adaptability, species of the genus Enterococcus survive in various environments. Thus, for the majority of species, the optimal temperature is between +35 and $+37{ }^{\circ} \mathrm{C}$, however, a few species thrive at $+45^{\circ} \mathrm{C}$ and even at low temperatures around $+10{ }^{\circ} \mathrm{C}$. Exposure to a brief heat shock with a temperature at or slightly above the normal growth range provides cells the ability to acquire resistance to a lethal heat shock due to a higher temperature (Jobin et al., 1998). Indeed, in response to sudden temperature fluctuations, living organisms respond with rapid changes in gene expression, resulting in the massive synthesis of a group of proteins called heat shock proteins (HSPs) (Lim and Gross, 2011). This synthesis notes a universal phenomenon occurring in most organisms. Even though HSPs are present in different bacteria, the heat shock response reflects the amazing diversity of bacterial gene regulation in various bacteria, including lactic acid bacteria (Auffray et al., 1995). 


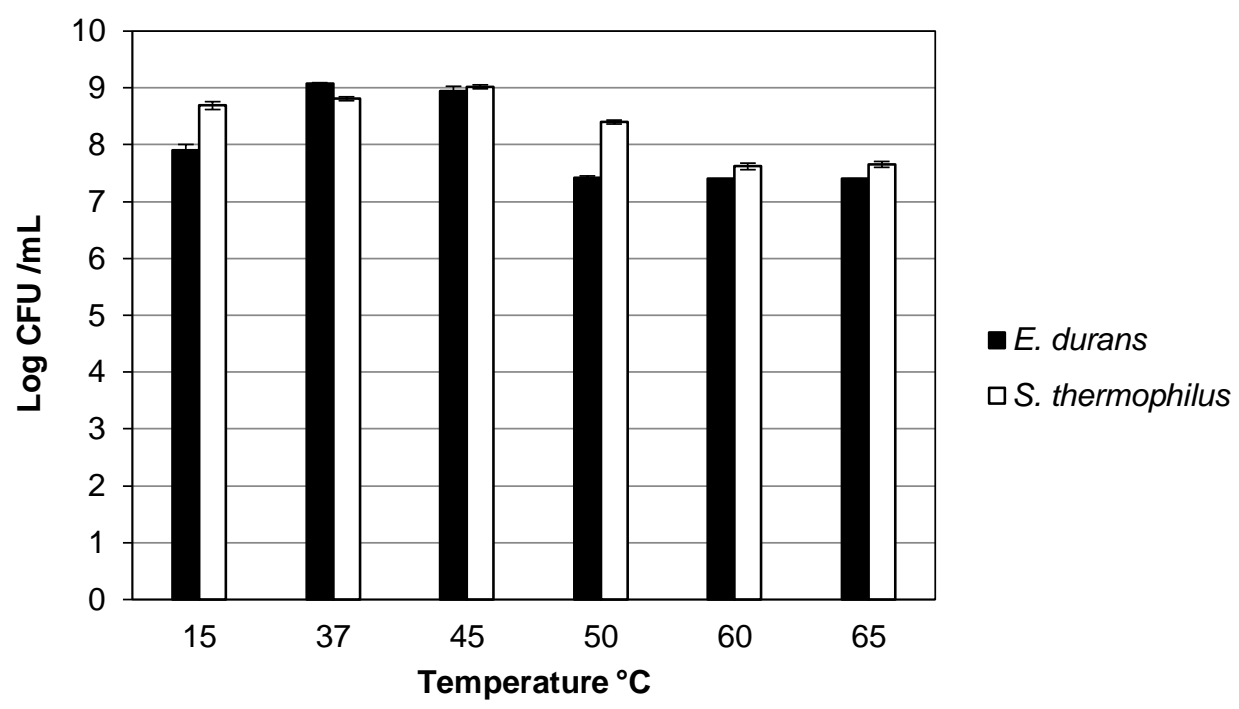

Figure 2. Temperature effect on the growth and viability of both lactic strains.

Resistance to $\mathbf{p H}$. An important characteristic of probiotic lactic acid bacteria used as adjuvants is their tolerance of bile and resistance to gastric juices. Although the degree of tolerance required for maximum growth in the GIT is not determined, the selection of species with improved acid resistance appears to be judicious (Dressman et al.,1990) . Under fasting conditions, the accepted $\mathrm{pH}$ value of gastric juice is in the vicinity of 2 (Nami et al., 2019). Therefore, this $\mathrm{pH}$ has been used as a standard for in vitro tests, evaluating the survival of probiotic cultures in the human stomach (Nami et al., 2019). According to the results displayed in Table 2, $\mathrm{pH}$ variations significantly affected the growth of both strains $(\mathrm{P}<0.001)$, they were able to survive at acid $\mathrm{pH}$, a slight reduction compared to the control was recorded at $\mathrm{pH}=2$ after $3 \mathrm{~h}$ of incubation, in the order of 1.0 and $0.99 \log \mathrm{cfu} / \mathrm{mL}$ for $S$. thermophilus and E. durans respectively. At $\mathrm{pH}=3$, the reduction in survival rate was in the order of 1 and $0.15 \log \mathrm{cfu} / \mathrm{mL}$ for $S$. thermophilus and E. durans respectively, E. durans appears to be more tolerant.

The tolerance of $E$. durans strain to acidic conditions was also studied by Nami et al. (2019) who demonstrated that Enterococcus isolates could be excellent candidates for the production of functional foods to promote health due to their high tolerance of low $\mathrm{pH} 2.5$, especially E. durans ES11, ES20 and ES32.

However, Boke et al. (2010) observed a considerable reduction in viability at $\mathrm{pH} \leq 3.0$, for all strains tested, including $S$. thermophilus, the sensitivity to acid is greater for strains with low EPS production. According to this study, the resistance of some lactic strains to stressful conditions (acidic $\mathrm{pH}$ ) can be explained by the fact that these bacteria are producers of EPS, and that these polymers could play a protective role. Lactic acid bacteria are equipped with stress sensing systems to activate defenses, allowing them to readapt to difficult conditions or environmental changes. DNA repair mechanisms can also be characterized in these bacteria as a response to oxidative stress and acidic stress (Chen et al., 2019). 
Growth at acid pH

\begin{tabular}{|c|c|c|c|}
\hline & $\begin{array}{c}\text { Time } \\
\text { (h) }\end{array}$ & E. durans $(\log$ CFU/mL) & S. thermophilus $(\log$ CFU/mL) \\
\hline \multicolumn{4}{|c|}{ Digestion in a solution simulating gastric juice } \\
\hline $\mathrm{pH} 2$ & 0 & $8.225 \pm 0.00$ & $8.245 \pm 0.005$ \\
& 3 & $7.233 \pm 0.002$ & $7.225 \pm 0.028$ \\
\hline $\mathrm{pH} 3$ & 0 & $7.164 \pm 0.016$ & $8.3 \pm 0.011$ \\
& 3 & $7.018 \pm 0.018$ & $7.305 \pm 0.005$ \\
\hline \multicolumn{4}{|c|}{ Medium with acid pH } \\
\hline $\mathrm{pH} 2$ & 0 & $7.477 \pm 0.00$ & $7.477 \pm 0.00$ \\
& 3 & $8.365 \pm 0.005$ & $8.37 \pm 0.00$ \\
\hline \multirow{2}{*}{ pH 3 } & $\mathbf{0}$ & $\mathbf{7 . 4 7 7} \pm \mathbf{0 . 0 0}$ & $\mathbf{7 . 4 7 7} \pm \mathbf{0 . 0 0}$ \\
& $\mathbf{3}$ & $\mathbf{8 . 3 9 5} \pm \mathbf{0 . 0 1 7}$ & $\mathbf{8 . 4 \pm 0 . 0 0}$ \\
\hline
\end{tabular}

Growth in the presence of increasing concentrations of bile salts. Lactic acid bacteria being the most representative probiotics, which are used in the production of dairy products, and vegetable-based foods. Bile tolerance is a crucial property, commonly consistent with the growing ability of bacteria that act as probiotics (Begley et al., 2005). Figure 3 illustrates the response of the studied strains to increasing concentrations of bile salts. Both strains survive in the bile salts presence, without substantial reduction (1 to $3 \%$ ). The viability percentage of $S$. thermophilus was comparable to that of the control, namely $99 \%, 98 \%$ and $96 \%$ for bile salts concentrations of $0.3,0.5,1 \%$ respectively. The tolerance of E. durans to different bile salts concentrations was much higher than that of $S$. thermophilus, and the viability rates recorded were even higher than those of the control, preserving $100 \%$ of the initial population. Bile is a digestive secretion involved in the fats emulsification and solubilization process in the human digestive tract. This secretion can affect the phospholipids and proteins of the cell membranes and thus disrupt cell homeostasis.

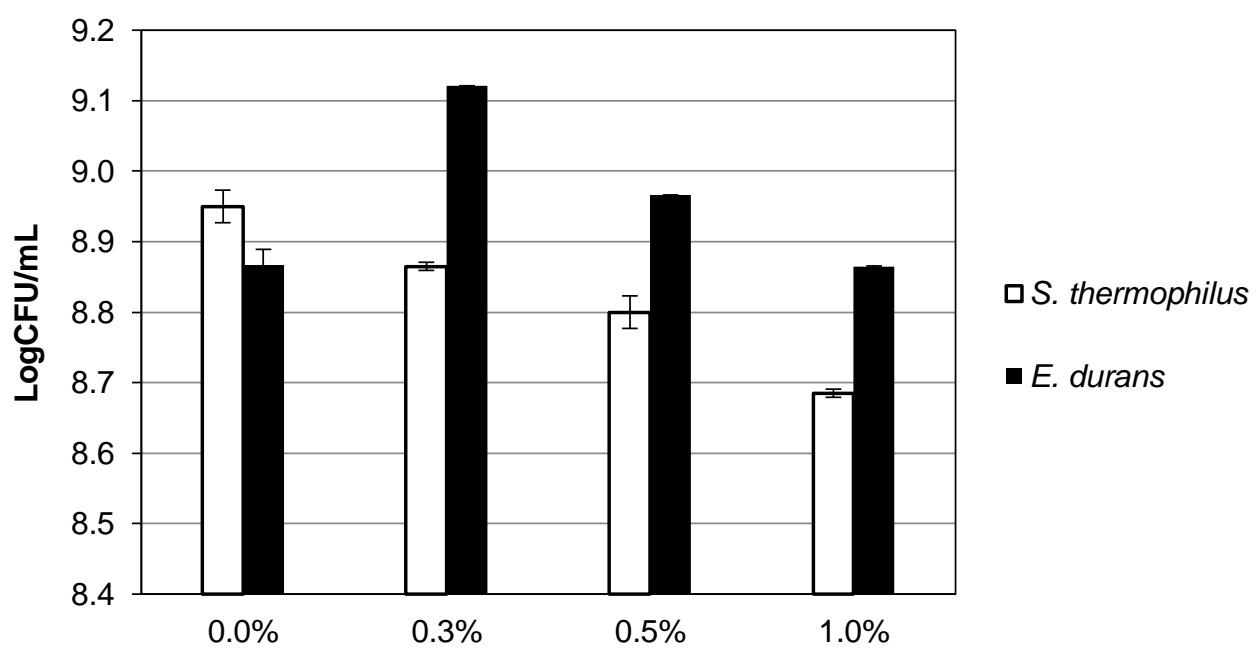

Bile salts concentratins, $\%$

Figure 3. Growth in the presence of bile salts 
It is therefore crucial for probiotics to be able to tolerate bile for surviving and colonizing the gastrointestinal tract. Indeed, it is recommended to use bile salts concentrations of $0.15-0.3 \%$ for the probiotic bacteria selection (Boke et al., 2010). Tuncer and Tuncer (2010) proved viability maintenance of S. thermophilus ST 8.01 after $24 \mathrm{~h}$ incubation in the presence of $0.3,0.5$, and $1 \%$ bile salts. The highest inhibition percentage was recorded at $1 \%$. In contrast, Vinderola and Reinheimer, 2003), reported low resistance of $S$. thermophilus strains in the presence of bile salts. Pieniz et al. (2014), showed that the survivability of $E$. durans LAB18s was maintained in the presence of all tested bile salts concentrations (up to 1.5\%). However, Li et al. (2020), estimated the survival rate of $E$. durans at $56 \%$ in the presence of $0.3 \%$ bile. Thus, strains producing more EPS exhibited a significant protective effect against bile salts (0.3\%). Furthermore, Bagci et al. (2019), evaluating the probiotic characteristics of Enterococcus genus strains isolated from human milk and colostrum, showed that these isolates exhibited high tolerance to acids (up to $\mathrm{pH}$ 3.0 ) and bile $(0.5 \%)$, suggesting their strong ability to survive in the upper gastrointestinal tract.

Aggregation capacity. The aggregation capacity is an important factor in the colonization of the gut by probiotics thus preventing the adhesion of pathogens (Lee et al., 2008). The percentages of cells aggregation of the bacterial strains are displayed in Figure 4.

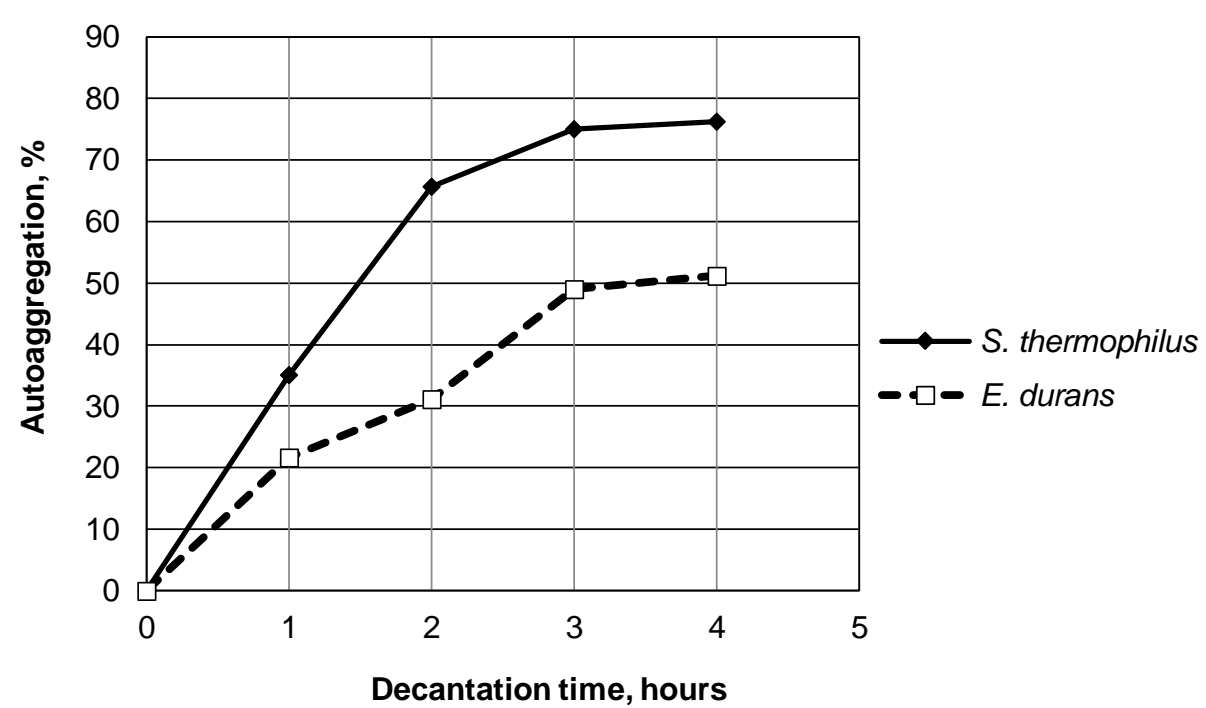

Figure 4. Adhesion level of the two strains.

The autoaggregation percentages were increased in parallel with the prolongation of the decantation time for both strains $(\mathrm{P}<0.05)$ they vary from 35 to $76 \%$ and from 21 to $51 \%$ for $S$. thermophilus and $E$. durans, respectively. The autoaggregation capacity recorded by $S$. thermophilus after $4 \mathrm{~h}$ of incubation was greater than that of $E$ durans for the same duration (76\% vs 51\%, p-values $\leq 0.05$ ). Tuncer and Tuncer (2014) reported that the aggregation percentage recorded for $S$. thermophilus ST8.01 was $49.55 \pm 6.24 \%$. On the other hand, Lee 
et al. (2008) recorded for an E. durans isolate an autoaggregation rate in the vicinity of $50 \%$. Furthermore, in their study on the estimation of the adhesive power of probiotics, Xu et al. (2009) noted that the autoaggregation capacity of probiotic strains is higher than those of pathogens. They reported that the autoaggregation values displayed by probiotic strains ranged from $36 \%$ to $51 \%$. The cell aggregation process is based on an interaction between cell surface elements such as lipoteichoic acids, lectin-like proteins, as well as soluble proteins and pheromones (Boris et al, 1997), it can be a kind of host defense against infections. Besides, probiotics adhere differently, thus it is a trait that depends on the strain and the characteristics of the cell surface, namely hydrophobicity and extracellular protein profile Collado, 2009; Ayyash et al., 2018)

Adhesion to solvents. The hydrophobic potential of the cell surface of probiotics is a criterion to determine their adhesion to intestinal epithelial cells. More hydrophobic properties might provide probiotics having a competitive position (Bagci et al., 2019; TerzićVidojević et al., 2015) allowing the colonization of the human gastrointestinal tract and expression of their benefits; however, some studies have demonstrated that hydrophobicity is not at all a unique factor governing the adhesion of microbes to the cell surface (Bagci et al., 2019). The two strains' affinity to solvents is reported in Figure 5.

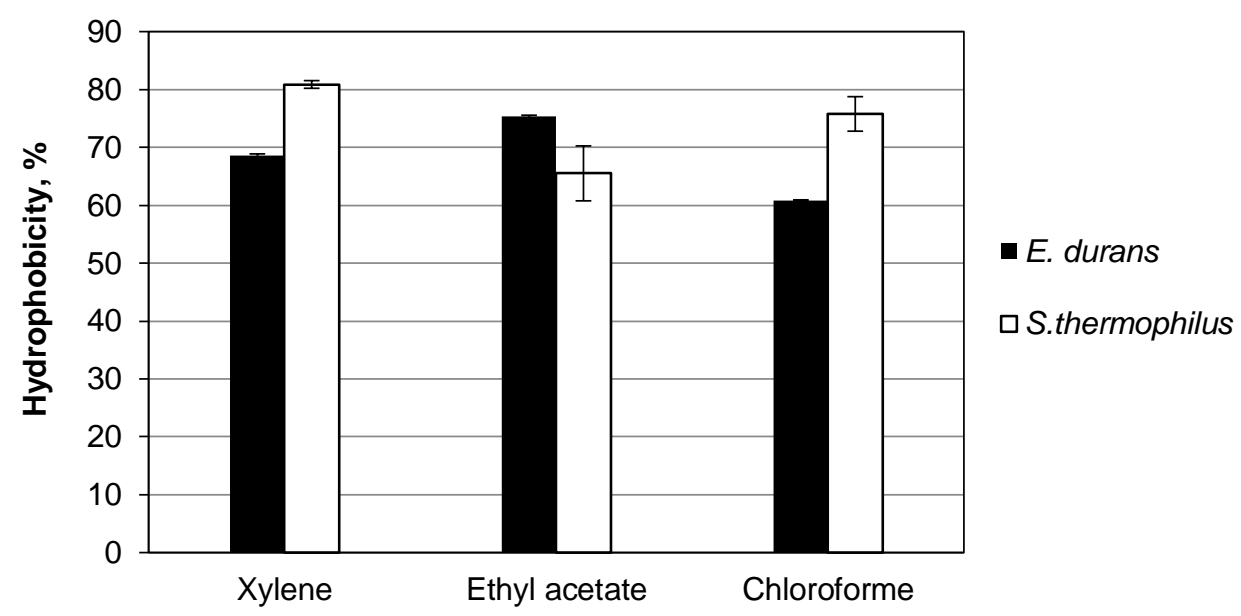

\section{Solvents}

Figure 5. Strains adhesion to solvents

The adhesion percentages to xylene (apolar solvent) were higher than $50 \%$ for the two lactic strains $E$. durans and $S$. thermophilus, i.e. $61 \%$ and $81 \%$, respectively. With ethyl acetate (basic mono-polar solvent), the adhesion rates were around 75 and 77\%, for E. durans and $S$. thermophiles, respectively. The percentage of hydrophobicity of cells (using xylene as a solvent) might be classified as strongly hydrophobic (> 50\%), moderately hydrophobic (20-50\%) and hydrophilic ( $<20 \%)$. According to this classification, S. thermophilus and E. durans can be classified as strongly hydrophobic (Hydrophobicity $>50 \%$ ). The difference in E. durans affinity to the three solvents was highly significant $(\mathrm{P}<0.001)$. Tuncer and Tuncer (2014) also recorded a high affinity (67\%) of S. thermophilus ST8.01 to xylene. Thus in accordance with the results obtained for E. durans, Nami et al. (2019) revealed in their study 
of probiotic characterization and safety assessment of enterococcal isolates from various artisanal dairy products that hydrophobicity values ranged from 23 to 58\%, with several isolates recording percentages above 50\%. Ayyash et al. (2018) registered hydrophobicity below 50\% for isolates of the genus Streptococcus and Enterococcus. The higher the aggregation capacity and hydrophobicity, the better the probiotic cells can attach to the epithelial cells thus increasing its efficiency. According to the present study, the percentage of aggregation and hydrophobicity of both strains were higher than 50\%. Some reports have indicated that the origin and surface characteristics of the strains may be determinant in the hydrophobicity of their surfaces, generating differences in the affinity of the microbes to various solvents, the majority of probiotic bacteria used as starters show a higher affinity to organic solvents ( $>32 \%$ ) Vinderola and Reinheimer, 2003). The hydrophobic character of the cell surface is related to the presence of components of protein nature, while hydrophilicity is associated with the presence of polysaccharides (Kos et al., 2003).

Antibiotic resistance. One of the clinical interests of the use of probiotics is the prevention and treatment of antibiotic-associated diarrhea. Thus, the tolerance of probiotics to antibiotics is a desired trait. However, this resistance should not be entrusted to other bacteria. The determination of antibiotic susceptibility of strains intended for safe use in the food sector is a fundamental aspect of the choice to avoid anarchic spread of antibiotic resistance genes through horizontal transfer (Terzić-Vidojević et al., 2015). Antibiotic resistance results are outlined in Table 3 .

Antibiotic resistance

Table 3

\begin{tabular}{|lcccc|}
\hline \multicolumn{1}{|c|}{ Antibioresistance / Sensibility } & & & \\
& $\mathrm{C}_{10}$ & $\mathrm{GM}$ & $\mathrm{AN}_{30}$ & $\mathrm{TE}_{30}$ \\
\hline E. durans & $\mathrm{S}$ & $\mathrm{S}$ & $\mathrm{R}$ & $\mathrm{MS}$ \\
S. thermophiles & $\mathrm{R}$ & $\mathrm{S}$ & $\mathrm{R}$ & $\mathrm{R}$ \\
\hline
\end{tabular}

MS: moderately susceptible, $\mathrm{S}$ : susceptible, R resistant.

It is noticeable that the two strains behave differently to the different antibiotics tested. S. thermophilus was sensitive only to gentamicin. In contrast, Enterococcus durans showed significant resistance $(\mathrm{P}-$ values $<0.05)$ to tetracycline and nalidixic acid. Tuncer and Tuncer (2014) reported that $S$. thermophilus ST8.01 exhibited susceptibility to all antibiotics tested including tetracycline, chloramphenicol and gentamicin. Zhou et. al. (2012), evaluating the resistance of some lactic strains to 11 antibiotics, reported that several strains of $S$. thermophilus were resistant to chloramphenicol, only $11 \%$ were sensitive to gentamicin, while $44 \%$ showed resistance to tetracycline. Thus, Tosi et al (2007) showed that $S$. thermophilus strains isolated from various environments were sensitive to all 6 antibiotics tested, including gentamicin, and some were resistant to tetracycline. In a further study, Abamecha et al (2015) indicated that 34\% of Enterococcus isolates exhibited resistance to gentamicin, $64 \%$ to tetracycline, and 34\% to choloramphenicol. According to TerzićVidojević et al. (2015), the presence of antibiotic resistance factors varies between strains and regions. According to the results of their study, 29\% of Enterococcus isolates including Enterococcus durans were susceptible to the antibiotics tested (including gentamicin, tetracycline, and chloramphenicol) and almost 59\% of these isolates were resistant to two or more antibiotics. They reported that out of a total of 636 dairy enterococcal isolates, only five strains under the $E$. durans species have technological potential and meet the safety criteria 
required for use in the dairy industry. The problem of antimicrobial resistance continues to grow worldwide, compromising the effectiveness of the treatment of bacterial infections. The massive use of antibiotics in humans and animals has caused a high probability of developing resistance that could be transmitted through food (Blom and Mørtvedt, 1991; Zhou et al., 2012). Furthermore, the major risk of resistance dissemination is the presence of antibiotic resistance genes on mobile components. Whenever possible, microorganisms used as food additives should be targeted first to the organism with the lowest resistance (Tosi et. al., 2007), which requires further characterization to determine the genetic basis of resistance.

Antagonistic effect. The results of the two lactic strains' antibacterial activity are presented in Table 4.

Antibacterial activity of S. thermophilus CNRZ 447 and E. durans NCBI 53345

Table 4 (intensity according to inhibitory zone)

\begin{tabular}{|c|c|c|}
\hline \multirow{2}{*}{ Lactic strain } & \multicolumn{2}{|c|}{$\begin{array}{c}\text { Antibacterial activity } \\
\text { (intensity according to diameter - mm) }\end{array}$} \\
\cline { 2 - 3 } S. thermophilus & $\boldsymbol{E}$ coli & S. aureus \\
\hline E. dueans & $+++(13,745 \pm 0,72 \% / 10.5-11.5 \mathrm{~mm}))$ & $+++(9,84 \pm 0,542 \% / 7.5-9 \mathrm{~mm})$ \\
\hline
\end{tabular}

(- ) No inhibition, (+) inhibitory zone 0.1-1 mm; (++) inhibitory zone 1.1-2.0 mm; $(+++)$ inhibitory zone $>2.1 \mathrm{~mm}$ (Ayyash et al., 2018).

These results reveal a significant antagonistic activity against the two opportunistic pathogens tested, E. coli and $S$. aureus. The inhibition percentages were 13-9.84\% for $S$. thermophilus and 12-9\% for E. durans against E. coli and $S$. aureus respectively. Lactic acid bacteria have always been used in the preservation of food by producing antimicrobial substances. In fact, through fermentation, carbohydrates are reduced into a range of low molecular weight organic molecules such as, acids, lactic, acetic, propionic and ethanol (Blom and Mørtvedt, 1991). Pieniz et al. (2014) reported that E. durans LAB18s displayed a broad spectrum of antimicrobial activity, inhibiting several pathogens such, E. coli and $S$. aureus. Thus, Belgacem et al. (2010) reported that some bacteriocin-producing enterococci isolates reveal many biochemical qualities according to their technological performance in the food industry. Enterocins (bacteriocins) produced by species of the genus Enterococcus are effective against Gram-negative and Gram-positive bacteria. Their resistance to a wide range of temperatures and $\mathrm{pH}$, as well as their broad spectrum of activity, makes them of great technological interest (Tosoni et al., 2019). Akpinar et al. (2011) reported that all $S$. thermophilus strains exhibited antimicrobial activity against $K$. pneumoniae. Besides, $S$. thermophilus strains SL4 and SY2 had an antimicrobial action on all bacteria tested including Staphylococcus aureus and Escherichia coli. Among S. thermophilus strains, some generate a bacteriocin called thermophilin, which is effective against several food spoilage bacteria. Being technologically and biochemically valuable, this bacteriocin is conceivable as a potent biopreservative (Aktypis et al., 2007). Also, Enterococcus, Lactococcus and Pediococcus, are also among the lactic acid bacteria frequently applied as natural preservatives, due to their potential production of metabolites with antimicrobial properties, including organic acids, hydrogen peroxide, antimicrobial enzymes and bacteriocins (Wu et al., 2014). 
Exopolysaccharides production. The yield of EPSs produced by the two lactic strains is elucidated in Table 5.

\section{EPS productivity of S. thermophilus CNRZ 447 and E. durans NCBI 53345}

Table 5

\begin{tabular}{|c|c|}
\hline Lactic strains & $E P S(m g / L)$ \\
\hline E. durans & $1661 \pm 27^{\mathrm{a}}$ \\
S. thermophilus & $176 \pm 4^{\mathrm{a}}$ \\
\hline
\end{tabular}

Values with different superscript letters $(\mathrm{a}, \mathrm{b})$

are significantly different $(\mathrm{P}<0.05)$.

S. thermophilus, which is a strain generally used for its technological qualities as a starter, was found to be less productive of EPSs than E. durans ( 176 vs $1661 \mathrm{mg} / \mathrm{L}, \mathrm{P}<0.05$ ). The performance obtained was comparable to the maximum EPS yield of $S$. thermophilus species (Abdellah et al., 2015; Kanamarlapudi and Muddada, 2017). In agreement with our previous study (Boubakeur et al., 2018), the level of EPSs produced by S. thermophilus was $200 \mathrm{mg} / \mathrm{L}$. It was possible to significantly improve the yield from 200 to $826 \mathrm{mg}$ glucose/ $\mathrm{L}$, adopting as an approach, the polyphenolic extract of Thymus fontanesii. Abdellah et al. (2015) in their study evaluating biofilm formation by thermophilic EPS+ lactic acid bacteria noted that the EPS levels of enterococci were 0.07 and $0.242 \mathrm{~g} / \mathrm{L}$, the fewest of all isolated lactic acid strains. Besides, Mostafa et al (2009) reported that for one Enterococcus species, the maximum EPS production after 6 hours of fermentation was $23 \mathrm{~g} / \mathrm{L}$.

HPLC profile of the produced exopolysaccharides. The HPLC profile of the EPS produced by $S$. thermophilus CNRZ 447 (previously published profile, Khadem et al., 2020) and $E$. durans is presented in Figure 6 (A, B) and 7 (C, D) respectively.

Chromatograms "A and B" revealed that the EPS generated by S. thermophilus CNRZ 447 was composed mainly of two triholosides predominantly consisting of glucose. The exact monosaccharide composition was insufficiently determined. However, S. thermophilus species is reported to produce heteropolysaccharides (Kanamarlapudi and Muddada, 2017). On the other hand, EPS produced by E. durans revealed peaks at 7 and 9 min that corresponded to oligosaccharides, and a single peak, resulting from elution at $20.4 \mathrm{~min}$, that probably corresponded to sorbitol. The EPSs produced by lactic bacteria display very varied structures. Indeed, the composition in monosaccharides, the links between the units, the presence of repeated side chains and substitutions are often at the origin of divergences between the EPSs. However, the structural characterization of the produced polymers still requires a more detailed identification. 

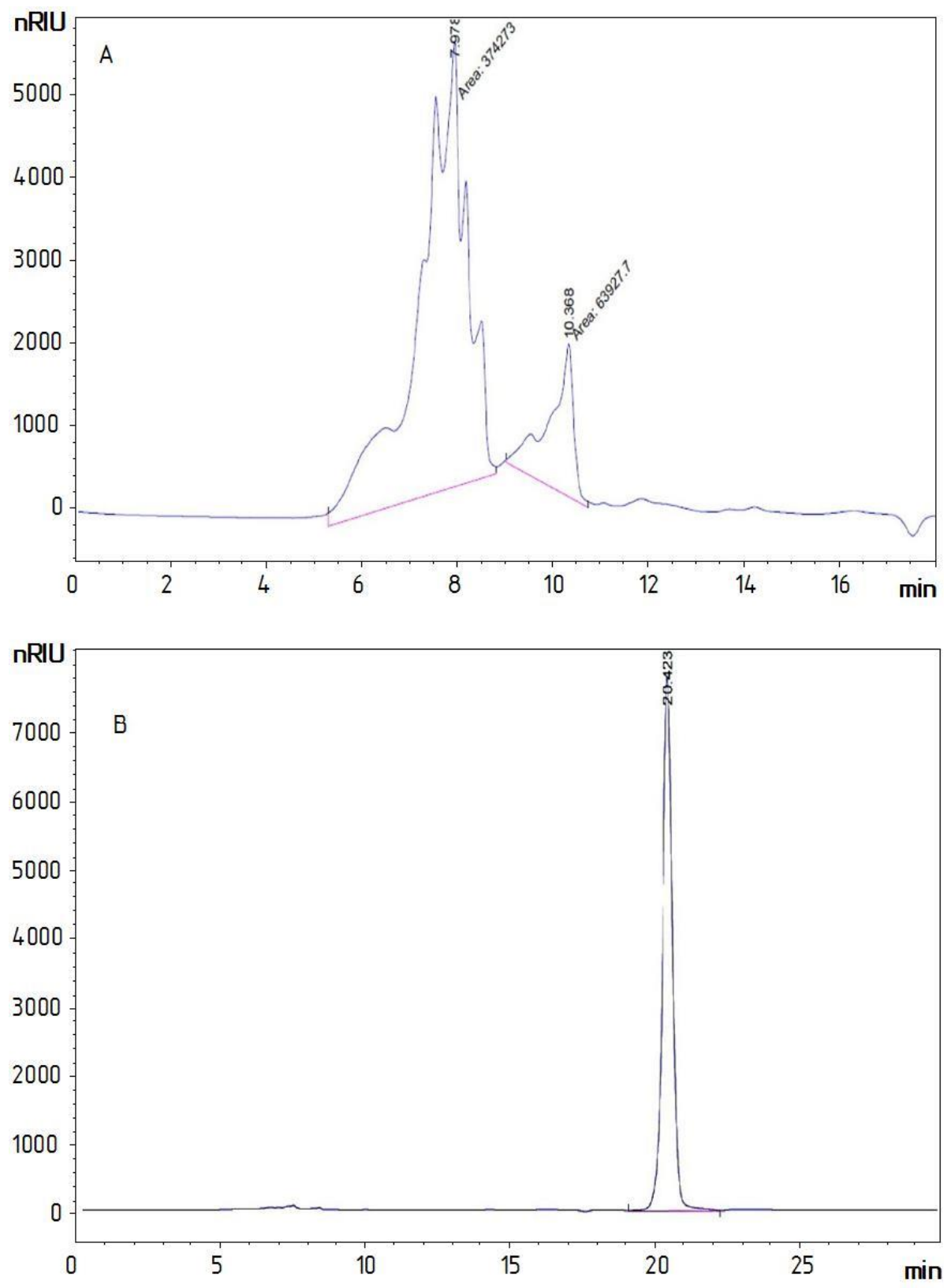

Figure 6. HPLC profile of the EPS of S. thermophilus CNRZ 447 [56]:

$\mathrm{A}$ - the two distinct triholosides (between 7 and 10 minutes residues.

B - a single characteristic peak at $\mathbf{2 0 . 4}$ minutes was observed for the hydrolyzed EPS. 

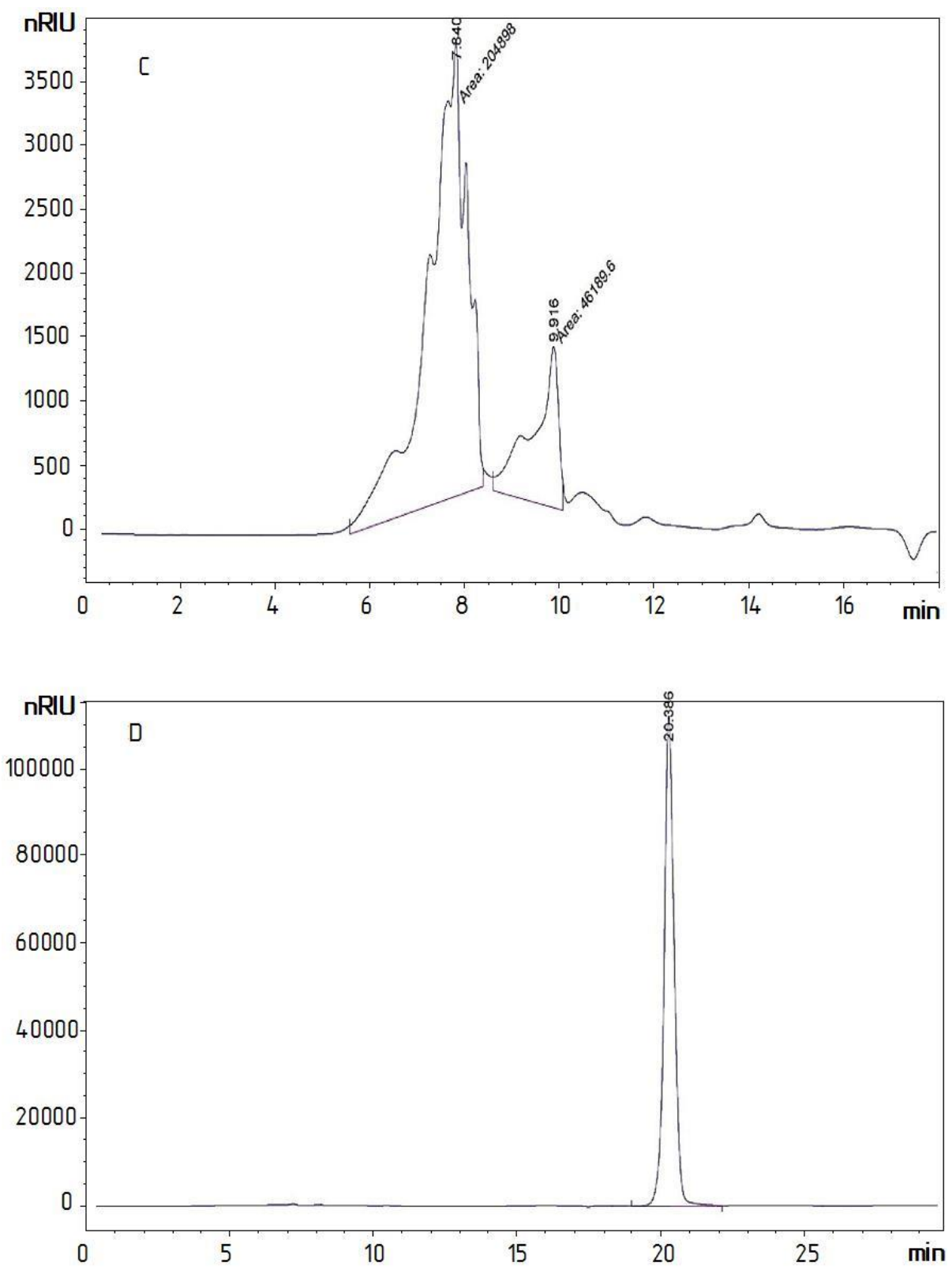

Figure 7. HPLC profile of $E$. durans NCBI 53345 EPS:

C - The EPS oligosaccharides (between 7 and 9 minutes).

D - a single characteristic peak at 20.3 minutes observed for hydrolyzed EPS. 


\section{Conclusion}

1. The in vitro study revealed that both E. durans NCBI 53345 and S thermophilus CNRZ 447 strains have a promising probiotic potential.

2. Exopolysacchrides production and specific characterizing of these strains contribute to the protection of microbial cells against extreme environments (temperature variation, low $\mathrm{pH}$ and bile salts).

3. The strains investigated could be recommended as potential culture starter and probiotics.

The in vitro study revealed that the two strains S. thermophilus CNRZ 447 and E. durans NCBI 53345 have a promising probiotic potential. Thus, according to the findings of the probiotic potential assessment of the two lactic strains, it is suggested that the production of the exopolysaccharides characterizing these two strains potentially contributes to their protection against extreme environments (temperature variation, low $\mathrm{pH}$ and bile salts). Indeed, this investigation has allowed supposing that the high production of EPS can be a pivotal trait in the screening of probiotic strains.

Acknowledgment. The experimental research was mainly carried out in alternation in the research laboratory "Bioconversion, Microbiological Engineering, and Sanitary Safety" (BGMSS) of the Natural and Life Sciences Faculty of Mascara University and the laboratories of Biochemistry and Microbiology of the Natural and Life Sciences Faculty of Tiaret University. The identification of $E$. durans, was made at the Center for Scientific and Technical Research in Physical and Chemical Analysis (CRAPC) in Bous-Ismail, Tipaza, Algeria. The chromatographic analysis of exopolysaccharides was carried out in the research center of Trakya University, Edirne-Turkey. The authors express their thanks and gratitude to the directors and staff of these laboratories and research centers.

\section{References}

Abamecha A. Wondafrash B., Abdissa, A. (2015), Antimicrobial resistance profile of Enterococcus species isolated from intestinal tracts of hospitalized patients in Jimma, Ethiopia, BMC Research Notes, 8(1), pp. 1-7.

Abdellah M., Ahcène H., Benalia Y., Saad B., Abdelmalek B. (2015), Evaluation of biofilm formation by exopolysaccharide-producer strains of thermophilic lactic acid bacteria isolated from Algerian camel milk, Emirates Journal of Food and Agriculture, pp. 513521.

Akers K.S., Cardile A. P., Wenke J. C., Murray C. K. (2015), Biofilm Formation by Clinical Isolates and Its Relevance to Clinical Infections. [In:] Biofilm-based Healthcareassociated Infections Volume I, G. Donelli), pp. 193, 1-28.

Akpinar A., Yerlikaya O., Kiliccedil S. (2011), Antimicrobial activity and antibiotic resistance of Lactobacillus delbrueckii ssp. bulgaricus and Streptococcus thermophilus strains isolated from Turkish homemade yoghurts, African Journal of Microbiology Research, 5(6), pp. 675-682.

Aktypis A., Tychowski M., Kalantzopoulos G. and Aggelis G. (2007), Studies on bacteriocin (thermophilin T) production by Streptococcus thermophilus ACA-DC 0040 in batch and fed-batch fermentation modes, Antonie van Leeuwenhoek, 92(2), pp. 207-220.

Andrew J.M. (2008), BSAC standardized disc susceptibility testing method (version 7), Journal of Antimicrobial Chemotherapy, 62, pp. 256-278. 


\section{—Biotechnology. Microbiology -}

Anukam K. C., Koyama, T. (2007), Bile and acid tolerance of Lactobacillus plantarum KCA1: A potential probiotical agent, International Journal Dairy Science , 2 (3), pp. 275280.

Auffray Y., Lecesne E., Hartke A., Boutibonnes P. (1995), Basic features of the Streptococcus thermophilus heat shock response, Current Microbiology, 30(2), pp. 8791.

Ayyash M., Abushelaibi A., Al-Mahadin S., Enan M., El-Tarabily K., Shah, N. (2018), Invitro investigation into probiotic characterisation of Streptococcus and Enterococcus isolated from camel milk, $L W T, 87$, pp. 478-487.

Bagci U., Togay S. O., Temiz A., Ay, M. (2019), Probiotic characteristics of bacteriocinproducing Enterococcus faecium strains isolated from human milk and colostrum, Folia Microbiologica, 64(6), pp. 735-750.

Balouirin M. Sadiki M. and Ibnsouda S. K. (2016), Methods for in vitro evaluating antimicrobial activity: A review, Journal of Pharmaceutical Analysis, 6(2), pp. 71-79.

Bauer A. W. (1966), Antibiotic susceptibility testing by a standardized single disc method, Am J clin pathol, 45(4), pp. 149-158.

Begley M., Gahan C. G., Hill C. (2005), The interaction between bacteria and bile, FEMS microbiology reviews, 29(4), pp. 625-651.

Belgacem Z. B., Abriouel H., Omar N. B., Lucas R., Martínez-Canamero M., Gálvez A., Manai, M. (2010), Antimicrobial activity, safety aspects, and some technological properties of bacteriocinogenic Enterococcus faecium from artisanal Tunisian fermented meat, Food Control, 21(4), pp. 462-470.

Blom H., Mørtvedt C. (1991), Anti-microbial substances produced by food associated microorganisms, Biochemical Society Transactions, 19(3), pp. 694-698.

Bogsan C. S., Nero L. A., Todorov S. D. (2015), From Traditional Knowledge to an Innovative Approach for Bio-preservation in Food by Using Lactic Acid Bacteria. [in:] Beneficial Microorganisms in Food and Nutraceuticals, Ed Liong M.T, London, Springer, pp. 2-28.

Boke H., Aslim B., Alp G. (2010), The role of resistance to bile salts and acid tolerance of exopolysaccharides (EPS) produced by yogurt starter bacteria, Archives of Biological Sciences, 62(2), pp. 323-328.

Boris S., Suarez J. E., Barbes C. (1997), Characterization of the aggregation promoting factor from Lactobacillus gasseri, avaginal isolate. Journal of applied microbiology, 83(4), pp. 413-420.

Boubakeur B., Drobo S. M., Khadem H., Mullier C., Tirtouil A. (2018), Influence of the exopolysaccharides of polyphenol-conditioned lactic acid bacteria on gut microecology and bacterial translocation, Ukrainian Journal of Ecology 8(3), pp. 1-9.

Chen W., Yu L., Shi Y. (2019), Safety Evaluation of Lactic Acid Bacteria. [in:] Lactic Acid Bacteria: Omics and Functional Evaluation, Chen W, Singapore: Springer, pp. 371409.

Charteris W. P., Kelly P. , M., Morelli L., Collins J. K. (1998), Development and application of an in vitro methodology to determine the transit tolerance of potentially probiotic Lactobacillus and Bifidobacterium species in the upper human gastrointestinal tract, Journal of applied microbiology 84(5), pp. 759-768.

Collado C. M. (2009), Role of probiotic in health and diseases. [In:] Handbbok of probiotic and prebiotic, $2^{\text {nd }}$ ed. Y.K Lee and S. Salminen, p. 608, pp. 257-350. John Wiley et Sons.

Cowan S. T. (2004), Manual for the identification of medical bacteria, Barrow G. I., FelthamR. K. A, New York. Cambridge university press, pp. 21-42. 
Drabo M. S., Khadem H., Benatmane N. E., Ouhab A., Zohra M. F., Soualmi K., Boubakeur B. (2019), Qualité microbiologique du blé dur fermenté de Matmor Hamoum: Indispositions digestives, microflore avantageusement technologique et potentiels pathogènes, International Journal of Innovation and Applied Studies, 27(1), pp. 11-18.

Dressman J. B., Berardi R. R., Dermentzoglou L. C., Russell T. L., Schmaltz S. P., Barnett J. L., Jarvenpaa K. M. (1990), Upper gastrointestinal (GI) pH in young, healthy men and women, Pharmaceutical research, 7(7), pp. 756-761.

Dubois M., Gilles K. A., Hamilton J. K. , Pebers P. A., Smith F. (1956), Colorimetric method for determination of sugars and related substances. Analytical Chemistry, 28(3), pp. 350-356.

Fang Q. H., Zhong J. J. (2002), Submerged fermentation of higher fungus Ganoderma lucidum for production of valuable bioactive metabolites ganoderic acid and polysaccharide, Biochemical Engineering Journal 10(1), pp. 61-65.

FAO/WHO (2001), Health and nutritional properties of probiotics in food including powder milk with live lactic acid bacteri, Report of a joint FAO/WHO expert consultation.

Gousia P., Economou V., Sakkas H., Leveidiotou S., Papadopoulou C. (2011), Antimicrobial resistance of major foodborne pathogens from major meat products, Foodborne pathogens and disease, 8(1), pp. 27-38.

Gregirchak N., Stabnikova O., Stabnikov V. (2020) Application of lactic acid bacteria for coating of wheat bread to protect it from microbial spoilage, Plant Foods for Human Nutrition, 75, 223-229.

Haddaji N., Krifi B., Lagha R., Khouadja S., Bakhrouf A. (2015), Effect of high temperature on viability of Lactobacillus casei and analysis of secreted and Groel proteins profiles, African Journal of Bacteriology Research, 7(3), pp. 29-35.

Jobin M. P., Delmas F., Garmyn D., Divies C., Guzzo J. (1998), Caractérisation des protéines de choc thermique de faible poids moléculaire chez les bactéries lactiques, Le Lait, 78(1), pp. 165-171.

Kanamarlapudi S.L.R.K., Muddada, S. (2017), Characterization of exopolysaccharide produced by Streptococcus thermophilus CC30. BioMed Research International, pp. 111.

Khadem H., Tirtouil A., Drabo M. S., Boubakeur, B. (2020), Influence of ultrasounds conditioning on biotechnological performances of the lactic acid bacteria stain streptococcus thermophilus CNRZ 447: growth, exopolysaccharides, biofilm, and aggregation, Biotechnologia, 101(2), pp. 159-165.

Kos B. Suskovic J., Vukovic S., Simprag M., Frece J., Matosic S. (2003), Adhesion and aggregation ability of probiotic strain Lactobacillus acidophilus M92, Journal of Applied Microbiology, 94, pp. 981-987.

Lee K., Lee H.G., Choi Y.J. (2008), Proteomic analysis of the effect of bile salts on the intestinal and probiotic bacterium Lactobacillus reuteri. Journal of Biotechnology, 137(1-4), pp. 14-19.

Li M., Wang Y., Cui H., Li Y., SunY., Qiu H. J. (2020), Characterization of lactic acid bacteria isolated from the gastrointestinal tract of a wild boar as potential probiotics, Frontiers in veterinary science, 7(49), pp. 1-10.

Lim B., Gross C. A. (2011), Cellular response to heat shock and cold shock. [in:] Bacterial Stress Responses, Storzg, G., Hengge, R. Washington, ASM Press,pp. 91-114.

Mostafa H., El-Mezawy A., Geis A., Heller, K. J. (2009), Exopolysaccharide production by Enterococcus faecium. Milchwissenschaft, 64(4), pp. 361-365. 


\section{—Biotechnology. Microbiology —}

Mulaw G. Sisay T., Muleta D., Tesfaye A. (2019), In vitro evaluation of probiotic properties of lactic acid bacteria isolated from some traditionally fermented Ethiopian food products, International journal of microbiology, pp.1-32.

Nami Y., Vaseghi Bakhshayesh R., Mohammadzadeh Jalaly H., Lotfi H., Eslami S., Hejazi M. A. (2019), Probiotic Properties of Enterococcus Isolated From Artisanal Dairy Products, Frontiers in Microbiology, 10 (300), pp. 1-13.

O'Grady B., Gibson G. R. (2005), Microbiota of the human gut. [in:] Probiotic Dairy Products, Ed. Tamime, Adnan Y.Oxford, Blachwell, pp. 1-15.

Oleksy-Sobczak M., Klewicka E. (2019), Optimization of media composition to maximize the yield of exopolysaccharides production by Lactobacillus rhamnosus strains, Probiotics and antimicrobial proteins, pp. 1-10.

Pavlovic M., Huber I., Konrad R., Busch U. (2013), Application of MALDI-TOF MS for the Identification of Food Borne Bacteria, The Open Microbiology Journal, 7(1), pp. 135141.

Pieniz S., Andreazza R., Anghinoni T., Camargo F., Brandelli A. (2014), Probiotic potential, antimicrobial and antioxidant activities of Enterococcus durans strain LAB18s, Food Control, 37, pp. 251-256.

Růžičková M., Vítězová M., Kushkevych I. (2020), The characterization of Enterococcus genus: resistance mechanisms and inflammatory bowel disease, Open Medicine 15(1), pp. 211-224.

Terzić-Vidojević A., Veljović K., Begović J., Filipić B., Popović D., Tolinački M., Golić, N. (2015), Diversity and antibiotic susceptibility of autochthonous dairy enterococci isolates: are they safe candidates for autochthonous starter cultures, Frontiers in Microbiology, 6, (954), pp. 1-10.

Tosi E. A., Ortega R.M.E., Cazzoli, A. F. (2007), Food preservative based on propolis: Bacteriostatic activity of propolis polyphenols and flavonoids upon Escherichia coli, Food chemistry 104, pp. 1025-1029.

Tosoni N. F., Perini H. F., Terra M. R., Katsuda M. S., Furlaneto M. C., Maia L. F. (2019), Antimicrobial activity of enterocin obtained from Enterococcus durans on Shiga-like toxin-producing Escherichia coli, Ciência Rural, 49(9), pp. 1-7.

Tuncer B. Ö., TuncerY. (2014), Exopolysaccharide producer Streptococcus thermophilus ST8. 01 strain. A potential probiotic culture, GIDA/The Journal of FOOD, 39(4), pp. 195-202.

Varmanen P., Savijoki K. (2011), Responses of lactic acid bacteria to heat stress. [in:] Stress responses of lactic acid bacteria, Tsakalidou, E., Tsakalidou, k, London,Springer, pp. 55-66.

Vinderola C. G., Reinheimer J. A. (2003), Lactic acid starter and probiotic bacteria: a comparative "in vitro" study of probiotic characteristics and biological barrier resistance, Food Research International, 36(9-10), pp. 895-904.

Wu Q., Tun H. M., Leung F. C. C., Shah N. P. (2014), Genomic insights into high exopolysaccharide-producing dairy starter bacterium Streptococcus thermophilus ASCC 1275, Scientific reports, 4(1), pp. 1-8.

$\mathrm{Xu}$ H., Jeong H. S., Lee H. Y., Ahn, J. (2009), Assessment of cell surface properties and adhesion potential of selected probiotic strains, Letters in applied microbiology, 49(4), pp. 434-442.

Zhou N., Zhang J. X., Fan M. T., Wang J., Guo G., Wei X. Y. (2012), Antibiotic resistance of lactic acid bacteria isolated from Chinese yogurts, Journal of dairy science, 95(9), pp. 4775-4783. 


\title{
Анотації
}

\section{Харчові технології}

\section{Вплив додавання соєвого шроту, обробленого ультратонким подрібненням і мікрохвильовим опромінюванням, на якість хрусткого печива}

\author{
Фанг Ванг ${ }^{1,2}$, Валерій Сукманов ${ }^{1,3}$, Дзі Зенг ${ }^{2}$ \\ 1 - Сумський національний аграрний університет, Суми, Украӥна \\ 2 - Хенанський інститут науки і технологій, Сіньсянь, Китай \\ 3 - Полтавський державний аграрний університет, Полтава, Украӥна
}

Вступ. Мета дослідження - визначити вплив додавання соєвого шроту, обробленого ультратонким помелом і мікрохвильовим опроміненням, на якість хрусткого печива.

Матеріали і методи. Вологі залишки бобів сушили в сушильній шафі з постійною температурою при $50{ }^{\circ} \mathrm{C}$ протягом 48 год і подрібнювали в машині надтонкого подрібнення KCW-701S на частоті 30 Гц. Обробку бобового борошна проводили в мікрохвильовій печі, співвідношення бобів до води - 1:7 при високому рівні нагрівання протягом 6 хв, потім підсушували в печі при $50{ }^{\circ} \mathrm{C}$ протягом 48 год і просіювали. Значення кольору визначалось на вимірювачі хроматичних аберацій $\mathrm{Cr}-400$, текстури на аналізаторі TA-XT Plus. Сенсорна оцінка проведена за 100-бальною гедоністичною шкалою за кольором, смаком, текстурою і загальною прийнятністю.

Результати і обговорення. Використання борошна соєвого шроту, обробленого ультратонким шліфуванням і мікрохвильовим опромінюванням у складі хрусткого печива, змінює його споживні й органолептичні властивості. Колір став більш темним (зменшення параметра $L^{*}$ ), більш червоним (більш високі значення $a^{*}$ ) і менш жовтим (більш низькі значення $b^{*}$ ). Твердість хрусткого печива поступово збільшується із збільшенням кількості борошна із соєвого шроту: при додаванні в кількості 15\% твердість печива досягала максимуму 2328,49 (Н). При додаванні борошна зі шроту в кількості 20\% спостерігаался тенденція до зменшення твердості печива. Зі збільшенням додавання борошна із соєвого шроту збільшується вміст харчових волокон, зменшується вміст глюкози в тісті, що впливає на формування глютенової сітки і призводить до збільшення твердості хрусткого печива. Коли вміст харчових волокон продовжує збільшуватися, збільшується жироутримувальна здатність, тому твердість хрусткого печива знижується. Збільшення кількості внесеного до рецептурного складу соєвого шроту суттєво впливає на сенсорні характеристики хрусткого печива. Однак істотної різниці в загальній оцінці хрусткого печива, що містить 15 та 20\% соєвого шроту, не спостерігалося.

Висновки. Додавання борошна соєвого шроту в кількості 15-20\% значно вплинуло на колір, текстуру і сенсорні властивості хрусткого печива порівняно 3 контролем. Хрустке печиво, приготоване за розробленою технологією, набуло золотистого кольору та приємного бобового аромату.

Ключові слова: соя, шрот, хрустке печиво, надтонке подрібнення, НВЧ опромінення. 


\title{
Поліфункціональні властивості $\beta$-глюкану з вівса у складі морозива молочно- овочевого
}

\author{
Вікторія Сапіга $^{1}$, Галина Поліщук ${ }^{1}$, Магдалена Буньовська ${ }^{2}$, \\ Ірина Шевченко ${ }^{1}$, Тетяна Осьмак ${ }^{1}$ \\ 1 -Національний університет харчових технологій, Україна \\ 2 - Жешувський університет, Польщза
}

Вступ. Метою дослідження $є$ вивчення впливу $\beta$-глюкану вівсяного на в'язкісношвидкісні показники сумішей і фізико-хімічні характеристики морозива молочноовочевого.

Матеріали і методи. Морозиво молочно-овочеве з масовою часткою жиру $3 \%$ та $\beta$-глюканом вівсяним у кількості $0,5-1,0 \%$ зі стабілізаційною системою та без неї, а також контрольні зразки морозива молочного класичного. Застосовано ротаційну віскозиметрію та загальновідомі методи дослідження опору таненню, збитості й дисперсності повітряної фази морозива.

Результати і обговорення. Досліджено структуруючу здатність $\beta$-глюкану у складі морозива з низьким вмістом жиру і сухих речовин. Ефективна в'язкість сумішей морозива з $\beta$-глюканом у кількості $0,5-1,0 \%$ знаходиться в діапазоні рекомендованих значень. Суміші морозива молочного з $\beta$-глюканом характеризуються тиксотропною здатністю, що підтверджується високим ступенем відновлення зруйнованої структури. Комплексне застосування $\beta$-глюкану і ферментованого овочевого пюре, яке містить розчинний пектин і розм'якшені рослинні волокна, дає змогу суттєво покращити в'язкісно-швидкісні характеристики сумішей: ефективна в'язкість підвищується на 11,5$15,9 \%$, ступінь відновлення в середньому - на 10\%. Морозиво молочно-овочеве низькожирне за вмісту $\beta$-глюкану у кількості $0,75-1,0 \%$ набуває кремоподібної консистенції. Підвищення збитості й опору таненню морозива $3 \beta$-глюканом обумовлено утворенням специфічної вторинної пінної мікроструктури. Така мікроструктура відрізняється наявністю додаткового каркасу з мікробульбашок, який обгортає більш крупні повітряні включення і надає їм додаткової механічної стійкості під час отеплення. Таким чином доведено, що $\beta$-глюкан $є$ універсальним інгредієнтом, який спроможний, окрім збагачення, виконувати структуруючу і стабілізуючу функції у складі морозива молочно-овочевого низької жирності.

Висновки. Проведені дослідження доводять доцільність застосування $\beta$-глюкану вівсяного у кількості $0,75-1,0 \%$ в складі морозива молочно-овочевого 3 низьким вмістом жиру.

Ключові слова: морозиво, $\beta$-глюкан, овочеве пюре, в'язкість, тиксотропна здатність, піна. 


\title{
Функціонально-технологічні властивості харчової нанодобавки на основі подвійного оксиду дво- та тривалентного заліза в ліофільних колоїдно- дисперсних системах
}

\author{
Ірина Цихановська ${ }^{1}$, Олена Стабнікова ${ }^{2}$, Олександр Александров ${ }^{1}$, \\ Роман Тріщ ${ }^{1}$, Ольга Благій ${ }^{1}$, Анастасія Нікуліна ${ }^{1}$ \\ 1-Украӥнська інженерно-педагогічна академія, Харків, Україна, \\ 2- Національний університет харчових технологій, Киї, Украӥна
}

Вступ. Обгрунтовано функціонально-технологічні властивості харчової добавки на основі подвійного оксиду дво- та тривалентного заліза Магнетофуд $\left(\mathrm{Fe}_{3} \mathrm{O}_{4}\right)$ в ліофільних колоїдно-дисперсних системах.

Матеріали і методи. Використовували модельні системи на основі наночастинок добавки Магнетофуд, води, агару, пектину та яєчного білка. Ефективну в'язкість і тиксотропні властивості визначали на ротаційному віскозиметрі; міцність збивних та гелевих мас досліджували за граничним напруженням зсуву; зміну стійкості піни фіксували за осіданням стовпа піни в часі.

Результати i обговорення. Вивчено загущувальні, тиксотропні, структуроутворювальні, стабілізувальні властивості наночастинок харчової добавки на основі подвійного оксиду дво- та тривалентного заліза Магнетофуд в «ліофільних колоїдах», що пов'язано із кластерофільністю та самоорганізацією наночастинок $\mathrm{Fe}_{3} \mathrm{O}_{4}$ в електростатичні комплекси з білками та полісахаридами. Додавання нанодобавки в «ліофільні колоїди» збільшує в'язкість пінних систем у 1,10-1,15 раза, гелевих систем - у 1,22-1,27 раза для агару та в 1,24-1,29 раза для пектину; уповільнює процеси руйнування гелевих структур в 1,15-1,22 раза і прискорює процеси їх відновлення після припинення механічного впливу на 8,8-9,2\%, підвищуючи іï здатність до тиксотропії в 1,4-1,5 раза.

Дослідженнями граничного напруження зсуву колоїдно-дисперсних систем визначено підвищення механічної міцності в пінних системах на 11,5-12,6\% для агару і на $8,2-9,1 \%$ для пектину; в гелевих системах - в 1,32-1,8 раза для агару і в $1,49-1,57$ раза для пектину. Встановлено збільшення швидкості структурування гелевих мас в $1,73 \pm 0,01$ рази для агару і в $1,67 \pm 0,01$ раза для пектину порівняно 3 контролем та скорочення кількості гелеутворювача на 10,0-12,0\% для агару і на 7,0-9,0 для пектину. Крім того, збільшується піноутворювальна здатність яєчного білка в 1,14-1,40 раза при постійній піностійкості 99,0土1,0\% за рахунок стабілізувальної дії наночастинок $\mathrm{Fe}_{3} \mathrm{O}_{4}$.

Висновки. Вперше досліджено загущувальна, тиксотропна, структуроутворювальна, стабілізувальна дія наночастинок $\mathrm{Fe}_{3} \mathrm{O}_{4}$ в «ліофільних колоїдах» для обгрунтування функціонально-технологічних властивостей харчової добавки на основі подвійного оксиду дво- та тривалентного заліза.

Ключові слова: функиіональність, нанодобавка, оксид заліза, колоїди. 
Зміни летких сполук оливкової олії із сортів Айвалік (Едреміт) та Услу залежно від умов і часу зберігання

\author{
Пелін Гюнч Ергонюл ${ }^{1}$, Алев Юксель Айдар ${ }^{1}$, Туба Гельделі ${ }^{1}$, \\ Анналіса Ментана ${ }^{2}$, Мауриціо Квінто ${ }^{2}$ \\ 1 - Маніський університет Челана Баяра, Маніса, Туреччина \\ 2 - Університет Фоджа, Фоджа, Італія.
}

Вступ. Визначено вміст летких ароматичних сполук в оливковій олії з турецьких сортів оливок Едреміт (Айвалік) і Услу.

Матеріали і методи. Оливки зібрані в регіоні Акхісар/Маніса, який є одним 3 найважливіших місць вирощування оливок у Туреччині майже на стадії дозрівання. Зібрані оливки зберігалися у футлярі та капронових мішках у тих же умовах до аналізу. Визначення летких ароматичних сполук проводили твердофазною мікроекстракцією Headspace (HS-SPME) і газовою хромато-мас-спектрометрією (GC-MS).

Результати і обговорення. Було ідентифіковано 46 різних летких сполук. Невідповідні умови зберігання оливок негативно вплинули на ароматичні профілі аромату олій.

Найпоширенішими сполуками в олії із сорту Едреміт (Айвалік) були гексанал, $\alpha$ фарнезен і диметилпальмітамін, із сорту Услу - $\alpha$-фарнезен і 2-гексанал. В олії, отриманій з оливок Едреміт, які зберігалися в нейлонових мішках протягом 14 днів, спостерівся підвищений вміст1-гексанолу.

Підвищення концентрації 2-гексаналу під час витримування можна пояснити активністю грибкових ферментів у ліпоксигеназному шляху плодів оливи, тоді як 5гептен-2-он 6-метилу і 1-бутанол 3-метилу в оливковій олії Едерміт і Услу виявлено не було; вони утворювалися як під час зберігання в мішках, так і в коробках через мікробну активність в оливках. Було вилучено три основні компоненти (PCs), що становлять $81,27 \%$ загальної дисперсії зразків оливкової олії, вилучених із сорту Услу, та $80,14 \%$ - із сорту Едреміт. Перші PCs, PC1, PC2 і РС3 становили 45,15 i 41,31\%, 21,90 i 21,39\%, 14,21 і 17,43\% для сортів Uslu i Edremit відповідно.

Висновки. Рекомендується зберігати оливки при температурі $5{ }^{\circ} \mathrm{C}$ в боксах 3 кондиціонером не менше 30 днів, щоб зменшити розвиток грибків і зберегти бажаний аромат.

Ключові слова: оливки, олія, зберігання, леткі сполуки, аромат. 


\section{Фізико-хімічні, антиоксидантні та органолептичні властивості плодової пастили із сортів полуниці «Мальга» $\mathbf{i}$ «Мурано»}

\section{Крайовський університет, Крайова, Румунія}

Віолета Ноур

Вступ. Полуниця визнана джерелом антиоксидантів завдяки високому вмісту антоціанів, інших фенольних сполук і аскорбінової кислоти. Мета цього дослідження - охарактеризувати фруктову пастилу, виготовлену 3 двох сортів полуниці 3 використанням меду і лимонного соку як інгредієнтів.

Матеріали і методи. Свіжі фрукти перетирали в пюре, змішували 3 медом i лимонним соком, а потім сушили в дегідраторі при $57^{\circ} \mathrm{C}$ протягом 6 годин. Як плодові гомогенати, так і шкірки характеризували з точки зору вмісту вологи, загального вмісту розчинних речовин, титрованої кислотності, кольору за системою CIE L*a*b*, загального вмісту фенолів за методом Фоліна-Чіокальтеу, загального вмісту флавоноїдів за методом нітрату алюмінію, загального вміст антоціанів за диференціальним рН спектрофотометричним методом і антиоксидантну активність за процедурою DPPH (2-дифеніл-1-пікрилгідразил). Для оцінки полуничної пастили на колір, солодкість, кислинку, смак, текстуру і загальну прийнятність використали 9бальну гедонічну шкалу.

Результати і обговорення. В результаті додавання і висушування меду та лимонного соку в пастилі з обох сортів полуниці спостерігалося значне збільшення вмісту розчинних твердих речовин і титрованої кислотності. Гомогенати свіжої полуниці були світлішими (вищі значення $L^{*}$ ) порівняно зі шкіркою фруктів. Крім того, параметр забарвлення а* показав значне зниження в обох сортів після сушіння, що може бути пов'язано 3 окисленням антоціанів, а також термічною деградацією. Загальний вміст фенолів, флавоноїдів та антоціанів був вищим як у свіжому гомогенаті, так і в шкірці сорту «Мальга», ніж у «Мурано». Проте антиоксидантна активність DPPH була дещо вищою в «Мурано» (35,21 ммоль тролокса/100 г), ніж у гомогенатів «Мальга» $(34,45$ ммоль тролокса/100 г), але відмінності не були суттєвими. Після зневоднення вміст антоціанів у пастилі з полуниці зменшився на 67,38\% («Мурано») і 64,07\% («Мальга»), тоді як загальний вміст фенолів зменшився на 43,81\% («Мурано») і 32,33\% («Мальга»). Крім того, після сушіння спостерігалося зниження антиоксидантної активності DPPH на 40,5\% («Мурано») і 38,5\% («Мальга»). За органолептичною оцінкою пастила з полуниці «Мурано» виділяється порівняно 3 «Мальга» більш червоним кольором, вона більш солодка і менш кисла, має приємнішу текстуру.

Висновки. Окрім привабливого зовнішнього вигляду, смаку й аромату, пастила 3 полуниці $\epsilon$ джерелом природних антиоксидантів, включаючи антоціани та інші фенольні сполуки.

Ключові слова: полуниця, фруктова шкірка, зневоднення, антоичіан, фенол, антиоксидант. 
Біорозкладна плівка на основі таро-крохмалю з різною концентрацією желатину 3 качиної кістки: фізичні та бар'єрні властивості

Тріас Аю Лаксанаваті, Мухаммад Хаббіб Хірзін, Магфіротул Аманія Державна політехніка Баньювангі, Баньювангі, Індонезія

Вступ. Дослідження спрямоване на покращення фізичних властивостей біологічно розкладних плівок на основі таро-крохмалю, доданому із желатином качиної кістки та пластифікатором гліцерином за допомогою розчинно-відливного методу.

Матеріали і методи. Для визначення ефекту різних методів оброблення використали нефакторну, повністю рандомізовану схему (CRD) 3 ANOVA i тест DUNCAN. Використовували різні концентрації желатину з качиної кістки - 0,5, 15, 25 i 35\% від загальної маси твердих речовин (таро-крохмаль і желатин 3 качиної кістки). Функціональні групи біологічно розкладних плівок аналізували за допомогою FTIR. Морфологічну структуру продукту досліджували за допомогою сканувальної електронної мікроскопії (SEM).

Результати і обговорення. Швидкість пропускання водяної пари складала 0,465

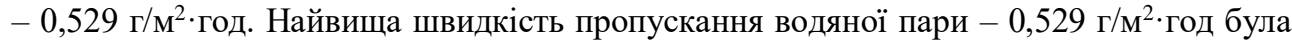
при концентрації 35\% желатину качиної кістки. Фактором, що впливає на величину швидкості пропускання водяної пари, $€$ хімічна природа матеріалу полімеру. Водопоглинання становило 85,17-40,47\%, а найвище водопоглинання спостерігалося при концентрації желатину з качиної кістки $0 \%$. Для оцінки значення водостійкості отриманої плівки використовують відсоток водопоглинання. Розчинність у воді становила 31,08-64,60\%. Найвище значення розчинності у воді $(64,60 \%)$ спостерігалося при концентрації желатину з качиної кістки $35 \%$, оскільки його додавання зменшує міжмолекулярні сили плівки та підвищує активність води, щоб вільні молекули води могли зайняти матрицю у плівці.

Спектр FTIR для біорозкладних плівкових продуктів показав пік хвильового числа на рівні 3600-3000 см-1, що вказує на наявність груп N-H та О-Н. Наявність груп $\mathrm{N}-\mathrm{H}$ і О-Н у плівках, що піддаються біологічному розкладанню, може сприяти процесу деградації, оскільки вони мають гідрофільні властивості, які дають змогу молекулам води отримувати доступ до матриці плівки та потрапляти в неї.

Результати SEM-аналізу показали, що біорозкладна плівка таро-крохмалю 3 додаванням желатину качиної кістки є однорідною і гнучкою, має компактну структуру.

Висновки. Додавання желатину 3 качиної кістки впливає на швидкість пропускання водяної пари і на розчинність у воді та водопоглинання.

Ключові слова: біоплівка, крохмаль, желатин, качина кістка, бар'єр. 


\title{
Вплив комбінування амілолітичних ферментних препаратів на вуглеводний склад мальтозних сиропів із крохмалю
}

\author{
Наталія Сабадаш ${ }^{1}$, Олена Грабовська ${ }^{2}$ Ігор Фесич ${ }^{1}$, \\ Аліна Авраменко ${ }^{1}$, Анастасія Сергієнко ${ }^{1}$ \\ 1 - Національний університет харчових технологій \\ 2 - Київський національний торговельно-економічний університет
}

Вступ. Мета дослідження - вивчити вплив комплексу зцукрюючих амілолітичних ферментних препаратів $\beta$-амілази та пуллуланази на вуглеводний склад мальтозних сиропів.

Матеріали і методи. Предметом дослідження $\epsilon$ амілолітичні ферментні препарати (E1100) - бактеріальна $\alpha$-амілаза, $\beta$-амілаза та пуллуланаза, кукурудзяний крохмаль, крохмальні гідролізати та мальтозні сиропи. Процес гідролізу проводили шляхом проведення двох послідовних стадій: розріджування та зцукрювання. Використовували фізико-хімічні методи аналізу, вуглеводний склад гідролізатів визначали хроматографічним методом.

Результати і обговорення. Найбільше значення глюкозного еквівалента (ГЕ) при зцукрюванні до мальтози досягається за оптимального ступеня розріджування крохмальної суспензії, який відповідає величині глюкозного еквівалента 10-15\%. Розріджені гідролізати з більшим значенням ГЕ мають більшу кількість коротких крохмальних молекул, які зцукрюються $\beta$-амілазою дуже повільно, тетрасахариди ще більш резистентні до іiі дії, а трисахариди не розщеплюються зовсім, оскільки цей мальтогенний фермент виявляє велику спорідненість 3 високомолекулярними субстратів. Розріджені гідролізати з меншим значенням ГЕ мають високу в'язкість, налипають на стінках обладнання, схильні до ретроградації, що веде до втрат.

Для отримання мальтозних сиропів найкраще використовувати зцукрюючі ферментні препарати $\beta$-амілази та пуллуланази з розрахунку 0,03 од.3А/г та 0,0006 од.АП/Г СР крохмалю відповідно. Визначено, що за тривалості зцукрювання 24 год вміст мальтози в гідролізатах досягає значення $60 \%$ до маси редукувальних речовин (РP) при цьому вміст глюкози незначний (біля 2,7\% до маси РР). Низький вміст глюкози є основним показником якості сиропів при виробництві карамелі та багатьох інших харчових продуктів.

Висновки. Встановлено кінетичні закономірності, що дають змогу визначити оптимальні умови процесу розріджування, а також зцукрювання при використанні комплексу зцукрюючих ферментних препаратів $\beta$-амілази та пуллуланази у виробництві мальтозних сиропів.

Ключові слова: мальтоза, сироп, зиукрювання, фермент, $\alpha$-амілаза, $\beta$-амілаза, пуллуланаза. 


\title{
Вплив кокосових продуктів, мескітового борошна і стевії на теплофізичні та якісні властивості темного шоколаду
}

\author{
Живка Горанова ${ }^{1}$, Іорданка Алексієва $^{2}$, Тодорка Петрова ${ }^{1}$ \\ 1 - Інститут збереження та якості харчових продуктів, Сільськогосподарська \\ академія, Пловдив, Болгарія \\ 2 - Університет харчових технологій, Пловдив, Болгарія
}

Вступ. Мета дослідження - визначити вплив кокосових продуктів і мескітового борошна на теплові властивості темного шоколаду зі стевією.

Матеріали і методи. Для приготування чорного шоколаду використали какаомасло, какао терте, стевію, кокосове борошно, порошок мескіту, кокосове масло. Шоколадні зразки готувалися за класичною технологією. Визначення енергетичної цінності зразків темного шоколаду проводили за допомогою процедур АОАС. Для визначення температур плавлення зразків шоколаду використовували диференціальний сканувальний калориметр.

Результати і обговорення. Збільшення масової концентрації функціональних інгредієнтів призводить до збільшення вмісту білків, жирів і зниження вмісту вуглеводів і ліпідів. Нижчі концентрації вуглеводів виявлені в шоколаді $1(38,11 \%)$ i шоколаді 2 (45,50\%). Зі статистичної точки зору $(\mathrm{p}<0,05)$ можна констатувати, що $\epsilon$ помітні відмінності між концентрацією вуглеводів у шоколаді зі стевією 0,01 і 0,03\%. Ці відмінності можна пояснити більшим вмістом вуглеводів у кокосовому борошні.

Тип підсолоджувача і функціональні інгредієнти істотно не змінили властивості плавлення зразків темного шоколаду $(\mathrm{p}>0,05)$. Однак низькі температури плавлення близько $27-35^{\circ} \mathrm{C}$ вказують на те, що під час виробництва зразків виникли легкоплавкі поліморфні форми. Для стевії, включаючи темний шоколад, значення початкової (Tonset), пікової (Tpeak) і кінцевої температури (Tend) становили 25,01-28,57 ${ }^{\circ} \mathrm{C}$, $33,95-34,64{ }^{\circ} \mathrm{C}$ і $38,69-38,01{ }^{\circ} \mathrm{C}$. Щодо параметра $\Delta \mathrm{H}$, то він коливався від 32,60 до 33,06 Дж/г.

Зразки з функціональними інгредієнтами мають значно вищі значення показника антиоксидантної активності - 97,21-112,62 мкмоль ТЕ/г с.р.

Висновок. Результати профілю плавлення, а також поживних і антиоксидантних властивостей показали, що на якісні властивості шоколаду зі стевією істотно впливає співвідношення функціональних інгредієнтів (мескітового борошна та кокосової продукції).

Ключові слова: шоколад, кокос, мескіт, стевія, підсолоджувач, плавлення. 


\section{Сорбційні характеристики помадних цукерок на основі тагатози}

Оксана Дорожинська, Олена Кохан, Юлія Камбулова Національний університет харчових технологій, Київ, Україна

Вступ. Проведені дослідження з метою встановлення сорбційних характеристик помадних цукерок на основі сахарози та на основі комбінації тагатози з фруктозою.

Матеріали і методи. Досліджували помадні цукерки, виготовлені на основі сахарози та на основі тагатози з додаванням фруктози у співвідношенні 9:1 на ваговій вакуумній адсорбційній установці 3 пружинними кварцовими вагами із застосовуванням гравіметричного методу.

Результати і обговорення. Встановлено, що криві сорбції обох зразків досліджуваних цукерок мають ідентичний характер і відносяться до III типу ізотерм, що характерно до мікропористих адсорбентів з малою енергією взаємодії адсорбент адсорбат. Досліджувані криві сорбції сигмоподібні, з досить розвиненим гістерезисом, що свідчить про цілком незворотний процес зневоднення. Після процесу десорбції у зразках на сахарозі і тагатозі з фруктозою залишається незначна частина адсорбованої вологи - 0,55 та $0,37 \%$ відповідно.

Коефіцієнти детермінації обох моделей БЕТ та Френдліха, що були застосовані для аналізу, знаходяться в межах 0,85-0,97, що свідчить про їх придатність для опису ізотерм досліджуваних виробів. Аналіз константи, що характеризує енергетику адсорбції, засвідчує, що в зразку на основі тагатози і фруктози адсорбція буде на $18 \%$ вища, ніж у контрольному зразку.

Кількість адсорбованої вологи у досліджуваних зразках цукерок при низьких значеннях $\mathrm{a}_{\mathrm{w}}$ має незначну відмінність, тоді як у зоні капілярної вологи $\left(\mathrm{a}_{\mathrm{w}}=1,0\right)$ це значення значно різнилося: кількість адсорбованої вологи в контрольного зразка помадних цукерок на сахарозі становила $0,6498 \mathrm{~cm}^{3} / \Gamma$, тоді як у зразку на основі тагатози і фруктози $-1,5499 \mathrm{~cm}^{3} / \Gamma$. Кількість міцнозв'язаної вологи в зразку на основі тагатози і фруктози є більшою, ніж у контрольному зразку і становить 8,33\%, тоді як в контрольному зразку $-5,24 \%$.

Висновки. Дослідження ізотерм сорбції дало змогу спрогнозувати поведінку зразків цукерок під час їх зберігання за різних значень відносної вологості повітря. Отримані дані можна використати для раціонального підбору пакувального матеріалу та способу пакування для подовження термінів зберігання розроблених помадних цукерок на основі тагатози.

Ключові слова: помадна иукерка, тагатоза, сорбиія, зберігання. 


\title{
Обгрунтування впливу властивостей зернової маси на процеси екстрагування та гідратації
}

\author{
Тетяна Янюк, Тетяна Тракало, Галина Ляшко, \\ Олена Галинська, Наталія Грюнвальд \\ Націіональний університет харчових технологій, Київ, Україна
}

Вступ. Метою дослідження $є$ отримання експериментальних результатів визначення кількості незамерзаючої води в сумішах 3 насіння льону, де вуглеводи представлені в основному гетерополісахарідами, а також амаранту, зерна вівса, рису, де вуглеводи представлені в основному монополісахаридами.

Матеріали і методи. Як розчинники вибрали воду та молочну сироватку. Екстракти готували шляхом додавання розчинника до гідратованої сировини, при цьому їхня вологість становила: насіння льону - 6,3\%, насіння амаранту $-9,4 \%$, вівса $-10,5 \%$, рису $-11,8 \%$. Температура зразків становила $25^{\circ} \mathrm{C}$. Стан води в отриманих екстрактах на різних стадіях гідратації досліджували методом диференціальної сканувальної калориметрії (ДСК)

Результати і обговорення. В пробах, де розчинником використовували воду, загальна вологість становила $92,4 \%$, зв'язана - 3,77\%, а в зразках з розчинником молочна сироватка - 83,49\% і 13,44\% відповідно. Після першого етапу обробки (перколяції) ці показники були такими: загальна вологість становила 99,91\%, а зв'язана волога - 0,09\%. Механічна обробка, яка була використана для інтенсифікації процесів екстракції та гідратації, забезпечила перерозподіл фракційного складу вологи на користь зв'язаної води. При використанні сироватки як розчинника цей перерозподіл $є$ ще більш вираженим. Звичайно, на це впливає змінений сироваткою $\mathrm{pH}$ середовища, але основним фактором є вуглеводи, кількість яких у сироватці становить до $6,0 \%$.

Маса замерзаючої води в обробленому зразку суспензії амаранту зросла до 2,561 мг 3 початкової 2,164 мг в необробленому зразку. А маса зв'язаної води в обробленому зразку становила 0,519 мг, тоді як у необробленому - 0,136 мг. У зразках вівсяних суспензій початковий і оброблений піки були майже однаковими; зсуву в бік низьких температур не спостерігалося. В обробленому зразку рисової суспензії спостерігався другий невеликий пік, тому загальна площа необробленого зразка зросла. Це означає, що маса замерзаючої води в рисі зросла до 2,590 мг з 2,275 мг після обробки в необробленому зразку, в той же час маса зв'язаної води зросла до 0,280 мг з 0,055 мг в необробленому зразку. Відсоток загальної вологи в суспензії насіння амаранту, кількості замерзаючої води після обробки зменшився на $10,84 \%$, у вівсяній суспензії на 4,69\%, у суспензії рису - на 7,4\%. При цьому для суспензії насіння амаранту кількість зв'язаної води зросла на 10,94\%, для суспензії вівса - на 4,67\%, для рису - на $7,4 \%$.

Наявність солі або кислоти також впливає на повноту і швидкість процесів набухання і вологого поглинання, а також на перерозподіл води в подрібненій зерновій сировині.

Висновки. Механічна обробка, що використовується для інтенсифікації процесів екстрагування та гідратації, забезпечила перерозподіл фракційного складу вологи на користь зв'язаної вологи.

Ключові слова: зернові, зволоження, екстракиія, гідромодуль, шліфування. 


\title{
Антиоксидантна характеристика чайно-трав'яних композицій
}

\author{
Олег Кузьмін, Наталія Стукальська, Лариса Михонік, \\ Ольга Коваль, Володимир Польовик, Ганна Березова \\ Національний університет харчових технологій, Київ, Украӥна
}

Вступ. Метою дослідження є визначення антиоксидантної здатності настоїв рослинної сировини та оцінка їх перспективності для створення чайно-трав'яних композицій.

Матеріали і методи. Антиоксидантну здатність чайно-трав'яних композицій визначали за методом редоксметрії та $p H$-метрії; сенсорні показники - за експертним методом; результати математико-статистичної обробки - за методом лінійної кореляції Пірсона.

Результати і обговорення. Рівень $p H$ для водних настоїв рослинної сировини має значення від 2,35 од. $p H$ (Hibiscus sabdariffa) до 6,55 од. pH (Calamintha nepeta). Отримано мінімальне теоретичне значення ОВП $\left(E h_{\text {min }}\right)$ для водних настоїв рослинної сировини, яке має значення від 267,0 мВ (Calamintha nepeta) до 519,0 мВ (Hibiscus sabdariffa). Встановлено фактичне виміряне ОВП настоїв $\left(E h_{a c t}\right)$ - від 37,0 мВ (Daucus carota) до 203,0 мВ (Hibiscus sabdariffa). Водні настої з рослинної сировини мають значення відновної здатності (енергія відновлення $-R E_{\text {inf }}$ ) в діапазоні значень від $R E_{\text {inf }}$ - 150,8 мВ (Vitis vinifera) до $R E_{\text {inf }}-316,0 \mathrm{mB}$ (Hibiscus sabdariffa). Для ресторанного бізнесу у виробництві напоїв перспективними є водні настої Hibiscus sabdariffa і Citrus limonum, які отримали підвищені антиоксидантні характеристики $R E_{\text {inf }}-316,0 \mathrm{mV}$ та $R E_{i n f}-298,0 \mathrm{mV}$ відповідно та позитивну сенсорну оцінку. Доведено, що енергія відновлення/окислення рослинної сировини $\left(R E_{\text {plant }}\right)$ відносно розчинника підготовленої води знаходиться в діапазоні значень від 45,8 мВ (Vitis vinifera) до 211,0 мВ (Hibiscus sabdariffa). На основі математико-статистичного аналізу встановлено, що фізико-хімічні параметри в діапазоні значень 3 дуже високою кореляцією $(r 0,9-1,0)$ включають такі показники: $p H, E h_{\min }, R E_{i n f}, R E_{\text {plant. }}$ Виявлено раціональний склад чайно-трав'яної композиції: Hibiscus sabdariffa - 30 \%; Matricaria chamomilla - $20 \%$; Ilex paraguariensis - $10 \%$; Rosae fructus - $10 \%$; Mentha piperita - $10 \%$; Citrus sinensis $-8 \%$; Citrus limonum - $7 \%$; Calendulae flores - $5 \%$.

Висновки. Для технології ресторанного господарства запропоновано застосування чайно-трав'яних композиції з рослинної сировини Hibiscus sabdariffa, Matricaria chamomilla, Ilex paraguariensis, Rosae fructus, Mentha piperita, Citrus sinensis, Citrus limonum, Calendulae flores, які володіють підвищеними антиоксидантними характеристиками та сенсорними показниками для виробництва напоїв.

Ключові слова: трав'яний чай, настій, антиоксидант, окисно-відновний потенияіал, якість. 


\section{Процеси і обладнання}

\section{Утворення токсичних речовин при сумісному спалюванні в харчових виробництвах}

Ірина Дубовкіна, Олександр Сігал, Наталія Ніжник Інститут технічної теплофізики Національної академії наук Украӥни, Київ, Украӥна

Вступ. Метою наукової роботи є визначення впливу водню на процес утворення токсичних речовин при сумісному спалюванні з природним газом і вибір раціональних способів застосування для стабільної роботи обладнання харчових виробництв на новому паливі за умови дотримання вимог промислової та екологічної безпеки.

Матеріали і методи. Під час досліджень використовувались загальнонаукові та спеціальні методи. Контроль основних параметрів у процесі експериментальних досліджень включав: вимірювання геометритричних розмірів положення мікрозонда, термопари і капіляра для введення краплинної рідини, витрати всіх складових суміші для горіння, газовий аналіз продуктів згорання.

Результати і обговорення. Відокремлені вимірювання $\mathrm{NO}$ i $\mathrm{NO}_{2}$ показали, що залежність частки $\mathrm{NO}_{2}$ від вмісту $\mathrm{H}_{2}$ у розчині, що подається до ламінарного факела метану, $\epsilon$ неоднозначною та істотно залежить від місця відбору проби в перетині фронту полум'я.

Інтенсивне зростання концентрації оксидів азоту спостерігається вже у початкових перетинах фронту полум'я з моменту початку розігрівання суміші ще до досягнення максимальної температури. Причому чим вища концентрація вноситься у фронт факела розчину $\mathrm{H}_{2} \mathrm{O}_{2}$ (відповідно менша частка водню у розчині), тим інтенсивніше відбувається зростання вмісту оксидів азоту.

При внесені у фронт полум'я $30 \%$ розчину $\mathrm{H}_{2} \mathrm{O}_{2}$ рівень концентрації $\mathrm{NO}$ практично досягає початкового, тобто одержаного без внесення краплинної вологи

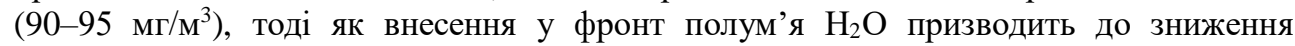

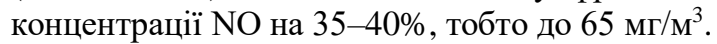

Це можливо пояснити тим, що перекис водню інтенсивніше, ніж вода, утворює радикал ОН, що бере активну участь в окислені вуглеводнів і СО. Радикал ОН утворює $3 \mathrm{H}_{2} \mathrm{O}_{2}$ гідроперодксид-радикал $\mathrm{HO}_{2}$, який дисоціює з утворенням супероксид-іона $\mathrm{O}_{2}$ - , що дає з $\mathrm{H}_{2} \mathrm{O}_{2}$ радикал $\mathrm{OH}$.

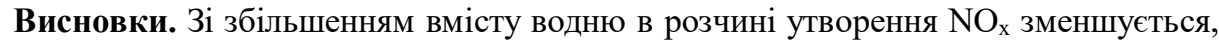
що можна пояснити витратами кисню у швидких реакціях, які потребують менших енерговитрат.

Ключові слова: водень, теплова установка, оксиди азоту, перекис водню, фронт полум'я. 


\title{
Біотехнологія, мікробіологія
}

\section{Регуляція біологічної активності поверхнево-активних речовин у процесі культивування Acinetobacter calcoaceticus IMB B-7241 на гліцерині}

\author{
Тетяна Пирог ${ }^{1,2}$, Дар'я Луцай ${ }^{1}$, Ганна Ярова ${ }^{1}$ \\ 1 - Національний університет харчових технологій, Київ, Україна \\ 2 - Інститут мікробіології та вірусологї̈ НАНУ, Київ, Україна
}

Вступ. Метою наукової роботи є дослідження біологічної активності поверхневоактивних речовин (ПАР), синтезованих Acinetobacter calcoaceticus IMB B-7241 у середовищі з гліцерином різного ступеня очищення і підвищеним вмістом катіонів кальцію (активаторів НАД $\Phi^{+}$-залежної глутаматдегідрогенази - ключового ферменту біосинтезу поверхнево-активних аміноліпідів, відповідальних за антимікробну активність комплексу ПАР).

Матеріали і методи. Культивування A. calcoaceticus IMB B-7241 здійснювали у рідких мінеральних середовищах з використанням як субстратів очищеного гліцерину $\mathrm{i}$ відходів виробництва біодизелю в еквімолярній за вуглецем концентрації. Базове середовище не містило хлориду кальцію, вміст $\mathrm{CaCl}_{2}$ у модифікованих середовищах становив 0,1 i 0,2 г/л. Поверхнево-активні речовини екстрагували 3 супернатанту культуральної рідини модифікованою сумішшю Фолча (хлороформ - метанол $-1 \mathrm{H} \mathrm{HCl}=$ 4:3:2). Кількість адгезованих клітин і ступінь руйнування біоплівки за наявності ПАР визначали спектрофотометричним методом, антимікробну активність поверхневоактивних речовин - за показником мінімальної інгібуючої концентрації (МІК).

Результати і обговорення. Встановлено, що додаткове внесення $0,1-0,2$ г/л хлориду кальцію у середовище культивування A. calcoaceticus IMB B-7241 з очищеним гліцерином супроводжувалося синтезом поверхнево-активних речовин, мінімальні інгібуючі концентрації яких щодо бактерій (Bacillus subtilis БТ-2, Enterobacter cloacae C-8, Staphylococcus aureus БМС-1) і дріжджів (Candida albicans Д-6) становили 1,01-21,3 мкг/мл і були у 1,4-29 разів нижчими, порівняно з МІК ПАР, отриманих у базовому середовищі (1,83-58,8 мкг/мл). Адгезія бактеріальних і дріжджової тест-культур на абіотичних матеріалах (кахель, сталь, скло), оброблених такими ПАР, була на 8-13\% нижчою, а ступінь руйнування біоплівок на 5-19 \% вищим порівняно 3 показниками, встановленими для ПАР, одержаних на базовому середовищі. Підвищення антимікробної й антиадгезивної активності поверхнево-активних речовин, синтезованих на відходах виробництва біодизелю, спостерігали лише в разі внесення у середовище хлориду кальцію в концентрації 0,2 г/л. ПАР, синтезовані за наявності в середовищі 3 відходами виробництва біодизелю катіонів кальцію, виявилися ефективнішими деструкторами бактеріальних біоплівок порівняно з отриманими в базовому середовищі ПАР тільки за невисоких концентрацій (0,7-5,5 мкг/мл).

Висновок. Отримані результати засвідчують можливість регуляції біологічної активності поверхнево-активних речовин A. calcoaceticus IMB B-7241 зміною у складі середовища культивування з очищеним гліцерином і відходами виробництва біодизелю вмісту катіонів кальцію - активаторів НАД $\Phi^{+}$-залежної глутаматдегідрогенази (ключового ферменту біосинтезу поверхнево-активних аміноліпідів). Поверхнево-активні речовини, синтезовані в різних умовах культивування A. calcoaceticus IMB B-7241 на очищеному гліцерині і відходах виробництва біодизелю, $є$ ефективнішими декструкторами біоплівок і антимікробними та антиадгезивними агентами порівняно 3 описаними в літературі ліпопептидами та рамноліпідами, утворюваними на гліцерині.

Ключові слова: Acinetobacter calcoaceticus IMB B-7241, поверхнево-активні речовини, глічерин, регуляція. 


\title{
Пробіотичні та технологічні властивості екзополісахаридів Stretptococcus thermophilus CNRZ 447 i Enterococcus durans NCBI 53345
}

\author{
Бадра Бубакер ${ }^{1}$, Хафіда Хадем ${ }^{1}$, Мустафа Сангало Драбо르, \\ Ахмад Алі ${ }^{3}$, Айча Тіртуїл Меддах ${ }^{4}$ \\ 1 - Університет Ібн Халдуна, Тіарет, Алжир \\ 2 - Університет Уагадугу, Уагадугу, Буркіна-Фасо \\ 3 - Мумбайський університет Відьянагарі, Мумбаї, Індія \\ 4 - Університет Мустафи Стамбоулі, Маскара, Алжир
}

Вступ. Метою дослідження $\epsilon$ визначення пробіотичних i технологічних властивостей Streptococcus thermophilus CNRZ 447 та Enterococcus durans NCBI 53345.

Матеріали і методи. Дослідження проводили партіями з різними значеннями $\mathrm{pH}$ (2 і 3), температури $\left(15,37,45,50,60\right.$ i $\left.65^{\circ} \mathrm{C}\right)$, вмісту жовчних солей $(0,3,0,5$ і $1 \%$ ) та антибіотиків ( C10, GM, AN30 і TE30). Антагоністичний ефект був реалізований проти E. coli та S. aureus. Бактеріальну адгезію та виробництво екзополісахаридів проводили в оптимізованих умовах культивування. Потім екзополісахарид профілювали за допомогою HPLC з використанням системи Agilent LC 1260 у поєднанні $з$ детектором показника заломлення.

Результати і обговорення. Штами довели значну здатність до персистування in vitro в умовах, що імітують шлунково-кишковий тракт людини. Вони вижили при $\mathrm{pH}$ 2 і 3 протягом 3 год інкубації. Спостерігається мінімальне зниження на 1\% і 0,99 log КУО для обох бактеріальних штамів S. thermophilus i E. durans при рН 2. Невелике зниження росту штамів було відзначено за наявності жовчних солей у різних концентраціях (зафіксовані дисконтні рівні від 1 до 3\%), що свідчить про їхню здатність виживати в шлунково-кишковому тракті. Відзначено значну толерантність до коливань температури. Ідеальні температури для росту E. durans та S. thermophilus були, відповідно, 37 та $45{ }^{\circ} \mathrm{C}$. Швидкість автоагрегації, зареєстрована після 4 год декантації, становить 76 і 51\% для S. thermophilus і $E$ durans відповідно. Зафіксовано гідрофобність поверхні 81 і 61\% для S. thermophilus і E. durans, антагоністичну здатність проти $E$. coli i $S$. aureus, а також резистентність до антибіотиків. $S$. thermophilus був стійкий до 3 із 4 досліджених антибіотиків. Тим часом E. durans був стійкий до тетрацикліну і налідиксової кислоти. Було помітно значне вироблення екзополісахаридів. E. durans був більш плідним у виробництві екзополісахаридів (ESP), ніж S. thermophilus (1661 \pm 27 мг/л проти 176 \pm 4 мг/л). EPS, вироблений $S$. thermophilus CNRZ 447, в основному складався із двох триголозидів, які складалися переважно з глюкози. Аналіз E. durans EPS показав піки через 7 і 9 хв, що представляють олігосахариди, і один пік, елюювальний через 20,4 хв, який, імовірно, $\epsilon$ сорбітом.

Висновок. Випробувані штами продемонстрували багатообіцяючий пробіотичний потенціал і високу здатність до вироблення екзополісахаридів.

Ключові слова: пробіотик, резистентність, екзополісахарид, S. thermophiles, E. durans. 


\title{
Instructions for authors
}

\author{
Dear colleagues!
}

The Editorial Board of scientific periodical

"Ukrainian Food Journal"

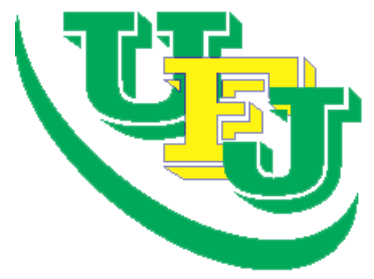

invites you for publication of your research results.

A manuscript should describe the research work that has not been published before and is not under consideration for publication anywhere else. Submission of the manuscript implies that its publication has been approved by all co-authors as well as by the responsible authorities at the institute where the work has been carried out.

It is mandatory to include a covering letter to the editor which includes short information about the subject of the research, its novelty and significance; state that all the authors agree to submit this paper to Ukrainian Food Journal; that it is the original work of the authors.

\section{Manuscript requirements}

Authors must prepare the manuscript according to the guide for authors. Editors reserve the right to adjust the style to certain standards of uniformity.

Language - English

Manuscripts should be submitted in Word.

Use 1.0 spacing and $2 \mathrm{~cm}$ margins.

Use a normal font 14-point Times New Roman for text, tables, and sings on figures,

1.0 line intervals.

Present tables and figures in the text of manuscript.

Consult a recent issue of the journal for a style check.

Number all pages consecutively.

Abbreviations should be defined on first appearance in text and used consistently thereafter. No abbreviation should be used in title and section headings.

Please submit math equations as editable text and not as images (It is recommend software application MathType or Microsoft Equation Editor)

Minimal size of the article (without the Abstract and References) is 10 pages. For review article is 25 pages (without the Abstract and References). 


\section{Manuscript should include:}

Title (should be concise and informative). Avoid abbreviations in it.

Authors' information: the name(s) of the author(s); the affiliation(s) of the author(s), city, country. One author has been designated as the corresponding author with e-mail address. If available, the 16-digit ORCID of the author(s).

Declaration of interest

Author contributions

Abstract. The abstract should contain the following mandatory parts:

Introduction provides a rationale for the study (2-3 lines).

Materials and methods briefly describe the materials and methods used in the study (3-5 lines).

Results and discussion describe the main findings (23-26 lines).

Conclusion provides the main conclusions (2-3 lines).

The abstract should not contain any undefined abbreviations or references to the article.

Keywords. Immediately after the abstract provide 4 to 6 keywords.

Text of manuscript

References

Manuscripts should be divided into the following sections:

- Introduction

- Materials and methods

- Results and Discussion

- Conclusions

- References

Introduction. Provide a background avoiding a detailed review of literature and declare the aim of the present research. Identify unexplored questions, prove the relevance of the topic. This should be not more than 1.5 pages.

Materials and methods. Describe sufficient details to allow an independent researcher to repeat the work. Indicate the reference for methods that are already published and just summarize them. Only new techniques need be described. Give description to modifications to existing methods.

Results and discussion. Results should be presented clearly and concisely with tables and/or figures, and the significance of the findings should be discussed with comparison with existing in literature data.

Conclusions. The main conclusions should be drawn from results and be presented in a short Conclusions section.

Acknowledgments(if necessary). Acknowledgments of people, grants, or funds should be placed in a separate section. List here those persons who provided help during the research. The names of funding organizations should be written in full.

Divide your article into sections and into subsections if necessary. Any subsection should have a brief heading.

\section{References}

Please, check references carefully. 
The list of references should include works that are cited in the text and that have been published or accepted for publication.

All references mentioned in the reference list are cited in the text, and vice versa.

Cite references in the text by name and year in parentheses. Some examples:

(Drobot, 2008); (Qi and Zhou, 2012); (Bolarinwa et al., 2019; Rabie et al., 2020; Sengev et al., 2013).

Reference list should be alphabetized by the last names of the first author of each work: for one author, by name of author, then chronologically; for two authors, by name of author, then name of coauthor, then chronologically; for more than two authors, by name of first author, then chronologically.

If available, please always include DOIs links in the reference list.

\section{Reference style}

\section{Journal article}

Please follow this style and order: author's surname, initial(s), year of publication (in brackets), paper title, journal title (in italic), volume number (issue), first and last page numbers, e.g.:

Popovici C., Gitin L., Alexe P. (2013), Characterization of walnut (Juglans regia L.) green husk extract obtained by supercritical carbon dioxide fluid extraction, Journal of Food and Packaging Science, Technique and Technologies, 2(2), pp. 104-108.

The names of all authors should be provided, but in case of long author lists the usage of "et al" will also be accepted. Journal names should not be abbreviated.

\section{Book} Sydney.

Deegan C. (2000), Financial Accounting Theory, McGraw-Hill Book Company,

\section{Book chapter in an edited book}

Coffin J.M. (1999), Molecular biology of HIV, In: Crandell K.A. ed., The evolution of $H I V$, Johns Hopkins Press, Baltimore, pp. 3-40.

\section{Online document}

Mendeley, J.A., Thomson, M., \& Coyne, R.P. (2017), How and when to reference, Available at: https://www.howandwhentoreference.com

\section{Conference paper}

Arych M. (2018), Insurance's impact on food safety and food security, Resource and Energy Saving Technologies of Production and Packing of Food Products as the Main Fundamentals of Their Competitiveness: Proceedings of the 7th International Specialized Scientific and Practical Conference, September 13, 2018, NUFT, Kyiv, pp. 52-57.

\section{Figures}

All figures should be made in graphic editor using a font Arial.

The font size on the figures and the text of the article should be the same.

Black and white graphic with no shading should be used.

The figure elements (lines, grid, and text) should be presented in black (not gray) colour.

Figure parts should be denoted by lowercase letters (a, b, etc.). 
All figures are to be numbered using Arabic numerals.

Figures should be cited in text in consecutive numerical order.

Place figure after its first mentioned in the text.

Figure captions begin with the term Figure in bold type, followed by the figure number, also in bold type.

Each figure should have a caption describing what the figure depicts in bold type.

Supply all figures and EXCEL format files with graphs additionally as separate files.

Photos are not advisable to be used.

If you include figures that have already been published elsewhere, you must obtain permission from the copyright owner(s).

\section{Tables}

Number tables consecutively in accordance with their appearance in the text.

Place footnotes to tables below the table body and indicate them with superscript lowercase letters.

Place table after its first mentioned in the text.

Ensure that the data presented in tables do not duplicate results described elsewhere in the article.

\section{Suggesting / excluding reviewers}

Authors are welcome to suggest reviewers and/or request the exclusion of certain individuals when they submit their manuscripts.

When suggesting reviewers, authors should make sure they are totally independent and not connected to the work in any way. When suggesting reviewers, the Corresponding Author must provide an institutional email address for each suggested reviewer. Please note that the Journal may not use the suggestions, but suggestions are appreciated and may help facilitate the peer review process.

\section{Submission}

Email for all submissions and other inquiries:

$$
\text { ufj_nuft@meta.ua }
$$




\section{Шановні колеги!}

Редакційна колегія наукового періодичного видання «Ukrainian Food Journal» запрошує Вас до публікації результатів наукових досліджень.

\section{Вимоги до оформлення статей}

Мова статей - англійська.

Мінімальний обсяг статті - $\mathbf{1 0}$ сторінок формату А4 (без врахування анотацій і списку літератури).

Для всіх елементів статті шрифт - Times New Roman, кегль - 14, інтервал - 1 .

Всі поля сторінки - по 2 см.

1. УДК.

\section{Структура статті:}

\section{2. Назва статті.}

3. Автори статті (ім'я та прізвище повністю, приклад: Денис Озерянко).

4. Установа, в якій виконана робота.

5. Анотація. Обов'язкова структура анотації:

- Вступ (2-3 рядки).

- Матеріали та методи (до 5 рядків)

- Результати та обговорення (пів сторінки).

- Висновки (2-3 рядки).

6. Ключові слова (3-5 слів, але не словосполучень).

\section{Пункти 2-6 виконати англійською і українською мовами.}

7. Основний текст статті. Має включати такі обов'язкові розділи:

- Вступ

- Матеріали та методи

- Результати та обговорення

- Висновки

- Література.

За необхідності можна додавати інші розділи та розбивати їх на підрозділи.

8. Авторська довідка (Прізвище, ім'я та по батькові, вчений ступінь та звання, місце роботи, електронна адреса або телефон).

9. Контактні дані автора, до якого за необхідності буде звертатись редакція журналу.

Рисунки виконуються якісно. Скановані рисунки не приймаються. Розмір тексту на рисунках повинен бути співрозмірним (!) тексту статті. Фотографії можна використовувати лише за їх значної наукової цінності.

Фон графіків, діаграм - лише білий. Колір елементів рисунку (лінії, сітка, текст) - чорний (не сірий).

Рисунки та графіки EXCEL з графіками додатково подаються в окремих файлах.

Скорочені назви фізичних величин в тексті та на графіках позначаються латинськими літерами відповідно до системи СІ.

У списку літератури повинні переважати англомовні статті та монографії, які опубліковані після 2010 року. 


\section{Оформлення цитат у тексті статті:}

\begin{tabular}{|c|c|}
\hline Кількість авторів статті & Приклад цитування у тексті \\
\hline 1 автор & (Arych, 2019) \\
\hline 2 і більше авторів & (Bazopol et al., 2021) \\
\hline
\end{tabular}

Приклад тексту із цитуванням: It is known (Bazopol et al., 2006; Kuievda, 2020), the product yield depends on temperature, but, there are some exceptions (Arych, 2019).

У цитуваннях необхідно вказувати одне джерело, звідки взято інформацію.

Список літератури сортується за алфавітом, літературні джерела не нумеруються.

\section{Правила оформлення списку літератури}

B Ukrainian Food Journalвзято за основу загальноприйняте в світі спрощене оформлення списку літератури згідно стандарту Garvard. Bci елементи посилання розділяються лише комами.

\section{1. Посилання на статтю:}

Автори А.А. (рік видання), Назва статті, Назва жсурналу (курсивом), Том (номер), сторінки.

Ініціали пишуться після прізвища.

Всі елементи посилання розділяються комами.

1. Приклад:

Popovici C., Gitin L., Alexe P. (2013), Characterization of walnut (Juglans regia L.) green husk extract obtained by supercritical carbon dioxide fluid extraction, Journal of Food and Packaging Science, Technique and Technologies, 2(2), pp. 104-108.

\section{2. Посилання на книгу:}

\section{Автори (рік), Назва книги (курсивом), Видавництво, Місто.}

Ініціали пишуться після прізвища.

Всі елементи посилання розділяються комами.

Приклад:

2. Wen-Ching Yang (2003), Handbook of fluidization and fluid-particle systems, Marcel Dekker, New York.

\section{Посилання на електронний ресурс:}

Виконується аналогічно посиланню на книгу або статтю. Після оформлення даних про публікацію пишуться слова Available at: та вказується електронна адреса.

Приклади:

(2013), Svitovi naukovometrychni bazy, Available at:

http://www.nas.gov.ua/publications/q_a /Pages/scopus.aspx

Cheung T. (2011), World's 50 most delicious drinks, Available at: http://travel.cnn.com/explorations/drink/worlds-50-most-delicious-drinks-883542

Список літератури оформлюється лише латиницею. Елементи списку українською та російською мовою потрібно транслітерувати. Для транслітерації з українською мови використовується паспортний стандарт.

Зручний сайт для транслітерації з української мови: http://translit.kh.ua/\#lat/passport

Стаття надсилається за електронною адресою: ufj_nuft@meta.ua 
Ukrainian Food Journal публікує оригінальні наукові статті, короткі повідомлення, оглядові статті, новини та огляди літератури.

\section{Тематика публікацій в Ukrainian Food Journal:}

Харчова інженерія

Харчова хімія

Мікробіологія

Фізичні властивості харчових продуктів

Якість та безпека харчових продуктів
Процеси та обладнання

Нанотехнології

Економіка та управління

Автоматизація процесів

Упаковка для харчових продуктів

Періодичність виходу журналу 4 номери на рік.

Результати досліджень, представлені в журналі, повинні бути новими, мати чіткий зв'язок з харчовою наукою і представляти інтерес для міжнародного наукового співтовариства.

Ukrainian Food Journal індексується наукометричними базами:

Index Copernicus (2012)

EBSCO (2013)

Google Scholar (2013)

UlrichsWeb (2013)

Global Impact Factor (2014)

Online Library of University of Southern Denmark (2014)

CABI full text (2014)

Directory of Research Journals Indexing (DRJI) (2014)

Universal Impact Factor (2014)

Directory of Open Access scholarly Resources (ROAD) (2014)

European Reference Index for the Humanities and the Social Sciences (ERIH PLUS) (2014)

Directory of Open Access Journals (DOAJ) (2015)

InfoBase Index (2015)

Chemical Abstracts Service Source Index (CASSI) (2016)

Emerging Sourses Citaton Index (2018)

Рецензія рукопису статті. Матеріали, представлені для публікування в «Ukrainian Food Journal», проходять «Подвійне сліпе рецензування» двома вченими, призначеними редакційною колегією: один $є$ членом редколегії і один незалежний учений.

Авторське право. Автори статей гарантують, що робота не є порушенням будь-яких авторських прав, та відшкодовують видавцю порушення даної гарантії. Опубліковані матеріали є правовою власністю видавця «Ukrainian Food Journal», якщо не узгоджено інше.

Детальна інформація про Журнал, інструкції авторам, приклади оформлення статті та анотацій розміщені на сайті:

\section{http://ufj.nuft.edu.ua}




\section{Ukrainian Food Journal}

\section{Редакційна колегія}

Головний редактор:

Олена Стабнікова, д-р., Національний університет харчових технологій, Украӥна

\section{Члени міжнародної редакційної колегії:}

Агота Гієдре Райшене, д-р, Литовський ініститут аграрної економіки, Литва Валерій Мирончук, д-р. техн. наук, проф., Національний університет харчових технологій, Украӥна

Віктор Стабніков, д-р техн. наук, проф., Національний університет харчових технологій, Украӥна

Владімір Груданов, д-р. техн. наук, проф., Білоруський державний аграрний технічний університет, Білорусь

Егон Шніцлер, д-р, професор, Державний університет Понта Гросси, Бразилія Йорданка Стефанова, д-р, Пловдівський університет "Паісій Хілендарскі", Болгарія Крістіна Попович, д-р., доц., Технічний університет Молдови

Марк Шамцян, д-р., доц., Чорноморська асочіація з харчової науки та технологї, Румунія

Лелівельд Хуб, асоиіація «Міжнародна гармонізаџійна ініціатива», Нідерланди

Октавіо Паредес Лопес, д-р., проф, Центр перспективних досліджень

Національного політехнічного інституту, Мексика.

Паскаль Дюпьо, д-р, Університет Клод Бернард Ліон 1, Франиія

Семіх Отлес, д-р., проф, Університет Еге, Туреччина

Соня Амарей, д-р., проф, Університет «Штефан чел Маре», Сучава, Румунія

Станка Дамянова, д-р., проф, Русенський університет «Англел Канчев», філія

Разград, Болгарія

Стефан Стефанов, д-р., проф., Університет харчових технологій, Болгарія

Тетяна Пирог, д-р. біол. наук, проф., Національний університет харчових технологій, Украӥна

Томаш Бернат, д-р., проф., Щецинський університет, Польщиа

Юлія Дзязько, Д-р. хім. наук, с.н.с., Інститут загальної та неорганічної хімії імені B. I. Вернадського НАН Украӥни

Юрій Білан, д-р., проф., Жешувський технологічний університет, Польща

Ясміна Лукінак, д-р, проф., Осієкський університет, Хорватія.

\section{Члени редакційної колегії:}

Агота Гісдре Райшене, д-р, Литовський ініститут аграрної економіки, Литва Анатолій Сайганов, д-р. екон. наук, проф., Інститут системних досліджень в АПК НАН Беларусі

Валерій Мирончук, д-р. техн. наук, проф., Начіональний університет харчових технологій, Україна 
Віктор Стабніков, д-р техн. наук, проф., Національний університет харчових технологій, Украӥна

Володимир Ковбаса, д-р. техн. наук, проф., Національний університет харчових технологій, Украӥна

Владімір Груданов, д-р. техн. наук, проф., Білоруський державний аграрний технічний університет, Білорусь

Галина Сімахіна, д-р. техн. наук, проф., Національний університет харчових технологій, Украӥна

Егон Шніцлер, д-р, професор, Державний університет Понта Гросси, Бразилія Йорданка Стефанова, д-р, Пловдівський університет "Паісій Хілендарскі", Болгарія Крістіна Попович, д-р., доц., Технічний університет Молдови

Лада Шерінян, д-р. екон. наук, професор., Національний університет харчових технологій, Украӥна

Марк Шамцян, д-р., доц., Чорноморська асочіачія з харчової науки та технології, Румунія

Микола Сичевський, д-р. екон. наук, проф., Інститут продовольчих ресурсів НАAН Украӥни

Лелівельд Хуб, асоиіачія «Міжнародна гармонізаџійна ініціатива», Нідерланди

Октавіо Паредес Лопес, д-р., проф, Центр перспективних досліджень

Національного політехнічного інституту, Мексика.

Олександр Шевченко, Д-р. техн. наук, проф., Національний університет харчових технологій, Украӥна

Олена Грабовська, д-р. техн. наук, проф., Національний університет харчових технологій, Украӥна

Олена Драган, д-р. екон. наук, проф., Начіональний університет харчових технологій, Украӥна

Ольга Рибак, канд. техн. наук, доц., Тернопільський національний технічний унівреситет імені Івана Пулюя, Украӥна

Паскаль Дюпьо, д-р, Університет Клод Бернард Ліон 1, Франція

Семіх Отлес, д-р., проф, Університет Еге, Туреччина

Соня Амарей, д-р., проф, Університет «Штефан чел Маре», Сучава, Румунія

Станка Дамянова, д-р., проф, Русенський університет «Англел Канчев», філія

Разград, Болгарія

Стефан Стефанов, д-р., проф., Університет харчових технологій, Болгарія

Тетяна Пирог, д-р. біол. наук, проф., Національний університет харчових технологій, Украӥна

Томаш Бернат, д-р., проф., Щецинський університет, Польщза

Юлія Дзязько, д-р. хім. наук, с.н.с., Інститут загальної та неорганічної хімії імені B.I. Вернадського НАН Украӥни

Юрій Білан, д-р., проф., Жешувський Технологічний Університет, Польща

Ясміна Лукінак, д-р, проф., Осієкський університет, Хорватія.

Олексій Губеня (відповідальний секретар), канд. техн. наук, доц., Національний університет харчових технологій, Україна. 
Contents of Volume 10 (Year 2021)
Зміст тому 10

(2021 рік)

\begin{tabular}{|c|c|c|}
\hline Food Technology & & Харчові технології \\
\hline Issue 1 & & № 1 \\
\hline $\begin{array}{l}\text { Volodymyr Ivanov, Oleksandr } \\
\text { Shevchenko, Andrii Marynin, } \\
\text { Viktor Stabnikov, Oleksii Gubenia, } \\
\text { Olena Stabnikova, Anastasiia } \\
\text { Shevchenko, Oleksandr Gavva, } \\
\text { Anatoliy Saliuk } \\
\text { Trends and expected benefits of the } \\
\text { breaking edge food technologies in } \\
\text { 2021-2030 }\end{array}$ & $\begin{array}{l}7- \\
36\end{array}$ & $\begin{array}{l}\text { Володимир Іванов, Олександр } \\
\text { Шевченко, Андрій Маринін, Віктор } \\
\text { Стабников, Олексій Губеня, Олена } \\
\text { Стабнікова, Анастасія Шевченко, } \\
\text { Олександр Гавва, Анатолій Салюк } \\
\text { Тренди і очікувані переваги } \\
\text { передових харчових технологій у } \\
\text { 2021-2030рр }\end{array}$ \\
\hline $\begin{array}{l}\text { Zhuzha Khatchapuridze, Givi } \\
\text { Gugulashvili, Vitali hvachliani, } \\
\text { Angelika Ploeger, Levan Gulua, } \\
\text { Tamar Turmanidze } \\
\text { In-vitro functional efficacy of extracts } \\
\text { from Caucasian Rhododendron } \\
\text { (Rhododendron caucasicum) and } \\
\text { Rkatsiteli wines as pancreatic lipase } \\
\text { inhibitors }\end{array}$ & & $\begin{array}{l}\text { Жужа Хачапурідзе, Гіві Гугулашвілі, } \\
\text { Віталій Гвахчляні, Анжеліка } \\
\text { Пльогер, Леван Гулуа, Тамар } \\
\text { Турманідзе } \\
\text { Функціональна ефективність in vitro } \\
\text { екстрактів кавказького } \\
\text { рододендрона (Rhododendron } \\
\text { саисалісит) і вин Rkatsiteli як } \\
\text { інгібіторів панкреатичної ліпаз }\end{array}$ \\
\hline $\begin{array}{l}\text { Debora Conde Molina, Carla } \\
\text { Quevedo, Valeria Arqueros } \\
\text { Sodium chloride substitution in } \\
\text { industrial white slice diary bread }\end{array}$ & $\begin{array}{l}51- \\
61\end{array}$ & $\begin{array}{l}\text { Дебора Конде Моліна, Карла } \\
\text { Кеведо, Валерія Аркерос } \\
\text { Заміна хлориду натрію в } \\
\text { промисловому тостовому хлібі }\end{array}$ \\
\hline $\begin{array}{l}\text { Galyna Simakhina, Nataliya } \\
\text { Naumenko } \\
\text { Antioxidant effectiveness of plant } \\
\text { cultures }\end{array}$ & $\begin{array}{l}62- \\
76\end{array}$ & $\begin{array}{l}\text { Галина Сімахіна, Наталія Науменко } \\
\text { Антиоксидантна ефективність } \\
\text { рослинних культур }\end{array}$ \\
\hline $\begin{array}{l}\text { Piotr Stanikowski, Monika Michalak- } \\
\text { Majewska, Ewa Jabłońska-Ryś, } \\
\text { Waldemar Gustaw, Robert Gruszecki } \\
\text { Influence of sous-vide thermal } \\
\text { treatment, boiling, and steaming on the } \\
\text { colour, texture and content of } \\
\text { bioactive compounds in root } \\
\text { vegetables }\end{array}$ & $\begin{array}{l}77- \\
89\end{array}$ & $\begin{array}{l}\text { Пьотр Станіковський, Моніка } \\
\text { Міхалак-Маєвська, Ева Яблонська- } \\
\text { Рись, Вальдемар Густав, Роберт } \\
\text { Грушецький } \\
\text { Вплив термічної обробки тиском, } \\
\text { кип'ятіння і пропарювання на колір, } \\
\text { текстуру і вміст біоактивних сполук } \\
\text { у коренеплодах }\end{array}$ \\
\hline $\begin{array}{l}\text { Jéssica Iwasenko Giacomozzi, Bárbara } \\
\text { Ruivo Válio Barretti, Vanessa Soltes de } \\
\text { Almeida, Camila Delinski Bet, Marco } \\
\text { Aurélio da Silva Carvalho Filho, Luiz } \\
\text { Gustavo Lacerda, Ivo Mottin Demiate, } \\
\text { Egon Schnitzler } \\
\text { Technological properties of potato } \\
\text { starch treated by Heat-Moisture } \\
\text { Treatment with addition of organic } \\
\text { acids }\end{array}$ & $\begin{array}{l}90- \\
99\end{array}$ & $\begin{array}{l}\text { Джессіка Івасенко Джакомочиі, } \\
\text { Барбара Руіво Валіо Барретті, Ванесса } \\
\text { Солтес де Альмейда, Каміла Делінські } \\
\text { Бет,Марко Ауреліо да Сільва Карвальо } \\
\text { Філхо, Луї Густаво Ласерда, Іво } \\
\text { Моттін Деміат, Егон Шніилер } \\
\text { Технологічні властивості } \\
\text { картопляного крохмалю після } \\
\text { гідротермічного оброблення з } \\
\text { додаванням органічних кислот }\end{array}$ \\
\hline
\end{tabular}




\begin{tabular}{|c|c|c|}
\hline $\begin{array}{l}\text { Ana Leahu, Cristina Ghinea, Sorina } \\
\text { Ropciuc } \\
\text { Mass transfer during osmotic } \\
\text { dehydration of quince using different } \\
\text { osmosis solutions }\end{array}$ & $\begin{array}{l}100- \\
111\end{array}$ & $\begin{array}{l}\text { Ана Леаху, Крістіна Гінея, Соріна } \\
\text { Ропчук } \\
\text { Масообмін під час осмотичної } \\
\text { дегідратації айви з використанням } \\
\text { різних видів осмосу }\end{array}$ \\
\hline $\begin{array}{l}\text { Sevim Kose, Matevz Pompe, Bekir } \\
\text { Tufan, Marjan Veber, } \\
\text { Drago Kocar, Eva Petkovsek } \\
\text { Nutritional value of fish soup from } \\
\text { cultured brook trout (Salvelinus } \\
\text { fontinalis, Mitchill, 1814) }\end{array}$ & $\begin{array}{l}112- \\
123\end{array}$ & $\begin{array}{l}\text { Севім Косе, Матевз Помпе, Бекір } \\
\text { Туфан, Мар'ян Вебер, } \\
\text { Драго Кочар, Єва Петковшек } \\
\text { Харчова цінність рибного супу з } \\
\text { культивованої форелі } \\
\text { (Salvelinus fontinalis, Mitchill, 1814) }\end{array}$ \\
\hline $\begin{array}{l}\text { Rajendran Neravathu Sivan, } \\
\text { Balakrishnan Saraswathy } \\
\text { Harikumaran Thampi } \\
\text { Extraction, rheological and textural } \\
\text { analyses and grading of pectin from } \\
\text { stem pith of banana }\end{array}$ & $\begin{array}{l}124- \\
135\end{array}$ & $\begin{array}{l}\text { Раджендран Неравату Сіван, } \\
\text { Балакрішнан Сарасваті } \\
\text { Харікумаран Тампі } \\
\text { Вилучення, реологічний і } \\
\text { текстурний аналіз пектину із } \\
\text { стовбурової кісточки банана } \\
\end{array}$ \\
\hline $\begin{array}{l}\text { Yuliya Kryzhova, Marya Antonuk, } \\
\text { Viktor Stabnikov, Olena Stabnikova } \\
\text { Stability of selenium and iodine in the } \\
\text { functional meat products prepared } \\
\text { with seaweeds under different cooking } \\
\text { procedures }\end{array}$ & $\begin{array}{l}136- \\
144\end{array}$ & $\begin{array}{l}\text { Юлія Крижова, Марія Антонюк, } \\
\text { Віктор Стабніков, Олена } \\
\text { Стабнікова } \\
\text { Зберігання селену та йоду у } \\
\text { функціональних м’ясних продуктах } \\
\text { з додаванням водоростей } \\
\end{array}$ \\
\hline $\begin{array}{l}\text { Rosen Chochkov, Denka Zlateva, } \\
\text { Dana Stefanova } \\
\text { Effect of Spirulina platensis and Kelp } \\
\text { algae on the content of thiamine and } \\
\text { riboflavin in wheat bread }\end{array}$ & $\begin{array}{l}145- \\
157\end{array}$ & $\begin{array}{l}\text { Росен Чочков, Денка Златева, Дана } \\
\text { Стефанова } \\
\text { Вплив водоростей Spirulina platensis } \\
\text { і ламінарії на вміст тіаміну та } \\
\text { рибофлавіну в пшеничному хлібі }\end{array}$ \\
\hline $\begin{array}{l}\text { Daniela Pauliuc, Mircea Oroian, } \\
\text { Paula Ciursa } \\
\text { Organic acids content, sugars content } \\
\text { and physicochemical parameters of } \\
\text { Romanian acacia honey }\end{array}$ & $\begin{array}{l}158- \\
170\end{array}$ & $\begin{array}{l}\text { Даніела Паулюк, Мірча Ороян, } \\
\text { Паула Сіурса } \\
\text { Вміст органічних кислот, цукрів і } \\
\text { фізико-хімічні показники меду } \\
\text { румунської акації }\end{array}$ \\
\hline Issue 2 & & № 2 \\
\hline $\begin{array}{l}\text { Galin Ivanov, Atanaska Markova, } \\
\text { Gabor Zsivanovits, Mihaela Ivanova } \\
\text { Effect of storage temperatures on } \\
\text { Kashkaval texture }\end{array}$ & $\begin{array}{l}237- \\
248\end{array}$ & $\begin{array}{l}\text { Галин Іванов, Атанаска Маркова, } \\
\text { Габор Зівановіu, Михаела Іванова } \\
\text { Вплив температури зберігання на } \\
\text { текстуру сиру «Кашкавал» }\end{array}$ \\
\hline $\begin{array}{l}\text { Jan Kłobukowski, Marzena } \\
\text { Danowska-Oziewicz, Filip } \\
\text { Kłobukowski, Krystyna Skibniewska } \\
\text { Nutritional value of protein in wheat- } \\
\text { rye bread manufactured with addition } \\
\text { of flour from low-alkaloid cultivars of } \\
\text { lupin }\end{array}$ & $\begin{array}{l}249- \\
262\end{array}$ & $\begin{array}{l}\text { Ян Клобуковський, Маржена } \\
\text { Дановська-Озевич, Філіп } \\
\text { Клобуковський, Кристина } \\
\text { Скібнєвська } \\
\text { Харчова цінність білка в пшенично- } \\
\text { житньому хлібі, виготовленому з } \\
\text { додаванням борошна з } \\
\text { низькоалкалоїдних сортів люпину }\end{array}$ \\
\hline
\end{tabular}




\begin{tabular}{|c|c|c|}
\hline $\begin{array}{l}\text { Nataliia Hryhorenko, Natalia } \\
\text { Husiatynska, Olha Kalenyk } \\
\text { Substantiation of a rational method of } \\
\text { purification of sugar sorghum juice in } \\
\text { the technology of food syrup } \\
\text { production }\end{array}$ & $\begin{array}{l}263- \\
276\end{array}$ & $\begin{array}{l}\text { Наталія Григоренко, Наталія } \\
\text { Гусятинська, Ольга Каленик } \\
\text { Обгрунтування раціонального } \\
\text { способу очищення соку сорго } \\
\text { цукрового в технології отримання } \\
\text { харчового сиропу }\end{array}$ \\
\hline $\begin{array}{l}\text { Tetiana Osmak, Stanistaw Mleko, } \\
\text { Oksana Bass, } \\
\text { Artur Mykhalevych, Uliana Kuzmyk } \\
\text { Enzymatic hydrolysis of lactose in } \\
\text { concentrates of reconstituted } \\
\text { demineralized whey, intended for ice } \\
\text { cream production. }\end{array}$ & $\begin{array}{l}277- \\
288\end{array}$ & $\begin{array}{l}\text { Тетяна Осьмак, Станіслав Млеко, } \\
\text { Оксана Басс, Артур Михалевич, } \\
\text { Уляна Кузьмик } \\
\text { Ферментативний гідроліз лактози в } \\
\text { концентратах відновленої } \\
\text { демінералізованої сироватки, } \\
\text { призначених для виробництва } \\
\text { морозива }\end{array}$ \\
\hline $\begin{array}{l}\text { Dilruba Baykara, Esra Pilavcı, Mehdi } \\
\text { Meran, Zihni Onur Çalışkaner } \\
\text { Antimicrobial properties and } \\
\text { application of fig seed oil as an } \\
\text { additive for chitosan-based films. }\end{array}$ & $\begin{array}{l}289- \\
300\end{array}$ & $\begin{array}{l}\text { Ділруба Байкара, Есра Пілавчі, } \\
\text { Мехді Меран, Зігні Онур } \\
\text { Шалишканер } \\
\text { Антимікробні властивості олії з } \\
\text { насіння інжиру як компоненту } \\
\text { плівок на основі хітозану } \\
\end{array}$ \\
\hline $\begin{array}{l}\text { Oleksandr Khareba, Oleg Kuzmin, } \\
\text { Olena Khareba, Victor Marynchenko, } \\
\text { Margaryta Karputina, Iryna Koretska } \\
\text { Antioxidant characteristics of non- } \\
\text { traditional spicy-aromatic vegetable } \\
\text { raw materials for restaurant technology }\end{array}$ & $\begin{array}{l}301- \\
320\end{array}$ & $\begin{array}{l}\text { Олександр Хареба, Олег Кузьмін, } \\
\text { Олена Хареба, Віктор Маринченко, } \\
\text { Маргарита Карпутіна, Ірина } \\
\text { Корецька } \\
\text { Антиоксидантна характеристика } \\
\text { нетрадиційної пряно-ароматичної } \\
\text { овочевої сировини для технології } \\
\text { ресторанного господарства }\end{array}$ \\
\hline $\begin{array}{l}\text { Viktoria Sapiga, Galina Polischuk, } \\
\text { Natalia Breus, Tetiana Osmak } \\
\text { Enzymatic destruction of protopectin in } \\
\text { vegetable raw materials to increase its } \\
\text { structuring ability in ice cream }\end{array}$ & $\begin{array}{l}321- \\
332\end{array}$ & $\begin{array}{l}\text { Вікторія Сапіга, Галина Поліщук, } \\
\text { Наталія Бреус, Тетяна Осьмак } \\
\text { Ферментативна деструкція } \\
\text { протопектину в овочевій сировині } \\
\text { для підвищення її структурувальної } \\
\text { здатності у складі морозива }\end{array}$ \\
\hline $\begin{array}{l}\text { Eugenia Covaliov, Natalia Suhodol, } \\
\text { Aurica Chirsanova, Tatiana Capcanari, } \\
\text { Carolina Grosu, Rodica Siminiuc } \\
\text { Effect of grape skin powder extract } \\
\text { addition on functional and } \\
\text { physicochemical properties of } \\
\text { marshmallow }\end{array}$ & $\begin{array}{l}333- \\
345\end{array}$ & $\begin{array}{l}\text { Євгенія Ковальов, Наталія Суходол, } \\
\text { Ауріка Кірсанова, Татьяна Капканарь, } \\
\text { Кароліна Гросу, Родійа Сімінюк } \\
\text { Вплив екстракту порошку шкірки } \\
\text { винограду на функціональні та } \\
\text { фізико-хімічні властивості зефіру }\end{array}$ \\
\hline $\begin{array}{l}\text { Yurii Bulii, Anatolii Kuts, Ivan Yuryk, } \\
\text { Andrii Forsiuk } \\
\text { Improving the efficiency of mass- } \\
\text { exchange between liquid and steam in } \\
\text { rectification columns of cyclic action }\end{array}$ & $\begin{array}{l}346- \\
360\end{array}$ & $\begin{array}{l}\text { Юрій Булій, Анатолій Куи, Іван } \\
\text { Юрик, Андрій Форсюк } \\
\text { Підвищення ефективності } \\
\text { масообміну між рідиною і парою в } \\
\text { ректифікаційних колонах циклічної } \\
\text { дії }\end{array}$ \\
\hline
\end{tabular}




\begin{tabular}{|c|c|c|}
\hline $\begin{array}{l}\text { Andrii Marynin, Vasyl Pasichny, } \\
\text { Svitlana Litvynchuk, Liubomyr } \\
\text { Khomichak, Inha Kuznietsova, Svitlana } \\
\text { Vysotska } \\
\text { Influence of water activity on the } \\
\text { properties of wheat flour }\end{array}$ & $\begin{array}{l}375- \\
386\end{array}$ & $\begin{array}{l}\text { Андрій Маринін, Василій Пасічний, } \\
\text { Світлана Літвінчук, Любомир } \\
\text { Хомічак, Інга Кузнєцова, Світлана } \\
\text { Висоцька } \\
\text { Вплив показника активності води на } \\
\text { властивості борошна пшеничного }\end{array}$ \\
\hline Issue 3 & & № 3 \\
\hline $\begin{array}{l}\text { Mykola Oseyko, Nataliia Sova, } \\
\text { Kristina Chornei } \\
\text { Substantiation of hemp seeds storage } \\
\text { and processing technologies for } \\
\text { functional, dietary and specialty } \\
\text { products. Review. }\end{array}$ & $\begin{array}{l}427- \\
458\end{array}$ & $\begin{array}{l}\text { Микола Осейко, Наталія Сова, } \\
\text { Крістіна Чорней } \\
\text { Обгрунтування технологій } \\
\text { зберігання і переробки насіння } \\
\text { конопель для функціональної, } \\
\text { дієтичної та спеціальної продукції. } \\
\text { Огляд }\end{array}$ \\
\hline $\begin{array}{l}\text { Ali Güler } \\
\text { Physical, chemical and sensory } \\
\text { properties of sour grape based } \\
\text { beverages and monitoring of their } \\
\text { quality changes during storage }\end{array}$ & $\begin{array}{l}459- \\
478\end{array}$ & $\begin{array}{l}\text { Алі Гюлер } \\
\text { Фізико-хімічні та органолептичні } \\
\text { властивості напоїв на основі кислого } \\
\text { винограду та моніторинг їх якості } \\
\text { під час зберігання }\end{array}$ \\
\hline $\begin{array}{l}\text { Paula Ciursa, Mircea Oroian, Daniela } \\
\text { Pauliuc } \\
\text { Detection of raspberry honey } \\
\text { adulterated with agave, maple, rice, } \\
\text { corn and inverted sugar syrups using } \\
\text { instrumental techniques }\end{array}$ & $\begin{array}{l}479- \\
491\end{array}$ & $\begin{array}{l}\text { Паула Чюрса, Мірча Ороян, Даніела } \\
\text { Паулюк } \\
\text { Виявлення фальсифікацій } \\
\text { малинового меду агавовим, } \\
\text { кленовим, рисовим, кукурудзяним } \\
\text { та інвертованим цукровим сиропами } \\
\text { з використанням інструментальних } \\
\text { прийомів }\end{array}$ \\
\hline $\begin{array}{l}\text { Inna Hetman, Larysa Mykhonik, } \\
\text { Anastasiia Shevchenko } \\
\text { Influence of spontaneous fermentation } \\
\text { leavens from cereal flour on the } \\
\text { indicators of the technological process } \\
\text { of making wheat bread }\end{array}$ & $\begin{array}{l}492- \\
506\end{array}$ & $\begin{array}{l}\text { Інна Гетьман, Лариса Михонік, Олег } \\
\text { Кузьмін, Анастасія Шевченко } \\
\text { Вплив заквасок спонтанного } \\
\text { бродіння з борошна круп'яних } \\
\text { культур на показники } \\
\text { технологічного процесу } \\
\text { виготовлення пшеничного хліба }\end{array}$ \\
\hline $\begin{array}{l}\text { Müberra Bektaş, Müge Hendek Ertop } \\
\text { Phytic acid content and in-vitro } \\
\text { digestibility of several cereal and } \\
\text { legume types treated with different } \\
\text { processes }\end{array}$ & $\begin{array}{l}507- \\
523\end{array}$ & $\begin{array}{l}\text { Мюберра Бекташ, Мюге Хендек } \\
\text { Ертоп } \\
\text { Вміст фітинової кислоти та } \\
\text { засвоюваність in vitro злакових і } \\
\text { бобових культур, оброблених } \\
\text { різними способами } \\
\end{array}$ \\
\hline $\begin{array}{l}\text { Viktor Stabnikov, Andrii Marinin, } \\
\text { Olena Stabnikova } \\
\text { Main trends in application of novel } \\
\text { natural additives for food production. }\end{array}$ & $\begin{array}{l}524- \\
551\end{array}$ & $\begin{array}{l}\text { Віктор Стабников, Андрій Марінін, } \\
\text { Олена Стабнікова } \\
\text { Основні напрями застосування } \\
\text { нових натуральних інгредієнтів в } \\
\text { виробництві харчових продуктів }\end{array}$ \\
\hline
\end{tabular}




\begin{tabular}{|c|c|c|}
\hline $\begin{array}{l}\text { Anastasiya Demidova, Tamara } \\
\text { Nosenko, Volodymyr Bahmach, } \\
\text { Evgeniya Shemanska, Svitlana } \\
\text { Molchenko } \\
\text { Study on antioxidants extraction from } \\
\text { oak bark and their use for oxidation } \\
\text { stability of sunflower oil }\end{array}$ & $\begin{array}{l}552- \\
563\end{array}$ & $\begin{array}{l}\text { Анастасія Демидова, Тамара } \\
\text { Носенко, Володимир Бахмач, } \\
\text { Свгенія Шеманська, Світлана } \\
\text { Мольченко } \\
\text { Дослідження процесу екстрагування } \\
\text { антиоксидантів з кори дуба та їх } \\
\text { використання для окиснювальної } \\
\text { стійкості соняшникової олії }\end{array}$ \\
\hline $\begin{array}{l}\text { Sergii Shulga, Oksana Shulga, Natalya } \\
\text { Simurova } \\
\text { Modification of potato starch with } \\
\text { adipic acid and research of } \\
\text { modification product as raw materials } \\
\text { for food biodegradable packaging. }\end{array}$ & $\begin{array}{l}564- \\
575\end{array}$ & $\begin{array}{l}\text { Сергій Шульга, Оксана Шульга, } \\
\text { Наталія Сімурова } \\
\text { Модифікація картопляного } \\
\text { крохмалю хлорангідридом } \\
\text { адипінової кислоти та дослідження } \\
\text { продукту модифікації як сировини } \\
\text { екологічного пакування харчових } \\
\text { продуктів }\end{array}$ \\
\hline $\begin{array}{l}\text { Svitlana Mykolenko, Yana Hez, } \\
\text { Oleksandr Pivovarov } \\
\text { Effect of bioactivated amaranth grain } \\
\text { on the quality and amino acid } \\
\text { composition of bread }\end{array}$ & $\begin{array}{l}576- \\
591\end{array}$ & $\begin{array}{l}\text { Світлана Миколенко, Яна Гезь, } \\
\text { Олександр Півоваров } \\
\text { Вплив біоактивованого зерна } \\
\text { амаранту на якість та } \\
\text { амінокислотний склад хліба }\end{array}$ \\
\hline $\begin{array}{l}\text { Dana Huţ, Sonia Amariei } \\
\text { Effects of the sugar and fat substitution } \\
\text { on the rheological properties of the pie } \\
\text { dough }\end{array}$ & $\begin{array}{l}592- \\
604\end{array}$ & $\begin{array}{l}\text { Дана Гуиу, Соня Амарей } \\
\text { Вплив заміни цукру та жиру на } \\
\text { реологічні властивості тіста для } \\
\text { пирогів }\end{array}$ \\
\hline Issue 4 & & № 4 \\
\hline $\begin{array}{l}\text { Fang Wang, Valerii Sukmanov, Jie } \\
\text { Zeng } \\
\text { Effect of the addition of soybean dregs } \\
\text { treated by ultrafine grinding and } \\
\text { microwave technology on the quality } \\
\text { of crispy biscuits }\end{array}$ & $\begin{array}{l}678- \\
690\end{array}$ & $\begin{array}{l}\text { Фанг Ванг, Валерій Сукманов, Дзі } \\
\text { Зенг } \\
\text { Вплив додавання соевого шроту, } \\
\text { обробленого ультратонким } \\
\text { подрібненням і мікрофвильовим } \\
\text { опромінюванням, на якість } \\
\text { хрусткого печива }\end{array}$ \\
\hline $\begin{array}{l}\text { Victoria Sapiga, Galina Polischuk, } \\
\text { Magdalena Buniowska, Iryna } \\
\text { Shevchenko, Tetiana Osmak } \\
\text { Polyfunctional properties of oat } \beta \text { - } \\
\text { glucan in the composition of milk- } \\
\text { vegetable ice cream }\end{array}$ & $\begin{array}{l}691- \\
702\end{array}$ & $\begin{array}{l}\text { Вікторія Сапіга, Галина Полішук, } \\
\text { Магдалена Буньовска, Ірина } \\
\text { Шевченко, Тетяна Осьмак } \\
\text { Поліфункціональні властивості } \beta \text { - } \\
\text { глюкану з вівса у складі морозива } \\
\text { молочно-овочевого }\end{array}$ \\
\hline $\begin{array}{l}\text { Iryna Tsykhanovska, Olena } \\
\text { Stabnikova, Oleksandr Alexandrov, } \\
\text { Roman Trishch, Olga Blagiy } \\
\text { Functional and technological properties } \\
\text { of food nanoadditive based of double } \\
\text { oxide of bi- and trivalent iron in } \\
\text { lyophilic colloidal dispersed systems }\end{array}$ & $\begin{array}{l}703- \\
716\end{array}$ & $\begin{array}{l}\text { Ірина Цихановська, Олена } \\
\text { Стабнікова, Олександр } \\
\text { Александров, Роман Тріш, Ольга } \\
\text { Благій, Анастасія Нікуліна } \\
\text { Функціонально-технологічні } \\
\text { властивості харчової нанодобавки на } \\
\text { основі подвійного оксиду дво- та } \\
\text { тривалентного заліза в ліофільних } \\
\text { колоїдно-дисперсних системах }\end{array}$ \\
\hline
\end{tabular}




\begin{tabular}{|c|c|c|}
\hline $\begin{array}{l}\text { Pelin Günç Ergönül, Alev Yüksel } \\
\text { Aydar, Tuba Göldeli, Annalisa } \\
\text { Mentana, Maurizio Quinto } \\
\text { Changes in volatile compounds of } \\
\text { Ayvalık (Edremit) and Uslu olive oils } \\
\text { depending on conditions and time of } \\
\text { storage }\end{array}$ & $\begin{array}{l}717- \\
735\end{array}$ & $\begin{array}{l}\text { Пелін Гюнч Ергонюл, Алев Юксель } \\
\text { Айдар, Туба Гельделі, Анналіса } \\
\text { Ментана, Мауріціо Квінто } \\
\text { Зміни летких сполук оливкової олії } \\
\text { із сортів Айвалік (Едреміт) та Услу } \\
\text { залежно від умов і часу зберігання }\end{array}$ \\
\hline $\begin{array}{l}\text { Violeta Nour } \\
\text { Physico-chemical, antioxidant and } \\
\text { sensorial properties of fruit leathers } \\
\text { made from "Malga" and "Murano" } \\
\text { strawberry cultivars }\end{array}$ & $\begin{array}{l}736- \\
748\end{array}$ & $\begin{array}{l}\text { Віолета Ноур } \\
\text { Фізико-хімічні, антиоксидантні та } \\
\text { органолептичні властивості } \\
\text { плодової пастили із сортів полуниці } \\
\text { «Мальга» та «Мурано» }\end{array}$ \\
\hline $\begin{array}{l}\text { Trias Ayu Laksanawati, Muhammad } \\
\text { Habbib Khirzin, Maghfirotul } \\
\text { Amaniyah } \\
\text { Biodegradable film based on taro } \\
\text { starch with variations of duck bone } \\
\text { gelatin concentration: physical and } \\
\text { barrier properties }\end{array}$ & $\begin{array}{l}749- \\
760\end{array}$ & $\begin{array}{l}\text { Наталія Сабадам, Олена } \\
\text { Грабовська, Ігор Фесич, Аліна } \\
\text { Авраменко, Анастасія Сергієнко } \\
\text { Біорозкладна плівка на основі таро- } \\
\text { крохмалю з різними концентрації } \\
\text { желатину з качиної кістки: фізичні } \\
\text { та бар'єрні властивості }\end{array}$ \\
\hline $\begin{array}{l}\text { Nataliia Sabadash, Olena Hrabovska, } \\
\text { Igor Fesych, Alina Avramenko, } \\
\text { Anastasiia Serhiienko } \\
\text { Effect of the combined use of } \beta \text { - } \\
\text { amylase and pullulanase on the } \\
\text { carbohydrate composition of maltose } \\
\text { syrups }\end{array}$ & $\begin{array}{l}761- \\
773\end{array}$ & $\begin{array}{l}\text { Наталія Сабадаш, Олена } \\
\text { Грабовська, Ігор Фесич, Аліна } \\
\text { Авраменко, Анастасія Сергієнко } \\
\text { Вплив комбінування амілолітичних } \\
\text { ферментних препаратів на } \\
\text { вуглеводний склад мальтозних } \\
\text { сиропів із крохмалю } \\
\end{array}$ \\
\hline $\begin{array}{l}\text { Zhivka Goranova, Iordanka Alexieva, } \\
\text { Todorka Petrova } \\
\text { Effect of coconut products, mesquite } \\
\text { flour and stevia on the thermal and } \\
\text { quality properties of dark chocolate }\end{array}$ & $\begin{array}{l}774- \\
785\end{array}$ & $\begin{array}{l}\text { Живка Горанова, Іорданка } \\
\text { Алексієва, Тодорка Петрова } \\
\text { Вплив кокосових продуктів, } \\
\text { мескітового борошна та стевії на } \\
\text { теплові та якісні властивості } \\
\text { темного шоколаду }\end{array}$ \\
\hline $\begin{array}{l}\text { Oksana Dorozhynska, Olena Kokhan, } \\
\text { Yuliia Kambulova } \\
\text { Sorption characteristics of fondant } \\
\text { candies based on tagatose }\end{array}$ & $\begin{array}{l}786- \\
796\end{array}$ & $\begin{array}{l}\text { Оксана Дорожинська, Олена Кохан, } \\
\text { Юлія Камбулова } \\
\text { Сорбційні характеристики помадних } \\
\text { цукерок на основі тагатози }\end{array}$ \\
\hline $\begin{array}{l}\text { Tetiana Yaniuk, Tetiana Trakhalo, } \\
\text { Halyna Liashko, Olena Galynska, } \\
\text { Nataliia Hriunvald } \\
\text { Substantiation of grain mass } \\
\text { properties' effect on the processes of } \\
\text { extraction and hydration }\end{array}$ & $\begin{array}{l}797- \\
806\end{array}$ & $\begin{array}{l}\text { Тетяна Янюк, Тетяна Тракало, } \\
\text { Галина Ляшко, Олена Галинська, } \\
\text { Наталія Грюнвальд } \\
\text { Обгрунтування впливу властивостей } \\
\text { зернової маси на процеси } \\
\text { екстрагування та гідратації }\end{array}$ \\
\hline $\begin{array}{l}\text { Oleg Kuzmin, Nataliia Stukalska, } \\
\text { Larysa Mykhonik, Olga Koval, } \\
\text { Volodymyr Polyovyk, Ganna Berezova } \\
\text { Antioxidant characteristics of tea- } \\
\text { herbal compositions }\end{array}$ & $\begin{array}{l}807- \\
827\end{array}$ & $\begin{array}{l}\text { Олег Кузьмін, Наталія Стукальська, } \\
\text { Лариса Михонік, Ольга Коваль, } \\
\text { Володимир Польовик, Ганна Березова } \\
\text { Антиоксидантна характеристика } \\
\text { чайно-трав'яних композицій }\end{array}$ \\
\hline
\end{tabular}




\begin{tabular}{|c|c|c|}
\hline Processes and Equipment & & Процеси і обладнання \\
\hline Issue 1 & & № 1 \\
\hline $\begin{array}{l}\text { Viktor Vytvytskyi, Ihor Mikulionok, } \\
\text { Oleksandr Sokolskyi, Oleksandr } \\
\text { Gavva, Liudmyla Kryvoplias-Volodina } \\
\text { Design and technological parameters of } \\
\text { equipment influence on the lateral } \\
\text { pressure coefficient and reduced } \\
\text { friction coefficient of granular } \\
\text { polyvinyl chloride }\end{array}$ & $\begin{array}{l}182- \\
197\end{array}$ & $\begin{array}{l}\text { Віктор Витвицький, Ігор Мікульонок, } \\
\text { Олександр Сокольський, Олександр } \\
\text { Гавва, Людмила Кривопляс-Володіна } \\
\text { Вплив конструктивно-технологічних } \\
\text { параметрів обладнання на коефіцієнт } \\
\text { бічного тиску та приведеного } \\
\text { коефіцієнта тертя гранульованого } \\
\text { полівінілхлориду }\end{array}$ \\
\hline Issue 2 & & № 2 \\
\hline $\begin{array}{l}\text { Valerii Mykhailov, Viacheslav } \\
\text { Onyshchenko, Andrii Pak, Vadym } \\
\text { Bredykhin, Oleksii Zahorulko } \\
\text { Investigation of frying process of meat } \\
\text { sausages in glued casings from } \\
\text { intestinal raw materials }\end{array}$ & $\begin{array}{l}387- \\
398\end{array}$ & $\begin{array}{l}\text { Валерій Михайлов, В’ячеслав } \\
\text { Онищенко, Андрій Пак, Вадим } \\
\text { Бредикін, Олексій Загорулько } \\
\text { Особливості процесу смаження } \\
\text { м'ясних ковбасних виробів } \\
\text { у склеєних оболонках з кишкової } \\
\text { сировини }\end{array}$ \\
\hline Issue 3 & & № 3 \\
\hline $\begin{array}{l}\text { Oleksandr Obodovych, Oleksandr } \\
\text { Shevchenko, Valerii Myronchuk, Anna } \\
\text { Lymar, Vitalii Sydorenko, Roman } \\
\text { Yakobchuk } \\
\text { Intensification of the process of } \\
\text { obtaining inverted sugar syrup under } \\
\text { the conditions of rotor-pulsation } \\
\text { processing }\end{array}$ & $\begin{array}{l}605- \\
614\end{array}$ & $\begin{array}{l}\text { Олександр Ободович, Олександр } \\
\text { Шевченко, Валерій Мирончук, Анна } \\
\text { Лимар, Віталій Сидоренко, Роман } \\
\text { Якобчук } \\
\text { Інтенсифікація процесу отримання } \\
\text { інвертного цукрового сиропу } \\
\text { застосуванням роторно- } \\
\text { пульсаційного оброблення }\end{array}$ \\
\hline Issue 4 & & № 4 \\
\hline $\begin{array}{l}\text { Iryna Dubovkina, Oleksandr Sigal, } \\
\text { Veronica Rikhter, Nataliya Nizhnyk } \\
\text { Toxic substances formation in co- } \\
\text { incineration process for food } \\
\text { production }\end{array}$ & $\begin{array}{l}828- \\
839\end{array}$ & $\begin{array}{l}\text { Ірина Дубовкіна, Олександр Сігал, } \\
\text { Вероніка Ріхтер, Наталія Ніжсник } \\
\text { Утворення токсичних речовин при } \\
\text { сумісному спалюванні в харчових } \\
\text { виробництвах }\end{array}$ \\
\hline Biotechnology, Microbiology & & Біотехнологія, мікробіологія \\
\hline Issue 1 & & № 1 \\
\hline $\begin{array}{l}\text { Tetiana Pirog, Olesya Paliichuk, Daria } \\
\text { Lutsai, Liliia Kliuchka, Tetiana } \\
\text { Shevchuk } \\
\text { Effect of cations on the activity of } \\
\text { NADP+-dependent glutamate } \\
\text { dehydrogenase in Acinetobacter } \\
\text { calcoaceticus IMV B-7241, } \\
\text { Rhodococcus erythropolis IMV Ac- } \\
5017 \text { and Nocardia vaccinii IMV B- } \\
7405 \text { grown on industrial waste }\end{array}$ & $\begin{array}{l}198- \\
208\end{array}$ & 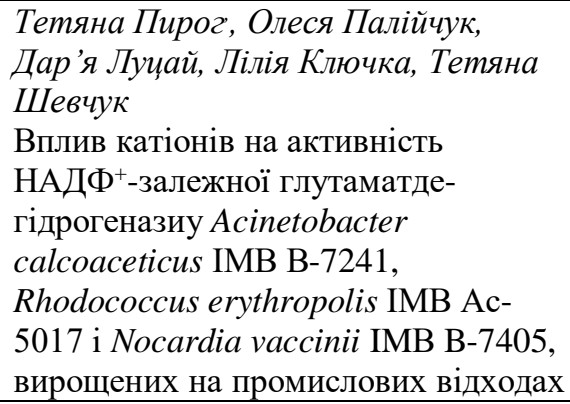 \\
\hline
\end{tabular}




\begin{tabular}{|c|c|c|}
\hline Issue 3 & & № 3 \\
\hline $\begin{array}{l}\text { Oksana Skrotska, Yevhen Kharchenko, } \\
\text { Yuliia Laziuka, Andrii Marynin, } \\
\text { Maksym Kharchuk } \\
\text { Biosynthesis and characterictics of } \\
\text { silver nanoparticles obtained using } \\
\text { Saccharomyces cerevisiae M437. }\end{array}$ & $\begin{array}{l}615- \\
631\end{array}$ & $\begin{array}{l}\text { Оксана Скрочька, Свген Харченко, } \\
\text { Юлія Лазюка, Андрій Маринін, } \\
\text { Максим Харчук } \\
\text { Біосинтез та характеристика } \\
\text { наночасток срібла отриманих } 3 \\
\text { використанням Saccharomyces } \\
\text { cerevisiae M437 }\end{array}$ \\
\hline $\begin{array}{l}\text { Andrii Voronenko, Tetyana Pirog } \\
\text { Intensification of microbial } \\
\text { exopolysaccharide ethapolan synthesis } \\
\text { on the mixture of energy-excessive } \\
\text { substrates }\end{array}$ & $\begin{array}{l}632- \\
645\end{array}$ & $\begin{array}{l}\text { Андрій Вороненко, Тетяна Пирог } \\
\text { Інтенсифікація синтезу мікробного } \\
\text { екзополісахариду етаполану на } \\
\text { суміші енергетично надлишкових } \\
\text { субстратів }\end{array}$ \\
\hline Issue 4 & & № 4 \\
\hline $\begin{array}{l}\text { Tetiana Pirog, Daria Lutsai, Hanna } \\
\text { Yarova } \\
\text { Regulation of biological activity of } \\
\text { surfactants under cultivation of } \\
\text { Acinetobacter calcoaceticus IMB B- } \\
7241 \text { on glycerol }\end{array}$ & $\begin{array}{l}840- \\
852\end{array}$ & $\begin{array}{l}\text { Тетяна Пирог, Дар’я Луияай, Ганна } \\
\text { Ярова } \\
\text { Регуляція біологічної активності } \\
\text { поверхнево-активних речовин у } \\
\text { процесі культивування Acinetobacter } \\
\text { calcoaceticus IMВ В-7241 на } \\
\text { гліцерині }\end{array}$ \\
\hline $\begin{array}{l}\text { Badra Boubakeur, Hafidha Khadem, } \\
\text { Moustapha Sangalo Drabo, Ahmad } \\
\text { Ali, Aicha Tirtouil Meddah } \\
\text { Probiotic properties and } \\
\text { exopolysaccharides production of } \\
\text { Stretptococcus thermophilus CNRZ } \\
447 \text { and Enterococcus durans NCBI } \\
53345\end{array}$ & $\begin{array}{l}853- \\
872\end{array}$ & $\begin{array}{l}\text { Бадра Бубакер, Хафіда Хадем, } \\
\text { Мустафа Сангало Драбо, } \\
\text { Ахмад Алі, Айча Тіртуїл Меддах } \\
\text { Пробіотичні та технологічні } \\
\text { властивості екзополісахаридів } \\
\text { Stretptococcus thermophilus CNRZ } \\
447 \text { i Enterococcus durans NCBI } \\
53345\end{array}$ \\
\hline
\end{tabular}




\section{Ukrainian Food Journal}

\section{Volume 10, Issue 4 2021}

\section{Том 10, № 4 2021}

Підп. до друку 30.12.2021 р. Формат 70х100/16.

Обл.-вид. арк. 17.56. Ум. друк. арк. 16.64.

Гарнітура Times New Roman. Друк офсетний.

Наклад 100 прим. Вид. № 06н/21.

НУХТ. 01601 Київ-33, вул. Володимирська, 68

Свідоцтво про державну реєстрацію друкованого засобу масової інформації

KB 18964-7754P

видане 26 березня 2012 року. 